UNIVERSIDADE DE SÃO PAULO

FACULDADE DE FILOSOFIA, LETRAS E CIÊNCIAS HUMANAS

DEPARTAMENTO DE GEOGRAFIA

PROGRAMA DE PÓS-GRADUAÇÃO EM GEOGRAFIA HUMANA

(CONTRA)HEGEMONIA E TERRITÓRIO DO MOVIMENTO DOS TRABALHADORES RURAIS SEM

TERRA (MST) NO SUDESTE PARAENSE

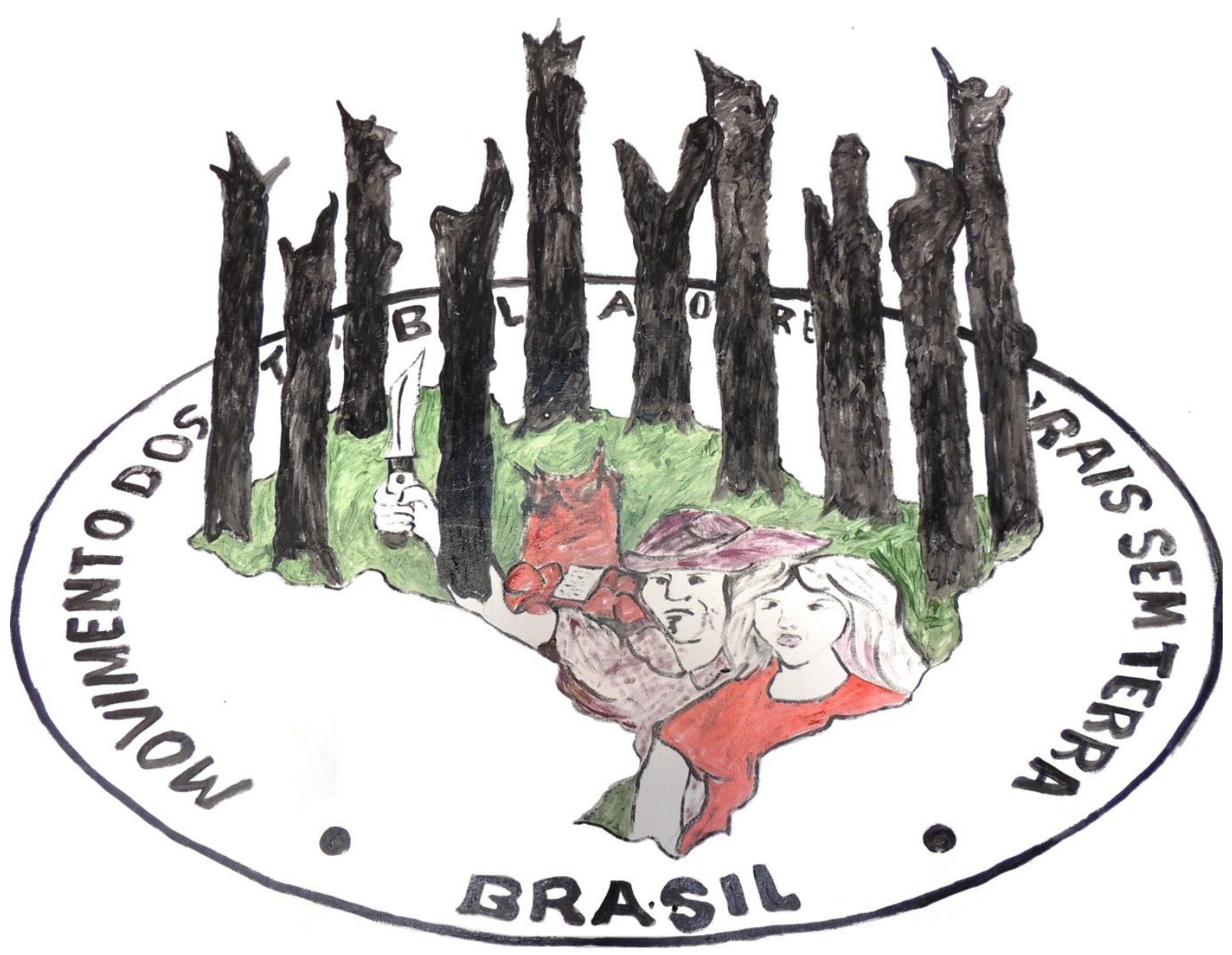

Rogério Rego Miranda

São Paulo 


\begin{tabular}{|c|c|}
\hline & Faculdade de Filosofia, Letras e Ciências Humanas \\
& Departamento de Geografia \\
\hline
\end{tabular}

ROGÉRIO REGO MIRANDA

\section{(CONTRA)HEGEMONIA E TERRITÓRIO DO}

Movimento dos Trabalhadores RuRais SEM

TERRA (MST) NO SUDESTE PARAENSE

São Paulo 


\section{U N I V E R S I D A D E D E S Ã O P A ULO}

aculdade de Filosofia, Letras e Ciências Humanas

Departamento de Geografia

Programa de Pós-Graduação em Geografia Humana

(CONTRA)HEGEMONIA E TERRITÓRIO DO MOVIMENTO DOS

TRABALHADORES RURAIS SEM TERRA (MST) NO SUDESTE PARAENSE

Rogério Rego Miranda

Tese apresentada ao Programa de PósGraduação em Geografia Humana da Faculdade de Filosofia Letras e Ciências Humanas da Universidade de São Paulo para obtenção do título de Doutor em Geografia.

Orientador: Prof. Dr. Júlio César Suzuki

São Paulo 
Autorizo a reprodução e divulgação total ou parcial deste trabalho, por qualquer meio convencional ou eletrônico, para fins de estudo e pesquisa, desde que citada a fonte.

Catalogação na Publicação

Serviço de Biblioteca e Documentação

Faculdade de Filosofia, Letras e Ciências Humanas da Universidade de São Paulo

Miranda, Rogério Rego

M 672 ( (Contra)hegemonia e território do Movimento dos Trabalhadores Rurais Sem Terra (MST) no sudeste paraense / Rogério Rego Miranda : orientador Júlio César Suzuki. - São Paulo, 2017. $380 \mathrm{f}$.

Tese (Doutorado) - Faculdade de Filosofia, Letras e Ciências Humanas da Universidade de São Paulo. Departamento de Geografia. Área de concentração: Geografia Humana.

1. Geografia Agrária. 2. Questão Agrária. 3. MST. 4. Amazônia. 5. Sudeste Paraense. I. Suzuki, Júlio César, orient. II. Título. 
MIRANDA, Rogério Rego. (Contra)hegemonia e território do Movimento dos Trabalhadores Rurais Sem Terra (MST) no sudeste paraense. Tese apresentada ao Programa de Pós-Graduação em Geografia Humana da Faculdade de Filosofia Letras e Ciências Humanas da Universidade de São Paulo para obtenção do título de Doutor em Geografia.

Banca Examinadora

Prof. D. (a): Instituição:

Julgamento: Assinatura:

Prof. D. (a): Instituição:

Julgamento: Assinatura:

Prof. D. (a): Instituição:

Julgamento: Assinatura:

Prof. D. (a): Instituição:

Julgamento: Assinatura:

Prof. D. (a): Instituição: Assinatura: 
Dedico este trabalho aos meus pais, Maria José Rego Miranda e Reinaldo Torres Miranda, por me lembrarem, todos os dias, de que a beleza da vida não está nos bens materiais e sim na sua principal dádiva, que é a família. 


\section{AGRADECIMENTOS}

Realizar o agradecimento ao término de um trabalho de tese de doutorado, por um lado, após quatro longos anos de pesquisa, é sempre impreciso, pois foram diversos os sujeitos que contribuíram para o trabalho, logo, corre-se o perigo de não mencionar todos, ao menos nominalmente. Por outro, esse fato revela que, embora o processo laboral seja muitas vezes solitário, ele nunca deixará de ser coletivo.

O fluxo de ideias que compõe o trabalho final é produto de múltiplas interações e discussões, seja na academia, de maneira mais formal; seja nos trabalhos de campo, em que os conceitos são forjados da realidade concreta, mostrando que são historicamente e geograficamente construídos a partir de sujeitos reais, com suas perdas, conflitos, redefinições de ideias, e, acima de tudo, mostrando que outro projeto de sociedade é possível; seus territórios são a materialização dessa contra-hegemonia, muitas vezes negada, invisibilizada ou simplesmente reduzida a experiências específicas com o intuito de inferiorizar os sujeitos subalternos e a possibilidade de projetos alternativos. Por esse motivo, agradeço inicialmente aos camponeses que em suas experiências de luta pela terra, marcadas pela violência do latifúndio, não perderam sua sensibilidade - pelo contrário, recebiam-me com muita alegria, dedicação, simplicidade e um cafezinho... Compartilharam suas histórias que muitas vezes me fizeram indagar: como conseguiam? Por que perseguiam esse projeto? E qual o significado dele para suas vidas?

Nesse caso, apenas simbolicamente, coloco alguns nomes de assentados que me acolheram em suas residências e/ou me ajudaram no trabalho de campo, mas que representam a comunidade. Assim agradeço ao "Carlinhos" (in memorian), da $1^{\circ}$ de Março, que veio a óbito pouco depois de eu sair do assentamento e há poucos meses de recuperar seu lote de terra - sua visão de coletivo e seu esforço de me acompanhar nos lotes em sua moto carinhosamente apelidada por ele de "brejeira", e que aguentava todas as condições adversas das estradas, sempre permanecerão em meus pensamentos. Igualmente tenho uma admiração imensa pela "Regina", que me acolheu no IALA Amazônico, assentamento Palmares II, e pelo companheiro de visitas nos lotes, “Zenilto". Do assentamento Onalício Barros, agradeço ao seu "Pitbull"; no P.A. Canudos, ao seu "Careta"; no P.A. Cabanos, ao seu "Nena" que me concedeu o privilégio de me tornar seu amigo; no Lourival Santana, ao seu "Antônio dos Reis"; no P.A. 26 de Março, às companheiras "Isabel" e "Giselda"; e, no assentamento 17 de Abril, ao seu "Gouveia" e ao Antônio Lopes Milanes. Saliento também a importância e a amizade de algumas lideranças do MST como Charles Trocate, Ayala e Maria Raimunda, 
além do companheiro Emmanuel Wambergue, ou simplesmente "Manu", cuja trajetória de luta é territorialmente reconhecida na região sudeste paraense e que me mostrou por meio de suas histórias seu conhecimento sobre a complexidade da realidade estudada.

Em um segundo momento, agradeço aos meus familiares, com destaque para meus pais, Maria José Rego Miranda e Reinaldo Torres Miranda, por me possibilitarem o amor e o exemplo de vida. Agradeço igualmente à Lourdimar Neves Borges (minha segunda mãe), ao Edilson ("Didi”) por sempre ser solícito e à minha irmã, Samara Rego Miranda, que mesmo a quilômetros de distância está comigo em meus pensamentos e, desta vez, ajudou na tradução de alguns textos em inglês. Tenho um agradecimento especial à Nayara de Souza Cabral, minha namorada que hoje se tornou esposa, pela cumplicidade, companheirismo mesmo quando não podia the dar minha presença, ajuda na transcrição de textos e, acima de tudo, o amor que garante alegria aos meus dias. Também agradeço aqueles que nos acolheram em São Paulo, demonstrando que mesmo em uma grande metrópole, em que a solidão é muito presente, a solidariedade e amizade igualmente fazem parte de seu espaço, nesse caso deixo meu apreço pelo seu Israel e dona Rachel. E, por fim, agradeço a Deus por me proporcionar essa família maravilhosa e as condições emocionais de desenvolver meus trabalhos; mesmo que em vários momentos eu o negue, ele se reafirma em minha vida pela beleza das pessoas que colocou em meu caminho.

Em um terceiro momento, agradeço à UNIFESSPA pela liberação para que eu cursasse meu doutorado na Universidade de São Paulo, instituição de ensino superior onde no Pará desenvolvi relações de trabalho e de amizade. Nesse sentido, agradeço, da Faculdade de Geografia, aos amigos Hugo Rogério Hage Serra, Rogério Marinho e Marcos Alexandre Pimentel da Silva, este último outrora orientador e hoje companheiro de trabalho na pesquisa, a quem agradeço pelas discussões de ideias sobre a tese e outros trabalhos. Também foram importantes as conversas com Haroldo Souza e Fernando Michelloti, que me apresentaram a realidade do sudeste paraense por meio de trabalhos de campo conjuntos e nas atividades da Residência Agrária, das quais participou o amigo e companheiro de debates calorosos Bruno Manheiro. Igualmente agradeço aos bolsistas do Laboratório de Estudos Regionais e Agrários do Sul e Sudeste do Pará (LERASSP) Kamilla de Oliveira Lopes, Lais Alves dos Santos, Hinckley Wendell do Nascimento Mendes e Francileno da Trindade Batista, por me ajudarem na sistematização dos questionários, possibilitando, assim, a construção de um banco de dados.

Em um quarto momento agradeço à CAPES pela bolsa Prodoutoral (Programa de Formação Doutoral Docente) que me possibilitou desenvolver esta pesquisa de maneira 
ampliada, ou seja, forneceu-me recursos para percorrer os assentamentos e acampamentos organizados pelo MST no sudeste paraense, assim como para fazer visitas a outras realidades, como o Pontal do Paranapanema em Presidente Prudente/São Paulo, além de auxiliar minha estadia em São Paulo para cursar as disciplinas, momento de grande importância para a discussão dos temas referentes a esta tese e de interação com meu orientador, Júlio Cesar Suzuki, ao qual tenho um agradecimento especial devido à liberdade de pensamento que me foi concedida, ao criterioso debate realizado em nossas orientações, a seriedade na correção do trabalho e a paciência que apresentou para com este seu orientando. É importante frisar que tenho uma dívida também com os professores doutores Manoel Fernandes de Sousa Neto e Bernardo Mançano Fernandes pelas contribuições fundamentais na banca de qualificação. Agradeço especialmente ao último pela oportunidade de estágio no NERA (Núcleo de Estudos, Pesquisas e Projetos de Reforma Agrária) da UNESP de Presidente Prudente. 


\section{RESUMO}

A territorialização do Movimento dos Trabalhadores Rurais Sem Terra (MST) no sudeste paraense se desenvolve no final da década de 1980 e se intensifica nos anos de 1990. Nesse sentido, o objetivo geral de nossa pesquisa é o de analisar as formas de territorialização contra-hegemônicas implementadas pelo MST, a partir da organização dos assentamentos, no sudeste paraense, tendo como recorte espacial os PAs consquistados por esse movimento socioterritorial, no período de 1994 a 2016. Para tanto, utilizamos, como procedimentos metodológicos, a pesquisa bibliográfica e documental; observação sistemática; entrevistas semi-estruturadas; questionários; registros fotográficos e a produção de uma cartografia temática. Em termos de referencial teórico, pautamo-nos principalmente nos escritos de Gramsci para compreender o conceito de hegemonia e para a formulação do que denominamos de um território contra-hegemônico dos movimentos socioterritoriais do espaço agrário do sudeste paraense, com especial atenção ao MST. Inicialmente, o MST atua na luta pela terra, utilizando-se principamente, enquanto tática, da ocupação de terras que desembocaram em acampamentos e esses, por sua vez, em assentamentos, o que não ocorre em uma linha evolutiva, mas sim de maneira gradual, conflitiva e em muitos casos com a manutenção e/ou expansão do território do capital agropecuário e mineral da região, mediante as reintegrações de posse, expropriação ou violência física que corrobora para a desterritorialização dos sujeitos do campo. Paralelamente, o movimento socioterritorial promove uma série de manifestações conjuntas ou não com outros movimentos sindicais, com destaque à Fetagri, o que favorece a constituição de alianças territoriais mobilizadas em tempos-espaços específicos ou mais duradouros, constituindo um bloco histórico-geográfico em aberto, móvel e em reformulação constante. Com a consquista dos Projetos de Assentamentos e a organização de acampamentos, o MST constitui uma rede geográfica solidária camponesa de luta pela terra que fortalece a sua territorialidade no sudeste paraense e ao mesmo tempo se utiliza da política de escalas que possibilita a sua atuação em diversos níveis escalares e igualmente se torna um mecanismo para que o movimento socioterritorial, em conjunto com outros de atuação nacional e internacional, redefina políticas públicas ou crie outras mais adequadas aos interesses das classes subalternas do campo, com destaque ao Pronera. Nesse contexto, o MST amplia sua luta pela terra para sua permanência na terra, com a produção de um outro projeto de desenvolvimento territorial divergente do agropecuário e mineral, analisado, aqui, como contra-hegemônico, pautado principalmente no tripé terraprodução-educação. Para este fim, além da conquista do território, busca-se a constituição de um consenso ativo advindo da classe subalterna, cuja emancipação perpassa pela cisão com o sistema de valores dominantes e a consequente reapropriação dos aparelhos privados de hegemonia, que permitem a construção coletiva da Educação do Campo e da Agroecologia entre os movimentos socioterritoriais e sindicais, os assentados e acampados, Universidade Unifesspa -, Instituto Federal - Campus Rural de Marabá do IFPA -, e o IALA Amazônico.

Palavras-Chave: Território, MST, Movimento Socioterritorial, Contra-hegemonia, Amazônia, Sudeste Paraense. 


\begin{abstract}
The territorialization of the movement of rural workers without land (MST) in southeast Pará developed during the late 1980's and intensifyed in 1990. In this sense, the general purpose of our research is to analyze the forms of territorialization and the contra-hegemonic social movement implemented by MST, from organization of settlements, in southeast Pará, having as spatial clipping the settlement projects conquered by this socio-territorial movement, from 1994 to 2016. To present our hypothesis, we use, as methodological procedures, bibliographical and documentary research, systematic observation, structured interviews, questionnaires, photographic records, and the production of a thematic cartography. In terms of theoretical reference, we are primarily guided by Gramsci's writings in order to understand the concept of hegemony and the formulation of what we call a territory contra-hegemony of the socio-territorial movements on southeast Pará agrarian space, with particular attention to MST. Initially, MST operates fighting for land, using especially, as a tactic, occupation of land that fall into camps and these, in turn, in settlements, which does not occur in an evolutionary line, but rather in a gradual way, conflicting with in many cases the maintenance and/or expansion of the territory of agricultural and mineral capital in the region, through the re-integrations of ownership, expropriation or physical violence corroborating the deterritorialization of the field subjects. In parallel, the Socio-territorialist movement promotes a series of joint demonstrations or not with other union movements, highlighting FETAGRI, which favors the formation of territorial alliances mobilized in specific or more durable timeframes, constituting an open, mobile historical-geographical block in constant reformulation. With the conquest of settlement projects and the organization of camps, MST constitutes a rural solidarity network that fights for land while strengthens its territoriality in southeast Pará. At the same time, it uses the policy of scales which enables its performance at various scalar levels further becoming a mechanism for the socio-territorial movement. This movement combined with other national and international activities, redefines public policies and creates other movements more suited to the interests of the sub-alternate classes of the field, with emphasis on PRONERA. In this context, MST extends its figth for survival on Earth, with the production of another project of divergent territorial development of agricultural and mineral, analyzed, here, as contra-hegemony, mainly guided on the landproduction-education tripod. To this end, in addition to the conquest of territory, the constitution of an active consensus is sought from the sub-alternate class, whose emancipation passes through the division with the system of dominant values and consequent reappropriation of private appliances of hegemony, allowing collective construction of education on countryside and agroecology between socio-territorialist and trade union movements, the settled and the camped, University (UNIFESSPA), Federal Institute (IFPA Rural Campus), and the Amazon Iala.
\end{abstract}

Keywords: territory, MST, Socio-territorial Movement, contra-hegemony, Amazon, southeast para. 


\section{RÉSUMÉ}

La territorilisation du Mouvement des Sans Terre au le Sudeste du Pará se developpe á la fin des années 1980 et s'intensifique durant les annés de 1990. En ce sens, l'objetif général de notre recherche est dánalyser les formes de territorialisation contre-hégémoniques conduites par le MST, a partir de l'organisation des projets d'instalation au sudeste du Pará, ayanr comme référence localisée les Projets d’instalations conquis par ce mouvement socioterritorial durant la période 1994 á 2016. Avec cet objectif, nous utilisons comme procédures métodologiques la recherche bibliographique et documentaire, l'observation systématique, l'entretien semi-structurée, questionaires, registres photografiques et production d'une cartographie tematique. Comme référenciel theorique, nous nous basons principalement des écrits de Cramsci pour comprendre le concept d'hégemonie et pour la formulation de ce que nous apelons de territoire contre-hégemonique des mouvements socioterritoriaux de l'espace agraire du sudeste du Pará avec atention espéciale au MST. Dans un premier temps, le MST agit á la lutte pour la terre en utilisant principalement comme tactique, l'occupation des terres qui se tradiiuit d'abord en campements et, ceux-ci ensuite á partir des «projets d'installation»; ce procédé n'évolue pas de forme lineaire mais de forme graduelle, conflictive et, dans beaucoup de cas, termine par la manutention et/ou expansion du territoire du capital agraire et mineral de la région atravers les reintegrations de possession, les expropriations ou expulsions violentes qui contribuent á la desterritorialisation des petits paysans. En même temps, le mouvement socio-territotial organise une serie de manifestations avec ou non d'autres mouvements syndicaux en particuler la Fetagri; ceci permet la constitution d'alliances territoriales, mobilisées en temps-espaces spécifiques ou plus durables et permet d'établir un bloc historico geographique ouvert, agil et en constant renouvellement. Avec la conquête des Projets d'installation et l'organisation des campements, le MST maintient un réseau paysan geographique e solidaire de la lutte por la terre qui fortifie sa territorialité au sudeste du Pará; en même temps aussi il utilise une politique d'échelle qui permet d'agir á des niveaux supérieurs pour devenir un instrument pour que le mouvement socio-territorial joint á d'autres mouvements nationaux ou même internationaus redéfine politiques publiques ou les renouvelle plus adaptées aux interets des petits paysans com par exemple le Pronera. Dans ce sens, le MST amplie sa lutte pour la terre non seulement pour sa permanence dans cette terre mais aussi pour un nouveau projet de developpement territorial, divergent de l'agro-minéral, contre-hégémonique: ce projet est basé sur le trépied terreproduction-éduc. A cet effet, en plus de la conquête du territoire, il y a la recherche permanente de constitution d'un consensus atif originaire de la classe paysanne dont l'émancipation supére la simple rupture avec le système des valeurs dominantes et la conséquante re-appropriation des appareils privatisés de hégemonie, por permettre une contruction colective de l'Éducation Paysanne, de l'Agroecologie dans les mouvements socioterritoriaux e syndicaux, des «installés » et des «sous campement», de 1'Université UNIFESSPA, de I'Institut Technique IFPA-campus rural de Marabá e du IALA Amazonique.

Mots-clefs: Territoire, MST, Mouvements socioterritoriaux, Contre-hegémonie, Amazonie, Sudeste du Pará. 


\section{LISTA DE SIGLAS}

AMZA

ASTRARURAL Associação dos Trabalhadores Rurais de Novo Horizonte

APROCTRAM

ASPRAM

AMORA

APROCNOB

ASPCTRA

ASPROCFAC

APROCAN

APROCALS

APROTERRA

ASPRUPAM

APROCPAR

ASSOPAR

APROFAP

ATP

ATR

BASA

CAT

CPT

CEBs

CIMI

CNBB

CVRD

COOPERPRAM

COOPALMAS

COOPCAL

CUT

CSN

CONTAG

DECA

EFC

FATA

FECAT

FETAGRI

FETRAF

FHC
Associação de Produção e Comercialização dos Trabalhadores Rurais do Assentamento $1^{\circ}$ de Março

Associação dos Produtores Rurais do Assentamento $1^{\circ}$ de Março

Associação de Mulheres Organizadas na Reforma Agrária

Associação dos Trabalhadores Rurais da Vila Onalício Barros

Associação de Produção e Comercialização do PA 17 de Abril

Associação de Produção e Comercialização das Famílias dos Trabalhadores Rurais do Projeto de Assentamento Canudos

Associação de Produção e Comercialização do Assentamento Canudos

Associação de Produção e Comercialização do Assentamento Lourival Santana

Associação dos Trabalhadores Rurais do Assentamento 26 de Março

Associação dos Pequenos Produtores Rurais do Assentamento 26 de Março

Associação de Produção e Comercialização dos Trabalhadores Rurais do Assentamento Palmares

Associação Rural de Reivindicação de Créditos

Associação dos Produtores Familiares de Palmares

Associação Terra e Paz

Associação dos Trabalhadores Agroextrativistas da

Reserva de Mata

Grande

Banco da Amazônia S.A

Centro Agroambiental do Tocantins

Comissão Pastoral da Terra

Comunidades Eclesiais de Base

Conselho Indigenista Missionário

Conferência Nacional dos Bispos do Brasil

Companhia Vale do Rio Doce

Cooperativa de Produtores Rurais do Assentamento $1^{\circ}$ de Março

Cooperativa Mista de Transporte e Turismo dos Condutores Automotivos de Veículos Utilitários do Assentamento Palmares do Município de Parauapebas

Cooperativa Agromineral de Produção e Comercialização do Assentamento Nega Madalena

Central Única dos Trabalhadores

Conselho de Segurança Nacional

Confederação Nacional dos Trabalhadores na Agricultura

Delegacia de Conflitos Agrários

Estrada de Ferro Carajás

Fundação Agrária do Tocantins-Araguaia

Federação de Cooperativas Araguaia-Tocantins

Federação de Trabalhadores da Agricultura

Federação Nacional dos Trabalhadores e Trabalhadoras na Agricultura Familiar

Fernando Henrique Cardoso 


\begin{tabular}{|c|c|}
\hline FUNAI & Fundação Nacional do Índio \\
\hline GETAT & Grupo Executivo de Terras do Araguaia-Tocantins \\
\hline IBGE & Instituto Brasileiro de Geografia e Estatística \\
\hline INCRA & Instituto Nacional de Colonização e Reforma Agrária \\
\hline IFPA & Instituto Federal do Pará \\
\hline ITERPA & Instituto de Terras do Pará \\
\hline LASAT & Laboratório Sócio-Agronômico do Tocantins \\
\hline LERASSP & Laboratório de Estudos Regionais e Agrários do Pará \\
\hline LCP & Liga dos Camponeses Pobres \\
\hline MAB & Movimento de Atingidos por Barragem \\
\hline MDA & Ministério do Desenvolvimento Agrário \\
\hline MIRAD & Ministério da Reforma Agrária e do Desenvolvimento \\
\hline MPA & Movimento de Pequenos Agricultores \\
\hline MST & Movimentos dos Trabalhadores Rurais Sem Terra \\
\hline MTST & Movimento Tucuruiense Sem Terra \\
\hline OI & Organização Independente \\
\hline OTC & Organização dos Trabalhadores no Campo \\
\hline PAs & Projetos de Assentamentos \\
\hline $\mathrm{PC}$ & Polícia Civil \\
\hline PM & Polícia Militar \\
\hline PMM & Prefeitura Municipal de Marabá \\
\hline $\mathrm{PF}$ & Polícia Federal \\
\hline PT & Partido dos Trabalhadores \\
\hline PGC & Programa Grande Carajás \\
\hline PFC & Projeto Ferro Carajás \\
\hline PNRA & Programa Nacional de Reforma Agrária \\
\hline PROCERA & Programa de Crédito Especial para a Reforma Agrária \\
\hline PRONAF & Programa Nacional de Fortalecimento da Agricultura Familiar \\
\hline PRONERA & Programa Nacional de Educação na Reforma Agrária \\
\hline PSOL & Partido Socialismo e Liberdade \\
\hline SCA & Sistema Cooperativista dos Assentados \\
\hline SIPRA & Sistema de Informações de Projetos de Reforma Agrária \\
\hline SPI & Serviço de Proteção ao Índio \\
\hline STR & Sindicato dos Trabalhadores Rurais \\
\hline SPVEA & Superintendência do Plano de Valorização Econômica da Amazônia \\
\hline SUDAM & Superintendência do Desenvolvimento da Amazônia \\
\hline SUFRAMA & Superintendência do Desenvolvimento da Zona Franca de Manaus \\
\hline UDN & União Democrática Ruralista \\
\hline UFPA & Universidade Federal do Pará \\
\hline UNIFESSPA & Universidade Federal do Sul e Sudeste do Pará \\
\hline UHT & Usina Hidrelétrica de Tucuruí \\
\hline
\end{tabular}




\section{LISTA DE FIGURAS}

Figura 1 - Figura da Capa - Arte pintada na parede da biblioteca "José Saramargo" no PA 17 de Abril, Eldorado dos Carajás, 2016......................................................................... 1

Figura 2 - Burgo do Itacaiúnas, onde emergrem as disputas pelos territórios...................... 87

Figura 3 - Região dos castanhais do Médio-Tocantins-Pará (1948-1980)........................... 98

Figura 4 - Ocupação indígena antes da economia da borracha e da castanha no sudeste do Pará 101

Figura 5 - Área dos castanhais e de exploração de minérios no sudeste paraense, 19501980. 104

Figura 6 - Estrutura fundiária do "Polígono dos Castanhais" na década de 1980.

Figura 7 - Terras Indígenas no Sudeste do Pará. 118

Figura 8 - Plebiscito por eleições diretas para direção escolar em Palmares II, 2017 297

\section{LISTA DE FOTOS}

Foto 1 - Trabalho escolar na biblioteca "José Saramargo" no PA 17 de Abril 22

Foto 2 - Acampamento nacional da juventude sem terra Oziel Alves Pereira, em Eldorado dos Carajás em 2016. 42

Foto 3 - Acampamento Hugo Chavez. 141

Foto 4 - Assentamento 26 de Março. 141

Foto 5 - Entrada da fazenda do grupo Revemar, que trabalha com concessionárias de automóveis na cidade de Marabá-PA 148

Foto 6 - Entrada da empresa agropecuária JBS, no município de Tucumã-PA 150

Foto 7 - Entrada da usina siderúrgica Sinobras no município de Marabá-PA. 150

Foto 8 - Entrada da Unidade Operacional Onça Puma da VALE no município de Ourilândia do Norte-PA

Foto 9 - Mina da Serra de Carajás, local de extração do minério de ferro 151

Foto 10 - Estrada de Ferro Carajás carregada de minério de ferro 151

Foto 11 - Casa improvisada, acampamento Helenira Resende, Marabá-PA 173

Foto 12 - Moradias precárias, acampamento Roseli Nunes, Tucumã-PA

Foto 13 - A cerca que antes era uma barreira hoje foi rompida para dar lugar ao acampamento Helenira Resende - Marabá/PA 
Foto 14 - Interior da residência de uma das acampadas do acampamento Reseli Nunes, em Tucumã-PA.

Foto 15 - Encontro da Via Campesina na Curva do S em Eldorado dos Carajás, 2016. ...... 213

Foto 16 - Monumento em homenagem aos dezenove sem terra mortos no massacre de

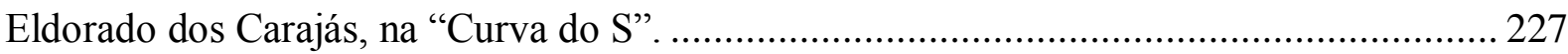

Foto 17 - Cruzes simbolizando o local do massacre na "Curva do $\mathrm{S}$ "................................. 229

Foto 18 - Canteiro de obras da duplicação da EFC....................................................... 238

Foto 19 - Tratores redefinindo a paisagem do assentamento para a duplicação da EFC. ..... 238

Foto 20 - Reintegração de posse da Fazenda Cabaceiras no ano de 1999............................ 246

Foto 21 - Ação violenta da Policia Militar no despejo da Fazenda Cabeiras, 1999. ............ 247

Foto 22 - Marcha para a ocupação da Fazenda Peruano, 2004........................................ 252

Foto 23 - Ocupação da Fazenda Peruano, 2004.......................................................... 252

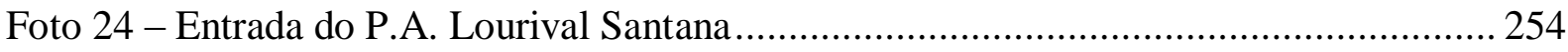

Foto 25 - Área de produção de cacau dos assentados. ..................................................... 258

Foto 26 - Extração de ouro em um dos lotes do P.A. Nega Madalena. ................................ 260

Foto 27 - Solo revirado devido ao garimpo no P.A. Nega Madalena. ............................... 261

Foto 28 - Acampamento Hugo Chavez em Marabá, 2015 ............................................... 270

Foto 29 - Assentamento Palmares II em Parauapebas, EMEF Crescendo na Prática, 2015. 270

Foto 30 - Ocupação da EMEFM “Crescendo na Prática” e obstrução da estrada, 2017....... 296

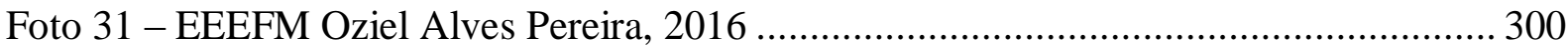

Foto 32 - Salão de reunião e aulas do IALA Amazônico ................................................... 337

Foto 33 - Horta mandala do IALA Amazônico ...................................................................... 340

\section{LISTA DE GRÁFICOS}

Gráfico 1 - Ocupações de terra no sudeste paraense, 1988 a 2015................................... 162

Gráfico 2 - Acampamentos no sudeste paraense - 2002 a 2015........................................ 168

Gráfico 3 - Origem dos acampados nos acampamentos organizados pelo MST no sudeste

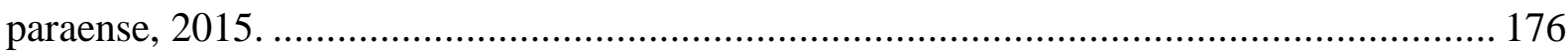

Gráfico 4 - Profissões exercidas anteriormente pelos acampados, 2015. ......................... 177

Gráfico 5 - Acampados que trabalham fora do acampamento - 2015 .............................. 178

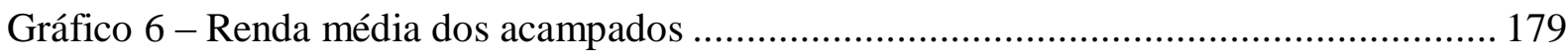

Gráfico 7 - Renda proveniente de programa social ou aposentadoria/benefício. ................. 180

Gráfico 8 - Acampados que desenvolvem cultivos e criações........................................... 180 
Gráfico 9 - Número de PAs criados por ano no sudeste paraense - 1987-2016.................. 192

Gráfico 10 - Trajetória geográfica dos assentados..................................................... 202

Gráfico 11 - Profissões exercidas antes de serem assentados.......................................... 203

Gráfico 12 - Participação na ocupação da terra e no período do acampamento................... 204

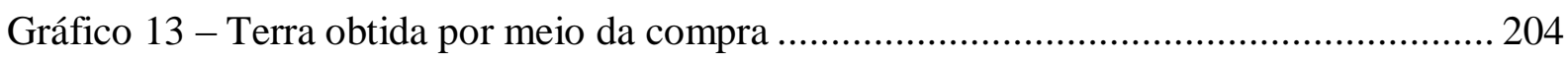

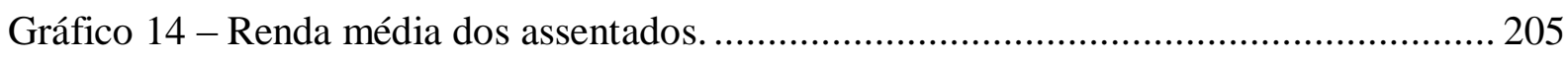

Gráfico 15 - Cultivos desenvolvidos pelos assentados. .............................................. 206

Gráfico 16 - Criações desenvolvidas pelos assentados. .................................................. 206

Gráfico 17 - Número de contratos do Pronaf para pecuária e agricultura no sudeste paraense,

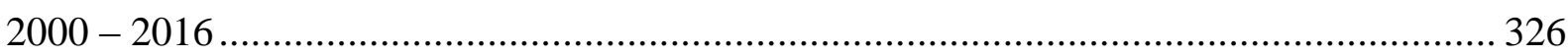

Gráfico 18 - Valor $(\mathrm{R} \$)$ dos créditos do Pronaf para pecuária e agricultura no sudeste paraense, $2000-2016$.

\section{LISTA DE MAPAS}

Mapa 1 - Área de atuação do GETAT, 1980-1987......................................................... 111

Mapa 2 - Estrutura fundiária do antigo "Polígono dos Castanhais", 2016......................... 128

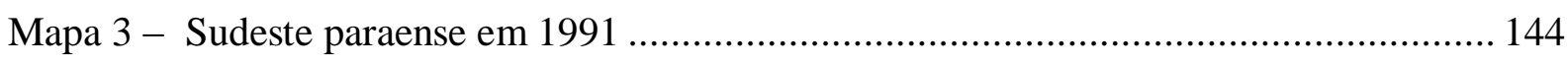

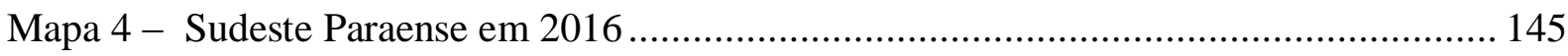

Mapa 5 - Eixo Agropecuário e Mineral - Sudeste Paraense, 2016................................. 149

Mapa 6 - Áreas em conflito no sudeste paraense, 2006 - 2015...................................... 155

Mapa 7 - Ocupações de terra no sudeste paraense, 1988 a 2015 ..................................... 164

Mapa 8 - Acampamentos organizados por movimentos sociais e sindicais no sudeste

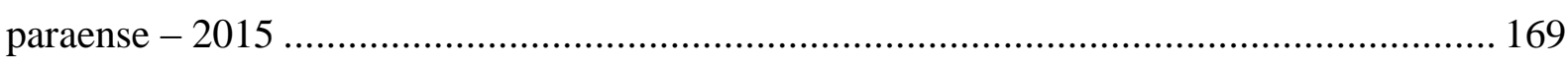

Mapa 9 - Acampamentos organizados pelo MST - Sudeste Paraense, 2015..................... 171

Mapa 10 - Assentamentos organizados pelo MST - Sudeste Paraense, 2016.................... 195

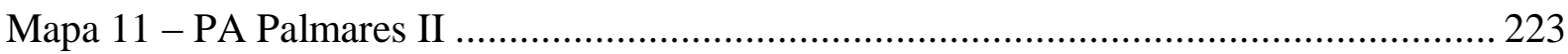

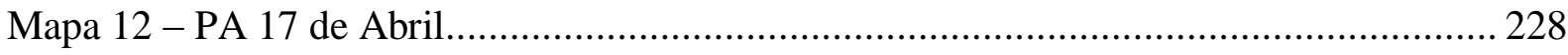

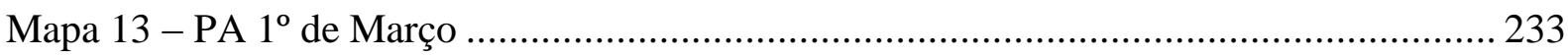

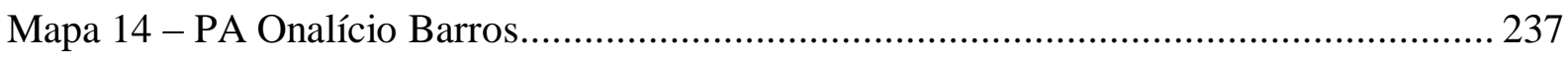

Mapa 15 - PA Cabanos ......................................................................................... 242

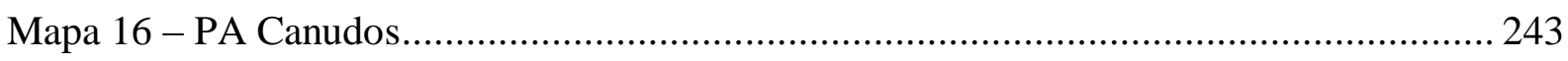

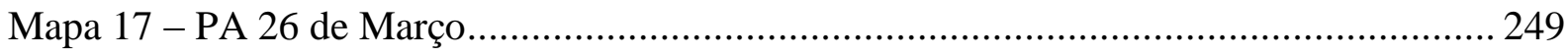

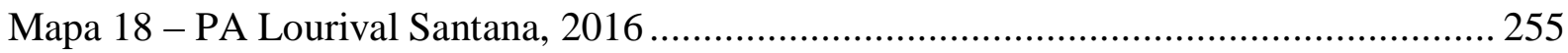


Mapa 19 - PA Nega Madalena, 2016.

Mapa 20 - Número de contratos para agricultura e pecuária no sudeste paraense, 20002016.

\section{LISTA DE PRANCHAS}

Prancha 1 - Evolução territorial do sudeste paraense - 1872-1970 143

\section{LISTA DE QUADROS}

Quadro 1 - Impacto dos Grandes Projetos nas terras indígenas na sub-região sudeste do estado do Pará.

Quadro 2 - Formação territorial do sudeste paraense e disputas territoriais por hegemonia.138

Quadro 3 - Formas acampamentos organizadas pelo MST no sudeste paraense - 2015 .... 183 Quadro 4 - Acampamentos implementados a partir da organização do MST no sudeste paraense, 2015 186

Quadro 5 - Principais contradições e conflitos nos projetos de assentamento organizados pelo MST no sudeste paraense 200

Quadro 6 - Formas assentamento organizadas pelo MST no sudeste paraense - 2016 ....... 208 Quadro 7 - Assentamentos implementados a partir da organização do MST no sudeste

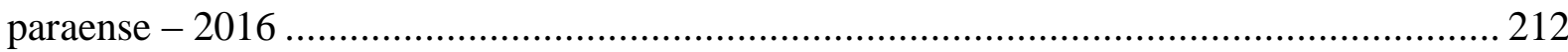

Quadro 8 - Cursos e projetos ofertados pelo PRONERA no estado do Pará, 2001-2011 ..... 287 Quadro 9 - Espacialização das Estações Conhecimento da Fundação Vale no Pará, 2016 .. 299 Quadro 10 - Disputas territoriais no âmbito da educação nos assentamentos organizados pelo

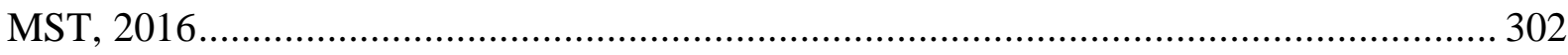

Quadro 11 - Principais formas de cooperação agrícola.................................................. 308

Quadro 12 - Relação de cooperativas e associações nos PAs organizados pelo MST.......... 322

Quadro 13 - Territorialização contra-hegemônica do MST no sudeste paraense 343

\section{LISTA DE TABELAS}

Tabela 1 - Estrutura fundiária do estado do Pará e de suas mesorregiões, 2006.

Tabela 2 - Áreas em conflito no Pará e no sudeste paraense, 2006-2015. 
Tabela 3 - Número de ocupações no estado do Pará, sudeste paraense e suas microrregiões 1988 a 2015

Tabela 4 - Movimentos sociais e sindicais envolvidos na organização das ocupações de terra no sudeste paraense - 1989 a 2015

Tabela 5 - Número de acampamentos no estado do Pará, sudeste paraense e suas microrregiões - 2002 a 2015

Tabela 6 - Movimentos sociais e sindicais envolvidos na construção do acampamento no sudeste paraense, 2002 a 2015

Tabela 7 - Número de assentamentos por microrregião do sudeste paraense e o percentual ocupado pelo território - 2016

Tabela 8 - Financiamentos PRONAF e PROCERA para agricultura e pecuária nos PAs pesquisados, 2016

\section{LISTA DE ORGANOGRAMAS}

Organograma 1 - Estrutura organizativa do Assentamento 26 de Março. 250

Organograma 2 - Processo de construção da territorialidade do MST por assentamentos e acampamentos no sudeste paraense, 1994-2016 264

Organograma 3 - Rede de comercialização do gado de corte e de leite no sudeste paraense 325 


\section{SUMÁRIO}

INTRODUÇÃO 22

1. TERRITÓRIOS EM DISPUTA: HEGEMONIA DO CAPITAL E CONTRAHEGEMONIA DOS MOVIMENTOS SOCIAIS …………........................................... 42

1.1. Formação Econômico-Social (FES) e sua dimensão geográfica ....................................... 44

1.2. Conceito de hegemonia e as contribuições gramscianas ...............................................57

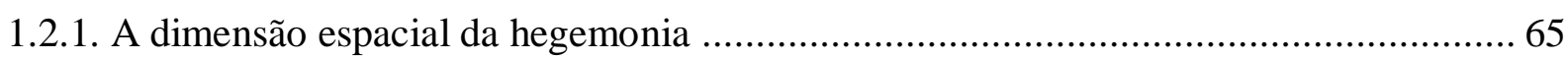

1.2.2. Contra-Hegemonia e movimentos sociais (o novo moderno príncipe?) ……………..... 69

1.2.3. Da escala geográfica à política de escala.................................................................. 70

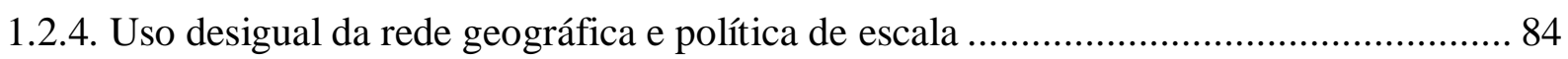

2. O SUDESTE PARAENSE E A DIMENSÃO TERRITORIAL DA FRONTEIRA ….. 87

2.1. Formação territorial do sudeste paraense: acumulação desigual de tempos e espaços ..... 90

2.1.1. Disputas territoriais pela forma de apropriação da natureza: território comunal/coletivo

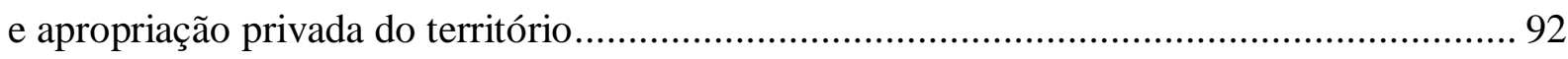

2.1.2. Das terras livres ao monopólio dos recursos da natureza .............................................. 95

2.1.3. Redefinição da hegemonia regional e inserção de novos sujeitos ............................... 106

2.2. A organização da luta posseira no sudeste paraense .................................................... 120

2.3. Da luta dos posseiros à organização do MST ........................................................... 129

2.4. Luta camponesa, movimentos sociais e dinâmica da fronteira ....................................... 135

3. ESTRATÉGIAS CONTRA-HEGEMÔNICAS DO MOVIMENTO DOS TRABALHADORES RURAIS SEM TERRA (MST) NO SUDESTE PARAENSE ..... 141

3.1. O território do sudeste paraense no contexto atual ................................................... 142

3.2. Formas de organização do MST e construção de um território contra-hegemônico ...... 156

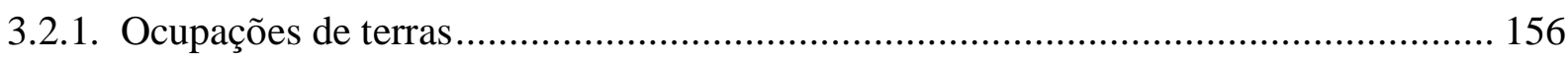

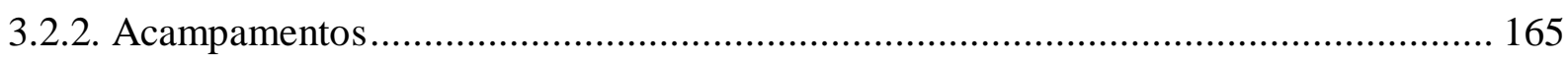

3.2.3. Adentrando nos espaços de resistência de construção de uma contra-hegemonia ...... 170

3.3. Adentrando nos assentamentos: da luta pela terra à luta pela permanência na terra. ..... 187

4. CONSTRUÇÃo TERRITORIAL DA REDE GEOGRÁFICA SOLIDÁRIA CAMPONESA DE LUTA PELA TERRA NO SUDESTE PARAENSE …………......... 213

4.1. Territorialização do MST a partir dos assentamentos ..................................................... 214

4.1.1. Projeto de Assentamento Palmares II................................................................ 217

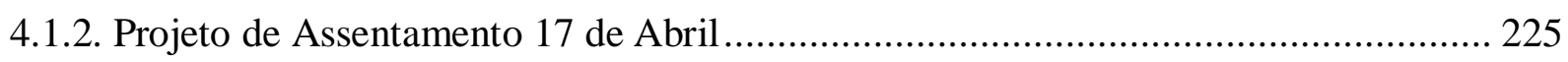

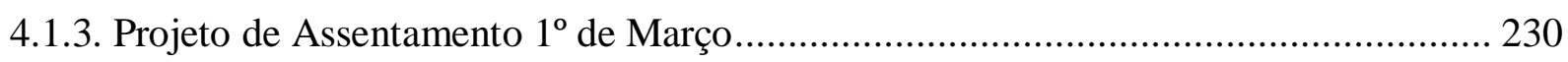




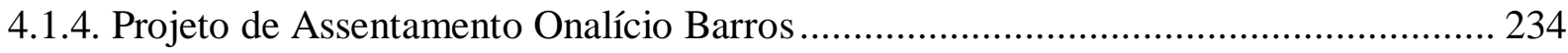

4.1.5. Projetos de Assentamento Cabanos e Canudos ...................................................... 239

4.1.6. Projeto de Assentamento 26 de Março ..................................................................... 244

4.1.7. Projeto de Assentamento Lourival Santana ...................................................... 251

4.1.8. Projeto de Assentamento Nega Madalena .............................................................. 256

5. TERRITORIALIZAÇÃO CONTRA-HEGEMÔNICA DO MST NO SUDESTE PARAENSE A PARTIR DA REAPROPRIAÇÃO DOS APARELHOS PRIVADOS DE

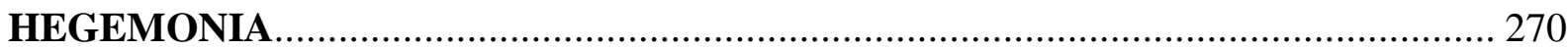

5.1. A Escola nos assentamentos e o projeto da educação do campo emancipatória ............ 273

5.2. A agroecologia como unidade da educação e da luta pela/na terra .............................. 305

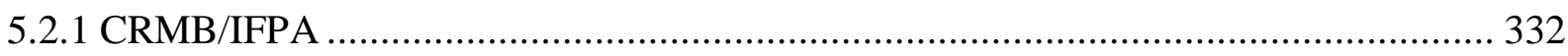

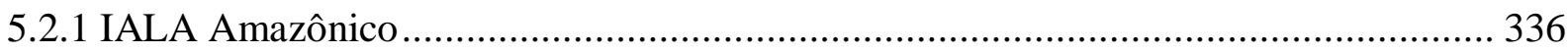

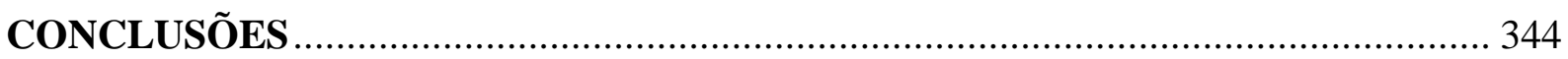

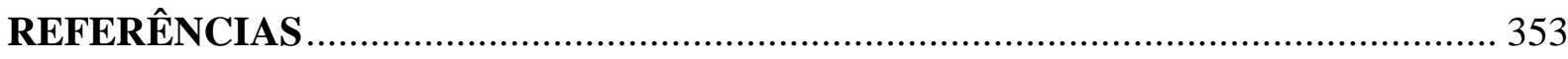

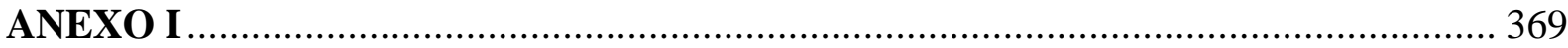

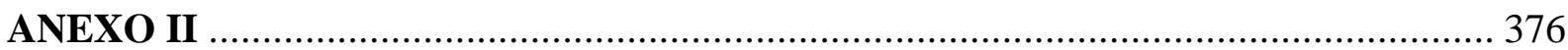




\section{INTRODUÇÃO}

Foto 1 - Trabalho escolar na biblioteca "José Saramargo" no PA 17 de Abril

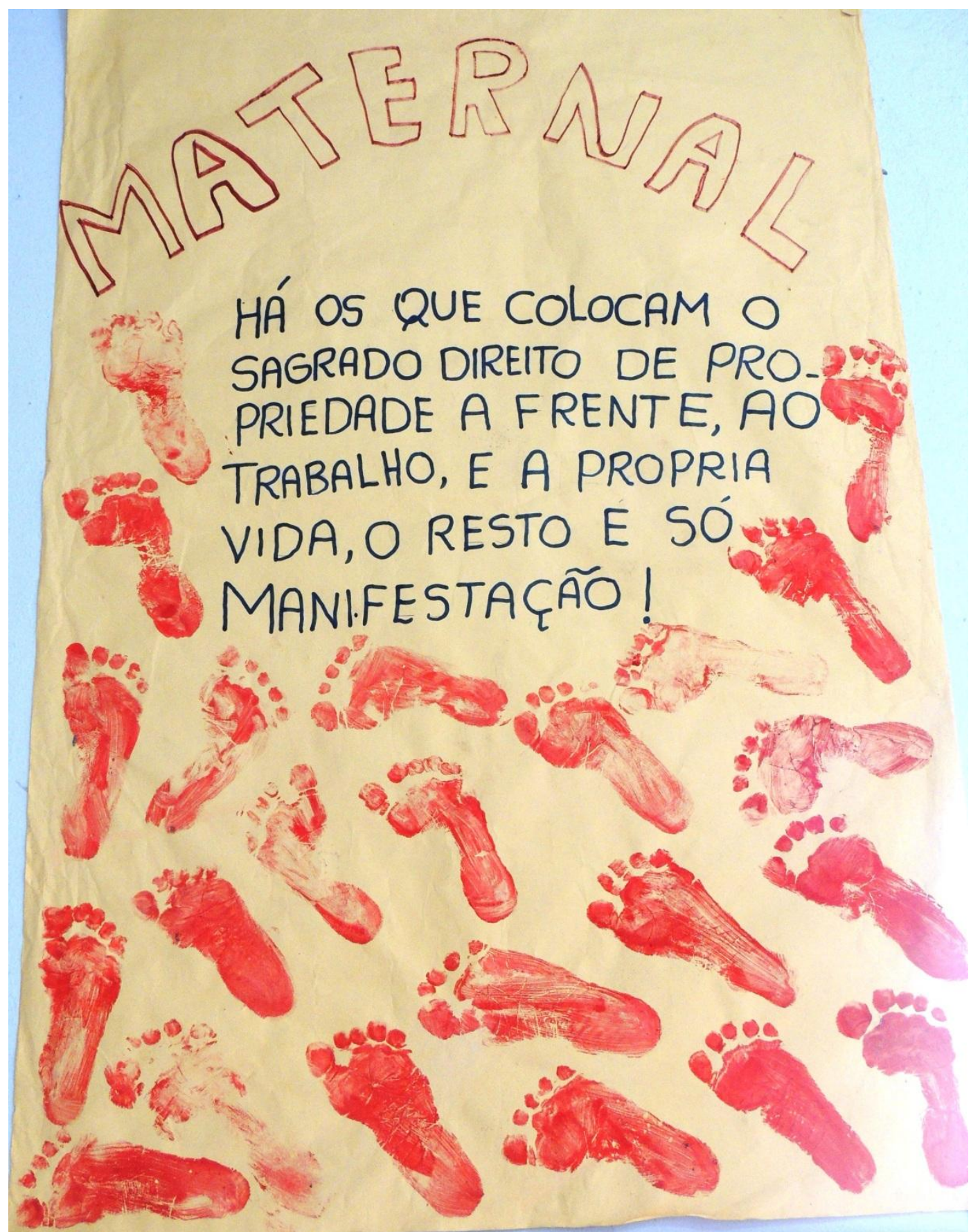

Fonte: Rogério Rego Miranda, Eldorado dos Carajás, 2016.

arame é uma peste! As entranhas da terra, Cansadas de serem violadas Pelo discurso

Pelo vácuo dos arames, Estão abertas! E lá sangra grito dos despossuídos E a mão camponesa acena Sua hora! [...] Charles Trocate, 2002. 
O sudeste paraense na Amazônia é historicamente marcado por diversos conflitos territoriais envolvendo indígenas, castanheiros, fazendeiros, grileiros, garimpeiros, posseiros, sem-terra, empresas mineradoras, dentre outros, o que confere à mesorregião em questão a condição de uma das áreas mais conflituosas do Brasil, visto a grande concentração de terras existente e a massa de trabalhadores do campo que lutam para mudar esse quadro social, como bem assevera a epígrafe supracitada do militante e poeta Charles Trocate.

Nessas disputas por território participam diversos movimentos sociais, como quilombolas, indígenas, posseiros que integram a FETAGRI (Federação de Trabalhadores da Agricultura) ou a FETRAF (Federação Nacional dos Trabalhadores e Trabalhadoras na Agricultura Familiar) e sem-terra que participam do MST (Movimento dos Trabalhadores Rurais Sem Terra).

Como a realidade do sudeste paraense é diversa em termos de movimentos sociais, em virtude da desterritorialização de povos e comunidades tradicionais provocadas pela intensa atuação de empresas agropecuárias e mineradoras, além de empreendimentos estatais, como hidrelétricas, que concorrem para o aparecimento do MAB (Movimento dos Atingidos por Barragem), em nosso estudo tivemos de realizar a seleção de um movimento social que estivesse de acordo com nossos propósitos de pesquisa e em consonância com os estudos que já havíamos realizado em outras realidades, a saber, o nordeste paraense; neste estudo, refletimos sobre o impacto das políticas públicas na reprodução camponesa e as metamorfoses da relação entre o rural e o urbano na dinâmica camponesa, em colônias agrícolas provenientes do final do século XIX.

Em nossas pesquisas, o campesinato ganha centralidade devido a sua presença marcante na realidade amazônica em suas múltiplas manifestações, salvaguardando suas especificidades geográficas. E estas são importantes para mostrar as diversas formas de lutas empreendidas por esses sujeitos em virtude das condições materiais de sua reprodução. Isso porque no nordeste paraense observamos um processo de colonização que primou por um modelo de modernização espacial que tinha como pressuposto a pequena propriedade, ou seja, a agricultura desenvolvida em lotes de, geralmente, 25 hectares, e praticada por agricultores que, em sua maior margem, eram nordestinos oriundos do Maranhão e do Ceará, muito embora o governo incentivasse sobremaneira a migração europeia - por isso alguns focos de migrantes franceses, italianos, dentre outros. Essa formação territorial possibilitou ao nordeste paraense apresentar ainda hoje uma das menores concentrações de terras do Pará, apesar de esse quadro atualmente passar por sérias transformações decorrentes da entrada de grandes empresas do setor de mineração, como o grupo Votorantim, de frigoríficos, como o Mercúrio, 
e do agronegócio, para a exploração do dendê (Vale) e da pecuária, o que levou a um processo de expropriação dos pequenos produtores ou a uma relação de dependência dos camponeses.

Ao iniciarmos, no ano de 2010, os estudos no sudeste paraense, por conta da atividade docente na Universidade Federal do Sul e Sudeste do Pará (UNIFESSPA), observamos que, diferentemente da realidade estudada outrora, esta é grafada pela elevada concentração de terras e pelos conflitos pela terra, elementos também presentes em outras realidades paraenses, mas que nesta mesorregião ganham uma extensão territorial maior e envolvem um grau mais elevado de conflito, de acordo com os dados da CPT (Comissão Pastoral da Terra) (CPT, 2015) e da Rede Dataluta (Banco de Dados da Luta pela Terra) (DATALUTA, 2016), isto porque a sua colonização, iniciada no século XIX, já priorizou a apropriação privada de grandes áreas para a reprodução do capital mercantil e, hoje, também financeiro, com a entrada de empresas mineradoras e do agronegócio, desterritorializando indígenas, posseiros, ribeirinhos, trabalhadores rurais que vinham trabalhar nos grandes projetos etc. Essa massa de expropriados vai desenvolver estratégias para lutar pelos seus territórios, ganhando força ao se organizar em movimentos sociais e sindicatos a partir da década de 1970 e 1980, levando a criação de assentamentos que são relativamente recentes, sendo os primeiros datados do final da década de 1980, segundo o INCRA (Instituto Nacional de Colonização e Reforma Agrária).

Como nossa pesquisa atual almeja estudar os movimentos sociais de luta pela terra e sua organização, para propor outro projeto territorial de sociedade, ou seja, outra hegemonia, o Movimento dos Trabalhadores Rurais Sem Terra (MST) se tornou o nosso objeto de estudo, pois historicamente realiza alianças e ações que puderam alicerçar a luta pela terra no Brasil e no Pará, com destaque ao sudeste paraense.

Segundo Rocha (2015), a formação do MST no Pará apresenta quatro momentos importantes. O primeiro se refere ao período entre 1984 e 1990, no qual o MST, ainda muito incipiente no estado, buscou apoio local na CUT (Central Única dos Trabalhadores) em Belém, mas logo se interiorizou no sul do Pará (Xinguara), onde tentou ocupar algumas fazendas, como a Ingá, em Conceição do Araguaia, porém sem efeitos positivos devido à falta de experiência dos militantes, à falta de apoio das entidades regionais e à repressão por parte dos latifundiários e da polícia.

No segundo momento (1990-1996), o MST vai se apropriar da luta histórica dos posseiros, que se organizavam individualmente e com base no tripé homem-arma-lote, para desenvolver outras estratégias de atuação territorial, que tinham por premissa tomar decisões compartilhadas com as famílias acampadas, entrar em conflito com o aparato institucional, 
por meio de ocupações de prédios públicos, especialmente o INCRA, e construir a organicidade mediante a formação política de militantes. Nessa época, a coordenação migra para Marabá, por lá encontrar mais apoio de outros segmentos de luta social e um número maior de pessoas sem-terra. Com essas medidas, o movimento realiza a ocupação de fazendas consideradas griladas, devolutas ou improdutivas: entre as primeiras está a ocupação da Rio Branco, que resultou na criação dos assentamentos Rio Branco, Palmares I e Palmares II. No entanto, a ocupação que ganhou maior repercussão foi a da Fazenda Macaxeira, por ter resultado no episódio conhecido como "Massacre de Eldorado de Carajás" (ROCHA, 2015).

O terceiro momento (1996- 2000) corresponde ao de estadualização do MST, que amplia suas bases territoriais para o nordeste paraense, criando um escritório político em Belém (Secretaria da Regional Belém) e iniciando ocupações de terras nessa sub-região, como a Fazenda Bacuri/Tanay em Castanhal, em 1998, posteriormente assentamento João Batista II; a Fazenda TABA, em Mosqueiro (distrito da capital paraense), no ano de 1999. Daí em diante foram feitas várias outras ocupações de áreas que vieram a se tornar assentamentos, inclusive em outras sub-regiões, como baixo Tocantins e sudeste paraense.

No quarto momento (2000-2009), houve a consolidação de alianças internas com a CPT, os STRs (Sindicatos de Trabalhadores Rurais), alguns partidos políticos como PT (Partido dos Trabalhadores) e PSOL (Partido Socialismo e Liberdade), e estabeleceram-se outras novas alianças com movimentos indígenas, quilombolas, ribeirinhos, de forma a possibilitar o aparecimento de um bloco histórico camponês. O movimento atuou em outras escalas geográficas, até mesmo internacionais, em virtude da ação conjunta com a VIA CAMPESINA; também fortaleceram-se parcerias com universidades, a exemplo da UFPA (Universidade Federal do Pará) e da UNIFESSPA (Universidade Federal do Sul e Sudeste do Pará) por meio de formação dos militantes e assentados (ROCHA, 2015).

Como podemos observar, o MST corresponde a um dos movimentos que mais têm ganhado força nos últimos anos - seja no Brasil, seja no sudeste paraense -, pois além de propor formas organizativas diferenciadas quanto à organização da luta pela terra, idealiza elementos novos quanto à produção voltada para a agroecologia em contraposição ao agronegócio; a educação baseada em uma pedagogia pautada na educação do campo, divergindo de uma mais vinculada ao mercado e à cidade; a organicidade como mecanismo de resolução de problemas ou de tomadas de decisão, o que, em outras palavras:

[...] indica no Movimento o processo através do qual uma determinada ideia ou tomada de decisão consegue percorrer de forma ágil e sincronizada o conjunto das instâncias que constituem a organização, desde o núcleo de base de cada acampamento e assentamento até a direção nacional do MST, 
em uma combinação permanente de movimentos ascendentes e descendentes capazes de garantir a participação efetiva de todos na condução da luta em suas diversas dimensões. (CALDART, 2000, p. 162 grifado no original)

Por fim, o MST propõe uma reforma agrária mais ampla e radical em que não se busca unicamente a posse da terra, mas as condições de viver nela, visto que a primeira luta é pela conquista da terra e a segunda é pela permanência nela.

Com efeito, o MST apresenta elementos interessantes em termos de outro projeto hegemônico. Gramsci (2014) entendia que a hegemonia apresentava duas componentes importantes, o "domínio" e a "direção":

A supremacia de um grupo social se manifesta de duas maneiras, como "domínio" e como "direção intelectual e moral". Um grupo social é dominante dos grupos adversários que tende a "liquidar" ou submeter, mesmo que com a força armada, e é dirigente dos grupos afins e aliados. Um grupo social pode e deve ser dirigente já antes de conquistar o poder governativo (esta é uma das condições principais para a própria conquista do poder); depois, quando exercita o poder e na medida em que o mantém fortemente em sua mão, torna-se dominante, mas deve continuar sendo “dirigente". (GRAMSCI, 2014, p. 62-63)

O conceito de hegemonia de Gramsci foi cunhado a partir dos pressupostos de Lênin e, por esse motivo, com ele terá algumas similaridades teóricas. Inicialmente se deve sublinhar a íntima relação entre teoria e prática, teoria e ação política. Pauta-se na tese de que a superação das contradições de classe corresponde à superação das contradições filosóficas, que se referem, no plano ideológico, à expressão de contradições sociais não solucionadas por meio especulativo, apenas através da revolução. Essa unidade entre teoria e prática faz da política a real filosofia, pois não é apenas analítica, e sim revolucionária, por meio de sua ação. Essa práxis permite a Gramsci afirmar que a teoria e o desenvolvimento da hegemonia do proletariado, fazendo alusão à ditadura do proletariado de Lênin, apresenta um caráter filosófico, visto que essa hegemonia compreenderia a transformação, a edificação de uma outra sociedade em suas múltiplas dimensões da realidade. Logo, a revolução é econômica e política, mas igualmente intelectual e moral, aproximando-se da ideia de revolução cultural de Lênin. Com efeito, o conceito de hegemonia de Gramsci possui uma grande amplitude, indo de uma estrutura econômico-política até o modo de pensar a ideologia e o conhecimento dos sujeitos (GRUPPI, 1978).

Lênin trabalhou com a noção de hegemonia, ainda que não use o termo, ao discutir sobre a ditadura do proletariado, que corresponde à direção de um determinado tipo de alianças. No bojo do debate sobre o apoio ou não à democracia burguesa, Lênin esboça a ideia de que seria necessário o avanço da revolução democrática, que embora mais benéfica à 
burguesia, ampliaria as liberdades políticas do proletariado, possibilitando construir suas lutas, e seria nesse contexto que as massas identificariam que a democracia ainda é limitada, pelo menos enquanto perdurar a propriedade privada dos meios de produção. Dessa forma, a burguesia deveria temer o desenvolvimento da revolução democrática, pois poderia haver a instauração do socialismo. Esse raciocínio leva à necessidade da hegemonia, relacionada à capacidade dirigente do proletariado em meio à revolução democrática. Nesse aspecto, existe uma diferença quanto ao significado de hegemonia para Gramsci e para Lênin. Para o primeiro, o termo se refere em determinados momentos à capacidade dirigente e, em outros, compreende simultaneamente a direção e a dominação. O último concebe hegemonia restrita à função dirigente (GRUPPI, 1978).

De acordo com Costa (2011), Gramsci, ao aprofundar as reflexões de Lênin sobre a hegemonia, analisa o papel do Estado na sociedade capitalista desenvolvida, considerando que nos países avançados, no período da consolidação da ordem liberal burguesa, entre os séculos XIX e XX, a sociedade civil constrói instituições e organizações que atuam incisivamente no cotidiano das massas. Gramsci nesse momento prioriza, por um lado, a análise da superestrutura devido ao surgimento de diversos movimentos de massa no século $\mathrm{XX}$, mediante a instauração de sindicatos, associações, partidos etc., o que possibilitou a "socialização da política", garantindo a estabilidade do Estado burguês, mas, por outro, criou condições materiais para a resistência contra ele. Assim, o Estado não apareceria apenas na sua faceta coercitiva, manifesto no seu aparato político-militar, mas igualmente por meio dos organismos privados da sociedade civil, como escolas, igrejas, sindicatos, mídias, dentre outros, os quais difundem a ideologia burguesa e corroboram a ampliação e dominação desta classe, através do convencimento acerca da legitimidade de suas ações sobre os dominados. Entretanto, esses aparelhos privados também difundem outros valores, mesmo que em escala reduzida, visto que no seu seio se desenvolve a mesma luta ideológica que é desferida na sociedade, havendo a possibilidade de circulação de outras ideias que se identifiquem com alternativas aos "de baixo".

Ainda no que tange ao conceito de hegemonia, Dias (1996) chama atenção para o fato de haver interpretações que restringem tal conceito, pois enfatizam as alianças de classe de maneira imediatista, além de considerar abstratamente a hegemonia como a subordinação/coordenação da classe dominante em relação às demais, sejam elas aliadas ou não; ou se sobrevaloriza o partido sem considerar as complexas determinações de sua intervenção, possuindo a hegemonia uma expressão instrumental, distanciando-a da práxis que a fundamenta. Para Dias (1996, p. 10): 
[...] a questão central é o nexo entre a capacidade de construção de uma visão de mundo (Weltanschauung) e realização da hegemonia. A capacidade que uma classe fundamental (subalterna ou dominante) tenha de construir sua hegemonia decorre da sua possibilidade de elaborar sua visão de mundo própria, autônoma. Esse processo de "construção da hegemonia", que ocorre no cotidiano antagônico das classes, decorre da sua capacidade de elaborar sua visão de mundo autônoma e da centralidade das classes. Essa centralidade, tomada como "síntese de múltiplas determinações", e não como um a priore lógico, como um "efeito da estrutura", é determinante no exercício da hegemonia. Diferenciar-se, contrapondo-se como visão de mundo às demais classes, afirma-se como projeto para si e para a sociedade; ser direção das classes subalternas e dominadas na construção de uma nova forma civilizatória. Para tal, é fundamental ter a capacidade de estruturar o campo de lutas a partir do qual ela poderá determinar suas frentes de intervenção e articular suas alianças.

Embora o MST não exerça plenamente o "domínio" e a "direção", devido à própria fragmentação da classe trabalhadora implementada pelo capital, apresenta a possibilidade de outro projeto vindo "de baixo". Difunde, ainda que residualmente e de maneira difusa, por meios diversos (escolas, universidades, mídia escrita e digital, manifestações, ocupações, acampamentos etc.) a crítica à sociedade capitalista e, no caso do sudeste paraense, ao modelo agropecuário e mineral extremamente caro à região; difunde também a necessidade de se pensar um novo modelo de desenvolvimento que perpasse a reforma agrária popular.

Com relação à atuação do MST e à luta pela reforma agrária, Rossetto (2011) relata que entre o ano de sua fundação, em 1984, e o início de 1990, momento de implementação do neoliberalismo no Brasil, os movimentos sociais almejavam uma reforma agrária clássica, de cunho burguês, visto que o modelo urbano-industrial de desenvolvimento econômico do país subordinou a agricultura à indústria. Nesse período a reforma agrária se apresentava como um mecanismo de fortalecimento do mercado interno e de consolidação do capitalismo no campo, mediante a abertura de fronteiras agrícolas, mas foi a ação dos movimentos sociais que forçou a continuidade do tema da reforma agrária no cenário político nacional levando à elaboração do Primeiro Plano Nacional de Reforma Agrária em 1985 e à aprovação do princípio da função social da terra na Constituição Federal de 1988.

Entretanto, mesmo essa reforma agrária burguesa foi esgotada juntamente com o modelo de desenvolvimento urbano-industrial, visto que, a partir da década de 1990, o país se volta para a exportação de produtos primários, surgindo novos confrontos em torno do modelo de agricultura a ser praticado nacionalmente. Em suma, temos, por um lado, a consolidação do modelo baseado no agronegócio, afirmando um bloco hegemônico composto por latifundiários, que objetivam a expansão de áreas agricultáveis com uso intensivo de tecnologia, para maximizar o lucro; por outro, se constituiu historicamente o bloco de 
movimentos e segmentos de lutas sociais que defendem a agricultura camponesa, como o próprio MST, o MAB, o Movimento de Pequenos Agricultores (MPA), uma parcela do sindicato rural, a exemplo da Confederação Nacional dos Trabalhadores na Agricultura (CONTAG) e a FETRAF. Estes defendem a terra como um bem coletivo, as sementes como patrimônio da humanidade e a soberania alimentar para todos os povos, resultando em uma proposta de reforma agrária popular que, embora não seja aquela socialista, diverge da proposta burguesa, porque apresenta as seguintes premissas: acumular forças sociais em um momento de descenso social; desconstruir gradualmente o projeto burguês pautado no agronegócio; indicar alternativas para agricultura; disputar junto à sociedade o apoio em prol da agricultura camponesa, de forma a conformar uma nova força hegemônica (ROSSETTO, 2011).

Karriem (2012) também analisa o potencial do MST como um movimento que apresenta uma alternativa contra-hegemônica ao agronegócio. Para o autor, as lutas pela terra são realizadas como parte de um projeto popular de transformação social para o Brasil, apresentando aproximações com a prolongada "guerra de posição" de Gramsci, para implementar uma hegemonia alternativa. Nesse contexto, discorre sobre o processo de desenvolvimento do MST, para o qual indica quatro momentos importantes, a saber: de 1979 a 1985, período de gênese do movimento, motivada pela modernização do campo e a expulsão de diversos trabalhadores rurais; de 1985 a 1990, período de sua territorialização nacional, promovendo alianças com movimentos urbanos e a CPT e construindo um movimento de massa e popular que tem a luta pela terra como elemento de mudança social, e possui um caráter nacional-popular; de 1990 a 1995, momento de implementação do modelo de desenvolvimento econômico neoliberal, ao qual o MST se opôs veementemente e, por isso, ampliou sua atuação em todas as regiões brasileiras; de 1995 em diante houve a incorporação do discurso e da prática agroecológica, o que foi de encontro ao agronegócio e seu pacote tecnológico, e significou uma mudança na lógica produtiva dos assentamentos, de modo que a agroecologia praticada pelo MST não se mostra apenas como uma resposta ao modelo agrícola hegemônico que desterritorializa pequenos agricultores, mas foi integrada à práxis do movimento como forma de pensar uma outra concepção hegemônica do mundo, além de abrir possibilidades para rever práticas agrícolas perdidas em função do uso de agrotóxicos e sementes geneticamente modificadas.

Wainwright (2005), ao discutir a construção da hegemonia por um dado grupo social, identifica que ela é duplamente geográfica, visto que é constituída por meio de relações espaciais, as quais se tornam hegemônicas, e a geografia, por seu turno, é naturalizada e 
sedimentada pelo senso comum, mediante práticas políticas e culturais. Seguindo esse raciocínio, Karriem (2012) relaciona hegemonia e espaço compreendendo que são resultantes de práticas espaciais que normatizam ideias dominantes no cotidiano.

Em certa medida essa correlação entre espaço (social) e hegemonia é desenvolvida também por Lefebvre (2000). Esse autor compreende o espaço como produto e produtor, pois adentra nas relações de produção e nas forças produtivas, sendo dinâmico e relacional (articula-se em diversas escalas, do local ao global), se dialetizando como produto e produtor, pois assim como resulta das relações econômicas e sociais, também as produz. Igualmente se transforma de acordo com os interesses das sociedades que o produzem, embora seja um processo gradual, havendo apropriação do espaço preexistente, organizando-o de acordo com a nova racionalidade, no momento atual a operada pelo capitalismo, pela dominação da classe hegemônica: a burguesia. O conceito de hegemonia, em termos gramscianos, segundo Lefebvre (2000), permite analisar a ação da burguesia em relação ao espaço, designando não apenas a influência e o uso da coerção, mas identificando que a hegemonia é exercida sobre a sociedade em geral, nas suas mais variadas dimensões, pelas diversas instituições e representações sociais - dessa forma, a classe dominante se mantem hegemônica em todos os meios, incluindo o saber. Entendemos que, nesse processo de dominação, o espaço não é passivo (ao contrário, é até mesmo instrumental, visto que a hegemonia se exerce por meio dele), mas composto por uma lógica implícita, por meio do uso do saber e das técnicas. Entretanto, o espaço não é imune às contradições e resistências contra o capitalismo e suas formas de coerção e representação.

Desta feita, em decorrência das desigualdades e contradições geográficas manifestas em guetos, favelas, periferias, acampamentos, dentre outras formas de precariedade espacial a que os sujeitos são submetidos, é que explodem lutas sociais, organizadas ou não em movimentos, dos quais surgem resistências e possibilidades de outro projeto hegemônico, como afirmou Gramsci (2014b, p. 268):

[...] a nova construção só pode surgir de baixo para cima, na medida em que todo um estrato nacional, o mais baixo econômica e culturalmente, participe de um fato histórico radical que envolva toda a vida do povo e ponha cada qual, brutalmente, diante das próprias responsabilidades inderrogáveis.

Parece ser essa a proposta do MST, exposta por Rossetto (2011) anteriormente, salvaguardando as devidas escalas espaciais de ações e contradições nas quais o movimento está envolto. Para Semeraro (2011) essas lutas empreendidas pelo MST e por outros movimentos sociais têm assumido uma radicalidade e uma capilaridade que se alastra no 
sentido de reivindicação do controle pelo território (terra, água, floresta, minérios, biodiversidade etc.), deixando transparecer que buscam reinventar o Estado, no qual sejam governantes e não excluídos, além de produzirem uma consciência crítica e uma concepção política, cultural, econômica alternativa que se aglutina com outras mobilizações internacionais, questionando o modelo hegemônico de "civilização", embora apresentem ainda grandes debilidades e contradições.

Diante do exposto buscamos mostrar a importância do MST na luta pela reforma agrária popular, que envolve um projeto e uma mudança social mais ampla, além de uma disputa por projetos hegemônicos no espaço agrário brasileiro. Não queremos com isso afirmar a inexpressividade ou menor importância dos demais movimentos sociais já elencados acima, mas salientar que no contexto da realidade a ser pesquisada, qual seja, o sudeste paraense, o MST corresponde ao movimento social de maior expressão territorial, não em termos de números, mas qualitativamente, em decorrência do grau (além dos assentamentos que organizou desde a ocupação da terra até a organização de Projetos de Assentamentos, estabeleceu alianças que favoreceram positivamente a construção de assentamentos por parte de outros movimentos sociais) e da natureza (não almeja apenas a terra, mas a construção de um projeto territorial que possibilite a permanência do sujeito na terra a partir de um modelo de agricultura camponesa) da organização dos assentamentos.

Os Projetos de Assentamentos (PA) selecionados para pesquisa foram: $1^{\circ}$ de Março, em São João do Araguaia; 26 de Março, em Marabá; 17 de Abril, Cabanos, Canudos e Lourival Santana, de Eldorado dos Carajás; Palmares II e Onalício Barros, em Parauapebas; e Nega Madalena, de Tucumã - tais PAs correspondem àqueles organizados pelo MST na subregião paraense em destaque, entre os anos de 1994 e 2016.

Nessa área de estudo o MST desenvolveu, e ainda hoje o faz, uma estratégia territorial contra-hegemônica, almejando fazer frente à forte ofensiva do capital financeiro que se articula a outras frações do capital existentes na região, gerando diversos conflitos territoriais. Entendemos que o território está “imerso em relações de dominação e/ou de apropriação sociedade-espaço, que desdobra-se ao longo de um continuum que vai da dominaçãoeconômica mais 'concreta' e 'funcional' à apropriação mais subjetiva e/ou 'culturalsimbólica'” (HAESBAERT, 2004, 95-96).

Essa perspectiva territorial possibilita analisar os movimentos de luta pela terra, cujos debates perpassam por um viés de classe social, como a dos camponeses, e por uma via 
étnica, como a dos povos e comunidades tradicionais ${ }^{1}$, cujos disputa e embate almejam a politização de sua identidade. Segundo Almeida (2008, p. 30), o "critério políticoorganizativo sobressai combinado com uma 'política de identidades', da qual lançam mão os sujeitos sociais objetivados em movimento para fazer frente aos seus antagonistas e aos aparatos de Estado".

A disputa territorial por parte desses movimentos sociais do campo se realiza por meio de diversas estratégias. Desse modo, entendemos que o MST busca construir a sua territorialidade mediante uma organização política (luta pela reforma agrária e, consequentemente, pela socialização dos recursos naturais, ou seja, a terra de trabalho, na qual a terra possui valor de uso; luta por políticas públicas mais adequadas às particularidades dos assentamentos etc.), econômica (baseada na economia de excedentes ${ }^{2}$, de forma a possibilitar a reprodução camponesa com autonomia, ainda que relativa) e cultural (construção de uma identidade particular, por exemplo, com propostas educacionais ímpares, como a educação do campo) próprias.

O território do movimento social se estrutura no próprio movimento, devido a muitos dos sujeitos que o compõem almejarem uma fração do território em que possam sobreviver. Todavia, isso lhes é geralmente negado, o que os coloca em conflito com diversos sujeitos, como o Estado e os empresários do agronegócio, e força esses sujeitos a migrar continuamente. Mas, assim como Martins (1997a) nos ensina que não existem sujeitos excluídos da economia e sim incluídos precariamente, podemos afirmar que os sem-terra não estão totalmente desterritorializados, pois se reterritorializam constantemente no próprio fluxo, ou melhor, na mobilidade, ainda que precariamente.

Essa territorialização precária se torna de fundamental importância à análise da realidade do sudeste paraense, em virtude de sua produção espacial se desenvolver principalmente a partir de migrantes, como goianos, paraenses e principalmente maranhenses, que, segundo Velho (1981), desenvolvem frentes de expansão, realizadas a partir de

\footnotetext{
${ }^{1}$ Almeida (2008, p. 12) define como "povos e comunidades tradicionais' aqueles sujeitos cuja existência coletiva incorpora, como critério político-organizativo, uma diversidade de situações" correspondentes aos chamados ribeirinhos, castanheiros, pescadores, seringueiros, quebradeiras de coco babaçu e quilombolas que buscam ingressar em movimentos sociais, almejando o reconhecimento de sua forma particular de territorialização.

${ }^{2}$ Para Martins (2009, p. 190 grifado no original), "o excedente não é o resto ou a sobra. Não se trata de que o agricultor assegure para si e sua casa a subsistência e só depois venda o que sobrou. Trata-se de uma economia de excedentes porque o raciocínio que preside a organização da produção, isto é, o que plantar e sobretudo quanto plantar e até onde plantar está organizado a partir da ideia de que do que se planta uma parte deveria destinar-se primeiramente à subsistência da família do produtor e um excedente deveria ser produzido para troca ou comércio".
} 
determinadas atividades econômicas que se configuram na área em questão, a exemplo da exploração do caucho, da castanha, do garimpo, da pecuária e dos minérios.

Tais migrantes parecem encarnar a condição contraditória de que nos fala Sayad (1998), isto é, há uma dissonância entre o direito (condição temporária de migrante) e o fato (condição permanente de migrante). Portanto, não existe muita clareza sobre se a migração vem a ser um estado provisório que se prolonga indefinidamente, ou se se refere a um estado imutável, mas que perpetua o anseio de que seja tal estado passageiro.

Carvalho (1980) analisa um pouco dessa situação dos migrantes que iam trabalhar na construção da Transamazônica, na ânsia de se fixarem na região. A migração consistia em uma estratégia para adquirir terrenos e segurança, porém esses elementos lhes foram negados pela perda da terra e pela insegurança quanto à continuidade no lugar, sendo o trabalhador recolocado continuamente na condição de migrante e sem-terra.

O sonho de acesso à terra no campo é empurrado para mais longe, tendo assim de se mover sempre em busca dessa possibilidade eminente que possa vir a se concretizar em um dado tempo-espaço futuro. Nesse processo de migração e de luta pela terra, a perda e a insegurança são elementos constantes na vida desses sujeitos.

Esses migrantes serão os responsáveis pela ocupação do sudeste paraense e, devido à ação

de determinados sujeitos econômicos, serão expropriados de suas terras e/ou permanecerão na condição de mão de obra volante, situação que os leva a ações de luta e resistência, engrossando os movimentos sociais.

De acordo com Souza (2002), o sudeste paraense apresenta três importantes períodos de reordenação espacial. O primeiro na década de 1970, mediante a política de distribuição de lotes, provocando um forte movimento migratório para a região. E nesse contexto, algumas famílias permaneceram; outras foram obrigadas a abandonar seus estabelecimentos e se dedicar a atividades não agrícolas; e muitas procuraram diferentes frentes de trabalho.

O segundo momento refere-se à ocupação da área pela atividade agropecuária com fortes incentivos estatais ao capital privado nacional e internacional; além da exploração mineral, estimulando uma nova leva de força de trabalho a atuar nas obras de infraestrutura, acirrando os conflitos sociais, especialmente aqueles ligados a posse da terra. Também se evidencia o garimpo, a exemplo de Serra Pelada na década de 1980 (SOUZA, 2002).

Por fim, no terceiro momento, observa-se uma redução do incremento populacional; o fechamento de garimpos; e a ausência de uma política pública que realize de fato a reforma agrária, favorecendo o aparecimento de uma grande massa de sujeitos desterritorializados, que 
passam a lutar pela permanência no território e a pressionar o Estado para atingir esse fim (SOUZA, 2002).

Muitos desses migrantes que vão para o sudeste paraense e lá se territorializam precariamente, em suas trajetórias de vida trabalharam como agricultores, peões, rendeiros, garimpeiros. Tendo sido expulsos de suas propriedades, ocuparam fazendas sem muito sucesso, e entraram para movimentos sociais como uma alternativa de realizar o desejo de acesso à terra (SOUZA, 2002).

A Amazônia, no contexto supracitado, recebe inúmeros incentivos fiscais e creditícios, que foram, porém, direcionados aos empresários nacionais e estrangeiros e aos grandes projetos, o que concorreu para o aumento da concentração de terras, especialmente no sudeste paraense, provocando, ao contrário do que o governo militar propagandeava, um desenvolvimento da miséria e da pobreza, principalmente em função da diminuição dos postos de trabalho oferecidos inicialmente; da expulsão dos índios de suas reservas; do remanejamento de ribeirinhos, em decorrência do represamento do rio, ocasionado pela construção da Usina Hidrelétrica de Tucuruí (UHT); da retirada violenta dos posseiros existentes na área pela ação de grileiros e empresários.

Por esse processo de latifundiarização da região e pelo esgotamento do modelo de desenvolvimento implementado, a partir da década de 1990, o governo necessita redirecionar suas políticas públicas de financiamento, abarcando igualmente pequenos e médios proprietários de terras: os créditos disponibilizados são, em parte, destinados à pequena produção, mas o montante maior ainda privilegia a grande empresa capitalista. Também nessa década, o governo passa a realizar projetos de assentamentos que amenizam o conflito social instalado na região, proporcionado pelo alto grau de marginalização a que esses povos e comunidades tradicionais foram relegados. Pela organização em movimentos sociais, esses sujeitos conseguem alguns direitos.

Com base nesse debate teórico e empírico é que nos lançamos ao entendimento da relação entre a construção da territorialidade do MST e a produção de um projeto contrahegemônico no sudeste paraense. Por esse motivo propomos, a título de problemática: Quais as formas de territorialização contra-hegemônicas implementadas pelo Movimento dos Trabalhadores Rurais Sem Terra (MST), a partir da organização dos assentamentos no sudeste paraense?

Com o intuito de responder a essa problemática geral é que formulamos questões específicas que auxiliarão sua melhor compreensão, a saber: 
1. Quais as estratégias desenvolvidas pelo MST para se territorializar no sudeste paraense?

2. Quais as estratégias para a construção de um projeto contra-hegemônico nos assentamentos do sudeste paraense, organizados a partir do MST?

3. Quais as propostas contra-hegemônicas desenvolvidas pelo MST nos assentamentos que organiza no sudeste paraense?

Essas questões anseiam delimitar melhor a nossa pesquisa sobre o espaço agrário do sudeste paraense, levando em consideração a territorialização do MST e a construção de uma ação contra-hegemônica que, embora inacabada e incipiente, corrobora uma redefinição territorial na sub-região marcada pela violência e pela expropriação promovida pelos sujeitos econômicos hegemônicos.

Nesse sentido, nossa pesquisa de tese de doutorado tem como objetivo geral analisar as formas de territorialização contra-hegemônicas implementadas pelo MST, a partir da organização dos assentamentos no sudeste paraense, no período de 1994 a 2016. E, para esse fim, desenvolvemos objetivos específicos, quais sejam:

1. Identificar e analisar as estratégias desenvolvidas MST para se territorializar no sudeste paraense.

2. Identificar e analisar as estratégias para a construção de um projeto contra-hegemônico nos assentamentos do sudeste paraense, organizados a partir do MST.

3. Identificar e analisar as propostas contra-hegemônicas desenvolvidas pelo MST nos assentamentos que organiza no sudeste paraense.

Esse trabalho ambiciona centrar seus esforços nas "resistências" como elemento de pesquisa, alçando indicar que os "de baixo" também promovem transformações no e a partir do território, redefinindo o jogo de forças que o permeia, como bem asseverou Martins (1993, p. 64):

Prefiro, porém, percorrer o caminho oposto. E indagar qual é o impacto das populações indígenas e camponesas sobre a expansão capitalista, quando são implantados os grandes projetos econômicos [...]. Na realidade, o processo não é unilateral. Há uma reciprocidade de consequências, o que não quer dizer equidade. Os grupos vitimados por esses programas lançam neles contradições, tensões, desafios.

É por esse viés analítico que vamos discutir o espaço agrário do sudeste paraense, no qual, embora a modernização seja avassaladora, cria aberturas, rupturas e resistências que guardam os germes de outro projeto hegemônico produzido no cotidiano das lutas e das experiências da escassez, impactando o projeto "natural" de incorporação dos territórios pelo 
capital, por meio do agronegócio, da mineração ou de hidrelétricas e vias férreas, que rasgam territórios tradicionalmente ocupados por assentados, indígenas, ribeirinhos, dentre outros ${ }^{3}$.

É importante ressaltar, segundo Suzuki (2007), que a modernização da agricultura no Brasil não deve ser interpretada como um apêndice do movimento de modernização da cidade, no sentido da predominância da população urbana sobre a rural, que ocorre a partir das décadas de 1950, 1960 e 1970. Isto porque ao compreender a modernização da agricultura como um "movimento de re-elaboração da base técnica, bem como das relações de submissão do trabalho, ao longo da história do homem, entendendo que, com a absolutização da propriedade privada e a produção da cidade capitalista, ocorre uma metamorfose do processo de modernização" (SUZUKI, 2007, p. 85), que no Brasil ocorre no momento de valorização do conhecimento tecnicocientífico proveniente da ascensão do capitalismo industrial europeu que avança por meio dos projetos implantados ao longo do século XIX. Na Amazônia, particularmente, isso pode ser observado pelos trabalhos de EMMI (1999) no sudeste paraense e por nossa dissertação de mestrado (MIRANDA, 2009) que versa sobre a modernização da agricultura e a complexificação da relação rural e urbana no nordeste paraense.

\section{PROCEDIMENTOS DE METODOLÓGICOS}

Para dar conta dos objetivos propostos, valemo-nos dos seguintes procedimentos metodológicos.

Inicialmente foram realizados discussões teórico-conceituais a partir de levantamento e análise bibliográfica em que tivemos o cuidado de sistematizar os principais elementos das discussões teóricas a respeito do tema estudado. Momento em que realizamos a elaboração de fichamentos e resenhas, para estabelecer um diálogo reflexivo entre a teoria e o objeto de investigação escolhido e averiguar o "estado" do conhecimento atual sobre o problema

\footnotetext{
${ }^{3}$ Para Suzuki (2013) essas sociedades tradicionais apresentam um forte vínculo com a natureza, não em uma relação determinista, mas salientando a forte relevância da natureza frente as múltiplas determinações que definem as sociedades tradicionais. Essas, por sua vez, fundamentam-se em dois aspectos importantes, a saber: (a) o distanciamento referente aos distintos modos de vidas que constituem em relação aos da sociedade urbanoindustrial, manifesta pela relação umbilical com a natureza, logo, o tempo cíclico é uma marca da reprodução (i)material dos sujeitos; (b) aproximação decorrente da mediação da sociedade urbano-industrial, que influencia os territórios tradicionais e a forma de organização dos sujeitos e seus modos de vida. $\mathrm{O}$ distanciamento e a aproximação negam a visão dualista em torno do moderno e do tradicional, que estão imbricados, visto que o que se observa é a "presença do moderno em níveis distintos, inserido em temporalidades históricas diversas, como a do caiçara, do caboclo, do ribeirinho, do quilombola, do jangadeiro, do pescador etc." (SUZUKI, 2013, p. 631).
} 
(MINAYO et al., 1994). Nessa fase, examinamos as teorias e as conceituações referentes ao tema da territorialização dos movimentos sociais e conceito de hegemonia e a sua dimensão territorial, além de acessar artigos, dissertações e teses sobre o MST e sua territorialidade no Brasil e no sudeste paraense, com vistas a compreender o seu desenvolvimento histórico e geográfico e ações que ajudem a conformar outro projeto hegemônico. Por fim, sistematizamos informações sobre os assentamentos que foram organizados pelo MST no sudeste paraense, a saber: $1^{\circ}$ de Março (São João do Araguaia), 26 de Março (Marabá), 17 de Abril, Cabanos, Canudos e Lourival Santana (Eldorado dos Carajás), Palmares II, Onalício Barros (Parauapebas) e Nega Madalena (Tucumã).

Foi realizada análise documental acerca de dados secundários, ou seja, que já foram analisados, mas que reelaboramos de acordo com nossos objetivos de pesquisa (GIL, 2009), quais sejam, a produção agrícola, pecuária e a estrutura fundiária, obtidos junto ao Sistema IBGE de Recuperação Automática (SIDRA) do Instituto Brasileiro de Geografia e Estatística (IBGE), além de dados do Sistema Integrado de Projetos de Reforma Agrária (SIPRA), para obtermos informações dos assentamentos, no que se refere à dimensão territorial, número de assentados e fazendas desapropriadas. Esses elementos nos possibilitaram entender o grau de importância política e econômica dos assentamentos selecionados para pesquisa. Por fim, analisamos dados do Programa Nacional de Fortalecimento da Agricultura Familiar (PRONAF) junto ao Ministério do Desenvolvimento Agrário (MDA) e à sede regional do Instituto Nacional de Colonização e Reforma Agrária (INCRA), em Marabá, para avaliarmos a implementação das políticas públicas nos assentamentos. Também fizemos uso de levantamentos efetuados pela CPT, os quais indicam quantitativamente as áreas em conflito e de acampamentos, e da Rede Dataluta, referente à espacialização da luta pela terra (manifestações e ocupações de terra) e à territorialização da luta pela terra (assentamentos), indicando as possibilidades histórico-geográficas de os sujeitos lutarem pelo território.

Foi feita produção cartográfica, na qual utilizamos o software livre QGIS, para sistematizar informações obtidas em trabalho de campo (localização dos assentamentos e acampamentos organizados pelo MST, dos lotes de terra visitados nos assentamentos e dos principais empreendimentos agropecuários e minerais referentes à hegemonia do capital na sub-região sudeste do Pará) e registradas por meio de GPS (Global Positioning System) e da análise documental (principais áreas em conflito, ocupações de terras e área territorial dos assentamentos). Também empregamos o software livre Draftsight para o desenho técnico referente a uma cartografia histórica do sudeste paraense. 
Foram realizados observações sistemáticas, por meio das quais estreitamos nossa relação com o grupo pesquisado no momento do trabalho de campo, desenvolvendo uma participação relativa no cotidiano dos sujeitos estudados, por meio da observação dos eventos de seu dia a dia (MINAYO et al., 1994). Nesse momento da pesquisa, que durava entre 15 (quize) dias a dois meses em média em cada assentamento, coletamos dados primários, obedecendo aos seguintes procedimentos:

a) Entrevistas semiestruturadas, que consistem em conciliar entrevistas estruturadas - com perguntas previamente formuladas - e não estruturadas - em que o informante aborda livremente o tema proposto (MINAYO et al., 1994). Esse procedimento metodológico foi aplicado junto aos assentados dos PAs selecionados para pesquisa, com o objetivo de entender o processo de ocupação da terra e as formas de luta pela terra; junto às lideranças do MST, para apreender as formas de territorialização que esse movimento social, suas alianças e ações, (re)constroem para propor um outro projeto territorial hegemônico e diverso do agronegócio, no sudeste paraense particularmente, mas alinhado com suas ações na escala nacional e internacional; às lideranças da CPT para discutir o seu papel na luta pela terra e sua relação com o MST e outros movimentos sociais para a construção de um outro projeto territorial contra-hegemônico; às lideranças da FETAGRI, para observar sua relação com o MST e as formas como desenvolve a luta pela terra no sudeste paraense; às lideranças da FETRAF para visualizar sua relação com o MST e outros segmentos de luta social e as formas de territorialização propostas. Essas entrevistas almejam compreender as alianças que se estabelecem entre os movimentos sociais de luta pela terra no sudeste paraense, mas salvaguardando suas diferenças em termos de ações e projetos.

b) Questionário definido como uma técnica de pesquisa que dispõe de um certo número de questões apresentadas por escrito às pessoas, almejando obter informações da realidade (GIL, 1999). Em nosso estudo aplicamos os questionários junto aos assentados dos PAs de forma a obter dados relativos à origem desses sujeitos (processo migratório); à estrutura econômica e política da família (grau de envolvimento com movimentos sociais, em especial o MST, formas de organização de luta pela permanência no assentamento face às precariedades existentes, produção agropecuária, renda e financiamento); ao modo como observam a estrutura educacional do assentamento e a relação do ensino com a história do PA e do MST; por fim, aos aspectos socioculturais, com o 
intuito de avaliar se ainda resguardam formas organizativas simbólico-culturais importantes às ações coletivas e que possam auxiliar na construção de um outro projeto hegemônico, a exemplo da organicidade e a mística que são marcantes no momento do acampamento. Nesse sentido, utilizamos a proporção de $25 \%$ a $30 \%$ do total de assentados em cada PA para a aplicação dos questionários, salientando que aqueles responderam que moravam em vilas ou lotes. No segundo caso, georreferenciamos os lotes para posterior confecção de mapas temáticos e buscamos indagar aquelas pessoas que residiam em pontos diferentes do assentamento. Dessa feita, obtivemos a seguinte quantidade de questionários por assentamento: $1^{\circ}$ de Março, 99 questionários; 26 de Março, 89 questionários; 17 de Abril, 175 questionários; Cabanos, 40 questionários; Canudos, 30 questionários; Lourival Santana, 60 questionários; Palmares II, 144 questionários; Onalício Barros, 27 questionários; Nega Madalena, 25 questionários.

c) Registros fotográficos foram realizados com o intuito de possibilitar o reconhecimento da paisagem dos assentamentos, salientando a organização espacial destes, a produção agrícola e pecuária e as formas de manifestações coletivas em prol de melhorias sociais e de ações pela reforma agrária, tanto nos assentamentos quanto nos acampamentos organizados pelo MST. As paisagens dos acampamentos possibilitam o entendimento de uma das formas de luta pela terra, que se refere ao acampamento em fazendas consideradas improdutivas ou em situação irregular, além do fato de os acampamentos receberem ajuda dos assentamentos, mostrando a articulação territorial existente entre ambos. Esse procedimento ilustra a luta pela terra e o resultado dessa ação, que muitas vezes não produz uma territorialização mais includente, ao contrário, muitas precariedades ainda persistem (educação, saúde, crédito rural, saneamento básico etc.).

Salientamos que embora os acampamentos não sejam o foco de nossa pesquisa, realizada nos assentamentos, eles ajudam a compreender o processo de elaboração e debate do projeto territorial no qual os sem-terra possuem condições de se territorializar pela luta, conformando o que denominamos rede geográfica de solidariedade camponesa de luta pela terra entre acampamentos e assentamentos. Dessa forma, fizemos trabalho de campo em seis acampamentos organizados pelo MST até 2015. Permanecemos nesses espaços em média de três a cinco dias e aplicamos questionários em um percentual mínimo de $10 \%$ dos acampados, assim obtivemos 59 questionários no Helenira Resende; 60 questionários no 
Hugo Chaves - ambos no município Marabá -; 59 questionários no Dalcídio Jurandir no município de Eldorado dos Carajás; 60 questionários no Frei Henri no município de Curionópolis; 62 questionários no João Canuto no município de Sapucaia; e 27 questionários no Roseli Nunes no município de Tucumã, totalizando 327 questionários. Também procedemos entrevistas semiestruturadas com as lideranças de cada acampamento, para entender a organização interna desses locais e sua geografia de luta.

Por fim, nos detemos sobre a análise dos dados coletados em campo, fazendo a devida correlação e reflexão teórico-metodológica e teórico-empírica e, assim, desenvolvemos a versão final desta tese de doutoramento.

O plano de redação da tese é composto por cinco capítulos. O primeiro versa sobre a construção teórica acerca da noção de Formação Econômico-Social (FES), salientando sua dimensão territorial, alçando dialogar com o conceito de hegemonia em Gramsci, visto que a construção da hegemonia não se realiza da mesma maneira em todos os lugares, ao contrário, apresenta particularidades históricas que precisam ser consideradas ao se pensar um projeto revolucionário pelas classes subalternas. Esse projeto, proposto por nós como contrahegemônico, apresenta uma dimensão territorial visto que a disputa empreendida pelos movimentos sociais, com destaque ao MST, envolve a construção de assentamentos, mas igualmente advoga por uma agricultura camponesa.

O segundo capítulo analisa a formação do sudeste paraense, tendo em vista a sua dimensão territorial da fronteira, entendida aqui como o conflito de territorialidades que coexistem no mesmo espaço-tempo. No seio da produção territorial do sudeste paraense, marcada por contradições, emergem diversos movimentos sociais, dentre eles o MST, que inicialmente se ampara em experiências regionais dos sindicatos e na Igreja, mas reinventa as formas de luta e resistência, apresentando um papel importante na construção da possibilidade de outro projeto hegemônico, oposto ao das empresas mineradoras e do agronegócio.

Em seguida, o terceiro capítulo debate a ação do MST no âmbito do sudeste paraense, impactando os grandes projetos e redefinindo a geografia do espaço agrário dessa realidade, ainda que de maneira gradual e pontual, por meio de ocupações, acampamentos e assentamentos que organiza em conjunto com outros movimentos sociais ou não. Essas estratégias configuram um processo de espacialização e territorialização da luta pela terra, com o intuito de construir uma contra-hegemonia face às ações hegemônicas do capital.

O quarto capítulo discute como o MST, por meio das experiências dos assentamentos e da organização da luta pela terra, pode contribuir para a construção de um projeto contrahegemônico, aberto, dialético, à luz da formação territorial do sudeste paraense. Por esse 
motivo analisamos primeiramente a construção dos PAs pesquisados para, em seguida, compreender a formação da rede geográfica solidária camponesa de luta pela terra, que se articula local e regionalmente, inclusive com articulação de outros movimentos sociais para conformar um bloco histórico e geográfico, mas igualmente se utiliza da política de escala para ampliar a área de disputa e angariar melhorias nos PAs.

Por fim, no quinto capítulo discutimos as iniciativas do MST, em articulação com diveros outros sujeitos, de disputar os aparelhos privados de hegemonia, desde os assentamentos até os outros meandros da sociedade civil, a partir de um modelo de desenvolvimento territorial pautado na agricultura camponesa, com destaque a agroecologia, diversa do modelo do agronegócio, semeando experiências que podem germinar e contribuir para um projeto hegemônico dos "de baixo". 


\section{TERRITÓRIOS EM DISPUTA: HEGEMONIA DO CAPITAL E CONTRA- HEGEMONIA DOS MOVIMENTOS SOCIAIS}

Foto 2 - Acampamento nacional da juventude sem terra Oziel Alves Pereira, em Eldorado dos Carajás em 2016.

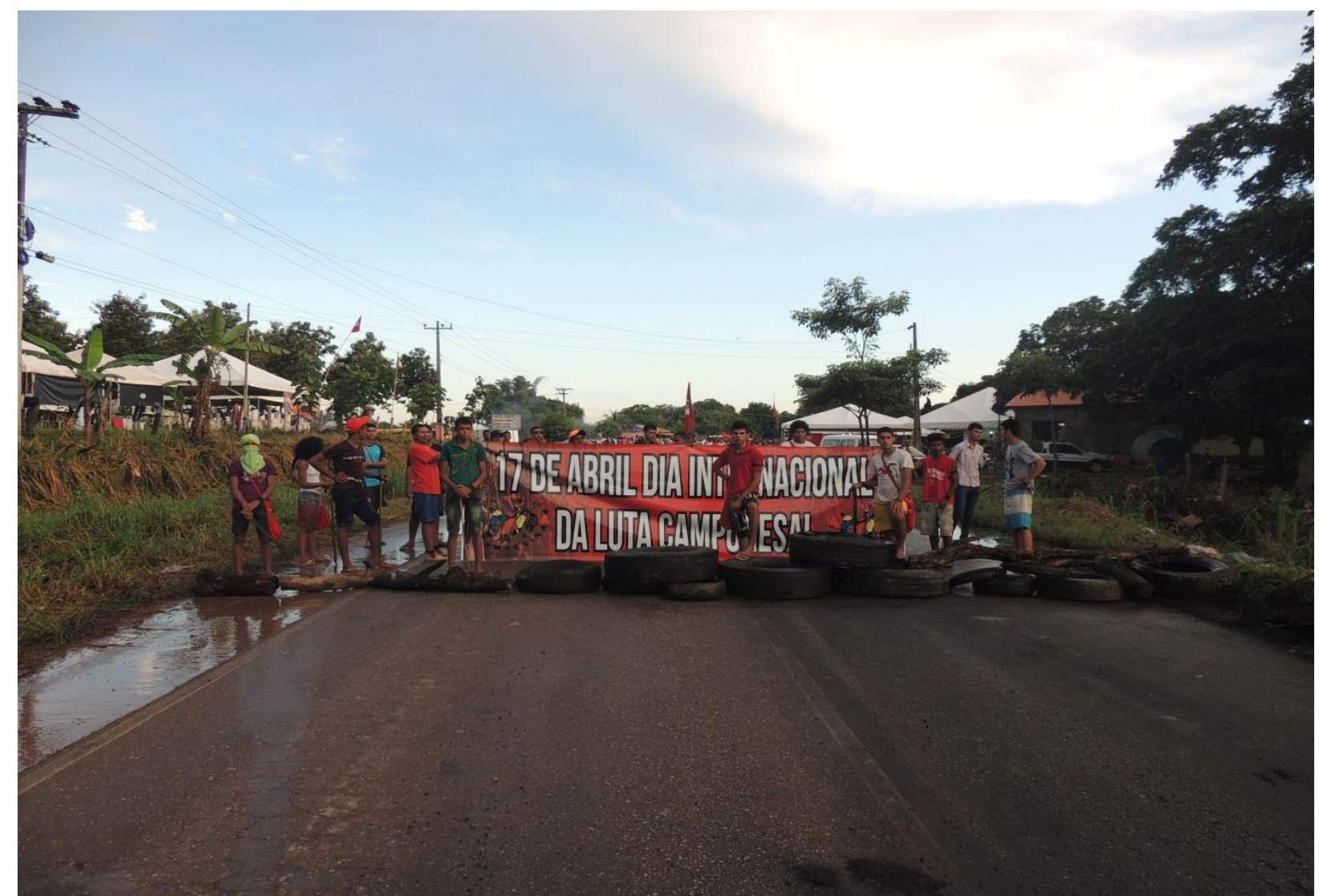

Fonte: Rogério Rego Miranda, Eldorado dos Carajás, 2016.

[...] nenhuma sociedade se coloca tarefas para cuja solução já não existam, ou estejam em vias de aparecimento, as condições necessárias e suficientes; - e que nenhuma sociedade deixa de existir antes de haver expressado todo o seu conteúdo potencial (GRAMSCI, 2014a, p. 314-315). 
Diversos autores se debruçaram sobre a temática da hegemonia, seja em termos de como determinados países se constituem enquanto potências mundiais no âmbito econômicopolítico, seja analisando as formas pelas quais grupos sociais e/ou empresariais estabelecem estratégias que lhes possibilitem hegemonizar um setor da economia, ou ainda, um ou mais territórios.

A hegemonia faz parte do léxico de marxistas, a exemplo de Boron (2004), Burawoy (2010) e Arrighi (2003); de pós-marxistas como Laclau; Mouffe (2015); ou mesmo póscoloniais como Ceceña (2005) e Ornelas (2010). Entretanto, todos estes apresentam como raiz comum do debate os estudos de Gramsci, muito embora as interpretações e ampliações do conceito de hegemonia sejam diversas.

O presente capítulo busca realizar um resgate das contribuições gramscianas para compreendermos o conceito de hegemonia, apesar de este não estar plenamente formulado e finalizado pelo autor em questão, visto que a maior parte dos seus estudos está nos Cadernos do Cárcere, elaborados na prisão, e muitos dos escritos estão inacabados, mas são esses "fios soltos" que mantém a riqueza de suas ideias, pois segundo Bianchi (2007), nesses cadernos manifestam-se diversas temporalidades que refletem as diferentes formas de exercício da hegemonia, assim como a complexa diacronia dos textos representa a unidade do pensamento de Gramsci em relação às múltiplas dimensões da realidade.

Nosso propósito com este estudo é identificar os principais fundamentos que constituem os mecanismos de hegemonia, porém almejamos analisá-los a partir de dois objetivos, a saber: a) analisar geograficamente a produção da hegemonia, em outras palavras, a construção dos territórios hegemônicos e contra-hegemônicos, que estabelecem entre si, para além de dicotomias simples, uma relação dialética; b) discutir como os movimentos sociais propõem um projeto contra-hegemônico, ainda que nas fissuras e mediante relações de poder desiguais, nos quais estão imersos e articulados, contraditoriamente, com o capital.

Esses dois objetivos nos possibilitam clarificar as formas de territorialização contrahegemônicas desenvolvidas pelo Movimento dos Trabalhadores Rurais Sem Terra (MST) no sudeste paraense, sem perder de vista que este é um território resultante de um processo conflituoso, mas produtor de experiências de um novo projeto societal, indicando que o exercício do poder não é unilateral e sim múltiplo - apesar de não apresentar as mesmas condições de hegemonia - e que é marcado por diversas contradições.

Destarte, uma primeira premissa fundamental para a definição de hegemonia corresponde à noção de formação econômico-social, especialmente porque ela subsidiará a 
compreensão da particularidade em que essa hegemonia pode ser desenvolvida, sem perder de vista as relações externas que apresenta (a totalidade).

\subsection{FORMAÇÃO ECONÔMICO-SOCIAL (FES) E SUA DIMENSÃO GEOGRÁFICA}

Marx, em sua obra Introdução à crítica da economia política, indica que o tema do seu trabalho era a produção material, partindo da ideia da produção humana em sociedade e a produção de indivíduos socialmente determinada, em contextos históricos diferentes (feudal, capitalista etc.), que apresentam entre si determinadas características em comum. Segundo o autor, a "produção em geral é uma abstração, mas uma abstração razoável, pelo fato de que põe realmente em relevo e fixa o caráter comum, poupando-nos, portanto, as repetições" (MARX, 2008, p. 240). Desta feita, preocupa-se em entender as regularidades e homogeneidades, porém sem perder de vista a diversidade. É nesse contexto que Marx formula a ideia de formação econômico-social, em que vestígios do passado são arrastados pelo presente. Em suas palavras:

A sociedade burguesa é a organização histórica da produção mais desenvolvida, mais diferenciada. As categorias que exprimem suas condições, a compreensão de sua própria organização a torna apta para abarcar a organização e as relações de produção de todas as formas de sociedades desaparecidas, sobre cujas ruínas e elementos se acha edificada, e cujos vestígios, não ultrapassados ainda, leva arrastando, enquanto que tudo o que fora antes apenas indicado se desenvolveu, tomando toda sua significação etc.[...].

Como, além disso, a sociedade burguesa não é em si mais do que uma forma antagônica do desenvolvimento, certas relações pertencentes a formas anteriores nela só poderão ser novamente encontradas completamente esmaecidas, ou mesmo disfaçadas; por exemplo, a propriedade comunal. (Marx, 2008, p. 264-265)

Marx chama à atenção o fato de que em uma dada forma de sociedade existe uma produção determinada, superior às demais, identificando sua posição de influência sobre as outras.

No caso da sociedade burguesa, a indústria corresponderia à produção dominante, subjugando a agricultura, sendo esta dominada pelo capital. Fato semelhante ocorre com a renda territorial, posto que nas formas em que predomina a propriedade rural, sobressai-se a íntima relação com a natureza, mas naquelas formas em que o capital domina, destaca-se o elemento social produzido historicamente. "Não se compreende a renda territorial sem o capital; entretanto, compreende-se o capital sem a renda rural. O capital é a potência econômica da sociedade burguesa, que domina tudo.” (MARX, 2008, p. 267) 
Segundo Sereni (2013), essa noção de "formação" (social) em Marx tem um caráter dinâmico e processual, ao contrário da ideia de forma, porque naquela busca-se distinguir “diversas e sucessivas épocas históricas, qualificadas como 'progressivas' e caracterizada cada uma [...] por uma série ascendente de 'tipos', todos compreendidos naquela mesma formação" (SERENI, 2013, p. 305). Em outros termos,

Esta categoria expressa a unidade (e, agregaremos, a totalidade) das diferentes esferas: econômica, social, política e cultural da vida de uma sociedade; e a expressa, além disso, na continuidade e ao mesmo tempo na descontinuidade de seu desenvolvimento histórico. (SERENI, 2013, p. 315 , grifado no original)

Lefebvre (1969) igualmente reflete sobre a noção de formação econômico-social em Marx e, também em Lênin, salientando a maior profundidade analítica dada à FES pelo último. Lefebvre assinala que a ideia de "formação" se refere a uma realidade em constante transformação, de maneira histórica e objetiva, ao passo que "econômico-social" significa dois aspectos inseparáveis e diferentes da formação, quais sejam: o econômico, que se refere às forças produtivas e às relações práticas dos indivíduos em sociedade com a natureza, e o social, que indica as relações estabelecidas entre os homens, as relações de produção, classes e forças sociais. Em suma, para Marx, "formação econômico-social" faz referência à sociedade como o conjunto da história de seu desenvolvimento:

Para Marx, o desenvolvimento da sociedade e a sua história constituem um todo (uma totalidade); mas cada momento da história, cada regime ou modo de produção constitui também um conjunto, um todo (ou uma totalidade) que é necessário estudar em si mesmo, sem o separar do desenvolvimento total. (LEFEBVRE, 1969, p. 190 grifado no original)

Lênin (1955) parte dessas premissas marxianas para formular sua compreensão de formação econômico-social. Em seu texto Quem são os amigos do povo e como eles lutam contra os social-democratas, por um lado, polemiza com os subjetivistas, ou melhor, com a sociologia subjetivista, para a qual o conceito de formação econômico-social é supérfluo, pois não trabalha a sociedade em geral, haja vista que Marx investigou a lei de desenvolvimento da formação capitalista. Marx introduziu o materialismo na sociologia, possibilitando-a tratar de modo rigoroso e científico os problemas históricos e sociais. Avançando na crítica, Lênin (1955) indica que os sociólogos subjetivistas distinguiram com dificuldade, na complexa rede de fenômenos sociais, entre os que são importantes e os que não o são, apresentando problemas para encontrar um critério objetivo para essa diferenciação. Por outro, para Lênin:

A análise das relações sociais materiais permitiu imediatamente que se observassem a repetição e a regularidade e se sintetizassem os sistemas dos diversos países num conceito fundamental de formação social. Somente esta síntese permitiu que se passasse da descrição dos fenômenos sociais (e de 
sua avaliação do ponto de vista do ideal) à análise rigorosamente científica dos mesmos, a qual evidencia, por exemplo, que é que diferencia um país capitalista de outro e investiga o que é comum a todos eles. (LÊNIN, 1955, p. 114)

A hipótese exposta acima possibilitou a existência de uma sociologia científica, pois apenas reduzindo as relações sociais às relações de produção e estas, por sua vez, ao nível das forças produtivas se conseguiu uma base sólida para representar o desenvolvimento das formações sociais como processo histórico natural. Marx formulou esta hipótese tendo em vista as formações econômico-sociais (dentre as quais sobressaiu o sistema da economia mercantil), e mediante dados substantivos analisou as leis que regem o funcionamento dessa formação e o seu desenvolvimento, salientando que sua análise se limita às relações de produção existentes entre os membros da sociedade, compreendendo como esta se transforma em uma economia capitalista e cria classes antagônicas (burguesia e proletariado); e como desenvolve as atividades do trabalho social e fornece com ele um elemento que entra em contradição irreconciliável com os fundamentos da própria organização capitalista. Esses elementos seriam o esqueleto de $O$ Capital, mas Marx avançou e explicou a estrutura e o desenvolvimento de uma formação social determinada exclusivamente pelas relações de produção, estudando as superestruturas correspondentes a essas relações de produção (LÊNIN, 1955).

De acordo com Gruppi (1979), a análise marxista se enriqueceu com a noção de formação econômico-social de Lenin, cujo debate possibilitou compreender a sociedade não como uma formação indistinta, assentada em uma explicação pautada em leis universais, mas de cunho meta-histórico, deixando de lado a relação concreta entre os diversos elementos que a compõem. Para Lênin, a sociedade se desenvolve em distintas formações econômicosociais, das quais se determinam as leis particulares que as regem. Assim, "a abstração determinada se forma em função da reconstrução da determinação concreta". (GRUPPI, 1979 , p. 10, grifado no original)

Esta noção de formação econômico-social foi levada a cabo por Lênin em sua obra principal, $O$ desenvolvimento do capitalismo na Rússia, em que o autor se contrapõe à tese dos populistas de que em seu país não haveria um progresso do capitalismo, visto que negam suas contradições. Em outras palavras, para eles não seria possível o desenvolvimento do capitalismo na Rússia tendo em vista a inexistência de um mercado adequado, logo, o capitalismo corresponderia a um caminho desviante que deveria ser evitado com o intuito de salvaguardar a comunidade camponesa. Lênin (1988), no entanto, adverte que a desagregação e a pauperização da comunidade camponesa são condições para o desenvolvimento do 
capitalismo, visto que a "liberação" de uma parcela dos produtores dos meios de produção implica a transferência desses meios para outros sujeitos, convertendo-os em capital; consequentemente, os novos proprietários desses meios irão produzir, sob a forma de mercadorias, os produtos que outrora eram consumidos pelo produtor, ampliando o mercado interno. Igualmente indica os diferentes interesses de classe no interior da Revolução Russa, manifestos na dualidade da classe campesina:

A revolução está trazendo cada vez mais à luz a dualidade do campesinato, evidente quer do ponto de vista da sua situação, quer do ponto de vista do seu papel. De um lado, os imensos remanescentes da economia baseada na corveia e toda sorte de resíduos da servidão diante de uma pauperização inédita e da ruína dos camponeses pobres explicam plenamente as raízes profundas do movimento revolucionário camponês, do espírito revolucionário do campesinato enquanto massa. De outro, a estrutura internamente contraditória de classe dessa massa, seu caráter pequeno burguês, o antagonismo interno entre as tendências proprietárias e proletárias manifestaram-se claramente no processo revolucionário, na natureza dos diferentes partidos e nas numerosas correntes políticas e ideológicas. As vacilações do pequeno proprietário arruinado, vacilando entre a burguesia contrarrevolucionária e o proletariado revolucionário, são tão inevitáveis como este outro fenômeno que se observa em toda sociedade capitalista: uma insignificante minoria de pequenos produtores se enriquece, "sobe na vida", se aburguesa, enquanto a imensa maioria se arruína completamente, transformando-se em trabalhadores assalariados ou paupérrimos ou vivem eternamente no limite da condição proletária. (LÊNIN, 1979, p. 9-10)

Lefebvre (1969), ao apontar os avanços de Lênin com relação à noção de formação econômico-social, indica que cada formação apresenta leis particulares subordinadas às leis gerais da formação econômico-social, salientando que a lei geral estipula que o desenvolvimento da sociedade é condicionado pelo desenvolvimento das forças produtivas. Em suma, a formação econômica se refere tanto à história e ao desenvolvimento da sociedade em geral quanto a momentos ou fases sucessivos - em outros termos, a modos de produção. Essa FES indica que o desenvolvimento histórico e social não avança homogeneamente, logo, as formações econômico-sociais sucessivas na história, coexistindo no momento atual com o capitalismo, não são externas à ele, uma vez que as "formas sucessivas de propriedade e de posse do solo, o artesanato, a pequena produção e o pequeno comércio, veem-se a pouco e pouco subordinados ao grande capital. O crescimento do capitalismo não se faz duma maneira, é multiforme e multilateral”. (LEFEBVRE, 1969, p. 201, grifado no original)

Desta feita, o capital ora dissolve as relações preexistentes, ora corrói e sujeita estas relações e, por conseguinte, as "estruturas de formações anteriores ao capitalismo podem ou desaparecer ou permanecer gozando duma independência aparente. A realidade essencial 
exprime-se numa lei: a lei da subordinação ao capitalismo das formas e estruturas anteriores". (LEFEBVRE, 1969, p. 202, grifado no original)

Outro avanço de Lênin $(1955 ; 1988)$ consistiu na lei do desenvolvimento desigual, ideia também embrionária em Marx (2008), de fundamental importância à noção de formação econômico-social, pois Lênin aponta que na escala mundial coexistem níveis de desenvolvimento díspares, o que ocorre igualmente no interior dos países capitalistas - a exemplo das regiões -, acarretando uma redefinição dos princípios revolucionários do marxismo, haja vista a impossibilidade de uma revolução simultânea em todos os países. Em resumo, "significa que as forças produtivas, as relações sociais e as superestruturas (políticas, culturais) não avançam igualmente, simultaneamente, ao mesmo ritmo histórico". (LEFEBVRE, 1969, p. 225-226)

Martins (1996), ao discutir o pensamento lefebvriano acerca de Marx e Lênin, discorre sobre a noção de FES, que objetiva indicar o tempo das relações sociais, pois embora "nascidas" em momentos históricos diferentes, coexistem entre si assimetricamente numa relação de "descompasso e desencontro". Ainda segundo Martins, Lefebvre encontra uma relação entre o espacial e o temporal, sugerida nos textos marxianos, e sua interpretação sobre a noção de formação econômico-social se distancia e se alarga em relação à visão marxista de caráter economicista, que via na lei do desenvolvimento desigual uma gradação de riqueza sintetizada na dicotomia simplista entre desenvolvimento e subdesenvolvimento. Isto porque:

Lefebvre entende que a desigualdade dos ritmos do desenvolvimento histórico decorre do desencontro que na práxis faz do homem produtor de sua própria história e, ao mesmo tempo, o divorcia dela, não o torna senhor do que faz. Sua obra ganha vida própria, torna-se objeto e objetivação que subjuga em renovada sujeição o seu sujeito. A formação é econômica e social porque abrange simultaneamente esses dois âmbitos da práxis: a natureza (o econômico) e a sociedade (o social). O homem age sobre a natureza na atividade social de atender suas necessidades. Constrói relações sociais e concepções, ideias, interpretações que dão sentido àquilo que faz e àquilo de que carece. Reproduz, mas também produz - isto é, modifica, revoluciona - a sociedade, base de sua atuação sobre a natureza, inclusive a sua própria natureza. Ele se modifica, edifica a sua humanidade, agindo sobre as condições naturais e sociais da sua existência, as condições propriamente econômicas. (MARTINS, 1996, p. 19)

Esta visão de Lefebvre, apropriada por Martins (1996), abre várias possibilidades quanto ao desenvolvimento desigual do tempo (história) e do espaço (geografia), pois esse último materializa as temporalidades coexistentes e provenientes de relações sociais de momentos diversos. 
A dimensão espacial da formação econômico-social foi discutida por diversos geógrafos brasileiros como Santos (1977), Moraes (1982), Silva (1991) e Moreira (2007).

Um dos precursores desse debate no Brasil foi Milton Santos (1977) que critica o interesse significativo da Geografia pela forma em detrimento da formação, desconsiderando o dinamismo social que produz e metamorfoseia as formas. Por compreender que existe uma relação umbilical entre a história e o espaço, o autor considera a formação econômico-social como uma categoria fundamental para a proposição de uma teoria do espaço social, visto que se refere ao processo de diferenciação das sociedades internamente e em relação às forças externas. A base explicativa corresponde à produção, para a qual o trabalho do homem é central na transformação do espaço de acordo com leis historicamente definidas. Nesse sentido não é possível pensar em formação econômico-social (FES) sem uma base espacial, daí o autor propor a ideia de Formação Econômica, Social e Espacial (também usa as expressões formação espacial e formação socioespacial).

As FESs permitem o conhecimento de uma sociedade na sua totalidade e em suas frações, sem perder de vista o desenvolvimento societal. Seu estudo genético possibilita reconhecer as similaridades entre as FESs, assim como a especificidade de cada uma, distinguindo-as e em seu interior apreendendo o particular como uma parte do todo, um momento deste, o qual, por sua vez, se reproduz nessas frações. Como a sociedade é mutável suas funções são igualmente dinâmicas, logo, apresentam formas que se alteram de acordo com o movimento totalizador da formação econômico-social que se articula ao modo de produção (SANTOS, 1977).

Em termos metodológicos, o modo de produção se refere ao todo que se apresenta como a possibilidade de realização e as FESs são partes desse todo, correspondem à realização da possibilidade, sua dimensão concreta. Na verdade, existe uma indissociabilidade entre Modo de Produção (MP), FES e espaço, visto que os processos que engendram o MP (sejam eles produção, circulação, distribuição e consumo) são definidos historicamente e espacialmente em um movimento uníssono materializado em uma formação social, que contém o complexo das distintas formas técnicas e organizacionais da produção, referente às variadas relações de produção existentes que possuem uma referência espacial - aliás, a diferenciação dos lugares é resultado do arranjo espacial dos MPs particulares, que, consequentemente, vão apresentar um "valor" distinto de acordo com os níveis qualitativos e quantitativos dos modos de produção e suas combinações. Em termos gerais, "os modos de produção escrevem a História no tempo, as formações sociais escrevem-na no espaço, compreendem a sua dimensão particular e concreta” (SANTOS, 1977, p. 88). 
Essas contribuições vão influenciar os demais autores supracitados, embora em graus variados. Moraes (1982) propõe que a aproximação entre a geografia e o materialismo histórico deve ser balizada em termos metodológicos e com base na teoria do conhecimento, atendo-se ao procedimento analítico e explicativo e a questões de princípios e de posicionamento frente à realidade. Para esse fim, Lukács (1970) fornece importantes considerações metodológicas. Apesar de não tratar do espaço de maneira mais direta, discute questões gerais acerca de método, concepção, possibilidade de estudar os sujeitos individualizados, de existência e formas de manifestações específicas. Isso porque a proposta lukacsiana se fundamenta na gnoseologia da existência, indicando a anterioridade do ser em relação à consciência, logo, o pensamento é colocado como uma apropriação humana do real mediada pelo trabalho. A realidade e o conhecimento são dinâmicos, por isso o saber é aproximado, sendo absoluto e relativo. Nesse sentido, a reflexão tem como critério de validade a existência (não fragmentada) do seu objeto no real que deve ser apreendido numa perspectiva genética, em que se pesquisam as relações em suas formas fenomênicas e se observa em quais condições essas formas podem vir a ser mais complexas e mediatizadas, sempre considerando as conexões e não suas partes isoladas. A ciência, assim, é construída no processo de trabalho no momento em que se estabelece no homem a consciência da causalidade do mundo exterior. O trabalho, por seu turno, tem uma perspectiva finalista (teleológica) e em seu ato, ação e pensamento se diferenciam, sendo o último uma interioridade do sujeito, a qual deve se sujeitar à causalidade do mundo exterior para concretizar seus objetivos, e que necessita realizar um planejamento e uma avaliação anterior a sua materialização no real. Ao materializar um produto (segunda natureza) por meio do trabalho, a consciência objetiva-se.

Com base nesses elementos, Moraes (1982) propõe uma ontologia do espaço, a qual enquanto natureza em si (orgânica e inorgânica) é a realidade em que se forma o ser social, que por meio do trabalho teleológico transforma o mundo exterior, conferindo-lhe uma marca e tornando funcionais para o homem os objetos naturais. Com o desenvolvimento das forças produtivas, a partir da elevação do pensamento, ao construir categorias particulares e conexões mais mediatizadas, há um afastamento da primeira natureza e chega-se a uma consciência do espaço coletivo e da demarcação territorial (emergem noções como distância, fronteira, extensão etc. que são inferências da prática). A apreensão do espaço se realiza pela apropriação, entendida como uma categoria histórica concreta, remetendo à natureza em movimento, historicizada e transformada. Nesse sentido, a natureza é vista como potencialidade da apropriação humana, com o intuito de satisfazer suas necessidades. "O ser é 
apreendido como o processo histórico-concreto de valorização do espaço, parte movente movida da totalidade social" (MORAES, 1982, p. 50). Sua especificidade é definida na existência de marcos territoriais (formas históricas de valorização do espaço que funcionam como forças produtivas da sociedade) que condicionam determinadas relações sociais em decorrência da sua organização espacial, a qual é igualmente engendrada por relações sociais.

Entendendo o ser como a valorização do espaço, devem-se considerar as mediações em que o modo de produção lhe define o movimento. Assim, Moraes (1982) diferencia o "valor do espaço" e o "valor no espaço". No primeiro caso o valor corresponde à potencialidade natural e no segundo o valor é criado, resultado do trabalho. Ambos se manifestam em unidade visto que:

a substantivação de um dado potencial implica no dispêndio de uma quantidade de trabalho que se materializa no espaço. Porém, se o móvel que condiciona a apropriação de uma dada porção do globo estiver numa ou noutra forma de valor, o resultado e a dinâmica do processo de apropriação serão diferentes. (MORAES, 1983, p. 51)

Moreira (2007), por seu turno, compreende que o espaço corresponde a uma entidade que reúne dois processos importantes para a análise de uma formação econômico-social, a saber: a produção social e o controle de suas instituições e relações de classes. Para o autor, o processo que produz o espaço geográfico é o mesmo que produz a formação econômicosocial, e, por esse motivo, apresenta estrutura e leis de movimento desta, consequentemente, denominada de formação espacial ou formação socioespacial, tal qual propôs Santos (1977). A formação espacial apresenta a estrutura e está contida na formação econômico-social, em uma relação dialética que possibilita, pelo conhecimento da estrutura e dos movimentos da formação espacial, compreender tais elementos da formação econômico-social. Dessa maneira, é perceptível, por meio dos objetos que compõem o arranjo espacial, a aglutinação do espaço e das relações que compõem a estrutura da formação econômico-social, evidenciando que esses elementos do arranjo espacial adentram uma lógica que reproduz aquela do modo de produção a que pertencem. Esses objetos espaciais só podem ser apreendidos no interior da totalidade social, devendo-se distinguir as relações sociais que a originam e lhes ordenam. Assim, o arranjo espacial corresponde à estrutura da totalidade social, logo, o conhecimento das leis que definem o processo de reprodução social, base da totalidade, é que deve ser suporte da análise espacial; assim, o arranjo espacial revela as leis da reprodução social.

A formação espacial resulta de dois conjuntos de interações que se articulam, a saber: a interação homem-meio e as interações homem-homem. Salientamos que os homens se 
relacionam com a natureza através das relações sociais desenvolvidas por eles no processo de produção de bens necessários à existência, dos quais o trabalho é o elemento mediador que transforma a natureza. Portanto, a análise da formação espacial refere-se igualmente a do processo do trabalho dentro da produção. "A formação espacial é o todo estrutural do espaço produzido" (MOREIRA, 2007, p. 67). Isso porque os homens suprem suas necessidades convertendo terra em vida por meio do trabalho social.

O arranjo espacial proveniente dessa formação socioespacial materializa os objetos produzidos e acumulados no processo de desenvolvimento das sociedades, em termos técnicos e intelectuais. E para que essa produção seja contínua é imprescindível que o ato de produzir resulte em bens de consumo e bens que possibilitem a continuidade da produção. Esta pode ser simples (quando é repetida nas mesmas proporções ano após ano) ou ampliada (ao se repetir de maneira mais ampla a cada ano), sendo a última modalidade a responsável pelo aumento da riqueza . Nesse processo, o espaço apresenta uma significativa participação, visto que os objetos do arranjo espacial são os elementos que dispõem os homens em termos de condições de reprodução. Logo, o controle sobre esses meios de reprodução são bastante disputados em termos de exercício de poder dentro da formação econômico-social (MOREIRA, 2007).

Os objetos espaciais no modo de produção capitalista são meios de produção e reprodução do capital, em outros termos, correspondem aos meios pelos quais a força de trabalho, ao produzir mercadoria, produz mais-valia e sua incorporação ampliada ao capital. Desta feita, o controle desses objetos implica o controle da reprodução da sociedade capitalista. A formação espacial materializa a luta entre capital e trabalho pelo controle dos meios e modos de reprodução - inicialmente porque a extração de elementos da primeira natureza garante a reprodução sob a forma de matéria-prima ou capital circulante, posteriormente porque por meio da recriação de condições geográficas de reprodução se dinamiza a reprodução do capital fixo. Por fim, o uso do capital circulante e fixo resulta na reprodução da sociedade capitalista. A permanência da ordem espacial garante a reprodução ampliada da sociedade na história em termos de uma existência duradoura, clarificando o vínculo umbilical entre formação espacial e formação econômico-social (MOREIRA, 2007).

A produção de bens é decorrente das necessidades de consumo, salientando que a produção e o consumo são regidos por leis historicamente determinadas da sociedade, próprias de cada modo de produção, ratificando que os bens provenientes da produção desaparecem no momento do consumo, logo, esta precisa ser refeita continuamente para que exista a reprodução. Aqui se colocam as articulações das instâncias que definem como 
formação econômico-social uma sociedade determinada e dessas instâncias com a formação espacial enquanto totalidade na História. Na sociedade capitalista existe uma estrutura social de classes que definirá o processo da formação econômico-social em geral, sobremaneira no processo de produção: ao se reproduzirem as relações econômicas existentes, se reproduzirá igualmente a estrutura de classes em geral, e para a sua continuidade se faz necessária a superestrutura com suas relações sociais, jurídicas, políticas, ideológicas e culturais que possibilitam a perpetuação da infraestrutura (economia) (MOREIRA, 2007).

Nesse contexto, a formação econômico-social é estruturada por três níveis de relações (instâncias), quais sejam: a infraestrutura referente à instância econômica, e duas relativas a superestruturas (instância jurídico-política e instância cultural-ideológica). Essas instâncias se articulam e se diferenciam. Se não, vejamos.

$\mathrm{Na}$ instância infraestrutural (econômica), o espaço apresenta um arranjo espacial econômico, que resulta da forma como se exprimem no interior desta instância as forças produtivas e as relações de produção. As primeiras articulam a força, os objetos e os meios de trabalho: estes dois últimos são os meios de produção, enquanto as forças produtivas diferenciam-se entre forças de trabalho e meios de produção. Apenas "quando a força de trabalho põe os meios de produção em movimento é que as forças produtivas se unificam e ganham vida como um todo, efetivamente atuando como forças" (MOREIRA, 2007, p.71). Assim, o espaço se situa como força produtiva de duas maneiras: objeto de trabalho (primeira natureza) e meio de trabalho (segunda natureza). Há uma simbiose entre as relações de produção e o conjunto das forças produtivas, o que dá lugar a uma contradição à medida que as relações de produção regulam e definem o movimento de conjunto das forças produtivas, organizando-as como meios de reprodução, liberando ou não o seu desenvolvimento, contraditando o grau de desenvolvimento das forças produtivas e o controle das relações de produção. No capitalismo há um alto grau de desenvolvimento das forças produtivas, pois há uma forte mediação da técnica na relação entre homem e natureza, o que gera uma ampla divisão social e territorial do trabalho. Incluem-se aí as relações de produção que se expressam a partir da relação de propriedade, ou seja, a força de trabalho pertence ao trabalhador, que a vende em troca dos meios de subsistência; ao passo que os meios de produção são da burguesia, que necessita da força de trabalho para transformar esses meios em forças produtivas; para tanto, a burguesia compra essa força, de modo que, ao fundir a totalidade das forças produtivas, leva-as a produzir mais-valia. Essas relações de propriedade vão se transformando no interior do movimento da produção capitalista, logo, diferenciam-se e multiplicam-se em outras formas, a exemplo da relação de trabalho, de troca, dentre outras, 
o que complexifica as relações de produção, que uma vez configuradas como espaço fazemno instância de regulação das relações sociais (MOREIRA, 2007).

Instâncias superestruturais (jurídico-política e cultural-ideológica): há uma relação entre a regulação do espaço e a instância superestrutural, que leva à apreensão de um arranjo espacial jurídico-político e de um ideológico-cultural em termos de paisagem. As instâncias superestruturais mobilizam o espaço como forma de controlar possíveis conflitos que adentram os processos econômicos mediante as contradições estruturais do sistema capitalista. O arranjo espacial jurídico-político é sobremaneira regulado pelo Estado com objetivos diversos, a exemplo da regulação das relações entre classes ou frações de classes sociais, conquista de territórios, alocação do capital, dentre outros, mostrando seu vínculo demasiado com a infraestrutura. O arranjo espacial ideológico, por sua vez, apresenta as instituições pelas quais os valores são veiculados, reproduzidos e assimilados no interior da sociedade, como escola, igrejas, prisões etc. Espaços específicos que sintetizam o todo, desenvolvendo as noções de mundo e hierarquia, em múltiplas escalas (MOREIRA, 2007).

Em suma, para Moreira (2007), a formação espacial, enquanto um conceito de totalidade, pode auxiliar na análise das formas de organização das sociedades nos diversos tempos da História. Torna-se necessário descortinar a essência nas aparências, apreendendo as leis que regulam as formas ou estruturas, tal qual o arranjo espacial, compreendido como uma estrutura de objetos espaciais que apresentam uma localização-distribuição que possibilita uma descrição e uma análise, da qual se pode depreender a formação espacial.

Silva (1991) também busca debater o caráter ontológico do espaço, que se coloca como uma subtotalidade, uma formação. Logo, constitui um objeto apreendido pela consciência. Salientamos que a formação apresenta a forma e o processo, sendo o lugar a expressão mais elementar da geografia em sua objetivação enquanto espaço-terrestre, mas que se manifesta como território, região e área - portanto, como forma -, e é igualmente uma totalidade de relações de localização, desta feita, é um complexo de formas que se materializam como relações, portanto como processos. "Daí que formação é um ser (forma e processo) que é e vem a ser, como resultado do trabalho, determinação do modo de produção" (SILVA, 1991, p.107).

A formação é matéria, mas também produção social tal qual o modo de produção que em sua manifestação natural e social só podem ser explicados como formações acrescidas de suas particularidades e singularidades, por essa razão são construções lógico-reais que possibilitam a apreensão do natural e do social. "As formações naturais e sociais supõem o trabalho e, por isso, relações de produção [...]. Então, a formação geográfica põe-se como 
lugar e, desde logo, como habitat e habitar" (SILVA, 1991, p. 108). Todavia corresponde igualmente ao lugar de trabalho, consumo e circulação. Em suma, a formação natural-social é uma manifestação geográfica do modo de produção, pois exprime sua particularidade e singularidade em termos de recortes do real. Possui uma determinação originária: "seu ser é posto como contradição de momentos do movimento" (SILVA, 1991, p. 108), concorrendo para que a formação possua uma limitação temporal de existência definida na espacialidade do modo de produção. "A formação geográfica se põe, então, como organização do espaço: organização em si e organização para o homem. Daí como valor em si e valor para outro" (SILVA, 1991, p. 108).

Silva (1991) trabalha a ideia de formação espacial com base nas proposições de Moraes (1982) e de Moreira (2007), porém busca discutir a noção de formação social pautada nas interpretações de Hindess e Hist (1978) e a relação entre FES e MP baseado em Thiollent (1976), Luporini (1976), Sereni (1976), Dhoquois (1976), Texier (1976) e Labica (1976). Para fazer sua proposição de relacionar a formação social ao espaço, empresta o argumento de Castells (1977), que faz uma reflexão sobre o espaço como base material indispensável ao desenvolvimento das atividades humanas, mas que, como uma grandeza física, não diz muito sobre as relações sociais. Porém, enquanto espaço construído historicamente pelas relações sociais, ele as condiciona, embora não as determine. Existe um significado social das mais variadas formas de espaço e sua divisão. A cada modo de produção ou estágio deste existe uma redefinição do espaço em termos teóricos e das relações concretas definidas entre os diferentes espaços. Assim, as especificidades espaciais manifestam a instância dominante de um modo de produção, que no caso do capitalismo é o econômico. Entretanto, o espaço é construído conjunturalmente, ou seja, em termos de formação social. Seguindo essa linha de raciocínio, Silva (1991) indica que a discussão empreendida por Castells (1977) é realizada paralelamente ao objeto da geografia e para considerar esse elemento retoma os argumentos de Santos (1977).

Esses autores apresentam elementos analíticos comuns, muito embora diferenças sejam perceptíveis e importantes de serem destacadas. Em termos de aproximações possuem o objetivo de construir uma teoria do espaço social a partir do debate da Formação EconômicoSocial - apesar de Moraes (1982) desenvolver a categoria particularidade a partir de Lukács (1970) - o qual expressa o caráter particular, concreto e historicamente determinado do modo de produção. Nessa mediação entre FES e espaço, este, pelo seu arranjo espacial, materializa o movimento, as leis e os elementos constituintes da FES, assim como a condiciona, ou seja, é resultado e ao mesmo tempo produz a FES, existindo uma relação dialética entre eles. Outro 
aspecto comum é a categoria trabalho como mediação entre o espaço (orgânico-inorgânico) e o homem, que para satisfazer suas necessidades transforma o espaço natural (primeira natureza) em espaço social (segunda natureza), o qual manifesta os elementos da FES e a condiciona. No caso do capitalismo, reproduzirá e condicionará (relativamente) as relações desiguais, contraditórias e conflitivas entre as classes sociais - o aspecto do conflito foi mais bem explorado por Moreira (2007).

Entretanto, questionamentos devem ser tecidos, isto porque algumas lacunas ficaram no meio do caminho, as quais são provenientes do momento histórico em que os textos foram produzidos e a filiação filosófica e teórica (muitas vezes eclética) assumida pelos autores. Santos (1997), por exemplo, segundo Peet (1996), apresenta em sua proposição uma síntese de distintas matrizes epistemológicas, dentre as quais destaca a influência do existencialismo sartreano ao observar a "materialidade local exercendo um efeito sobre os seres humanos numa espécie de inércia-dinâmica; condicionada pelo espaço, a práxis humana é forma realmente ativa que recria o espaço" (PEET, 1996, p.165); mas Peet também torna visível o peso do estruturalismo althusseriano - embora Milton Santos criticasse seu viés economicista - ao relacionar a autonomia relativa de Althusser ao espaço e a suas relações. Ainda de acordo com Peet, essas ideias na época (1970-1980) eram revolucionárias, possibilitando a integração sofisticada do marxismo a outras teorias sociais. Entretanto, o que resulta desse ecletismo?

Sócrates (2016), ao discutir epistemologicamente o debate da categoria trabalho na geografia brasileira, descortina algumas incongruências analíticas nos autores supracitados, isto porque, no intuito de combater a fragmentação disciplinar oriunda da crise sofrida pelas ciências no fim dos anos 1950 e começo da década de 1960, a ciência geográfica apresenta soluções "internalistas" com proposições que vão desde uma perspectiva mais aplicada e manualística, com formas fenomenológicas que se aproximam de proposições lógicoidealistas, até uma crítica do trabalho distante dos problemas socioeconômicos reais, conservando uma "aglutinação eclética" cujo sistema, salvaguardado pelo nome de dialético, não apresenta contradição.

As proposições de articular FES e espaço pouco adentram na luta de classes que produzem as contradições bastante discutidas por Lênin (1955) e Gramsci (1987) e que definirão a produção do espaço, no capitalismo, marcada por encontros-desencontros espaçotemporais conforme propõem Lefebvre (1969) e Martins (1996), os quais são produtos de ritmos sociais desencontrados que expressam a multiplicidade de sujeitos e escalas de atuação, nos quais se apresentam o Estado, latifundiários, empresas, mas igualmente ribeirinhos, quilombolas, posseiros, sem-terra etc. 
Essa perspectiva da noção de FES na produção do espaço será retomada no capítulo II, no qual se salienta a dimensão do conflito, que, por esse motivo, vamos tratar como formação territorial. No momento, é importante colocar em relevo que a FES é imprescindível ao debate da hegemonia, discutir como a FES apresenta importância na construção do espaço e viceversa e, como a hegemonia, igualmente realizada pelo conflito, manifesta também uma base territorial.

É nesse sentido que iremos discutir o conceito de hegemonias a partir de Gramsci, sublinhando a sua dimensão territorial, a qual subsidiará a compreensão dos movimentos sociais.

\subsection{CONCEITO DE HEGEMONIA E AS CONTRIBUIÇÕES GRAMSCIANAS}

O conceito hegemonia, proposto por Gramsci (1968), trabalha a noção de FES ao discutir sobre o "Oriente" e o "Ocidente", fazendo uma reflexão sobre as condições da revolução nestas duas realidades. Em suas palavras:

Parece-me este o significado da "frente única" [...]. Só que Ilitch não teve tempo de aprofundar sua fórmula, mesmo considerando que ele só podia aprofundá-la teoricamente, quando, ao contrário, a tarefa fundamental era nacional, isto é, exigia um reconhecimento do terreno e uma fixação dos elementos de trincheira e de fortaleza representados pelos elementos de sociedade civil etc. No Oriente, o Estado era tudo, a sociedade civil era primitiva e gelatinosa; no Ocidente, havia entre o Estado e a sociedade civil uma relação apropriada e, ao oscilar o Estado, podia-se imediatamente reconhecer uma robusta estrutura da sociedade civil. O Estado era apenas uma trincheira avançada, por trás da qual se situava uma robusta cadeia de fortalezas e casamatas; em medida diversa de Estado para Estado, é claro, mas exatamente isto exigia um acurado reconhecimento de caráter nacional (GRAMSCI, 1968, p. 74-75).

Existe uma diferença qualitativa quanto à forma de interação entre Estado (sociedade política) e sociedade civil no "Oriente" e no "Ocidente" que advém das diferenciações provenientes de formações sociais distintas em nível político, econômico e cultural. Portanto, para Gramsci (1968), no Oriente, a sociedade civil ainda era pouco organizada e frágil, ao passo que, no Ocidente, a sociedade civil detinha uma maior autonomia em relação ao Estado, gozando de uma articulação mais complexa, e o Estado desenvolvia uma teia de relações cada vez mais amplas.

\footnotetext{
${ }^{4}$ Ilitch se refere ao pensador russo Vladimir Ilitch Lênin.
} 
Para autores como Simionatto (2011), Costa (2011) e Coutinho (2001), “Oriente” e "Ocidente" não se tratavam de conceitos geográficos, mas sim histórico-políticos. Entretanto, é importante lembrar que toda relação social se expressa espacialmente. Baratta (2011), ao discutir criticamente o trabalho de Said (2003) sobre Gramsci, concorda com ele acerca da consciência geográfica dos estudos gramscianos, produzindo uma análise coerente a partir de formações e experiências díspares que não podem ser enquadradas em um esquema de equivalências, devido às especificidades e identidades territoriais.

Não podemos esquecer-nos do clássico trabalho de Gramsci, Alguns temas da questão meridional, no qual já se esboçam elementos que definirão o conceito de hegemonia, ou seja, a necessidade de construção de alianças entre o operariado do Norte italiano e os camponeses do Sul, destacando-se a direção emancipatória do proletariado na condução da "hegemonia proletária”, marcada pela solidariedade e não pela verticalidade das relações entre as classes. Pois, para Gramsci (1987, p. 139, grifo nosso), “o proletariado pode se tornar classe dirigente e dominante na medida em que consegue criar um sistema de alianças de classes que lhe permita mobilizar contra o capitalismo e o Estado burguês a maioria da população trabalhadora [...]", mediante o consenso dessa população. Nesse texto, o autor "geografiza" as relações sociais, analisando as relações de poder existentes entre as porções Setentrionais e Meridionais da Itália que não tem a ver com uma perspectiva cartográfica (de localização simplesmente), mas de que maneira nessas realidades produzem-se desigualdades espaciais que, ao invés de polarizá-las, tal qual faziam os intelectuais da burguesia, constituem uma questão nacional, pois são produtos das formas de dominação (coerção) e direção (consenso) da burguesia que se articulava aos proprietários rurais.

Gramsci (2014a), ainda ao debater sobre as significações que o problema da realidade exterior pode vir a suscitar, retoma a ideia de "Oriente" e "Ocidente" para indicar que estas são noções objetivas, embora sejam produtos de uma convenção social, ou melhor, são construtos histórico-culturais. Seguindo suas argumentações, adverte:

Que significaria Norte-Sul, Leste-Oeste, sem o homem? Elas são relações reais e, contudo, não existiriam sem o homem e sem o desenvolvimento da civilização. É evidente que Leste e Oeste são construções arbitrárias, convencionais, isto é, históricas, já que fora da história real qualquer ponto da terra é simultaneamente Leste e Oeste. Isto pode ser visto mais claramente pelo fato de que estes termos se cristalizaram, não a partir do ponto de vista de um hipotético e melancólico homem em geral, mas do ponto de vista das classes cultas europeias, que, através de sua hegemonia mundial, fizeram com que fossem aceitos por toda parte. O Japão é Extremo Oriente não só para a Europa, mas talvez também para o americano da Califórnia e para o próprio japonês, o qual, através de cultura política inglesa, poderá chamar o Egito de Oriente Próximo. Assim, através do 
conteúdo histórico que se anexou ao termo geográfico, as expressões Oriente e Ocidente terminaram por indicar determinadas relações entre conjuntos de civilizações diversas. (GRAMSCI, 2014a, p. 137-138)

Esse texto revela a preocupação de Gramsci com a objetividade do real, ou ainda, a objetividade do mundo exterior, e destaca a relação umbilical entre o racional e o real, indicando igualmente que as ciências e suas categorias analíticas são construtos da sociedade, portanto, historicamente determinadas e dinâmicas, e, por isso, não estão fora da disputa ideológica das classes sociais - daí a referência europeia, naquele contexto hegemônica, para a definição de "Oriente" e "Ocidente" ou Leste-Oeste.

Para Gramsci (2014a), "Oriente" e "Ocidente” não são pontos estanques no mapa e, sim, processos sociais que apresentam uma contraposição diacrônica, uma vez que países orientais podem vir a sofrer processos de ocidentalização (COUTINHO, 2001). Embora a geografia não fosse uma preocupação epistemológica para Gramsci, com certeza seus temas suscitam um debate espacial, especialmente o conceito de hegemonia, conforme discutiremos posteriormente.

Com base nessa ideia de "Oriente" e "Ocidente", Gramsci (2001) elabora os conceitos de "guerra de posição" e "guerra de movimento". No caso das sociedades orientais a questão central da luta de classes reside na tomada do Estado, ou seja, na guerra de movimento ou guerra manobrada de ataque frontal ao poder.

Nas sociedades ocidentais, se faz necessária a conquista da hegemonia no seio da sociedade civil - em outros temos, utiliza-se a guerra de posição, isto porque nos Estados considerados mais avançados “onde a 'sociedade civil' tornou-se uma estrutura muito complexa e resistente às 'irrupções' catastróficas do elemento econômico imediato (crises, depressões etc.); as superestruturas da sociedade civil são como o sistema das trincheiras na guerra moderna". (GRAMSCI, 2001, p. 73)

Nesse sentido Gramsci (2014b) inova com relação ao conceito de hegemonia, o qual se expressa por parte de um grupo social ao exercer "domínio" e "direção" intelectual e moral. De um modo geral, por um lado, esse grupo domina os demais, submetendo-os às suas determinações de forma coercitiva ou pelo consenso. Por outro, dirige os grupos com os quais desenvolve alianças. Essa direção deve ser construída antes mesmo da conquista governamental e, quando esta ocorre, não se deve abdicar do papel dirigente.

Essa concepção de hegemonia se atrela ao que Gramsci (2001) denomina de Estado ampliado, o qual, para além de sua face governamental, se expressa pelo aparelho privado de hegemonia ou sociedade civil - em outros termos, não se limita à sociedade política "ou 
ditadura, ou aparelho coercitivo, para moldar a massa popular segundo o tipo de produção e a economia de um dado momento" (GRAMSCI, 2005, p. 84), ao passo que existe uma relação de "equilíbrio" entre a sociedade política e a sociedade civil "ou hegemonia de um grupo social sobre toda a sociedade nacional, exercida através de organizações ditas privadas, como a Igreja, os sindicatos, as escolas etc." (GRAMSCI, 2005, p. 84). De acordo com Schlesener (2007), o aparelho privado ${ }^{5}$ de hegemonia é assim denominado por apresentar relativa autonomia em relação à sociedade política e só emerge com as revoluções democráticoburguesas, constituindo-se em instituições nascidas da correlação de forças sociais que resultaram nesses novos Estados, do aumento da participação política dos cidadãos, dos conflitos atrelados ao desenvolvimento do modo de produção capitalista materializados em sindicatos, partidos, dentre outros, do sistema escolar em seus vários níveis e das Igrejas, além de organizações tradicionais que se reorganizaram em função do novo momento histórico.

Desta feita, o exercício do poder (hegemonia) é realizado pela confluência das funções da sociedade política e da sociedade civil, sendo a primeira responsável pelo "domínio" (coerção) e a segunda pela direção da sociedade mediante o consenso, com o intuito de legitimar o poder. (SCHLESENER, 2007)

A hegemonia remete às relações entre infraestrutura e superestrutura ou à maneira como as classes sociais se inter-relacionam e exercem suas funções no interior do bloco histórico (sistema de alianças desenvolvidas entre as classes sociais) (SIMIONATTO, 2011). Nesse bloco histórico existe a correlação de forças na qual se disputa a direção, concorrendo para o aparecimento de uma crise de hegemonia da classe dominante à medida que esta perde o consenso. Dessa forma, deixa de ser dirigente e se torna apenas dominante, utilizando-se sobremaneira da força coercitiva, visto que as massas populares estão em vias de se desvencilharem das ideologias tradicionais, desacreditando das ideais dominantes. "A crise consiste justamente no fato de que o velho morre e o novo não pode nascer: neste interregno, verificam-se os fenômenos patológicos mais variados" (GRAMSCI, 2001, p. 184).

Com relação às vias de se sanar essa crise, colocam-se duas possibilidades. De um lado, a reestruturação da classe dominante mediante a coerção, visto que a deflagração contínua da brutalidade implica, em longo prazo, um ceticismo difuso, podendo surgir uma

\footnotetext{
5 O "privado" dos aparelhos de hegemonia se refere ao fato de que a adesão aos mesmos ocorre de maneira voluntária e não coercitiva, manifestando uma face relativamente autônoma em relação a sociedade política. É importante frisar que "Gramsci põe o adjetivo 'privado' entre aspas, querendo com isso significar que - apesar desse seu caráter voluntário ou 'contratual' - eles têm uma indiscutível dimensão pública, na medida em que são parte integrante das relações de poder em dada sociedade (COUTINHO, 1994, 54-55).
} 
nova combinação, com o recrudescimento do pensamento antigo (como o religioso). Por outro, pode haver condições favoráveis para a expansão da hegemonia das classes anteriormente dominadas com a construção de outra direção (consenso) e de um novo domínio.

Nessa correlação de forças, Gramsci (1968) distingue três momentos ou graus, a saber:

1. a relação de forças sociais está articulada à estrutura, sendo independente da vontade dos homens. “À base do grau de desenvolvimento das forças materiais de produção estruturam-se os agrupamentos sociais, cada um dos quais representa uma função e ocupa uma posição determinada na produção" (GRAMSCI, 1968, p. 49). Essa relação constitui uma realidade rebelde, sendo esse dispositivo fundamental para avaliação das condições necessárias para a sua transformação, permitindo o controle do grau de realismo e de viabilidade das várias ideologias que resultou no seu desenvolvimento;

2. o segundo momento corresponde ao da relação de forças políticas, na qual se realiza a "avaliação do grau de homogeneidade, de autoconsciência e de organização alcançado pelos grupos sociais" (GRAMSCI, 1968, p. 49). Esse momento, por seu turno, apresenta diferenciação de grau, referente aos momentos diversos da consciência política coletiva no âmbito da história. O primeiro grau é denominado de econômico-corporativo, e por ele se avalia a solidariedade de classe, "sente-se a unidade homogênea do grupo profissional e o dever de organizá-la, mas não ainda a unidade do grupo social mais amplo" (GRAMSCI, 1968, p. 49). O segundo grau compreende a tomada de consciência sobre a necessidade de confluência de interesses entre todos os membros do grupo social, ainda que no âmbito econômico. O Estado aparece como meio de se conquistar uma igualdade político-jurídica em relação aos grupos dominantes, reivindicandose direitos de participação na vida política, alçando modificá-la ainda que nos parâmetros existentes. O terceiro grau corresponde ao da conscientização de que os "próprios interesses corporativos, no seu desenvolvimento atual e futuro, superam o círculo corporativo de grupo meramente econômico, e podem e devem tornar-se os interesses de outros grupos subordinados" (GRAMSCI, 1968, p. 49). Essa fase sublinha a passagem da estrutura para a esfera das superestruturas complexas, em que as ideologias produzidas anteriormente se tornam "partido" e se confrontam até que uma delas ou a combinação de várias se confirme preponderante, difundindo-se em todos os meandros da sociedade, definindo a 
unidade econômico-política e intelectual-moral. Com efeito, as questões em torno das quais gravitam as lutas não se colocam mais em um plano corporativo e sim "universal", emergindo a hegemonia de um grupo social fundamental em relação aos outros grupos subalternos. O Estado se transforma no organismo difusor dessa hegemonia em um plano "universal".

3. O último momento é o da relação de forças militares criando mecanismos defensivos e decisivos em instantes determinados.

$\mathrm{O}$ caso específico da passagem do momento econômico-corporativo para o éticopolítico, fundamental para a construção do bloco histórico ${ }^{6}$, é definido por Gramsci como "catarse":

Pode-se empregar a expressão "catarse" para indicar a passagem do momento meramente econômico (ou egoístico-passional) ao momento éticopolítico, isto é, a elaboração superior da estrutura em superestrutura na consciência dos homens. Isto significa, também, a passagem do "objetivo ao subjetivo" e da "necessidade à liberdade". A estrutura, de força exterior que esmaga o homem, assimilando-o e o tornando passivo, transformando-se em meio de liberdade, em instrumento para criar uma nova forma ético-política, em origem de novas iniciativas. A fixação do momento "catártico" torna-se assim, parece-me, o ponto de partida de toda a filosofia da práxis; o processo catártico coincide com a cadeia de sínteses que resultam do desenvolvimento dialético. (2014a, p. 314-315)

Esse momento ético-político inauguraria a transformação de uma condição passiva dos grupos subalternos para a construção de outra hegemonia (proletária) mediante uma ação coletiva e com uma direção baseada no consenso ativo, na participação da massa e na autoorganização, e não pelo consenso passivo (manipulador) da hegemonia burguesa.

A transição esboçada acima deveria partir do papel dirigente do partido, considerado por Gramsci (1968) o moderno príncipe, fazendo alusão à Maquiavel. O partido, salvaguardando as particularidades internas das nações, pode vir a fundar um novo Estado de acordo com as condições materiais e determinações históricas. Esse partido é resultado da ação de um grupo social, mas em condições específicas os partidos podem se aglutinar ao redor de um único grupo ao exercerem uma função de equilíbrio e arbitragem em relação aos

\footnotetext{
${ }^{6}$ Para Urquidi (2007) existe uma diferença entre bloco histórico e massa, pois o primeiro se refere a formação de blocos sociais gravitando em torno de uma classe fundamental, enquanto a massa se compõe de outros sujeitos que não são necessariamente limitados ao proletariado ou a burguesia. Mas ao mesmo tempo a massa corresponde a um componente do bloco histórico, ou seja, "a massa seria um tipo de intersubjetividade composta por várias classes, a partir da centralidade de uma delas, no momento da crise, e constituída num bloco histórico" (URQUIDI, 2007, p.124).
} 
interesses do seu próprio grupo e de outros, por meio do consenso e do estabelecimento de alianças.

O partido apresenta duas facetas: o partido da elite, que possui a função de dirigir, no âmbito cultural e da ideologia, um elevado número de partidos aliados; e o partido não alinhado à elite, mas de massas populares, não tendo outra função senão a de uma fidelidade genérica, nesse caso a massa é de "manobra" e é inundada por discursos morais. Mas em determinados momentos históricos esses grupos sociais se desvinculam de seus partidos tradicionais, abrindo espaço para ações coercitivas, porque está em curso a crise de hegemonia da classe dirigente, a qual fracassou em algum empreendimento político imposto pela força ou pela mobilização das massas que apresentam reivindicações e, mesmo desorganizadas, se rebelam. Claro está que o potencial de reorganização da classe dirigente tradicional é maior do que o processo organizativo das classes subalternas, e a classe dirigente mantém o exercício do poder mesmo que para isso faça concessões e realize promessas demagógicas. (GRAMSCI, 1968)

Em decorrência desses ritmos diferentes e do grau assimétrico de organização da classe dirigente e dos grupos subalternos, o partido assume um papel seminal na construção da hegemonia (proletária), até pedagógica, pois possui a "função, que é diretiva e organizativa, isto é, intelectual" (GRAMSCI, 2000, p. 25), possibilitando que os movimentos espontâneos (da classe subalterna) se politizem e ganhem um caráter universal e não individual (econômico-corporativista).

Liguori (2011) comenta que é em relação ao partido político de classe operária que Gramsci analisa o tema dos movimentos de massa. Essa temática é exposta por Gramsci (1968) ao tratar sobre a "espontaneidade e a direção consciente". Para o autor a ideia de "espontaneidade" é polissêmica em decorrência de o fenômeno a ela referente ser multilateral. Adverte o autor que não existe espontaneidade "pura", pois "no movimento "mais espontâneo', os elementos de 'direção consciente' são simplesmente impossíveis de controlar, não deixaram nenhum documento comprovável” (GRAMSCI, 2001, p. 194). Essa espontaneidade é comum às classes subalternas, ou ainda, aos

elementos mais marginais e periféricos destas classes, que não alcançaram a consciência de classe "para si" e que, por isto, sequer suspeitam que sua história possa ter alguma importância e que tenha algum valor deixar traços documentais dela. (GRAMSCI, 2001, p. 194)

Os movimentos "espontâneos" apresentam uma multiplicidade de elementos de "direção consciente", mas estes estão no nível da ciência popular, ou seja, do senso comum, marcado por uma concepção de mundo tradicional da classe popular. Com efeito, em todo 
movimento dessa natureza há um elemento de direção consciente, ainda que permaneça latente, primitivo, expressando-se indiretamente pela existência de grupos sociais que lutam com base no método da espontaneidade. A esse respeito, Gramsci retoma o movimento operário de Turim, cujo elemento de "espontaneidade" não foi

"negligenciado, menos ainda desprezado: foi educado, orientado, purificado de tudo o que de estranho podia afetá-lo, para torná-lo homogêneo em relação à teoria moderna, mas de modo vivo, historicamente eficiente". (2001, p. 196)

Existe, desse modo, uma unidade entre "espontaneidade" e "direção consciente", que corresponde a uma ação política concreta das classes subalternas e não apenas uma ação ingênua e voluntarista; o espontâneo aparece, nesse caso, não no sentido pejorativo, mas como uma potência:

"Espontâneos" no sentido de que não se devem a uma atividade educadora sistemática por parte de um grupo dirigente já consciente, mas que se formaram através da experiência cotidiana iluminada pelo "senso comum", ou seja, pela concepção tradicional popular do mundo, aquilo que muito simplificadamente se chama de "instinto" e que, ele próprio, é somente uma conquista histórica primitiva e elementar. (GRAMSCI, 2001, p.196-197)

Essa acepção acerca dos movimentos espontâneos deveria ser mais bem trabalhada pela teoria moderna, leia-se o partido, visto que há entre tais movimentos uma diferença de grau e não de qualidade, devendo existir uma passagem da teoria para a espontaneidade (senso comum) e vice-versa. Em outras palavras, "os movimentos 'espontâneos' dos estratos populares mais amplos tornam possível o advento ao poder da classe subalterna mais avançada em razão do enfraquecimento do objetivo do Estado” (GRAMSCI, 2001, p. 198).

Essas premissas de Gramsci são importantes para percebermos que entre o movimento espontâneo e a direção consciente existe um continuun e não uma oposição, logo o primeiro é necessário ao processo de construção da hegemonia, embora não seja suficiente, pois caberia ao partido "dar-lhes uma direção consciente, a elevá-los a um plano superior, inserindo-os na política" (GRAMSCI, 2001, p. 198). Desse modo, não poderia haver separação entre partido e movimento de massa.

Como podemos observar, a teoria construída por Gramsci acerca da hegemonia é subsidiada por noções importantes como Oriente e Ocidente, guerra de posição e guerra de movimento, Estado ampliado, sociedade política e sociedade civil, momento econômicocorporativo e momento ético-político, catarse, movimentos espontâneos e partido, dentre outros a serem devidamente explorados posteriormente. Mas sua proposição analítica do real nos remete a uma questão importante suscitada por Lefebvre (2000), e que indicamos na 
introdução deste trabalho, qual seja, se a hegemonia deixaria o espaço à parte do processo social. Para Lefebvre, existe uma relação umbilical entre espaço e hegemonia e é essa ideia que queremos discutir.

\subsubsection{A dimensão espacial da hegemonia}

Ao observarmos o trabalho de Gramsci, por um lado, de fato não notamos uma preocupação mais acurada sobre a geografia ou o espaço, pois o tempo era sua categoria principal. E Gramsci buscou compreendê-lo a partir da filosofia da práxis, concebida como uma fase transitória do pensamento filosófico, pois na sua compreensão o movimento histórico se caracterizaria pela transição do reino da necessidade ao reino da liberdade, em outros termos, a filosofia da práxis representa a consciência plena das contradições, própria do reino da necessidade, marcada por uma sociedade desigual e de classes. A filosofia da práxis coloca o próprio filósofo, individualmente ou enquanto grupo social universal, envolto na contradição. Ela "é uma expressão das contradições históricas - aliás, é sua expressão mais completa porque consciente - isto significa que [...] está ligada à 'necessidade' e não à 'liberdade' " (GRAMSCI, 2014a, p. 204-205).

Por outro, muitas interpretações gramscianas têm um fundo espacial, ao discutir, por exemplo, sobre o Oriente e Ocidente, a questão meridional, as relações internacionais e a cidade e o país. Como bem asseverou Baratta (2011, p. 37), "há de se notar que o esquema de raciocínio territorial gramsciano se aplica tanto aos grandes espaços (Norte e Sul da Itália) como aos espaços particulares (cidade e campo de toda a realidade local)". Ainda, citamos Ekers e Loftus (2012), para os quais não existiria uma redução espacial ou naturalização das relações espaciais nos Cadernos do Cárcere, visto que, para os autores, o espaço seria o momento fundamental da filosofia da práxis. Vários outros trabalhos vão enveredar nessa ideia de ver na produção intelectual de Gramsci contribuições à geografia (ver ANGELI, 1996 e SILVA, 2013).

Alguns desses trabalhos de aproximação dos estudos gramscianos com a geografia nos ajudam a entender melhor a relação entre a hegemonia e o território, ponto crucial de nosso trabalho. Se não, vejamos.

Lefebvre (1976), ao fazer uma análise crítica da obra de Gramsci, pontua alguns avanços e limites em relação ao conceito de hegemonia (burguesa), indicando que esta se expressa pela conquista de instituições, de ações pedagógicas, da ideologia, em outras 
palavras, por um árduo trabalho cultural e institucional, no qual, para além da coerção, o consenso era fundamental ao exercício de poder. A classe dominante funciona como unidade atuando no âmbito da política do Estado.

Para o autor, Gramsci apresenta insights acerca das táticas e estratégias políticas partindo das representações hegelianas de sociedade civil e sociedade política, mas realiza uma ruptura política com Hegel ao pensar esses conceitos pelo viés da filosofia da práxis. Não existe, assim, uma leitura dogmática da realidade e se oferece uma proposta original da ação, na qual o intelectual orgânico é responsável por organizar, dirigir e educar, processo no qual é igualmente educado. Além de indicar interpretações refinadas do materialismo histórico - ou melhor, sobre o conhecimento do movimento histórico, uma vez que, para o exercício do poder, o conhecimento é primordial -, o moderno príncipe usa da força do conhecimento para dominar e dirigir. $\mathrm{O}$ conhecimento sobre os interesses díspares permite uma maior habilidade de manobra desses interesses, favorecendo a conquista da hegemonia.

O conceito de hegemonia materializa seu caráter político no momento em que é concebido em toda a sua amplitude, ou seja, como interpretação do materialismo histórico. Para uma classe se tornar hegemônica deve ter uma estratégia de longo prazo e várias táticas; para construir a materialidade dessa hegemonia, necessita de um grupo ativo e coeso que maneje as condições objetivas e subjetivas, as circunstâncias e conjunturas, a situação econômica e as forças sociais, tendo o partido um papel fundamental enquanto pensador coletivo. A conquista da hegemonia perpassaria do momento econômico-corporativo ao éticopolítico, que seria uma espécie de "lei da ação", fundada com base na observação das revoluções europeias, levando Gramsci a confundir conceito histórico com conceito teórico. Além disso, há o fato de que a hegemonia (ainda que seja proletária) pode seguir em direção a uma ditadura. Lefebvre (1976) finaliza afirmando que esses aspectos não impossibilitam ver em Gramsci um pensador que teoriza sobre a vontade de poder, seu ponto forte.

É com base nessas observações acima que Lefebvre (2000) analisa a potência do conceito de hegemonia articulada ao processo de produção do espaço.

Kipfer (2008) faz uma apreciação interessante sobre as ressonâncias gramscianas na obra de Lefebvre, ao indicar como ele vai trabalhar a imersão do Estado (próximo à ideia de sociedade civil) na vida cotidiana, e, por conseguinte, realiza a sua crítica ao Estado, como uma forma potencialmente hegemônica, e à própria vida cotidiana, inundada por um modo de vida baseada na intensiva mercantilização, portanto central à reprodução do capital, na medida em que diminui as possibilidades de revolução. Porém como essa dimensão do espaço (cotidiano) não se desenvolve sem contradições, lutas políticas podem surgir. Contrariando o 
processo de homogeneização do espaço, movimentos sociais perturbam a ordem e se rebelam objetivando a diferença, a expressão de outros valores e visões de mundo, ou melhor, afirmam o direito à diferença (não aquela cooptada e manipulada pelo capital). Com efeito, enquanto Gramsci entende os projetos hegemônicos implicitamente como alianças que abrangeriam divisões espaciais em múltiplas escalas, Lefebvre articula o conceito de hegemonia com a produção do espaço, indicando que, no capitalismo avançado, a hegemonia é incompleta, inconclusa e multidimensional.

Para além das polêmicas que o texto de Kipfer (2008) suscita, o importante é mostrar que o espaço, ao ser produzido e apropriado desigualmente por classes ou frações de classes, é envolto por projetos territoriais que se (des)encontram e visam se tornar hegemônicos por meio de ações que almejam atuar nas múltiplas dimensões e escalas geográficas, estabelecendo alianças, temporárias ou não, de interesses comuns ou alinhados a uma estratégia do grupo hegemônico.

Para Jessop (2005) a filosofia da práxis de Gramsci apresenta uma face espacial e outra histórica das suas categorias analíticas. Ele apresentava um pensamento espacial, todavia não priorizava um raciocínio espacial, por isso não vai aprofundar seus insights geográficos. De acordo com o autor, Gramsci era sensível à especificidade histórica das relações sociais, mas igualmente à sua localização, diferenciando-se no lugar, no espaço e com a escala. Como esses três conceitos não são trabalhados teoricamente por Gramsci, coloca-se em evidência a relevância do seu aprofundamento para os sentidos tomados em nossa reflexão de incorporações críticas de Gramsci para a análise dos movimentos sociais do campo brasileiro.

O lugar compreendido como um local marcado por relações interpessoais desenvolvidas na vida cotidiana, prenhe de memória coletiva e identidade social - e por isso mesmo mutável ou contestado, sendo articulado a outros locais de diferentes identidades, limites e significados - foi objeto da reflexão gramsciana ao discorrer sobre o folclore, o senso comum, a cultura popular, o modo como as práticas cotidianas são definidas pela vida em diversos tipos de cidade e de campo, no projeto dos locais, nas formas construídas e nas disputas pelo controle sobre os lugares (fábricas, edifícios públicos, ruas, bairros etc.) (JESSOP, 2005).

O espaço social, por sua vez, manifesta as possibilidades estrategicamente seletivas para o desenvolvimento das relações sociais que se produzem ao longo do tempo e do espaço. Gramsci vai considerar o espaço ao debater a territorialização do poder e os processos de formação do Estado político; a divisão territorial do trabalho entre campo e cidade, norte e sul 
e economias regionais e nacionais; também nos diversos imaginários espaciais e escalares e diferentes representações do espaço. Para Gramsci, o espaço não possui autonomia das relações sociais específicas, ao contrário, estas o (re)produzem, não se deixando cair em um fetichismo espacial ou sendo seduzido pelo determinismo geográfico corrente no século XIX - isso porque o espaço é tratado em termos relacionais, especialmente no estudo acerca dos usos locais e particulares da linguística, tendendo para uma unidade territorial ou fragmentada, além das influências externas sobre as línguas nacionais. Ao debater sobre os Estados nacionais, estes são analisados em suas interações complexas com os demais Estados e as forças políticas em outras escalas, anunciando, ainda que de maneira muito incipiente, um materialismo histórico-geográfico (JESSOP, 2005).

Por fim, para Jessop (2005), a escala é definida como uma hierarquia que abriga, ou não, e limita espaços de tamanhos diversos e, também, é produto de lutas sociais por controle e poder. E Gramsci seria sensível às questões de escala, hierarquias escalares de poder econômico e político e suas manifestações territoriais e não territoriais. Sua análise se propunha a discutir a dimensão particular do espaço sem perder de vista as conexões com outras escalas; dessa forma, se debruça sobre as relações de hegemonia e dominação em nível local, regional, nacional, transatlântico e hemisférico. Assim, para além de uma hierarquia simples de escalas, partindo do local ao global, Gramsci pensou nas maneiras pelas quais hierarquias diversas, mas atreladas, de escalas atuam como uma fonte econômica, política e socioeconômica de instabilidade.

Jessop (2005) nos coloca diante da complexidade espaço-temporal que a filosofia da práxis de Gramsci suscita, indicando três conceitos que são fundamentais para a geografia e que, muito embora não fossem de interesse teórico para Gramsci, estavam subjacentes em suas análises, indicando a riqueza destas para a ciência geográfica e, principalmente, para o estudo da hegemonia.

No caso da hegemonia dos grupos capitalistas dominantes, o território é um instrumento de domínio (coerção) - seja pela exclusão que promovem em relação aos recursos (terra, água, floresta) seja pela reclusão dos grupos subalternos em periferias, que não têm o direito ao centro ou à cidade - e/ou é instrumento de direção (consenso passivo) - a propriedade privada da terra é um elemento de unidade, que desaprova qualquer ato rebelde que a conteste, afinal ela pode ser conquistada pela labuta diária, individual e pelos meios competitivos do mercado, discurso central do modelo neoliberal em curso - instrumento esse que se alastra em todas as esferas da sociedade, do cotidiano e do corpo, disciplinando-os aos ritmos programados do capital, até à esfera do Estado, que se transverte de instituições que 
arbitram as disputas pelo/no território, mas se expressa também pelos aparelhos privados de hegemonia, que objetivam a disseminação de um único projeto de desenvolvimento territorial. Entretanto, isso não se dá sem conflitos, pois o desenvolvimento geográfico desigual formação econômico-social - dessa hegemonia capitalista provoca uma diferenciação do território que se expressa pela elevada desigualdade, suscitando o levante rebelde de alguns movimentos sociais que lutam por construir uma contra-hegemonia com projetos territoriais alternativos e advindo dos "de baixo", articulados em diversas escalas, mediante um consenso ativo, com a coparticipação dos sujeitos coletivos. Dessa forma, o território não é instrumental e sim condição de reprodução social mais solidária, que se manifesta em um projeto de desenvolvimento territorial distinto, o qual envolve uma nova visão de mundo e estratégias que nos permitam sair do momento econômico-corporativo para o ético-político.

Elaborada essa aproximação entre o conceito de hegemonia e o de território, cabe ao presente momento indagar se as premissas teóricas de Gramsci ainda apresentam validade para momento histórico-geográfico que vivenciamos atualmente, especialmente ao sudeste paraense.

\subsubsection{Contra-Hegemonia e movimentos sociais (o novo moderno príncipe?)}

Liguori (2011) expõe questões importantes quanto à validade, no contexto atual, dos elementos analíticos apresentados por Gramsci e discutidos anteriormente, visto que hoje a sociedade se apresenta cada vez mais articulada e complexa face à globalização, marcada por uma forte capacidade hegemônica dos modelos neoliberais de vida e trabalho, especialmente com a derrocada do socialismo, o que nos faz refletir sobre a capacidade dos movimentos sociais de engendrarem projetos contra-hegemônicos.

Para o autor, existem aqueles movimentos com uma forte base na estrutura de classes da sociedade e outros identificados como per issues, que congregam forças diversas e heterogêneas, logo, os movimentos sociais são multiformes. Outro complicador reside na impossibilidade de os partidos políticos serem atualmente "nomenclatura de uma classe" devido à crise política e à forma que o partido assumiu, divorciando-se dos movimentos. $\mathrm{O}$ partido igualmente concorre com outras agências hegemônicas, a exemplo das de comunicação de massa, com forte apreço ao individualismo e à competitividade como valores universais.

Por um lado, essas complexidades do mundo atual nos fazem rever algumas das concepções gramscianas, a exemplo do partido político como sujeito de direção consciente 
das classes subalternas, visto que parecem atuar mais como instrumentos da classe dominante, embora não devam ser descartados como formas de direção na sociedade civil. Por outro, emergem cada vez mais movimentos sociais com nível de organização e proposição maior do que no tempo de Gramsci.

Esses movimentos são foco de nossa análise, por entendermos que constroem formas alternativas de visão de mundo, estabelecendo uma guerra de posição que culmina na luta por hegemonia nos meandros da sociedade civil.

A definição de movimentos sociais não é uma tarefa fácil, mas apresenta características comuns, sintetizadas por Gohn (2009, p. 14)

Um movimento social é sempre expressão de uma ação coletiva e decorre de uma luta sociopolítica, econômica ou cultural. Usualmente ele tem os seguintes elementos constituintes: demandas que configuram sua identidade; adversários e aliados; bases, lideranças e assessorias - que se organizam em articuladores e articulações e formam redes de mobilizações; práticas comunicativas diversas que vão da oralidade direta aos modernos recursos tecnológicos; projetos ou visões de mundo que dão suporte a suas demandas; e culturas próprias nas formas como sustentam e encaminham suas reivindicações. Os movimentos sociais propriamente ditos, criados e desenvolvidos a partir da sociedade civil, têm nos direitos a fonte de inspiração para a construção de sua identidade. Podem ser direitos, individuais ou coletivos.

Esses movimentos são a expressão contraditória das relações e condições econômicas, políticas e culturais que as permeiam, conformam blocos históricos resultantes de sínteses dialéticas de elementos objetivos e subjetivos, de conteúdo e de forma (GRZYBOWSKI, 1990).

Os movimentos, no entanto, apresentam uma expressão territorial cuja análise deve considerar os seguintes pressupostos: a) os conflitos apresentam uma feição dialética e aberta dos processos instituintes; b) o conflito territorial deve ser analisado em suas diferentes escalas geográficas; c) por fim, os movimentos sociais possuem a capacidade de trazer à tona as contradições marcadas no território, não apenas mostrando a sua realidade atual, mas sugerindo outras possibilidades inscritas no real, sendo portador de outra ordem, que implica em novas posições e reações socialmente produzidas (GONÇALVES, 2006).

Nesse sentido, para melhor compreensão desses movimentos sociais é importante destacar dois aspectos que compõem o território, a saber: escala geográfica e rede.

\subsubsection{Da escala geográfica à política de escala}


Com relação à escala, vários autores vêm discutindo a importância de se diferenciar a escala cartográfica da escala geográfica. Para Raffestin et al. (1983), a escala cartográfica, por um lado, trabalha com uma base geométrico-matemático de relações cartesianas de proporcionalidade, em que quanto menor a escala maior é a representação da superfície terrestre, ao passo que quanto maior a escala o nível de detalhamento é mais elevado em relação a uma área restrita do território. A escala geográfica, por outro, se refere às relações sociais que produzem o espaço, não é um dado a priori, natural e a-histórico.

Melazzo e Cloves (2008) fazem uma reflexão importante sobre a escala, debatendo-a como noção, conceito e teoria. Enquanto noção (ideia trabalhada por diferentes matrizes científicas), a escala se apresenta como uma representação métrica do mapa, cujo uso seria dado pelos objetivos do pesquisador. Em seu aspecto conceitual, ela revela a relação social, objetivando analisar a natureza qualitativa dos fenômenos, que podem sofrer variação de acordo com a escala geográfica. Para Castro (2005, p. 136), conceitualmente a escala apresenta quatro campos fundadores:

[...] o referente, a percepção, a concepção e a representação. Estes campos definem, pois, uma figuração do espaço que não é somente uma caracterização de um espaço mais amplo do que aquele que pode ser apreendido em sua globalidade, ou seja, é a imagem que substitui o território que ela representa. Neste sentido, a escala é a escolha de uma forma de dividir o espaço, definindo uma realidade percebida/concebida, é uma forma de dar-lhe uma figuração, uma representação, um ponto de vista que modifica a percepção mesma da natureza deste espaço, e, finalmente, um conjunto de representação coerentes e lógicas que substituem o espaço observado. As escalas, portanto, definem modelos espaciais de totalidades sucessivas e classificadoras e não uma progressão linear de medidas de aproximação sucessivas.

Por fim, na sua acepção teórica, a escala é compreendida à luz da teoria do desenvolvimento desigual; dessa forma, é produto do capital, refere-se a espaços de materialização e negação de seus movimentos internos. Corresponde às diferenciações geográficas resultantes e necessárias à superação, ainda que momentânea, das contradições do capital, mas também revela as arenas de disputa política (MELAZZO; CLOVES, 2007).

Essa perspectiva é coadunada por Harvey (2004), ao propor uma análise da realidade contemporânea a partir do(s) desenvolvimento(s) geográfico(s) desigual(is), na qual observa a dimensão espacial da acumulação do capital, visto que sem a expansão geográfica, a necessária reorganização territorial e o desenvolvimento geográfico desigual o capitalismo sucumbiria. Em outras palavras, a permanente realização do "ajuste espacial" das contradições inerentes ao capital, atrelada à inserção desigual dos territórios e das formações sociais no mercado global, originou uma geografia histórica mundial de acumulação do 
capital. Pelo fato de o espaço ser densamente variado em suas múltiplas dimensões, os fluxos de capital terão mais facilidade de adentrar em alguns lugares do que em outros; e o contato com o mercado capitalista global por parte das formações sociais vai contribuir para que algumas delas se insiram mais rapidamente nas formas capitalistas de troca de mercado, enquanto outras não realizaram plenamente essa inserção por motivos variados.

A teoria dos desenvolvimentos geográficos desiguais envolve dois componentes de fundamental importância, a saber: a produção de escalas espaciais e a produção da diferença geográfica. Com relação ao primeiro elemento é necessário indicar que existe uma mudança qualitativa na forma de um fenômeno se apresentar nas escalas geográficas, como a global, continental, nacional, regional e local, embora elas estejam interligadas hierarquicamente, portanto um dado fenômeno local pode interferir em nível global e vice-versa. A escala é um produto histórico, por esse motivo, é dinâmica. Ela depende das inovações tecnológicas na área de comunicação e transporte e de condições econômico-políticas que se modificam e, por fim, resulta da luta de classes e de outras modalidades de luta social, definindo as escalas em que se deve desenvolver a luta de classes (HARVEY, 2004).

Com relação à produção da diferença geográfica, observa-se que em qualquer escala existe um conjunto de processos que promovem diferenças espaciais de diversas formas (modo de vida, uso dos recursos etc.), formando um mosaico que é um “" 'palimpsesto' composto de acréscimos históricos de legados parciais sobrepostos em múltiplas camadas uns sobre os outros" (HARVEY, 2004, p. 111). Essas diferenças geográficas são reproduzidas ou modificadas de acordo com os processos político-econômicos e socioecológicos desenvolvidos no presente, salientando que, no contexto atual, a globalização acelera essas transformações espaciais. Os dois componentes mencionados acima ajudam a pensar as diferenciações e interações inter/intraescalares, ou seja, que os fenômenos sociais não podem ser pensados em uma única escala.

A compreensão dos desenvolvimentos geográficos desiguais auxilia na avaliação das contradições existentes na globalização, possibilitando definir os campos de atuação política. Isso ocorre por que a globalização implica em uma autodestruição e desvalorização dos lugares em várias escalas, provocando a agudização dos problemas sociais por meio do desemprego, da degradação das relações de trabalho etc.; por um lado, concentra o poder e desenvolve poucos lugares, por outro, surgem ações de oposição e resistência que almejam uma integração contrária ao modelo neoliberal de globalização em curso, as quais ocorrem de maneira articulada em diversas escalas, contribuindo para a reavaliação das lutas populares em diferentes escalas. 
O último ponto é de grande relevância, pois se refere à importância da escala geográfica na (re)definição da ação dos movimentos sociais, que alguns autores, a exemplo dos que estão dispostos abaixo, vão denominar de política de escala. Essa proposta é bastante discutida pela literatura contemporânea, especialmente a anglo-saxã, que trouxe um debate de fôlego acerca da ideia de "política de escala".

MacKinnon (2010) afirma que a década de 1990 apresentou um crescimento substancial em termos de uma literatura específica sobre a economia política da escala na geografia humana, a qual perpassa por diversas críticas nos anos 2000 por leituras pósestruturalistas que almejam construir um senso de espaço relacional, múltiplo e aberto, indicando que a escala era entendida como relações sociais muito hierarquizadas e fixas, com relações verticais entre os territórios delimitados. Nesse sentido, grosso modo, existiriam duas vertentes principais acerca da escala na geografia humana: uma primeira pautada na economia política que enfatiza a coexistência de "múltiplas espacialidades", com o intuito de não privilegiar uma determinada dimensão particular das relações espaciais, que se desenvolvem a partir de uma perspectiva polimórfica e multidimensional; uma segunda que busca se fundamentar no pós-estruturalismo e projeta a necessidade das práticas escalares e a performatividade da escala, havendo certo divórcio da dimensão material da escala.

Com base nessas duas vertentes, MacKinnon (2010) apresenta o estado da arte dos debates contemporâneos sobre a escala e ao mesmo tempo uma conciliação entre as duas proposições, tecendo comentários importantes.

Por um lado, a primeira abordagem se refere à economia política que se debruça sobre a construção social das escalas como entidades materiais, revelando a produção social do espaço sob o capitalismo. A crítica dessa perspectiva elaborada pelo pós-estruturalismo se fundamenta em sua reificação e essencialização das escalas. Embora não as considere como fixas, privilegia o tamanho físico das instituições sociais e jurisdições estaduais. Todavia, há de se considerar a noção de escalas como produtos de processos sociais, políticos, econômicos e culturais mais amplos - em outras palavras, derivado de um processo heterogêneo, conflituoso e prenhe de contradições, sendo passível de mudanças em suas extensões, conteúdos, importância e interações relativas. Assim, a escala constitui um produto de processos mais amplos e de relações sociais, deslocando a centralidade das relações globallocal para a preocupação com a política de escala, que compreende a escala como um instrumento de construção social do poder, ou seja, incorpora e manifesta as relações de poder subjacentes entre os sujeitos. Considera também a tensão entre fluidez e fixidez, uma vez que a última é demasiadamente considerada ao avaliar as escalas como entidades materiais que 
atuam como plataformas para o desenvolvimento das relações sociais; logo, as escalas acabam sendo privilegiadas em detrimento dos processos sociais que de fato as produzem. As alegações de reificação da escala têm base em referências anteriores à escala enquanto atividade social. Para os pós-estruturalistas os espaços e os locais são sempre emergentes, por isso estão em um processo contínuo de "se tornar" por meio das práticas sociais. Entretanto, para além dessa pseudorreificação simples, defensores da economia política entendem a escala como produto e produtora dos processos sociais. Desta feita, o esforço em torno da "política de escala" é o viés mais aberto da economia política, admitindo uma visão relacional das relações escalares, discutindo os agenciamentos ao debater sobre como diferentes forças sociais objetivam explorar, manipular e transformar as relações escalares (MACKINNON, 2010).

As abordagens pós-estruturalistas, por outro, entendem a escala como uma construção epistemológica que representa ordenações espaciais específicas, não apresentando uma manifestação ontológica. Assim, seu estudo avalia sua importância como um dispositivo de representação ou um quadro implantado discursivamente por diversos sujeitos coletivos ou que não buscam angariar formas particulares de reconhecimento e vantagem. Essa proposta emerge da preocupação de explicar como as escalas são socialmente produzidas por meio da prática social e do discurso, além dos meios em que as escalas passam a ser envolvidas em formas de identificação e de tomada de lugar. Desta feita, enquanto a economia política prioriza a dimensão material da construção da escala, os pós-estruturalistas se debruçam sobre os processos discursivos dela (MACKINNON, 2010).

Outro debate sobre a escala se refere à existência de diferentes matrizes filosóficas, que vão desde uma perspectiva materialista até outra mais idealista. Jones (1998), por exemplo, por um viés idealista, questiona se a escala é compreendida como uma categoria ontológica fundamental ou uma categoria epistemológica, embora esteja inclinada pela segunda assertiva, porque compreende que os sujeitos em uma determinada disputa política apresentam argumentos sobre a escala discursivamente, representando sua posição (global ou local) a partir de seus interesses. Assim, a escala seria uma espécie de tropo da representação, que enquadra a espacialidade política, logo, não é neutra, visto que cada tropo manifesta sua retórica e sua capacidade de moldar o significado do espaço. Seu caráter epistemológico se articula ao nosso conhecimento do poder e do espaço e, como noção, deve ser devidamente contextualizado no âmbito sociocultural e histórico. A escala, ao ser interpretada a partir de certas qualidades, fornece seu poder tanto para as regras da ordem social quanto para as práticas de representação que caminham lado a lado. 
Para Grandi (2014), a linha de pensamento materialista advém das críticas às abordagens quantitativistas dos estudos espaciais dos anos 1950 e 1960, sendo fundamentada principalmente no marxismo, e suas reflexões se direcionam para a economia política das escalas, enfatizando a dimensão político-econômica da produção social das escalas. Já a idealista se inspira na tradição neokantiana e suas discussões sublinham aspectos e dinâmicas atreladas à dimensão discursiva das escalas, compreendidas como metáforas espaciais da realidade produzidas socialmente.

É claro que não existe uma divisão tão nítida entre essas perspectivas, e há inclusive autores que buscam uma conciliação entre elas. MacKinnon (2010) vai propor a noção de políticas escalares, que apresentaria uma abordagem integrativa, baseada no realismo crítico propõe uma realidade externa, que reconhece que só se pode conhecer por meio de conceitos e representações socialmente mediadas -, entre a economia política e o pós-estruturalismo, visto que ambos apresentam em comum a preocupação da construção social da escala, observando as relações escalares, a sua fluidez e a dimensão de processos espaciais mais amplos da escala. Dessa maneira, em certos aspectos, as duas vertentes oferecem insights complementares para a construção da escala. De um lado, centrando os esforços nos processos de produção material e a reestruturação capitalista e, de outro, na prática social e no discurso. Não estamos propondo aqui a integração teórica, mas a reunião de elementos de tratamento da escala por meio do conceito de políticas escalares.

Esse conceito é constituído por quatro fundamentos: em primeiro lugar, ele substitui a implicação de que a política de escala se fundamenta na ideia de que vários projetos e ações políticas apresentam aspectos escalares, pautando-se principalmente em Brenner (2001), ao distinguir os sentidos singular e plural da escala. A escala é uma dimensão importante da atividade política e não seu foco principal, assim, a política escalar, numa perspectiva realista de espaço, define-se pelas relações políticas que a constituem ao invés de possuir uma existência anterior, salientando-se que não se reduz completamente a essas relações, pois escalas são estabelecidas. As dimensões escalares dos projetos e movimentos políticos se vinculam à perspectiva da economia política que destaca a fluidez da escala e os esforços dos sujeitos para se deslocar entre as escalas, não entendendo-as como um ente conceitual dado que é colocado sobre os problemas da pesquisa. Nesse sentido, a ideia é deixá-las emergir como uma dimensão de confronto político de acordo com sua importância empírica.

Em segundo lugar, a política escalar se foca na implantação estratégica da escala por diferentes sujeitos, organizações e movimentos; coadunando com o pós-estruturalismo, a escala é uma construção epistemológica, todavia não se esgota nela, uma vez que sua 
construção se atrela aos esforços de determinados sujeitos, organizações e movimentos que ontologicamente buscam "corrigir" ou "deslocar" as escalas como formas materiais de relações de poder emergentes; assim, existe uma natureza material-discursiva da luta escalar. Do ponto de vista crítico-realista, isso significa reconhecer a importância dos discursos e representações para a construção social dos objetos e relações, mantendo ao mesmo tempo certa independência dos objetos em relação às concepções dos sujeitos individuais. Por essa perpectiva crítico-realista os discursos dominantes podem vir a ter consequências inesperadas, de importância igual a suas formas de resistência e contestação, sendo significativo considerar a articulação entre as categorizações e as condições materiais que estruturam os arranjos escalares, para que os sujeitos sociais, organizações e movimentos tenham a capacidade de manipular as dimensões discursivas e materiais da escala para alcançar suas agendas.

Um terceiro fundamento se refere à influência e aos efeitos das estruturas escalares pré-existentes, produzidas por processos anteriores à construção social; por fim, em quarto lugar, a política escalar se refere à criação de novos arranjos e configurações escalares que se desenrolam no ponto de interação entre projetos e escalas herdadas e emergentes (MACKINNON, 2010).

Uma outra diferenciação na leitura acerca da natureza da escala se refere ao seu entendimento enquanto categoria da prática - são categorias da experiência cotidiana, produzidas e implementadas pelos sujeitos sociais - ou categoria de análise - relativamente distantes da experiência e formuladas pelos cientistas sociais - conforme propõe Moore (2008). Para esse autor, existe uma cisão entre as categorias, de forma que as categorias da prática se referem ao senso comum e à maneira como este interpreta o mundo, incorporando termos reificados no pensamento social, essencializados e naturalizados, os quais, muitas vezes, são incorporados sem crítica pelos cientistas sociais como categorias de análise, tal qual se faz com as escalas geográficas (local, nacional e global), cuja noção se refere a realidades espaciais existentes em níveis, plataformas ou arenas.

Essa separação, no entanto, entre categorias da prática e da análise é controversa, pois estabelece um fosso entre as formas de conhecimento, ou seja, aquele formal e acadêmico e o do senso comum, inclusive hierarquizando-os. Desta feita, concordamos com Grandi (2014) ao reconhecer que essa diferenciação esvazia o conteúdo político da categoria de análise, ao compreender que qualquer análise (e suas categorias) são necessariamente práticas sociais, assim como as escalas geográficas são resultantes da prática social, seja da análise científica ou da ação cotidiana dos sujeitos, por esse motivo resultante da materialidade ou da teoria. Ainda que utilizados como categoria de análise, as escalas e seus arranjos produzem efeitos 
concretos sobre a sociedade, portanto, condicionam comportamentos e exercem poder. Seu uso crítico nos leva a considerar que as escalas são continuamente mutáveis, em decorrência das necessidades prático-concretas dos sujeitos. Essa perspectiva destaca o papel ativo dos sujeitos que as produzem e é "condizente com as abordagens sobre movimentos sociais que destacam os processos e ações sociais e esvaziam as estruturas de seu poder explicativo global" (GRANDI, 2014, p. 252).

Essas perspectivas duais e/ou integradoras indicam a complexidade do debate acerca da escala e/ou da política de escala. Porém, em nossa análise dos movimentos sociais, é importante salientar a importância da produção social da escala e o modo como esta apresenta uma materialização concreta, fluida, dinâmica e aberta, decorrente das práticas sociais envolvendo os mais diferentes sujeitos, que manipulam, controlam, articulam e se (re)produzem por meio das escalas, revelando a importância delas ao exercício do poder, que é assimétrico, hierárquico e múltiplo. Em outras palavras, a hegemonia se desenvolve mobilizando as escalas, seja em termos de sua manutenção, seja na construção de uma resistência a ela. Para fundamentarmos essa proposição nos deteremos aos estudos de Cox (1998); Brenner (2000; 2001) e Smith (2000, 2002, 2004).

No trabalho de Cox (1998), duas questões serão centrais. A primeira se refere ao debate sobre a política de escala enfatizar sua forma em termos de área, a exemplo da ideia de "saltar escalas" que se pauta na conotação da arena, de espaços limitados que indicam um conjunto de caixas, cada uma com sua política própria. Dessa forma, seria mais produtiva a utilização da metáfora da rede para a espacialidade da escala, ou melhor, as redes de associações, para a compreensão da política do espaço. As redes indicam a desigualdade na penetração da forma areal, igualmente com muita dificuldade são contidas por essa forma devido a os limites serem porosos - as políticas governamentais, por exemplo, podem ser objetos de recurso em esferas mais elevadas de autoridade, isso porque as redes de associação são construídas através das fronteiras nacionais ou não.

A segunda questão se refere ao conteúdo e à forma da política de escalas, dos quais deriva uma distinção elaborada pelo autor entre espaços de dependência e espaços de engajamento. Os espaços de dependência são definidos

[...] por aquelas relações sociais mais ou menos localizadas das quais dependemos para a realização de interesses essenciais e para o qual não há 
substituto em lugar algum; eles definem condições espaciais específicas para nosso bem-estar material e nosso senso de significância. (COX, 1998, p. 2). ${ }^{7}$

Esses espaços estão inseridos em conjuntos maiores de relações sociais de amplitude global que continuamente os ameaçam em termos de dissolução. Os mais diversos sujeitos se organizam com intuito de salvaguardar as condições de perpetuação dos seus espaços de dependência; entretanto, para alcançar esse fim devem interagir com outros centros de poder social (governo local, imprensa nacional ou internacional etc.), e, ao fazê-lo, constroem uma forma diferente de espaço, o qual é denominado "espaço de compromisso", em referência ao local em que a política garante o desenvolvimento do espaço de dependência. Para a manutenção destes é igualmente preciso constituírem-se redes de associação que permitam as condições necessárias à sua existência, o que cria espaços de engajamento. Essa relação umbilical entre espaços de dependência e espaços de engajamento é discutida a partir do processo de reprodução do capital e sua interferência na escala local, cujos interesses dos sujeitos, para serem garantidos, devem mobilizar outras escalas. Se não, vejamos.

A política de escala é mobilizada pelo capital para sanar suas contradições, visto que o capital móvel, em sua incessante busca por níveis mais elevados de lucro, tem a tendência em desvalorizar o capital em sua forma física. A diversidade de formas espaciais fixas compromete os sujeitos uma vez que assegura suas condições de reprodução em lugares particulares, mas a dependência desses sujeitos em relação a uma economia local ou regional é por razões bem diferentes: para os empresários o objetivo é o lucro, aos trabalhadores o mercado de trabalho local é o meio de sobrevivência. Entrementes, os sujeitos são partícipes de um conjunto mais extenso de relações de troca do que aquelas circunscritas ao âmbito de um determinado lugar; consequentemente, a realização dos interesses locais implica na transformação da geografia do lugar, como processos migratórios, ampliação ou redução de empresas etc. O problema que se coloca ao local, em termos abstratos, é garantir que o valor em suas formas móveis permaneça a fluir por meio de suas relações sociais. Em suma, os sujeitos apresentam interesses em torno da apropriação, realização de lucros, renda, salários, impostos, dentre outros, mas as mudanças nas geografias econômicas globais possuem impacto na realização desses objetivos locais, os quais se processam nos espaços de dependência, definidos dessa maneira porque a mudança de local para a satisfação dessas

\footnotetext{
7 “(...) defined by those more-or-less localized social relations upon which we depend for the realization of essential interests and for which there are no substitutes elsewhere; they define place-specific conditions for our material well-being and our sense of significance."
} 
necessidades é bastante difícil. Destacamos que esses espaços de dependência ocorrem em diversas escalas e para alguns sujeitos pode existir mais de um, correspondendo aos diferentes momentos da circulação (espacial) do capital. Nesses espaços, o que está em jogo são os interesses locais e a capacidade de realizá-los é definida pelas condições de exercer um controle territorial, em termos de ações e interações das pessoas tanto dentro como entre os espaços de dependência, ação essa muitas vezes exercida pelo Estado, o que coloca a questão de como influenciar suas agências. Para esse fim, projeta-se a intencionalidade de construir uma rede de associações que incorporem diretamente as instituições estatais ou sujeitos que as influencie. Essa rede define o chamado espaço de engajamento, porque até certo ponto as ações políticas podem se proceder dentro dos limites do espaço de dependência que é acessado por diversos antagonistas, promovendo tensões; todavia, existem situações em que é necessário "saltar escalas", mobilizando agências estatais extralocais, como instituições centrais, constituindo espacialmente redes de associações muito mais extensas (espaços de engajamento) para atingir seus objetivos. Salientamos que, como os espaços de dependência se realizam em múltiplas escalas, "saltar escalas" não significa ir necessariamente do menor para o maior: o inverso é plenamente possível.

Brenner (2001), semelhantemente à proposição de Cox (1998), entende que a escala não se restringe a uma plataforma autoevidente ou pré-definida para os processos geográficos, pois ela se encontra em contínua mutação, tal qual está sendo discutido pela política de escala, que sai da visão tradicional euclidiana, fixa e geométrica, e passa a compreender a escala no seio do processo, evolução, dinamismo e contestação sociopolítica.

Todavia, os avanços contemporâneos sobre o debate da escala vêm acompanhados de perigos metodológicos, dentre os quais se destaca a confusão analítica do conceito de escala, aplicado de maneira indiscriminada a uma gama de fenômenos espaciais, relações e processos. Em outras palavras, muitos estudos confundem a noção de escala com outros conceitos geográficos importantes, como lugar, localidade, território e espaço, comprometendo o potencial analítico e teórico da escala. Por um lado, com o intuito de contribuir para o desenvolvimento de uma abordagem socioespacial em que as dimensões escalares das espacialidades sociais sejam bem delimitadas Brenner, (2001) vai propor a análise da estruturação escalar, que ocorre exatamente porque apesar do capitalismo ter se diferenciado em hierarquias escalares no período atual de reestruturação global, observa-se uma transformação na organização escalar, em que o projeto neoliberal busca forjar novas hierarquias que não restrinjam a mobilidade do capital e as relações de mercado. Por outro, movimentos de oposição resistem, com a finalidade de frear ou reverter esse avanço 
neoliberal, e, para esse fim, mobilizam escalas geográficas de maneira estratégica, seja por meio de "salto de escalas" para contornar práticas institucionais hegemônicas, seja prevendo diferentes arranjos escalares pautados na ideia de democracia radical e justiça social.

Ao adentrar no debate sobre a política de escala, dois significados distintos devem ser qualificados acerca da sua noção. O primeiro é denominado de singular: nesse sentido, a política de escala denota a produção, a reconfiguração e/ou a contestação de um dado aspecto da organização socioespacial que se encontra limitada por uma arena geográfica (local, urbano, regional, nacional...). A preposição "de", nesse aspecto singular, indica uma unidade geográfica relativamente diferenciada e com limites bem definidos - em outros termos, a escala é apresentada como uma fronteira que separa a unidade geográfica investigada das demais. O segundo significado é identificado como plural, no qual a noção de uma política de escala se reporta à produção, à reconfiguração e/ou à contestação de determinadas diferenciações, ordenações e hierarquias entre as escalas geográficas. Por seu turno, a preposição "de" é empregada com o intuito de definir a produção de unidades espaciais diferenciadas, mas igualmente suas inserções e posicionamentos em relação a uma multiplicidade de unidades espaciais que se encontram no interior de uma diversidade de camadas, conformando uma configuração geográfica hierarquicamente tabular - logo, se refere ao processo de dimensionamento por meio do qual diversas unidades espaciais se estabelecem, diferenciam-se e são hierarquizadas, e, em determinados contextos, redefinidas, reorganizadas uma em relação à outra. Com efeito, a escala é compreendida como uma modalidade de hierarquização e re-hierarquização por meio da qual processos de diferenciação espaciais se desenvolvem materialmente e discursivamente. Esse último aspecto consegue captar a relacionalidade das escalas geográficas e sua posição (mutável) como unidades diferenciadas contidas em hierarquias espaciais de vários níveis.

Por fim, o autor propõe uma leitura da conotação plural das políticas de escala a partir da política da estruturação escalar, ou melhor, como uma política de escalonamento. Para esse fim, apresenta algumas sugestões metodológicas para a sua compreensão:

1) A estruturação escalar corresponde a uma dimensão dos processos espaciais.

1) Os processos de estruturação escalar são constantemente redefinidos por meio das rotinas sociais cotidianas e lutas, isso porque conotam uma dinâmica de desenvolvimento em que as estruturas da ação social coletiva são permanentemente reproduzidas, alteradas e transformadas pela própria ação social coletiva. 
2) Os processos de estruturação escalar são dialeticamente interligados com outras formas de estruturação espacial. Assim, a diferenciação escalar de um dado processo social se realiza em conjunto com outras formas de estruturação espacial, responsáveis por igualmente alterar as geografias desse processo.

3) Há diversas formas e padrões de estruturação escalar, logo, seu estudo deve apresentar: a) uma análise de como, por que e quando o processo social investigado é subdividido em uma hierarquia vertical de escalas geográficas interligadas e separadas, devendo especificar; b) as unidades espaciais importantes na hierarquia; c) o seu papel específico; d) a construção histórica e sua consequente mutação dentro da hierarquia; e) sua relação; f) específica e historicamente evoluindo para outras unidades dentro da hierarquia.

4) As escalas se desenvolvem relacionalmente no interior das hierarquias interligadas e das redes interescalares dispersas, salientando que o significado, a função, a dinâmica de uma escala são apreendidos relacionalmente a partir de múltiplos pontos, ou seja, de cima para baixo e vice-versa, para os lados etc. Cada escala se constitui através de sua posicionalidade que historicamente evolui no interior de uma grade relacional maior, verticalmente "esticada" e horizontalmente "dispersa" de processos espaciais, relações e interdependências.

5) As escalas possuem múltiplas espacialidades, logo, não podem ser restritas a sua dimensão areal e geométrica. Igualmente devemos considerar que a espacialidade complexa dos processos de tomada da escala pode ser mais bem explicitada ao ser discutida ao lado de outros conceitos - lugar, localização, território, rede etc.

6) As hierarquias escalares são mosaicos não piramidais, não existindo uma única hierarquia escalar integrada e sim um mosaico de geometrias escalares desigualmente sobrepostas e densamente interligadas.

7) Os processos de estruturação escalar produzem efeitos causais contextualmente específicos, assim, a depender da situação, a articulação escalar pode vir a ser uma "progenitora" dos processos sociais ou pode simplesmente ser a estrutura na qual se dá o desenvolvimento histórico de um processo social.

8) Os processos escalares podem se cristalizar em correções escalares, porque interagem entre si para produzir estruturas hierárquicas articuladas de organização que enquadram aspectos importantes da vida cotidiana dentro das correções escalares, compostas de hierarquias geográficas relativamente estabilizadas nas 
quais atividades organizadas em determinadas escalas tendem a predominar sobre as outras.

9) As escalas fixas podem apresentar a evolução subsequente das configurações escalares. Essas configurações são continuamente (re)organizadas e, com o desenvolvimento das lutas sociopolíticas, podem vir a ter mudanças substanciais que alterem drasticamente as novas hierarquias da escala; salientamos que essas alterações são produtos de contextos histórico-geográficos específicos.

10) Os processos de estruturação escalar constituem geografias e coreografias do poder social. Isto é, por um lado, as hierarquias escalares podem criar formas de inclusão/exclusão e de dominação/subordinação que fortalecem determinados sujeitos, alianças e organizações em detrimento de outros, a partir de critérios como classe, gênero, raça e nacionalidade. Por outro, tais hierarquias podem vir a funcionar como arenas de lutas por poder social, mas igualmente podem servir como seus objetos, na medida em que são desafiados e se tornam instáveis no transcorrer das lutas sociais.

Por fim, apresentamos a proposta de Smith (2000), que foi um dos precursores do debate da política de escala. Em seu texto sobre o veículo projetado aos sem-teto, o autor compreende que esse recurso, embora não resolva o problema da exclusão social, indica a armadilha geográfica da cidade que, na imobilidade, segrega os sem-teto, ao mesmo tempo que identifica a ampliação das possibilidades de sobrevivência deles, pois representa um meio de reprodução social e grafa uma política espacial menos excludente no interior da cidade, por prover maior mobilidade ao possibilitar o acesso a outros lugares distantes para reciclagem, mendicância, para dormir e fugir da pressão cotidiana. O uso do "veículo do sem-teto" recupera a espacialidade local enfatizando o papel constitutivo da escala geográfica

Nesse sentido, para Smith (2000), existe a necessidade de se "saltar escalas" como uma forma de rebeldia aos limites impostos pelo capital no que diz respeito à escala de ação dos sujeitos subalternos, relegados geralmente a periferias ou áreas longínquas que ainda não foram devidamente territorializadas pelo capital. Essa política de escalas é importante para pensar as lutas sociais. Segundo o autor, é necessária uma melhor teorização acerca da escala, visto que ela apresenta aspectos importantes: primeiro, a escala corresponde ao meio pelo qual se expressa a diferenciação espacial; em segundo lugar, sua compreensão fornece uma linguagem mais adequada à diferença espacial; um terceiro elemento se refere ao fato de a escala ser um construto social, visto que é produto da sociedade, se materializa por suas atividades e, por conseguinte, produz e é produzida por configurações geográficas de 
interação social; por último, a produção da escala corresponde ao espaço de luta política. Em outras palavras:

A construção da escala não é apenas uma solidificação ou materialização espacial de forças e processos sociais contestados [...]. A escala é um progenitor ativo de processos sociais específicos. De um modo tanto literal quanto metafórico, a escala contém a atividade social e, ao mesmo tempo, proporciona uma geografia já dividida em compartimentos, na qual a atividade social tem lugar. A escala demarca o sítio da disputa social, tanto o objeto quanto a resolução dessa disputa. Vista dessa forma a produção da escala pode começar a fornecer a linguagem que torna possível uma política mais substantiva e tangível [...]. É a escala geográfica que define as fronteiras e limita as identidades em torno das quais o controle é exercido e contestado. (SMITH, 2000, p. 144)

Smith (2000) apresenta esquematicamente a sua proposição de escalas geográficas específicas, a saber: corpo, casa, comunidade, cidade, região, nação e globo. E, para cada uma delas, propõe-se a analisar quatro aspectos, quais sejam, a) identidade ou as características que tornam a escala coerente; b) diferenças internas; c) fronteiras existentes entre as escalas; d) possibilidades políticas de resistência que são intrínsecas à produção dessas escalas geográficas - em outros termos, a redefinição das fronteiras ou o "saltar escalas" $"$.

Em outro trabalho, Smith (2002) se aproxima da ideia de política de escala plural proposta por Brenner (2001) ao interpretá-la buscando a interação das escalas, isto porque conceitualmente é importante considerar a conexão entre a hierarquia das escalas (re)produzidas nas paisagens do capitalismo e as abstrações conceituais através dos quais apreendemos acontecimentos e processos espaciais. Portanto, a escala possui uma manifestação material, mas também é o âmbito de resolução ou abstração que utilizamos para compreender as relações sociais. Dessa forma, a produção da escala implica a questão da diferença como posicionamento, isto é, dependendo da apropriação metafórica do espaço, o conflito e a negociação entre diferentes posições relativas têm por consequência um juízo social simultâneo sobre a identidade do sujeito e a diferença (seu posicionamento em relação ao "outro). Esse processo envolve conflito e negociação e imprime limites socialmente estabelecidos de diferença e igualdade, ainda que sejam constantemente forjados na prática social, a exemplo da questão de quem é incluído e quem se inclui como "negro", que pode ser reformulada como uma indagação acerca da escala socialmente construída na qual se

\footnotetext{
${ }^{8}$ Por compreender que as escalas são bastante amplas, ou seja, existindo a escala do corpo até a global, MARSON e SMITH (2001) vão realizar um debate com Brenner (2001), que entende ser o corpo e a família compreendidos por outros conceitos geográficos.
} 
estabelece a identidade social e a política negra. Dessa maneira, a escala da luta e a luta sobre a escala são dois lados da mesma moeda. Por fim, é importante notar que muitas das (re)estruturações escalares são realizadas pelo capital, mas não é verdadeiro afirmar que uma escala geográfica é imposta de cima para baixo, pois a construção da escala resulta e contribui com a luta social baseada na classe, no gênero, na raça e em outras diferenças sociais.

Em suma, é importante frisar que a política de escala nos remete à compreensão de que ela é um produto social, que se materializa em uma feição zonal, pois apresenta limites (constituindo arenas políticas), provenientes de particularidades/diferenças históricogeográficas, que estão em contínua transformação e redefinição; todavia igualmente possui uma face reticular, devido às escalas estarem articuladas verticalmente a partir de relações de poder que se manifestam a partir de múltiplos pontos do território (produzindo espaços de dependência e espaços de engajamento, mediante as redes de associação), não apenas de cima para baixo, ou do global para o local, visto que hoje é perceptível a flexão escalar (SMITH, 2004), proveniente da reorganização da escala, cuja estrutura territorial herdada é chamada para cumprir outras funções ou é refeita para se adequar às novas necessidades sociais, resultando em relações não mais entre Estados-nações apenas, mas entre empresas e Estados, ou entre cidades e empresas e/ou Estados.

Essa política de escala, por seu turno, não é produto do capital unicamente, uma vez que, ao manifestar o conflito entre capital e trabalho, torna possível observar a luta territorial em diversas escalas e pela escala, a exemplo dos movimentos sociais, que em sua prática cotidiana, desenvolvem alianças em diversos lugares com outros sujeitos, como Organizações Não Governamentais e sindicatos, articulam-se em diversos níveis espaciais (local, municipal, estadual, regional, nacional, supranacional, continental e mundial) dependendo do grau de organização; e disputam o direito ao acesso dessas múltiplas territorialidades, ou, ainda, "saltam escalas" com o intuito de ampliar seu território, em condições não mais precarizadas (para isso se utilizam dessa estratégia para construir uma outra hegemonia, ainda que em condições adversas e assimétricas de poder e com conquistas pontuais e graduais).

\subsubsection{Uso desigual da rede geográfica e política de escala}

As escalas geográficas participam ativamente da construção da hegemonia esboçada pelos movimentos sociais, visto que possibilitam uma maior universalização das lutas. Todavia o acesso a essas escalas é possibilitado pelas redes geográficas. Elas apresentam por propriedade primaz a conexidade, ou seja, a articulação com vários pontos do território de 
forma a possibilitar fluxos de toda ordem, pessoas, mercadorias, informações. Os nós dessa rede são lugares de conexões e de poder econômico-político e cultural. (DIAS, 2005)

As redes produzem um potencial de interconexão elevado entre os lugares, levando ao que Harvey (1999) denomina de compressão do espaço-tempo, possibilitada pelos avanços substanciais no setor de telecomunicação e transporte. Entretanto, a rede, por ser um produto da sociedade capitalista, materializa suas contradições e assimetrias econômico-políticas, excluindo uma parcela considerável da população, devido ao que Massey (2000) conceitua como geometrias do poder:

Agora, quero discutir uma única coisa, o que se poderia chamar de geometria do poder de tudo isso: a geometria do poder da compressão tempo-espaço, pois diferentes grupos sociais e diferentes indivíduos posicionam-se de formas muito distintas em relação a esses fluxos e interconexões. Não me refiro simplesmente à questão de quem se movimenta e de quem não o faz, embora essa questão seja um elemento importante; trata-se também do poder em relação aos fluxos e ao movimento. Diferentes grupos sociais têm relacionamentos distintos com essa mobilidade diferenciada: algumas pessoas responsabilizam-se mais por ela do que outras; algumas dão inicio aos fluxos e movimentos, outras não; algumas ficam mais em sua extremidade receptora do que outras. Algumas são efetivamente aprisionadas por ela. (MASSEY, 2000, p. 179 grifado no original)

Essa íntima relação entre território e rede levou Haesbaert (2004) a definir o que ele chama de território-rede, visto que no momento atual o controle do espaço não está circunscrito a sua face apenas zonal (contínua ou contígua), e sim igualmente reticular, pois nossos referencias identitários não estão apenas no âmbito do enraizamento e sim na própria mobilidade. Desta feita, "territorializar-se significa também, hoje, construir elou controlar fluxos/redes e criar referenciais simbólicos num espaço em movimento, no e pelo movimento". (HAESBAERT, 2004, p. 280 grifado no original)

As redes, contraditoriamente, apresentam um caráter territorializador e desterritorializador. Logo, os fluxos que as perpassam ora possuem um efeito de sustentação e de estruturação de novos territórios, ora desarticulam territórios. Assim, as redes territoriais (que, diferentemente de redes técnicas ou físicas, possuem um papel importante nos processos de (re)territorialização, para construir territórios no âmbito do controle ou domínio material e simbólico) podem favorecer a integração de um território, a exemplo do Estado-nação, mas também a (des)territorialização, na medida em que as relações econômicas com o exterior podem significar a perda do controle interno do Estado. (HAESBAERT, 2004)

O controle sobre os territórios-rede se dá pelos pontos de acessibilidade (pontos de conexão). A eficácia do poder atualmente está na capacidade e rapidez de atuar nas diversas 
escalas geográficas nos diferentes tipos de território. Assim, quanto mais restritos a uma modalidade do território e a uma escala específica de ação, mais facilmente perderemos o poder de controle sobre fenômenos e ações. (HAESBAERT, 2004)

Os territórios-rede em certa medida podem vir a potencializar a política de escalas, especialmente porque há uma apropriação maior dessa forma de territorialização por parte dos movimentos sociais, conforme atestou Souza (2013a).

Semeraro (2006), ao avaliar a ação dos movimentos sociais no Brasil a partir da década de 1990, indica que esses sujeitos coletivos apresentam hoje uma versão mais moderna e complexa das forças populares, com reinvindicações propositivas que almejam disputar a direção do país, sendo sujeitos partícipes na sociedade civil, a qual não deve ser entendida como pertencente a um único grupo dirigente, embora hegemônico. Deve ser lida na sua relação dialética com o Estado, correspondendo ao espaço de luta contra-hegemônica dos sujeitos subalternos. Os movimentos sociais compreendem "novos dirigentes" capazes de articular os interesses locais e extralocais.

A luta desses sujeitos é eminentemente territorial seja pela necessidade de superação da precariedade a que são relegados seja pela necessidade de outro projeto de desenvolvimento territorial que, no caso específico de nossa pesquisa, não se restringe a uma mera redistribuição de terra, apesar de ser um ponto crucial: a bandeira da reforma agrária é muito mais ampla e complexa, tem em seu seio uma proposta original, multidimensional e multiescalar, e os sujeitos atuam em rede para a sua efetivação. Essas são premissas basilares para a compreensão da territorialização do MST no sudeste paraense. 
Figura 2 - Burgo do Itacaiúnas, onde emergrem as disputas pelos territórios...

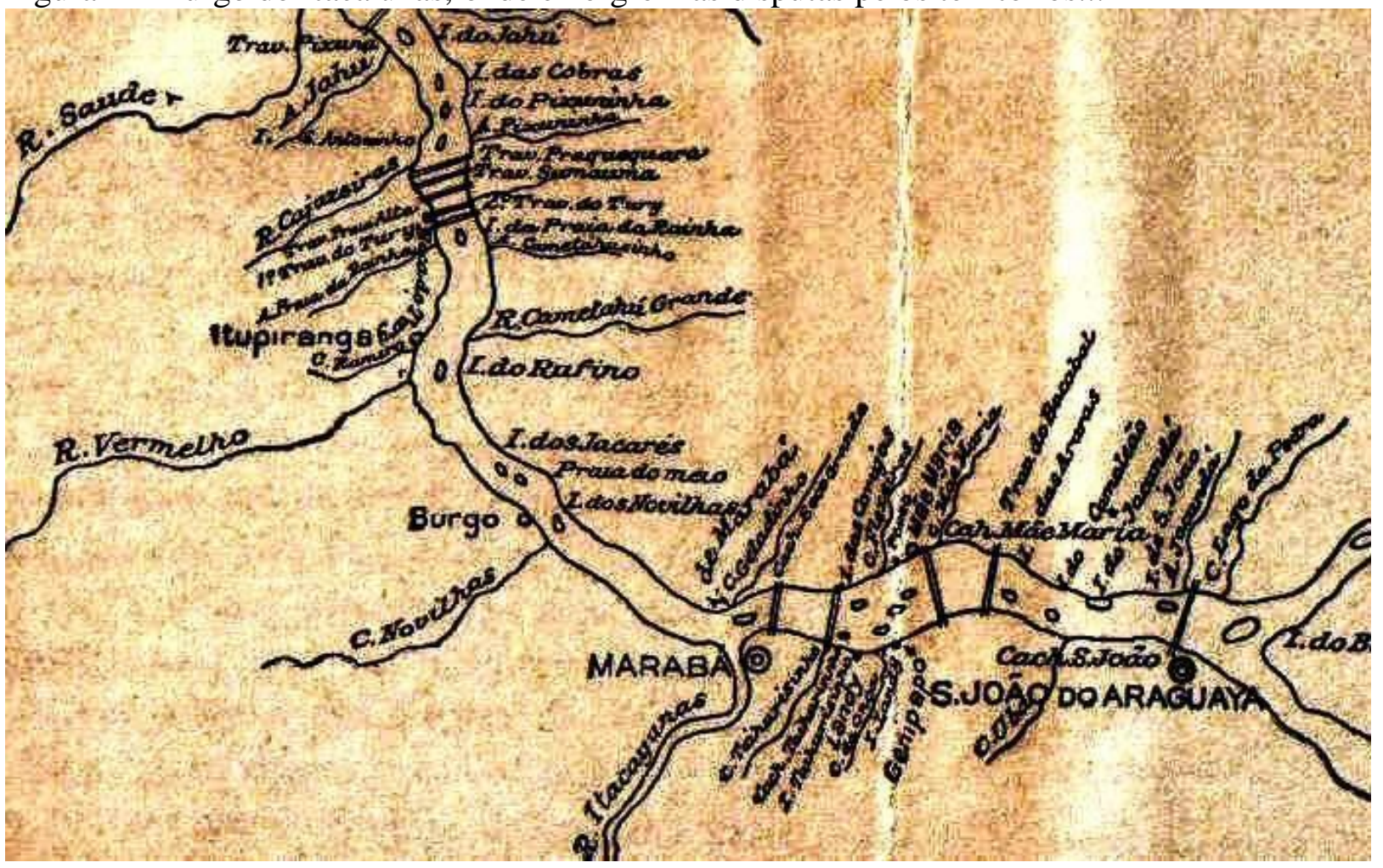

Fonte: Rodrigues (1943, p.210). 
Tuas pernas grossas de Tocantins descansando em praias.

Teu ventre coleante de Pirucaba. E alguém te possuiu, cunhatã rica de cauchais e castanhais nativos, com cipós-paus descendo em teu pescoço de árvore-mogno. Te tornaste dissoluta- Messalina do Tocantins, com gestos de pajelança abrindo as pernas na porta do Cabelo Seco. Um dia, negro Basilão te botou um olhar de quebrar

E veio da boca do Sororó um hálito quente de malária. Veio vindo, veio vindo, veio vindo... começaste a plantar homens no teu ventre, trémulos do frio da sezão do teu fascínio. Depois os mataste com a tua cabo-de-tala, com teu quarenta-e-quatro, nas tuas salas de festa do povo,

Jurema, Pindura-Saia, Barro Branco... Agora, tu te divertes com música alienígena e assassinas em massa na sala vasta do teu latifúndio.

Ficaste louca, Marabá! Trocaste tuas tranças verdes de árvores seculares pela peruca rala do capim. Os teus rios já nem correm, constrangidos por barragens onde teu último mito se afogou de vergonha no perau do Vita Eterna.

A sinfonia do Capitariquara foi abafada pelas águas do rio que atrofiaram e o rock \& roll azucrina teus ouvidos. Ainda tão nova e já és saudade. Saudade do que tu foste nos teus varjões, nas tuas matas, onde o passo aveludado da onça demarcava a fronteira da nossa herança. Ex-amante de posseiros, puta do latifúndio, tentas te matar ria fogueira da tua inconsequência.

E já nem és mais castanheira, caucheira, mulher de tropeiro, colecionadora de folclore.

De ti, resta somente um tambor do Divino

batendo a nossa saudade lá da Santa rosa.

Teus dentes, brancos dos diamantes do Jaú, estão ficando amarelos pela nicotina do ouro.

E hoje és apenas uma Serra. Pelada. Nada mais.

(MORBACH In: BRAZ, 1998, p. 58-59).

A sub-região do sudeste paraense, como mostra a epígrafe que abre esse capítulo, vem sendo alvo de grupos hegemônicos capitalistas que redefinem o território amazônico a partir de sua lógica de organização e interesses, os quais geralmente colidem com as outras racionalidades dos povos e comunidades preexistentes, emergindo conflitos e resistências que 
desembocam em diversas formas de violência, sejam elas físicas ou simbólicas, e buscam negar a geografia dos sujeitos subalternos.

É exatamente essa geografia dos "de baixo" que queremos recuperar nesse trabalho, buscando um olhar nativo, como propõe Maués (1999), no qual as outras Amazônias se tornam visíveis, e que outros territórios não sejam obscurecidos por um único, o hegemônico.

É necessário (re)escrever sobre a produção espacial daqueles que estão às margens, ou como propõe Gramsci (2014b), a história dos grupos sociais subalternos.

Nesse segundo capítulo vamos nos deter na formação territorial do sudeste paraense, compreendendo que o território materializa a história, que resultou na sua conformação e estrutura atual. Para a apreensão disso, é necessário descortinar seu processo de formação, por isso a definição de formação territorial, que busca analisar melhor a gênese dos conjuntos espaciais contemporâneos, muito embora no passado tais conjuntos não apresentassem necessariamente unidade e integração (MORAES, 2000). Salientamos que os territórios não se consolidam exclusivamente pelo uso da força e da violência, pois envolvem

[...] instâncias de legitimação do domínio e do poder praticados, o que redunda em forças jurídicas de reconhecimentos dos direitos de soberania (interna e/ou externamente aos espaços em questão). Nesse sentido o território é também uma construção política, que deve ser reiterada por meio de pactos e disputas sociais. Até por isso, a formação territorial apresenta ainda uma faceta de estrita elaboração ideológica, resultando em construtos discursivos que comandam tanto a consciência dos lugares quanto sua produção material. (MORAES, 2000, p. 22)

Partindo dessa premissa de Moraes (2000), é possível observar que a formação territorial envolve múltiplos sujeitos, processos e dimensões da realidade, que expõem as disputas pela hegemonia do território, em um primeiro momento muito mais pautado por questões geopolíticas - ocupação para salvaguardar o domínio - e, posteriormente, pela determinação de uma racionalidade econômica (capitalista), que se fundamenta na construção de um conjunto de valores da classe dominante que se universalizam com o intuito de subjugar as classes subalternas, porém não sem resistências.

Para a compreensão da formação territorial do sudeste paraense tomamos como referencia os conflitos oriundos das disputas pelo território, destacando a emergência dos movimentos sociais como uma força importante para o questionamento da estrutura fundiária e do projeto agropecuário e mineral pensado para a realidade em questão.

Para este fim, partimos da noção de Formação Econômico-Social (FES) esboçado inicialmente por Marx (2008) e aprofundado por Lênin (1955; 1988) e Lefebvre (1969), assim como de desenvolvimento geográfico desigual proposto por Harvey (2004) - discutidos no 
capítulo I - pois ela nos permite compreender a dimensão da fronteira que se desenvolve na realidade do sudeste paraense. Se não, vejamos.

\subsection{FORMAÇÃO TERRITORIAL DO SUDESTE PARAENSE: ACUMULAÇÃO DESIGUAL DE TEMPOS E ESPAÇOS}

A formação territorial do sudeste paraense é marcada por temporalidades e espacialidades próprias de formações econômico-sociais anteriores que ainda permanecem, reproduzindo-o e/ou transformando-o, originando conflitos territoriais, que se articulam com processos desenvolvidos em outras escalas, conformando uma área de fronteira.

Não trabalharemos de maneira separada a fronteira como frente de expansão e frente pioneira, pois, como afirma Martins (2009), essas visões divergentes da fronteira - frente de expansão (foca o olhar nas relações internas dos sujeitos sociais preexistentes na região, como os indígenas e camponeses) e frente pioneira (foca no processo de modernização empreendido pelas relações capitalistas de produção) - na verdade refletem a sua contraditória diversidade, marcada por tempos históricos distintos, mas contemporâneos.

Segundo Velho (1981, p. 13), as frentes de expansão são compreendidas "preliminarmente e operacionalmente como sendo constituídas dos segmentos extremos da sociedade brasileira que se internavam em áreas antes não exploradas, e apenas ocupadas por sociedades indígenas". As situações diferenciadas de incremento e/ou retração populacional se apresentam desigualmente, logo, as frentes de expansão se manifestam diferentemente nas regiões. Essa acepção foi bastante trabalhada pelo autor ao debater a realidade do sudeste paraense, foco de nossa pesquisa, entretanto discute-a à luz dos momentos econômicos que indicam, em certa medida, fases econômicas fixas, poucos dinâmicas, incoerente com a noção de formação econômico-social, que consideramos de fundamental importância analítica.

Com relação à frente pioneira, Leo Waibel (1955) indica primeiramente que o conceito de pioneiro corresponde àquele que procura expandir a área territorial, mas também ampliá-la, criando novos e mais elevados padrões de vida, havendo melhoras tecnológicas e culturais. A zona pioneira, por sua vez, ocorre com a expansão acelerada da agricultura e um grande afluxo populacional, isto é, quando a agricultura e o povoamento promovem um boom, concorrendo para a elevação do preço das terras, desmatamento e construção de cidades e povoados. A frente pioneira "exprime um movimento social cujo resultado imediato é a incorporação de novas regiões pela economia de mercado. Ela se apresenta como fronteira econômica". (MARTINS, 1975 grifado no original) Nessa linha de interpretação da fronteira, 
sublinha o processo de modernização e a ação do pioneiro (o empreendedor) desconsiderando ou pormenorizando a ação dos sujeitos preexistentes, como os indígenas.

Nesse sentido, concordamos com Martins (2009) ao entender que fronteira no Brasil, e na Amazônia particularmente, é definida pela situação de conflito social. Para o autor, "nesse conflito, a fronteira é essencialmente o lugar da alteridade" (MARTINS, 2009, p. 133). Inicialmente se apresenta como o lugar do encontro daqueles grupos sociais díspares (índios e "civilizados", grandes proprietários de terra e camponeses). Entretanto, o conflito corrobora para que a fronteira seja, simultaneamente, o lugar de descoberta e de desencontro do outro, decorrentes de modos de vida divergentes, mas principalmente pelo desencontro de temporalidades históricas, visto que "cada um desses grupos está situado diversamente no tempo da História” (MARTINS, 2009, p. 133). Nesse tempo da fronteira, Martins, de acordo com Suzuki (2016), sobrevaloriza a figura da vítima, apresentando uma posição diferente do seu texto "Frente Pioneira: Contribuição Para Uma Caracterização sociológica", publicado no livro Capitalismo e tradicionalismo (MARTINS, 1975), visto que nele a fronteira era definida como frente de expansão e frente pioneira, noções explicitadas anteriormente. Ao valorizar a vítima em sua acepção de fronteira, Martins (2009) supera a ideia de temporalidade única, na qual se visualiza apenas a presença de uma figura central (SUZUKI, 2016) ${ }^{9}$, em outros termos, hegemônica.

Essas temporalidades, oriundas de tempos históricos diferentes, que se chocam, criando um conjunto de tensões sociais, apresentam uma dimensão espacial, ou melhor, expressam territorialidades (re)construídas em contextos diversos, mas que por apresentarem racionalidades diferentes ora são extintas, como é caso de alguns grupos indígenas ao entrarem em conflito com castanheiros, garimpeiros ou grandes proprietários de terra; ou são redefinidas, com a construção de territórios precarizados em periferias urbanas. Essas formas de território "concedidas" pelo capital aos grupos subalternos são contestadas pelos movimentos sociais que emergem nessa fronteira, ampliando a luta, a resistência e os conflitos, atuando inclusive em diversas escalas geográficas, a exemplo do MST.

\footnotetext{
${ }^{9}$ Esse autor possui diversos trabalhos que versam sobre as contribuições de Martins para a compreensão da realidade brasileira, especialmente no que tenge à ideia de frentes de expansão e frente pineira e renda capitalizada, noções bastante importantes em seus trabalhos sobre Rondonópolis (SUZUKI, 1996) e São Paulo (2002).
} 
Com efeito, articulam-se três elementos analíticos importantes, a saber: formação econômico-social, desenvolvimentos geográficos desiguais e fronteira. Essas são a base para a compreensão da formação territorial do sudeste paraense.

Por entender o sudeste paraense como uma fronteira, devemos salientar os conflitos territoriais que surgem no seu seio em decorrência das distintas racionalidades e propostas de uso e apropriação do território. A compreensão do presente nos indica as diversas camadas de formações sociais anteriores que ainda permanecem vívidas, mas subjugadas à lógica hegemônica do capital. Contudo, elas nos mostram a diversidade da fronteira e as possibilidades de outros projetos territoriais aqui definidos como contra-hegemônicos.

Nesse sentido, faz-se necessária a reconstrução da formação territorial do sudeste paraense para melhor compreensão do grau e da natureza dos conflitos por hegemonia que estão em jogo.

\subsubsection{Disputas territoriais pela forma de apropriação da natureza: território} comunal/coletivo e apropriação privada do território

A produção espacial do sudeste paraense, e de Marabá particularmente, de acordo com Velho (1981), está atrelada inicialmente a uma dinâmica de interiorização empreendida pelo governo de Portugal, ainda no período colonial, como uma forma de impedir possíveis avanços dos franceses no Tocantins, motivo pelo qual foram mandadas expedições de catequização e aprisionamento de indígenas, contribuindo para uma certa territorialização ao longo do médio Tocantins, embora de maneira muito tímida.

Nesse período inicial de produção territorial por parte dos sujeitos externos à Amazônia, que introduzem outras lógicas e racionalidades, houve uma apropriação dos elementos da natureza como meios de se desenvolver a circulação (de mercadorias, pessoas e informações), atividade para as quais os rios são fundamentais, especialmente o médio curso do Tocantins, que funcionou como via de transporte e comunicação durante a produção extrativista na região em relevo, com destaque para o atual município de Marabá, que ganhou um papel primordial no âmbito econômico e político regional.

O local que hoje corresponde ao seu município se vincula a um contexto nacional, em que a atividade pecuarista era subsidiária da produção de açúcar, e que tinha como centros de dispersão do produto as cidades de Salvador e Olinda. (VELHO, 1981)

Com a crise da economia açucareira, a pecuária começou a ter maior destaque e se estruturou como frente de expansão em várias áreas, como Goiás, Maranhão e, finalmente, ao 
longo do rio Tocantins, devido à sua importância como via de comunicação, havendo também o aparecimento de entrepostos ligados à sua navegação. Nesses locais se praticava uma agricultura ainda muito incipiente e de subsistência. Assim, iniciou-se uma disputa pelo controle da área de confluência dos rios Tocantins e Araguaia, mais especificamente por São João do Araguaia, que apresentava grande proximidade com as frentes pastoris. (VELHO, 1981)

E foi nessa trama de acontecimentos que se fundou a colônia agrícola do Itacayuna, cujo expoente perdurou de 1895 a 1913 e da qual se originou o atual município de Marabá, cuja formação se deu em consonância com a proclamação da República do Brasil; período de reorganização do trabalho, com a abolição da escravidão; e da passagem do sistema imperial ao federativo, ocasião em que as províncias se tornaram Estados-membros. (EMMI, 1999; VELHO, 1981)

O desenvolvimento de Marabá é decorrente de um conflito político-partidário entre lauristas e florianistas ${ }^{10}$ (denominado conflito de Boa Vista de Goiás), em que o segundo grupo perdeu e se dirigiu, sob a liderança do coronel Carlos Gomes Leitão, ao Itacayuna. Essa colônia agrícola era povoada por vaqueiros, agricultores, comerciantes e antigos proprietários de terras de Goiás e Maranhão, que tinham sua atividade econômica pautada no extrativismo da castanha e na criação de gado. (EMMI,1999)

Nesse período a economia da borracha encontrava-se em seu auge na região amazônica e os migrantes, em detrimento da agricultura, privilegiaram o extrativismo do látex e da castanha, ainda que essa última em menor proporção naquele momento.

A atividade gomífera alcançou seu apogeu no sudeste paraense com a descoberta de árvores de caucho (Castilla ulei), da qual se retirava a goma para fabricação de borracha; essa descoberta levou a uma migração intensa de nordestinos para o local. Diferentemente de outras áreas amazônicas, ali essa prática se tornou predatória, pois o caucho precisava ser derrubado para a retirada do látex, o que não ocorria com a seringueira (Hevea brasiliensis).

Todavia, essa porção territorial entrou em declínio devido ao descumprimento das cláusulas contratuais da colônia (Itacayuna) em relação ao Estado, o que levou a uma dificuldade financeira; a descoberta do caucho, por sua vez, inverteu as prioridades de caráter agrícola para a extração de goma, resultando em um aumento populacional significativo. Por fim, houve problemas políticos do líder da colônia devido à sua má administração, processo

\footnotetext{
${ }^{10}$ Partidários de Lauro Sodré e Marechal Floriano Peixoto, respectivamente.
} 
que levou à transição do burgo de Itacayuna ao povoado de Marabá. Este, por sua vez, se produziu sob os interesses de caráter essencialmente comerciais, cujo produto principal deixava de ser o caucho - que motivou uma série de conflitos por sua posse-, para ser a castanha, produto bastante utilizado nas primeiras décadas do século XX, e que se tornou uma atividade inicialmente interessante para amenizar a crise vivenciada em virtude do declínio da borracha (EMMI,1999).

Embora a economia baseada na extração de castanha ainda não tivesse se desenvolvido plenamente até o início do primeiro quartil do século XX, é importante salientar que a migração e a atividade gomífera desempenharam mudanças na geografia indígena, posto que muitos grupos indígenas já começavam a ser desterritorializados.

Esse fato foi descrito pelo antropólogo Nimuendajú (1946), que em suas pesquisas discute os índios Gaviões do "Ocidente" (ou da mata). Ele relata que ao longo do rio Tocantins, na confluência com o Araguaia, as florestas eram habitadas por uma tribo indígena discidente da tradição Pykobjê do Grajaú (no Maranhão), que migrou para a área a fim de evitar relações com as pessoas "civilizadas". Esse processo antecede o período de maior contato com os brancos da região, ocorrido principalmente após 1890, momento em que se observam:

[...] as invasões de seringueiros e, mais tarde, de castanheiros [que] levaram a encontros sangrentos e daí a reputação da enorme selvageria dos Gaviões. Especialmente na pequena cidade de Marabá, o centro dos comerciantes de borracha e castanha, produtos encontrados nos limites da região dos Gaviões, na confluência do rio Itacaiúnas, o povo clama constantemente pelo extermínio da tribo. (NIMUENDAJÚ, 1946, p. 20)

A desterritorialização indígena, e ulteriormente de camponeses migrantes que se instalaram nesse período, acentuou-se progressivamente por conta de a ação do capital mercantil estimular relações não-capitalistas de produção, como o aviamento, e a apropriação dos recursos da natureza como bens mercantilizáveis, provocando fortes impactos e conflitos com grupos sociais que residiam e/ou sobreviviam da/na floresta, que passa de um bem coletivo e de uso livre para um produto privado e monopolizado por grupos econômicos hegemônicos.

Esses territórios que viriam a ser apropriados mercadologicamente, com a anuência do Estado, foram denominados por Moraes (2005, p. 69) de fundos territoriais, que se referiam às fronteiras, aos "lugares ainda sob o domínio da natureza ou dos 'naturais' $[\ldots],[\ldots]$ estoques de espaços de apropriação futura, os lugares de realização da possibilidade de expansão". A potencialidade de uso futuro dos recursos existentes nesses fundos territoriais se projeta na 
consciência dos sujeitos econômicos, concorrendo para uma reavaliação do valor de tais fundos, hoje cada vez mais diminutos (MORAES, 2009), funcionando como uma espécie de reserva territorial.

\subsubsection{Das terras livres ao monopólio dos recursos da natureza}

A castanha (Bertholetia excelsa) era um produto utilizado pelos indígenas e migrantes em sua alimentação ou comercialização e esses grupos podiam explorar livremente as áreas de castanhais, com base no seu trabalho familiar.

Porém, como registrou Emmi (2002), com o aumento do comércio da castanha se iniciou um disciplinamento e controle sobre o uso e a apropriação das áreas de castanhais. Para esse fim criou-se em 1918 a Lei n. 1.747 que permitia a compra de terras devolutas do Estado e, após três anos, foi promulgada a Lei n. 1.947 que previa o aforamento perpétuo em terras devolutas do Estado. Em 1925, uma nova forma de controle foi implantada pelo Estado, qual seja, o arrendamento, que corresponderia a uma espécie de aluguel da terra por período de safra; a prática generalizou-se como modalidade de uso dos castanhais a partir de 1930, passando a ser um instrumento legal para o benefício político e econômico da oligarquia castanheira emergente em detrimento dos pequenos e médios produtores. Esse mecanismo findou concretamente a extração livre e possibilitou o monopólio do comércio da castanha. Ao lado do arrendamento, foi garantida pela lei a "extração livre" nos castanhais de servidão pública, também denominados "castanhais do povo", nos quais os coletores de menor expressão econômica podiam explorar o produto, mediante uma taxa de inscrição a ser paga nas prefeituras locais. Em outras palavras, a exploração livre da coleta no início do século XX passa a ser disciplinada pelo Estado:

Segundo dados do Instituto de Terras do Pará - ITERPA, em todo o Estado havia 27 castanhais de serventia pública, distribuídos por 11 municípios. Esses castanhais haviam sido destinados a esse fim por meio de leis específicas. A área total era de 169.770 hectares. Em Marabá esses "castanhais do povo" são referência obrigatória na memória social. Eles foram concedidos de 1920 a 1960, compreendendo uma área total de 29.890 hectares que correspondem às serventias do Landy, Geladinho, Jenipapo, Alto Bonito. A essas serventias podem-se acrescentar ainda os 4.356 hectares da légua patrimonial de Marabá, nos quais os castanhais eram livres. Este dado permite ter uma ideia da extensão da terra de uso comum que foi apropriada por grupos locais. (EMMI, 2002, p. 4)

A apropriação das áreas de servidão pública foi, no entanto, bastante conflituosa, com uso de grande violência por parte das oligarquias que se autointitulavam "donos dos 
castanhais", propriedade esta que não foi reconhecida pelos sujeitos expropriados, de tal modo que, embora fossem sufocadas, houve várias ações de resistência.

Os arrendamentos tinham regras a serem cumpridas por parte do arrendatário, como o beneficiamento do local, reflorestamento e plantio de cultivos agrícolas, sendo que esses lotes seriam de posse de um dado sujeito por cinco anos, podendo ser feito um novo contrato, caso não houvesse outros interessados. Essa cláusula contratual contribuiu para que muitos dos donos de castanhais não os beneficiassem efetivamente (DIAS, 1959).

A coleta e negociação da castanha eram voltadas principalmente, na época, ao mercado externo dos Estados Unidos e Inglaterra. Sua negociação estava pautada nos mesmos padrões de comercialização da borracha, feita por meio de casas aviadoras e de firmas exportadoras, que realizavam o monopólio da sua venda (DIAS, 1959).

Marabá, elevada à categoria de cidade em 1923, acabou se tornando, em 1928, uma das maiores produtoras de castanha do estado do Pará, com cerca de 15.304 hectolitros. (EMMI, 1999).

Após a crescente valorização desse recurso extrativista no mercado externo, as relações de trabalho passaram a ser cada vez mais sustentadas pelo sistema de aviamento, embora resguardassem algumas peculiaridades. Desse modo, o castanheiro - geralmente imigrante contratado nos sertões de Goiás e do Maranhão, nos municípios do baixo Tocantins, além de Marabá - era responsável pela extração da castanha, ganhava por hectolitro desse produto, a ser vendido obrigatoriamente ao dono do castanhal. Este, por sua vez, estipulava o preço do fruto e o pagava em forma de mercadorias, entretanto, o que era pago nunca cobria o valor total dos artigos adquiridos pelo trabalhador no barracão (alimentos, roupas, tabaco, terçado, querosene etc.), criando um ciclo de dependência constante (EMMI, 1999; VELHO, 1981).

Os patrões, por sua vez, para financiar os castanheiros, vendem com antecedência a produção de seu castanhal aos comerciantes em Marabá, e estes, por fim, às casas exportadoras de Belém (EMMI, 1999; VELHO, 1981).

O transporte da castanha ocorria principalmente por meio da rede hidrográfica do Araguaia-Tocantins, especialmente nos períodos de cheias, ficando extremamente dificultosa sua navegabilidade nos meses de estiagem (nessa estação, que vai de julho a dezembro, o produto em destaque ficava geralmente armazenado), além de apresentar trechos encachoeirados. Assim, nesse período da economia extrativista, havia uma grande relação com o rio, já que por ele circulava quase toda a produção econômica regional, sendo o médio Tocantins abastecido pelos portos de Belém e de outros estados. 
Para transpor os obstáculos hidrográficos, foi construída a Estrada de Ferro Tocantins (EFT), entre os anos de 1905 e 1944, que contornava a margem esquerda do rio Tocantins; e seguia de Jatobal (área do atual município de Jacundá, que foi inundado pelo lago formado pela Hidrelétrica de Tucuruí) a Tucuruí, por um trajeto de 117,2 quilômetros construídos (DIAS, 1958).

No entanto, as viagens estavam ainda muito influenciadas pelo regime fluvial. Por Marabá ter relações comerciais muito fortes com Belém, em momentos de enchente havia um tráfego quase diário de embarcações que transportavam a produção de castanha para a capital paraense, e de lá os comerciantes traziam vários tipos de alimentos e de outros produtos para serem revendidos. Mas em períodos de vazante, o número de viagens era reduzido, porque as corredeiras se tornavam perigosas. Logo, era necessário levar os artigos extrativistas até Jatobal, subindo o rio por 120 quilômetros. Desse ponto se fazia a baldeação da carga, que seguia para Tucuruí por meio da EFT. Dessa cidade iria novamente pelo rio em direção a Belém. (DIAS, 1958) - ver figura 3 -.

A reorganização territorial promovida na economia da castanha consolidou o poder econômico e político de determinados grupos da oligarquia local: enquanto alguns sujeitos econômicos especializavam-se em uma dada etapa da economia extrativa - como os comerciantes/financiadores mais capitalizados, que se sobressaíam pelo controle sobre o beneficiamento e a comercialização das castanhas -, outros grupos oligárquicos controlavam as terras e se legitimavam pela exploração da castanha, obtendo o monopólio dessa atividade mediante a extração do lucro comercial. Alguns grupos oligárquicos mais fortes desenvolviam tanto o comércio/financiamento quanto o arrendamento das terras de castanhais, obtendo igualmente o monopólio sobre a extração e sobre a circulação e o comércio desenvolvido por meio dos rios, uma vez que eram proprietários das embarcações, além de comercializarem os gêneros alimentícios para a subsistência dos castanheiros. (EMMI, 1999, 2002) 
Figura 3 - Região dos castanhais do Médio-Tocantins-Pará (1948-1980).

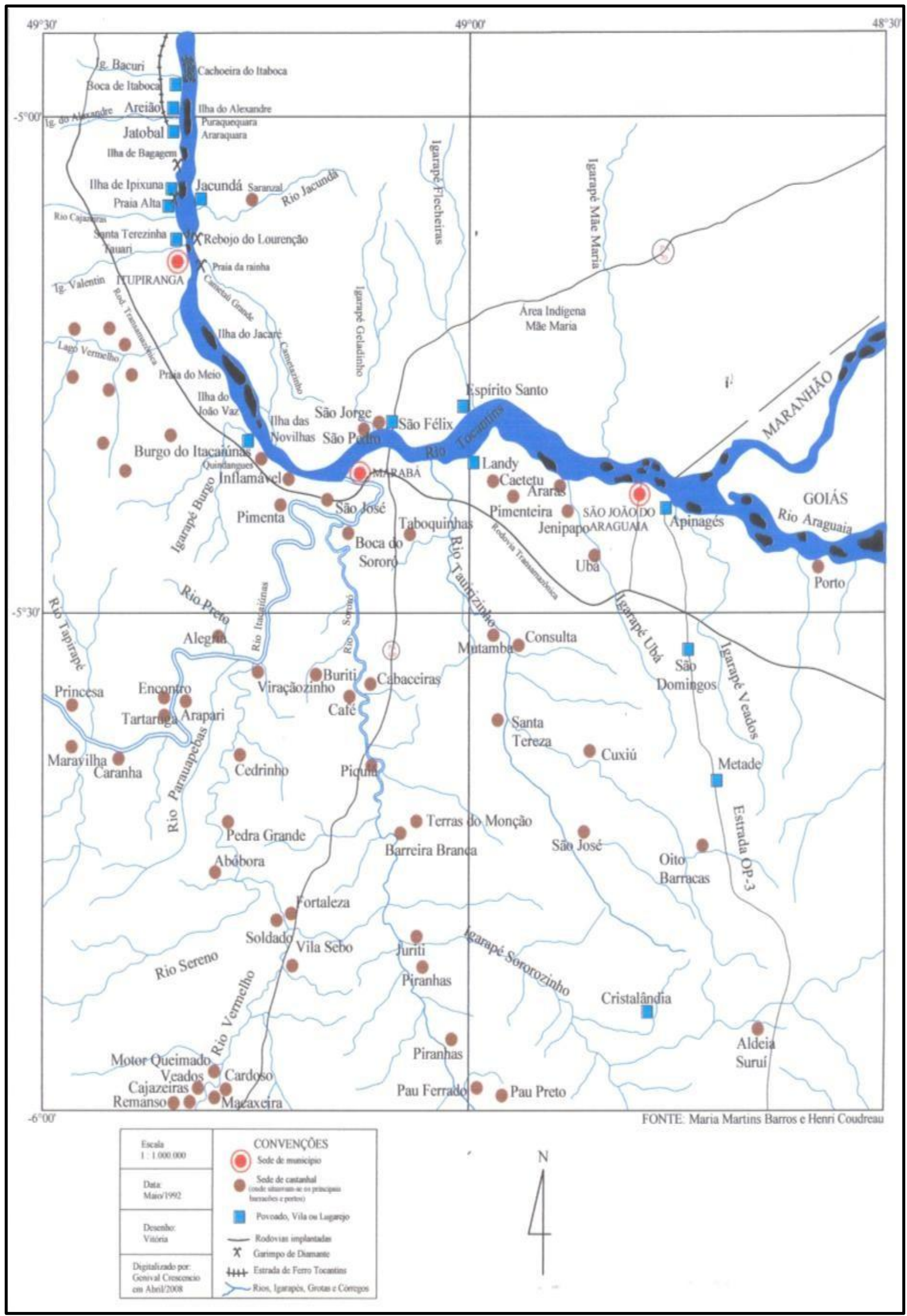

Fonte: Maria Martins Barros e Henri Coudreau apud CARNEIRO, Aldair José D., 2009. 
Com efeito, a reorganização do território do sudeste paraense deixou de obedecer a uma lógica dos povos e comunidades tradicionais (ao menos plenamente), para tornar-se condição de reprodução das relações mercantis e consolidação da hegemonia das "Oligarquias dos Castanhais", que

Por meio da apropriação da terra, passaram a dominar toda a atividade produtiva. Tendo a seu dispor os meios que os capacitavam a controlar a atividade produtiva desde a extração da castanha lá na mata, o transporte para Marabá, até a entrega para o exportador, estavam dadas as condições iniciais para que alguns desses grupos exercessem a dominação política local. A fonte da riqueza e do poder desses grupos repousava sobre o monopólio do crédito, do transporte e, aos poucos, sobre o controle dos castanhais. Tudo isso lhes permitia auferir os maiores lucros no processo de comercialização. A isso se acrescentava o controle dos próprios castanheiros pelo sistema da dívida e pela força organizada de jagunços e pistoleiros. (EMMI, 2002, p. 5)

Essa apropriação dos territórios antes coletivos se consolida em 1954, com a Lei n. 913, que definiu o aforamento como a principal forma de uso dos castanhais, indo ao encontro dos anseios dos grandes arrendatários que reclamavam não apenas um tempo maior de concessão das áreas arrendadas, mas uma apropriação concreta e mais duradoura dos castanhais. A lei supracitada, embora estipulasse que as áreas ainda seriam de propriedade do Estado, permitia ao foreiro o direito de uso por 99 anos (uma espécie de aforamento perpétuo), e como os aforamentos deveriam ser feitos com a anuência do Estado e as cláusulas dos títulos de aforamento não foram devidamente analisadas, os foreiros tornaramse "donos dos castanhais" (EMMI, 2002; VELHO, 1981).

Entretanto, as ações dessa oligarquia não eram apenas sobre os "castanhais do povo": se apropriavam igualmente de terras indígenas. Da Matta e Laraia (1978) demarcam temporalmente dois momentos distintos do contato entre os indígenas e os "civilizados". No primeiro momento, os intitulados "pioneiros" utilizavam as margens do rio Tocantins como parada, com o objetivo de construir núcleos pastoris ou agricolas, conforme foi indicado anteriomente, não havendo interesses econômicos que os impelissem à penetração da mata, o que perdurou do século XVII ao XIX. Desse modo, havia um certo desconhecimento acerca dos índios Gaviões (nome dado popularmente aos indigenas do grupo Jê). Mas o começo do século XX marca uma ruptura e um outro momento de interação, visto que o incremento da economia extrativista (inicialmente com o caucho e posteriomente com a castanha-do-Pará) viria a alterar a estrutura socioeconômica da região, havendo uma iniciativa de neutralização dos Gaviões, especialmente com a exploração da castanha, com o intuito de se apropriar das reservas desse produto em territórrios indígenas ao longo da margem direita do rio Tocantins. 
De acordo com Da Matta e Laraia (1978), na região entre os rios Tocantins e Xingu havia a predominância da ocupação de índios do grupo linguístico Jê, embora no passado tribos Tupi tivessem adentrado a área. Os grupos indígenas, até a década de 1960, se distribuíam espacialmente da seguinte maneira: a) os Akuáwa-Asurini tradicionalmente se territorializaram nas matas localizadas entre as cabeceiras do igarapé Trocara, afluente do Tocantins, e as margens do rio denominado Parakanân, provavelmente o Jacundá ou Pacajá; b) os Parakanân, considerados até então isolados, circulavam pelo alto Pucurui e o lugar de sua aldeia não era conhecido; c) os Suruí localizavam-se na porção que vai dos igarapés Gameleira (afluente do Araguaia) e Grotão dos Caboclos, um dos formadores do Sororó, afluentes do Itacaiúnas, um dos principais tributários do Tocantins (Ver figura 4, referente ao território indígena antes da economia da borracha e da castanha).

Com a expansão da economia da castanha, os contatos entre indígenas e castanheiros passaram a ser cada vez mais constantes e conflituosos. Segundo Da Matta e Laraia (1978), em 1947 os coletores de castanha estabeleceram uma "colocação" - local de moradia na mata - em um lugar denominado de Cajueiro, momento em que os indígenas Suruís tentaram uma aproximação, mas foram expulsos pelo proprietário da "colocação" e os seus empregados, que acabaram ferindo alguns dos índios, os quais se mudaram para uma aldeia distante oito quilômetros do local. Em 1952, o frei Gil Gomes inicia um processo de "pacificação" com os Suruí, cuja aldeia era composta por cem pessoas. Com essa aproximação, os Suruís buscam, em outubro de 1957, nas margens do Sororozinho (afluente do Sororó), mais uma vez interagir com os castanheiros, mas sem sucesso, pois são repelidos com tiros, ficando um assassinado e outros três feridos. 
Figura 4 - Ocupação indígena antes da economia da borracha e da castanha no sudeste do

Pará

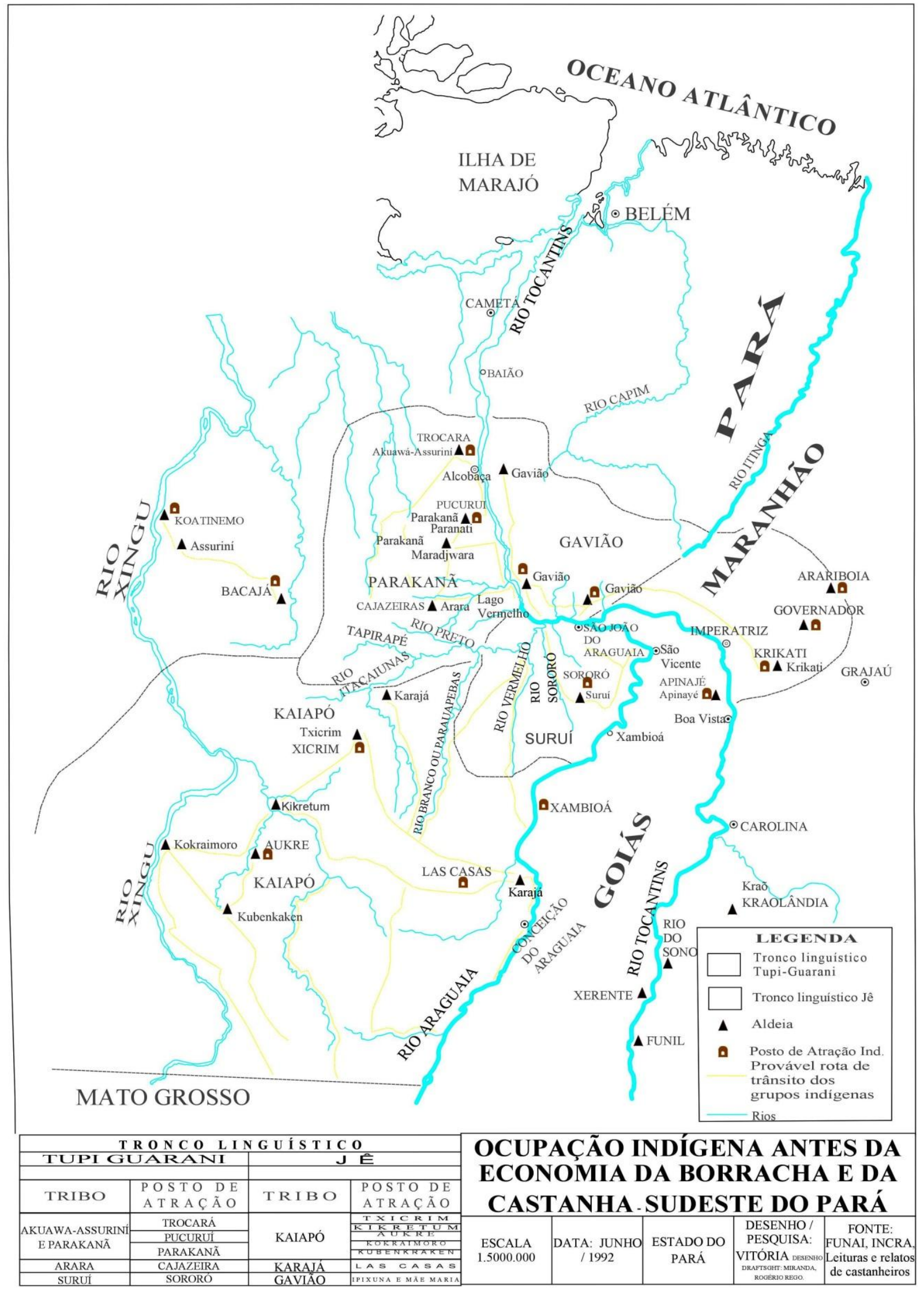

Fonte: BARROS (1992, p.52). Adaptação Rogério Rego Miranda. 
Esses (des)encontros relatados entre indígenas e castanheiros, corroborados igualmente por Ferraz (1984), que estudou os Parkatêjê - grupo Jê-Timbira -, levou quase à extinção étnica desses sujeitos, fato que só não ocorreu pela intervenção dos sujeitos dos órgãos indigenistas do SPI (Serviço de Proteção ao Índio) ${ }^{11}$, posteriormente FUNAI (Fundação Nacional do Índio) ${ }^{12}$, e também pela ação de missionários e de lideranças indígenas.

Embora a desterritorialização dos indígenas fosse iminente, eles traçaram algumas ações de resistência, como ataques aos "civilizados" ou mudanças quanto à sua organização territorial e política. No primeiro caso, por exemplo, na safra de 1930, próximo ao povoado de Joana Perez, os índios Akuáwa-Asurini atacaram e mataram castanheiros; ataques ocorreram também em maio do mesmo ano, no quilômetro 40, e deixaram dois mortos. Já em 1937, no quilômetro 11 também da EFT, os Akuáwa-Asurini entraram em contato com funcionários da SPI e, em seguida, foram abordados violentamente pelos trabalhadores da ferrovia: quando revidaram, mataram duas pessoas e feriram outra em um barracão (DA MATTA; LARAIA, 1978). Paternostro (1945), embora por uma perspectiva etnocêntrica, também indicava diversos ataques indígenas, que ocorriam como resposta a várias investidas dos castanheiros aos seus territórios.

Em uma segunda forma de resistência, no que se refere a sua organização políticoterritorial, os Parkatêjê, por exemplo, inicialmente criaram relações de troca com os "civilizados", chamados de Kupê, na qual permitiam a entrada dos castanheiros nas matas para retirarem castanha e em troca recebiam mantimentos e instrumentos de trabalho; esses acordos, no entanto, não impediram os conflitos. Posteriormente, segundo Ferraz (1984), os Parkatêjê utilizaram uma espécie de manipulação da etnicidade: primeiramente criaram mecanismos de semelhança com os "cristãos", imitando-os culturalmente (roupas, cabelos, organização espacial das casas), com o intuito de criar um modelo de comunicação. Todavia, com o decorrer do tempo esse modelo cultural Kupê se metamorfoseou, com o objetivo de criar uma diferenciação, um contraste em relação aos outros. Projetam a construção de uma contra-hegemonia baseada na afirmação de uma política identitária, demarcando "um nós frente a nós mesmos" (FERRAZ, 1984, p. 20, grifado no original), que passa a ser a

\footnotetext{
${ }^{11}$ O SPI foi criado pelo Decreto Lei $\mathrm{n}^{\circ}$ 8.072, de 20 de junho de 1910, com o objetivo de prestar assistência aos índios do território nacional brasileiro.

${ }^{12}$ A FUNAI foi criada pela Lei $n^{\circ} 5.371$, de 5 de dezembro de 1967, correspondendo ao órgão indigenista oficial do Estado brasileiro é vinculada ao Ministério da Justiça e tem por objetivo a demarcação, regularização fundiária e proteção de terras indígenas, além do registro, monitoramento e fiscalização destas áreas.
} 
perspectiva adotada a partir de um conjunto de práticas que potencializam a possibilidade de "ver a si mesmos a partir de uma ótica dominante" (FERRAZ, 1984, p. 20, grifado no original), na qual a existência perpassa um modo próprio de realização das coisas, por uma ação coletiva, reativando traços culturais (vestimentas, cabelo, cerimônias e organização espacial circular das aldeias). Essas iniciativas de resistência configuram a demarcação de uma temporalidade que é composta por um conjunto de experiências que se instituem no tempo, conscientemente por meio da reformulação das relações sociais, "tempo esse que supõe uma retomada ativa do passado e uma visão do futuro, do devir histórico" (FERRAZ, 1984, p. 24), demarcando assim uma forma de luta pelo território.

Nesse contexto, paralelamente ao extrativismo, outras atividades também se desenvolviam com fortes problemas para os indígenas. Em períodos de estiagem, devido aos rios baixarem e o veio mineral ficar descoberto, realizava-se o garimpo de diamantes e de cristal de rocha. O primeiro começou a ser explorado ao final da década de 1930 e se constituía em uma frente econômica superficial, apresentando resultados pouco expressivos e localizados, com pequenos surtos de curta duração, compreendendo uma prática complementar à castanha, embora tenha impulsionado o aparecimento de currutelas, que originaram, posteriormente, aglomerações urbanas (VELHO, 1981). O segundo minério passou a ganhar destaque durante a Segunda Guerra Mundial e contribuiu para diminuir a crise econômica de Marabá, ocasionada pela falta de compradores e a desvalorização da castanha internacionalmente nesse período (DIAS, 1958). Essa atividade atingiu a área tribal dos Suruí no baixo Araguaia, concorrendo para um maior contato e, consequente, "pacificação" dos indígenas (DA MATA; LARAIA, 1978). A respeito das áreas de castanhais apropriados privadamente e da exploração de minério, vejamos a Figura 5, a seguir. 
Figura 5 - Área dos castanhais e de exploração de minérios no sudeste paraense, 1950-1980*

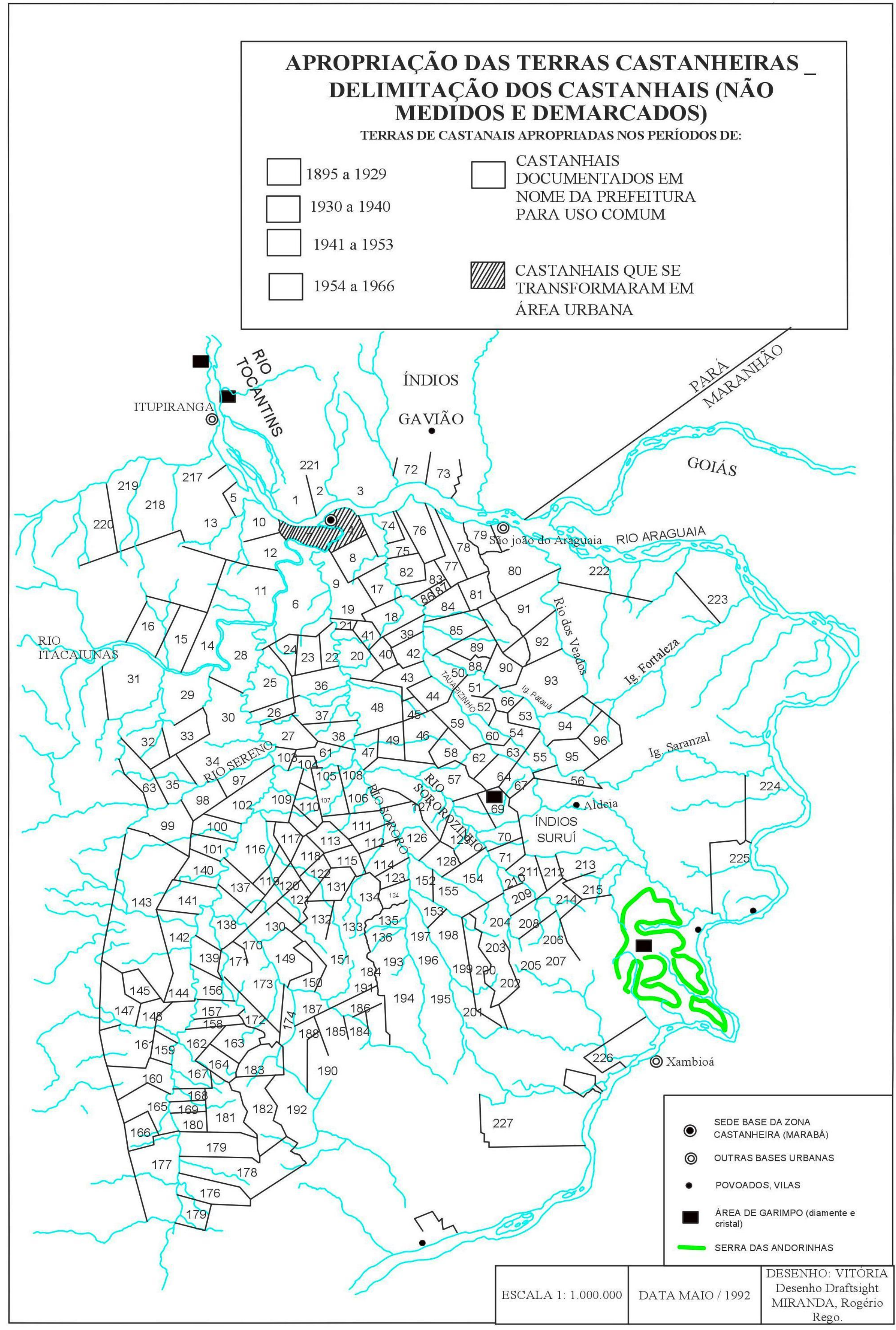

Fonte: BARROS (1992, p.55), adaptação MIRANDA, Rogério Rego.

* Ver no anexo 1 a lista dos proprietários das áreas dos castanhais numerados na figura 5. 
Ao lado da desterritorialização dos indígenas observamos o alto grau de exploração e precarização a que estavam submetidos os migrantes que vieram para a região do sudeste paraense, os quais vão conformar os chamados posseiros, caracterizados da seguinte maneira por Da Matta e Laraia (1978, p. 97-98):

São os posseiros de terras. Uma grande parte deles é composta por imigrantes que ali chegam fugindo da seca no Nordeste. A região, então, lhes parece propícia: as matas são bastante verdes, há água em abundância, e grandes extensões de terras estão desocupadas. Constroem os seus pequenos barracos, derrubam pedaços de floresta, plantam uma roça de milho, mandioca ou fumo, e enquanto esperam pela colheita vivem da caça ou da pesca. Passam grandes dificuldades no início, mas no segundo ou terceiro ano, a situação começa a ser menos difícil, precisam de pouco para viver e os seus produtos encontram um mercado certo em Tucuruí. Um dia descobrem que a terra já tem dono. Então ou continuam ali, porque aquele só quer da terra a castanha, ou seguem a sua peregrinação de camponeses sem terra. Alguns resistem e acabam presos ou mortos. Os mais felizes conseguem com o chefe uma outra parada.

Esse posseiro duplamente expropriado, seja por meio do trabalho seja por meio da expulsão de suas terras, desenvolveria ações de resistência e luta que foram base para o aparecimento dos movimentos sociais via sindicatos ou MST, objetivando, assim como os indígenas, grafar no território sua marca, sua temporalidade, sua existência.

Com o implemento da castanha e da mineração, pouco se investiu na agricultura, que ficou restrita a uma cultura de subsistência à beira dos rios e em ilhas - áreas pouco cobiçadas pelas outras atividades. Embora a agricultura apresentasse um pequeno excedente, que era comercializado em Marabá, a maior parte dos gêneros alimentícios era importada. Por esse motivo, houve, por um lado, o incentivo do governo municipal marabaense no que tange à produção agrícola, realizando loteamentos para posseiros; por outro, a pecuária se desenvolveu, ainda que de maneira reduzida, atrelada à produção de castanha, pois eram necessários ao seu transporte os jumentos, e nos próprios castanhais se criavam gados para o consumo local de sua carne. (DIAS, 1958, VELHO, 1981)

Com a criação dos aforamentos, mencionados anteriormente, houve um maior investimento nas áreas de castanhais, como abertura de estradas, construção de barracas, plantios e um aumento do rebanho bovino - considerado um investimento produtivo de retorno mais lento, mas complementar ao extrativismo. Essa pecuária começou a ganhar grandes incentivos por parte do governo paraense, devido às dificuldades de abastecimento regional. Com efeito, os fazendeiros reivindicam créditos e melhorias no transporte. Mediante os financiamentos governamentais, Marabá, que importava o gado de Goiás e do Maranhão, tornou-se autossuficiente e com um rebanho de maior qualidade. O transporte que 
inicialmente era feito por via aérea, foi posteriormente alterado com a construção da rodovia PA-70 (atual BR-222), que interliga Marabá a Belém; contudo, essa via perdeu sua importância com a construção da Belém-Brasília (BR-010). (VELHO, 1981)

Esse processo anuncia uma nova lógica de apropriação do território amazônico, em que o rio gradativamente foi perdendo sua centralidade enquanto via de circulação e articulação e cedeu lugar às estradas de rodagem. Além disso, atividades complementares (ou seja, a agropecuária e a mineração) deixaram a condição de secundárias e passarem a ser a base da produção econômica da sub-região sudeste do Pará, especialmente com a crise da atividade extrativista.

Não esqueçamos que a territorialização de determinados grupos econômicos impõe a desterritorialização de outros, como bem nos lembra Hébette et al. (1983), visto que, com a ocupação pelo capital mercantil, materializado na economia da castanha, várias índios foram expulsos violentamente de suas tribos, em especial os Gaviões. Essa expropriação de suas terras foi feita com a anuência do Estado, que concedia contratos de arrendamento e exploração de castanhais nessas áreas, deixando esses grupos indígenas restritos a pequenas reservas demarcadas pela FUNAI após muita luta e resistência. Contudo, esse quadro social pouco se altera, ao contrário, se aprofunda com a política proposta pelo governo federal à Amazônia e a chegada de outros migrantes à região, que uma vez desprovidos de condições mínimas de sobrevivência, irão compor diversos movimentos sociais.

\subsubsection{Redefinição da hegemonia regional e inserção de novos sujeitos}

A partir da década de 1970 se observa a implantação do projeto "desenvolvimentista" implementado pelo governo militar (1964-1985) que ambicionava integrar o Brasil através da malha rodoviária. No que concerne à Amazônia, objetivava modernizá-la e integrá-la ao Centro-Sul, pois a região amazônica, além de fornecedora de matérias-primas, deveria cumprir o papel de mercado consumidor (BRITO, 2001), configurando um novo padrão territorial na região e um outro papel na divisão territorial do trabalho, não mais ligado apenas a produtos extrativistas, mas de caráter mineral e agropecuário.

A efetivação inicial desse projeto se processou por uma ação estatal e particular, a chamada fronteira demográfica: implementaram-se políticas de incentivo à migração para a região, de forma a diminuir os conflitos agrários ocorrentes no Nordeste brasileiro e a constituir suficiente mão de obra para viabilizar o desenvolvimento da fronteira econômica, ou seja, a expansão do capital. 
De acordo com Hébette (2004), os movimentos migratórios tiveram duas grandes frentes de penetração na região. A primeira ocorreu no sentido Leste-Oeste e foi feita principalmente por nordestinos que se estabeleceram ao longo do Araguaia, a partir de 1960. Essa leva de migrantes era composta majoritariamente de maranhenses, normalmente pequenos agricultores, que inicialmente foram alocados pelo INCRA, mas houve também a presença daqueles migrantes "espontâneos", que adentraram na área dos castanhais e desenvolveram um processo de ocupação-expulsão-reocupação. A segunda frente de migração seguiu no sentido Sul-Norte, ao final da década de 1970, e se realizou ao longo do rio Tocantins (com pessoas oriundas de Imperatriz e Carolina) e da Belém-Brasília (com indivíduos advindos da região Sul do país). Empreendeu-se, assim, a "modernização" do espaço amazônico e se incentivaram novas relações sociais marcadas principalmente pelo mercado.

Para tanto, o Estado criou vários órgãos que buscavam planejar e executar a expansão econômica da Amazônia: a Superintendência do Desenvolvimento da Amazônia (SUDAM), substituta da Superintendência do Plano de Valorização Econômica da Amazônia (SPVEA); o Banco da Amazônia S.A (BASA) e a Superintendência do Desenvolvimento da Zona Franca de Manaus (SUFRAMA). Nessa modernização econômica da Amazônia, as instituições estatais cumpriram um papel fundamental:

Com base nessa ação governamental a política de desenvolvimento regional foi orientada para estabelecer "pólos de desenvolvimento". A esfera econômica dessa ocupação viria com a atração de capitais para a região por meio de incentivos monetários e fiscais e de criação de uma infra-estrutura para esses investimentos (com a construção de estradas, aeroportos, portos e hidrelétricas). A esfera geopolítica efetiva-se com a imigração inter-regional e estrangeira e a formação de assentamentos nas áreas de fronteira. (ACEVEDO MARIN, 2002, p. 8)

Dessa forma, estava alicerçado o novo projeto de expansão da fronteira amazônica, cujo rebatimento espacial se desenvolveu dando origem a uma nova configuração regional, privilegiando grandes grupos capitalistas, especialmente empresas multinacionais ligadas ao ramo agromineral, o que ampliou as desigualdades sociais.

Nesse contexto, instala-se na Amazônia um conjunto de infraestruturas nos campos de transporte, telecomunicações e energia - representado pelas hidrelétricas (Hidrelétrica de Tucuruí), ferrovias (Estrada de Ferro Carajás) e, principalmente, rodovias, que têm seu incremento inicial na região a partir do governo de Juscelino Kubitschek (1956-1961). Este, baseado no projeto de "Energia e Transporte" e de "Cinquenta Anos em Cinco", implantou as rodovias Belém-Brasília e Brasília-Acre. Mas essa mesma malha ganhou dimensões cada vez 
maiores com o governo militar a partir da construção, por exemplo, da Brasília-CuiabáSantarém e da Brasília-Cuiabá-Porto Velho-Rio Branco, além da Transamazônica. Logo, “a estrada agora é construída na terra firme por grandes empresas de construção civil, essa aliada umbilical dos militares na construção do 'Brasil Grande' ". (GONÇALVES, 2001, p. 102)

No plano geográfico, portanto, há uma mudança do espaço amazônico e, mais especificamente, de Marabá, que continua com a condição de centro econômico sub-regional, com o privilégio das rodovias em detrimento dos rios, além do uso da ferrovia como meio de transporte de minérios retirados do sudeste paraense, como forma de atender aos interesses dos novos sujeitos econômicos.

O Estado também implanta medidas que desarticulam as relações de poder regional, visto que nas estradas federais uma faixa de terra de cem quilômetros de ambos os lados pertencia agora ao governo federal, processo conhecido como federalização das terras estaduais, que transferiu para a União a maior parte das terras e contribuiu para o enfraquecimento da expressão política das elites locais, uma vez que muitas dessas margens foram apropriadas posteriormente por grandes projetos agropecuários, beneficiados por incentivos fiscais concedidos pelo Estado.

Paralelamente, com intuito de manter seu domínio político-econômico, os "donos de castanhais", embora não correspondessem a um grupo homogêneo, iniciaram algumas ações que vão se complementando. A primeira se refere aos "memoriais" enviados às autoridades estaduais e federais e aos órgãos responsáveis pela regularização fundiária como o INCRA e o ITERPA (Instituto de Terras do Pará), no fim dos anos 1970 e início dos 1980, porém sem respostas positivas. $\mathrm{O}$ conteúdo desses documentos ressaltava a necessidade de preservação da área dos castanhais e a preocupação com os conflitos fundiários, entretanto, o que buscavam era salvaguardar o domínio sobre as terras, em face do avanço da expansão agropecuária e mineral e do forte fluxo migratório, que concorriam para o aumento da disputa pelo mesmo território com posseiros, madeireiros, fazendeiros e grupos empresariais, além da militarização da região amazônica que implicou no aparecimento de órgãos fundiários atrelados à política de segurança nacional, a exemplo do GETAT. A segunda ação foi a proposição da criação do "Polígono Castanheiro do Tocantins" (EMMI; MARIN; BENTES, 1987). Foi por esse motivo que:

Em outubro de 1983, o Sindicato Rural de Marabá e a Associação dos Exportadores de Castanha do Brasil enviam um Memorial ao Ministro para Assuntos Fundiários, por meio do qual pretendem alertar as autoridades do país para os problemas decorrentes da queda da extração da castanha-dopará. Os signatários alinham os fatores responsáveis pelo declínio: o desequilíbrio ecológico, o corte indiscriminado, a instabilidade fundiária, as 
invasões predatórias, a falta de proteção eficaz sugerem a revisão fundiária, a mudança de natureza do título, a proteção florestal, além do fortalecimento dos órgãos administrativos policiais e judiciários, culminando com a recomendação da "criação de um polígono de preservação permanente ou utilização limitada dos castanhais". (EMMI, 1999, p. 142, grifado no original)

A estratégia da criação do "Polígono dos Castanhais" como uma ofensiva à perda da hegemonia por parte da oligarquia local mostra não apenas uma alteração na relação de poder, mas igualmente na forma do seu exercício, posto que ele não se realiza unicamente pela coerção. O "Polígono" aliás ganha força como uma categoria argumentativa importante no discurso dos donos dos castanhais, sendo inexistente em momentos anteriores. Como bem arguiu Emmi et al. (1987), o polígono enquanto significante adquire status de política oficial em decorrência de sua vinculação aos pleitos auferidos junto ao Estado. Com efeito, passa a representar uma posição de referência obrigatória no âmbito das demandas reivindicadas por esses sujeitos, ou seja, "essa denominação se reveste artificialmente de um estatuto epistemológico que a transfigura em instrumento de análise, fictício, despossuído de real significado" (EMMI; MARIN; BENTES, 1987, p. 12).

Em verdade, se o polígono constituiu uma iniciativa de manutenção ou de reestruturação da territorialidade dos donos dos castanhais, ele implica necessariamente em uma forma geométrica que imprimiria ao espaço um limite - que não é a-histórico e natural mas socialmente produzido -, com o intuito de apropriação privada de um dado recurso, no caso a castanha-do-pará e, principalmente, a terra.

Por esse motivo o discurso de criação do "polígono", transvertido de um ideal de preservação e de diminuição dos conflitos fundiários, criou um falso cenário no qual os “donos de castanhais" seriam aqueles que não desmatam e preservam a floresta, ao contrário dos posseiros e empresas que chegavam à região. Contudo, muitos deles já haviam se tornado fazendeiros, como as famílias Chady, Chamié e Mutram (EMMI; MARIN; BENTES, 1987), além de haver destruição da floresta castanheira em diversos castanhais de posse de grupos tradicionais, a saber: Peruano, Limão, São Pedro, Santa Cruz, Bia Fé, Centro Novo, Sacrifício. Com efeito, nesse novo momento os donos dos castanhais, mesmo não sendo mais o grupo hegemônico, utilizaram do argumento preservacionista para ocultar seus reais interesses: obter o monopólio da coleta e do comércio da castanha e a manutenção dos seus domínios sobre vastas áreas de terras (BENTES; MARIN; EMMI, 1988).

Nesse ínterim, com a intenção de cuidar dos assuntos fundiários principalmente no "Bico do Papagaio" - que compreende as terras ao sul e sudeste do Pará, oeste do Maranhão e 
norte de Goiás, posteriormente anexadas ao Tocantins (ver Mapa 1) - criou-se o Grupo Executivo de Terras do Araguaia-Tocantins (GETAT) em 1980, desfeito apenas em 1987, que sobrepunha regionalmente as funções do INCRA e da FUNAI (ASSIS, 2009) e estava vinculado ao Conselho de Segurança Nacional (CSN), representando a militarização da questão agrária na Amazônia (MARTINS, 1985). 
Mapa 1 - Área de atuação do GETAT, 1980-1987.

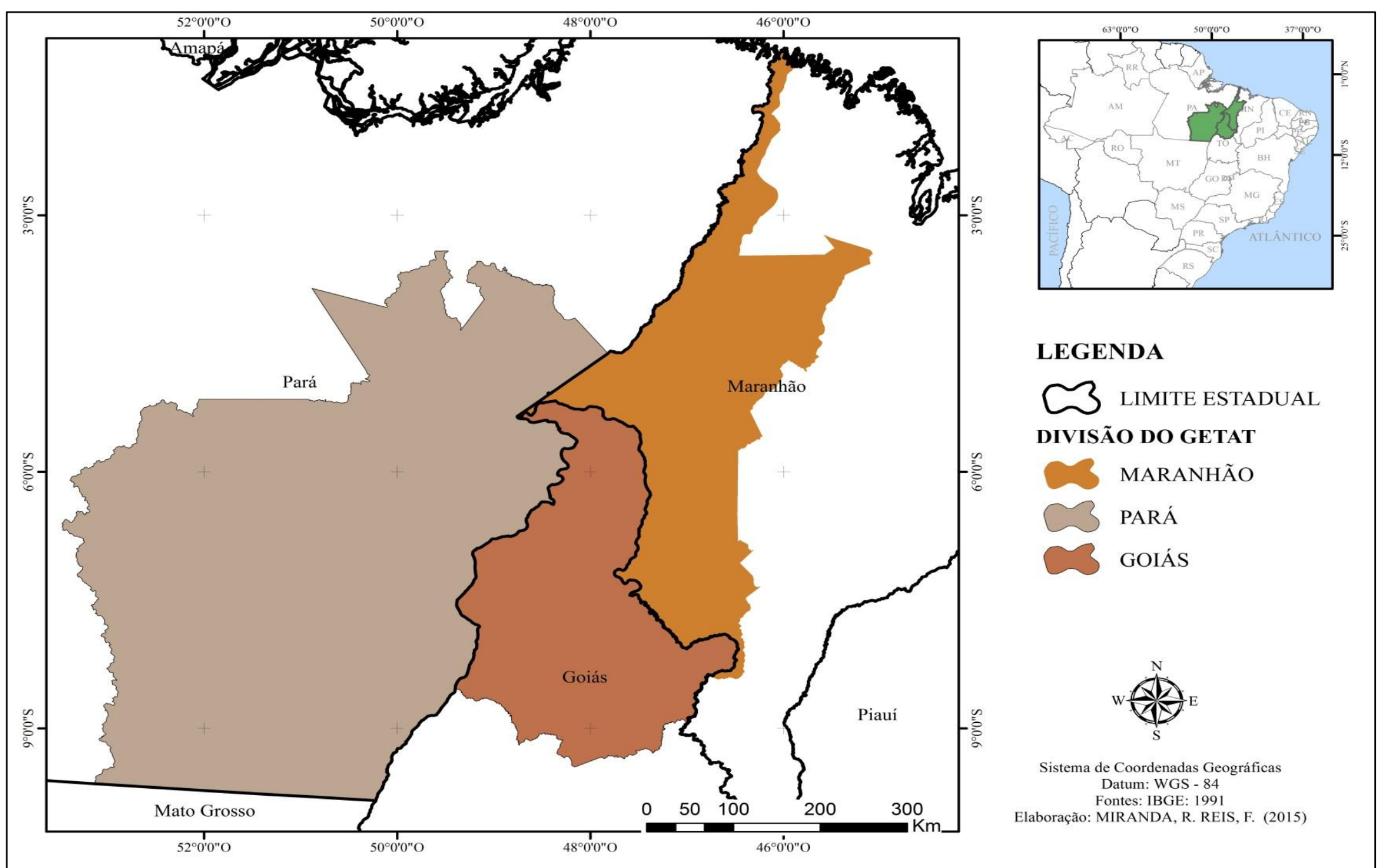


Suas atribuições estavam em consonância com a manutenção do regime de posse, uso e propriedade da terra, e entravam em desacordo com os anseios dos trabalhadores rurais que lutavam por uma reforma agrária mais radical. A ação do GETAT visava a ampliação do desenvolvimento capitalista na região, que só poderia ocorrer com a desestruturação de posseiros, indígenas, garimpeiros, dentre outros que oferecessem resistência à implantação dos projetos agropecuários, de empresas madeireiras e de extração mineral; em outras palavras, trata-se de assegurar terras a esses grupos econômicos, visto o grande fluxo migratório para a região (ALMEIDA, 1981). Segundo Almeida (1985), o GETAT, ao implementar a regularização fundiária, na verdade acabou reconhecendo irregularidades, porque não considerava as fraudes nos cartórios, e os atos de arrecadação; em verdade, visava à regularização de áreas pretendidas pelos empreendimentos, valorizando-as e possibilitando transações comerciais legítimas, contribuindo para a incorporação dessas áreas ao mercado de terras, caso em que criaria condições legais de ações de despejo e a definição dos garimpeiros, coletores de castanha e posseiros como "invasores", além de formalizar a apropriação de terras indígenas.

O GETAT não altera profundamente a estrutura fundiária regional, mas cria condições legais de incorporação das terras por parte do capital financeiro a exemplo do Banco Bamerindus, empresas mineradoras como a Companhia Vale do Rio Doce (CVRD), e de fazendeiros do Centro-Sul, legitimando o caráter rentista do capitalismo no Brasil e, particularmente, na Amazônia pois o capitalista (empresário) torna-se proprietário da terra (latifundiário), constituindo-se no titular da renda fundiária: nesse caso "a determinação histórica do capital não destrói a renda da terra nem preserva o seu caráter pré-capitalista transforma-a, incorporando-a, em renda capitalizada" (MARTINS, 2010, p. 22). Para Suzuki (2006), a noção de renda capitalizada é a mais adequada para compreensão da realidade brasileira e latino-americana, especialmente pela sua formação econômico-social ser marcada pela transição da riqueza pautada no escravo, ou outra forma semelhante de subjulgação do trabalhador ao longo da colonização, para a terra que foi transformada em mercadoria, tornando-se o fundamento da reprodução das relações sociais em geral.

Essa ação do GETAT não contempla plenamente os anseios da oligarquia dos castanhais, ao contrário, em áreas densamente povoadas houve o beneficiamento indireto de várias camadas camponesas, visto que seria impraticável a remoção desses sujeitos, tal qual aconteceu em Xinguara e Redenção, locais de grandes conflitos de terras que envolviam aproximadamente 10 mil trabalhadores (ALMEIDA, 1981). O "Polígono dos Castanhais" não chegou a ser reconhecido oficialmente, embora tivesse sido mencionado por um documento 
do GETAT de 1985, que indicava ser uma área de 1,2 milhões de hectares, abrangendo os municípios de Marabá, São João do Araguaia e Xinguara.

Em suma, por um lado, a oligarquia dos castanhais passava por uma crise de hegemonia, decorrente dos seguintes fatores: a) provenientes dos grandes projetos, as diferentes opções de trabalho que surgem para os antigos castanheiros tornaram-se um problema para os donos de castanhais, que não tinham mais a sua disposição uma mão de obra abundante e submissa às relações paternalistas que impunham; b) embora os latifúndios tradicionais não tivessem sofrido fisicamente grandes alterações, em termos de poder político foram enfraquecidos, devido aos latifundiários serem alijados dos processos de decisão e terem sua hegemonia local questionada, principalmente pelo poder público federal; c) houve uma concorrência com grupos externos pelos castanhais, e o monopólio das famílias tradicionais foi quebrado; d) também entraram em confronto com os posseiros que se instalaram em terras devolutas e desconheciam a propriedade improdutiva e o poder hegemônico dos donos dos castanhais ou protestavam contra isso; e) por fim, houve o deslocamento do centro de decisão política, no que se refere às questões locais, para a esfera do governo federal (EMMI E MARIN; 1996).

Por outro, essa oligarquia criou condições de se rearticular a partir de ações conflituosas que envolviam grupos de trabalhadores rurais recém-chegados, moradores antigos e tribos indígenas, que se "chocavam" com os representantes dessa oligarquia da castanha (e, também, com os empresários capitalistas que migraram para a região). Estes se utilizavam de algumas estratégias para manter seus domínios sobre os castanhais, a saber: a) avançavam sobre os castanhais do povo, configurando a "invasão dos castanhais", com o objetivo de manter seu comando sobre essas terras, expulsando violentamente aqueles que se apossavam delas, além de exercerem pressão via sindicato sobre órgãos governamentais como o INCRA, a fim de denunciar a ação dos "invasores" (faziam denúncias de saques por parte dos posseiros com o intuito de criminalizá-los e, assim, esconder a violência com que eram reprimidos); b) interrogavam a atuação de órgãos federais, pois não encontravam nestes suas pretensões contempladas; c) a reação de defesa da oligarquia decorreu dos conflitos entre a atuação de instituições estaduais e federais na região dos castanhais, sobretudo do descompasso de entendimento entre ITERPA e GETAT, pois o último demarcou terras aforadas, discordando da interpretação do primeiro, para o qual as terras de castanhais não poderiam ser tocadas; d) as famílias oligárquicas de expressão na região procuraram se legitimar na esfera política, a partir da candidatura a cargos públicos; e) as oligarquias 
articularam-se para impedir a desapropriação de terras dos castanhais em conflito, e assim, pedir a reintegração de sua posse. (EMMI; MARIN, 1996)

Esse revigoramento do poder regional é favorecido pela necessidade de o governo federal, na transição do governo ditatorial para à "Nova República", encontrar aliados político-partidários na região, havendo uma reconsideração dos interesses locais, que, por seu turno, deveriam lidar com os conflitos fundiários, com objetivo de diminuir as tensões no campo (ALMEIDA, 1981).

Nesse contexto, eclodem diversos conflitos por terra não apenas devido à ação violenta da oligarquia dos castanhais, mas porque entram em cena novos sujeitos econômicos atrelados à agropecuária e/ou à mineração, que atuam em diversas escalas geográficas e têm a anuência do Estado para se apropriar de territórios de indígenas e posseiros, tornando demasiadamente complexa a estrutura fundiária do intitulado "Polígono dos Castanhais".

Como a Figura 6 mostra, observamos no sudeste paraense a implantação do Programa Grande Carajás (PGC), que era composto pela mina da Serra de Carajás (Projeto Ferro Carajás), a Usina Hidrelétrica de Tucuruí (UHT) e a ALBRAS-ALUNORTE ${ }^{13}$. Esse programa, levado a cabo desde o período da ditadura civil-militar, iniciou-se com a "descoberta" de minério de ferro na Serra de Carajás, que, segundo Oliveira (1987), ocorreu em 1967 pela Cia. Meridional de Mineração (subsidiária da United States Steel Co.).

\footnotetext{
${ }^{13}$ Indústria de alumínio e de alumina localizada no município de Barcarena-Pará.
} 
Figura 6 - Estrutura fundiária do "Polígono dos Castanhais" na década de 1980.

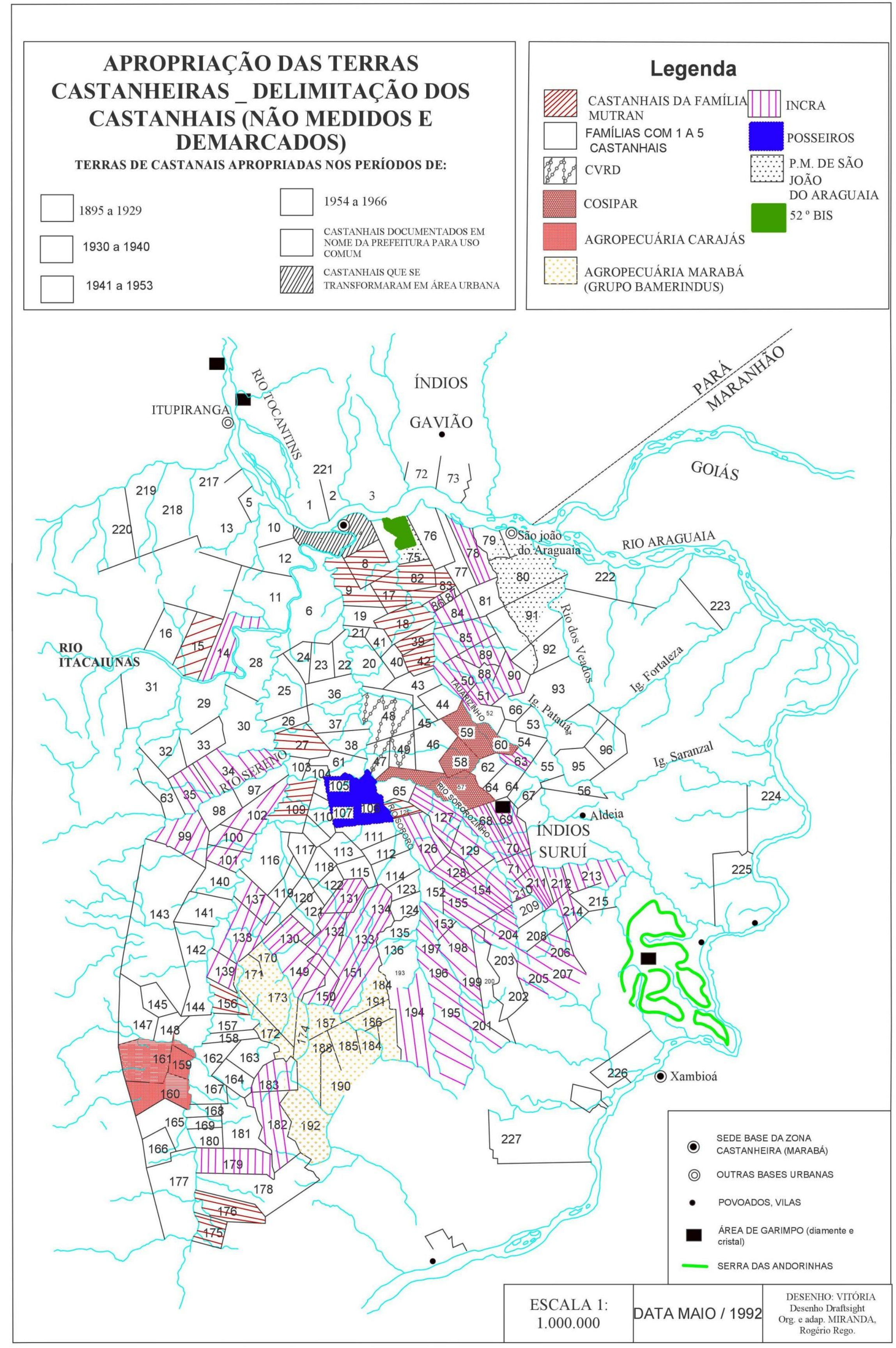

Fonte: BARROS (1992). Adaptação Rogério Rego Miranda. 
A exploração do ferro de Carajás começou a ser realizada a partir de um acordo entre o Estado-empresário e a multinacional, resultando na criação da AMZA (Amazônia Mineração S.A) em 15 de abril de 1970, empresa que tinha a participação da então estatal Cia. Vale do Rio Doce, com 50,9\% das ações, e da Cia. Meridional de Mineração (U. S. Steel) com 49,1\%. Essa associação foi desfeita na década de 1970 devido à crise do petróleo, momento em que a empresa norte-americana vendeu suas ações à CVRD por 50 milhões de dólares em junho de 1977, fato que levou à extinção da AMZA, e iniciou-se o Programa Grande Carajás em 1980 (OLIVEIRA, 1987), extinto em 1991.

Para a implantação do PGC houve uma política de migração realizada pelo governo federal que contribui para um crescimento populacional substancial ao longo da Estrada de Ferro Carajás (EFC) ${ }^{14}$, aumentando a concentração demográfica nas cidades de Marabá (PA), Imperatriz e Açailândia, ambas no Maranhão, além de antigos povoados de Parauapebas (atualmente elevada à condição de cidade), "km 30" (hoje Curionópolis) e "km 100" (Eldorado de Carajás), esses últimos localizados próximos às áreas de lavra da CVRD e de garimpos (a exemplo de Serra Pelada) no sudeste paraense, interligados pela PA-275 e suas vicinais. (COELHO et al., 2006; COELHO, 1997)

No ano de 1997 entrou em processo a privatização da Vale, fato que gerou questionamentos jurídicos sobre o tempo de concessão de direito de uso das áreas de lavras da empresa, firmado em 1986, posto que a sua venda invalidaria a concessão, o que levou o então presidente Fernando Henrique Cardoso (FHC) a assinar um outro decreto concedendo o direito de uso da Vale sobre a área de 411,948 hectares. Essa ação foi invalidada pelo Supremo Tribunal Federal, visto que após a Constituição de 1988 apenas o Congresso Nacional teria competência para realizar tal concessão. Isso fez com que o governo federal alterasse a situação jurídica da área de atuação da Vale, optando pela criação de Unidades de Conservação Federais, a exemplo da Floresta Nacional (Flona) Carajás, instituída em 1998,

\footnotetext{
${ }^{14}$ A Estrada de Ferro Carajás (EFC), de 889,34 quilômetros de extensão, interliga a mina de Carajás (PA) ao porto de Itaqui, em São Luiz (MA), por onde se escoa o ferro proveniente da província mineral de Carajás, que está sob o controle da Vale S.A., cuja propriedade era estatal até 1997. Porém, por conta da privatização da Vale, a EFC passou para a esfera da iniciativa privada, que detém hoje a maior parte de suas ações e amplia sua atuação na região sudeste do Pará, mediante a implantação de outros projetos de extração mineral como: a Serra Leste, localizada em Curionópolis onde se explora o minério de ferro; Salobo, uma das maiores reservas de cobre do Brasil que se localiza no município de Marabá; e o projeto Ferro Carajás S11D, localizado em Canaã de Carajás, onde a exploração do minério de ferro aumentará. Tais projetos necessitam da duplicação da ferrovia, obra que já está em execução e contará com uma ampliação de aproximadamente 504 quilômetros de ferrovia, do porto de Itaqui e do potencial energético. Daí a projeção das Usinas Hidrelétricas de Belo Monte, de Santa Izabel e de Marabá, sendo a primeira de grande porte e as outras, menores. Essas são algumas das infraestruturas que afetam diretamente as populações indígenas e camponesas da região sudeste do Pará.
} 
que passou a ser de responsabilidade da União: a área correspondia ao espaço de uso real da empresa, e quem decidia de forma mais concreta sobre seu uso era a própria empresa. Logo, a área continuou sendo efetivamente um território da Vale, hoje uma empresa privada, devido ao que ficou firmado no decreto de criação da Flona, no que tange a pesquisa, lavra, beneficiamento, transporte e comercialização dos minerais ali existentes. (COELHO et al., 2009)

Com a implantação desse empreendimento houve um forte impacto sobre as áreas indígenas (ver Figura 7), visto que com o Decreto n. 88.988/83 o governo federal possibilitou a exploração das terras indígenas por empresas mineradoras estatais ou privadas, embora o Estatuto do Índio definisse, em seu artigo $2^{\circ}$, parágrafo $1^{\circ}$, que a exploração dos recursos existentes no subsolo só poderia ser realizada em condição excepcional; no entanto, o que se observou foi o avanço da exploração mineral, mesmo em áreas demarcadas pela FUNAI. (VIDAL, 1986)

Esses indígenas que haviam sofrido diversas redefinições territoriais passam a ser mais uma vez desterritorializados, seja pelas hidrelétricas, a exemplo de Tucuruí que resultou na expulsão dos Gaviões da Montanha, seja pelas estradas, garimpos e fazendas que fizeram com que grupos antes relativamente territorializados passassem novamente a lutar pela terra, como os Kayapó, que tiveram a exploração da madeira e de garimpo em suas áreas. Esses índios, “de isolados, castanheiros, acaboclados ou rebeldes, transformaram-se em 'impactados', alvo de toda sorte de atenções e de todo tipo de indenizações". (VIDAL, 1991, p. 62) Cria-se uma luta pelo controle dos recursos, visto que, no caso do PGC, deveriam ser feitas algumas obras de infraestrutura e serviços para atender esses povos tradicionais, mas o conflito estava no tipo de ações que deveriam ser implementadas, pois a FUNAI propunha a demarcação de terras, mas não previa a manutenção dos sujeitos na área demarcada. (VIDAL, 1991)

Esta intervenção nas áreas indígenas não findou com o término da ditadura civilmilitar: ao contrário, vários projetos minerais ainda persistem nos seus territórios, conforme podemos observar no Quadro 1. 
Figura 7 - Terras Indígenas no Sudeste do Pará.

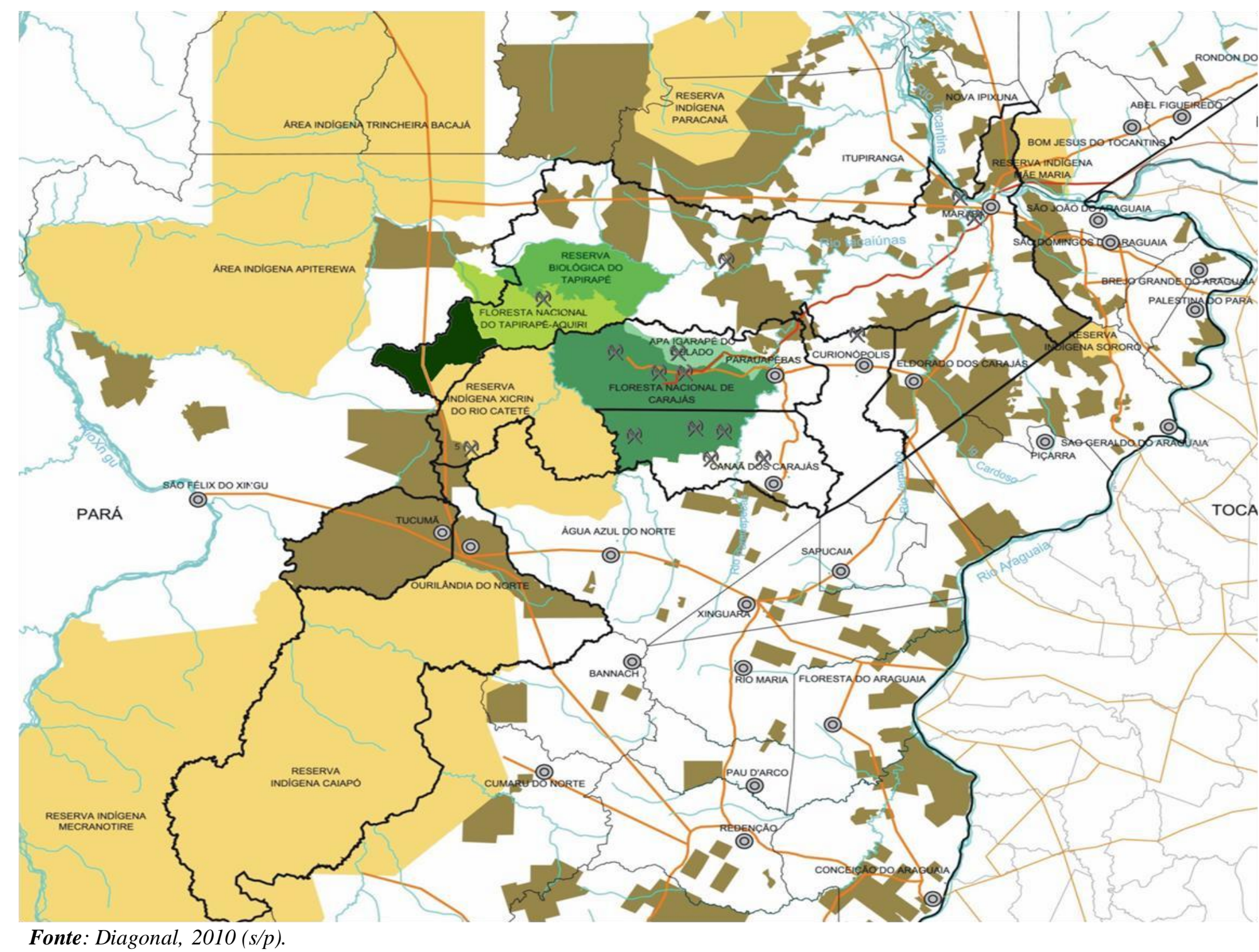

Assentamentos Rurais Áreas e Reservas Indigenas e UC's Area de Influência Direta e Indireta

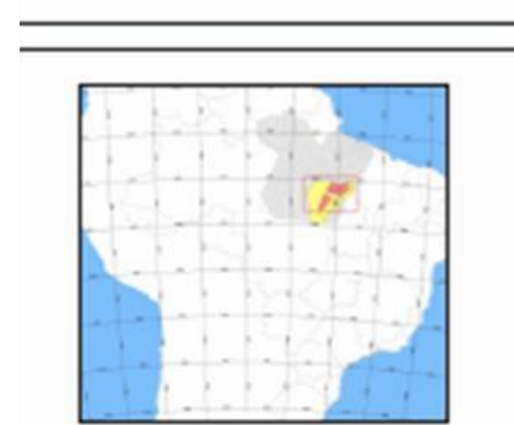

Loganda

$\sim$ Horogats

- Rodoribs

- Rodories am parmantasso

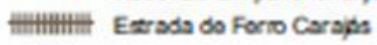

(2) Sosos Muricinals

6. Emproondmontos CVRO

Muncipios da AO

$\square$ Aceontamontos Rusis

Aross o Rosorvas indigones

Unidades de Conservaço

\APA do Golaso

$\square$ REBIO do Tapingos

$\square$ FLONAdo Coraphs

FLONAdO Taprapo Aquin

FLONAdo racouinas

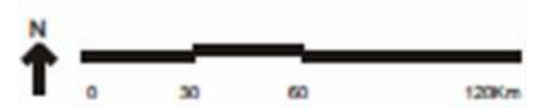


Quadro 1 - Impacto dos Grandes Projetos nas terras indígenas na sub-região sudeste do estado do Pará.

\begin{tabular}{|c|c|c|c|c|c|c|}
\hline \begin{tabular}{|c|}
$\begin{array}{c}\text { TERRA INDÍGENA } \\
\text { (Povo e número } \\
\text { de aldeias) }\end{array}$ \\
\end{tabular} & MUNICÍPIO & POPULAÇÃO & $\begin{array}{c}\text { EXTENSÃO } \\
\text { (ha) }\end{array}$ & $\begin{array}{l}\text { SITUAÇÃO } \\
\text { ATUAL }\end{array}$ & $\begin{array}{l}\text { SITUAÇÃO } \\
\text { CONFLITO/ } \\
\text { PROBLEMA }\end{array}$ & INCIDÊNCIA DE GRANDES PROJETOS \\
\hline $\begin{array}{l}\text { Trocará (Assurini) } \\
\text { 03 Aldeias }\end{array}$ & $\begin{array}{l}\text { Tucuruí e } \\
\text { Baião }\end{array}$ & 526 & $21.722,51$ & Registrada & & $\begin{array}{c}\text { Projeto Carajás na área a jusante da UHE Tucuruí; área cortada pela rodovia PA156; } \\
\text { plano estratégico de recursos hídricos nas bacias hidrográficas dos rios Araguaia e } \\
\text { Tocantins ; UHE Tucuruí e proposta de ação compensativa; hidrovia Araguaia- } \\
\text { Tocantins. }\end{array}$ \\
\hline $\begin{array}{l}\text { Ararandewa } \\
\text { (Amanayé) } \\
01 \text { Aldeia }\end{array}$ & $\underset{\text { Pará }}{\text { Goianésia do }}$ & 37 & 260.000 & $\begin{array}{l}\text { Sem providências e } \\
\text { reservada de acordo } \\
\text { com Dec. Estadual n. } \\
306, \text { de } 21 \text { mar1945. } \\
\end{array}$ & $\begin{array}{l}\text { Madeireiras e grandes } \\
\text { fazendas na área }\end{array}$ & $\begin{array}{c}\text { Projeto de manejo florestal empresarial sustentado da Madeireira CIKEL; } \\
\text { hidrovia Capim-Guamá. }\end{array}$ \\
\hline $\begin{array}{l}\text { Parakanã (Parakanã) } \\
\text { 06 Aldeias }\end{array}$ & $\begin{array}{l}\text { Itupiranga e } \\
\text { Novo } \\
\text { Repartimento }\end{array}$ & 1.000 & 317.000 & Registrada & & $\begin{array}{l}\text { Projeto Carajás; Plano estratégico de recursos hídricos nas bacias hidrográficas } \\
\text { dos Rios Araguaia e Tocantins; pavimentação da BR230 (Transamazônica); } \\
\text { ALPA; Mineração Buritirana; UHE Tucuruí; hidrovia Araguaia-Tocantins. }\end{array}$ \\
\hline $\begin{array}{lr}\text { Sororó } & \text { (Suruí- } \\
\text { Aikewara) } & 02 \\
\text { Aldeias } & \end{array}$ & $\begin{array}{l}\text { São Geraldo } \\
\text { do Araguaia }\end{array}$ & 400 & 26.257 & Registrada & & $\begin{array}{l}\text { Projeto Carajás: área cortada pela BR156; Programa de Aceleração do Crescimento } \\
\text { (PAC): pavimentação das rodovias; rodovia PA222; ferrovia Carajás e linhas de } \\
\text { transmissão de energia da Eletronorte e da Celpa; UHE Marabá; ALPA; duplicação da } \\
\text { estrada de ferro Carajás; hidrovia Araguaia-Tocantins. }\end{array}$ \\
\hline $\begin{array}{lr}\text { Nova } & \text { Jacundá } \\
\text { (Guarani } & \text { Mbyá) } \\
01 \text { Aldeia } & \end{array}$ & Jacundá & 46 & 480 & $\begin{array}{l}\text { Terra de uso } \\
\text { dominial }\end{array}$ & & $\begin{array}{l}\text { Plano estratégico de recursos hídricos nas bacias hidrográficas dos rios Araguaia } \\
\text { e Tocantins. }\end{array}$ \\
\hline $\begin{array}{l}\text { Guajanaíra } \\
\text { (Guajajara) } \\
\text { 01 Aldeia } \\
\end{array}$ & Itupiranga & 66 & 1.346 & $\begin{array}{l}\text { Terra em área de } \\
\text { Assentamento da } \\
\text { Reforma Agrária }\end{array}$ & $\begin{array}{c}\text { Área ocupada por } \\
\text { indígenas no PA Rio da } \\
\text { Esquerda do INCRA } \\
\end{array}$ & Projeto Carajás;Mineração Buritirana; ALPA. \\
\hline $\begin{array}{l}\text { Ororubá } \\
01 \text { Aldeia }\end{array}$ & Itupiranga & 63 & 1.160 & $\begin{array}{l}\text { Terra em área de } \\
\text { Assentamento da } \\
\text { Reforma Agrária }\end{array}$ & $\begin{array}{c}\text { Área ocupada por } \\
\text { indígenas no PA } \\
\text { Buritirana do INCRA } \\
\end{array}$ & Projeto Carajás; Mineração Buritirana; ALPA. \\
\hline $\begin{array}{l}\text { Kanain } \quad \text { (Atikum) } \\
01 \text { Aldeia }\end{array}$ & $\begin{array}{l}\text { Canaã dos } \\
\text { Carajás }\end{array}$ & 27 & 100 & $\begin{array}{l}\text { Terra em área de } \\
\text { Assentamento da } \\
\text { Reforma Agrária }\end{array}$ & $\begin{array}{c}\text { A expansão da } \\
\text { mineração pressiona } \\
\text { pequenos produtores a }\end{array}$ & Projeto Carajás;Mineração Sossego. \\
\hline 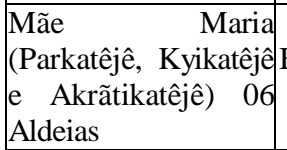 & $\begin{array}{l}\text { Bom Jesus do } \\
\text { Tocantins }\end{array}$ & 614 & $62.488,45$ & Registrada & & $\begin{array}{c}\text { Projeto Carajás: área cortada pela rodovia PA222; pela ferrovia Carajás e pelas } \\
\text { linhas de transmissão de energia da Eletronorte e da Celpa; UHE Marabá; ALPA; } \\
\text { duplicação da estrada de ferro Carajás; hidrovia Araguaia-Tocantins. }\end{array}$ \\
\hline
\end{tabular}

Fonte: Conselho Indigenista Missionário, Equipe de Marabá, Outubro de 2010. 
Como o quadro anterior identifica, além dos projetos implementados no passado, novos estão em desenvolvimento, como ações de madeireiras, empresas mineradoras (Vale) e empreendimentos hidrelétricos (Usina Hidrelétrica de Marabá).

Outros sujeitos igualmente impactados foram os posseiros, os quais estão mais diretamente ligados a nossa pesquisa devido a suas experiências de luta possibilitarem a emergência de movimentos sociais que reivindicam a criação de projetos de assentamento na área em questão.

\subsection{A ORGANIZAÇÃO DA LUTA POSSEIRA NO SUDESTE PARAENSE}

Esse contexto de mudanças no território amazônico provocou uma ação cada vez mais violenta dos "donos de castanhais", fazendeiros e empresas que chegavam à região, em relação aos posseiros. Sujeitos cuja relação com o território é singular, pois por definição não podem ser enquadrados como sem-terra, embora em determinados períodos possam vir a se encontrar expropriados da terra, visto que detêm sua posse e não sua propriedade; mas igualmente não são colonos provenientes da colonização oficial ou proprietários de uma área devoluta devidamente reconhecida ou demarcada por um órgão oficial, por isso vivem na insegurança de sua permanência territorial, com uma situação social precária devido a não serem reconhecidos enquanto donos da sua terra. Para Guerra (2001, p. 18), a definição de posseiro compreende o

"camponês a caminho de seu reconhecimento social", como "camponês em luta pela afirmação de sua identidade", como um camponês que, consciente de si mesmo tem que lutar por seu reconhecimento social, legal e político.

Para obter o reconhecimento de sua identidade por meio da permanência na terra, os posseiros iniciaram um movimento coletivo, associando-se para conquistar esse meio de produção fundamental a sua reprodução social, de forma a se libertarem do cativeiro da terra (MARTINS, 2010) e resistirem à besta-fera, ou seja, ao retorno das relações de exploração a que eram submetidos pelo aviamento, pela expulsão de suas terras etc., personificada agora na figura do fazendeiro, entendido aqui como o proprietário dos meios de produção, ainda que de forma ilícita. (VELHO, 2007)

Os conflitos envolvendo esses sujeitos eram distribuídos espacialmente em três frentes durante o período militar. A primeira área compreendia o espaço entre a rodovia BelémBrasília e o rio Tocantins, porção norte de Imperatriz e Marabá, que é cortada pelas estradas estaduais PA70 (atual BR222) - no sentido Leste-Oeste -, e a PA150 - no sentido Norte-Sul. 
Nessa extensão de terra, até o inicio da década de 1960, existiam grupos indígenas, mas a partir desse momento o território foi gradualmente ocupado por grandes proprietários (com fazendas de até 250 mil hectares) e grupos camponeses (com lotes de 50 a 200 hectares), impelindo os indígenas para uma reserva de aproximadamente 60 mil hectares, o que desencadeou um conflito entre posseiros ou pequenos proprietários e grileiros que utilizavam a força armada dos jagunços, havendo a mediação do GETAT, que tendia em favor dos grileiros. Esse conflito perdurou entre 1976 e aproximadamente 1984, momento em que lideranças camponesas foram feridas ou mortas. (HÉBETTE, 1991)

A segunda frente de conflito situava-se na área do "Polígono dos Castanhais" pretendida pela oligarquia castanheira. Nessa área os antigos empregados (castanheiros) e migrantes realizaram a ocupação de grandes extensões dos castanhais, especialmente no setor das "sobras". Na época foram identificadas 43 áreas de ocupação com um total de 200mil hectares, com 2.200 famílias. O embate se deu entre esses posseiros e os "donos dos castanhais", resultando em forte violência por parte dos últimos, mas culminou com o Estado tendo de conceder várias áreas aos posseiros, que somavam 229 mil hectares. (HÉBETTE, 1991)

Por fim, a terceira frente localizava-se na área impactada pela represa da Usina Hidrelétrica de Tucuruí, que alagou 240mil hectares de mata e de terra cultivada, incluindo lotes de colonização da Transamazônica. Este empreendimento desterritorializou vários grupos indígenas e uma população de aproximadamente quatrocentas famílias camponesas, constituída por moradores antigos da região e colonos recém-chegados, que se organizaram no Movimento dos Atingidos por Barragens (MAB). (HÉBETTE, 1991)

Como forma de resistência esses posseiros criaram alguns instrumentos que thes permitiram a conquista da terra, dentre eles o Sindicato dos Trabalhadores Rurais (STR), responsável pela organização da luta e obtenção do título da terra, além de estabelecerem alianças, especialmente com a Comissão Pastoral da Terra (CPT) e com outras entidades, por exemplo, de direitos humanos e educacionais.

Nesse período de "modernização" da Amazônia, no qual o regime militar empreendeu uma intensa repressão às lutas no campo, houve em nível nacional uma forte intervenção na Confederação Nacional dos Trabalhadores na Agricultura (CONTAG), recém-criada em 1963, e os sindicatos a ela associados eram vigiados pelos organismos de repressão. Nesse contexto, a Igreja passou a desempenhar um papel fundamental na organização dos camponeses na luta pela terra. (MEDEIROS, 2014) 
A partir de 1970, segmentos da Igreja que atuavam em defesa dos posseiros nas áreas afetadas pelas políticas de colonização, como a Amazônia, sofriam uma repressão dupla: por parte do regime e por setores da própria Igreja. Em 1974 alguns bispos iniciam a publicação de documentos que denunciavam a situação de conflito nas áreas de fronteira e, em 1975, surge a Comissão Pastoral da Terra, cuja luta pela reforma agrária seguia inicialmente os ditames do Estatuto da Terra ${ }^{15}$. Essa organização começa assessorar a luta posseira na Amazônia. (MEDEIROS, 2014)

Para Martins (1997b), a CPT, ao ser criada, rompe com o cenário de silêncio e temor da ditadura militar: sua fundação promove o aparecimento de outra forma de luta social, referente aos movimentos camponeses, que apresenta preocupações sociais e políticas, e

[...] proclama que os excluídos e os penalizados pela brutalização política e econômica não perdem a sua condição humana com o desenvolvimento capitalista. E por isso não perdem o direito àquilo que os faz dignos e humanos, que são as condições da sua sobrevivência. No caso das populações indígenas, os seus territórios. No caso das populações camponesas, o direito à terra. (MARTINS, 1997b, p. 77)

A CPT iniciou suas atividades no Pará em 1976, implantando-se na diocese de Marabá, com o apoio do bispo e seus sujeitos de pastoral, com o objetivo principal da luta pela reforma agrária, obtendo êxito quanto à organização camponesa, visto que os sindicatos eram fiscalizados de perto pelo governo (LEROY, 2000), como foi bem ilustrado pela fala do advogado da CPT:

Aqui na região então, nesse período, existia apenas o movimento sindical com os sindicatos em alguns municípios: Marabá, Itupiranga, Tucuruí, Conceição do Araguaia, em poucas cidades. Essas organizações dos trabalhadores sofreram a intervenção dos militares e os militares colocaram ali pessoas de confiança deles para justamente impedir a organização dos trabalhadores. Com isso, como os trabalhadores não podiam contar com os poucos sindicatos que existiam naquele período, porque estava sob o controle dos militares, inclusive a Federação dos Trabalhadores na Agricultura Familiar e a própria CONTAG, por exemplo, então eles passaram a procurar a Igreja Católica, que naquele contexto era a entidade que tinha um comprometimento muito grande com as causas sociais e que abria as portas para atender os camponeses nas reivindicações e nas denúncias que eles procuravam apresentar nesse espaço, e aí com a criação

\footnotetext{
${ }^{15}$ De acordo com Martins (1986), o Estatuto da Terra em certa medida foi aplicado no governo militar, visto que seu objetivo central não seria de redistribuir terras para os trabalhadores que dela vivem, mas proporcionar o avanço da agricultura empresarial. O estatuto de 1964 definia que o trabalhador que ocupasse a terra devoluta pelo período de um ano teria preferencia na sua aquisição. A Lei n. 6.383 de 1976 previa que o posseiro que residisse e cultivasse por um ano se tornava legítimo de possuir cem hectares. Mas o novo Estatuto da Terra dos militares redefiniu a ocupação, que deveria ser de três anos para adquirir o direito legal sobre a terra, tornando ainda mais difícil esse ato, devido às condições precárias a que os migrantes estavam submetidos, além da forte violência que sofriam, a exemplo da Amazônia.
} 
da CPT isso foi canalizado para CPT. Então a CPT passou aqui na região, foi instalado no mesmo ano de 1976 com uma equipe aqui em Marabá, outra equipe em Conceição do Araguaia e passou então a prestar assessoria, apoio aos camponeses que faziam a luta pela terra aqui pela conquista ou pela permanência na terra e também a luta contra violação dos seus direitos. [...] (Entrevistado José Batista Afonso, advogado da CPT de Marabá-Pará, 50 anos, entrevista concedida em 18 mar. 2015).

Como mecanismo de apoio aos posseiros na luta pela terra e pelos seus direitos, iniciou-se um processo de crítica em relação aos sindicatos e de disputa por esse espaço político, com o objetivo de recuperá-los da cooptação efetuada pelo governo em relação aos dirigentes. Dessa maneira, se desenvolveu uma luta intensiva nos sindicatos de Conceição do Araguaia, região de Marabá, Itupiranga, dentre outros, que aos poucos foram sendo retomados a partir da década de 1980, não sem perdas como foi o caso do assassinato de Raimundo Ferreira Lima, conhecido como "Gringo", que fez oposição nas eleições do sindicato de Conceição do Araguaia, mas foi morto antes de concorrer. Com efeito, a luta foi se fortalecendo, redefinindo as ações políticas dos sindicatos que passaram a ser um espaço de organização dos trabalhadores rurais frente ao latifúndio, sempre com o apoio da CPT, como na assessoria jurídica e técnica ${ }^{16}$.

Nesse contexto de organização camponesa pela CPT foram de suma importância as Comunidades Eclesiais de Base (CEBs), pois foi a partir delas que várias lideranças se formaram, atuando ulteriormente tanto nos sindicatos quanto em movimentos sociais como o MST, e constituindo-se em um lugar de debate e formação política, pois tinham mais liberdade nas discussões devido ao menor controle por parte dos militares. A atuação das CEBs se dava principalmente nas periferias das cidades e em áreas rurais onde se encontravam os posseiros oprimidos pela lógica do capital em franca expansão na região, tal qual nos revela o advogado da CPT.

[...] naquele período o único espaço em que as lideranças, os trabalhadores tinham para poder fazer, se reunirem, fazer a discussão política aproveitando do espaço religioso, era nessas comunidades, ou seja, era onde os militares tinham um certo... em função da briga com a Igreja ser um pouco mais complicada, onde se tinha um pouco mais de liberdade, onde os militares não tinham controle da situação. Então as comunidades eram o espaço onde se fazia a reflexão da fé, a leitura da Bíblia, o estudo da Bíblia ligado com a realidade, e partir daí se fazia também a discussão da própria vida

\footnotetext{
${ }^{16}$ Esse processo de luta dos posseiros pela terra e a relação destes com a CPT e os sindicatos é discutido neste trabalho a partir de pesquisa de campo junto às associações, sindicatos e lideranças que participaram dessas formas de organização camponesa.
} 
organizativa, política, luta pelos direitos e assim por diante. Então as comunidades [eclesiais de base] eram um espaço privilegiado de viver a fé e a luta, como o pessoal dizia: "era a fé e a luta juntas". [...] Porque era um espaço, vamos dizer assim, uma iniciativa puxada pela Igreja que era voltada para a base, para atingir justamente os mais pobres, então as comunidades elas proliferavam na periferia das cidades e na zona rural, onde estava $o$ povo pobre, oprimido, mais sofrido, o sem-teto, o sem-terra e era onde era mais fácil fazer um debate religioso falado com um debate da conscientização política também, então as comunidades tinham um papel, eu diria assim, muito importante nesse processo aí de trabalhar o processo de organização e conscientização dos trabalhadores, dos participantes da comunidade (Entrevistado José Batista Afonso, advogado da CPT de Marabá-Pará, 50 anos, entrevista concedida em 18 mar. 2015).

Nesse momento inicial de luta pela terra os sujeitos que começaram esse processo eram posseiros mais antigos que tinham trabalhado nos castanhais e os migrantes que vinham para a Transamazônica, tal qual foi identificado por Hébette (1991). Os migrantes chegavam à região em caminhões denominados de "paus de arara", ainda comuns em determinadas áreas rurais do sudeste paraense, e ocupavam lotes ao longo da estrada e de suas vicinais, mas havia determinados problemas, pois alguns locais já eram ocupados por indígenas, ribeirinhos e caboclos, indivíduos não considerados na colonização de uma "terra sem homens, para homens sem terra”. Isso iniciou um primeiro problema, inclusive para a organização dessas pessoas, visto que essa migração ocasionava tensão entre os sujeitos envolvidos, além do aparecimento de grileiros, fazendeiros com títulos de origem duvidosa, que requeriam a propriedade da terra em momentos posteriores ao estabelecimento desses migrantes. Outra dificuldade era de cunho cultural, visto que migraram mineiros, maranhenses, baianos etc., com noções diferentes quanto ao plantio, à relação com a terra e à própria organização camponesa.

Além da Transamazônica, foram abertas outras estradas, como já indicado anteriormente, a exemplo da PA150 (sentido Marabá-Goianésia etc.) e a PA70, passando por Rondon do Pará, Dom Eliseu, e outros lugares. Essas infraestruturas atravessavam a área dos "donos dos castanhais", iniciando outra frente de conflito. A partir da década de 1980 os conflitos pela terra cresceram substancialmente nessas áreas e, como já comentamos, a Igreja acabou contribuindo para a organização desses sujeitos.

Em relação aos castanhais, iniciaram-se nesse período conflitos no castanhal Pau Seco em Marabá, castanhal Rainha em Itupiranga, castanhal Cuxiú em São Domingos do Araguaia, e tais conflitos generalizaram-se pelos municípios de São Geraldo do Araguaia, Eldorado de Carajás, dentre outros. Salientamos que essas áreas eram requeridas pela oligarquia local como um território permanente e como o GETAT não modificou consideravelmente a 
estrutura fundiária regional, o uso da terra pouco foi alterado nesses locais que correspondiam ao pretenso "Polígono dos Castanhais"; logo, não foram criados lotes nesse perímetro. Entretanto os posseiros adotaram ali algumas estratégias para ocupação da terra.

Por se tratar de um espaço bastante extenso e com a presença ainda da mata nativa, os posseiros territorializavam-se nos castanhais mais periféricos. Desta feita, utilizavam-se da seguinte metodologia: um grupo de homens se dirigia ao interior dos castanhais e preparava a terra para o plantio de cultivos básicos, como o arroz, feijão, mandioca etc.; um outro grupo, geralmente armado, ficava responsável por vigiar o local, e após esse processo se retiravam ou seja, desenvolviam ações rotativas, não permanecendo no local, ao menos no início desse processo de ocupação da terra.

Nesse momento, a partir da formação de várias lideranças nas CEBs, ocorreu gradativamente uma retomada ou a criação dos sindicatos em determinados municípios, como Marabá, com o ideal de reforma agrária reforçada pelos conflitos que emergiam na região. Além do apoio da Igreja e dos sindicatos, os trabalhadores recebiam ajuda de pequenos comerciantes que lhes doavam remédios, alimentos e sementes e firmavam parcerias com comunidades rurais:

[...] quando tu ia plantar, porque eles não tinham terra, aí a gente inventou um sistema de empréstimo, que era o sistema deles, entre as comunidades de baixo emprestavam semente. Bom, claro que tinha comunidade como da Vila Santana que era no meio da Transamazônica, produção de arroz, que..., lá não tinha problema de terra, então eles emprestavam, aí te empresto um saco de arroz pra plantar e tu me dá dois na colheita, era o sistema que eles utilizavam, acho que até hoje deve existir ainda. Estou contanto essa história, mas se a gente vê porque que tem posseiro que tem PA hoje é por causa disso aqui que eu estou dizendo (Entrevistado Emmanuel Wambergue, exdirigente da CPT de Marabá-Pará, 69 anos, entrevista concedida em 24/ jun. 2013).

A década de 1980 é o momento de transição para a "Nova República", que foi precedida por um pacto político, que configura igualmente um pacto de classes em 1984. A ditadura civil-militar foi sustentada por uma articulação entre setores da burguesia, grandes proprietários do Sul e do Nordeste, a classe média, setores do sindicalismo pelego e os militares, mas entra em colapso ao final da década de 1970 devido aos conflitos entre esses segmentos do poder e o conjunto de conflitos e manifestações que surgem no campo e na cidade (greves, depredações, ocupações de terras), concorrendo para a proposição de outro pacto político que fundamentaria o governo democrático de 1985 , que não deixou de ser conservador, visto a ausência de representantes dos trabalhadores, todavia tentou realizar 
igualmente um pacto social com a cessação, por um período, das reivindicações sociais. (MARTINS, 1986)

Nesse momento de transição para a democracia, foi criado o Ministério da Reforma Agrária e do Desenvolvimento (MIRAD), já no primeiro governo civil, em 1985, e teve início o $1^{\text {o }}$ Programa Nacional de Reforma Agrária (PNRA), que previa o assentamento de trabalhadores em áreas desapropriadas, colonização e regularização fundiária, além de propor a participação de representações dos trabalhadores, mas essas premissas foram contestadas pelos representantes dos proprietários de terra que se organizaram na época na União Democrática Ruralista (UDR) e alegavam a defesa extrema do direito de propriedade, proposta que se tornou vencedora.

No sudeste paraense os posseiros, a partir de sua organização pelos sindicatos e a CPT, forçaram o governo, dito agora democrático, a criar assentamentos. Assim, o posseiro parecia sair de uma condição de "ocupação reprimida", marcada pela violência dos donos de castanhais, para uma "ocupação consentida", em que o Estado passava a deter a propriedade da terra e indicava desenvolver mecanismos de aquisição, redistribuição e controle sobre a terra, reconhecendo os anseios dos posseiros. No entanto, isso aconteceu parcialmente porque o MIRAD/INCRA não atendeu a todos os pleitos dos sindicatos, em verdade acabou contribuindo para a satisfação dos interesses dos pretensos donos de castanhais, visto que a maioria das áreas pretendidas pelos posseiros para assentamento não foram legitimadas e sim aquelas indicadas pela oligarquia (EMMI; MARIN, 1997), que acabou sendo premiada, pois em nível nacional estava no Ministério responsável pela política fundiária o senador paraense Jader Barbalho, que através da Portaria Ministerial n. 450 de dezembro de 1988, transformou dez castanhais em projetos de assentamento (ASSIS, 2007).

Esse ministério acabou adquirindo 61 castanhais na área do "Polígono dos Castanhais" em 1988, dos quais 44 pertenciam a componentes da família Mutran (essas propriedades somavam 151.229,8 hectares). Para essa oligarquia, a venda se tornou um excelente negócio economicamente, devido às indenizações serem muito acima do valor das terras no mercado (ASSIS, 2007). No período posterior, correspondente aos anos de 1995 a 2001, foram criados mais 44 projetos de assentamentos, com uma área de 27.171.739 hectares (ver a relação dos castanhais transformados em assentamentos no Anexo II). Destacamos que nessa porção do território estão cinco PAs que fazem parte de nosso estudo, quais sejam: 17 de Abril, Cabanos, Canudos, todos em Eldorado dos Carajás; $1^{\circ}$ de Março, em São João do Araguaia; e 26 de Março, em Marabá. 
A luta posseira a partir daí não findou, ao contrário, cresceu exponencialmente e se estabeleceu em duas frentes. A primeira continuava a ser pela reforma agrária, especialmente com a disputa que agora estabeleciam com novos sujeitos econômicos, como a Companhia Vale do Rio Doce, que ao se implantar na região estabeleceu limites para a criação de novos assentamentos pelo Estado, por ter interesses sobre o subsolo, além de disputar o território com aqueles há muito tempo instalados. (EMMI; ACEVEDO, 1997)

A segunda frente de batalha era a luta pela permanência no lote, visto que os projetos de assentamentos criados não lhes proporcionavam uma segurança territorial em decorrência das precariedades a que estavam submetidos, seja pela parca infraestrutura e ausência ou diminutos créditos, seja pela demora na titularidade de seus lotes que conferia insegurança quanto à permanência dos assentados no local, frente a ação de grileiros, fazendeiros e empresas. Assim, o "ato de assentar torna-se transitório". (EMMI; ACEVEDO, 1997, p. 256)

A experiência de luta dos posseiros no jogo assimétrico das relações de poder que permeia e configura o território, desde os âmbitos jurídico, político e econômico até o cultural-simbólico, mostra o reconhecimento, por parte desses indivíduos, dos seus direitos e a necessidade de criar estratégias que lhes possibilitem a (re)tomada do seu território. Sua geografia da resistência ainda hoje marca a região e se tornou base para a construção de movimentos sociais como o MST, foco principal de nosso estudo.

Por essa razão, podemos perceber pelo Mapa 2, referente à complexa estrutura fundiária da área que outrora correspondeu ao "Polígono dos Castanhais", a presença marcante de diversos assentamentos e ocupações de fazendas implementadas pela FETAGRIPA e pelo MST.

A retomada de parte do território, esboçada no Mapa 2, pelos posseiros e suas geografias mostra que o MST, ao emergir na região, encontrou um campo fértil de experiências sociais de luta que o ajudaram a se implantar e se desenvolver, enquanto o próprio movimento também contribuiu qualitativamente com as lutas. Embora não tenha iniciado a história da organização camponesa no sudeste, pois não encontrou um espaço sem contradições e desigualdades, o MST semeou novos olhares sobre um projeto de luta que seria mais amplo que a redistribuição de terra. 
Mapa 2 - Estrutura fundiária do antigo "Polígono dos Castanhais", 2016.

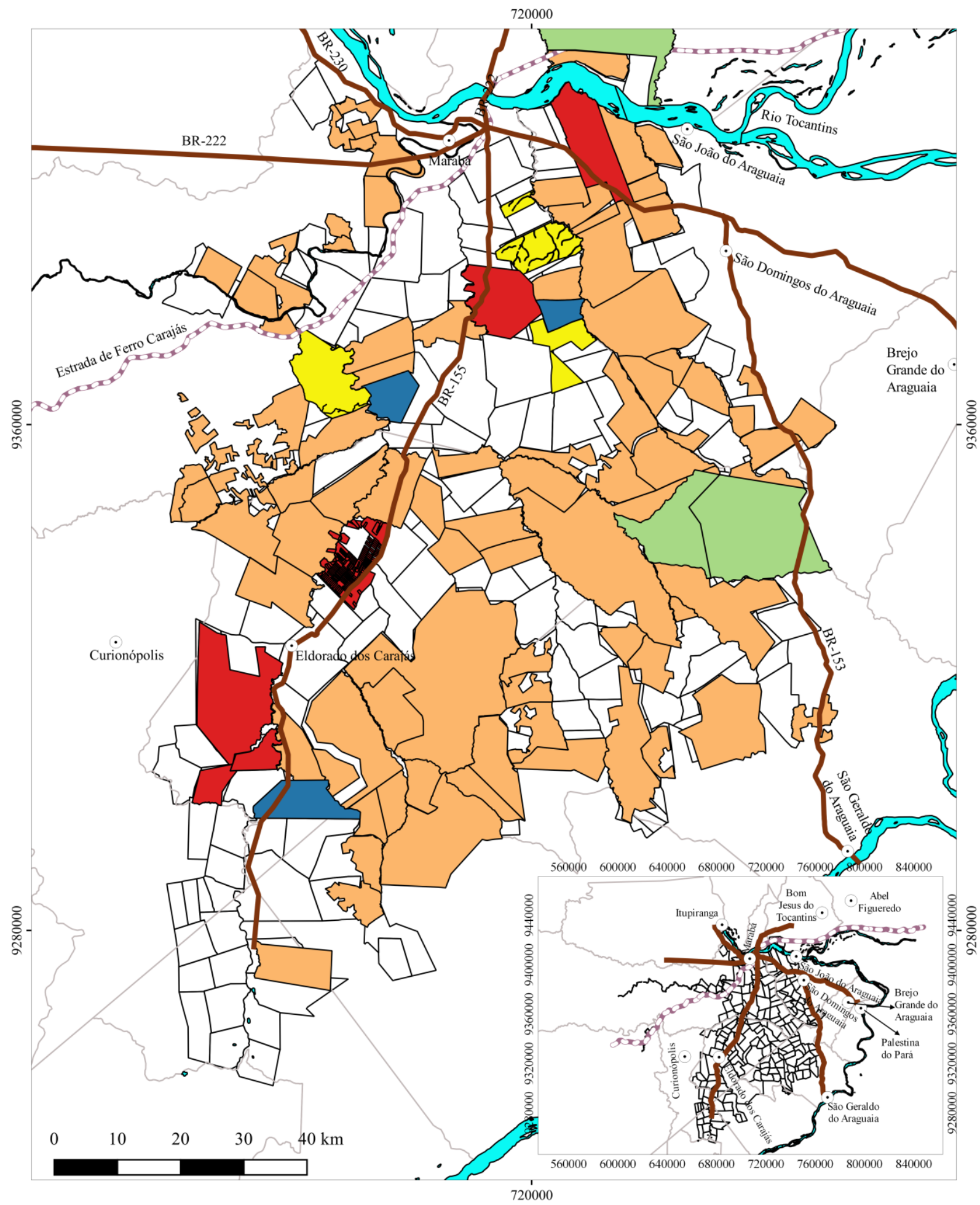

Legenda

\begin{tabular}{|c|c|}
\hline icipal & PAs Pesquisados \\
\hline Rodovia & Área ocupada pelo MST \\
\hline EFC & Área ocupada pela Fetagri \\
\hline Rio Tocantins & Reserva indígena \\
\hline Antigo Polígono dos Castanhais & Limite municipal \\
\hline
\end{tabular}

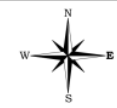

Sistema de Coordenadas UTM - Zona 22S

Datum: WGS - 84

Fonte: IBGE (2010); INCRA (2016); CAR (2016)

Elaboração: MIRANDA, R. R. (2017) 


\subsection{DA LUTA DOS POSSEIROS À ORGANIZAÇÃO DO MST}

Com o estímulo à grande propriedade, em prejuízo da agricultura camponesa ${ }^{17}$, o Estado contribuiu para o aumento da concentração de terras e a expansão do latifúndio (COSTA, 2000; HÉBETTE; MARIM, 1979). Isso ocasionou, principalmente no sudeste do Pará, vários conflitos agrários provenientes da desterritorialização de uma ampla massa de camponeses que se tornou sem-terra, mas que buscou se reterritorializar, mesmo em condições precarizadas, vendendo sua força de trabalho em fazendas ou em cidades, ou mesmo engrossando movimentos sociais de reivindicação do direito à terra, como o Movimento dos Trabalhadores Rurais Sem Terra (MST) no Pará.

Os sem-terra se caracterizam pela condição territorial fluida, ou seja, são migrantes que vieram para a Amazônia trabalhar nos grandes projetos, mas que em momento ulterior acabaram desempregados, desempenhado funções de vaqueiro, rendeiro, garimpeiro ou autônomo nas periferias urbanas das cidades do sudeste paraense, especialmente Marabá, Curionópolis e Parauapebas. Logo, a mobilidade faz parte do seu cotidiano, em face da grande instabilidade a que estão sujeitos em relação à permanência no local, além das precariedades a que estão submetidos nas relações de trabalho. Geralmente são oriundos do Nordeste brasileiro e desempenham atividades agrícolas nos seus locais de moradia, nas propriedades de parentes ou de particulares. Vêm para a região no anseio de conquistar a terra, contudo não a conseguem por outro meio que não seja a partir da organização coletiva e das lutas manifestas nos acampamentos e ocupações.

$\mathrm{O}$ movimento dos sem-terra nasce em meio ao enfrentamento e à resistência contra o modelo desenvolvimentista e agropecuário instaurado durante o regime militar, tendo como fundamento a luta contra a expropriação e a exploração existente no processo de reprodução do capitalismo. A construção do MST está assentada no bojo das discussões sobre democracia, em que a classe trabalhadora conquista novos espaços no campo e na cidade, momento em que surgem diversos movimentos sociais. Logo, o MST inicia sua gestação em meio a uma série de experiências de lutas populares enquanto estratégia político-cultural estabelecida no seio desses sujeitos sociais, que iniciam ocupações de terra em vários estados.

\footnotetext{
17 A agricultura camponesa caracteriza-se pela produção familiar em lotes de terra, em média de 100 a 200 hectares no sudeste paraense, cujas atividades são divididas entre os próprios membros da família, os quais possuem a propriedade da terra e desenvolvem um mercado de excedentes (MARTINS, 2009), em que a produção anseia principalmente pela sobrevivência do núcleo familiar.
} 
Essas lutas mais localizadas ganham repercussão no país através da Igreja e em menor parte pela mídia, mas foi pela troca de experiências que a articulação em nível nacional desses movimentos se estruturou, objetivando a superação do isolamento e a autonomia política. Nesse contexto, foram realizados encontros maiores reunindo lideranças estaduais por intermédio da CPT, especialmente no Centro-Sul, e dessas iniciativas se fundou e se organizou um movimento nacional dos camponeses sem-terra, que lutaria por reforma agrária, originando o MST (FERNANDES, 1999), cuja constituição formal e simbólica foi no Primeiro Encontro Nacional dos Sem Terra, no ano de 1984, realizado em Cascavel, no estado do Paraná, com representantes de dezesseis estados.

Segundo Stédile (1997), o MST “nascia” como um movimento de massa, cuja luta é realizada de diferentes formas, como ocupações de terra, assembleias, caminhadas, marchas, audiências massivas, ocupações de prédios públicos, dentre outras. Igualmente em sua construção se objetivou resgatar experiências de outros movimentos sociais de luta pela terra em geral, a exemplo das Ligas Camponesas. A partir desses elementos, o MST desenvolveu uma organização que tinha alguns princípios fundamentais ao seu crescimento: a unidade política e a construção de um movimento de caráter nacional:

Vinculação permanente com as massas. Não é possível organizar um movimento social sem um trabalho permanente de base e de enraizamento nas massas, na nossa base social.

Lutas de massa. Nunca nos iludimos com as boas vontades do governo ou autoridades de plantão. A Reforma Agrária somente avançaria com luta, e sobretudo com lutas de massa, em que o povo se envolvesse no maior número possível. Não há outro caminho de mudança social, sem que o povo esteja organizado e mobilizado. As negociações com o governo são necessárias e importantes, mas elas fazem parte de uma correlação de forças. E a correlação de forças só se altera favoravelmente ao povo se este povo lutar e demonstrar sua força. Fazer negociações sem mobilização popular é perder o jogo antecipadamente.

Divisão de tarefas. Todas as atividades dentro do movimento sempre foram realizadas pelo maior número possível de pessoas, e na forma de comissões.

Direção coletiva. Todas as instâncias do movimento, desde as comissões de base, dentro de um acampamento, até as instâncias nacionais são exercidas coletivamente na forma de colegiado, sem distinção de poder. E onde haja divisão de responsabilidades.

A disciplina. Nenhuma organização social, por menor que seja, nem mesmo um time de futebol, funciona se não houver um grau de disciplina, que é, na essência, a existência de regras coletivamente discutidas e respeitadas pelos indivíduos que quiserem fazer parte delas. Por isso, sempre tivemos claro que o crescimento do MST dependeria de métodos de trabalho que incorporassem a disciplina, o respeito às decisões coletivas, como princípio organizativo fundamental.

Formação de quadros. Nenhuma organização poderá ter sucesso se não preparar seus próprios quadros. Ou seja, se não preparar com estudo e capacitação, seus membros, para lutarem a fim de alcançar os objetivos sociais da organização. 
Por último, sempre procurarmos desenvolver a mística. Não como forma alienada, mas como uma liturgia que ajudasse a motivar nossa base, animá-la e conscientizá-la, através de símbolos de nossa cultura, de nossos valores, de que é necessário lutar. E de que é possível haver uma sociedade diferente, uma sociedade mais justa e fraterna. (STÉDILE, 1997, p. 104-105 grifo nosso)

Medeiros (2009) ressalta esses princípios elencados acima, os quais norteiam a organização do MST, identificando como eles qualificam o movimento enquanto um sujeito de inovação cultural, capaz de estimular mudanças comportamentais e de visões de mundo. Nesse sentido, ressalta alguns aspectos importantes: a) na dimensão organizativa do MST não existem mecanismos formais de filiação, a entrada dos sujeitos, em geral famílias, se dá por uma identificação com as bandeiras defendidas pelo movimento. Apresenta corresponsabilidades entre os membros, que se distribuem em núcleos que agrupam famílias ou vizinhos para debaterem problemas relativos ao acampamento ou assentamento, coordenações (regionais, estaduais e nacional) e entre essas existem direções plurais (em termos de gêneros, indivíduos etc.), setores (educação, saúde, produção, comunicação, dentre outros), coletivos e o Sistema Cooperativista dos Assentados (SCA), buscando desenvolver relações não hierárquicas e coletivas de poder. b) A dimensão produtiva envolve um debate sobre a mudança de modelo de desenvolvimento, como a recusa ao agronegócio e a valorização da agroecologia e da produção camponesa. c) A dimensão cooperativa da produção, por seu turno, se refere à valorização de experiências coletivas de produção, incentivando a solidariedade entre os sujeitos, embora isso não seja um ponto passível entre os assentados, haja vista a diversidade cultural e de interesses. d) A dimensão educacional é um dos pontos mais valorizados pelo MST - tão logo se cria um acampamento se luta pela escola nesse espaço; também foi discutida a "pedagogia da terra", na qual se destaca a luta dos trabalhadores do campo, suas expressões culturais, dentre outros aspectos. Definiu-se também como prioridade a educação de jovens e adultos, e de crianças que estariam fora da idade de escolarização, as chamadas cirandas, curso de formação para professores, cursos técnicos e de ensino superior a partir de parcerias com Universidades. e) A dimensão das ações espetaculares (simbólicas), que buscam produzir visibilidade aos pleitos do movimento e a difusão do significado da luta, da concepção de reforma agrária e dos modelos de desenvolvimento em disputa, além da mística que anseia mobilizar as emoções, a identificação de um grupo, envolvendo a valorização de símbolos do movimento que reforcem essa identidade. 
Essas premissas que orientam a organização do MST criam condições para a sua maior inserção territorial nos mais diversos estados brasileiros. Para Fernandes (1997, 1999), o MST constitui-se em um movimento eminentemente territorial, cuja luta por terra, cidadania e reforma agrária levou ao debate, em escala nacional, da construção de outro modelo de desenvolvimento da agricultura brasileira. Para o autor, o MST desenvolveu processos de espacialização e territorialização, tornando-se um movimento socioterritorial, visto a sua permanente espacialização, a qual resulta em territórios.

Essa espacialização corresponde ao registro no espaço social de um processo de luta, ou ainda, corresponde ao multidimensionamento do espaço de socialização política, grafado por meio de ações concretas (manifestações, ocupações, acampamentos etc.). Esse processo de luta transcorre no multidimensionamento do espaço de socialização política, apresentando três dimensões, a saber: o espaço comunicativo, correspondente ao lugar do conhecimento e aprendizado, sendo o primeiro momento da construção da cidadania, principiando uma nova experiência e outra práxis; o espaço interativo, que compreende a reflexão elaborada por esse sujeito coletivo sobre a dinâmica da sua história, na qual se encontram as experiências refletidas sobre a sua práxis, mediante o diálogo e a elaboração de propostas. Em outras palavras, é um espaço político de enfrentamento de ideias, sendo fundamental para a construção do conhecimento, tanto na formação dos sujeitos quanto para o crescimento organizativo do movimento, visto que

"é com a consciência da luta que os trabalhadores espacializam a luta pela
terra em um movimento socioespacial. Com a espacialização da luta, eles
conquistam novas frações do território. Com a conquista da terra, o
movimento se territorializa". (FERNANDES, 1997, p. 138)

Por fim, há o espaço de luta e resistência, que se concretiza pelas ocupações e acampamentos, pois é o momento de enfrentamento por parte dos trabalhadores em relação ao Estado e aos latifundiários. Esse espaço é de suma importância para resistir às diversas formas de violência e, assim, conquistar frações do território, isto é, projetos de assentamento (FERNANDES, 1997, 1999).

A territorialização do MST no sudeste paraense se inicia com o processo de organização dos camponeses e da construção de alianças com segmentos de luta regional. Articula-se com movimentos locais que se formam, por exemplo, a partir de organizações sociais impulsionadas pela Igreja, através das Comunidades Eclesiais de Base (CEBs) em Marabá, que fomentaram a criação de Sindicatos de Trabalhadores Rurais, além de partidos políticos ditos de esquerda, como o Partido Comunista do Brasil (PC do B) e o Partido dos Trabalhadores (PT) e clandestinos que vão incitar tal processo (ALMEIDA, 2006). 
Essas alianças, no entanto, foram marcadas por tensões visto que no Primeiro Congresso do MST os sindicalistas paraenses não aceitaram a implantação do MST no Pará, pois suas estratégias divergiam daquelas praticadas pelos posseiros, o que não representava o distanciamento deles em relação à questão fundiária regional (LEROY, 2000).

A primeira divergência residia em uma experiência de luta anterior desenvolvida pelos posseiros, os quais ocupavam as áreas de mata, conquistando gradativamente a terra, ao passo que o MST propunha como forma de resistência o acampamento, o que não era muito bem compreendido pelos posseiros:

[...] o MST que tinha essa prática, que inclusive o povo no início não começou, pra ocupar as áreas, nem chamavam de acampamento, não sabiam o que era, chamavam "ocupamento", quantas vezes não escutei: "gente, não existe essa palavra!". Mas é bem significativa: "ocupamento" (Entrevistado Emmanuel Wambergue, ex-dirigente da CPT de Marabá-Pará, 69 anos, entrevista concedida em 21 ago. 2014).

Os acampamentos geravam muita desconfiança também devido à violência por parte dos donos de castanhais ou fazendeiros:

[...] a questão do MST vir pra cá, mas só em 1991, [...] inclusive com a proposta de acampamento que naquela época era muito perigoso, eu falei com eles, eles iam entrar aonde é a Pimenteira agora, a Primavera Pimenteira, pertinho de Marabá, com caminhão e tudo, a sorte que a Policia Federal prendeu eles na saída de Marabá aqui, ainda bem porque os pistoleiros, Sebastião, Terezão e tudo estavam tudinho lá esperando eles, tu não podia fazer acampamento ainda, na cidade, sim, podia, dentro da cidade (Entrevistado Emmanuel Wambergue, ex-dirigente da CPT de Marabá-Pará, 69 anos, entrevista concedida em 21 ago. 2014).

Ainda com relação aos acampamentos os posseiros estavam acostumados a desenvolver ocupações em áreas distantes, no interior da mata, para não atrair atenção, e tais atividades eram realizadam apenas por homens. O MST, ao contrário mobilizava as famílias para fazer a ocupação da terra, que deveriam ser localizadas na margem da estrada e próximas à cidade:

[...] só agora, muito recente, de 2000 pra cá eles aceitam fazer acampamento na beira da estrada, mas numa condição, a gente entra na área e planta, que como que vou viver nesse acampamento? Quer dizer, esse que era o movimento sindical. Tudo bem! Eu ocupo, mas eu não quero ficar na beira da estrada. E vocês veem muitos "ocupamentos" que tem hoje, já é dentro e cortando o lote [...] (Entrevistado Emmanuel Wambergue, ex-dirigente da CPT de Marabá-Pará, 69 anos, entrevista concedida em 24/ jun. 2013).

Outra diferença quanto à organização dos trabalhadores está nos trabalhos de base, pois os sindicatos realizavam reuniões escondidas para não causar qualquer tipo de problema 
ou difusão de informações, enquanto o MST realizava com pessoas da cidade e do campo e sempre com muita gente, pois a ideia era criar uma visibilidade social e midiática:

Para criar problema! Não quer dizer que essa fazenda era o que a gente iria, criava o problema para pode negociar outra coisa. Inclusive os primeiros movimentos aqui foram terríveis porque eles terminaram todos na chefia, foi por muito tempo na cadeia [...]. (Entrevistado Emmanuel Wambergue, exdirigente da CPT de Marabá-Pará, 69 anos, entrevista concedida em 24 jun. 2013)

Com relação ao processo de construção desses acampamentos, o MST se instalou primeiramente no município de Conceição do Araguaia, com a organização do acampamento na Fazenda Ingá e, posteriormente, em outra fazenda no mesmo município, porém sem resultados positivos por conta da repressão dos latifundiários e da polícia. Em seguida, pelo pouco apoio local, realizaram um deslocamento para Marabá.

Nesse município, por volta de 1991, o MST realizou os trabalhos de base com ajuda do sindicato, cadastrando cerca de 3 mil famílias. A primeira decisão foi a ocupação da Fazenda Ponta de Pedras em São João do Araguaia, que não pode ocorrer devido à intervenção da Polícia Militar (PM), da Polícia Federal (PF) e Polícia Civil (PC) que fecharam a sede do MST, sem ao menos um mandato judicial, fato que culminou na prisão de sete dirigentes do referido movimento socioterritorial. Nesse mesmo contexto, os fazendeiros resolvem agir de maneira antecipada às ações do MST, pois antes atuavam com intensa violência contra os posseiros de maneira individual e fragmentada, mas no caso do movimento sem-terra, este se organizava nacionalmente e avançava em todos os estados, com uma estratégia de luta desconhecida para os fazendeiros (GOMES, 2009).

Com a desmobilização dessa ocupação, o MST recebe ajuda de pessoas do Maranhão ligadas ao movimento e, a partir de um novo trabalho de base, ocupa uma área denominada de “cinturão verde" em Parauapebas, no dia 26 de junho de 1994, com cerca de 1.500 famílias. A área em questão havia sido cedida pelo governo federal à Companhia Vale do Rio Doce e, para provocar pressão sobre o governo, as famílias acamparam em frente ao INCRA, em Marabá, durante cinco meses. Embora não tenham conseguido a terra no local supracitado, a luta dos militantes possibilitou a criação de um projeto de assentamento com a desapropriação da fazenda Rio Branco. A partir desse momento, outras ocupações foram realizadas e novos assentamentos, organizados com base na lógica do MST (GOMES, 2009). Esses elementos de territorialização do MST serão mais bem trabalhados em momento ulterior: o importante aqui é salientar sua importância para o contexto regional, combinando forças locais e nacionais a partir das alianças tecidas ao longo desse processo. 


\subsection{LUTA CAMPONESA, MOVIMENTOS SOCIAIS E DINÂMICA DA FRONTEIRA}

Essas formas de luta pela reforma agrária são uma resposta à barbárie produzida pela elite latifundiária, que, para manter sua dominação, se utiliza da violência manifesta nos assassinatos, ameaças de morte, expulsão, dentre outras. A modernidade no Brasil, pelo desenvolvimento contraditório e desigual do capitalismo, resultou, contraditoriamente, por um lado, nos latifundiários capitalistas e capitalistas latifundiários, representados pelo agronegócio, que clamam por mais recursos e negam o direito à reforma agrária; mas, por outro, gerou a luta dos trabalhadores do campo, que se rebelam cotidianamente para conquistar a terra. Por este motivo, eles avançam, ocupam, acampam, plantam, recuam, rearticulam-se, vão para as
beiras das estradas, acampam novamente, reaglutinam forças, avançam
novamente, ocupam mais uma vez, recuam outra vez se necessário for, não
param, estão em movimento, são movimentos sociais. (OLIVEIRA, 2005,
p.164)

A fronteira amazônica é reveladora desses conflitos e contradições, embora nosso trabalho tenha indicado apenas uma parte dos sujeitos representativos de temporalidades e geografias distintas, produtos de desenvolvimentos geográficos desiguais; este trabalho ambiciona mostrar a diversidade ocultada ou que se tenta ocultar pelo tempo-espaço hegemônico do capital, materializado hoje pelo projeto agropecuário e mineral no sudeste paraense. Entretanto, os movimentos sociais rompem as cercas, paralisam a ferrovia e a produção mineral, manifestam, ocupam, acampam e tornam mais uma vez visíveis esses outros sujeitos que são alijados do seu direito à terra, que lutam por seus territórios.

Em última instância, o que está em disputa também é o modelo de desenvolvimento, que está na base da questão agrária brasileira, assim como a luta pela terra.

Para Fernandes (2013), a questão agrária não deve ser reduzida a conflitos por terra, visto que o enfrentamento corresponde ao momento do conflito, mas para entendê-lo em seu movimento deve-se trabalhar com o conceito de conflitualidade, que é um processo permanentemente alimentado pelas contradições e desigualdades do capitalismo. Em outros termos:

O movimento da conflitualidade é paradoxal ao promover, concomitantemente, a territorialização-desterritorialização-reterritorialização de diferentes relações sociais. A realização desses processos geográficos gerados pelo conflito é mais bem compreendida quando analisada nas suas temporalidades e espacialidades. São processos de desenvolvimento territorial rural formadores de diferentes organizações sociais. (FERNANDES, 2013, p. 174, grifo nosso) 
Com efeito, concordamos com o autor ao entender que o conflito não deve ser lido como um processo externo ao desenvolvimento, ao contrário, ocorre em seu interior, é produzido em diversas escalas geográficas e é multidimensional. Por esses motivos, os conflitos por terra correspondem à defesa da implantação de modelos de desenvolvimento territorial rural.

A questão agrária no Brasil, e na Amazônia particularmente, expressa a conflitualidade e o desenvolvimento por meio de relações sociais diversas, responsáveis pela produção de diferentes territórios que se chocam continuamente.

A conflitualidade, por um lado, faz parte do processo de formação do capitalismo e do campesinato, ocorrendo devido à contradição gerada pela destruição, criação e recriação dessas relações sociais, ou seja, a agricultura camponesa e suas formas de resistência causam conflitos e desenvolvimento; a agricultura capitalista, por seu turno, se territorializa promovendo a expropriação do campesinato, gerando igualmente conflito e desenvolvimento. Em outras palavras, o capital se desenvolve desterritorializando o campesinato, por outro, contraditoriamente, também cria condições de sua recriação, a qual ocorre subjugada pela lógica da reprodução ampliada das contradições do capitalismo, ou mediante a luta pela terra, a partir de ocupações. Essas duas formas de reprodução camponesa produzem a conflitualidade que projeta outros modelos de desenvolvimento (FERNANDES, 2013). Assim,

De um lado, o capital expropria e exclui; de outro, o campesinato ocupa a terra e se ressocializa. A conflitualidade gerada pelo capital em seu processo de territorialização destrói e recria o campesinato, excluindo-o, subordinando-o, concentrando terra, aumentando as desigualdades. A conflitualidade gerada pelo campesinato em seu processo de territorialização destrói e recria o capital, ressocializando-se em sua formação autônoma, diminuindo as desigualdades, desconcentrando terra. Essa conflitualidade promove modelos distintos de desenvolvimento (FERNANDES, 2013, p. 181).

No caso da realidade em estudo, o tempo da fronteira implica em um choque de temporalidades, no qual o tempo hegemônico do capital torna os outros subalternos a sua lógica, logo os camponeses no sudeste paraense devem (re)encontrar seu próprio tempo, que há muito lhes foi "retirado" - por meio da exploração e do disciplinamento do tempo do trabalhador à racionalidade do capital mercantil e/ou financeiro, que cobra uma produtividade programada, que possibilite o crescimento dos lucros -, mas que foi reconquistado pela luta sindical e dos movimentos. Contudo, essa resistência teve um custo elevado quanto ao aproveitamento de experiências sociais de uso da terra de maneira alternativa, devido aos grandes esforços empreendidos para a conquista da terra e, posteriormente, para a 
permanência nela, vistas as precariedades a que estão envoltos os assentamentos, em termos de saúde, educação, crédito, produção, comercialização dos produtos etc., deixando pouco tempo para refletirem sobre suas práticas históricas de produção e de outros sujeitos que compõem a fronteira, como os indígenas. Uma das formas de (re)ver esse tempo está no debate empreendido pelo MST sobre agroecologia, educação do campo, cooperação na produção, dentre outros aspectos, debate que representa um outro modelo de desenvolvimento que vem sendo cada vez mais disputado na arena política.

À título de síntese esquemática do que foi apresentado neste capítulo em termos da formação territorial do sudeste paraense e das disputas por hegemonia que engendram a realidade regional, esboçamos o Quadro 2.

No próximo capítulo nos deteremos na construção das estratégias do MST para se territorializar no sudeste paraense e, neste processo, construir as bases de um projeto contrahegemônico, em termos gramscianos, frente ao projeto agropecuário e mineral. 
Quadro 2 - Formação territorial do sudeste paraense e disputas territoriais por hegemonia.

\begin{tabular}{|c|c|c|c|}
\hline $\begin{array}{l}\text { ESCALA REGIONAL } \\
\text { (AMAZÔNIA) }\end{array}$ & $\begin{array}{c}\text { ESCALA SUB- } \\
\text { REGIONAL (SUDESTE } \\
\text { PARAENSE) }\end{array}$ & $\begin{array}{c}\text { DISPUTAS } \\
\text { TERRITORIAIS }\end{array}$ & $\begin{array}{c}\text { PROJETOS } \\
\text { HEGEMÔNICOS }\end{array}$ \\
\hline \multicolumn{4}{|c|}{ Século XVII-XIX } \\
\hline $\begin{array}{l}\text { Economia voltada para o } \\
\text { extrativismo, especialmente } \\
\text { das "Drogas do Sertão". }\end{array}$ & $\begin{array}{l}\text { Apropriação incipiente do } \\
\text { médio Tocantins por parte do } \\
\text { governo de Portugal, como } \\
\text { forma de ocupar o território } \\
\text { para não perdê-lo aos } \\
\text { franceses. }\end{array}$ & $\begin{array}{l}\text { Ainda há poucos encontros } \\
\text { entre indígenas } \\
\text { portugueses, devido aos } \\
\text { primeiros estarem afastados } \\
\text { das margens dos rios, mas } \\
\text { existem ações de } \\
\text { catequização } \\
\text { aprisionamento em relação } \\
\text { aos índios. }\end{array}$ & $\begin{array}{l}\text { O capital comercial adentra } \\
\text { lentamente e em pontos } \\
\text { específicos do território } \\
\text { amazônico, especialmente } \\
\text { em Belém, ocupada por sua } \\
\text { posição estratégica na foz da } \\
\text { baía do Guajará, ao passo } \\
\text { que no sudeste paraense } \\
\text { poucos povoados vão sendo } \\
\text { construídos de maneira } \\
\text { temporária e improvisada. }\end{array}$ \\
\hline $\begin{array}{l}\text { Final do século XIX e } \\
\text { início do século XX se } \\
\text { desenvolve na Amazônia a } \\
\text { economia da borracha, } \\
\text { voltada ao mercado } \\
\text { internacional, com destaque } \\
\text { ao europeu. }\end{array}$ & $\begin{array}{l}\text { No inicio do século XX, a } \\
\text { sub-região adentra na } \\
\text { economia gomífera a partir } \\
\text { da exploração das árvores de } \\
\text { caucho, cujas relações de } \\
\text { trabalho se baseavam no } \\
\text { aviamento. Igualmente havia } \\
\text { a exploração da castanha de } \\
\text { maneira livre por migrantes } \\
\text { que chagavam à região e } \\
\text { pelos indígenas. }\end{array}$ & $\begin{array}{l}\text { A economia da borracha } \\
\text { contribui para uma } \\
\text { apropriação do interior da } \\
\text { mata por parte dos } \\
\text { migrantes, instaurando } \\
\text { contatos cada vez mais } \\
\text { frequentes com os indígenas, } \\
\text { e consequentemente, } \\
\text { conflitos por território. }\end{array}$ & 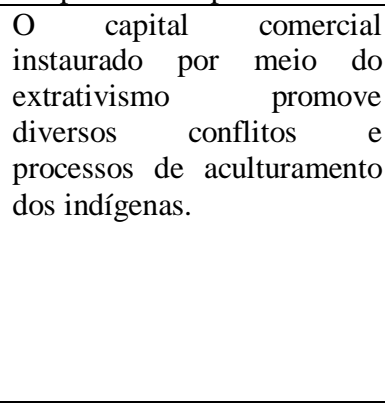 \\
\hline \multicolumn{4}{|c|}{ Primeira metade do século $\mathrm{XX}$} \\
\hline $\begin{array}{l}\text { A partir de } 1920 \text { há o } \\
\text { declínio da economia da } \\
\text { borracha, provocando uma } \\
\text { grave crise regional, ao } \\
\text { menos para os sujeitos } \\
\text { econômicos hegemônicos } \\
\text { (seringalistas/casas } \\
\text { aviadoras/bancos, dentre } \\
\text { outros), ao passo que } \\
\text { recrudesce os seringais } \\
\text { coletivos e a exploração } \\
\text { com base no trabalho } \\
\text { familiar. }\end{array}$ & $\begin{array}{l}\text { A castanha deixa de ser um } \\
\text { artigo secundário e passa ser } \\
\text { o principal produto } \\
\text { comercializado junto ao } \\
\text { mercado internacional. } \\
\text { A sua exploração se baseia } \\
\text { nas mesmas relações de } \\
\text { trabalho da economia da } \\
\text { borracha, salvaguardando } \\
\text { algumas especificidades. } \\
\text { Os castanhais que eram de } \\
\text { exploração livre são } \\
\text { gradativamente apropriados } \\
\text { pela oligarquia regional } \\
\text { emergente que se tornou a } \\
\text { "dona dos castanhais", } \\
\text { mediante ao monopólio } \\
\text { sobre as terras e a circulação } \\
\text { (embarcações a castanha e } \\
\text { transportavam a casta } \\
\text { as pessoas). }\end{array}$ & $\begin{array}{l}\text { A economia da castanha } \\
\text { impulsiona uma apropriação } \\
\text { cada vez mais incisiva sobre } \\
\text { o interior das matas, locais } \\
\text { da extração dos ouriços, } \\
\text { adentrando em diversos } \\
\text { territórios indígenas. } \\
\text { Os migrantes trabalhadores } \\
\text { dos castanhais vão compor } \\
\text { um grupo social muito } \\
\text { particular, denominados de } \\
\text { posseiros. }\end{array}$ & $\begin{array}{l}\text { A oligarquia se utiliza do } \\
\text { Estado para legitimar suas } \\
\text { ações de apropriação dos } \\
\text { castanhais e do discurso } \\
\text { etnocêntrico que torna os } \\
\text { indígenas "selvagens" que } \\
\text { deveriam ser pacificados, ou } \\
\text { melhor, reclusos em reservas } \\
\text { ou longe dos castanhais, } \\
\text { promovendo } \\
\text { desterritorialização, } \\
\text { aculturamento e morte destes } \\
\text { sujeitos. } \\
\text { Os indígenas por seu turno } \\
\text { estabelecem estratégias de } \\
\text { resistência. Inicialmente } \\
\text { procuram criar mecanismos } \\
\text { de aproximação dos } \\
\text { "civilizados", alterando suas } \\
\text { vestes e organização espacial } \\
\text { dos seus territórios, o que } \\
\text { não desestimulou os } \\
\text { conflitos, concorrendo para } \\
\text { desenvolverem a uma } \\
\text { politização étnica, com a } \\
\text { valorização e diferenciação } \\
\text { social e geográfica dos seus } \\
\text { territórios. }\end{array}$ \\
\hline
\end{tabular}




\begin{tabular}{|c|c|c|c|}
\hline $\begin{array}{l}\text { ESCALA REGIONAL } \\
\text { (AMAZÔNIA) }\end{array}$ & $\begin{array}{c}\text { ESCALA SUB- } \\
\text { REGIONAL (SUDESTE } \\
\text { PARAENSE) } \\
\end{array}$ & $\begin{array}{c}\text { DISPUTAS } \\
\text { TERRITORIAIS }\end{array}$ & $\begin{array}{c}\text { PROJETOS } \\
\text { HEGEMÔNICOS }\end{array}$ \\
\hline \multicolumn{4}{|c|}{ Segunda metade do Século XX } \\
\hline $\begin{array}{l}\text { A partir da década de } 1960 \\
\text { o governo federal promove } \\
\text { um projeto de } \\
\text { modernização da Amazônia } \\
\text { que propunha uma alteração } \\
\text { na sua geografia com a } \\
\text { implantação rodovias } \\
\text { hidrelétricas, rede de } \\
\text { federais, rede de } \\
\text { telecomunicações, além de } \\
\text { projetos que colonização } \\
\text { que pudessem subsidiar a } \\
\text { instalação de grandes } \\
\text { projetos agropecuários e } \\
\text { minerais. } \\
\text { Ao final da década de 1980 } \\
\text { tem inicio o processo de } \\
\text { redemocratização do Brasil } \\
\text { e aprofundamento das } \\
\text { desigualdades territoriais, } \\
\text { manifestas em uma } \\
\text { estrutura fundiária bastante } \\
\text { concentrada, cujas terras } \\
\text { são apropriadas pelos } \\
\text { projetos agropecuários e } \\
\text { minerais, a exemplo da } \\
\text { VALE. }\end{array}$ & $\begin{array}{l}\text { O governo federal cria } \\
\text { políticas que diminuem a } \\
\text { hegemonia da oligarquia } \\
\text { regional face ao } \\
\text { beneficiamento de grupos } \\
\text { econômicos externos à } \\
\text { Amazônia, provenientes do } \\
\text { Centro-Sul e empresas } \\
\text { multinacionais. Para este } \\
\text { fim, federaliza as margens } \\
\text { das estradas federais, } \\
\text { concede incentivos fiscais e } \\
\text { creditícios aos novos sujeitos } \\
\text { econômicos, cria o GETAT } \\
\text { com o intuito de dirimir os } \\
\text { conflitos fundiários, mas } \\
\text { principalmente para criar } \\
\text { condições de implantação } \\
\text { dos grandes projetos, } \\
\text { militarizando a questão } \\
\text { agrária; atua violentamente } \\
\text { na repressão as formas de } \\
\text { organização social de luta } \\
\text { pela terra que são criadas } \\
\text { neste contexto histórico. } \\
\text { Com o fim da ditadura civil- } \\
\text { militar o GETAT é extinto, } \\
\text { passando novamente para a } \\
\text { competência do INCRA os } \\
\text { assuntos fundiários, tendo } \\
\text { por incumbência a criação de } \\
\text { projetos de assentamento. }\end{array}$ & 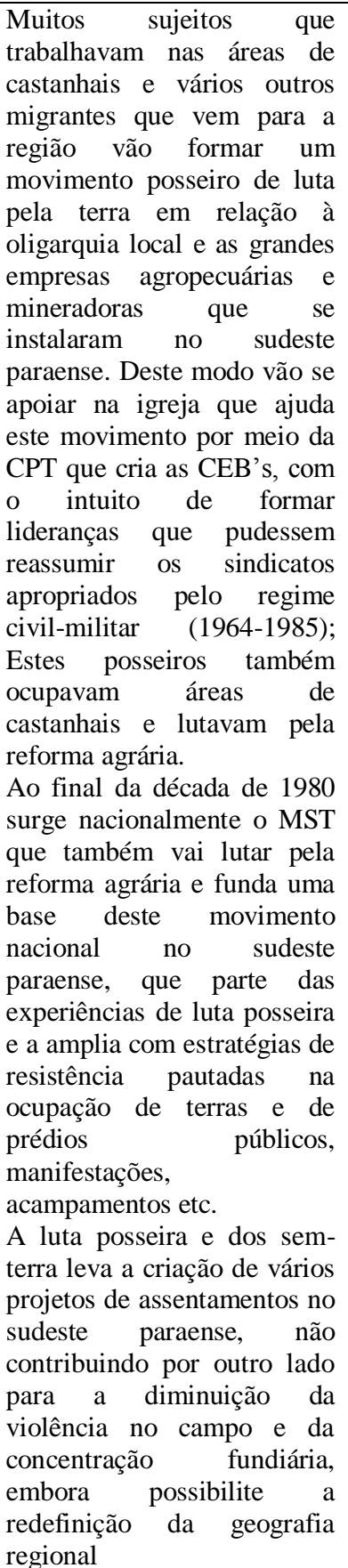 & $\begin{array}{l}\text { A oligarquia local busca } \\
\text { desenvolver estratégias para } \\
\text { não perder totalmente sua } \\
\text { hegemonia. Por este motivo } \\
\text { envia aos órgãos } \\
\text { competentes os chamados } \\
\text { "memoriais" relatando a } \\
\text { destruição da floresta e os } \\
\text { conflitos fundiários, e propõe } \\
\text { paralelamente a criação do } \\
\text { "Polígono dos Castanhais" } \\
\text { para salvaguardarem sua } \\
\text { posse sobre as terras, sob o } \\
\text { discurso preservacionista, } \\
\text { sendo que muitos destes } \\
\text { sujeitos já haviam se tornado } \\
\text { fazendeiros e exploravam a } \\
\text { madeira de suas áreas para } \\
\text { comercializarem. } \\
\text { Emergem vários movimentos } \\
\text { sociais e sindicais no sudeste } \\
\text { paraense que vão lutar pela } \\
\text { reforma agrária como a } \\
\text { FETAGRI, sindicatos, MAB, } \\
\text { além do movimento indígena } \\
\text { que se organiza em prol da } \\
\text { demarcação das suas terras e } \\
\text { constroem um movimento } \\
\text { nacional de luta pelos seus } \\
\text { territórios, a exemplo do } \\
\text { CIMI. } \\
\text { O MST surge como um } \\
\text { movimento socioterritorial } \\
\text { camponês que propõe para } \\
\text { além da redistribuição das } \\
\text { terras outro projeto de } \\
\text { desenvolvimento territorial, } \\
\text { ampliando a ideia de reforma } \\
\text { agrária. }\end{array}$ \\
\hline
\end{tabular}




\begin{tabular}{|c|c|c|c|}
\hline $\begin{array}{l}\text { ESCALA REGIONAL } \\
\text { (AMAZÔNIA) }\end{array}$ & $\begin{array}{c}\text { ESCALA SUB- } \\
\text { REGIONAL (SUDESTE } \\
\text { PARAENSE) }\end{array}$ & $\begin{array}{c}\text { DISPUTAS } \\
\text { TERRITORIAIS }\end{array}$ & $\begin{array}{c}\text { PROJETOS } \\
\text { HEGEMÔNICOS }\end{array}$ \\
\hline \multicolumn{4}{|c|}{ Início do século XXI } \\
\hline $\begin{array}{l}\text { A partir da década de } 2000 \\
\text { se aprofunda o modelo de } \\
\text { desenvolvimento neoliberal } \\
\text { no Brasil, o qual inicia na } \\
\text { década de 1990, e a } \\
\text { Amazônia é novamente } \\
\text { lócus dos grandes } \\
\text { empreendimentos } \\
\text { agropecuários, minerais e } \\
\text { logísticos (hidrelétricas, } \\
\text { rodovias e ferrovias). }\end{array}$ & $\begin{array}{l}\text { O sudeste paraense é alvo de } \\
\text { diversos empreendimentos } \\
\text { como Hidrelétrica de Marabá } \\
\text { e Santa Izabel, ampliam-se } \\
\text { os projetos minerais, por } \\
\text { exemplo, Onça Puma, Serra } \\
\text { Leste e S11D da VALE que, } \\
\text { para este fim, inicia a } \\
\text { duplicação da Estrada de } \\
\text { Ferro Carajás, sendo que } \\
\text { todas estas ações impactam } \\
\text { diretamente as áreas de } \\
\text { assentamentos e reservas } \\
\text { indígenas. }\end{array}$ & $\begin{array}{l}\text { Acirra-se ainda mais a } \\
\text { disputa por território face a } \\
\text { expansão dos grandes } \\
\text { empreendimentos, com } \\
\text { anuência do Estado, o qual } \\
\text { cria mecanismos de } \\
\text { dominação e consentimento } \\
\text { por meio dos aparelhos } \\
\text { privados de hegemonia. }\end{array}$ & $\begin{array}{l}\text { Os movimentos sociais } \\
\text { ampliam suas ações e } \\
\text { articulações em diversas } \\
\text { escalas geográficas e em rede } \\
\text { com o intuito de adensarem a } \\
\text { luta pela terra. Nesse } \\
\text { contexto sobressai-se o MST } \\
\text { que cria uma rede geográfica } \\
\text { solidária camponesa de luta } \\
\text { pela terra que se utiliza da } \\
\text { política de escala para } \\
\text { construir, de maneira aberta } \\
\text { e dialética, um projeto } \\
\text { territorial contra- } \\
\text { hegemônico. Para este fim } \\
\text { disputa a hegemonia por } \\
\text { meio da construção de um } \\
\text { consentimento ativo no seio } \\
\text { da sociedade política, desta } \\
\text { forma, disputa a apropriação } \\
\text { dos aparelhos privados de } \\
\text { hegemonia. }\end{array}$ \\
\hline
\end{tabular}

Fonte: elaborado por MIRANDA, Rogério Rego, a partir de Almeida (1981,1985), Emmi (1996, 1999), Emmi; Marin (1996), Velho (1981). 


\section{ESTRATÉGIAS CONTRA-HEGEMÔNICAS DO MOVIMENTO DOS TRABALHADORES RURAIS SEM TERRA (MST) NO SUDESTE PARAENSE}

Foto 3 - Acampamento Hugo Chavez.

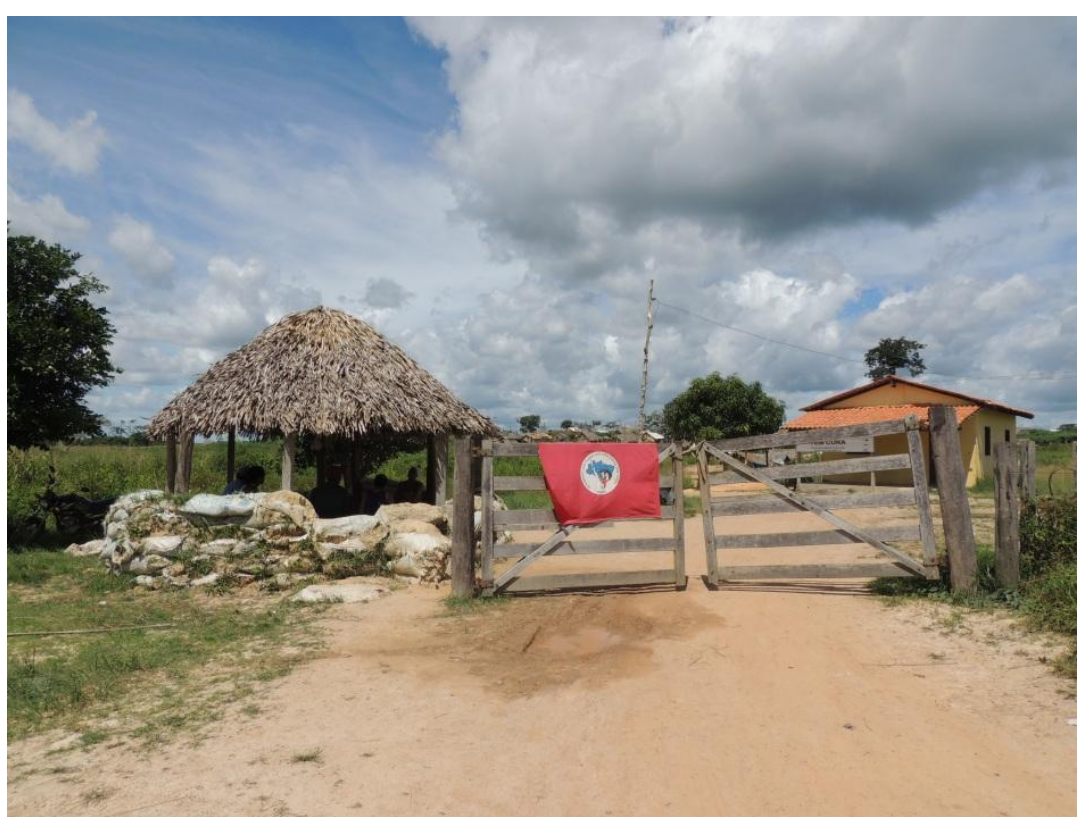

Fonte: Rogério Rego Miranda, Marabá, 2015.

Foto 4 - Assentamento 26 de Março.

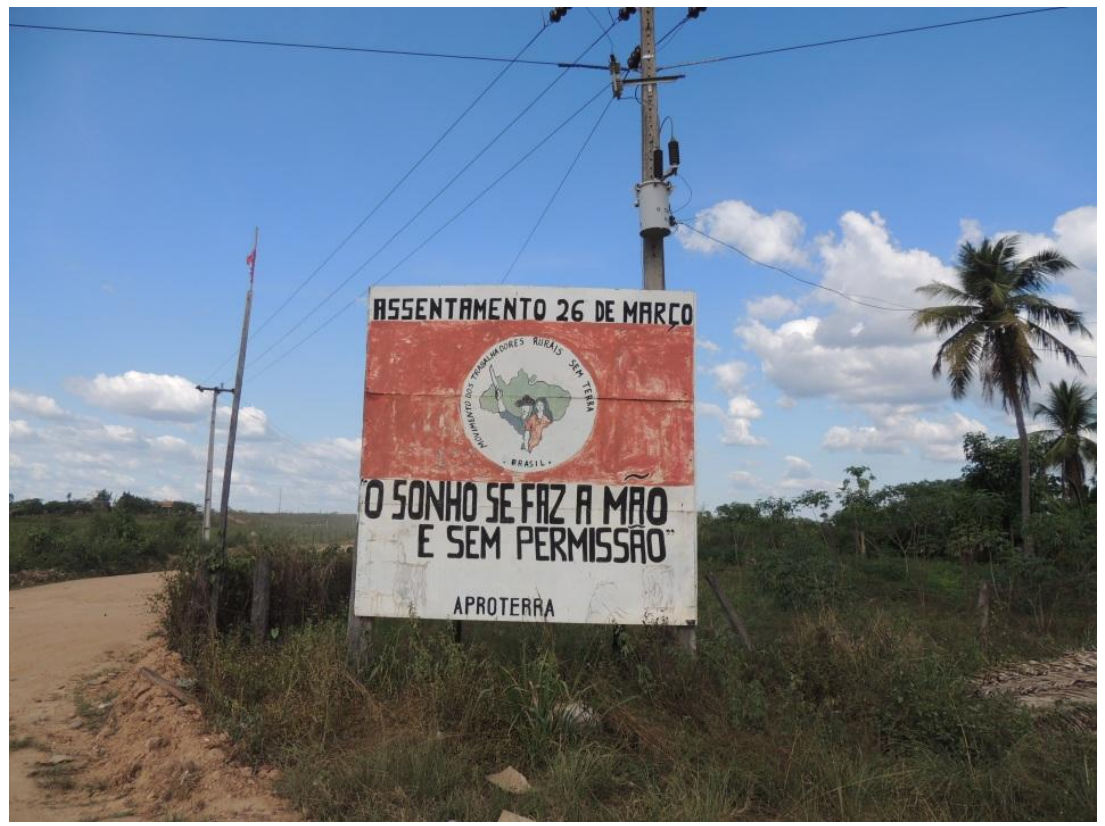

Fonte: Rogério Rego Miranda, Marabá, 2014.

"Bom! No tempo que nós não tinha nada, trabalhava no cativeiro dos fazendeiros... e hoje nós tem esse pedacinho de terra para trabalhar." (Aristeu da Silva, PA Palmares II, 74 anos, 16 abr. 2015) 
A construção da hegemonia, ou de uma contra-hegemonia, perpassa pela necessidade de compreensão da formação econômico-social de uma dada sociedade, ou em termos mais geográficos, pelo desenvolvimento geográfico desigual, que expõe as diferenças espaciais em suas múltiplas dimensões e escalas que interagem hierarquicamente, pois são resultantes e ao mesmo tempo resultam das relações de poder assimetricamente disputadas pelas frações do território, ou melhor, pelos grupos sociais que, ao construírem seus territórios - por exemplo, as empresas de mineração, do agronegócio e igualmente os assentados -, imprimem neles suas racionalidades, embora estes territórios igualmente condicionem (relativamente) as intencionalidades do capital e dos camponeses.

A luta por hegemonia implica em uma mudança quantitativa, mas principalmente qualitativa na forma de desenvolvimento proposto ao/no território. Esse modelo de desenvolvimento é disputado por diversos sujeitos que interagem, por vezes simultaneamente, em diversas escalas, o que é um elemento complicador para os movimentos sociais na contemporaneidade, visto que, ao almejarem a construção de outro projeto territorial, como o modelo de agricultura camponês frente ao agronegócio, precisam entender as particularidades que envolvem esse projeto, sem desvinculá-las da totalidade em constante movimento - ou seja, não há como pensar nessa disputa apenas na escala local, ao contrário, ela deve ser construída considerando a dimensão inter/intraescalar e articulada em rede.

Esses elementos analíticos que envolvem a forma como os movimentos sociais constroem suas estratégias de territorialização serão mais bem discutidos ao longo deste capítulo, analisando a experiência do Movimento dos Trabalhadores Rurais Sem Terra (MST) no sudeste paraense.

\subsection{O TERRITÓRIO DO SUDESTE PARAENSE NO CONTEXTO ATUAL}

A formação territorial do sudeste paraense nos possibilita a compreensão de dois aspectos importantes. O primeiro se refere à conformação física desse território (ver Prancha 1 e mapas 3 e 4), o qual é produto da produção social marcada pelo conflito, discutida no capítulo anterior. 
Prancha 1 - Evolução territorial do sudeste paraense - 1872-1970
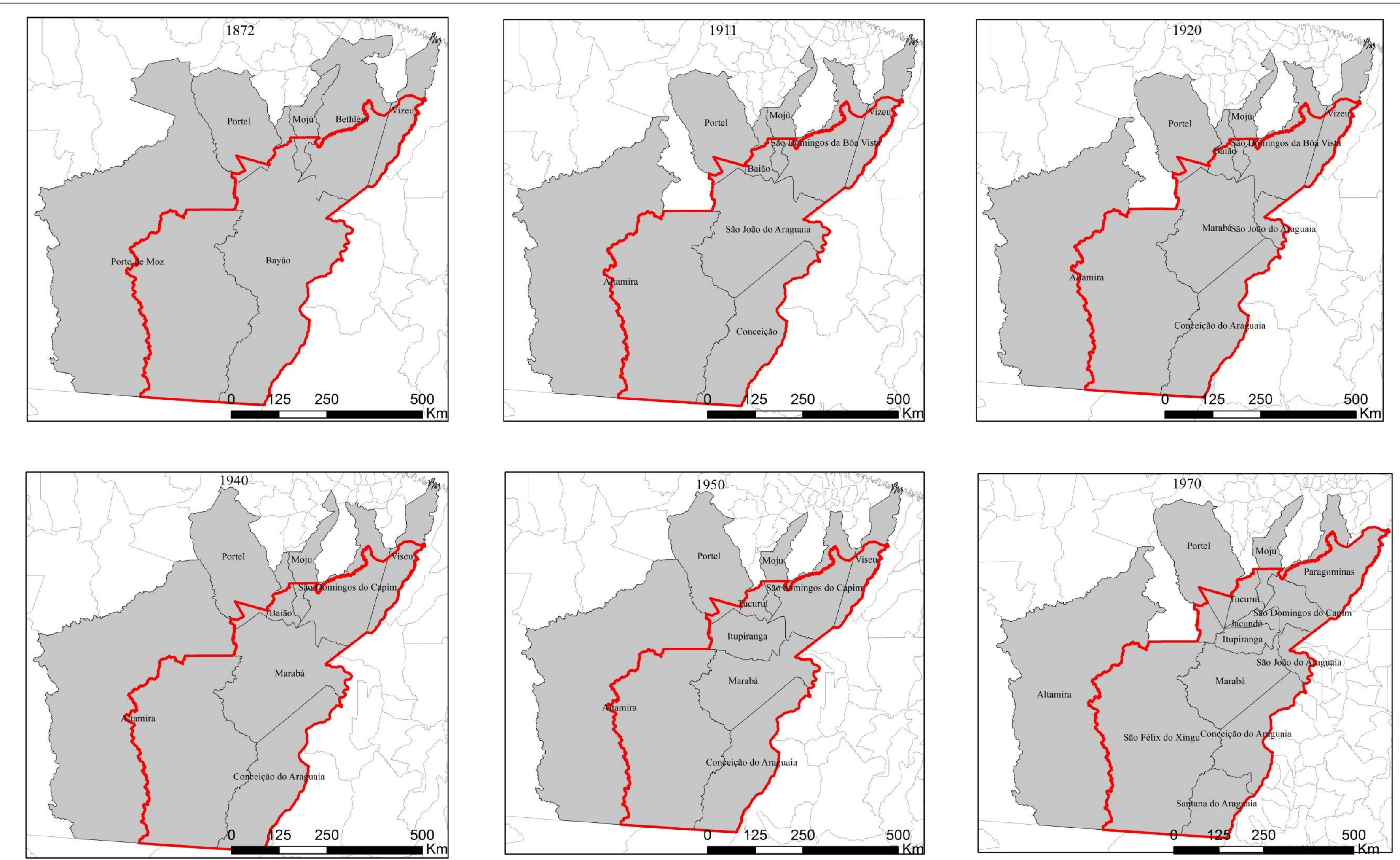

\section{Legenda}

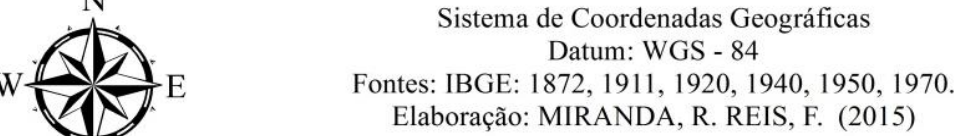
Sistema de Coordenadas Geográficas

Limite atual da região sudeste do Pará

Áreas dos municípios que foram transformados no território do sudeste paraense 
Mapa 3 - Sudeste paraense em 1991

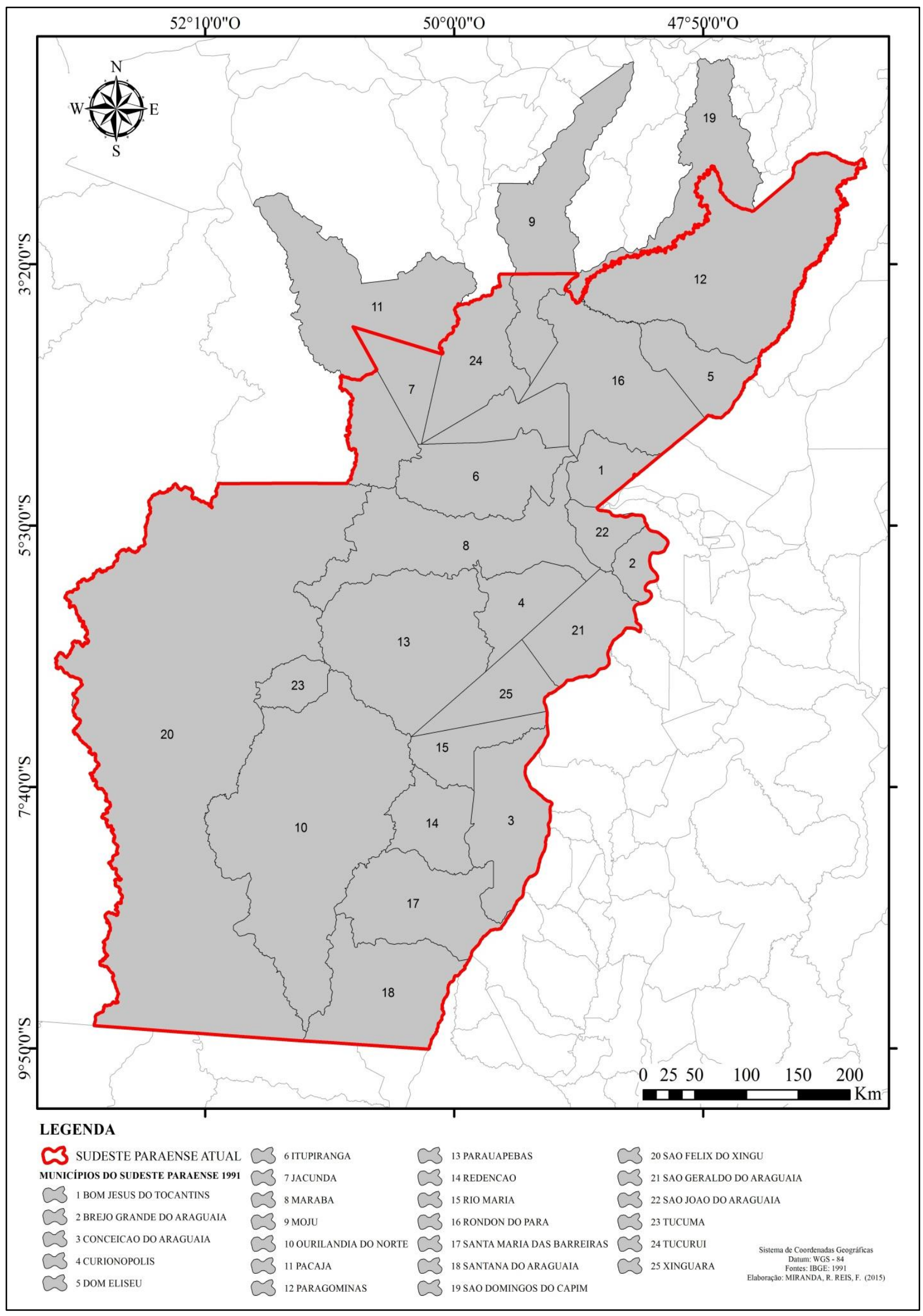


Mapa 4 - Sudeste Paraense em 2016

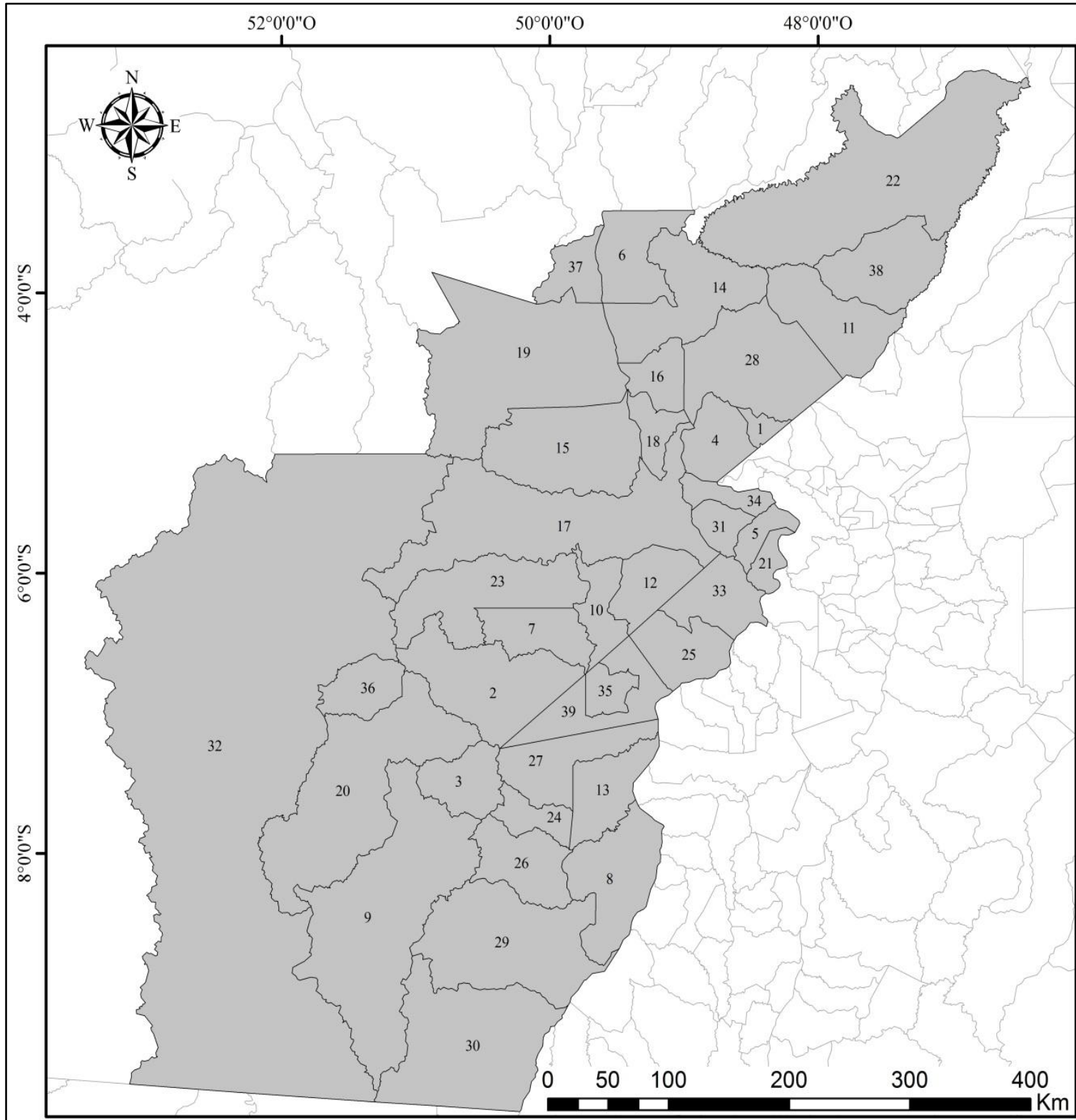

\section{LEGENDA}

MUNICÍPIOS DA REGIÃO SUDESTE

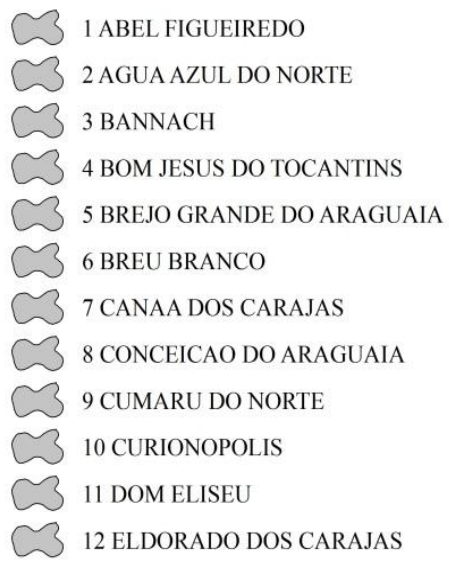

J 14 GOIANESIA DO PARA

$\checkmark 15$ ITUPIRANGA

316 JACUNDA

3 17 MARABA

C3 18 NOVA IPIXUNA

319 NOVO REPARTIMENTO

C 20 OURILANDIA DO NORTE

321 PALESTINA DO PARA

$\checkmark 22$ PARAGOMINAS

C 23 PARAUAPEBAS

$\checkmark 324$ PAU D'ARCO

$\checkmark 25$ PICARRA

C 26 REDENCAO
327 RIO MARIA

$\checkmark 28$ RONDON DO PARA

329 SANTA MARIA DAS BARREIRAS

33 SANTANA DO ARAGUAIA

331 SAO DOMINGOS DO ARAGUAIA

332 SAO FELIX DO XINGU

C3 33 SAO GERALDO DO ARAGUAIA

3 34 SAO JOAO DO ARAGUAIA

$\checkmark 35$ SAPUCAIA

3 36 TUCUMA

\37 TUCURUI

338 ULIANOPOLIS

C3 39 XINGUARA 
Essa dimensão concreta é oriunda também da fragmentação territorial (criação de municípios) ocorrida principalmente com a promulgação da Constituição de 1988 que promovia um ideal de descentralização. Assim, a criação de novos municípios é motivada pela urbanização manifesta na expansão populacional de centros urbanos, na ampliação de núcleos populacionais e no avanço do capital sobre novos espaços, elementos desenvolvidos especialmente pelos grandes projetos. Entretanto esses municípios igualmente são resultado de interesses econômicos e políticos das antigas oligarquias e de outros sujeitos (empresas e fazendeiros) (ROCHA, 2013).

O segundo aspecto a ser sublinhado acerca da formação territorial corresponde à sua estrutura fundiária, marcadamente concentrada.

A partir dos dados da tabela 1 podemos observar que o sudeste paraense se constitui como uma das mesorregiões de maior concentração de terras do estado do Pará. Lá encontramos 4.607 estabelecimentos (8,72\%), com uma área menor do que 10 hectares cada, que somam um total de 26.344 hectares de terra (0,24\%); estabelecimentos de 10 a menos de 100 hectares são em número de 35.893 (68,03\%) que apresentam juntos 1.564 .174 hectares $(14,1 \%)$; há 938 estabelecimentos $(1,78 \%)$ de 1.000 a menos de 2.500 hectares, que totalizam 1.481.905 hectares $(13,36 \%)$; por fim, na outra ponta extrema, temos aqueles com áreas territoriais superiores a 2.500 hectares que correspondem a 687 estabelecimentos $(1,3 \%)$, representando 5.155 .819 hectares $(46,48 \%)$.

As microrregiões do sudeste paraense que apresentam os maiores índices de concentração de terra, considerando somente as áreas acima de 2.500 hectares, são, em ordem decrescente: a microrregião de São Félix do Xingu com 186 estabelecimentos (2,05\%) que somam 1.806.420 hectares (63\%); a microrregião do Araguaia, em que 124 estabelecimentos (1,2\%) obtêm 859.577 hectares (41,83\%); a microrregião de Paragominas onde 153 estabelecimentos (2,89\%) possuem 798.603 hectares (44,43\%); a microrregião de Redenção detém 74 estabelecimentos $(1,2 \%)$ que somam 763.045 hectares $(51,54 \%)$; a microrregião de Marabá dispõe de 65 estabelecimentos $(1,13 \%)$, concentrando 449.902 hectares $(49,9 \%)$ acentuamos que 45 desses estabelecimentos encontram-se em Marabá -; a microrregião de Tucuruí contendo 48 estabelecimentos (0,47\%), que aglutinam 275.463 hectares $(22,33 \%)$; e, finalmente, a microrregião de Parauapebas com 37 estabelecimentos $(0,62 \%)$ que reúnem 202.809 hectares $(26,79 \%)$. 
Tabela 1 - Estrutura fundiária do estado do Pará e de suas mesorregiões, 2006.

\begin{tabular}{|c|c|c|c|c|c|c|c|c|}
\hline & & \multicolumn{7}{|c|}{ Uf / mesorregião } \\
\hline & & Pará & $\begin{array}{c}\text { Sudeste } \\
\text { paraense }\end{array}$ & $\begin{array}{c}\text { Baixo } \\
\text { Amazonas }\end{array}$ & Marajó & $\begin{array}{l}\text { Metropolitana } \\
\text { de Belém }\end{array}$ & $\begin{array}{l}\text { Nordeste } \\
\text { paraense }\end{array}$ & $\begin{array}{l}\text { Sudoeste } \\
\text { paraense }\end{array}$ \\
\hline \multirow{2}{*}{$\begin{array}{l}\text { Estabelecimentos } \\
\text { (menos de } 10 \text { ha) }\end{array}$} & Abs. & 69.928 & 4.607 & 8.896 & 9.468 & 3.729 & 39.811 & 3.417 \\
\hline & $\%$ & 31,51 & 8,72 & 30,16 & 38,09 & 47,03 & 49,24 & 13,1 \\
\hline \multirow{2}{*}{$\begin{array}{c}\text { Área } \\
(\text { menos de } 10 \text { ha })\end{array}$} & Abs. & 177.975 & 26.344 & 21.441 & 18.976 & 10.221 & 89.261 & 11.731 \\
\hline & $\%$ & $\mathbf{0 , 7 9}$ & 0,24 & 1,03 & 1,11 & 4,61 & 2,83 & 0,28 \\
\hline \multirow{2}{*}{$\begin{array}{l}\text { Estabelecimentos } \\
\text { (10 a menos de } 100 \text { ha) }\end{array}$} & Abs. & 99.378 & 35.893 & 11.076 & 5.894 & 3.725 & 31.347 & 11.443 \\
\hline & $\%$ & 44,76 & 68,03 & 37,53 & 23,7 & 47 & 38,76 & 43,84 \\
\hline \multirow{2}{*}{$\begin{array}{c}\text { Área } \\
\text { (10 a menos de } 100 \text { ha) }\end{array}$} & Abs. & 3.952 .168 & 1.564 .174 & 425.807 & 191.188 & 93.906 & 1.060 .581 & 616.513 \\
\hline & $\%$ & 17,6 & 14,1 & 20,62 & 11,22 & 42,38 & 33,74 & 14,54 \\
\hline \multirow{2}{*}{$\begin{array}{l}\text { Estabelecimentos } \\
\text { (100 a menos de } 1.000 \text { ha) }\end{array}$} & Abs. & 33.608 & 10.265 & 6.571 & 1.770 & 313 & 4855 & 9834 \\
\hline & $\%$ & 15,14 & 19,45 & 22,27 & 7,12 & 3,95 & 6 & 37,68 \\
\hline \multirow{2}{*}{$\begin{array}{c}\text { Área } \\
(100 \text { a menos de } 1.000 \text { ha) }\end{array}$} & Abs. & 7.296 .28 & 2.864 .436 & 1.066 .693 & 376.571 & 83.416 & 1.044 .806 & 1.860 .105 \\
\hline & $\%$ & 32,48 & 25,82 & 51,64 & 22,12 & 37,65 & 33,24 & 43,86 \\
\hline \multirow{2}{*}{$\begin{array}{c}\text { Estabelecimentos } \\
\text { (1.000 a menos de } 2.500 \text { ha) }\end{array}$} & Abs. & 1.824 & 938 & 97 & 124 & 13 & 199 & 453 \\
\hline & $\%$ & $\mathbf{0 , 8 2}$ & 1,78 & 0,33 & 0,5 & 0,16 & 0,25 & 1,74 \\
\hline \multirow{2}{*}{$\begin{array}{c}\text { Área } \\
(1.000 \text { a menos de } 2.500 \text { ha) }\end{array}$} & Abs. & 2.851 .988 & 1.481 .905 & 141.641 & 189.686 & 17.200 & 303.919 & 717.637 \\
\hline & $\%$ & 12,69 & 13,36 & 6,86 & 11,14 & 7,76 & 9,67 & 16,92 \\
\hline \multirow{2}{*}{$\begin{array}{c}\text { Estabelecimentos } \\
(2.500 \text { e mais ha) }\end{array}$} & Abs. & 1.198 & 687 & 53 & 140 & 5 & 119 & 194 \\
\hline & $\%$ & 0,54 & 1,3 & 0,18 & 0,56 & 0,06 & 0,15 & 0,74 \\
\hline \multirow{2}{*}{$\begin{array}{c}\text { Área } \\
(2.500 \text { e mais ha) }\end{array}$} & Abs. & 8.187.867 & 5.155 .819 & 409.763 & 926.448 & 16.804 & 644.354 & 1.034 .679 \\
\hline & $\%$ & 36,45 & 46,48 & 19,84 & 54,41 & 7,58 & 20,5 & 24,4 \\
\hline \multirow{2}{*}{$\begin{array}{l}\text { Estabelecimentos } \\
\text { (sem declaração) }\end{array}$} & Abs. & 16.092 & 377 & 2.810 & 7.463 & 141 & 4.542 & 759 \\
\hline & $\%$ & 7,25 & 0,71 & 9,52 & 30,02 & 1,78 & 5,62 & 2,91 \\
\hline \multirow{2}{*}{$\begin{array}{c}\text { Área } \\
\text { (sem declaração) }\end{array}$} & Abs. & --- & --- & 0 & 0 & 0 & 0 & 0 \\
\hline & $\%$ & --- & --- & 0 & 0 & 0 & 0 & 0 \\
\hline
\end{tabular}

Fonte: Censo Agropecuário, 2006. Organização: Rogério Rego Miranda. 
A estrutura fundiária desigual do sudeste paraense, tal qual a brasileira em geral, é produto da sua formação territorial, na qual o Estado via GETAT, MIRAD/INCRA, SUDAM, dentre outros órgãos, acabou beneficiando um conjunto de sujeitos econômicos que organizam o território regional visando a implementação de sua lógica de produção capitalista pautada no modelo agropecuário e mineral que define seu eixo territorial ao longo das principais rodovias federais e estaduais, conformando uma rede capitalista de produção devidamente articulada pelas fazendas, siderúrgicas e polos minerais (ver Mapa 5).

A espacialização desses grupos econômicos conforma a hegemonia do capital na região. Ao longo do trabalho de campo destacamos a forte presença das fazendas (ver Foto 5) com produção bovina voltada aos mercados nacionais e internacionais, seja pela venda do material genético de bois em grandes leilões seja pela comercialização de carne para grupos importantes do ramo agropecuário, como o JBS, que possui sede em Marabá, Tucumã e Redenção (ver Foto 6).

Foto 5 - Entrada da fazenda do grupo Revemar, que trabalha com concessionárias de automóveis na cidade de Marabá-PA

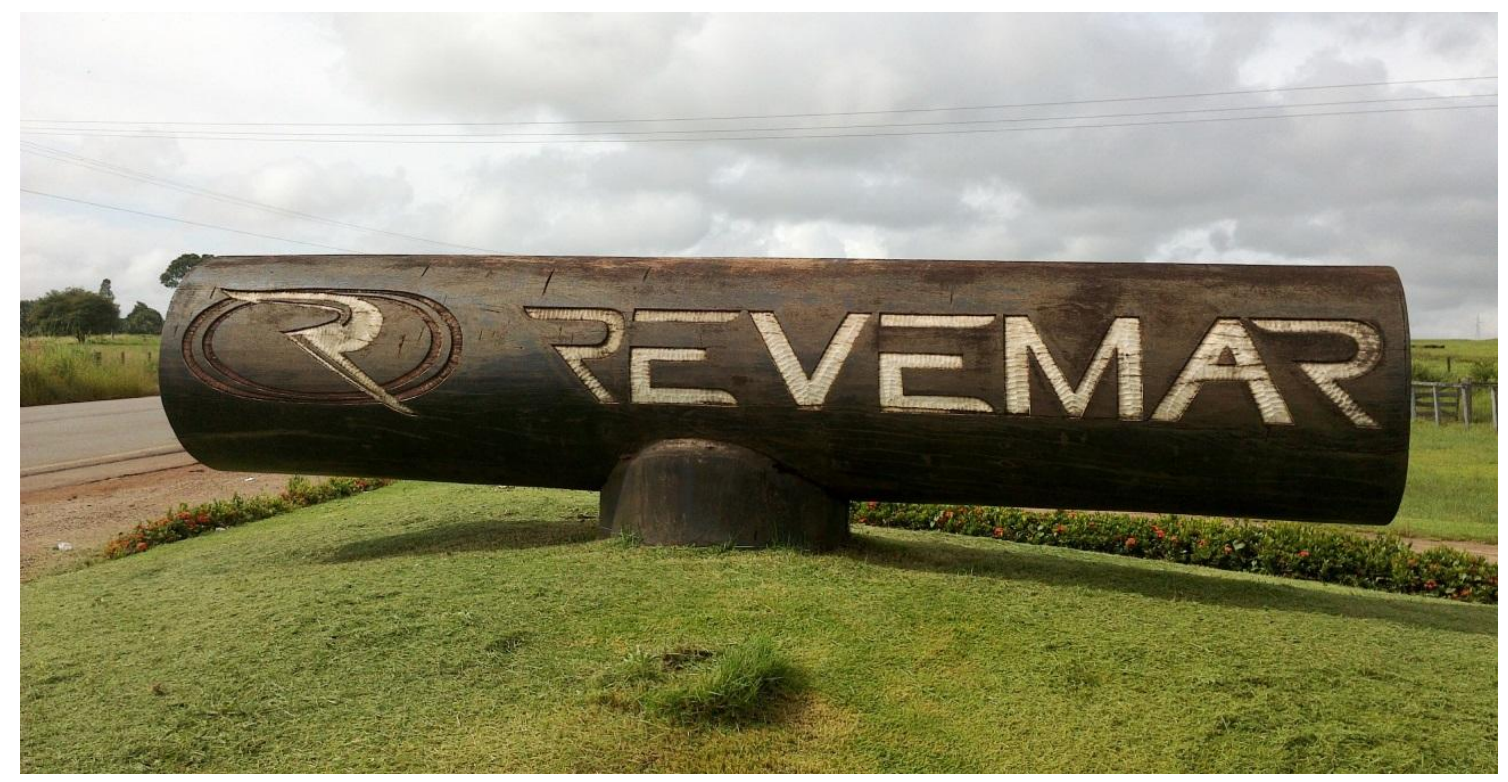

Fonte: Rogério Rego Miranda, Marabá, 2015. 
Mapa 5 - Eixo Agropecuário e Mineral - Sudeste Paraense, 2016.

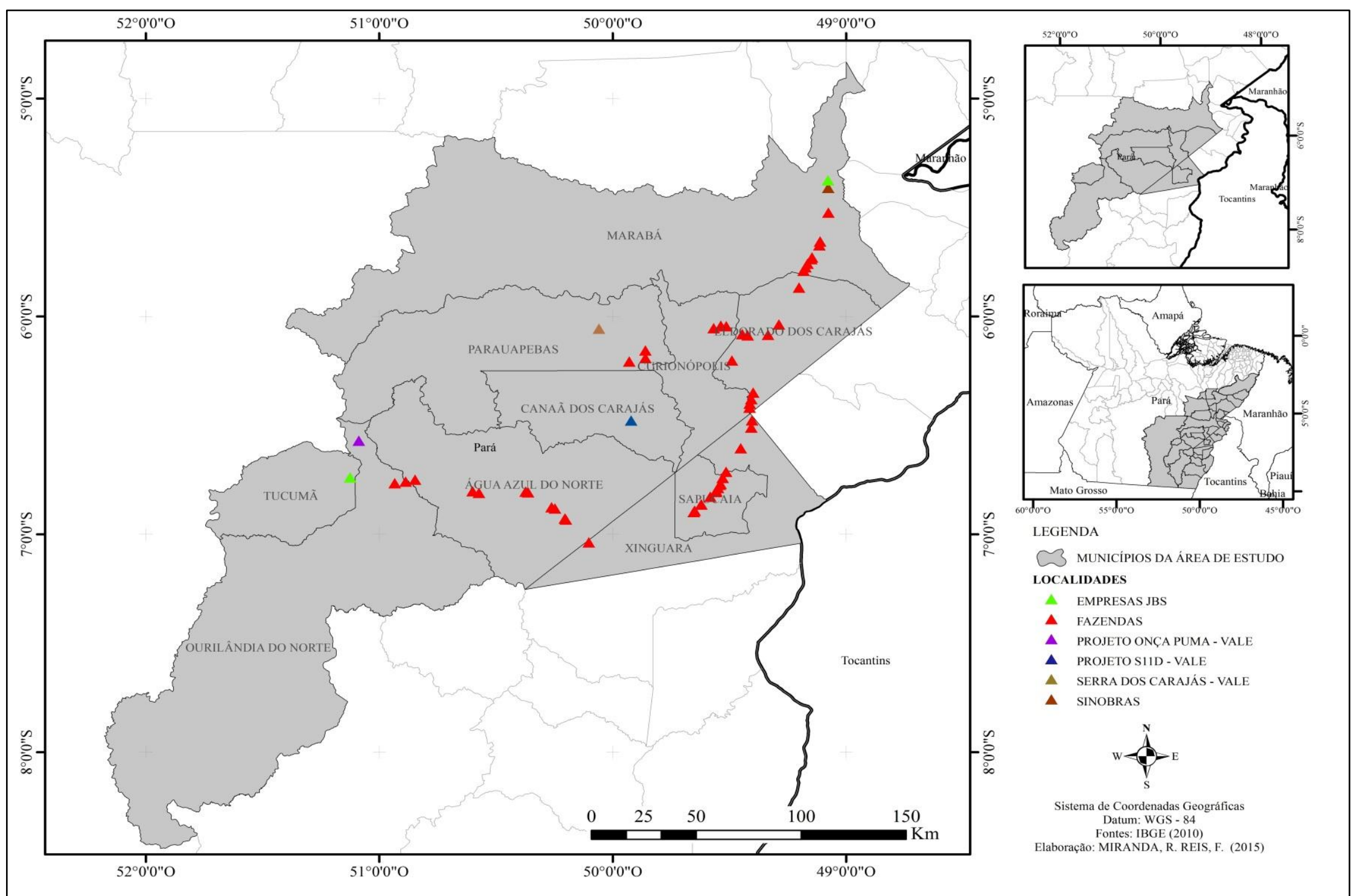


Foto 6 - Entrada da empresa agropecuária JBS, no município de Tucumã-PA

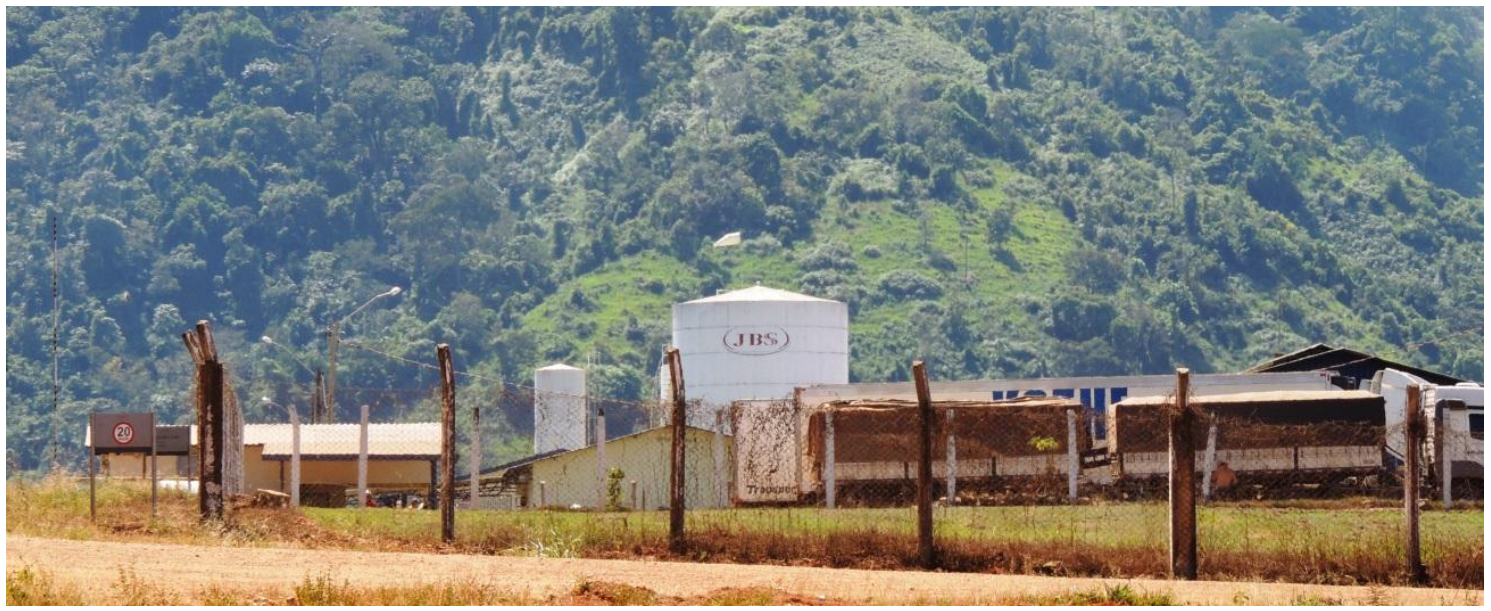

Fonte: Rogério Rego Miranda, Tucumã, 2015.

Nessa rede hegemônica é igualmente marcante a presença de empresas atreladas ao ramo siderúrgico, a exemplo da Siderúrgica Norte Brasil S.A. (SINOBRAS), indicada na Foto 7, que está localizada no distrito industrial de Marabá e é especializada na produção de aço.

Foto 7 - Entrada da usina siderúrgica Sinobras no município de Marabá-PA

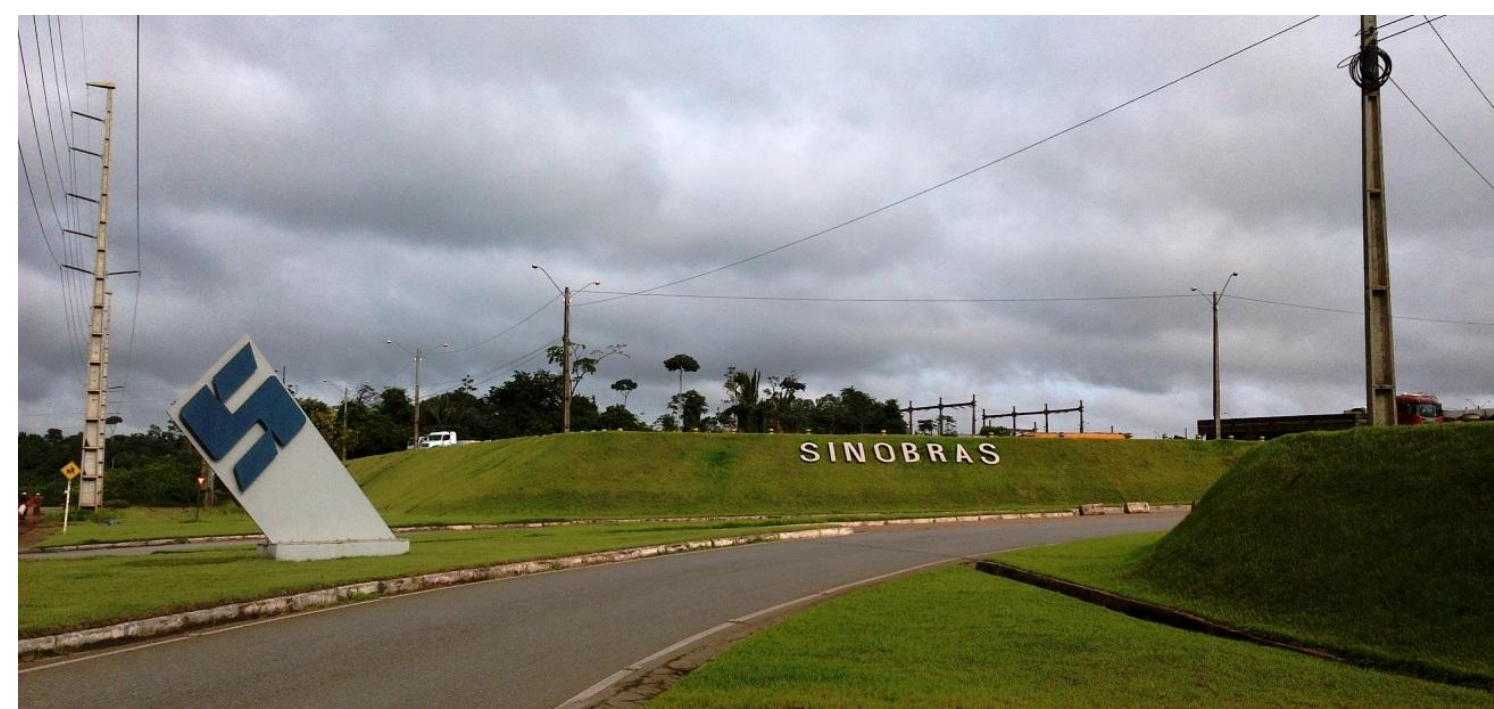

Fonte: Rogério Rego Miranda, Marabá, 2015.

Também observamos, na Foto 8 , a exploração dos minérios de ferroníquel desenvolvida no município de Ourilândia do Norte pelo projeto Onça Puma e, nas Fotos 9 e 10, a extração de ferro desenvolvida na Serra de Carajás, em Parauapebas, ambas sob a responsabilidade da VALE, coordenadora de vários outros, como o Projeto Ferro Carajás S11D, em Canaã dos Carajás, que, no momento de elaboração desta tese, estava em processo de instalação para a exploração de ferro, concorrendo para a duplicação da Estrada de Ferro Carajás, que pode vir a atravessar vários assentamentos, além de reservas indígenas. 
Foto 8 - Entrada da Unidade Operacional Onça Puma da VALE no município de Ourilândia do Norte-PA

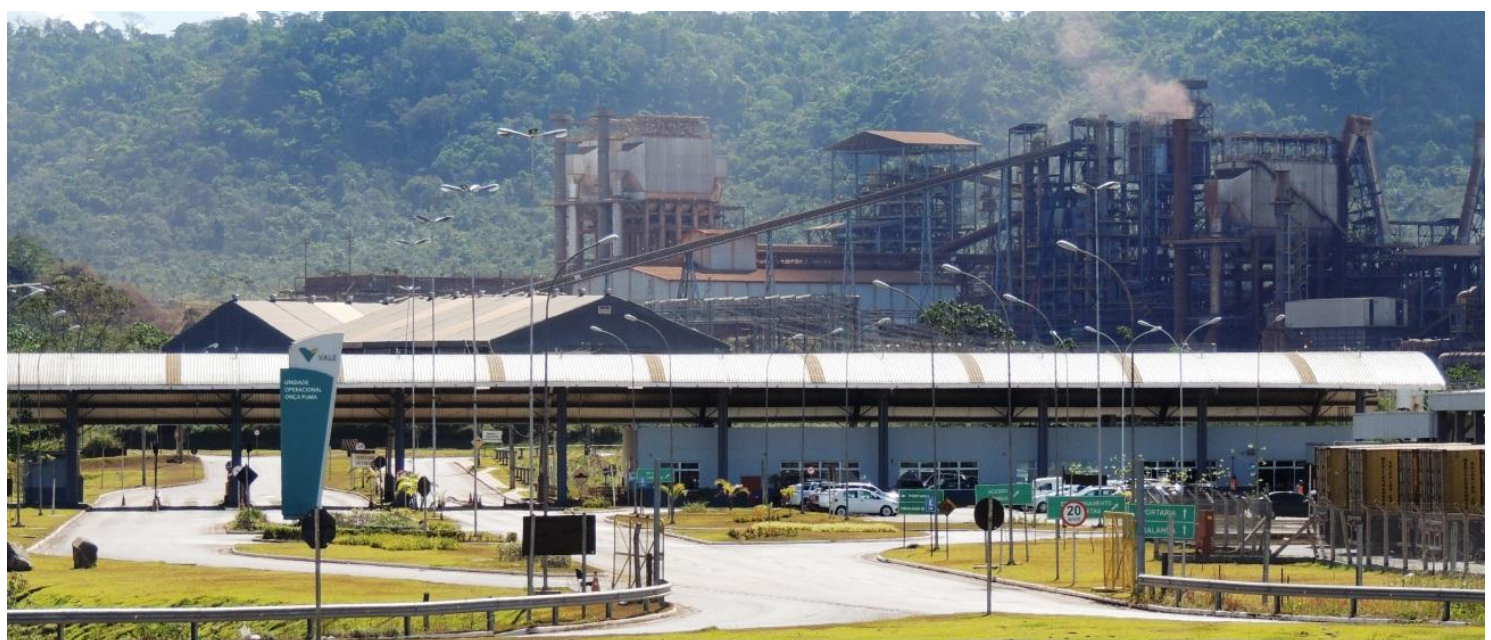

Fonte: Rogério Rego Miranda, Ourilândia do Norte, 2015.

Foto 9 - Mina da Serra de Carajás, local de extração do minério de ferro

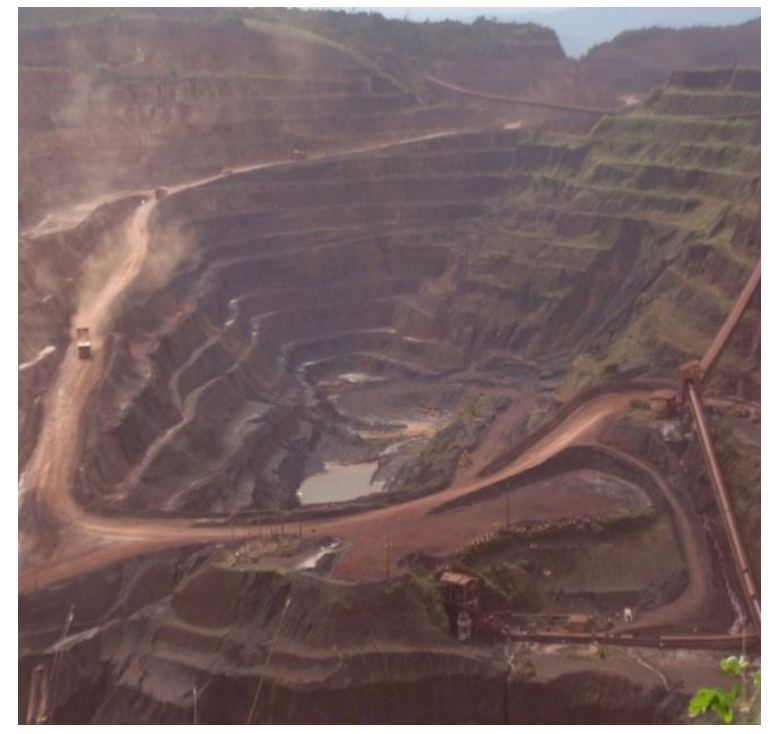

Fonte: Rogério Rego Miranda, Parauapebas, 2013.
Foto 10 - Estrada de Ferro Carajás carregada de minério de ferro

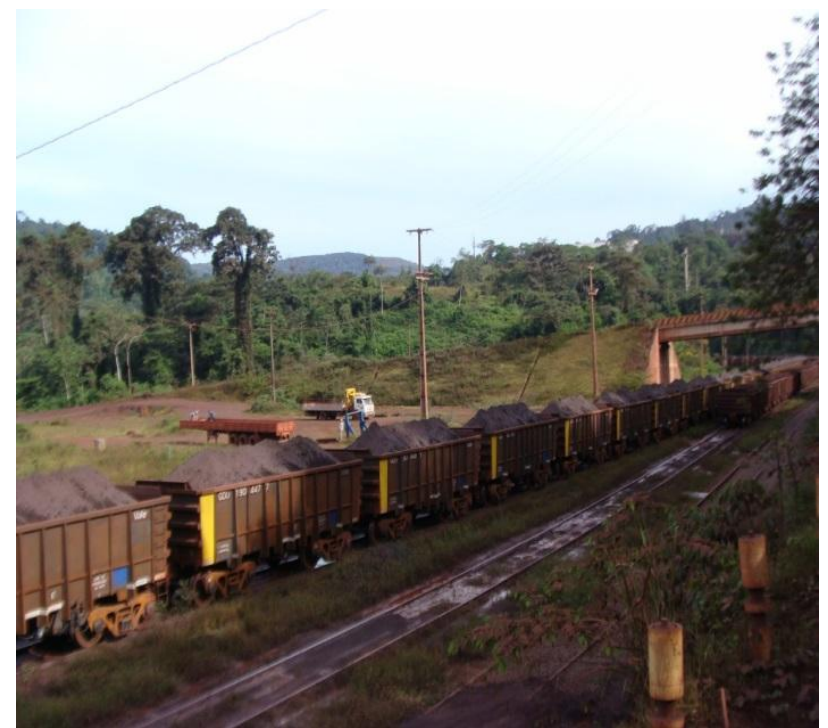

Fonte: Rogério Rego Miranda, Parauapebas, 2013. 
Para a expansão dessas atividades minerais está se implementando infraestruturas energéticas como a Usina Hidrelétrica de Belo Monte localizada no município de Altamira, ao longo do rio Xingu, além de usinas de menor porte nas bacias do Araguaia e do Tocantins denominadas de Usinas Hidrelétricas de Marabá e Santa Izabel, respectivamente, as quais, ao formarem um grande reservatório, irão impactar novamente povos indígenas e assentados.

A realidade da fronteira do sudeste paraense guarda em sua dinâmica a ação desses grupos hegemônicos que não agem em um espaço liso, em branco, e por esse motivo enfrentam diversos tipos de resistência por questões mais econômicas, como melhores indenizações, ou por determinados grupos não desejarem sair de suas terras, conquistadas ao longo de vários anos de luta e exploração.

Observa-se nesse choque de territorialidades a permanente luta pela terra e a necessária reforma agrária que tarda em chegar aos sujeitos mais pobres. Daí a existência de diversas áreas em conflito, conforme podemos ver na Tabela 2 a seguir.

Tabela 2 - Áreas em conflito no Pará e no sudeste paraense, 2006-2015.

\begin{tabular}{|c|c|c|c|c|c|c|c|}
\hline \multirow{2}{*}{$\mathbf{N}^{\mathbf{o}}$} & \multirow{2}{*}{$\begin{array}{c}\text { UF/ mesorregião/ } \\
\text { microrregião/ município }\end{array}$} & \multicolumn{2}{|c|}{ Áreas em conflito } & \multicolumn{2}{|c|}{ Famílias } & \multicolumn{2}{|c|}{ Área (ha) } \\
\hline & & Abs. & $\%$ & Abs. & $\%$ & Abs. & $\%$ \\
\hline & Pará $^{18}$ & 859 & 100 & 118.172 & 100 & 18.789 .637 & 100 \\
\hline & $\begin{array}{l}\text { Mesorregião do sudeste } \\
\text { paraense }\end{array}$ & 413 & 48,07 & 61.507 & 52,04 & 12.537 .495 & 66,72 \\
\hline $1^{\mathrm{o}}$ & $\begin{array}{c}\text { Microrregião de Marabá } \\
\text { (Brejo Grande do } \\
\text { Araguaia, Marabá, } \\
\text { Palestina do Pará, São } \\
\text { Domingos do Araguaia e } \\
\text { São João do Araguaia) } \\
\end{array}$ & 88 & 10,24 & 10.337 & 8,75 & 2.140 .840 & 11,39 \\
\hline $2^{o}$ & $\begin{array}{c}\text { Microrregião de Tucuruí } \\
\text { (Breu Branco, Itupiranga, } \\
\text { Jacundá, Nova Ipixuna, } \\
\text { Novo Repartimento e } \\
\text { Tucuruí) }\end{array}$ & 71 & 8,27 & 11.561 & 9,78 & 211.058 & 1,12 \\
\hline $3^{\circ}$ & \begin{tabular}{|c|} 
Microrregião de \\
Parauapebas (Água Azul \\
do Norte, Canaã dos \\
Carajás, Curionópolis, \\
Eldorado dos Carajás e \\
Parauapebas) \\
\end{tabular} & 66 & 7,68 & 12.083 & 10,22 & 4.457.016 & 23,72 \\
\hline
\end{tabular}

\footnotetext{
${ }^{18}$ Não foram identificados os municípios de ocorrência de sete dos registros de áreas em conflitos.
} 


\begin{tabular}{|c|c|c|c|c|c|c|c|}
\hline \multirow{2}{*}{$\mathbf{N}^{\mathbf{o}}$} & \multirow{2}{*}{$\begin{array}{c}\text { UF/ mesorregião/ } \\
\text { microrregião/ município }\end{array}$} & \multicolumn{2}{|c|}{ Áreas em conflito } & \multicolumn{2}{|c|}{ Famílias } & \multicolumn{2}{|c|}{ Área (ha) } \\
\hline & & Abs. & $\%$ & Abs. & $\%$ & Abs. & $\%$ \\
\hline $4^{\circ}$ & $\begin{array}{c}\text { Microrregião do Araguaia } \\
\text { (Conceição do Araguaia, } \\
\text { Floresta do Araguaia, } \\
\text { Santana do Araguaia e } \\
\text { Santa Maria das } \\
\text { Barreiras) }\end{array}$ & 63 & 7,33 & 8.255 & 6,99 & 727.638 & 3,87 \\
\hline $5^{\circ}$ & $\begin{array}{c}\text { Microrregião de } \\
\text { Paragominas (Abel } \\
\text { Figueiredo, Bom Jesus do } \\
\text { Tocantins, Dom Eliseu, } \\
\text { Goianésia do Pará, } \\
\text { Paragominas, Rondon do } \\
\text { Pará e Ulianópolis) }\end{array}$ & 53 & 6,17 & 6.696 & 5,67 & 94.805 & 0,50 \\
\hline $6^{\circ}$ & $\begin{array}{c}\text { Microrregião de São Félix } \\
\text { do Xingu (Bannach, } \\
\text { Cumaru do Norte, } \\
\text { Ourilândia do Norte, São } \\
\text { Félix do Xingu e Tucumã) }\end{array}$ & 47 & 5,47 & 9.374 & 7,93 & 4.718 .894 & 25,11 \\
\hline $7^{\circ}$ & $\begin{array}{c}\text { Microrregião de } \\
\text { Redenção (Pau D'Arco, } \\
\text { Piçarra, Redenção, Rio } \\
\text { Maria, Sapucaia, São } \\
\text { Geraldo do Araguaia e } \\
\text { Xinguara) } \\
\end{array}$ & 25 & 2,91 & 3.201 & 2,71 & 187.244 & 1,00 \\
\hline
\end{tabular}

Fonte: CPT, 2006-2015. Organização: Rogério Rego Miranda.

A tabela acima identifica que, entre os anos de 2006 e 2015, o Pará apresentou 859 áreas em conflito, envolvendo 118.172 famílias, que ocupam uma área de 18.789.637 hectares. Quase a metade desse número de conflitos está localizada no sudeste paraense, onde se concentram 413 casos de conflitos (48,07 \% de todo o estado do Pará), envolvendo 61.507 famílias (52,04\%) e ocupando uma área de 12.537 .495 hectares $(66,72 \%)$. Em ordem decrescente, a quantidade de conflitos por microrregião ao longo dos anos no sudeste paraense são: Marabá com 88 áreas em conflito (10,24\%), envolvendo 10.337 famílias $(8,75 \%)$ e ocupando 2.140 .840 hectares (11,39\%); Tucuruí com 71 áreas em conflito $(8,27 \%)$, envolvendo 11.561 famílias $(9,78 \%)$ e ocupando 211.058 hectares (1,12\%); Parauapebas com 66 áreas em conflito (7,68\%), envolvendo 12.083famílias (10,22\%) e ocupando 4.457.016 hectares (23,72\%); Araguaia com 63 áreas em conflito (7,33\%), envolvendo 8.255 famílias $(6,99 \%)$ e ocupando 727.638 hectares (3,87\%); Paragominas com 53 áreas em conflito $(6,17 \%)$, envolvendo 6.696 famílias $(5,67 \%)$ e ocupando 94.805 hectares $(0,50 \%)$; São Felix do Xingu com 47 áreas em conflito (5,47\%), envolvendo 9.374 famílias (7,93\%) e ocupando 
4.718.894 hectares (25,11\%); e Redenção com 25 áreas em conflito (2,91\%), envolvendo 3.201famílias $(2,71 \%)$ e ocupando 187.244 hectares $(1,00 \%)$.

Ao espacializarmos essas áreas em conflito no sudeste paraense observamos, no Mapa 6, que os municípios com maior ocorrência são Marabá, com 58 conflitos; São Félix do Xingu, com 30; Itupiranga e Santana do Araguaia, ambos com 29 conflitos; Eldorado dos Carajás, com 25, Conceição do Araguaia, com 20; e Breu Branco, com 18; os demais municípios oscilam entre 1 e 15 áreas em conflito entre os anos de 2006 e 2015.

Esses conflitos são resultados diretos de tensões existentes entre movimentos sociais ou famílias/pessoas que sofrem pressão para sair de seus territórios e a elite existente no campo do sudeste paraense, instaurando-se uma disputa por hegemonia desigual, multiescalar e dimensional, que mobiliza diversas redes. Nesse sentido, analisaremos as formas de resistência e a construção de uma contra-hegemonia no âmbito territorial por parte do MST no sudeste paraense. 
Mapa 6 - Áreas em conflito no sudeste paraense, 2006 - 2015.

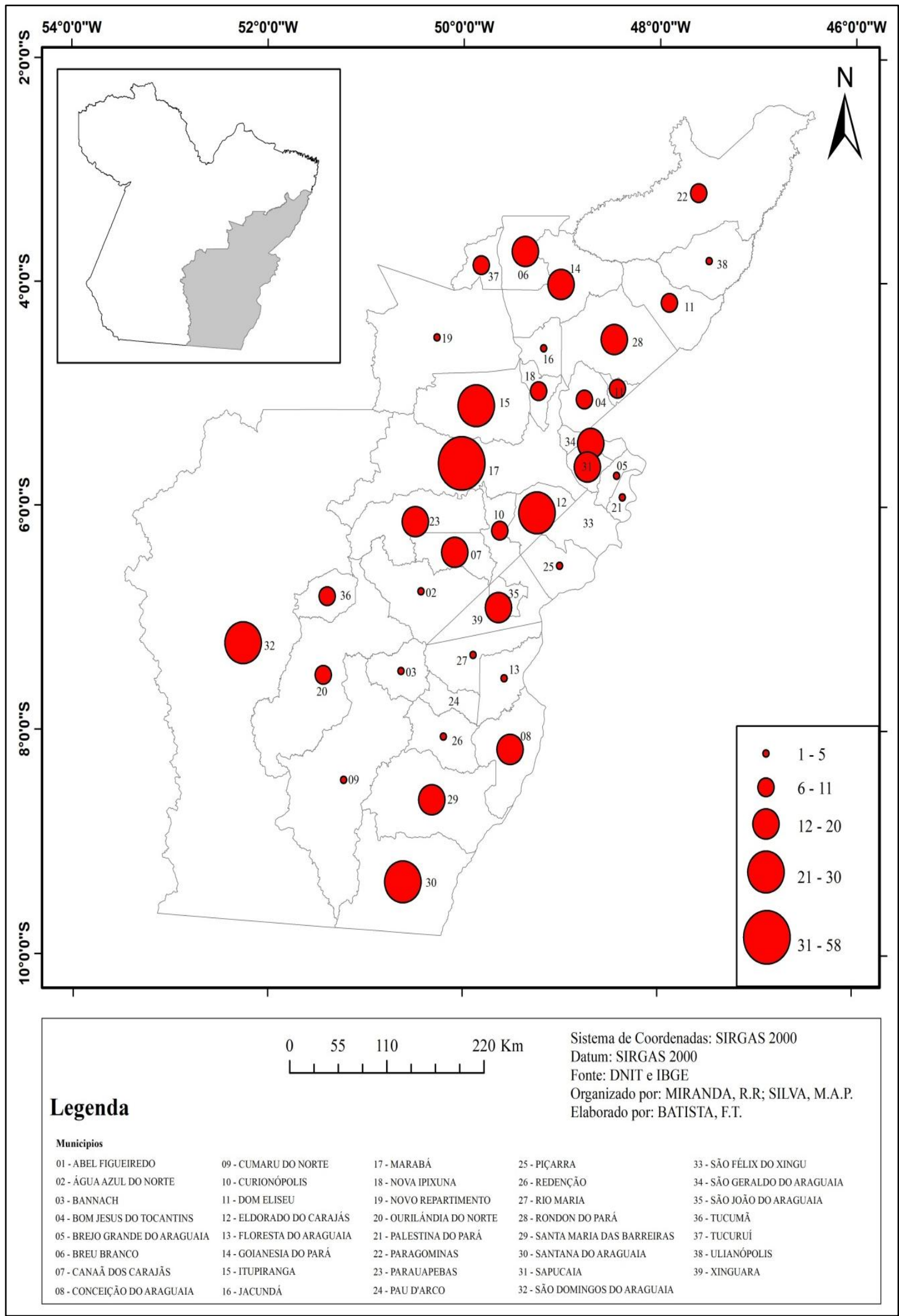

Fonte: CPT, 2002-2015; Rede Dataluta, 2016. Organização: Rogério Rego Miranda. 
3.2. FORMAS DE ORGANIZAÇÃo DO MST E CONSTRUÇÃO DE UM TERRITÓRIO CONTRAHEGEMÔNICO

O MST enquanto movimento socioterritorial organiza suas lutas no/por território utilizando estratégias bem interessantes na espacialização destas lutas, com destaque as ocupações de terras e acampamentos, os quais podem vir a resultar em assentamentos. Estas formas serão mais bem trabalhadas a seguir.

\subsubsection{Ocupações de terras}

Os movimentos sociais, dentre eles o MST, realizam as chamadas ocupações, que correspondem a "ações coletivas das famílias sem terra que, por meio da entrada em imóveis rurais, reivindicam terras que não cumprem a função social” (CPT, 2009, p. 11).

Geograficamente, para Fernandes (2001), as ocupações de terra compreendem uma das formas de os sem-terra espacializarem sua luta, constituindo igualmente um mecanismo de reprodução do campesinato, face ao processo desterritorizador empreendido pelo capital, embora ao conquistarem a terra os trabalhadores reinsiram-se "na produção capitalista de relações não-capitalistas de produção" (MARTINS, 2010) de maneira subordinada, visto que, para Martins, "o próprio capital engendra e reproduz relações não-capitalistas de produção, numa coexistência de tempos sociais de datas entre si diversas" [2010, p. 22]. É por esse motivo que:

A produção capitalista de relações não-capitalistas de produção expressa não
apenas uma forma de reprodução ampliada do capital, mas também a
reprodução ampliada das contradições do capitalismo - o movimento
contraditório não só de subordinação de relações pré-capitalistas, mas
também de criação de relações antagônicas e subordinadas não-capitalistas.
Neste caso, o capitalismo cria a um só tempo as condições da sua expansão,
pela incorporação de áreas e populações às relações comerciais, e os
empecilhos a sua expansão, pela não mercantilização de todos os fatores
envolvidos, ausente o trabalho caracteristicamente assalariado. (MARTINS,
2010, p. 21)

Com efeito, a ocupação da terra advém de uma inovação dos sem-terra no seu processo de ressocialização. É resultante de um conhecimento construído ao longo das lutas populares empreendidas contra o poder hegemônico do capital e se desenvolve nos processos de espacialização e territorialização mediante a produção de experiências de resistência dos sem-terra (FERNANDES, 2001). 
Sua realização é decorrente da necessidade de sobrevivência frente ao processo de exclusão promovido pala territorialização do capital, pelo qual o capitalismo avança em todo o espaço brasileiro, introduzindo relações capitalistas, expropriando o trabalhador de sua terra e/ou assalariando-o. Contraditoriamente, o capital igualmente desenvolve a reprodução de relações não-capitalistas, como o campesinato, promovendo uma relação desigual entre os camponeses e as empresas, devido à subordinação da produção camponesa pelo capital, o qual sujeita a renda da terra camponesa, processo denominado de monopolização do território. (OLIVEIRA, 2002)

Com relação às ocupações, Fernandes (2001) propõe alguns "tipos" tomando como referência a terra, as formas de organização das famílias e os tipos de experiências que produzem, com objetivo de melhor compreender os processos de espacialização e territorialização da luta. No que tange à organização dos grupos de famílias, apresenta duas modalidades de movimentos: isolados e territorializados. Estes são construídos por trabalhadores estruturados em sindicatos ou movimentos sociais, recebendo apoio políticoeconômico de distintas instituições de maneira conjunta ou separada, estabelecendo articulações ou alianças. Os movimentos isolados e os movimentos territorializados têm como referência a organização social e o espaço geográfico. No primeiro movimento se observa uma organização territorial circunscrita por circunstâncias próprias aos movimentos, atuando em lugares diferentes do espaço a partir de lutas de resistência frente ao latifúndio, construindo, dessa maneira, sua territorialidade. O movimento social territorializado, por sua vez, se organiza pela atuação simultânea em diferentes pontos do território, o que possibilita espacializar a luta pela terra e conquistar novas frações territoriais, sendo que um determinado movimento isolado pode vir a se tornar um movimento territorializado em decorrência do grau e da natureza de organização que assume no território, compreendendo a lógica da sociedade capitalista, suas contradições e desigualdades, propondo uma nova visão de mundo. (FERNANDES, 2001)

As ocupações podem ser compreendidas por meios de três tipos de experiências: espontâneas e isoladas, organizadas e isoladas, organizadas e espacializadas. As ocupações do primeiro tipo, espontâneas e isoladas, são organizadas por grupos diminutos com ações singulares de sobrevivência que, e ao ocuparem uma dada área, pela necessidade de sobrevivência, passam a constituir um movimento social, cujo caráter é espontâneo devido a possuírem uma preocupação prévia ao processo de formação de uma organização social, que ocorre ou não na ocupação, podendo formar um movimento social isolado. As do segundo tipo, organizadas e isoladas, podem ocorrer por pequenos grupos ou uma massa maior de 
famílias, que constroem, mediante trabalho de base e reuniões, o movimento antes da ocupação, que se pode findar ou consolidar após a conquista da terra. No último caso, organizadas e especializadas, as ocupações são geralmente desenvolvidas por movimentos territorializados e que resultam de um conhecimento adquirido de experiências advindas de vários outros lugares. Compõem um projeto político mais amplo e com uma agenda de lutas maior, transformando suas realidades (FERNANDES, 2001).

Por fim, a partir das práticas de lutas é possível distinguir dois tipos de ocupação: a ocupação de uma área determinada e a ocupação massiva. A diferença está no fato de que, para o primeiro tipo, a dimensão da área é um dos critérios de organização das famílias e de mobilização de grupos menores ou maiores, logo o objetivo é conquistar apenas aquela área ocupada e, no caso de não serem assentadas todas as famílias, se procede uma nova ocupação. No segundo tipo, a mobilização e a organização tem como critério central a necessidade de assentar a totalidade das famílias, desenvolvendo ocupações nas áreas que atendam a este fim, ou seja, ocupam diversas áreas caso seja necessário, podendo uma ocupação transformar-se em vários assentamentos. A ocupação se torna um instrumento de luta constante porque, ao passo que as famílias conseguem ser assentadas, várias outras se aglutinam em torno da luta (FERNANDES, 2001).

Essas diferentes modalidades de ocupação não se referem a "tipos ideais", mas a construtos analíticos advindos da práxis dos movimentos sociais e do movimento histórico e geográfico da realidade brasileira - elementos que nos ajudam a compreender melhor a atuação do MST em suas ações de luta pela terra, dentre elas a ocupação. Nesse caso, entendemos aquele como um movimento territorializado, mas em pleno processo de territorialização, por não ter ações fragmentadas e momentâneas; ao contrário, desenvolve ocupações organizadas e espacializadas, a partir de articulações/alianças com vários segmentos de luta social - no caso da realidade do sudeste paraense, a CPT, FETAGRI, FETRAF - seja em nível regional ou mesmo nacional, criando uma rede geográfica de luta pela terra que se materializa nessas alianças, mas igualmente nas ações, muitas vezes, simultâneas em diversos lugares, contribuindo para que os sem-terra "saltem escalas", isto é, não sejam passivos diante da reclusão ou territorialização precária que o capital lhes impõe, desenvolvendo uma política de escalas, objetivando participar do controle territorial da rede em diversos níveis escalares, entretanto a partir de novos horizontes interpretativos e de outros projetos territoriais, lutando pela construção de uma contra-hegemonia.

Nesse sentido, a partir de dados da CPT (2015) e da Rede Dataluta (2016), observouse que no Pará houve 569 ocupações registradas entre os anos de 1988 e 2015, com 
aproximadamente 85.638 famílias envolvidas. Desse total o sudeste paraense apresentou 443 ocupações computadas $(77,85 \%)$, com 61.628 famílias (71,96\%), e as microrregiões que apresentam o maior número de ocupações são respectivamente: a de Marabá com 133 (23,37\%), de Parauapebas com 78 (13,7\%), de Araguaia com 63 (11,07\%), de Redenção com 54 (9,49\%), de Tucuruí com 45 (7,9\%), de Paragominas com 40 (7,02\%) e São Felix do Xingu com 30 (5,27\%) (ver Tabela 3).

Tabela 3 - Número de ocupações no estado do Pará, sudeste paraense e suas microrregiões 1988 a 2015

\begin{tabular}{|c|c|c|c|c|c|}
\hline \multirow{2}{*}{$\mathbf{N}^{\mathbf{o}}$} & \multirow{2}{*}{$\begin{array}{c}\text { UF/ mesorregião / microrregião / } \\
\text { municipal }\end{array}$} & \multicolumn{2}{|c|}{ Ocupações } & \multicolumn{2}{|c|}{ Famílias } \\
\hline & & Abs. & $\%$ & Abs. & $\%$ \\
\hline & Pará & 569 & 100 & 85.638 & 100 \\
\hline & Mesorregião do sudeste paraense & 443 & 77,85 & 61.628 & 71,96 \\
\hline $1^{\mathrm{o}}$ & $\begin{array}{c}\text { Microrregião de Marabá } \\
\text { (Brejo Grande do Araguaia, Marabá, } \\
\text { Palestina do Pará, São Domingos do } \\
\text { Araguaia e São João do Araguaia) }\end{array}$ & 133 & 23,37 & 15.505 & 18,1 \\
\hline $2^{\circ}$ & $\begin{array}{c}\text { Microrregião de Parauapebas } \\
\text { (Água Azul do Norte, Canaã dos Carajás, } \\
\text { Curionópolis, Eldorado dos Carajás e } \\
\text { Parauapebas) }\end{array}$ & 78 & 13,7 & 16.382 & 19,12 \\
\hline $3^{\circ}$ & $\begin{array}{c}\text { Microrregião do Araguaia } \\
\text { (Conceiçãao do Araguaia, Floresta do } \\
\text { Araguai, Santana do Araguaia e Santa } \\
\text { Maria das Barreiras) }\end{array}$ & 63 & 11,07 & 6.690 & 7,81 \\
\hline $4^{\circ}$ & $\begin{array}{c}\text { Microrregião de Redenção } \\
\text { (Pau D'Arco, Piçarra, Redenção, Rio } \\
\text { Maria, Sapucaia, São Geraldo do Araguaia } \\
\text { e Xinguara) }\end{array}$ & 54 & 9,49 & 5.257 & 6,13 \\
\hline $5^{\circ}$ & $\begin{array}{c}\text { Microrregião de Tucuruí } \\
\text { (Breu Branco, Itupiranga, Jacundá, Nova } \\
\text { Ipixuna, Novo Repartimento e Tucuruí) }\end{array}$ & 45 & 7,9 & 9.317 & 10,87 \\
\hline $6^{\circ}$ & $\begin{array}{c}\text { Microrregião de Paragominas } \\
\text { (Abel Figueiredo, Bom Jesus do } \\
\text { Tocantins, Dom Eliseu, Goianésia do } \\
\text { Pará, Paragominas, Rondon do Pará e } \\
\text { Ulianópolis) }\end{array}$ & 40 & 7,02 & 4.555 & 5,31 \\
\hline $7^{\circ}$ & $\begin{array}{l}\text { Microrregião de São Félix do Xingu } \\
\text { (Bannach, Cumaru do Norte, Ourilândia } \\
\text { do Norte, São Félix do Xingu e Tucumã) }\end{array}$ & 30 & 5,27 & 3.922 & 4,57 \\
\hline
\end{tabular}

Fonte: CPT, 1988-2015; Rede Dataluta, 2016. Organização: Rogério Rego Miranda

Dessas ocupações, a FETAGRI foi responsável pela organização de 139; o MST, por sua vez, realizou 61 ocupações; a FETRAF conduziu 40 ocupações; outros movimentos sociais organizaram 15 ocupações e a CPT, 1 ocupação. É importante destacar que algumas dessas formas de resistência ocorreram conjuntamente, tais como entre MST e FETAGRI (2 
ocupações), MST e FETRAF (2 ocupações), MST e MLST (1 ocupação) e FETAGRI e CPT (1 ocupação), conforme identificado na Tabela 4.

Os anos de maior incidência dessas ocupações foram 1999, início do segundo mandato presidencial de Fernando Henrique Cardoso (FHC), e entre 2005 e 2009, período do governo de Luiz Inácio Lula da Silva (ver Gráfico 1). 
Tabela 4 - Movimentos sociais e sindicais envolvidos na organização das ocupações de terra no sudeste paraense - 1989 a 2015

\begin{tabular}{|c|c|c|c|c|c|c|c|c|c|c|c|c|c|c|c|c|c|c|c|c|c|c|c|c|c|c|c|}
\hline $\begin{array}{c}\text { Movimento } \\
\text { social/ } \\
\text { sindical } \\
\end{array}$ & 1989 & 1990 & 1991 & 1992 & 1993 & 1994 & 1995 & 1996 & 1997 & 1998 & 1999 & 2000 & 2001 & 2002 & 2003 & 2004 & 2005 & 2006 & 2007 & 2008 & 2009 & 2010 & 2011 & 2012 & 2013 & 2014 & 2015 \\
\hline $\begin{array}{c}\text { Não } \\
\text { identificado }^{19}\end{array}$ & 4 & 6 & 8 & 4 & 5 & 9 & 7 & 29 & 17 & 9 & 34 & 6 & 4 & 13 & 1 & - & 3 & 3 & 6 & 2 & 7 & 2 & 1 & 1 & 1 & 1 & - \\
\hline MST & - & - & - & - & - & - & - & 1 & 1 & 6 & 6 & 8 & 8 & - & 4 & 1 & 1 & 4 & 4 & 7 & 4 & - & 3 & - & 1 & 2 & - \\
\hline $\begin{array}{c}\text { CONTAG } \\
\text { (FETAGRI- } \\
\text { PA/STR) } \\
\end{array}$ & - & - & - & - & - & - & - & - & - & 1 & 1 & 4 & 9 & 1 & 4 & 15 & 40 & 23 & 3 & 14 & 4 & 3 & 1 & 4 & 5 & 1 & 6 \\
\hline FETRAF & - & - & - & - & - & - & - & - & - & - & - & - & - & - & - & - & - & 2 & 7 & 2 & 27 & 1 & 1 & - & - & - & - \\
\hline $\mathrm{CPT}$ & - & - & - & - & - & - & - & - & - & - & - & - & - & - & - & 1 & - & - & - & - & - & - & - & - & - & - & - \\
\hline $\begin{array}{c}\text { MST/ } \\
\text { FETAGRI }\end{array}$ & - & - & - & - & - & - & - & - & - & - & - & - & - & - & - & - & - & 2 & - & - & - & - & - & - & - & - & - \\
\hline $\begin{array}{c}\text { MST/ } \\
\text { FETRAF }\end{array}$ & - & - & - & - & - & - & - & - & - & - & - & - & - & - & - & - & - & - & - & 1 & 1 & - & - & - & - & - & - \\
\hline MST/MLST & - & - & - & - & - & - & - & - & - & 1 & - & - & - & - & - & - & - & - & - & - & - & - & - & - & - & - & - \\
\hline $\begin{array}{c}\text { CONTAG/ } \\
\text { CPT }\end{array}$ & - & - & - & - & - & - & - & - & - & - & - & 1 & - & - & - & - & - & - & - & - & - & - & - & - & - & - & - \\
\hline $\begin{array}{c}\text { Outros } \\
\text { movimentos } \\
\text { sociais } \\
\text { isolados }^{20} \\
\end{array}$ & - & - & - & - & - & - & - & - & - & - & - & - & - & - & 1 & 2 & - & 1 & 2 & 2 & 3 & - & 2 & 1 & - & 1 & - \\
\hline Total & 4 & 6 & 8 & 4 & 5 & 9 & 7 & 30 & 18 & 17 & 41 & 19 & 21 & 14 & 10 & 19 & 44 & 35 & 22 & 28 & 46 & 6 & 8 & 6 & 7 & 5 & 6 \\
\hline
\end{tabular}

Fonte: CPT, 1989-2015; Rede Dataluta, 2015. Organização: Rogério Rego Miranda.

\footnotetext{
${ }^{19}$ Não Informado.

${ }^{20}$ Sindicato dos Pequenos e Médios Produtores Rurais Assentados (SINPRA), OTC, LCP, Associação de Sem Terra (AST), ATR, OI, Associação de Pequenos Agricultores de Marabá (ASPARMAB).
} 
Gráfico 1 - Ocupações de terra no sudeste paraense, 1988 a 2015.

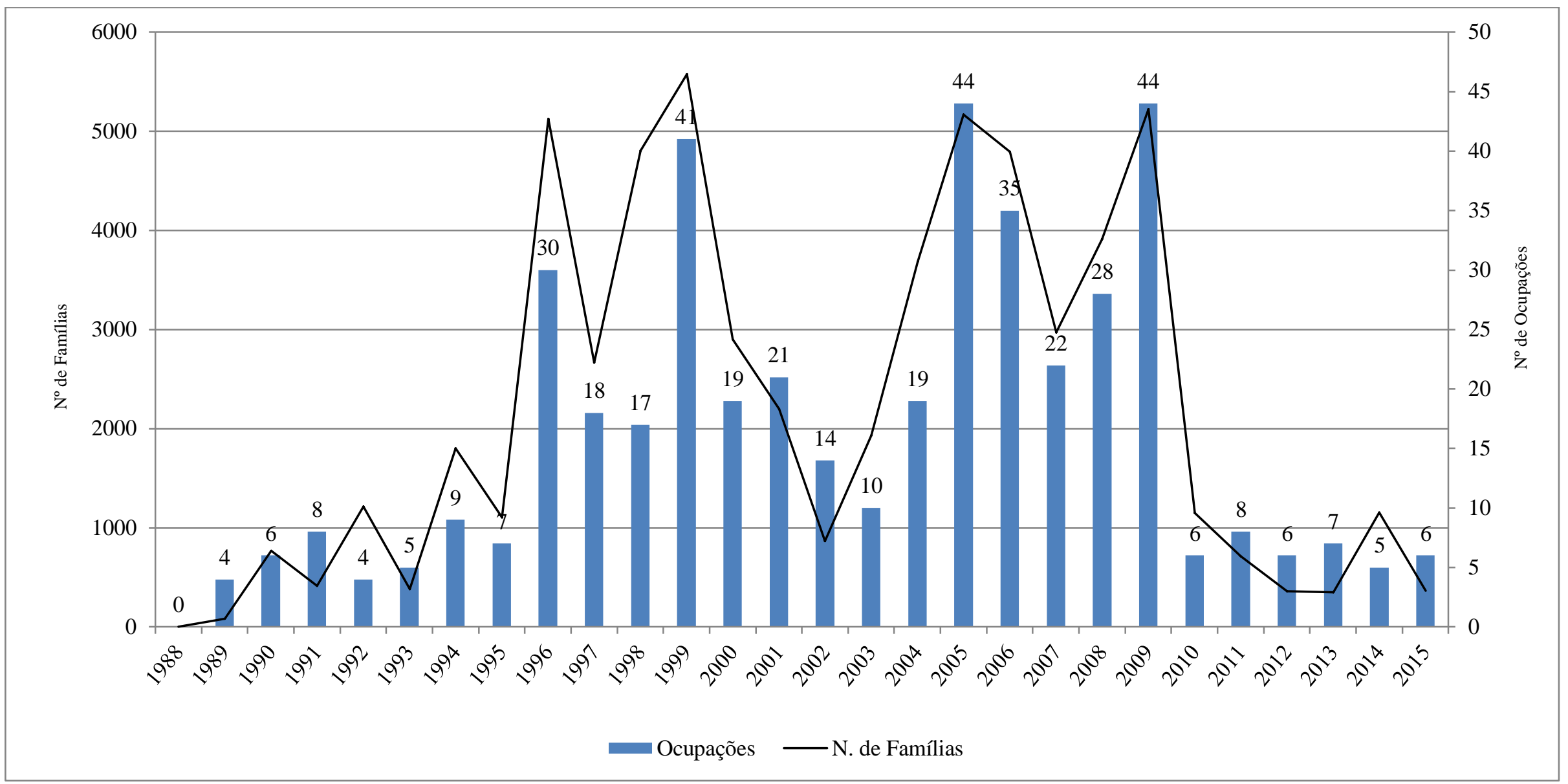

Fonte: CPT, 1988-2015; Rede Dataluta, 2016. Organização: Rogério Rego Miranda. 
O Mapa 7 a seguir localiza os principais municípios onde há maior ocorrência de ocupações de terra entre 1988 e 2015. Observamos que Marabá desponta com 97 ocupações; seguido de Parauapebas, com 29 ocupações; Conceição do Araguaia com 28 ocupações e Eldorado dos Carajás com 23 ocupações. São João do Araguaia, Rondon do Pará, Itupiranga, Rio Maria, Curionópolis, Xinguara, Breu Branco, Tucuruí, são Félix do Xingu e Redenção oscilam entre 10 e 19 ocupações; e, por fim, os demais municípios variam entre 1 e 9 ocupações.

Em relação ao MST, essas ocupações são antecedidas por duas ações: a primeira corresponde ao cadastro de pessoas em periferias urbanas e áreas rurais dos municípios próximos à futura ocupação; a segunda compreende o trabalho de base, no qual são realizadas reuniões para discutir o sentido da luta pela terra e o processo de apropriação, muitas vezes ilegal, por parte de fazendeiros e empresas mineradoras na região. Geralmente são reuniões articuladas por lideranças locais que já residem em assentamentos, fazem parte de acampamentos ou ainda advém de outras realidades como o Maranhão e o Tocantins, onde a ação do capital é igualmente incisiva através do cultivo de soja e eucalipto e da mineração. 
Mapa 7 - Ocupações de terra no sudeste paraense, 1988 a 2015.

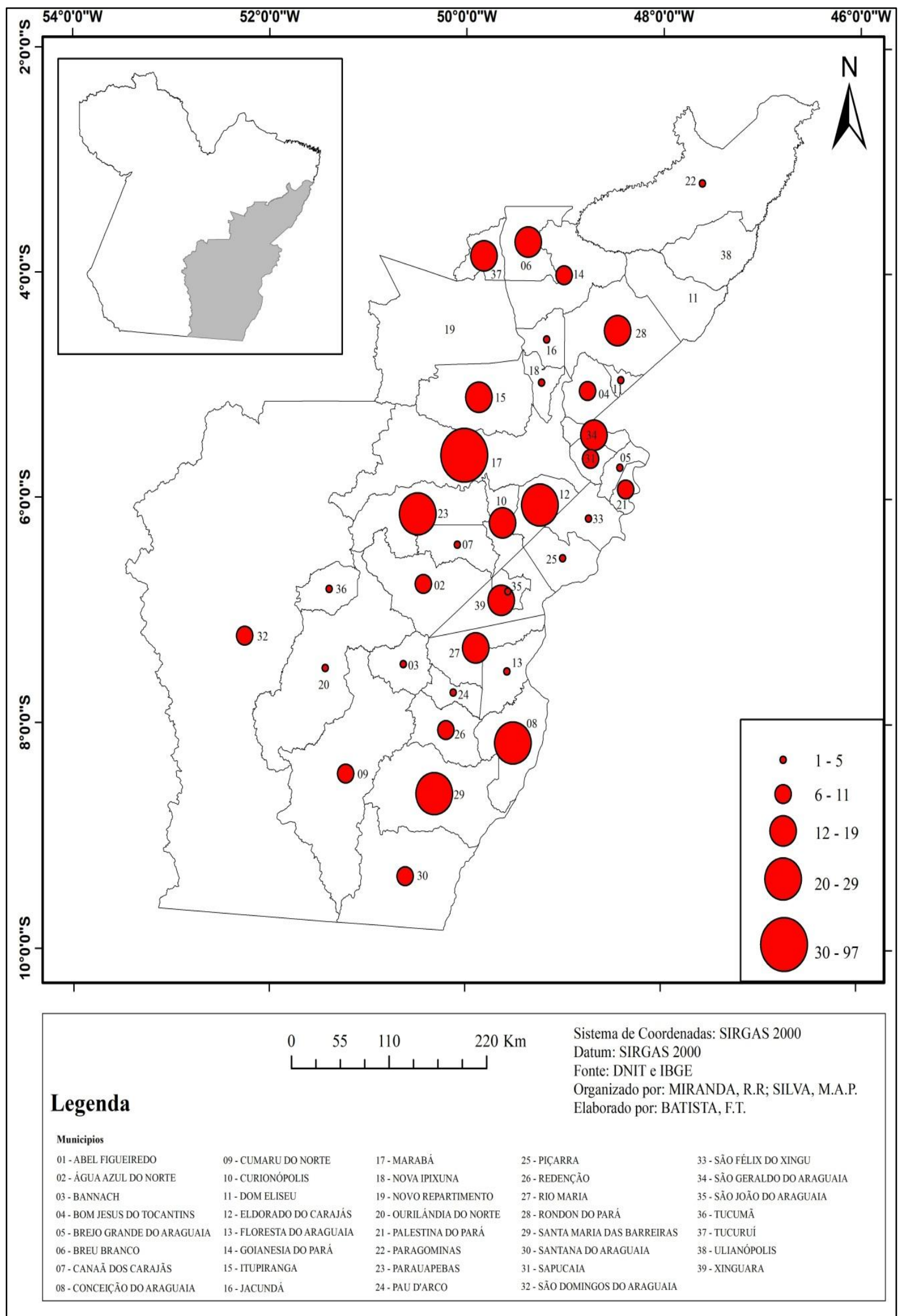

Fonte: CPT, 2002-2015; Rede Dataluta, 2016. Organização: Rogério Rego Miranda. 


\subsubsection{Acampamentos}

Outra estratégia desenvolvida são os acampamentos que, segundo a CPT, são “espaços de luta e formação, fruto de ações coletivas, localizados no campo ou na cidade, onde as famílias sem terra organizadas reivindicam assentamentos" (2009, p. 11).

Compreende uma ação posterior e complementar à ocupação, materializada como uma resistência a longo prazo contra a violência dos fazendeiros e os seus "guachebas" (denominação local dada pelos acampados aos grupos armados contratados pelos autoproclamados proprietários da terra), do Estado via ações de reintegração de posse e uso da força policial, e dos meios de comunicação que os intitulam "invasores", "criminosos" e "anarquistas" devido às interrupções do fluxo dos carros e transeuntes quando realizam marchas, passeatas ou manifestações para reivindicar celeridade da justiça quanto à reforma agrária.

Segundo Sigaud (2005), a ocupação de terras para a construção de acampamentos se tornou, a partir da década de 1980, uma forma propícia para reivindicar a reforma agrária no país, já que o Estado em certa medida legitima a intenção dos movimentos ao desapropriar áreas de fazendas ocupadas para posterior redistribuição das terras entre os acampados. Isso se confirma quando, na ausência ou ineficiência de uma política agrária para desenvolver as desapropriações, o governo, em certa medida, depende dos movimentos para indicar as áreas que devem ser objeto de sua intervenção, visto que as propriedades desapropriadas são aquelas ocupadas ou em que já existam acampamentos (definidas pelo INCRA como áreas em conflito) ${ }^{21}$. O Estado igualmente depende dos movimentos para a seleção dos destinatários da redistribuição das terras desapropriadas, indicados entre os que participaram da ocupação e/ou do acampamento e que foram reunidos pelo movimento, que, por sua vez, cria a possibilidade de acesso à terra.

Segundo Turatti (1999), os acampamentos correspondem a um novo processo de construção de sociabilidade, intermediando a condição de sem-terra e a produção de um espaço coletivo que é engendrado por solidariedade e conflito, até o momento em que possam

\footnotetext{
${ }^{21}$ É interessante perceber como o próprio INCRA reconhece a importância dos movimentos sociais no processo de reforma agrária, tal qual indica no seu site <http://www.incra.gov.br/Aquisicao_de_terras >, Acesso em: 13 maio 2016: "A aquisição de terras para a reforma agrária pode ser feita de diversas maneiras. A mais utilizada e conhecida é a desapropriação, seguida do processo de compra e venda. Nestes dois casos, imóveis de particulares são incorporados à reforma agrária. Toda aquisição começa com pesquisas cartoriais e locais feitas pelo Incra, bem como a partir de indicações - apresentadas pelos movimentos sociais - de fazendas que seriam passíveis de desapropriação" (INCRA, 2016, grifado no original).
} 
ser assentados. Para a autora, os acampamentos são visualizados como um território provisório e indefinido, com atividades produtivas escassas, circunscritas à manutenção dos acampados e serviços ocasionais de assalariamento para terceiros, cuja sociabilidade é mediada pela prevalência das garantias individuais e uma forte dependência em relação ao MST em termos de sobrevivência material e da obtenção das terras. Em suma, o acampamento é um momento intersticial de uma multiplicidade de processos. Para o MST, configura um espaço de concretização de uma ação rebelde, que se estabelece em uma terra com sujeitos que acreditam na luta devido à negação constante de seus direitos e condições dignas de vida, servindo como instrumento de pressão ao mesmo tempo que se transformam em um grupo social de ações coletivas, compartilhando valores e relações de solidariedade, ressignificando-se como sem-terra, desenvolvendo a árdua tarefa de se colocar contra o poder estabelecido e criando expectativas da conquista da terra.

O acampamento cria uma experiência espacial comunitária como uma estratégia política no seio do MST, elemento exposto por Scherer-Warren (1993, p. 55):

A afirmação de novas relações societárias dá-se através da reapropriação política do sentido das relações comunitárias. Estes movimentos creem no poder da força comunitária para a constituição histórica do grupo. É neste sentido que o Movimento dos Sem Terra criou uma nova forma de fazer política e de vida societária: os acampamentos coletivos. Enfatiza-se, neste caso, a importância das relações comunitárias como forma de luta e como modo de vida. (1993, p. 55)

Para Fernandes (2001), o acampamento corresponde ao espaço de luta e resistência e igualmente espaço interativo e comunicativo, congregando as três dimensões do espaço de socialização política.

Em termos quantitativos e espaciais, observamos que no Pará, de um total de 103 acampamentos desencadeados entre os anos de 2002 e 2015, envolvendo 19.215 famílias, 83 localizaram-se no sudeste paraense (80,58 \%), compreendendo 14.455 famílias nessa situação. Ao visualizarmos esses acampamentos por microrregião, eles se dispõem na seguinte ordem: Marabá com 19 (18,44 \%) acampamentos; Parauapebas com 19 (18,44 \%) acampamentos; Tucuruí com 17 (16,50 \%) acampamentos; Paragominas com 11 (10,67\%) acampamentos; Araguaia com 9 (8,73\%) acampamentos; São Felix do Xingu com 5 (4,85 \%) acampamentos; e Redenção com 3 (2,91 \%) acampamentos (ver Tabela 5). 
Tabela 5 - Número de acampamentos no estado do Pará, sudeste paraense e suas microrregiões - 2002 a 2015

\begin{tabular}{|c|c|c|c|c|c|}
\hline $\mathbf{N}^{\mathbf{0}}$ & \multirow{2}{*}{ UF/mesorregião/microrregião } & \multicolumn{2}{|c|}{ Acampamentos } & \multicolumn{2}{|c|}{ Famílias } \\
\hline $\mathbf{N}$ & & Abs. & $\%$ & Abs. & $\%$ \\
\hline & Pará & 103 & 100 & 19.215 & 100 \\
\hline & Mesorregião do sudeste paraense & 83 & 80,58 & 14.455 & 75,22 \\
\hline $1^{\circ}$ & $\begin{array}{c}\text { Microrregião de Marabá } \\
\text { (Brejo Grande do Araguaia, Marabá, } \\
\text { Palestina do Pará, São Domingos do } \\
\text { Araguaia e São João do Araguaia) } \\
\end{array}$ & 19 & 18,44 & 2.449 & 12,74 \\
\hline $2^{\circ}$ & $\begin{array}{c}\text { Microrregião de Parauapebas } \\
\text { (Água Azul do Norte, Canaã dos Carajás, } \\
\text { Curionópolis, Eldorado dos Carajás e } \\
\text { Parauapebas) }\end{array}$ & 19 & 18,44 & 3.168 & 16,48 \\
\hline $3^{\circ}$ & $\begin{array}{c}\text { Microrregião de Tucuruí } \\
\text { (Breu Branco, Itupiranga, Jacundá, Nova } \\
\text { Ipixuna, Novo Repartimento e Tucuruí) }\end{array}$ & 17 & 16,50 & 4.269 & 22,21 \\
\hline $4^{\circ}$ & $\begin{array}{c}\text { Microrregião de Paragominas } \\
\text { (Abel Figueiredo, Bom Jesus do Tocantins, } \\
\text { Dom Eliseu, Goianésia do Pará, } \\
\text { Paragominas, Rondon do Pará e } \\
\text { Ulianópolis) }\end{array}$ & 11 & 10,67 & 1.043 & 5,42 \\
\hline $5^{\circ}$ & $\begin{array}{c}\text { Microrregião do Araguaia } \\
\text { (Conceição do Araguaia, Floresta do } \\
\text { Araguaia, Santana do Araguaia e Santa } \\
\text { Maria das Barreiras) }\end{array}$ & 9 & 8,73 & 1.645 & 8,56 \\
\hline $6^{\circ}$ & $\begin{array}{c}\text { Microrregião de São Félix do Xingu } \\
\text { (Bannach, Cumaru do Norte, Ourilândia do } \\
\text { Norte, São Félix do Xingu e Tucumã) }\end{array}$ & 5 & 4,85 & 1.181 & 6,14 \\
\hline $7^{\circ}$ & $\begin{array}{c}\text { Microrregião de Redenção } \\
\text { (Pau D'Arco, Piçarra, Redenção, Rio Maria, } \\
\text { Sapucaia, São Geraldo do Araguaia e } \\
\text { Xinguara) }\end{array}$ & 3 & 2,91 & 700 & 3,64 \\
\hline
\end{tabular}

Fonte: CPT,2002-2015. Organização: Rogério Rego Miranda

O Gráfico 2 abaixo identifica os acampamentos resultantes da luta pela terra no sudeste paraense entre os anos de 2002 - 2015, período em que observamos um aumento no número de acampamentos, especialmente no ano de 2003, início do governo do presidente Luiz Inácio Lula da Silva (2003 a 2011). Houve, porém, uma redução nos anos subsequentes, com destaque aos anos de 2004 a 2009, e uma posterior retomada desses acampamentos a partir de 2010, final do mandato de "Lula" e início do da presidência de Dilma Vana Rousseff, ambos do Partido dos Trabalhadores. Há novamente uma diminuição a partir de 2012 e um crescimento em 2015. 
Gráfico 2 - Acampamentos no sudeste paraense - 2002 a 2015

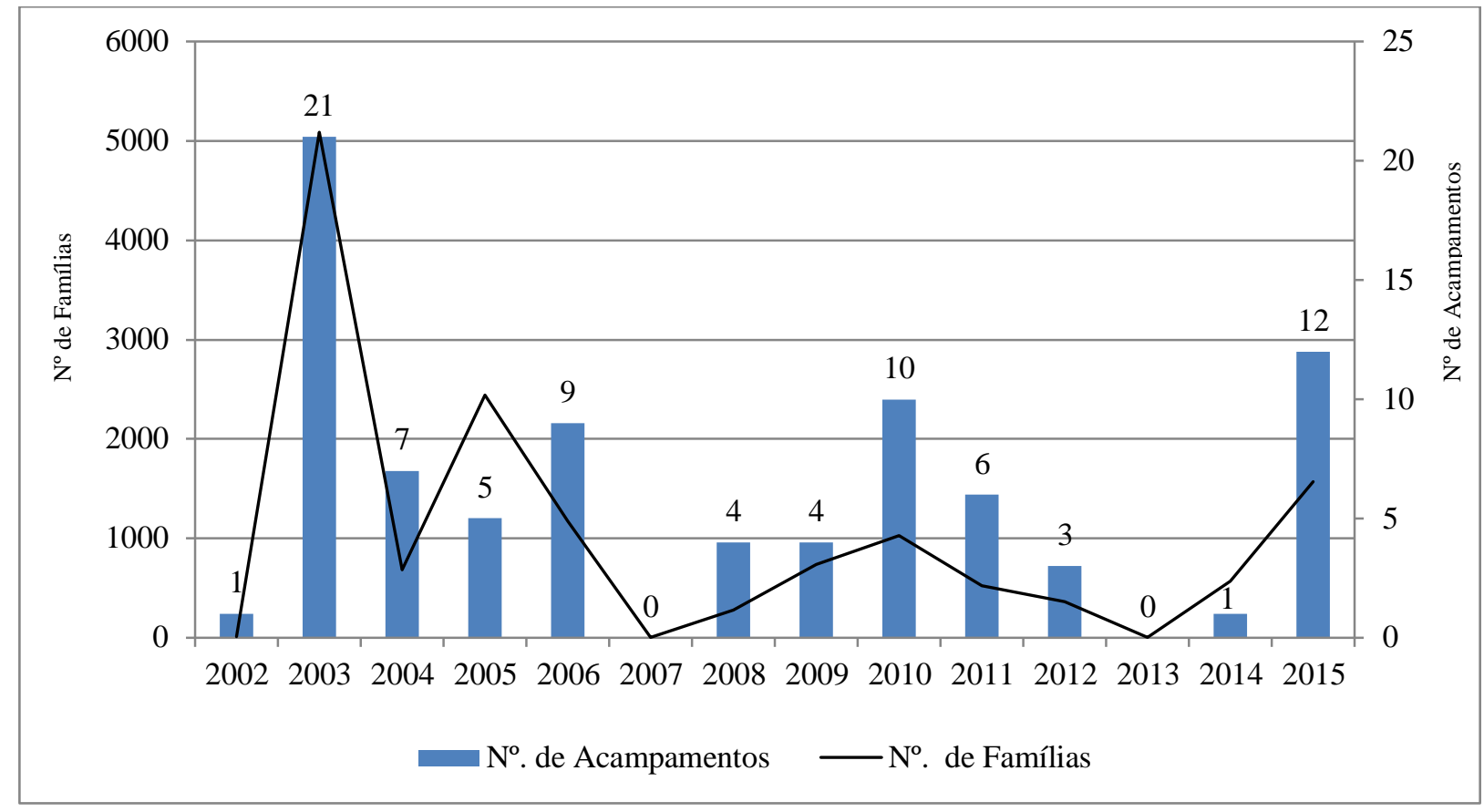

Fonte: CPT,2002-2015. Organização: Rogério Rego Miranda.

O Mapa 8 espacializa esses acampamentos ocorridos entre os anos de 2002 e 2015, identificando os municípios com maior incidência dessa forma de resistência, a saber: Marabá com 16 acampamentos; Canaã dos Carajás e Itupiranga com 7 acampamentos; Eldorado dos Carajás com 6 acampamentos; Tucuruí com 5 acampamentos; Santana do Araguaia com 4 acampamentos e os demais municípios do sudeste paraense oscilando entre 1 e 3 acampamentos. 
Mapa 8 - Acampamentos organizados por movimentos sociais e sindicais no sudeste paraense, 2015

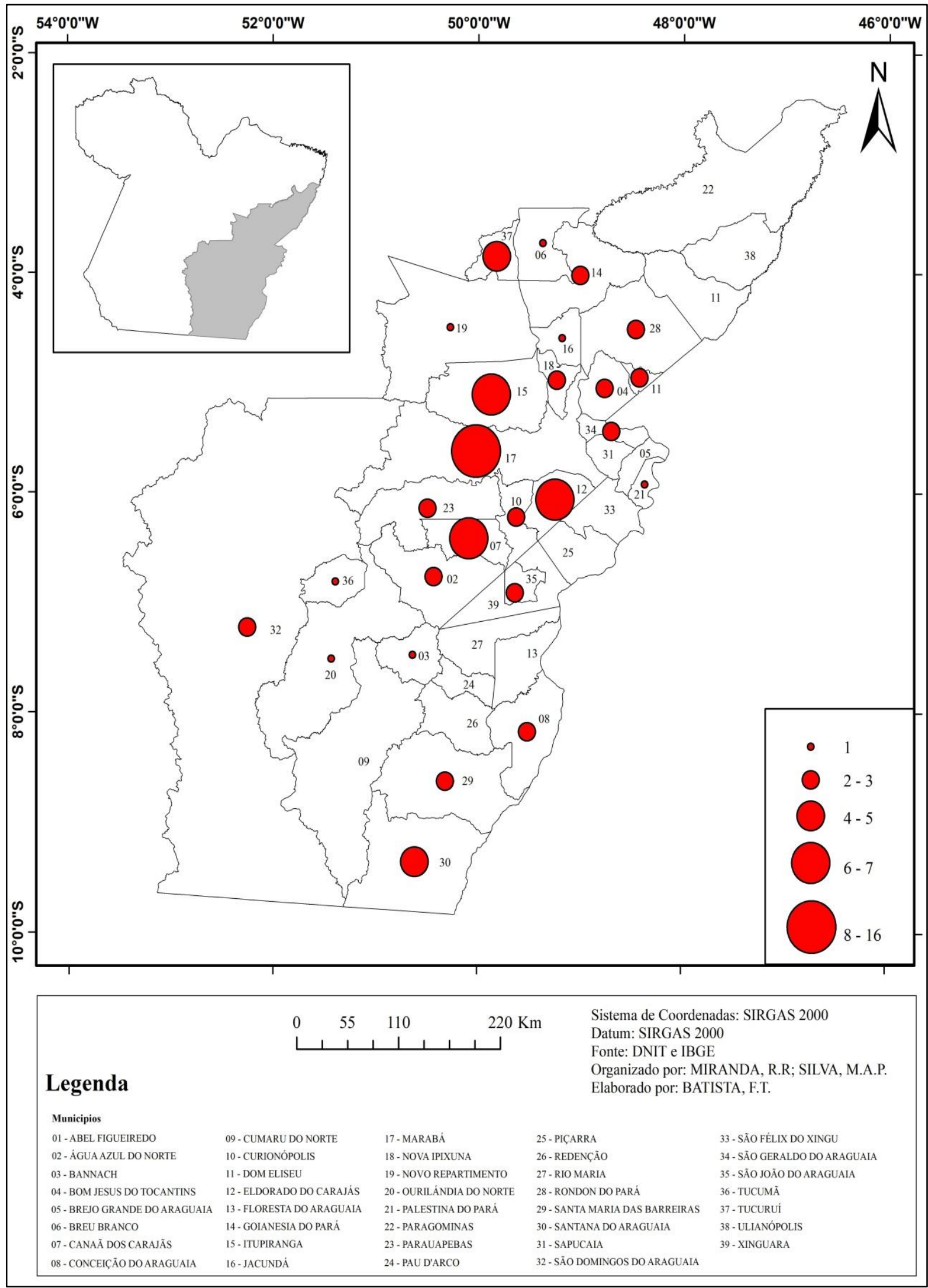

Fonte: CPT, 2002-2015; Rede Dataluta, 2016. Organização: Rogério Rego Miranda. 
A Tabela 6, por sua vez, refere-se aos movimentos sociais e sindicais envolvidos na organização dos acampamentos. Observamos que a FETAGRI-PA foi responsável por 40 acampamentos entre os anos de 2002 e 2015; ao passo que Outros Movimentos Sociais organizaram 20 acampamentos no mesmo período; o MST desenvolveu 13 acampamentos de 2003 até 2015; a CPT 3 acampamentos em 2003 e 2010 e, por fim, a FETRAF 2 acampamentos no ano de 2010.

Tabela 6 - Movimentos sociais e sindicais envolvidos na construção do acampamento no sudeste paraense, 2002 a 2015

\begin{tabular}{c|c|c|c|c|c|c|c|c|c|c|c|c|c|c}
\hline $\begin{array}{c}\text { Movimento } \\
\text { social/Movimento } \\
\text { sindical }\end{array}$ & $\mathbf{2 0 0 2}$ & $\mathbf{2 0 0 3}$ & $\mathbf{2 0 0 4}$ & $\mathbf{2 0 0 5}$ & $\mathbf{2 0 0 6}$ & $\mathbf{2 0 0 7}$ & $\mathbf{2 0 0 8}$ & $\mathbf{2 0 0 9}$ & $\mathbf{2 0 1 0}$ & $\mathbf{2 0 1 1}$ & $\mathbf{2 0 1 2}$ & $\mathbf{2 0 1 3}$ & $\mathbf{2 0 1 4}$ & $\mathbf{2 0 1 5}$ \\
\hline Não Informado & - & 1 & - & - & - & - & - & 2 & - & 2 & - & - & - & - \\
\hline MST & - & 2 & - & - & 1 & - & - & 2 & 2 & 2 & 1 & - & 1 & 2 \\
\hline $\begin{array}{c}\text { CONTAG } \\
\text { (FETAGRI- } \\
\text { PA/STR) }\end{array}$ & 1 & 14 & 4 & 3 & 5 & - & 2 & - & 1 & 1 & 2 & - & - & 7 \\
\hline CPT & - & 2 & - & - & - & - & - & - & 1 & - & - & - & - & - \\
\hline FETRAF & - & - & - & - & - & - & - & - & 2 & - & - & - & - & - \\
\hline $\begin{array}{c}\text { Outros } \\
\text { Movimentos }\end{array}$ & - & 2 & 3 & 2 & 3 & - & 2 & - & 4 & 1 & - & - & - & 3 \\
\hline Sociais Isolados & & $\mathbf{2 1}$ & $\mathbf{7}$ & $\mathbf{5}$ & $\mathbf{9}$ & $\mathbf{0}$ & $\mathbf{4}$ & $\mathbf{4}$ & $\mathbf{1 0}$ & $\mathbf{6}$ & $\mathbf{3}$ & $\mathbf{0}$ & $\mathbf{1}$ & $\mathbf{1 2}$ \\
\hline Total & $\mathbf{1}$ & $\mathbf{2 1}$ &
\end{tabular}

Fonte: CPT, 2002-2015. Organização: Rogério Rego Miranda.

\subsubsection{Adentrando nos espaços de resistência de construção de uma contra-hegemonia}

O Mapa 9 a seguir identifica os acampamentos organizados pelo MST atualmente. Se sobrepusermos essa cartografia ao Mapa 5, poderemos observar que grande parte dos acampamentos está no epicentro do latifúndio agropecuário e das empresas mineradoras, rompendo a cerca que aprisiona os sujeitos nas periferias urbanas e os impede de exercer o direito à terra, meio de produção fundamental para a reprodução dos sem-terra.

\footnotetext{
${ }^{22}$ Movimento Tucuruiense Sem Terra (MTST), Organização dos Trabalhadores no Campo (OTC), Associação dos Trabalhadores Rurais de Novo Horizonte (Astrarural), Organização Independente (OI), Associação Terra e Paz (ATP) e Liga dos Camponeses Pobres (LCP).
} 
Mapa 9 - Acampamentos organizados pelo MST - Sudeste Paraense, 2015.

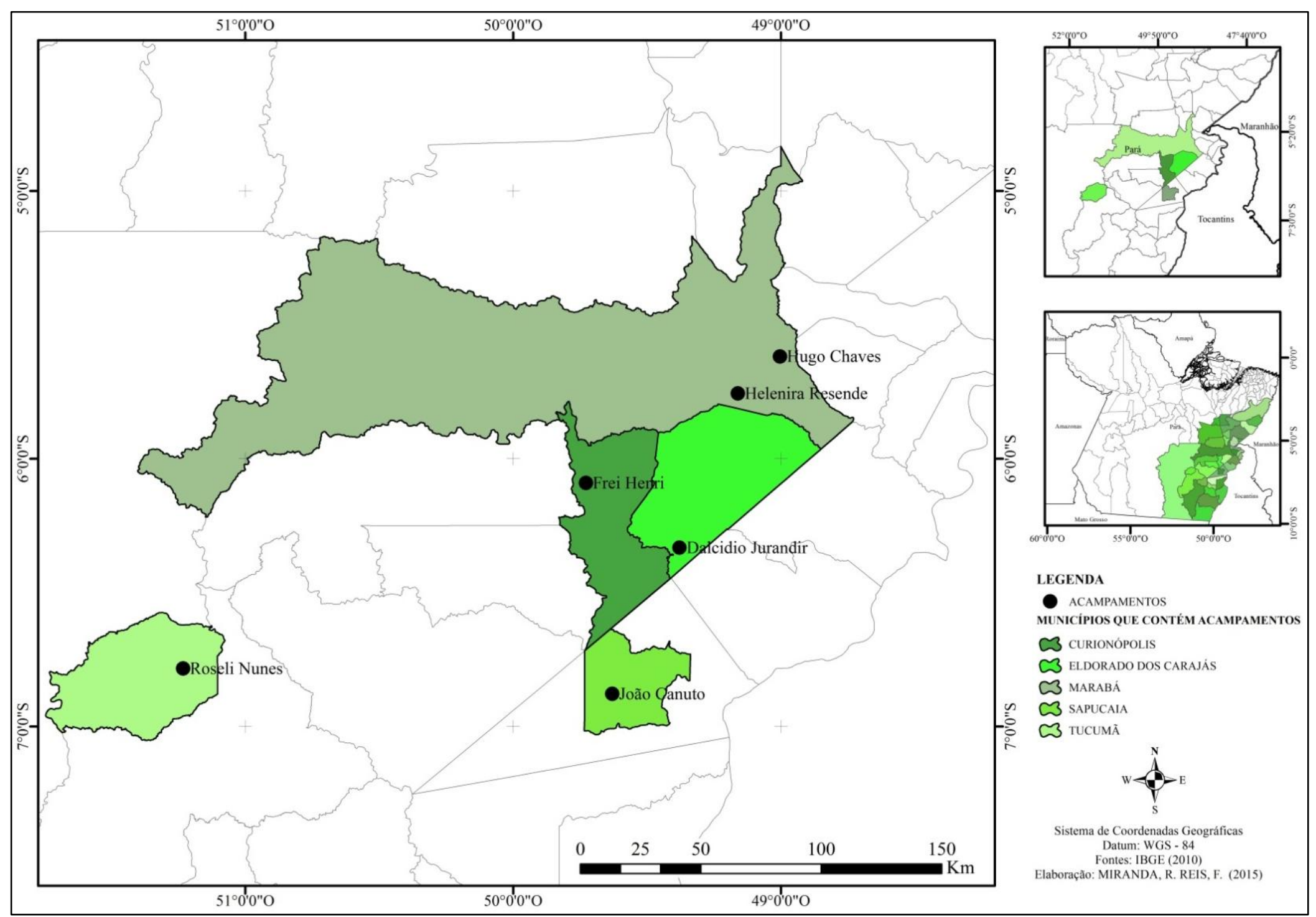

Fonte: IBGE. Organização: Rogério Rego Miranda. Desenho: Francisco Renan da Silva Reis 
De acordo com Sigaud (2000; 2005), esses espaços de resistência compreendem a formas acampamento, isso porque apresentam elementos comuns, salvaguardando as especificidades regionais e dos próprios movimentos sociais envolvidos. Assim, para Sigaud (2005), os acampamentos são mais do que um local de reunião de indivíduos para reivindicar a desapropriação da área, visto que manifestam:

[...] técnicas ritualizadas de realizar a ocupação, uma organização espacial, uma etiqueta para entrar no acampamento e nele se instalar, regras para ali conviver, um vocabulário próprio e elementos dotados de forte simbolismo, como a bandeira e a lona preta, que constituíam os marcos distintivos. Essa combinação de aspectos modelares constitui uma forma, a forma acampamento [...]. Trata-se de um modelo engendrado no Sul do país, ao longo do processo que desembocou na constituição do MST. (SIGAUD, 2005, p. 260)

No caso específico do sudeste paraense, em especial os acampamentos organizados pelo MST, a forma acampamento apresenta algumas particularidades. Incialmente, a definição da área a ser ocupada para a construção do acampamento segue determinados critérios, a saber: a) faz-se um levantamento junto ao INCRA, ITERPA, cartórios, dentre outros órgãos, para saber sobre a condição da propriedade, isto é, se corresponde à terra pública da União ou do estado, (principalmente em decorrência de muitas áreas de aforamento terem sido convertidas em fazendas de maneira irregular) além de observar se área é improdutiva ou apresenta outros elementos que possam configurar a fazenda como propicia à reforma agrária, a exemplo de crimes ambientais ou de casos de trabalho análogo ao escravo; b) faz-se um levantamento espacial da propriedade, para identificar a localização dos cursos d'agua, a proximidade com a cidade e a estrada, área de mata e possíveis locais mais viáveis para a instalação do acampamento, de forma a possibilitar uma relativa segurança contra a violência por parte de pistoleiros além de condições de sobrevivência; c) procede-se ao cadastro de pessoas nas periferias urbanas e/ou de filhos de assentados para os quais o lote de terra não é suficiente para a reprodução do núcleo familiar, ou mesmo de pessoas que já foram acampadas, mas não permaneceram nos antigos acampamentos devido às condições adversas que enfrentam cotidianamente; d) trabalho de base, conforme indicado anteriormente.

No que tange às condições de reprodução dos acampados, observamos que os acampamentos configuram uma forma de territorialização precária face às condições adversas que os acampados estão sujeitos, com pouca disponibilidade de saneamento básico e habitações improvisadas de lona, barro ou madeira nas quais residem várias pessoas (ver Fotos 11,12, 13 e 14). 
Foto 11 - Casa improvisada, acampamento Helenira Resende, Marabá-PA

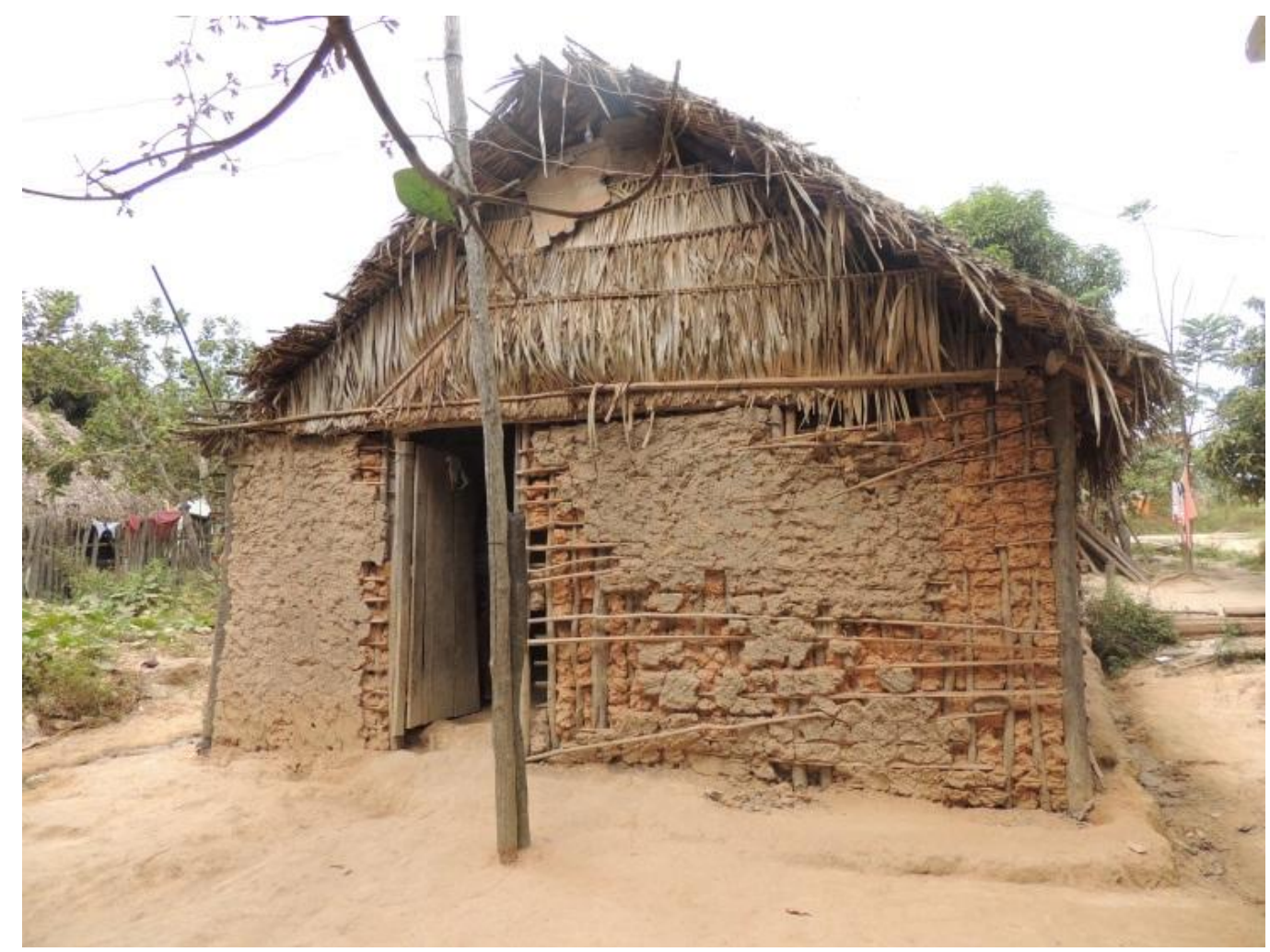

Fonte: Rogério Rego Miranda, Marabá, 2015.

Foto 12 - Moradias precárias, acampamento Roseli Nunes, Tucumã-PA

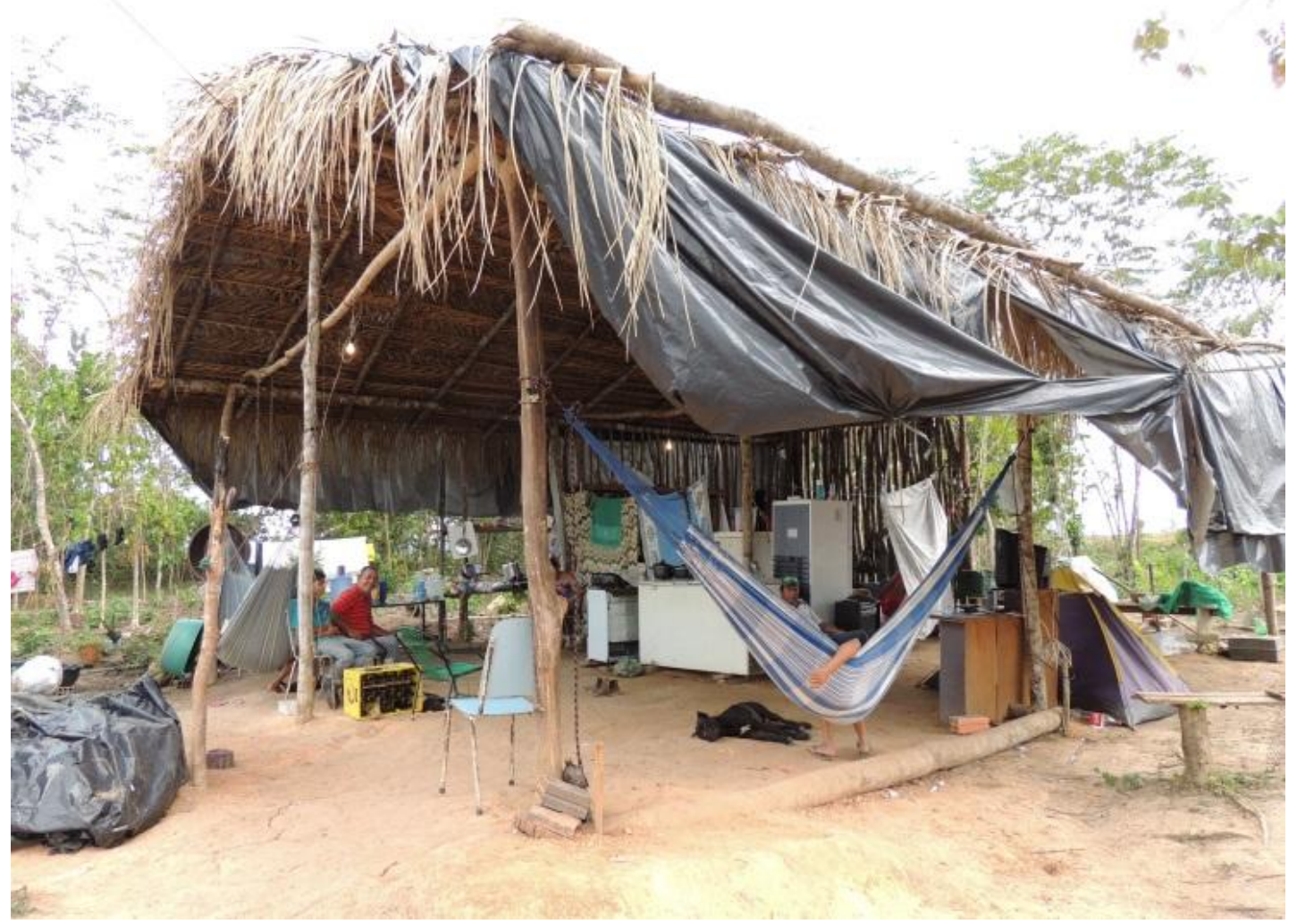

Fonte: Rogério Rego Miranda, Tucumã, 2015. 
Foto 13 - A cerca que antes era uma barreira hoje foi rompida para dar lugar ao acampamento Helenira Resende - Marabá/PA

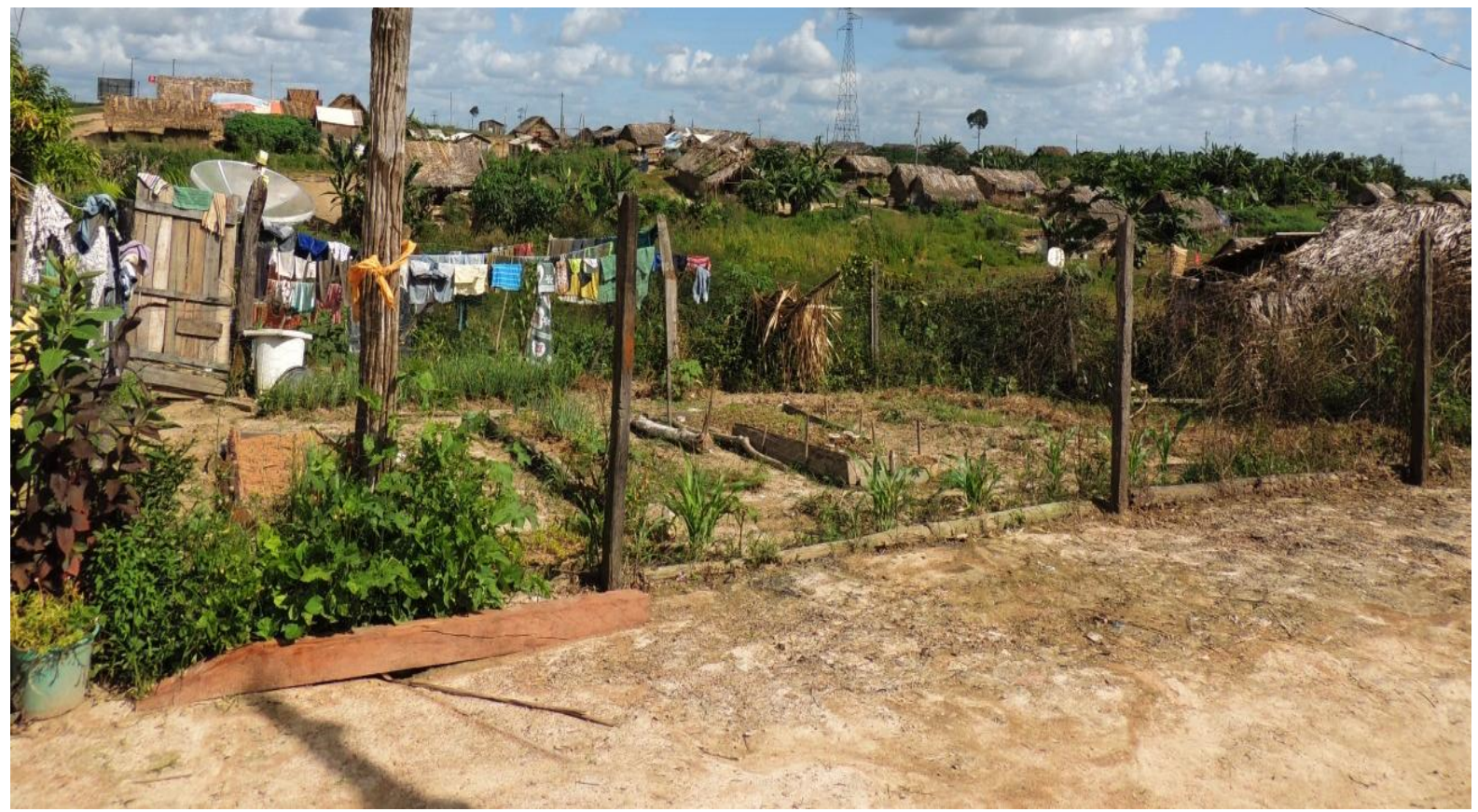

Fonte: Rogério Rego Miranda, Marabá, 2015.

Foto 14 - Interior da residência de uma das acampadas do acampamento Reseli Nunes, em Tucumã-PA.

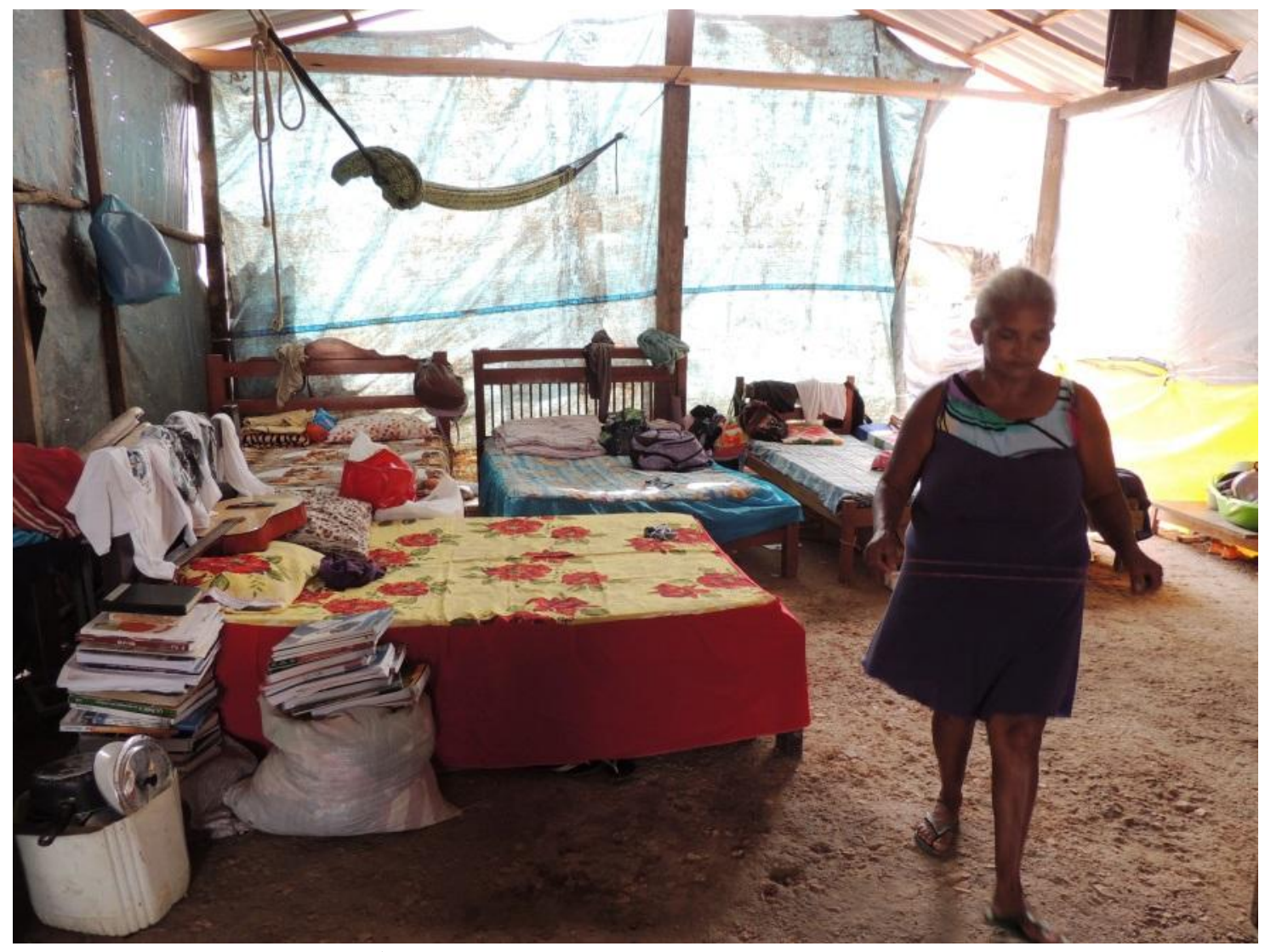

Fonte: Rogério Rego Miranda, Tucumã, 2015. 
Essas áreas se aproximam do que Haesbaert (2004) denomina de "aglomerados de exclusão" ou territorialização precária, que constituem situações em que o território apresenta limites, funções e fluxos não necessariamente controlados pelos que residem ali, além de processos extremos de instabilidade ou fragilização territorial. Em outras palavras,

mais do que espaços à parte, claramente identificáveis, são fruto de uma condição social extremamente precarizada, onde a construção de territórios "sob controle" [...] ou "autônomos" se torna muito difícil, ou completamente subordinada a interesses alheios (HAESBAERT, 2004, p. 327).

Essa condição precária do território não se define pela forma geográfica apenas, mas pelos processos que engendram, ou seja, a indefinição dos sujeitos sobre os limites da área que ocupam, visto que os conflitos com os fazendeiros e a demora de uma definição legal de desapropriação da fazenda impõem uma limitação/instabilidade da área ocupada para a construção das casas, das pequenas plantações, das escolas, dentre outras infraestruturas. Dessa maneira, os acampados ficam confinados em áreas negociadas com os proprietários por meio do INCRA, mas correndo riscos cotidianos de serem expulsos seja pela ação de pistoleiros seja por policiais que agem mediante mandatos de reintegração de posse. Como não controlam os limites onde se localiza o acampamento há uma restrição nos fluxos dos acampados, seja pela dificuldade de circulação em estradas (dependendo da localização do acampamento existe um debilidade no transporte das pessoas e das mercadorias), seja pela obstrução realizada pelos proprietários, impedindo a entrada e saída dos acampados para pesca, trabalho, lazer, dentre outras atividades, sob a penalidade de violência física, especialmente nos primeiros anos do acampamento.

A trajetória geográfica dos acampados geralmente é a dos migrantes oriundos do Nordeste brasileiro ou da segunda ou terceira geração de migrantes cujos pais vieram outrora trabalhar nos grandes projetos - hoje esses descendentes desenvolvem uma migração intrarregional em busca de emprego e melhorias de vida.

Conforme podemos observar no Gráfico 3, 140 acampados vieram do Maranhão, 80 são da própria região sudeste do Pará e 34 são do Tocantins, enquanto que 8 advém de outras mesorregiões paraenses (oeste, sudoeste e nordeste), 41 são de estados do nordeste brasileiro (Piauí, Ceará, Bahia, Pernambuco, Paraíba e Rio Grande do Norte), 13 advém de Goiás e, por fim, 11 vieram do sudeste do Brasil (Espirito Santo, Minas Gerais e São Paulo).

Embora muitos morassem em periferias urbanas, desenvolviam atividades agrícolas para terceiros em troca de salário, de uma parte da produção ou de uma diária (um valor monetário pago pelo dia trabalhado, que variava de $\mathrm{R} \$ 40,00$ a $\mathrm{R} \$ 50,00$ reais), elemento ainda constante no cotidiano de sobrevivência de muitos. Assim, constatamos por meio do 
Gráfico 4 que 126 acampados indicaram ter profissão anterior de lavrador e 10 declararam ser vaqueiros, compreendendo $41,59 \%$ do total de pessoas que lutam pela terra. Os demais, que perfazem 58,40\% (191 acampados), realizavam atividades assalariadas ou não, como pedreiro, serviços gerais, doméstica (trabalhando em casa de famílias) e garimpeiro, atividade ainda bastante presente na região.

Gráfico 3 - Origem dos acampados nos acampamentos organizados pelo MST no sudeste paraense, 2015.

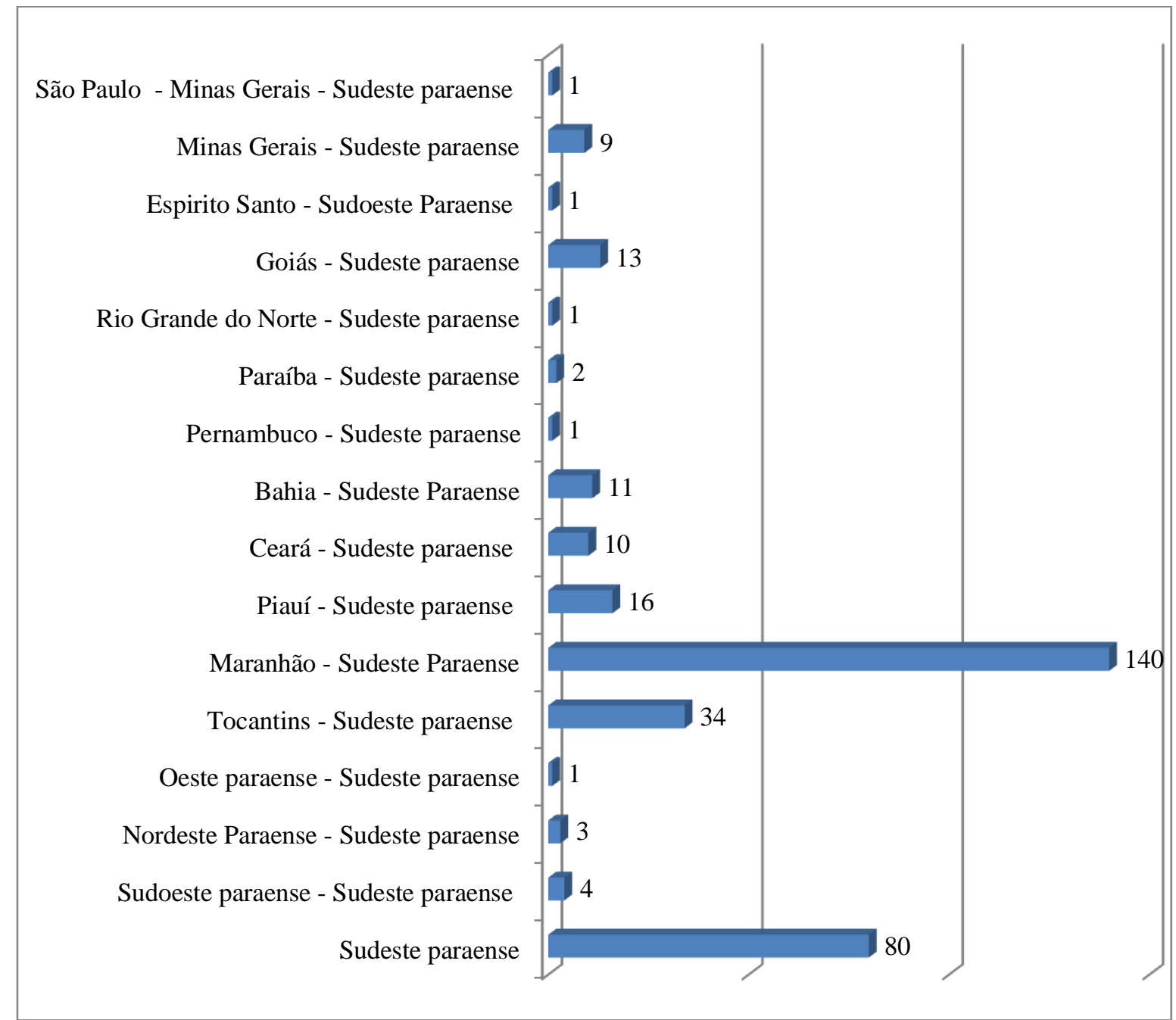

Fonte: Pesquisa de campo, 2015. 
Gráfico 4 - Profissões exercidas anteriormente pelos acampados, 2015.

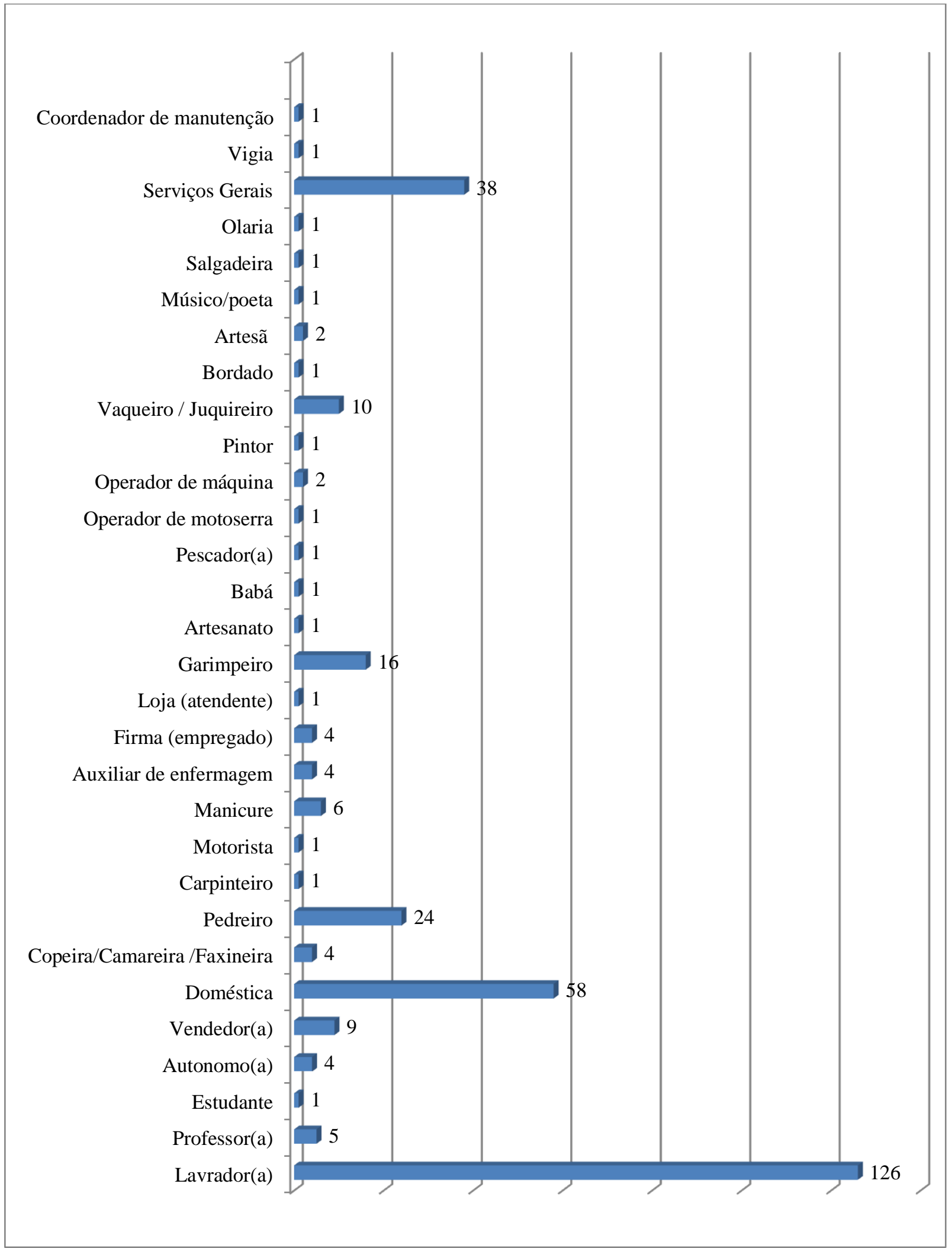

Fonte: Pesquisa de campo, 2015. 
Para garantir a sobrevivência, muitos ainda desenvolvem essas atividades laborais com o intuito de obterem alimentos, vestimentas e outros elementos que não conseguem dentro do acampamento (ver Gráfico 5).

Gráfico 5 - Acampados que trabalham fora do acampamento - 2015.

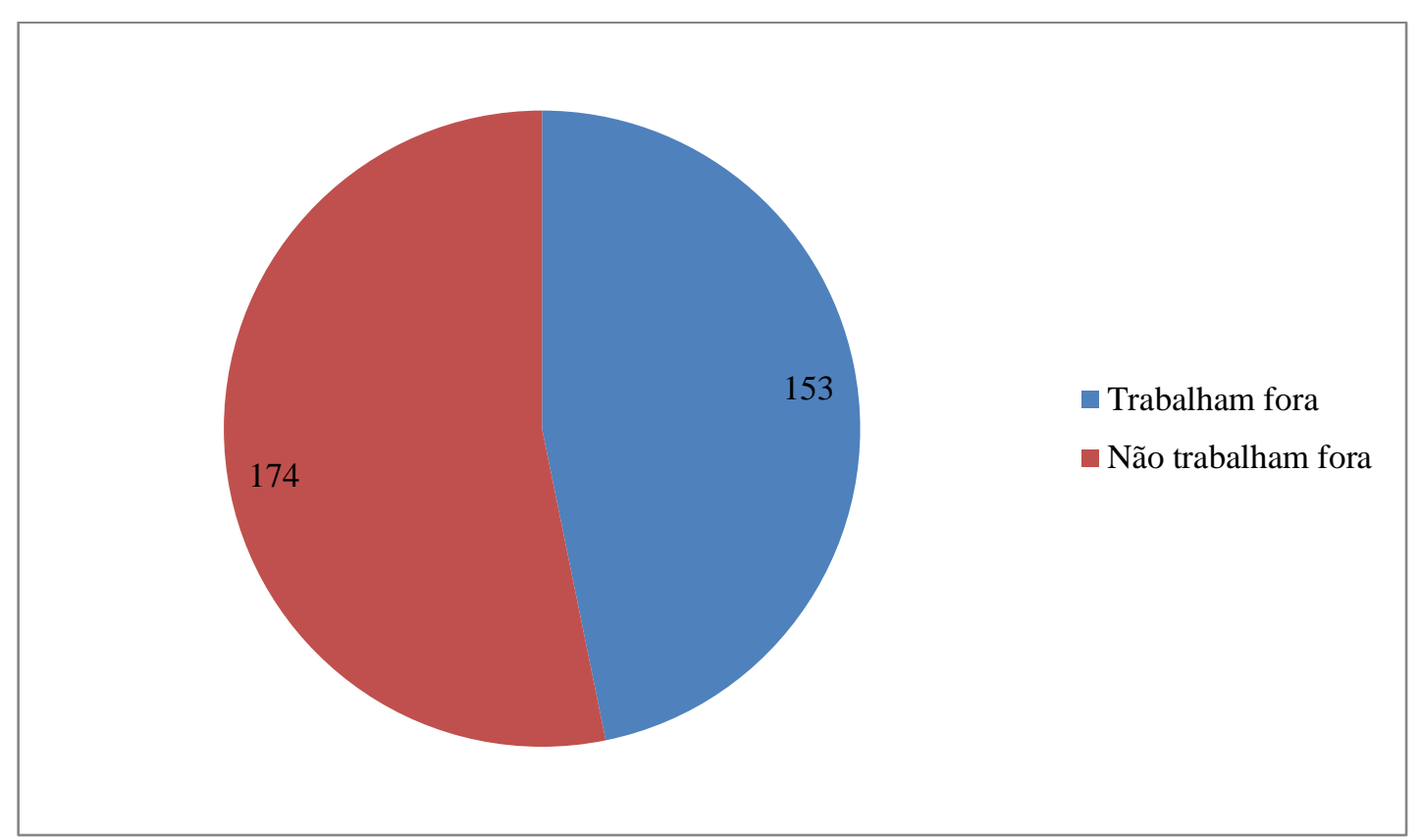

Fonte: Pesquisa de campo, 2015.

A renda média desses sujeitos é geralmente muito baixa, variando principalmente entre nenhuma renda e R \$599,00 reais mensais. Assim, dispusemos no Gráfico 6 que dentre os acampados, 28 declararam não receber nenhum valor, sobrevivendo de ajuda de pessoas do próprio acampamento ou de familiares residentes em outros lugares; a maioria das pessoas informou receber menos de um salário mínimo por mês, e boa parte declarou receber entre um e dois salários mínimos. Somente oito pessoas declararam receber mais de dois salários mínimo por mês. Dois entrevistados informaram não ter ideia de quanto conseguiam por mês em virtude da grande precariedade em que vivem. 
Gráfico 6 - Renda média dos acampados

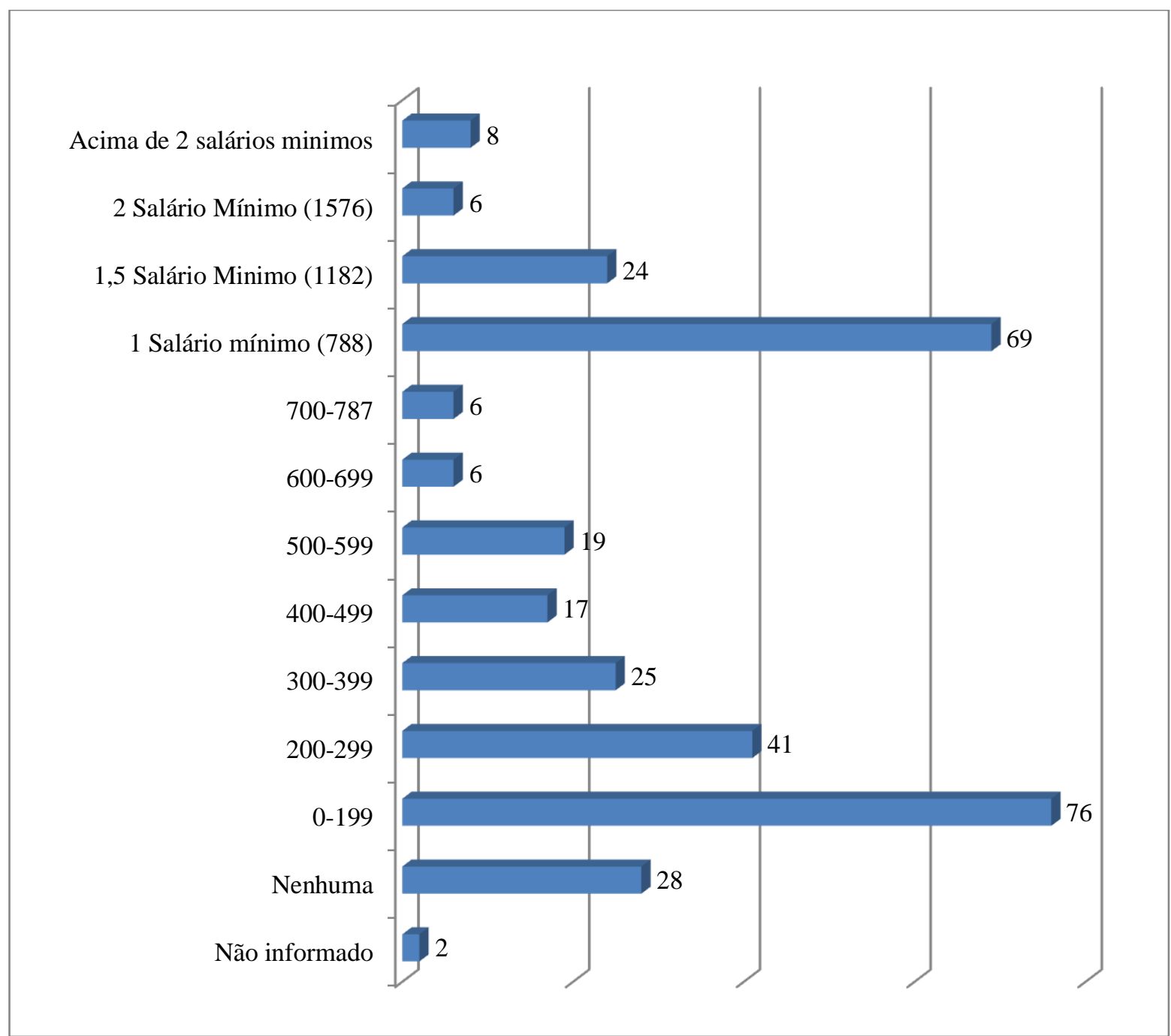

Fonte: Pesquisa de campo, 2015.

Outra fonte de renda além do trabalho exercido fora do acampamento são os programas sociais ou aposentadorias dos mais velhos que vivem nessas realidades. Com efeito, das pessoas questionadas, quase a metade revelou sobreviver de auxílios como bolsa família e aposentadoria, sendo que 35 pessoas recebiam ajuda de algum membro mais velho que tinham aposentadoria (ver Gráfico 7). 
Gráfico 7 - Renda proveniente de programa social ou aposentadoria/benefício.

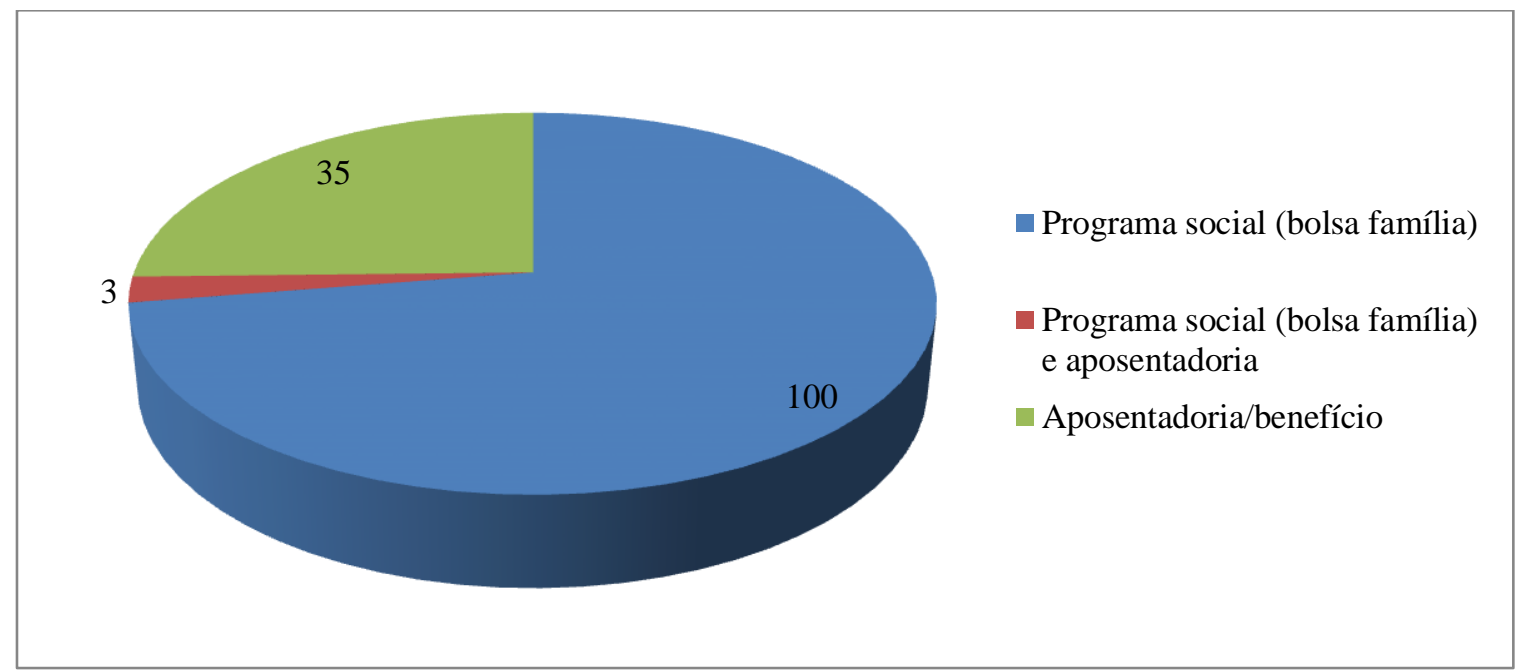

Fonte: Pesquisa de campo, 2015.

Para finalizar essa discussão acerca dos sujeitos que residem nos acampamentos, observamos que, embora as áreas em que desenvolvem suas relações cotidianas seja diminuta, constroem sistemas de produção e criação para garantir sua reprodução por meio do consumo daquilo que produzem ou pela venda desses víveres nas feiras próximas. Assim, podemos observar que cerca de $43 \%$ dos entrevistados cultivam em locais bastante reduzidos, mas com uma diversidade produtiva relativamente grande, da qual destacamos as hortaliças (cheiroverde, cebolinha, alface, cebola, tomate, couve-flor), mandioca e/ou macaxeira, milho, verduras (abóbora, maxixe, quiabo), feijão, fava e frutos (coco, manga, acerola, mamão, laranja, maracujá, banana, cupuaçu, melancia). Mais de $45 \%$ relatou ter algum tipo de criação, geralmente de galinhas e, em menor proporção, porcos (ver Gráfico 8).

Gráfico 8 - Acampados que desenvolvem cultivos e criações.

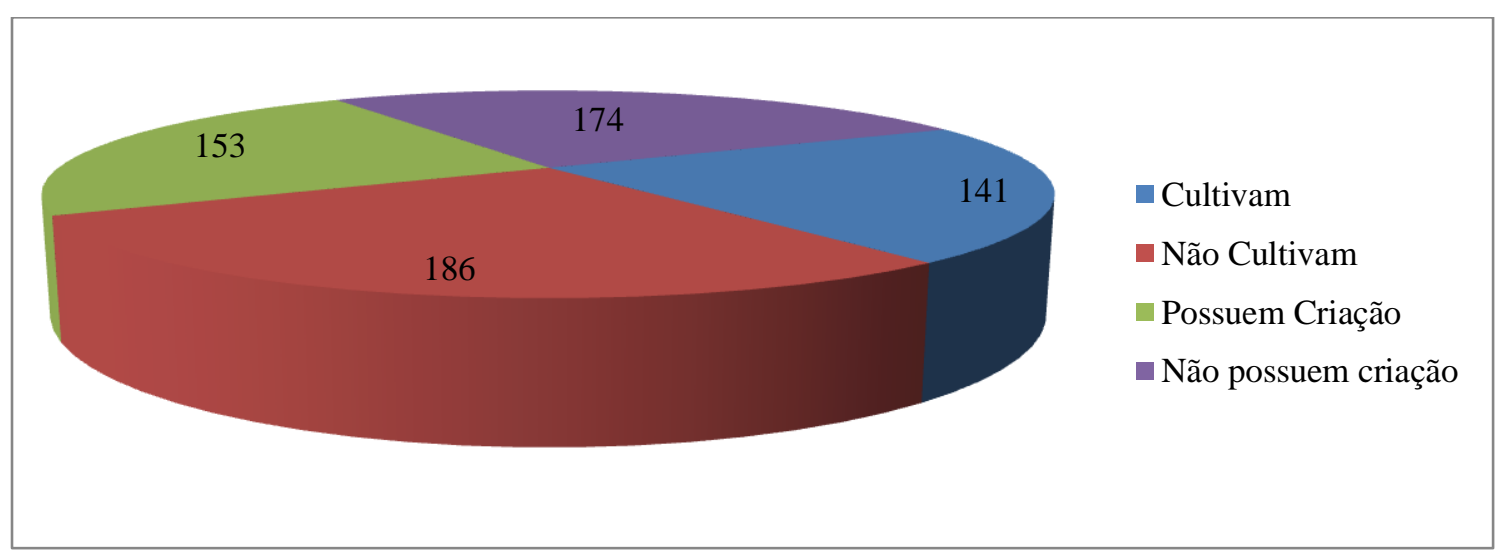

Fonte: Pesquisa de campo, 2015. 
Com relação à organização interna e espacial dos acampamentos, as famílias ficam agrupadas em núcleos de base que conformam quadras entrecortadas por ruas em cujas margens se localizam os barracos. A quantidade de pessoas por núcleo varia de acampamento para acampamento, pois depende do total de famílias que cada um apresenta. As famílias que compõem o núcleo ficam geograficamente próximas para que desenvolvam suas atividades cotidianas relativas à organização de possíveis manifestações, ocupações de prédios públicos, como o do INCRA e da prefeitura, marchas etc.; assim como para que trabalhem coletivamente na resolução de problemas diários, a exemplo do cumprimento das normas internas existentes (não pode haver o consumo de bebidas alcoólicas ou de drogas ilícitas, existem horários de entrada e saída dos acampamentos, não pode existir violência doméstica, roubos e outras ações que coloquem em risco a vida dos sujeitos e o projeto de conquista da luta pela terra).

De cada núcleo são retirados dois membros para coordenar, sempre um homem e uma mulher, responsáveis por intermediar as pautas levantadas pelo seu grupo; é a coordenação geral do acampamento que igualmente atribui funções aos grupos, mas vale lembrar que que as decisões são tomadas em coletivo por todos os partícipes do acampamento. Igualmente, de cada núcleo são retiradas pessoas dos dois gêneros para compor setores específicos, como saúde, educação, segurança, produção e juventude, que ficam responsáveis por ações específicas, tais como vigia da entrada e saída do acampamento, construção e negociação de pautas relativas a saúde, educação dentro do acampamento etc.

Os acampados desenvolvem, além das ações de luta coletiva, mutirões para levantar as casas, providenciar a construção das escolas, que, aliás, é uma das primeiras conquistas levadas a cabo pelos acampados. Inicialmente, algumas pessoas com algum grau de instrução iniciam as atividades no âmbito educativo, mas paralelamente mobilizam-se para que as prefeituras participem com livros, contratação de professores oriundos do próprio movimento sem-terra, a estruturação da escola, o transporte e o registro da unidade de ensino dentro do acampamento. Além disso, cultivam em comunidade hortaliças, verduras, macaxeira e plantas medicinais, embora isso não ocorra em todos os acampamentos.

O acampamento igualmente apresenta uma dimensão simbólica da luta, que se materializa nas bandeiras ateadas nas escolas, no barracão de reunião e reproduzidas nas placas de entrada do acampamento; também nos hinos cantados nos momentos de reunião interna, manifestações etc. A própria linguagem do MST se expressa no discurso de que a terra é de trabalho, ou quando se diz que a área não foi invadida, e sim ocupada, para se opor ao que é veiculado pela grande mídia regional e nacional; por isso se fala vamos entrar 
na terra. Substituem-se os nomes dos sujeitos individuais por um coletivo, ou seja, companheiros. Há outras expressões verbais que os identificam com o movimento, a exemplo das palavras de ordem ocupar, resistir e produzir e os nomes dos acampamentos fazem referência a lideres revolucionários regionais e nacionais ou a intelectuais comprometidos com a luta pela terra.

A mística se constrói principalmente através da linguagem. De acordo com Turatti (1999), ela pode ser considerada uma matriz discursiva que objetiva conscientizar a base do MST de seu papel histórico no processo de transformação societal. É acionada considerando o que o movimento almeja transmitir, o público-alvo e o contexto. Logo, ela se reveste de diversas formas simbólicas, mas com a mesma função de convencer, estabelecer confiança, legitimidade e conseguir adesão dos acampados e assentados. Para Stédile e Fernandes (1999), a mística é um fator de unidade, com o intuito de vivenciar os ideais.

Por fim, um elemento comum nos acampamentos são as formas de violência vivenciadas pelos sujeitos e manifestas pela ação de jagunços que atiram durante a noite ou mesmo durante o dia e/ou disparam foguetes. Há também os aviões contratados pelos grandes proprietários que despejam veneno sobre as plantações dos acampados, matando-as ou reduzindo-as drasticamente. Ocorre a intimidação física ao impedir a pesca, a caça e o uso da água - também se contamina a água, dentre várias outras ações, que chegam ao extremo do assassinato das lideranças do acampamento.

À titulo de síntese dos elementos constituintes da forma acampamento do sudeste paraense por meio da experiência daquelas áreas organizadas pelo MST, propomos o Quadro 3. 
Quadro 3 - Formas acampamentos organizadas pelo MST no sudeste paraense - 2015

\begin{tabular}{|c|c|c|}
\hline $\begin{array}{l}\text { Aspectos } \\
\text { qualitativos do } \\
\text { acampamento }\end{array}$ & $\begin{array}{l}\text { Elementos } \\
\text { definidores do } \\
\text { acampamento }\end{array}$ & Fala dos acampados \\
\hline \multirow{3}{*}{$\begin{array}{l}\text { O que significa ser } \\
\text { acampado }\end{array}$} & $\begin{array}{l}\text { Possibilidade de } \\
\text { acesso à terra e de } \\
\text { reprodução social da } \\
\text { família por meio do } \\
\text { trabalho na terra. }\end{array}$ & $\begin{array}{l}\text { “Aqui... eu estou em busca de um futuro melhor para meus filhos... ter uma vida mais digna. É o trabalho que eu sei fazer.” (Rony Marcel Souza } \\
\text { Carvalho, do Helenira Resende). } \\
\text { "É eu esperar receber essa terra e trabalhar. Eu nasci na roça e a gente da roça só fica feliz se trabalhar na roça.” (Francisco das Chagas Costa, do } \\
\text { Helenira Resende). } \\
\text { "Ficar aqui na espera para ver se ganha um pedacinho de terra para trabalhar, muitos pegam para vender, eu não, quero terra para trabalhar.” } \\
\text { (Sebastiana Maria Ferreira, do Helenira Resende). }\end{array}$ \\
\hline & $\begin{array}{l}\text { Territorialização } \\
\text { precária e indefinida; } \\
\text { condição transitória. }\end{array}$ & $\begin{array}{l}\text { "É muito difícil! É tão difícil que tem dia que não tem um grão de arroz para a família comer, a gente fica aqui mesmo na esperança da terra." } \\
\text { (Emília Coelho de Souza, do Helenira Resende). }\end{array}$ \\
\hline & $\begin{array}{l}\text { Espaço de luta e } \\
\text { socialização. }\end{array}$ & $\begin{array}{l}\text { “[...] É uma luta da gente, é difícil! A gente enfrenta muita dificuldade, só esses barracos com essas crianças é um sufoco. A gente sofre um } \\
\text { bocado, demora para ter um pedaço de terra” (Alcides Mendes de Souza, do Helenira Resende). } \\
\text { "É uma tentativa de realizar um sonho que a gente não conseguiu realizar lá atrás, ter uma terra. Acampamento é uma forma de conhecer com } \\
\text { quem a gente vai conviver.” (Sebastião de Deus Pereira, do Helenira Resende). } \\
\text { "É uma experiência de vida, porque eu nunca tinha participado de movimento social e a partir daí tive noção do que é... como podemos conviver } \\
\text { com as pessoas, experiência de vida.” (Elizete Barbosa, do Helenira Resende). } \\
\text { "É uma luta que a gente pensa um dia vencer, antes eu estava por gostar dos vizinhos e hoje estou para ganhar, como falam lá fora, mas aqui é } \\
\text { conquistar na luta com muito sacrifício.” (Eva as Silva Souza, do Frei Henri). }\end{array}$ \\
\hline $\begin{array}{l}\text { O que significa a } \\
\text { terra }\end{array}$ & $\begin{array}{l}\text { Possibilidade de } \\
\text { territorialização } \\
\text { duradoura e melhores } \\
\quad \text { condições de } \\
\text { reprodução social pelo } \\
\text { trabalho na terra. }\end{array}$ & $\begin{array}{l}\text { “A gente vai ter mais sossego, vai estar dentro de uma terra. Aí de tudo se planta um pouco, o que dá para se manter, para as crianças, tem a } \\
\text { mandioca, cria e é uma vida sossegada. Na rua (na cidade) tudo é difícil, mesmo para quem tem emprego.” (Alcides Mendes de Souza, do Helenira } \\
\text { Resende). } \\
\text { "É o nosso futuro! Um sonho de uma alimentação saudável, hoje só se vê o agronegócio.” (Doraci Alves de Melo, do Frei Henri). } \\
\text { "Futuramente... nasci na terra, trabalho na terra né! É um sustento! Acho que é melhor do que trabalhar empregado. Na rua (cidade) só trabalha na } \\
\text { chácara dos outros, no terreno dos outros.” (Raimundo Gomes dos Santos, do Hugo Chaves). } \\
\text { "É um meio de sobrevivência, que é um dos mais importantes. Da terra você produz vários tipos de alimentos [...]. É uma independência, com um } \\
\text { péaço de terra você se torna uma pessoa independente.” (Lindomar Leite Cardoso, do Frei Henri). } \\
\text { "Única chance de libertação de trabalhar para os outros é o movimento... esse pedacinho de chão chama-se liberdade, me libertei da escravidão de } \\
\text { trabalhar para os outros.” (Ademar Ferreira do Nascimento, do Roseli Nunes). }\end{array}$ \\
\hline
\end{tabular}




\begin{tabular}{|c|c|c|}
\hline \begin{tabular}{l}
\multicolumn{1}{c}{ Aspectos } \\
qualitativos do \\
acampamento
\end{tabular} & $\begin{array}{c}\text { Elementos } \\
\text { definidores do } \\
\text { acampamento }\end{array}$ & Fala dos acampados \\
\hline $\begin{array}{l}\text { Organização } \\
\text { socioespacial }\end{array}$ & $\begin{array}{l}\text { Os Núcleos de Base } \\
\text { são a forma de } \\
\text { organização interna } \\
\text { do acampamento. }\end{array}$ & $\begin{array}{l}\text {-“São núcleos de famílias [...] que existe um coordenador e uma coordenadora [...], essa coordenação que vai sentar com nossa militância, que é a } \\
\text { coordenação geral do acampamento [...] que vão discutir, avaliar, definir e encaminhar a decisão coletiva mesmo para encaminhar aos núcleos de } \\
\text { família. E ainda existem os setores, que é o setor de educação, saúde, produção, tem o coletivo de juventude [...] E é uma tarefa puxada porque no } \\
\text { início de acampamento, nos primeiros quatro, cinco anos são nove reuniões por semana [...] Um dos nossos segredos é planejamento, nos } \\
\text { planejando e decidindo coletivamente. Não existe chefe, não existe líder, não existe um dá ordem de cima para baixo. Tudo que tem de ser definido } \\
\text { internamente, tem que sentar com o coletivo e aí ainda vamos com a assembleia que é uma das nossas maiores instâncias para de cidir, tomar a } \\
\text { decisão do que vamos fazer internamente e externamente no movimento.” (Valdete Viturino, do João Canuto). }\end{array}$ \\
\hline Sociabilidade & $\begin{array}{l}\text { Sociabilidades mais } \\
\text { próximas, mas } \\
\text { mediadas pelo } \\
\text { conflito. }\end{array}$ & $\begin{array}{l}\text { - “[...] Assim (no acampamento) é mais tranquilo, convivência melhor com os companheiros, aprende a trabalhar em coletivo.” (Manuel Pereira } \\
\text { Gomes Jr., do Frei Henri). } \\
\text { - “É uma experiência única (no acampamento) porque é um companheirismo onde todos lutam por um objetivo só, se organiza entre nós, resolve os } \\
\text { problemas entre nós, somos unidos, somos uma família, apesar das desavenças.” (Joana D’arque Dinis, do Frei Henri). } \\
\text { - “A gente no começo não conhecia o movimento... é difícil, mas faz aquela comunidade.” (Antônio Pereira da Silva” (do Roseli Nunes) }\end{array}$ \\
\hline $\begin{array}{c}\text { Formas de } \\
\text { resistência e } \\
\text { estratégias de } \\
\text { permanência na terra }\end{array}$ & $\begin{array}{c}\text { Manifestações; } \\
\text { ocupações de prédios } \\
\text { públicos; criação de } \\
\text { escolas. }\end{array}$ & $\begin{array}{l}\text {-“[...] Uma das primeiras coisas que mantêm a nossa segurança na terra é um colégio desses [...], primeira coisa que você tem que fazer quando nós } \\
\text { ocupa a terra [...]. As manifestações são mais para adiantar os processos.” (Antônio Pereira, do Frei Henri). }\end{array}$ \\
\hline $\begin{array}{l}\text { Principais formas } \\
\text { de violência }\end{array}$ & $\begin{array}{l}\text { Veneno na plantação; } \\
\text { ações de pistoleiros e } \\
\text { policiais; despejos por } \\
\text { reintegração de posse } \\
\text { com destruição de } \\
\text { plantações, barracos e } \\
\quad \text { instrumentos de } \\
\quad \text { trabalho. }\end{array}$ & $\begin{array}{l}\text { “[...] Se eu não estou enganado foram seis conflitos que teve aqui dentro [...] com os pistoleiros da fazenda. Aqui tu não podia sair fora não, na hora } \\
\text { que tu sai os caras te atacavam [...] se nós saíssemos para pescar, eles tomavam, botavam o pessoal para correr [...], as mães de família não podiam } \\
\text { sair para pegar um peixe }[\ldots . .] \text { que eles atacavam e era com arma mesmo [...] nós não podia sair daqui, se nós sai daqui a polícia atacava nós [...] } \\
\text { nossas famílias começou a passar necessidade porque não tinha como sair para arrumar o pão para dá para nossos filhos.” (Informante A, do } \\
\text { Dalcídio Jurandir). }\end{array}$ \\
\hline
\end{tabular}

Fonte: Pesquisa de Campo; 2015. 
O Quadro 4 a seguir caracteriza bem cada um desses acampamentos pesquisados, ressaltando o período de ocupação da área, em que o tempo de resistência desses sujeitos (que varia entre 7 e 10 anos, a exemplo de Dalcídio Jurandir e João Canuto, respectivamente), e aqueles mais recentes, como o acampamento Hugo Chaves, existente desde 2014. Também destaca as motivações da ocupação da fazenda, que geralmente ocorre em terras públicas apropriadas indevidamente, por se constituírem em propriedade do Estado (área dos antigos castanhais). Ainda, analisa a situação desses acampamentos, ou seja, se existe algum processo de negociação para o devido assentamento das pessoas. É importante perceber que os acampamentos estão no eixo agropecuário e mineral, o que mostra a força da ação coletiva frente ao latifúndio, que se materializa na criação do território concreto representado pelo assentamento. 
Quadro 4 - Acampamentos implementados a partir da organização do MST no sudeste paraense, 2015

\begin{tabular}{|c|c|c|c|c|c|c|c|c|c|}
\hline Acampamento & \begin{tabular}{|c|}
$\mathbf{N}^{\mathbf{0}}$ de \\
Famílias
\end{tabular} & $\begin{array}{c}\text { Área } \\
\text { (ha) }\end{array}$ & \begin{tabular}{|c|} 
Ano de \\
ocupação
\end{tabular} & Fazenda & Proprietário & $\begin{array}{c}\text { Motivação da } \\
\text { ocupação }\end{array}$ & Situação & Município & Eixo Territorial \\
\hline Helenira Resende & $340-380$ & 14.000 & 2009 & Cedro & $\begin{array}{l}\text { Grupo Santa } \\
\text { Bárbara }^{23}\end{array}$ & $\begin{array}{c}\text { Área de terras } \\
\text { públicas }\end{array}$ & Sem negociação & Marabá & $\begin{array}{l}\text { Agropecuário e mineral } \\
\text { (UH de Marabá) }\end{array}$ \\
\hline Hugo Chávez & 565 & 3.600 & 2014 & $\begin{array}{l}\text { Santa } \\
\text { Tereza }\end{array}$ & $\begin{array}{c}\text { Rafael Saldanha } \\
\text { de Camargo }\end{array}$ & $\begin{array}{c}\text { Área de terras } \\
\text { públicas }\end{array}$ & Sem negociação & Marabá & $\begin{array}{l}\text { Agropecuário e mineral } \\
\text { (UH de Marabá) }\end{array}$ \\
\hline Dalcidio Jurandir & 390 & -- & 2008 & $\begin{array}{l}\text { Maria } \\
\text { Bonita }\end{array}$ & $\begin{array}{c}\text { Grupo } \\
\text { Agropecuária } \\
\text { Santa Bárbara } \\
\text { Xinguara S/A }\end{array}$ & $\begin{array}{c}\text { Área de terras } \\
\text { públicas }\end{array}$ & $\begin{array}{c}\text { Em negociação }(6,3 \\
\text { ha cada lote })\end{array}$ & $\begin{array}{c}\text { Eldorado de } \\
\text { Carajás }\end{array}$ & Agropecuário e mineral \\
\hline Frei Henri de Roisiers & 150 & 400 & 2010 & Fazendinha & Dão Baiano ${ }^{25}$ & $\begin{array}{c}\text { Área de terras } \\
\text { públicas }\end{array}$ & Sem negociação & $\begin{array}{l}\text { Parauapebas/ } \\
\text { Curionópolis }\end{array}$ & $\begin{array}{l}\text { Agropecuário e mineral } \\
\text { (Serra de Carajás) }\end{array}$ \\
\hline João Canuto & 142 & 35.900 & 2006 & \begin{tabular}{|c} 
Rio \\
Vermelho
\end{tabular} & $\begin{array}{c}\text { Irmãos } \\
\text { Quagliato }^{26}\end{array}$ & $\begin{array}{l}\text { Denúncia de } \\
\text { trabalho } \\
\text { análogo ao } \\
\text { escravo }\end{array}$ & \begin{tabular}{|c|} 
Em negociação por \\
meio de permuta com \\
a área Retiro Guerobal \\
de 3.630 ha (5 alq. \\
cada lote)
\end{tabular} & Sapucaia & $\begin{array}{c}\text { Agropecuário e mineral } \\
\text { (próximo ao projeto Onça } \\
\text { Puma da Vale em } \\
\text { Ourilândia do Norte) }\end{array}$ \\
\hline Roseli Nunes & 53 & 1.200 & 2011 & Caumé & $\begin{array}{l}\text { Leonardo } \\
\text { Mendonça }^{27}\end{array}$ & $\begin{array}{c}\text { Área de } \\
\text { narcotráfico }\end{array}$ & $\begin{array}{c}\text { Em negociação (1 } \\
\text { alq. e } 4 \text { linhas cada } \\
\text { lote })\end{array}$ & Tucumã & $\begin{array}{l}\text { Agropecuário e mineral } \\
\text { (próximo ao projeto Onça } \\
\text { Puma da Vale em } \\
\text { Ourilândia do Norte) }\end{array}$ \\
\hline
\end{tabular}

Fonte: Pesquisa de Campo; 2015.

\footnotetext{
${ }^{23}$ Grupo composto por diversos sujeitos, dentre os quais o sócio majoritário é o banqueiro Daniel Dantas.

${ }^{24}$ Rafael Saldanha de Camargo é um empresário regional que atua em diversos ramos, especialmente o imobiliário. Também foi réu, juntamente com Geraldo Teotônio Jota, pelo assassinato das lideranças do MST Onalicio Araújo Barros (Fusquinha) e Valentim Silva Serra (Doutor), ocorrido no dia 26 de Março de 1998.

${ }^{25}$ Dão Baiano; fazendeiro local.

${ }^{26}$ Proprietários da empresa QUAMASA - Quagliato da Amazônia Agropecuária S/A.

${ }^{27}$ O proprietário foi acusado e preso por narcotráfico juntamente com seu comparsa, Luís Fernando da Costa (Fernandinho Beira Mar).
} 


\subsection{ADENTRANDO NOS ASSENTAMENTOS: DA LUTA PELA TERRA À LUTA PELA PERMANÊNCIA NA} TERRA.

Os assentamentos resultantes dos processos de luta pela terra tais como ocupações e acampamentos referem-se a frações do território importantes ao projeto territorial do movimento sem-terra, visto que materializam a força do sujeito coletivo e possibilitam a reprodução camponesa. Mesmo assim, os assentados possuam uma autonomia relativa nesses lugares, uma vez que, como assevera Alentejano (2008), o trabalho e a posse da terra fazem parte das relações de trabalho, mas não se referem a totalidade das relações de trabalho. Portanto, deve-se inegavelmente avaliar os condicionantes e disciplinamentos impostos pelo Projeto de Assentamento.

Segundo Neves (1999), o assentamento corresponde a uma unidade espacial que abriga particularidades. Constitui-se de uma unidade social local que é base da construção de identidades de pertencimento, a partir de vivências e trocas de experiências comuns. No seu interior, posições sociais são redefinidas, assim como as relações de poder e a visão de mundo. Sua organização social materializa a (re)constituição de posições sociais em decorrência do jogo de forças nos quais se sobressaem as demandas e pressões daqueles que se desejam beneficiários da propriedade da terra, expressando efeitos que a obtenção do lote lhes assegura, cujo benefício dependente de intervenções por parte de autoridades estatais, da rede de relações em que interagem seus demandantes, opositores ou apoiadores e de mediadores (aqueles sujeitos intermediários no processo de objetivação do assentamento, tais como movimentos sociais, sindicais, partidos políticos, técnicos agrícolas etc.). A inserção em um processo de assentamento se define por uma participação em situações de mudanças desejadas, necessárias ou impostas, visto que os assentados não são necessariamente incorporados em virtude de uma manifestação da vontade política, mas sim por serem atingidos por medidas que tem como alternativa única a mudança das visões de mundo. Nesse contexto, não se deve negligenciar o papel do Estado, ainda que como um sujeito de ações ora contrárias ora favoráveis aos objetivos dos assentados, visto que sua atuação é acionada permanentemente. Assim, os assentados devem se integrar a mudanças compulsórias, aderindo a um sistema de crenças que leve efeitos positivos às transformações, logo, é desejável que incorporem a ideia de que a conquista dos recursos é alcançada apenas se os assentados se constituírem enquanto grupos de interesse, com o intuito de influenciar o poder político a responder a suas demandas, seja por meio de manifestações seja institucionalizando suas lutas. 
Carvalho (1999), por seu turno, compreende que o assentamento refere-se ao conjunto heterogêneo de famílias de trabalhadores rurais que vivem e produzem em um dado imóvel rural desapropriado ou adquirido pelo Estado, para que este cumpra com os dispositivos constitucionais referentes à reforma agrária. Dessa maneira, o projeto de assentamento é um produto formal resultante de um ato administrativo. Entretanto, também é produto de lutas sociais que se desenvolvem por um período longo em busca da redistribuição da terra. Com efeito, o assentamento seria um ponto de inflexão histórica, visto que sua criação implica no encerramento de um determinado processo político-social marcado pelo monopólio da terra e pelo conflito e institui o início de outro, engendrado pelo desenvolvimento de uma nova organização econômica, política, social e ambiental na área destinada ao assentamento. Nesse espaço "plasmar-se-á uma nova organização social, um microcosmos social, quando o conjunto de famílias de trabalhadores rurais sem-terra passarem a apossar-se formalmente dessa terra" (CARVALHO, 1999, p. 8). Esse processo transitório entre desapropriação e assentamento cria um artificialismo com o parcelamento da terra, a construção de estradas, a definição da área destinada às moradias etc. Inicia-se uma outra superestrutura política e ideológica pela construção das associações, cooperativas, igrejas, pelas relações de vizinhança, dentre outras, permeadas pelo consenso e/ou conflito. Constituem-se novas relações com o poder público, movimentos sociais, sindicatos e demais sujeitos. Por fim, o autor destaca que nos assentamentos não estão "os assentados", e sim indivíduos distintos, que possuem uma biografia na qual está manifesta a diversidade psicossocial e experiências que seu viver dialeticamente o/com mundo lhe proporcionou.

Fernandes (2005) busca compreender os assentamentos pelo prisma do território. Para o autor, os assentamentos são "territórios compostos de diversos espaços políticos de acordo com as presenças de diferentes movimentos camponeses na organização socioterritorial" (2005, p. 127). Ele entende que a construção desses assentamentos remete ao debate da reforma agrária, para o Estado geralmente definida como uma política compensatória. Logo, o Estado objetiva diminuir os conflitos fundiários, mas, para os movimentos socioterritoriais, são territórios que expressam a possibilidade de transformação da sociedade e são resultantes da luta frequente e intensa dos movimentos camponeses. Com efeito, o conceito de reforma agrária tornou-se uma arena de disputa. Enquanto política compensatória, por um lado, imprime um processo de controle social dos movimentos por parte do Estado e com a interferência do capital, alçando reforçar a ideia do fim do campesinato. Por outro, a reforma agrária como revolução política de transformação socioeconômica implica um processo de enfrentamento contínuo tal qual é advogado por movimentos socioterritoriais, com destaque 
para aqueles vinculados à Via Campesina. Essas definições acerca do conceito de reforma agrária correspondem a territórios em disputa no interior da sociedade e se inserem no espaço de realização das lutas pela terra e pela reforma agrária, envolvendo um processo de ressocialização e exclusão, visto que os assentamentos são resultantes dos projetos políticos em desenvolvimento.

Inspirado em Sigaud (2005), para quem existe uma forma acampamento, podemos inferir que há uma forma assentamento, não no sentido do epifenômeno, ou seja, em sua apresentação em termos da paisagem apenas, mas considerando os elementos expostos pelos autores supracitados, desde uma perspectiva sociológica até uma mais geográfica. Com base nas pesquisas realizadas no sudeste paraense, podemos considerar os seguintes elementos para compreender os assentamentos:

1) correspondem a um espaço juridicamente legalizado resultante de um ato administrativo do Estado, via INCRA, para garantir a propriedade aos assentados que possuem enquanto benefícios um lote de terra, créditos agrícolas, infraestrutura físico-social (estrada, energia elétrica, posto de saúde, escola, casas etc.), política (associações, cooperativas, igrejas, dentre outras) e cultural (áreas destinadas ao esporte, praça...) - tais elementos dependem do grau de organização do grupo social para mobilizar e lutar por tais direitos, visto que embora sejam garantidos por lei, não são instalados ou ofertados adequadamente;

2) são oriundos de um longo processo de luta social via ocupação e/ou acampamento, geralmente articulada a um movimento socioterritorial e/ou sindical, que no caso do MST visa não apenas a redistribuição de terras, mas a construção de um projeto territorial contra-hegemônico, almejando disputar a compreensão da reforma agrária, no sentido de que ela se estenda para além de uma perspectiva de política compensatória e de controle social e instaure elementos de uma reforma agrária revolucionária;

3) Internamente é constituída por uma nova organização social, econômica e política, que foge à organização do latifúndio que outrora existia ali, porém ganha outros contornos em termos territoriais que ora convergem para as experiências da forma acampamento ora divergem, muito embora com o passar do tempo e pelo processo de complexificação interna (entrada de indivíduos que não participaram da ocupação, não possuem vínculos com o movimento, pequenas e médias empresas etc.) haja uma grande metamorfose nas relações de vizinhança, nas formas interagir e lutar pelas melhorias, podendo levar até uma cisão territorial e um 
afastamento/aproximação em graus e de natureza variadas com o movimento socioterritorial que ajudou na organização da luta pela terra;

4) $\mathrm{O}$ assentamento apresenta uma grande diversidade de sujeitos, cujas biografias, ou melhor, trajetórias geográficas ${ }^{28}$, se entrecruzaram, (re)constroem redes de sociabilidade e de identidade, constituem outras relações de poder na quais se sobressaem lideranças do movimento socioterritorial, presidentes de associações e/ou cooperativas, grupos que participaram do período do acampamento, indivíduos que adquiriam a terra no momento transitório ou posterior à criação do assentamento e apresentam poucos vínculos com a história de luta pelo território, dentre outros sujeitos que ora convergem em determinadas reivindicações para o PA ora divergem pela compreensão que possuem acerca da terra e das táticas de mobilização.

Os assentamentos do sudeste paraense são produto de ocupações desenvolvidas desde o final da década de 1970 e ao longo de 1980, momento de diversos conflitos fundiários. Entretanto, os PAs representam uma ação tardia do Estado em reconhecer uma situação de reforma agrária engendrada pelos próprios camponeses, visto que o assentamento não lhes proporcionou o acesso à terra. Pelo contrário, esse fato só ocorreu pela organização e luta coletiva travada pelos acampados/assentados. Desse modo, os PAs compreendem um direito adquirido pelos pequenos produtores, mediante a posse e o trabalho na terra desenvolvido há anos, independente e muitas vezes contra o Estado. Logo, o direito à terra pouco tem haver com as regras formais de propriedade, ao passo que o projeto de assentamento é consequência de várias iniciativas sociais que venham a lhes garantir melhorias, e é resultado de um processo jurídico-político, cuja elaboração é efetuada por instituições ou organizações externas ao mundo camponês (MAGALHAES, 2009).

Atualmente o estado do Pará apresenta 1.143 assentamentos em áreas que somam 23.528.098 de hectares, nos quais existe a capacidade de assentar 317.310 famílias. O sudeste do Pará, por sua vez, apresenta 501 projetos de assentamento com uma superfície territorial de 4.503.440 hectares, com capacidade de abrigar aproximadamente 91.693 famílias (SIPRA/INCRA-SR 01/27/30, 2016; Rede Dataluta, 2016). Esse número de famílias deve ser

\footnotetext{
${ }^{28}$ Por trajetória geográfica compreendemos os espaços de passagem ocupados pelos sujeitos dos processos de migração geralmente forçada - em decorrência de busca de serviços, assalariados ou não, em grandes projetos, garimpos, fazendas etc., - sujeitos desterritorializados em virtude da expropriação e/ou término do período do trabalho a quem é imposta a necessidade de viver na mobilidade, que se busca findar por meio da luta pela terra.
} 
relativizado, pois muitos assentamentos já sofreram um forte processo de crescimento populacional e de fragmentação dos lotes.

O Gráfico 9 identifica ao longo do período compreendido entre os anos de 1987 e 2016 a quantidade de assentamentos criados anualmente no sudeste paraense. Nele, sobressaem-se dois momentos ímpares com relação aos PAs. O primeiro se refere ao intervalo temporal de 1996 a 1999, quando se deu a criação de 204 assentamentos em quatro anos, durante a presidência de Fernando Henrique Cardoso (FHC). No entanto, é relevante observar que esse grande número de assentamentos sucedeu o conhecido Massacre de Eldorado de Carajás, ocorrido no dia 17 de abril de 1996, que culminou na morte de dezenove sem-terra, número oficial do Estado, contestado pelo MST e os sem-terra que estavam presentes no evento. Esse conflito entre a Polícia Militar (PM) e os sem-terra ocasionou uma forte pressão da opinião pública nacional e internacional e intensificou as ações dos movimentos sociais que clamavam pela reforma agrária. Esses eventos resultaram na criação de novos assentamentos. 
Gráfico 9 - Número de PAs criados por ano no sudeste paraense - 1987-2016

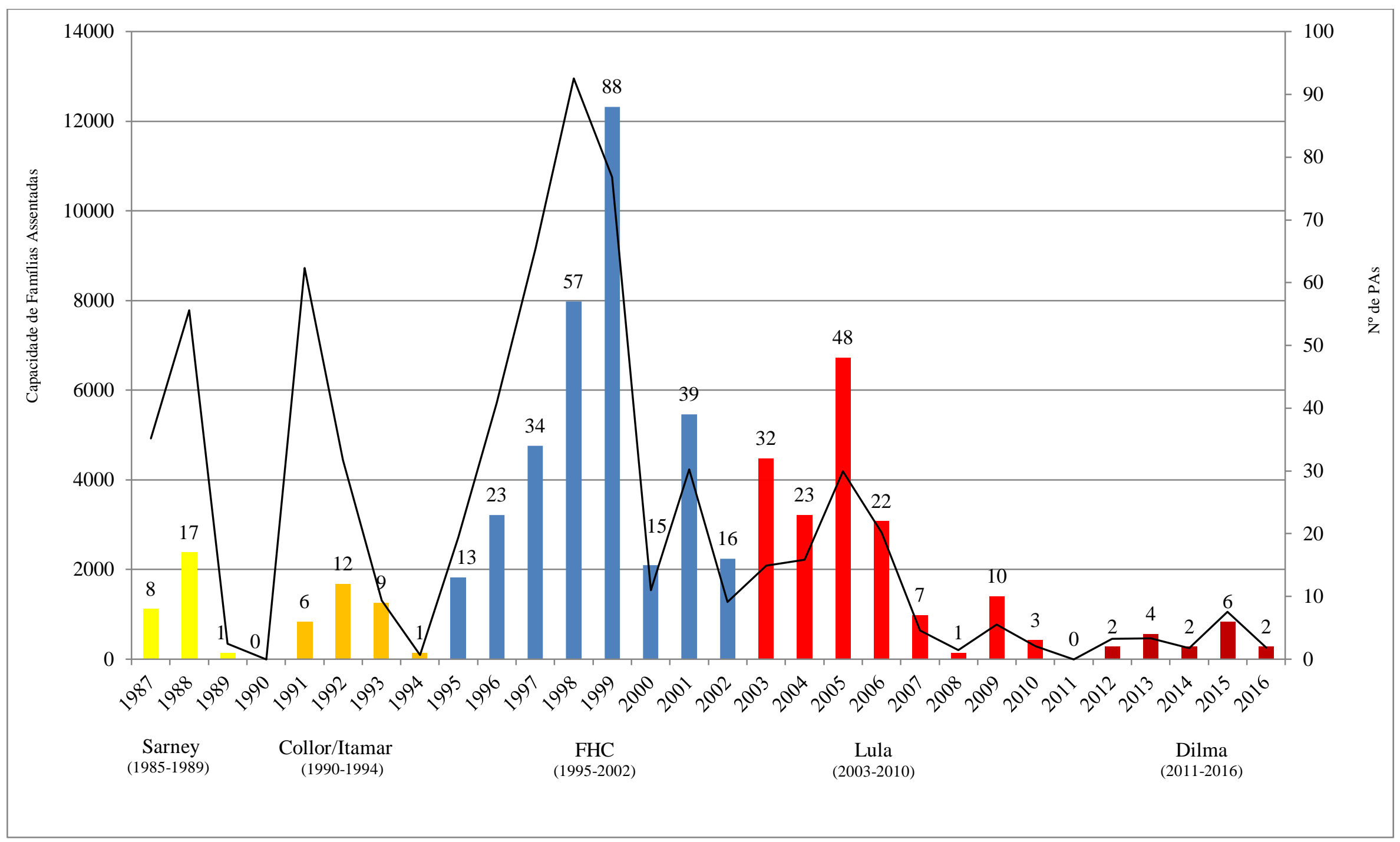

Fonte: INCRA/SIPRA, 2016; Rede Dataluta, 2016. Organização: Rogério Rego Miranda 
O segundo momento corresponde aos anos de 2003 e 2005, início do governo presidencial de "Lula", quando foram criados 108 PAs no sudeste paraense, por ocasião do aumento de acampamentos na região, como forma de pressionar a implementação da reforma agrária na gestão do Partido dos Trabalhadores (PT). No entanto, é notório que após esse período inicial do mandato, há uma diminuição considerável no número de novos assentamentos.

Apesar de esses assentamentos sofrerem intervenções estatais e privadas e disciplinamentos decorrentes de determinadas relações desenvolvidas com o mercado, variando em grau de acordo com os assentamentos pesquisados, é importante destacar que eles representam uma relativa mudança na geografia regional, marcadamente concentracionista em termos fundiários; embora essa concentração seja ainda bastante forte, os PAs compõem uma parte significativa do território, conforme podemos observar na Tabela 7.

Tabela 7 - Número de assentamentos por microrregião do sudeste paraense e o percentual ocupado pelo território -2016.

\begin{tabular}{|c|c|c|c|c|}
\hline $\begin{array}{c}\text { Meso/ } \\
\text { Microrregiões } \\
\text { do Sudeste } \\
\text { Paraense }\end{array}$ & $\begin{array}{c}\text { Número de } \\
\text { Assentamentos }\end{array}$ & $\begin{array}{c}\text { Território dos } \\
\text { assentamentos } \\
\left(\mathrm{Km}^{2}\right)\end{array}$ & $\begin{array}{c}\text { Território total } \\
\text { da meso/ } \\
\text { microrregião } \\
\left(\mathrm{Km}^{2}\right)\end{array}$ & $\begin{array}{l}\text { \% do território dos } \\
\text { assentamentos em } \\
\text { relação a } \\
\text { meso/microrregião } \\
\left(\mathrm{Km}^{2}\right) \\
\end{array}$ \\
\hline $\begin{array}{c}\text { Sudeste } \\
\text { Paraense }\end{array}$ & 501 & $45.036,43$ & $297.344,257$ & 15,14 \\
\hline Tucuruí & 98 & $10.784,64$ & $32.916,68$ & 32,76 \\
\hline Araguaia & 89 & $8.685,08$ & $31.195,31$ & 27,84 \\
\hline Marabá & 110 & $5.325,59$ & $19.936,31$ & 26,71 \\
\hline Redenção & 78 & $3.823,60$ & $21.269,42$ & 17,97 \\
\hline Parauapebas & 51 & $3.842,77$ & $23.056,37$ & 16,66 \\
\hline $\begin{array}{l}\text { São Félix do } \\
\text { Xingu }\end{array}$ & 30 & $9.420,25$ & $120.592,56$ & 7,81 \\
\hline Paragominas & 45 & $3.152,49$ & $48.377,60$ & 6,51 \\
\hline
\end{tabular}

Fonte: SIPRA SR-27, 2016; IBGE, 2014. Organização: Rogério Rego Miranda.

A Tabela 7 revela que os assentamentos representam praticamente um terço da área total de microrregiões importantes do ponto de vista agrário e mineral, a exemplo de Marabá, que possui diversas fazendas, empreendimentos hidrelétricos, grupos fortes do agronegócio e empresas siderúrgicas; no campo oposto, embora os assentamentos não possuam mais de $10 \%$ da área de determinadas microrregiões, ocupam espaços considerados estratégicos para o capital, com destaque para a microrregião de Parauapebas, que apresenta diversos projetos minerais da VALE. 
Especificamente os assentamentos organizados pelo MST no sudeste paraense somam um total de nove, a saber: $1^{\circ}$ de Março, 26 de Março, 17 de Abril, Cabanos, Canudos, Lourival Santana, Palmares II, Onalício Barros e Nega Madalena, dispostos espacialmente no eixo agropecuário e mineral, tal qual as ocupações e acampamentos, conforme podemos visualizar no Mapa 10.

A forma assentamento que resulta desses territórios expressa os períodos históricos de sua construção, as múltiplas temporalidades provenientes de trajetórias geográficas díspares dos sujeitos que compõem o assentamento, relações de poder que diferenciam os sujeitos e provocam processos de contradição e conflito interno, potencial diferenciado de construção de um projeto contra-hegemônico.

Neste contexto é importante sublinhar que o processo transitório de acampamento para assentamento é marcado por ações específicas, nas quais há um envolvimento ativo do MST. Primeiramente, há a negociação junto ao INCRA da área destinada à criação do projeto de assentamento. Após essa etapa, ocorre a definição coletiva, por meio de assembleias, acerca da organização espacial do futuro assentamento. Nesse momento, os acampados definem se o PA terá uma vila central (agrovila) ou se haverá vilas circulares: na agrovila central se localizam as principais infraestruturas coletivas e cada assentado tem uma parcela de terra para moradia, além dos lotes onde desenvolvem suas atividades agropecuárias e/ou extrativistas, os quais são entrecortados por vicinais e estão dispostos de maneira perpendicular à vila (como em Palmares II, 17 de Abril, $1^{\circ}$ de Março, Canudos, Nega Madalena, Lourival Santana e Onalício Barros); no caso de várias vilas circulares, estas tomam como refrência os núcleos de base, que orientam a disposição dos lotes circundantes, de forma que todos os lotes destinados à produção ficam próximos à área coletiva, projeto denominado de "raio de sol” (são assim os assentamentos Cabanos e 26 de Março). 
Mapa 10 - Assentamentos organizados pelo MST - Sudeste Paraense, 2016.

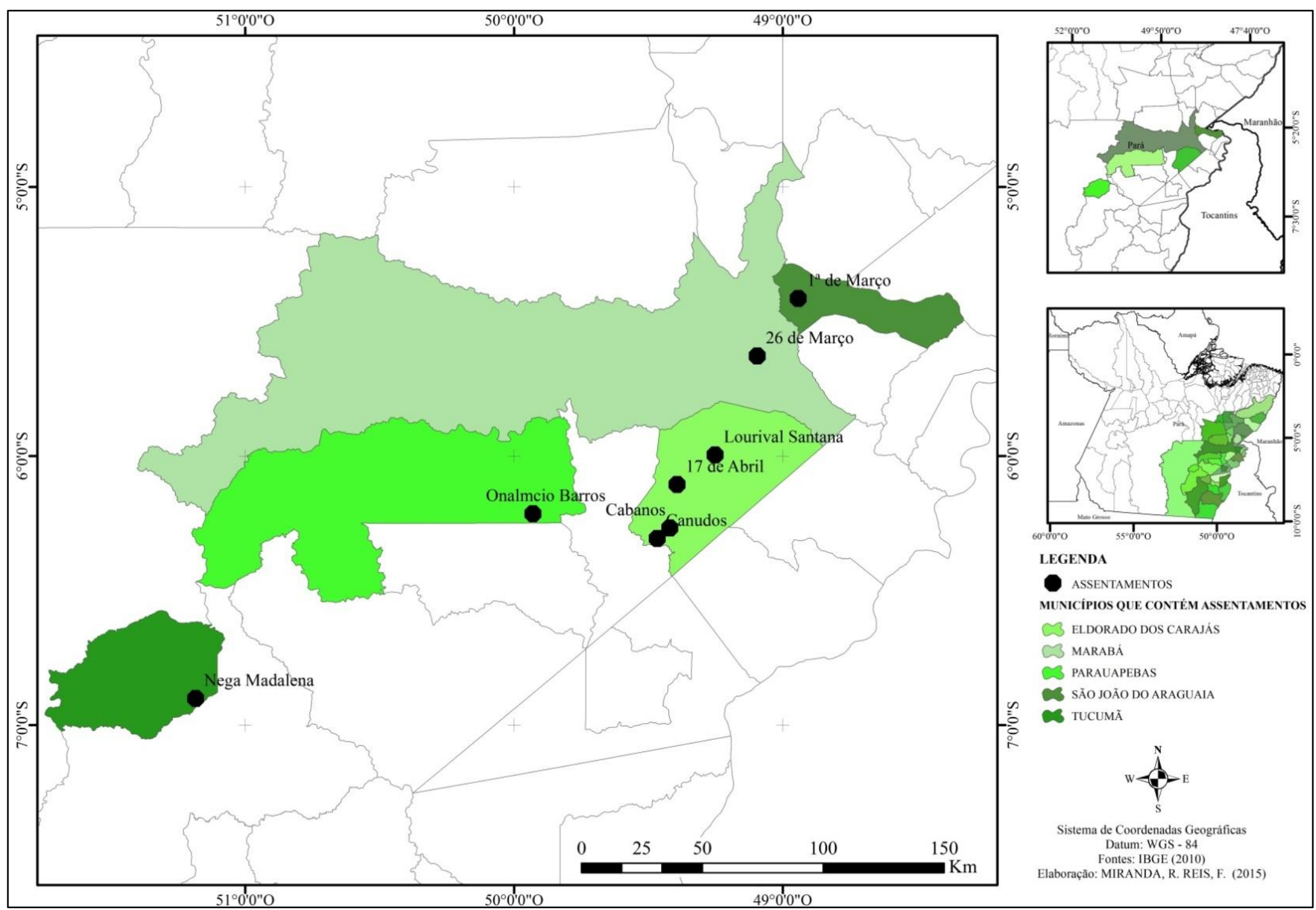

Fonte: IBGE, 2016. Organização: Rogério Rego Miranda. Desenho: Francisco Renan da Silva Reis. 
Então, é feita a divisão do assentamento por quadras, limitadas por vicinais, cursos d'água, a vila ou vilas etc. Cada quadra é composta por um conjunto de lotes cujo número varia de acordo com o total de famílias que compõe o núcleo de base existente no acampamento. Se existem, por exemplo, dez núcleos de base contendo 9 famílias cada, devem existir 10 quadras com 9 lotes cada.

Após definir o projeto, os futuros assentados fazem o sorteio dos lotes em uma assembleia, momento em que a área do PA já está devidamente parcelada e numerada. Esse procedimento corresponde ao rito "final" de passagem da condição de sem-terra para a de assentado, e há uma grande reunião das famílias para a definição de seus lotes. Os números correspondentes às parcelas de terra são colocados dentro de um saco ou fronha e cada núcleo familiar tem seu representante chamado para retirar o número referente a sua área.

É importante salientar que esse sorteio é realizado em duas etapas: na primeira, o representante (coordenador) do núcleo de base retira o número referente à quadra que será o local de vivência dos familiares; a segunda etapa corresponde ao sorteio do lote individual de cada família do núcleo de base na quadra definida anteriormente.

As áreas apresentam diferenciações geográficas, como proximidade da vila, da estrada principal, abundância ou não de água, área de pasto ou de mata, o que pode influenciar nas atividades que serão desenvolvidas. Esses e outros elementos provocam ansiedade, tristeza, frustração, felicidade, enfim, vários sentimentos que se misturam, pois cada um em seu imaginário já havia escolhido a porção que mais lhe agradava por conhecer bastante o território que outrora era uma fazenda e por ter expectativas atreladas a sua trajetória geográfica (atividades que desenvolveram anteriormente, formas de uso da terra com que estão mais acostumados etc.). Por esses motivos não são incomuns as "trocas de lotes": por exemplo, famílias que estão mais envolvidos com a agricultura ou extrativismo preferem a área de mata e permutam sua área de pastagem com famílias de vaqueiros, e assim por diante.

O sentido desse "rito" de passagem é buscar (re)criar no assentamento as relações de proximidade/vizinhança existentes no acampamento, para que permaneça ou se amplie a solidariedade entre os sujeitos e estes possam desenvolver projetos coletivos e prestar ajuda mútua.

Entretanto, como indicado anteriormente, ao longo dos anos há um processo de complexificação social e territorial internamente, que se define histórica e geograficamente em função do grau e da natureza do avanço do capital, que na região se atrela principalmente à dinâmica da mineração e da agropecuária. Nesse contexto, grosso modo, podemos categorizar alguns grupos sociais dos assentamentos, considerando alguns aspectos, a saber: a 
relação que estabelecem com a terra, a relação que desenvolvem com os sujeitos internos, a lógica produtiva e a relação com o MST.

Primeiramente observamos os assentados antigos, que participaram da ocupação ou tiveram familiares que estiveram nesse momento da luta pela terra e que buscam permanecer no assentamento, compreendendo-o como local de reprodução do seu núcleo familiar, espaço de resistência, abrigo, sossego, liberdade, trabalho e reconhecimento social da sua existência pelo governo e pela sociedade local, embora a mobilização por melhorias nas condições de existência continue (créditos, assistência técnica, energia elétrica...). Sua trajetória geográfica "mais recente" advém da condição de acampado, cuja luta era pela possibilidade de sair da posição de migrante, tendo em vista sua forte instabilidade territorial, não possuindo controle sobre o fluxo no/do território, inclusive do seu corpo e de seus familiares, concorrendo para o eminente processo de expropriação que é marcante em sua vida. Daí o assentamento (ou ser assentado) proporcionar-lhe segurança e estabilidade de seu território, ainda que relativa. É a conquista do direito de decidir sobre se fixar em um mundo que se define (embora não apenas) pelo fluxo.

Sua base produtiva é diversificada, embora se sobressaia a criação do gado de corte e especialmente de leite, que o insere em um sistema de dependência com atravessadores, empresas locais de laticínios ou fazendeiros. Em grande parte, a produção se realiza mediante trabalho familiar, utilizando o trabalho temporário em momentos específicos (colheita, utilização de veneno, construção de cerca, retirada da juquira, dentre outros), cujo pagamento se realiza pela "diária rural" no valor de $\mathrm{R} \$ 50,00$; também se realiza pela empreita (paga-se pelo total do serviço envolvido com uma porcentagem da produção); ou ainda pela "troca de diária", em que os assentados se comprometem em desenvolver determinadas atividades nos lotes um do outro, sem a mediação do dinheiro. A maior parte da labuta é feita com trabalho braçal e pouco uso de tecnologias ou maquinários, a não ser em momentos e lugares específicos em que são servidos com políticas públicas municipais. Sua relação com o MST ainda é forte seja por ser liderança seja por continuar a participar das reuniões internas ou externas do movimento; a estratégia de resistência possui fortes vínculos com o movimento, a exemplo do que acontece em menor ou maior grau para todos os assentamentos pesquisados.

Um segundo grupo é o dos pequenos agricultores que compraram os benefícios existentes nos lotes de antigos assentados que se desfizeram da propriedade por motivo de doença e/ou velhice ou por preferirem voltar para a cidade (nesse caso particular geralmente são pessoas mais novas que receberam o lote no início da transição para assentamento ou por herança de seus familiares); nesse grupo estão incluídos os que foram assentados pelo INCRA 
por um processo de retomada do lote. Esses sujeitos não participaram do processo de construção da luta pelo território do assentamento, logo, são despojados de vínculos com a história local e com o movimento. Entretanto são pessoas de menor poder aquisitivo e possuem entre um e no máximo dois lotes, tal qual aos assentados antigos, desenvolvem com eles relações de sociabilidade próximas e acabam incorporando suas estratégias de mobilização. Igualmente mantêm com a terra uma relação de trabalho para a reprodução do núcleo familiar e estão imersos nas mesmas relações de dependência econômica e de relações de trabalho que o primeiro grupo social.

Em terceiro lugar, temos os médios proprietários pecuaristas que fazem parte da história recente do assentamento e foram adquirindo vários lotes de terras, geralmente justapostos, por meio da compra, ainda que de maneira irregular. Em alguns casos extremos a aquisição da propriedade ocorreu por meio da coerção, como foi possível registrar no PA $1^{\circ}$ de Março. Esses sujeitos apresentam uma renda muito superior à média dos assentados e detém equipamentos modernos, como tratores (alugados por hora aos assentados menos capitalizados ao preço de $\mathrm{R} \$ 150,00)$, insumos agrícolas, mão de obra assalariada, como vaqueiros, e assistência técnica particular, assim como transporte para escoar a produção, em geral leite e, principalmente, gado de corte (negociado com açougues da região ou grandes empresas como a JBS, caso registrado no assentamento $1^{\circ}$ de Abril). Seus vínculos são muito mais externos do que internos, visto que possuem, além de atividades dentro do assentamento, outras nas cidades próximas.

Por fim, no limite observamos pequenos e médios incorporadores que adquiriram lotes para parcelá-los e criar chácaras para venda, tendo em vista a posição geográfica de proximidade com o rio e a cidade de Parauapebas, a exemplo do que ocorre em Palmares II. Igualmente, existem casos singulares da presença de empresas exploradoras de areia no assentamento Onalício Barros e de outras que trabalham com garimpo ilegal, em Nega Madalena.

Essa diversidade de sujeitos que hoje compõe de maneira mais duradoura (assentados antigos, pequenos agricultores, assentados pelo INCRA e médios proprietários pecuaristas) ou periódica (incorporadores, empresas exploradoras de areia e de garimpo) os assentamentos leva a disputas territoriais e a fortes contradições e conflitos internos, com especificidades em cada assentamento.

O Quadro 5 a seguir revela algumas contradições gerais resultantes do processo histórico que culminou na metamorfose territorial nos assentamentos: observamos que a organização espacial de proximidade entre os sujeitos, com referência nos núcleos de base do 
acampamento, foram gradativamente redefinidas em função da entrada de novos sujeitos econômicos e da necessidade de os sujeitos se voltarem para a produção individual em seus lotes, devido à reprodução do núcleo familiar, a dívidas contraídas pelo financiamento da produção e aos insucessos em ações mais cooperativas. Os conflitos internos decorrem de uma relação marcada pela relativa perda de solidariedade entre os assentados, embora ainda permaneçam a ajuda mútua e a interação pessoal próxima, especialmente entre assentados antigos, pequenos agricultores e assentados pelo INCRA.

Igualmente observamos conflitos provenientes de situações singulares, como ocorre nos PAs Onalício Barros e Palmares II, hoje atingidos pela duplicação da EFC, o que os levou a realizar manifestações e ocupações da via férrea, já que a VALE pouco considera os anseios dos assentados e os problemas que gera nessas realidades, fechando-se à negociação. No PA Nega Madalena, em virtude de problemas relativos às dificuldades de escoamento da produção, à ineficiência da assistência técnica e do financiamento da produção e à baixa renda dos assentados, muitos cedem parte do lote para que empresas relacionadas ao garimpo explorem ouro em suas terras concedendo-lhes uma porcentagem do que for encontrado. 
Quadro 5 - Principais contradições e conflitos nos projetos de assentamento organizados pelo MST no sudeste paraense

\begin{tabular}{|c|c|c|c|}
\hline Município & $\begin{array}{c}\text { Projeto de } \\
\text { assentamento }\end{array}$ & Contradições & Conflitos \\
\hline \multirow[t]{2}{*}{ Parauapebas } & Palmares II & $\begin{array}{c}\text { Alguns loteamentos rurais foram transformados em chácaras } \\
\text { destinadas ao lazer de pessoas oriundas de Parauapebas e } \\
\text { municípios próximos. }\end{array}$ & $\begin{array}{l}\text { Perda relativa da relação de solidariedade devido a entrada de } \\
\text { sujeitos alheios ao movimento e às formas de organização interna; } \\
\text { conflitos com a VALE por conta dos impactos causado pela } \\
\text { exploração mineral e da passagem da EFC no PA e sua } \\
\text { duplicação, tais como trepidação e rachadura nas casas, morte de } \\
\text { animais etc. }\end{array}$ \\
\hline & Onalício Barros & $\begin{array}{l}\text { Algumas áreas foram destinadas à exploração da areia por } \\
\text { empresas locais. }\end{array}$ & $\begin{array}{l}\text { Perda relativa da relação de solidariedade devido à entrada de } \\
\text { sujeitos alheios ao movimento e às formas de organização interna; } \\
\text { conflitos com a VALE por conta dos impactos que serão } \\
\text { provocados pela duplicação da EFC. }\end{array}$ \\
\hline \multirow{3}{*}{$\begin{array}{l}\text { Eldorado dos } \\
\text { Carajás }\end{array}$} & 17 de Abril & $\begin{array}{c}\text { Alguns lotes foram vendidos e/ou convertidos em terras de } \\
\text { negócio, destinadas à produção agropecuária, inclusive com } \\
\text { acumulação de vários lotes por empresários locais ou do sudeste } \\
\text { paraense. }\end{array}$ & \multirow{3}{*}{$\begin{array}{l}\text { Perda relativa da relação de solidariedade devido à entrada de } \\
\text { sujeitos alheios ao movimento, que priorizam a terra de negócio, } \\
\text { são contrários às formas de luta para obter melhorias no PA, tais } \\
\text { como as manifestações, e se colocam em discordância com a ação } \\
\text { do MST. }\end{array}$} \\
\hline & $\frac{\text { Cabanos }}{\text { Canudos }}$ & \multirow[b]{4}{*}{$\begin{array}{l}\text { Houve venda de alguns lotes para terceiros, o que provocou } \\
\text { alterações nas relações internas, e se intensificou a produção de } \\
\text { leite e de gado para corte. }\end{array}$} & \\
\hline & Lourival Santana & & \\
\hline Marabá & 26 de Março & & \multirow[b]{2}{*}{$\begin{array}{l}\text { Perda relativa da relação de solidariedade devido à entrada de } \\
\text { sujeitos alheios ao movimento que priorizam a terra de negócio, } \\
\text { são contrários às formas de luta para obter melhorias no PA, tais } \\
\text { como as manifestações, e se colocam em discordância com a ação } \\
\text { do MST. Nessa realidade há casos de conflitos físicos com médios } \\
\text { proprietários e/ou comerciantes que atuam na região, para forçar a } \\
\text { venda de lotes de alguns assentados. }\end{array}$} \\
\hline $\begin{array}{l}\text { São João do } \\
\text { Araguaia }\end{array}$ & $1^{\circ}$ de Março & & \\
\hline Tucumã & Nega Madalena & $\begin{array}{l}\text { Exploração clandestina de ouro nos lotes dos assentados, levando a } \\
\text { problemas de uso do solo. }\end{array}$ & $\begin{array}{c}\text { Perda relativa da relação de solidariedade devido à entrada de } \\
\text { sujeitos alheios ao movimento que priorizam a terra de negócio, } \\
\text { são contrários às formas de luta para obter melhorias no PA, tais } \\
\text { como as manifestações, e se colocam em discordância com a ação } \\
\text { do MST. }\end{array}$ \\
\hline
\end{tabular}

Fonte: Pesquisa de campo, 2016. 
Por fim, no PA $1^{\circ}$ de Março existem médios proprietários pecuaristas que criam situações para obrigar os assentados a vender suas terras: estes não possuem condições de cercar seus lotes adequadamente e acabam tendo suas áreas invadidas pelos animais dos médios proprietários, como porcos e gado, que comem ou destroem as plantações dos assentados; quando eles reclamam são ameaçados e, no limite, têm como única saída vender seus lotes para aqueles que os coagiram. No PA $1^{\circ}$ de Março também existe a possibilidade de alagamento parcial de algumas áreas em decorrência da construção da Hidrelétrica de Marabá (ver o trabalho de SILVA, 2014), levando os assentados a reivindicarem a regularização fundiária como forma de ter melhores condições de negociação em termos de indenizações ou mesmo para forçar a permanência no lugar.

Nessas realidades, se o MST possuía uma inserção permanente e significativa agora passa a ter sua atuação relativizada e em muitas situações, negada. Os símbolos do movimento começam a ser questionados pelos novos sujeitos, a exemplo da placa com a bandeira do MST na entrada do assentamento que muitas vezes é destruída; a mística que animava e reproduzia por meio lúdico a história da conquista do assentamento na data do seu aniversário de criação é substituída pela "cavalgada" (expressão cultural dos fazendeiros da região) ou compete com ela; as estratégias de luta como o bloqueio de estradas, ocupação do INCRA, marchas etc. são intitulados de práticas de baderneiros; outras associações desvinculadas do movimento são criadas; dentre outras práticas.

Para qualificarmos de maneira mais aprofundada os sujeitos que vivem nos assentamentos, discutiremos a seguir sua origem migratória, profissões exercidas antes de serem assentados, sua produção, sua renda, dentre outros elementos, tomando como referência os 689 questionários aplicados em nove assentamentos, conforme indicado na introdução desta tese.

Os assentados, como ilustra o Gráfico 10, são em grande parte migrantes oriundos do Maranhão e somam 48,33\% (333 assentados); ainda, 27,30\% dos indivíduos pesquisados (187 assentados) são de outros estados do Nordeste brasileiro; 5,9 \% (39 assentados) são da região Centro-Oeste; 5,9 \% (39 assentados) advêm do Sudeste; 1,50\% (5 assentados) migraram do Sul; por fim, 0,30\% (1 assentado) veio de Rondônia. Há também aqueles que migram internamente no estado do Pará, dos quais 10,60\% (73 assentados) são do próprio sudeste paraense e os outros 1,74\% (12 assentados), das mesorregiões nordeste e sudoeste do Pará. 
Gráfico 10 - Trajetória geográfica dos assentados.

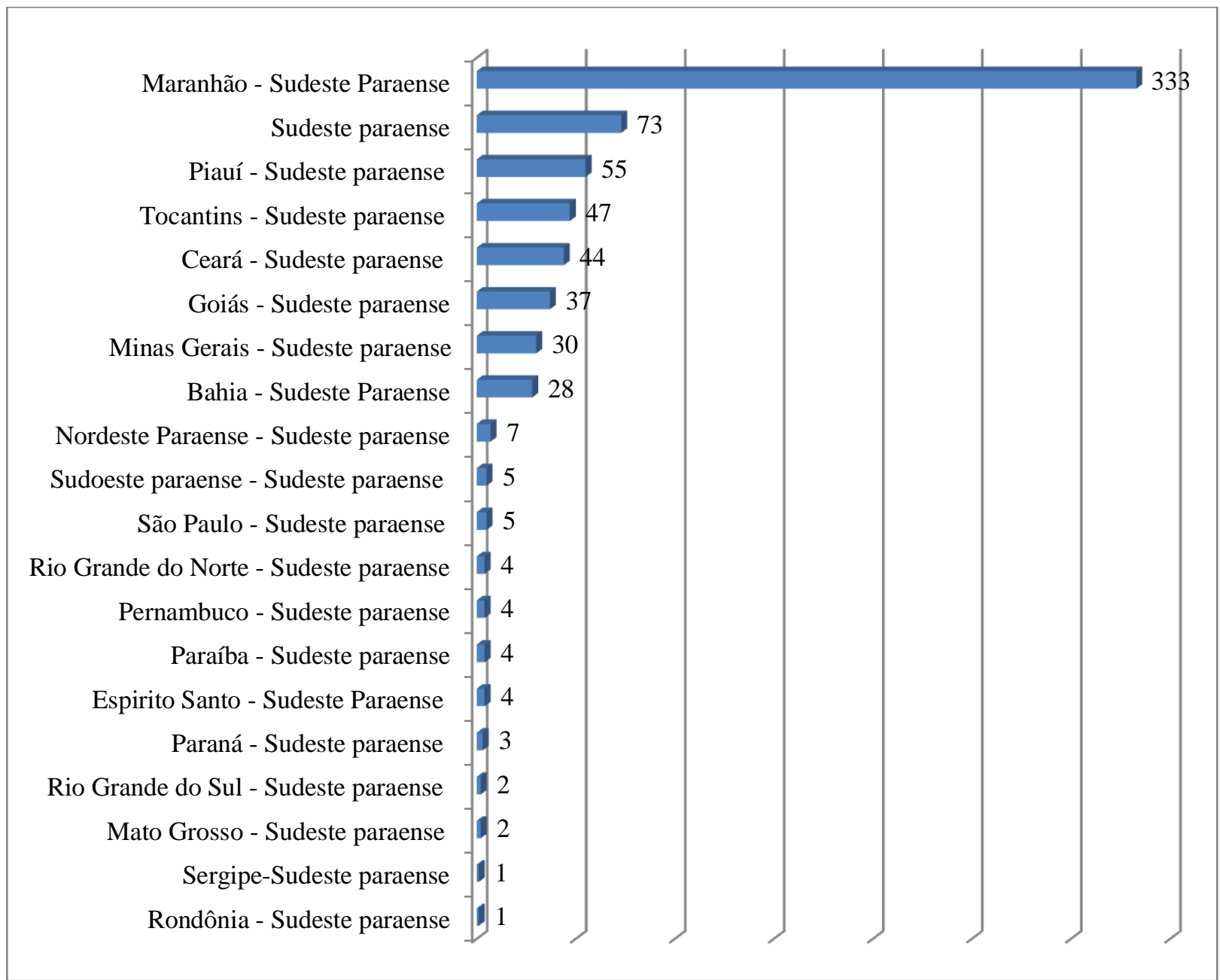

Fonte: Pesquisa de campo, 2016.

Os sujeitos que hoje vivem nos assentamentos desenvolviam atividades agrícolas anteriormente: 43,54\% dos pesquisados (300 assentados) afirmaram ser lavradores, trabalhando junto com seus pais ou para terceiros; outros 21,19\% (146 assentados) revelaram ter trabalhado no garimpo, ainda no período de Serra Pelada, especialmente na década de 1980 e início de 1990, ou em garimpos clandestinos que ainda hoje existem; também identificamos que 3,92\% (27 assentados) executavam outras atividades no espaço agrário eram carvoeiros, quebradeiras de coco babaçu, pescadores e madeireiros. Outros 31,49\% (217 assentados) indicaram trabalhar em atividades assalariadas ou não na área de marcenaria, construção civil, mineração, dentre outras (ver Gráfico 11). 
Gráfico 11 - Profissões exercidas antes de serem assentados.

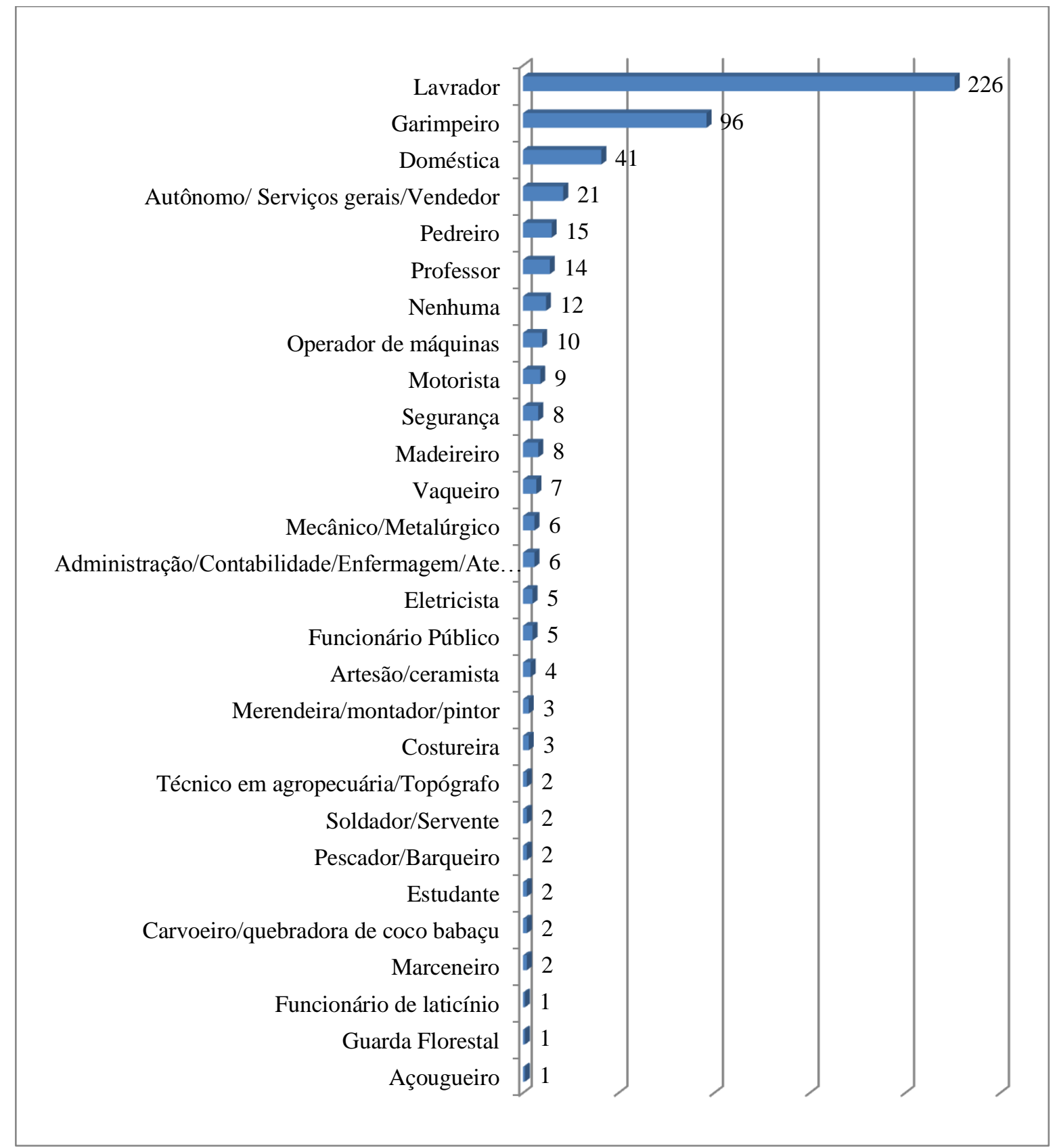

Fonte: Pesquisa de campo, 2016.

É importante salientar que uma parte dos assentados que atualmente residem no local não participou diretamente da ocupação das áreas dos seus respectivos assentamentos (cerca de 248 pessoas, 35,99\% do total - ver Gráfico 12), porque esses sujeitos constituem uma geração posterior ao período de luta pela terra, ou seja, é o(a) filho(a) que hoje ajuda na labuta diária. Existem situações em que parentes que outrora viviam em lugares diferentes passam a morar no assentamento e há pessoas que compraram os benefícios que existiam no lote ou requereram o lote comprando-o (221 pessoas declararam essa condição, compreendendo $32,08 \%$ do total de assentados - ver Gráfico 13). Ressaltamos que cerca de 62,70\% (432 
assentados) declararam que participaram da ocupação da fazenda que originou o PA e 66,47\% (458 assentados) afirmaram que não adquiriram a terra por meio da compra.

Gráfico 12 - Participação na ocupação da terra e no período do acampamento.

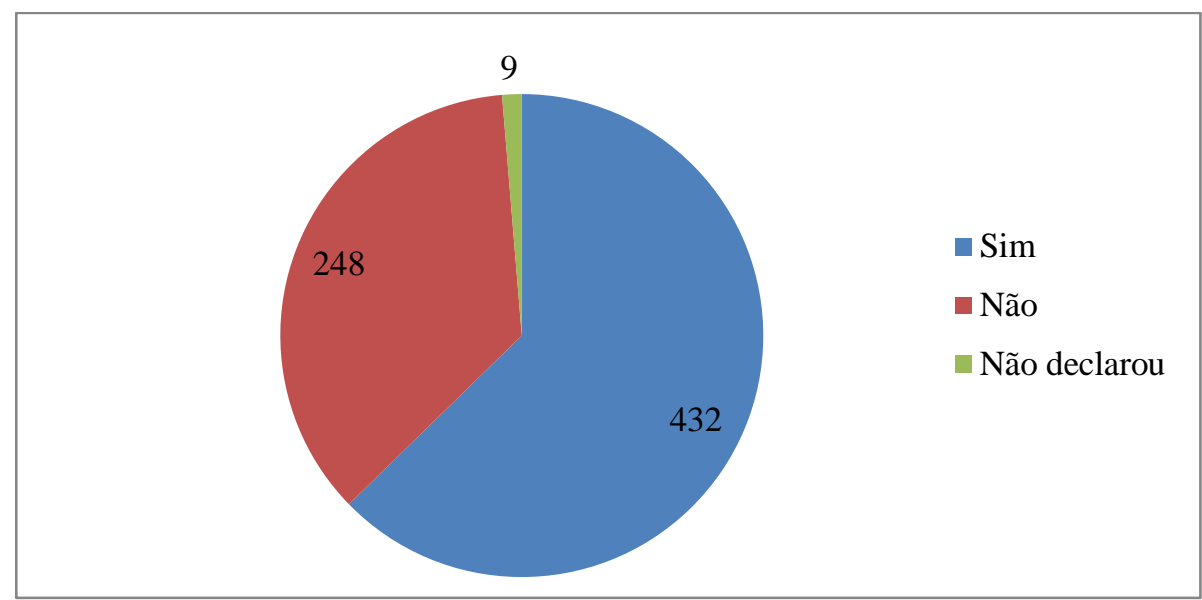

Fonte: Pesquisa de campo, 2016.

Gráfico 13 - Terra obtida por meio da compra

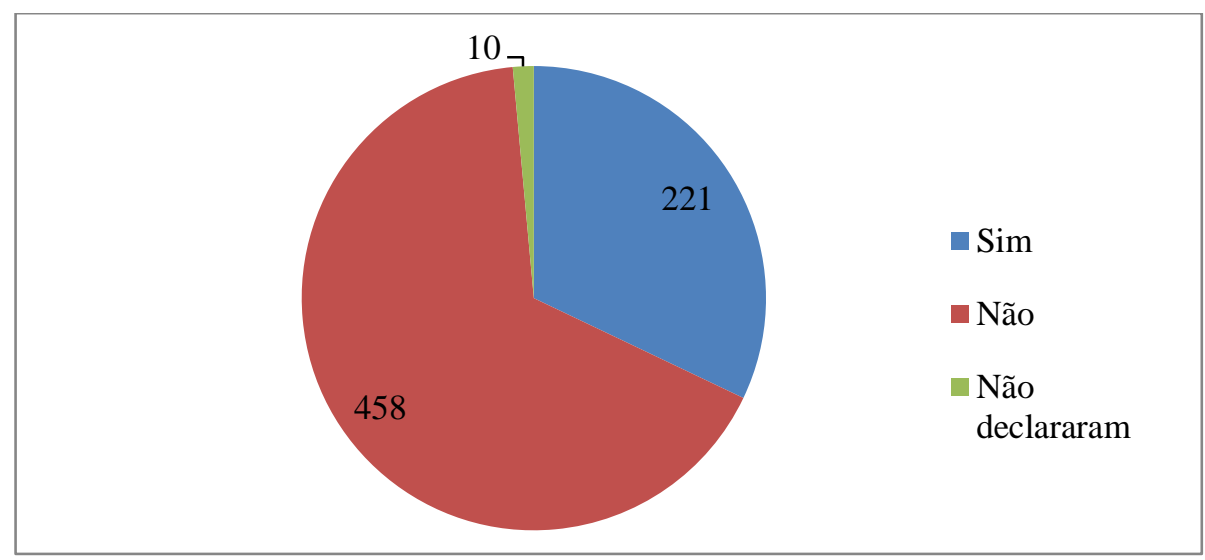

Fonte: Pesquisa de campo, 2016.

Com relação à renda média familiar dos assentados, observamos que 23,37\% (161 assentados) declararam receber um salário mínimo e meio; 16,98\% (117 assentados) indicaram possuir uma renda mensal de um salário mínimo; 14,37\% (99 assentados) ganham acima de dois salários; 7,55\% (52 assentados) informaram possuir ganhos em torno de dois salários mínimos; e 24,53\% (169 assentados) possuem uma renda oscilando entre $\mathrm{R} \$ 1,00$ e R \$800,00; ao passo que 7,98\% (55 assentados) relataram não possuir nenhuma renda; e $5,22 \%$ (36 assentados) não souberam ou não quiseram informar a renda (ver Gráfico 14). É importante notar que aqueles que recebem a partir de um salário mínimo desenvolvem atividades na agricultura e em outro setor, têm filhos empregados nas empresas próximas, 
possuem assistência por alguma política pública municipal que garante o acesso de seus produtos em feiras, a exemplo de Parauapebas, são aposentados ou recebem beneficio e/ou vendem sua produção diretamente para empresas, especialmente de laticínios.

Gráfico 14 - Renda média dos assentados.

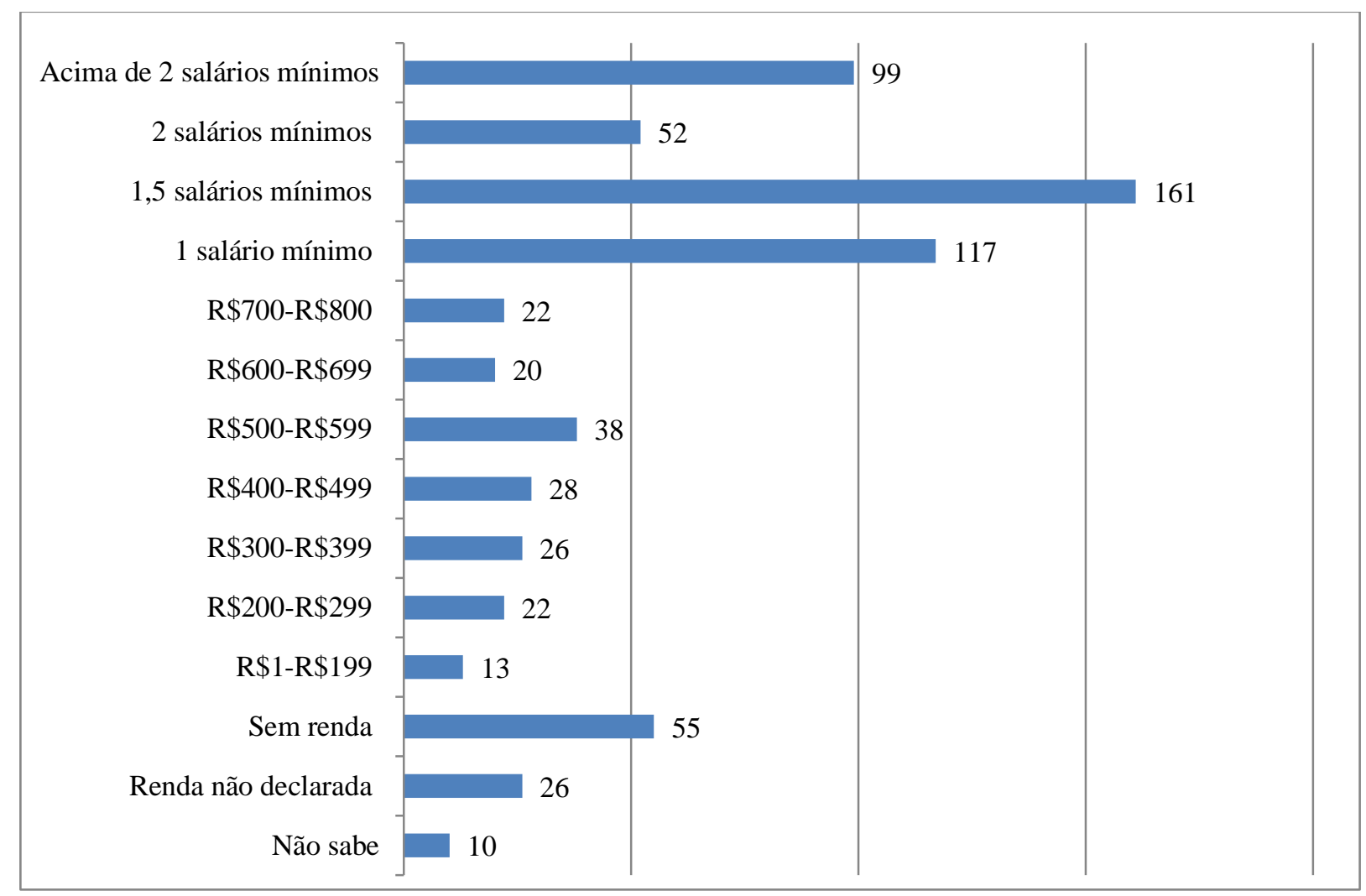

Fonte: Pesquisa de campo, 2016.

A produção desses sujeitos é diversificada e baseada no mercado de excedentes (MARTINS, 2009), de modo que a mão de obra familiar é fundamental para a reprodução dos assentados, haja vista a baixa renda que possuem, logo, produzem para sua sobrevivência e destinam uma parte dos víveres à venda, realizada através de atravessadores ou nas feiras das cidades mais próximas.

Desta feita, o Gráfico 15 ilustra que 689 pessoas plantam frutas regionais e outras variações (açaí, manga, cupuaçu, laranja etc.) e apresentam uma grande diversidade de cultivos como verduras, hortaliças, arroz, feijão, fava, mandioca e milho, além do capim para o gado: 536 pessoas declararam trabalhar com rebanho bovino (ver Gráfico 16), uma das principais criações dos assentados por conta de o leite servir de alimento diário e ser facilmente vendido para atravessadores, principalmente para empresa de laticínio localizada em Eldorado de Carajás (Laticínios Fortaleza S.A.). Outro fator que explica a elevada criação 
bovina é que os créditos concedidos via Pronaf são, em certa medida, direcionados para essa atividade, sob alegação de rentabilidade mais rápida; no entanto, isso atrela o camponês a um conjunto de relações de dependência com o banco, que concede o financiamento, com fazendeiros locais, que compram e vendem os bezerros aos assentados, e com empresas e atravessadores, que definem o preço do leite e da cabeça de gado comercializados na região. Além do gado, observamos a criação de equinos, utilizados no transporte das mercadorias e pessoas, caprinos, aves, porcos e peixe, vendidos e/ou consumidos pelo núcleo familiar.

Gráfico 15 - Cultivos desenvolvidos pelos assentados.

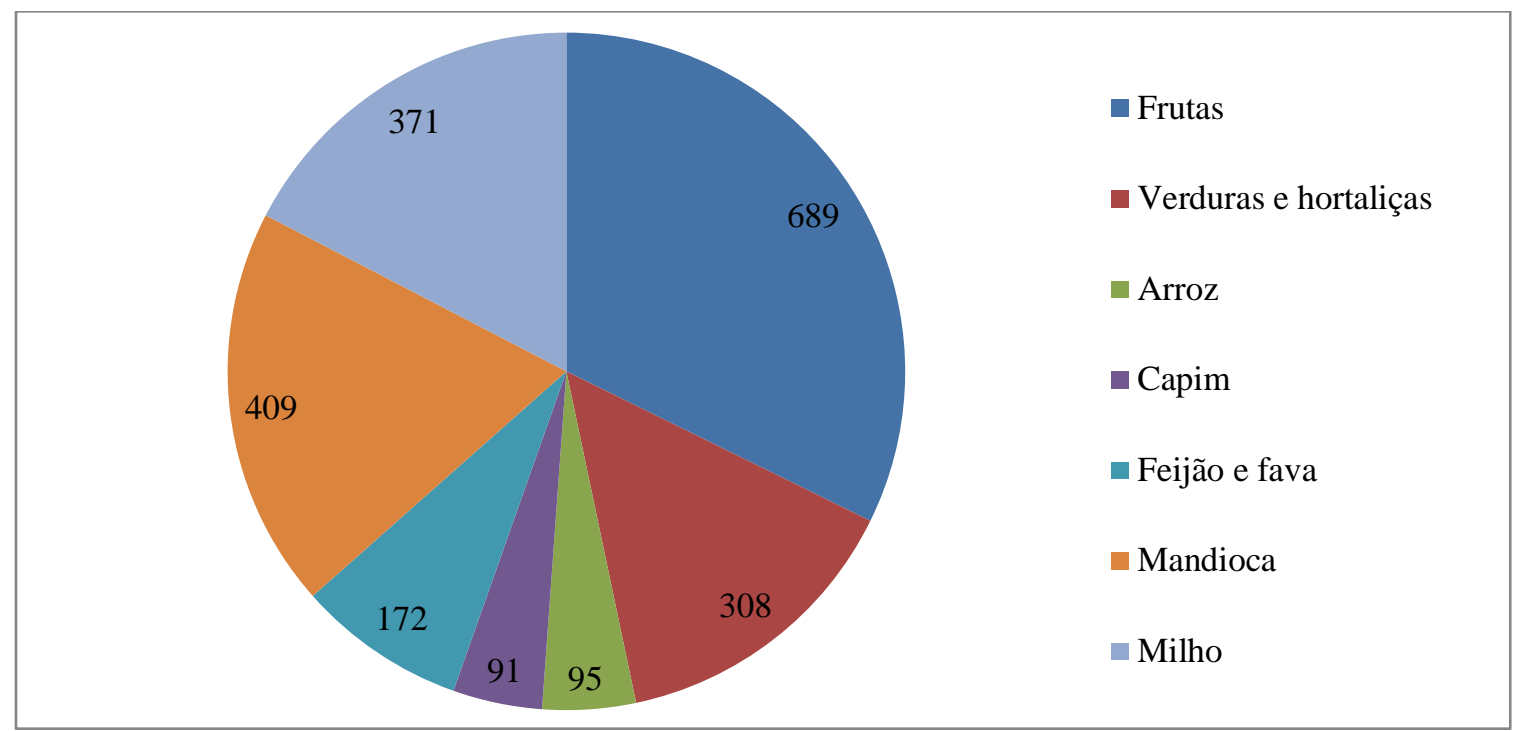

Fonte: Pesquisa de campo, 2016.

Gráfico 16 - Criações desenvolvidas pelos assentados.

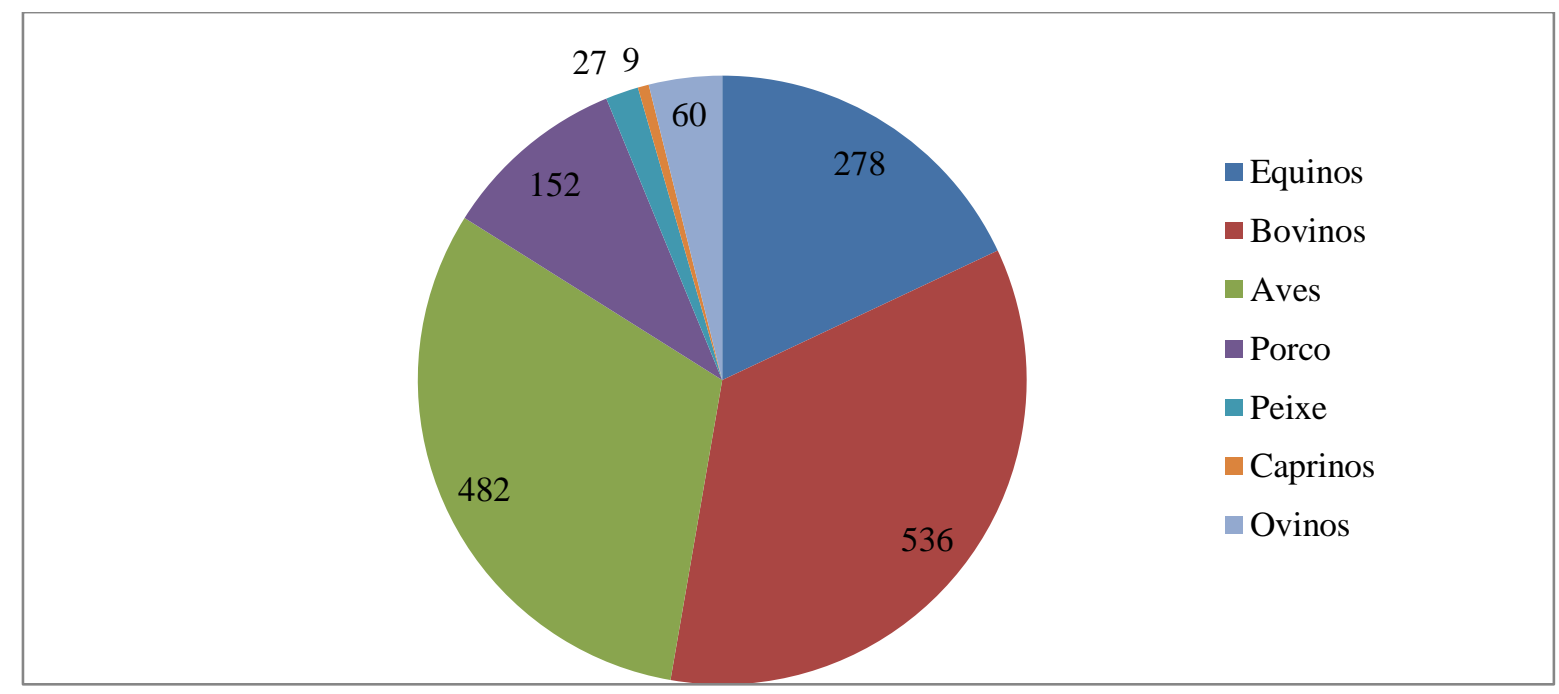

Fonte: Pesquisa de campo, 2016. 
Os elementos constituintes da forma assentamento referentes aos PAs pesquisados no sudeste paraense podem ser sintetizados no Quadro 6, no qual procuramos dar vazão às narrativas dos sujeitos, suas histórias de luta, percepções sobre o cotidiano contraditório e conflituoso em que estão envolvidos.

Os assentamentos estudados nesta pesquisa podem ser mais bem visualizados no Quadro 7, disposto após o Quadro 6. Nele observamos o número de famílias assentadas por PA, área total do PA, ano de ocupação e de criação do assentamento, indicando o período de resistência nos acampamentos, a fazenda ocupada e o município em que se situa.

Esses assentamentos manifestos como frações do território conquistadas pelos semterra, embora sejam envoltos em contradições e conflitos, visto que estão atrelados à dinâmica do capital, são condição para a continuidade da espacialização da luta pela terra no sudeste paraense, pois conformam, junto com os acampamentos, uma rede geográfica solidária camponesa de luta pela terra, cuja constituição territorial será discutida no próximo capítulo. 
Quadro 6 - Formas assentamento organizadas pelo MST no sudeste paraense - 2016

\begin{tabular}{|c|c|c|}
\hline $\begin{array}{c}\text { Aspectos } \\
\text { qualitativos da } \\
\text { forma } \\
\text { assentamento }\end{array}$ & $\begin{array}{c}\text { Elementos } \\
\text { definidores do } \\
\text { assentamento }\end{array}$ & Fala dos assentados \\
\hline & $\begin{array}{l}\text { Conquista do } \\
\text { acesso à terra e da } \\
\text { reprodução social } \\
\text { da família por } \\
\text { meio do trabalho } \\
\text { na terra }\end{array}$ & $\begin{array}{l}\text { “É uma das garantias para o futuro, para o filho, pretendo deixar de herança para o moleque." (José Carlos Silva Pereira, PA Onalício Barros, } 41 \text { anos, } 14 \\
\text { maio 2015) } \\
\text { "É onde nós cultiva, é criação, é uma coisa muito importante, é onde estamos criando nossos filhos.” (Raimundo Ferreira da Silva, PA Canudos, } 40 \text { anos, } 22 \\
\text { maio 2015) } \\
\text { "É uma base principal para qualquer família se estabelecer na vida, a terra é tudo para quem quer ela, para viver é tudo, porque nela tu podes criar, plantar, } \\
\text { colher, ajudar alguém, enfim... quem tem uma terra sabe!" (João da Silva Oliveira, PA Canudos, } 53 \text { anos, } 21 \text { maio 2015) } \\
\text { "Sobrevivo da terra! Para mim é muito importante ter um pedacinho de chão para viver sossegado, como eu vivo hoje. Criei todos os meus filhos aqui." } \\
\text { (Maria Iraci Cardoso, PA Palmares II, } 51 \text { anos, } 07 \text { maio 2015). } \\
\text { "Na época não tinha nada, se hoje tenho alguma coisa é daqui, era rodado, criei minha família tudo aqui, não tenho o que dizer daqui, se eu falar daqui estou } \\
\text { me discriminando.” (Antônio Manoel da Silva, PA } 17 \text { de Abril, } 50 \text { anos, } 20 \text { jun. 2016) } \\
\text { "Minha terra é minha família, aonde planto, colho e onde estou tentando progredir para dar um futuro melhor para minha família” (Maria Marcilene dos } \\
\text { Santos Souza, PA Lourival Santana, } 27 \text { anos, } 07 \text { jul. 2015). }\end{array}$ \\
\hline $\begin{array}{c}\text { O que significa ser } \\
\text { assentado }\end{array}$ & $\begin{array}{l}\text { Territorialização } \\
\text { relativamente } \\
\text { duradoura; } \\
\text { condiçãa } \\
\text { relativamente } \\
\text { permanente } \\
\text { (possibilidade de } \\
\text { deixar de ser } \\
\text { migrante por uma } \\
\text { estabilidade } \\
\text { territorial). }\end{array}$ & $\begin{array}{l}\text { “É porque quando o cabra não é assentado ele é rodado, está na terra de um e de outro e quando está na terra... quando não tem a terra o dono pode vim e } \\
\text { pedi a terra. O pai vivia na terra dos outros e quando pediam a terra ele quebrava a casa.” (Francisco das Chagas Barbosa, PA Onalício Barros, } 54 \text { anos, } 14 \\
\text { maio 2015) } \\
\text { Eu já passei tanta coisa antes de ter essa terrinha... primeiro agradeço a Deus e depois ao MST. Eu trabalhava em área alugada, diária e se eu não tivesse } \\
\text { conquistado esse pedaço de terra eu estava com os cacarecos para cima e para baixo [...] não tinha onde morar, morar todo mundo tinha, mas era um morar } \\
\text { desassossegado e aqui eu estou sossegado.” (Raimundo Drummond, PA Canudos, } 47 \text { anos, } 21 \text { maio 2015) } \\
\text { "Eu acredito que seria uma melhora para nosso bem estar, antes nós era igual maresia e não sabia se ia ou se ficava e com a terra melhorou cem por cento, } \\
\text { tem a terra, tem a casa... aqui é um tesouro, agora é ampliar esse tesouro.” (Raimundo Conceição Bastos, PA Cabanos, } 50 \text { anos, } 17 \text { maio } 2015 \text { ) } \\
\text { "Bom! Porque você não tendo uma propriedade, você não fica quieto... os outros lhe expulsam e você tendo sua terra, você fica tranquilo, ninguém tira dali, } \\
\text { porque é sua! (Antônio Pereira de Souza, PA Palmares II, } 67 \text { anos, } 21 \text { abr. 2015) } \\
\text { "Significa que tenho mais sossego, antes vivia caçando serviço no garimpo, vivia mais longe da família e hoje fico vinte e quatro horas com a família.” } \\
\text { (Raimundo Vieira da Silva, PA Palmares II, } 56 \text { anos, } 23 \text { abr. 2015) } \\
\text { "Eu já sofri muito pelas terras alheias, não ter direito de ter uma casa... mas pelo menos eu estou plantando e ninguém vai me tirar porque estou plantando } \\
\text { na terra alheia... era para se situar no lugar e mostrar para os filhos que a luta valeu a pena.” (Maria Olinda dos Santos Oliveira, PA } 17 \text { de Abril, } 61 \text { anos, } 18 \\
\text { jun. 2016) } \\
\text { "Significa ter algo que é da gente e não precisar está correndo de um lado para outro procurando como sobreviver.” (Edmilson Barros de Oliveira, PA } 26 \text { de } \\
\text { Março, } 50 \text { anos, } 30 \text { ago. 2014) } \\
\text { "Antes de eu ter essa terra nós não era nada, desempregado, humilhado nas fazendas alheias e na nossa terra é uma garantia, soberania alimentar... é aqui } \\
\text { que está nosso futuro, já sofremos muito.” (Luciana Medrado da Silva, PA Lourival Santana, } 28 \text { anos, } 08 \text { jul. 2015) }\end{array}$ \\
\hline
\end{tabular}




\begin{tabular}{|c|c|c|}
\hline $\begin{array}{c}\text { Aspectos } \\
\text { qualitativos da } \\
\text { forma } \\
\text { assentamento }\end{array}$ & $\begin{array}{c}\text { Elementos } \\
\text { definidores do } \\
\text { assentamento }\end{array}$ & Fala dos assentados \\
\hline $\begin{array}{c}\text { O que significa ser } \\
\text { assentado }\end{array}$ & $\begin{array}{l}\text { Espaço de } \\
\text { pertencimento, } \\
\text { liberdade e } \\
\text { (re)socialização }\end{array}$ & 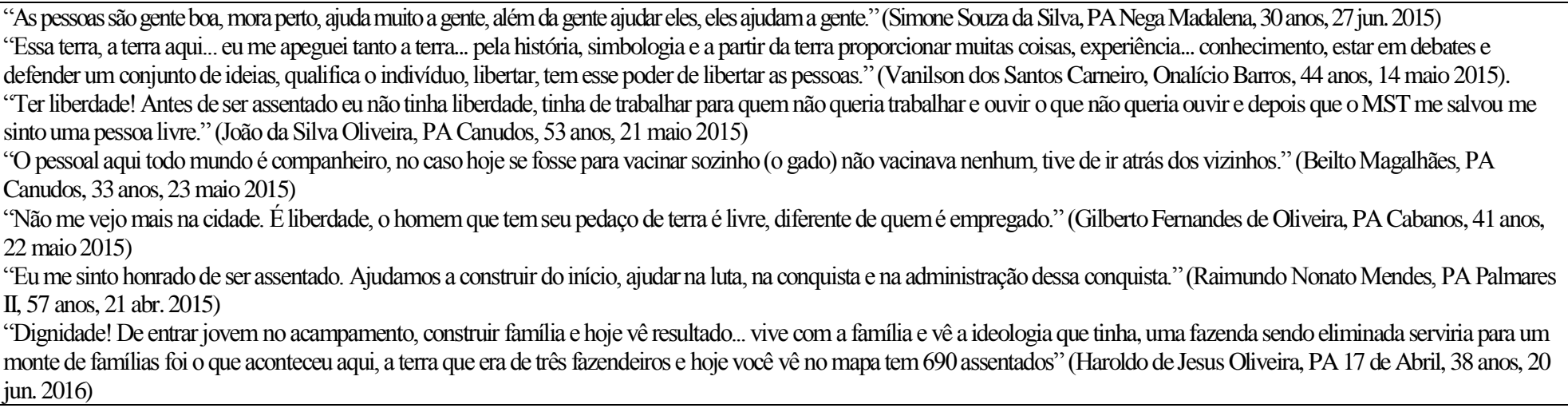 \\
\hline & $\begin{array}{l}\text { Segurança territorial } \\
\text { e saída da condição } \\
\text { de territorialização } \\
\text { precária que } \\
\text { representava a } \\
\text { forma } \\
\text { acampamento. }\end{array}$ & $\begin{array}{l}\text { “Consegui meu pedacinho de terra, foi uma luta que não foi em vão... os que não continuam talvez porque não sofreram o bastante.” (Jonathas Lima Pereira, PA Nega Madalena, } 29 \\
\text { anos, } 27 \text { jun. 2015) } \\
\text { "Dois passos a frente do que é acampado, acampamento é fase de geração, é vivendo como viver assentado... assentado está assentado, respira aliviado, saber que sua luta valeu, que } \\
\text { você conquistou de quando estava no acampamento.”(Vanderlene Araújo Melo, PA Onalício Barros, } 40 \text { anos, } 14 \text { maio 2015) } \\
\text { "Eu me sinto bem, a gente sofreu muito, na época que a gente veio para cá sofreu muito e hoje tem a casa onde morar e aí está bom.”(Angelina Cruz Silveira, PA Palmares II, } 62 \\
\text { anos, } 20 \text { abr 2015) } \\
\text { "Acho que assentado é algo reconhecido e legalizado, não ser esquecido, muitas vezes no acampamento é esquecido... ter escola, projeto.”(Nilta Rosa da Silva, PA Lourival } \\
\text { Santana, } 38 \text { anos, 06 jul. 2015) }\end{array}$ \\
\hline $\begin{array}{c}\text { O que significa a } \\
\text { terra }\end{array}$ & $\begin{array}{c}\text { Condição de } \\
\text { reprodução social do } \\
\text { núcleo familiar sem } \\
\text { os vínculos } \\
\text { empregatícios os } \\
\text { "aprisionavam" aos } \\
\text { disciplinamentos de } \\
\text { tempo do capital e às } \\
\text { condições precárias } \\
\text { de trabalho na cidade } \\
\text { ou no campo. }\end{array}$ & $\begin{array}{l}\text { "De primeiro vivia trabalhando para os outros, não tinha hora de começar e de parar e hoje pego a hora que quero e não tem problema." (Jair Moreira da Silva, PA Nega Madalena, } \\
56 \text { anos, } 27 \text { jun. 2015) } \\
\text { "É um bem que surgiu para a gente que Deus dá a oportunidade de viver em cima dela, plantar, criar... eu desejava tanto antes criar minhas vaquinhas, gado... meus meninos andam } \\
\text { naquele setor... na casa dos outros o dono não gosta, pensa que tá roubando... aqui passo dois, três dias acampado na beira do rio comendo peixe." (Francinete Silva, PA Nega } \\
\text { Madalena, } 53 \text { anos, } 27 \text { jun. 2015) } \\
\text { "Você sai de casa para ir para terra da gente, agora você está na sua casa e ir para terra dos outros é valorizar a terra dos outros é se rebaixar para os outros, pois vai trabalhar aí o } \\
\text { cabra diz você não fez o trabalho direito e é obrigado a um sem nada.”(Osmar Ferreira da Silva, PA Canudos, } 69 \text { anos, } 22 \text { maio 2015) } \\
\text { "Sai da escravidão do trabalho e do emprego, você tinha que trabalhar todo dia senão você era cortado e aqui eu trabalho o dia que eu quero... eu fui criado na cidade grande e não } \\
\text { tinha essa visão.” (Francisco Macambira da Silva, PA Cabanos, } 74 \text { anos, } 18 \text { maio 2015) } \\
\text { "Tendo uma terra de tudo que a pessoa planta tem... e não tem de plantar para os outros. Adoeci trabalhando para os outros e quando cheguei (no assentamento) já estava adoentado } \\
\text { e graças a Deus quando peguei a terra deu para criar o resto da família... se fosse trabalhando para os outros não tinha arranjado nada." (José Alves do Nascimento, PA } 17 \text { de Abril, } \\
67 \text { anos } 14 / \text { jun. 2016) } \\
\text { "Melhoria de vida, depois que fui assentado melhorou bastante a condição, tanto de ter um lugar fixo, quanto a questão financeira... não precisa estar se judiando trabalhando para os } \\
\text { outros e aqui a gente trabalha para gente mesmo." (Neodesedeque Medrado Silva, PA Lourival Santana, } 23 \text { anos, } 08 \text { jul. 2015) }\end{array}$ \\
\hline
\end{tabular}




\begin{tabular}{|c|c|c|}
\hline $\begin{array}{l}\text { Aspectos } \\
\text { qualitativos da } \\
\text { forma } \\
\text { assentamento }\end{array}$ & $\begin{array}{c}\text { Elementos } \\
\text { definidores do } \\
\text { assentamento }\end{array}$ & Fala dos assentados \\
\hline $\begin{array}{l}\text { Organização } \\
\text { socioespacial }\end{array}$ & \begin{tabular}{|c|} 
Incialmente se \\
resguarda a \\
organização \\
espacial no núcleo \\
de base do \\
acampamento, mas \\
depois as relações \\
se voltam para o \\
lote e a vila, a \\
organização política \\
se define pelos \\
setores (religião, \\
educaçãa, \\
juventude, saúde, \\
associação, etc.). \\
\end{tabular} & 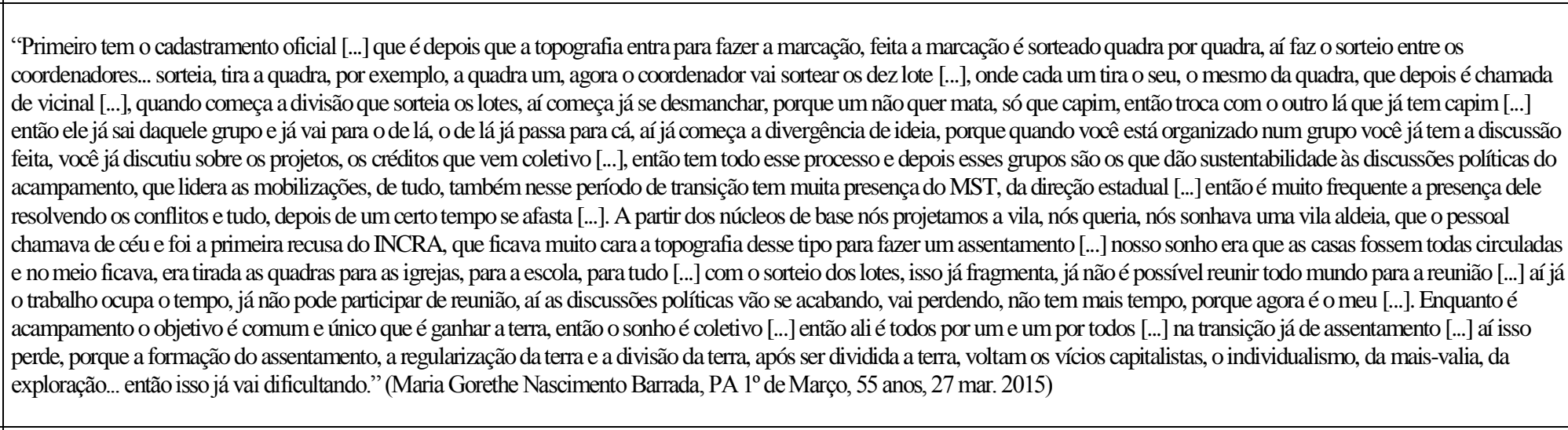 \\
\hline Sociabilidade & $\begin{array}{c}\text { Sociabilidades } \\
\text { relativamente mais } \\
\text { distantes, } \\
\text { individualistas e } \\
\text { mediadas pelo } \\
\text { conflito o que não } \\
\text { anula a existência } \\
\text { de relações de } \\
\text { vizinhança e de } \\
\text { ajuda mútua entre } \\
\text { determinados } \\
\text { grupos sociais. }\end{array}$ & 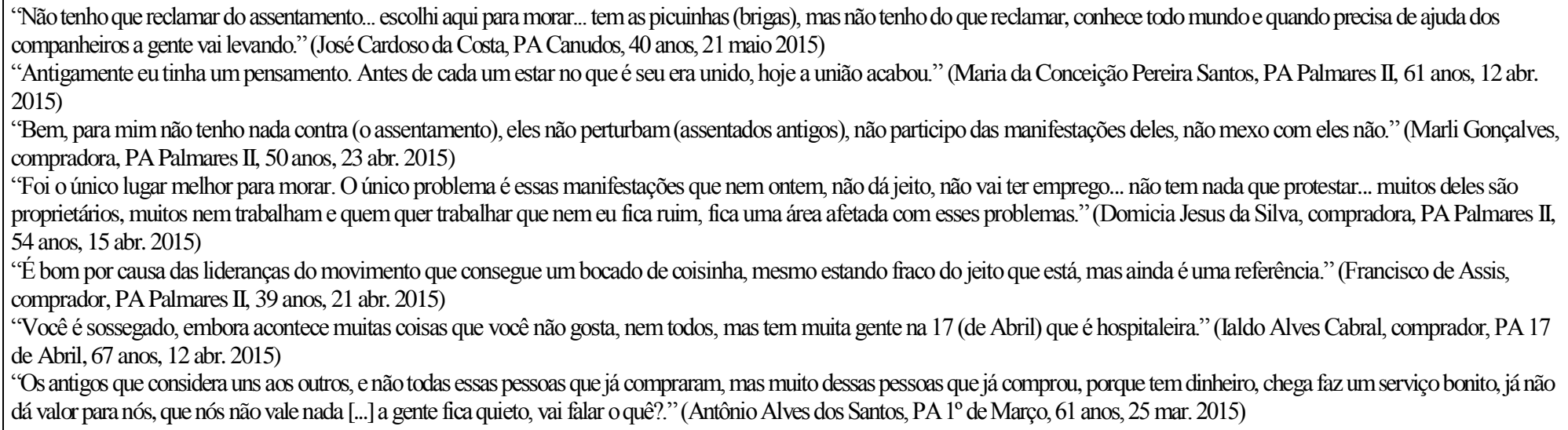 \\
\hline $\begin{array}{l}\text { Formas de } \\
\text { resistência e } \\
\text { estratégias de } \\
\text { permanência na } \\
\text { terra }\end{array}$ & $\begin{array}{l}\text { Manifestações } \\
\text { (bloqueio de } \\
\text { estradas, daEFC, } \\
\text { ocupação do } \\
\text { INCRA etc.) }\end{array}$ & $\begin{array}{l}\text { 'Nós estamos aqui reivindicando nossos direitos, nós não temos estrada, nemágua [...] queria que os caminhoneiros colaborassem com a gente, com a nossa luta, estamos lutando por } \\
\text { direito, por igualdade social [...] estamos reivindicando nosso direito por igualdade social, estamos aqui reivindicando a nossa escola, as estradas vicinais [...]." (assentados do PA } 1^{\circ} \text { de } \\
\text { Março, bloqueio da rodovia Transamazônica, } 06 \text { abr. 2015) }\end{array}$ \\
\hline
\end{tabular}




\begin{tabular}{|c|c|c|}
\hline $\begin{array}{c}\text { Aspectos } \\
\text { qualitativos da } \\
\text { forma } \\
\text { assentamento } \\
\end{array}$ & $\begin{array}{c}\text { Elementos } \\
\text { definidores do } \\
\text { assentamento }\end{array}$ & Fala dos assentados \\
\hline $\begin{array}{l}\text { Principais formas de } \\
\text { violência }\end{array}$ & $\begin{array}{c}\text { Reapropriação de } \\
\text { terras por parte de } \\
\text { médios } \\
\text { proprietários } \\
\text { pecuaristas; } \\
\text { intervenções de } \\
\text { empresas } \\
\text { mineradoras e do } \\
\text { Estado. }\end{array}$ & 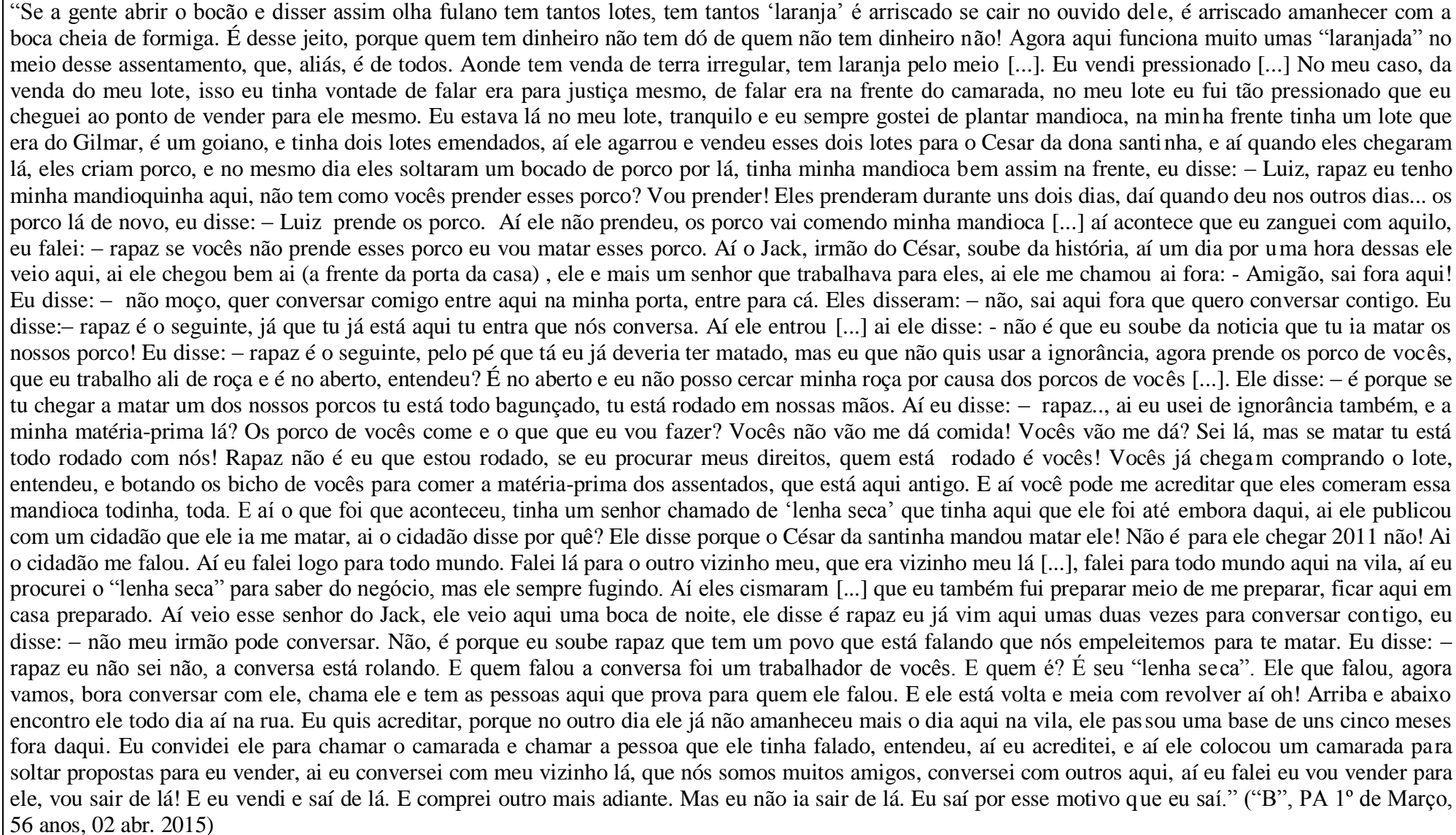 \\
\hline
\end{tabular}

Fonte: Pesquisa de Campo; 2016. 
Quadro 7 - Assentamentos implementados a partir da organização do MST no sudeste paraense - 2016

\begin{tabular}{|c|c|c|c|c|c|c|c|c|}
\hline Assentamento & $\begin{array}{c}N^{0} \text { de } \\
\text { famílias }\end{array}$ & Área (ha) & $\begin{array}{l}\text { Área por } \\
\text { lote (ha) }\end{array}$ & $\begin{array}{c}\text { Ano de } \\
\text { ocupação }\end{array}$ & $\begin{array}{l}\text { Data de } \\
\text { criação }\end{array}$ & Fazenda & Município & Eixo Territorial \\
\hline PA $1^{\circ}$ de Março & 350 & 10960,8292 & 50 & 1996 & $15 / 06 / 1998$ & São Tomé (Pastoriza) & $\begin{array}{l}\text { São João do } \\
\text { Araguaia }\end{array}$ & $\begin{array}{l}\text { Projetos hidrelétricos } \\
\text { (UH de Marabá) }\end{array}$ \\
\hline PA 26 de Março & 206 & 9774,0405 & 50 & 1999 & $19 / 12 / 2008$ & Cabaceiras & Marabá & Agropecuário e mineral \\
\hline PA 17 de Abril & 690 & 18089,7346 & 25 & 1996 & 19/06/1997 & Complexo Macaxeira & $\begin{array}{c}\text { Eldorado do } \\
\text { Carajás }\end{array}$ & Agropecuário e mineral \\
\hline PA Cabanos & 85 & 3426,0499 & 35 & 1998 & $07 / 03 / 2003$ & Volta do rio & $\begin{array}{l}\text { Eldorado do } \\
\text { Carajás }\end{array}$ & Agropecuário e mineral \\
\hline PA Canudos & 62 & 2836,7248 & 45,5 & 1998 & $16 / 08 / 2004$ & São José do Refugio & $\begin{array}{c}\text { Eldorado do } \\
\text { Carajás }\end{array}$ & Agropecuário e mineral \\
\hline $\begin{array}{l}\text { PA Lourival } \\
\text { Santana }\end{array}$ & $131-167^{29}$ & 3760,0857 & 25 & 2003 & $10 / 10 / 2013$ & Gleba peruana I e II & $\begin{array}{l}\text { Eldorado de } \\
\text { Carajás }\end{array}$ & Agropecuário e mineral \\
\hline PA Palmares & 517 & 14921,8902 & 50 & 1994 & $11 / 03 / 1996$ & Reunidas Rio Branco & Parauapebas & $\begin{array}{l}\text { Agropecuário e mineral } \\
\text { (Serra de Carajás) }\end{array}$ \\
\hline PA Onalício Barros & 68 & 1770,00 & 25 & 1998 & 2000 & Goias II & Parauapebas & $\begin{array}{l}\text { Agropecuário e mineral } \\
\text { (Serra de Carajás/S11D) }\end{array}$ \\
\hline PA Nega Madalena & 39 & $1.350,0000$ & 32,5 & 2008 & 2011 & Nega Madalena & Tucumã & $\begin{array}{l}\text { Agropecuário e mineral } \\
\text { (Projeto Onça Puma) }\end{array}$ \\
\hline
\end{tabular}

Fonte: SIPRA SR-27, 2015; Trabalho de campo, 2016.

${ }^{29} \mathrm{O}$ projeto de assentamento é relativamente recente e por este motivo ainda apresenta indivíduos não regularizados, logo, no Incra existem 131 assentados, mas no assentamento são 167 lotes com o mesmo número de famílias residentes. 
4. CONSTRUÇÃO TERRITORIAL DA REDE GEOGRÁFICA SOLIDÁRIA CAMPONESA DE LUTA PELA TERRA NO SUDESTE PARAENSE

Foto 15 - Encontro da Via Campesina na Curva do S em Eldorado dos Carajás, 2016.

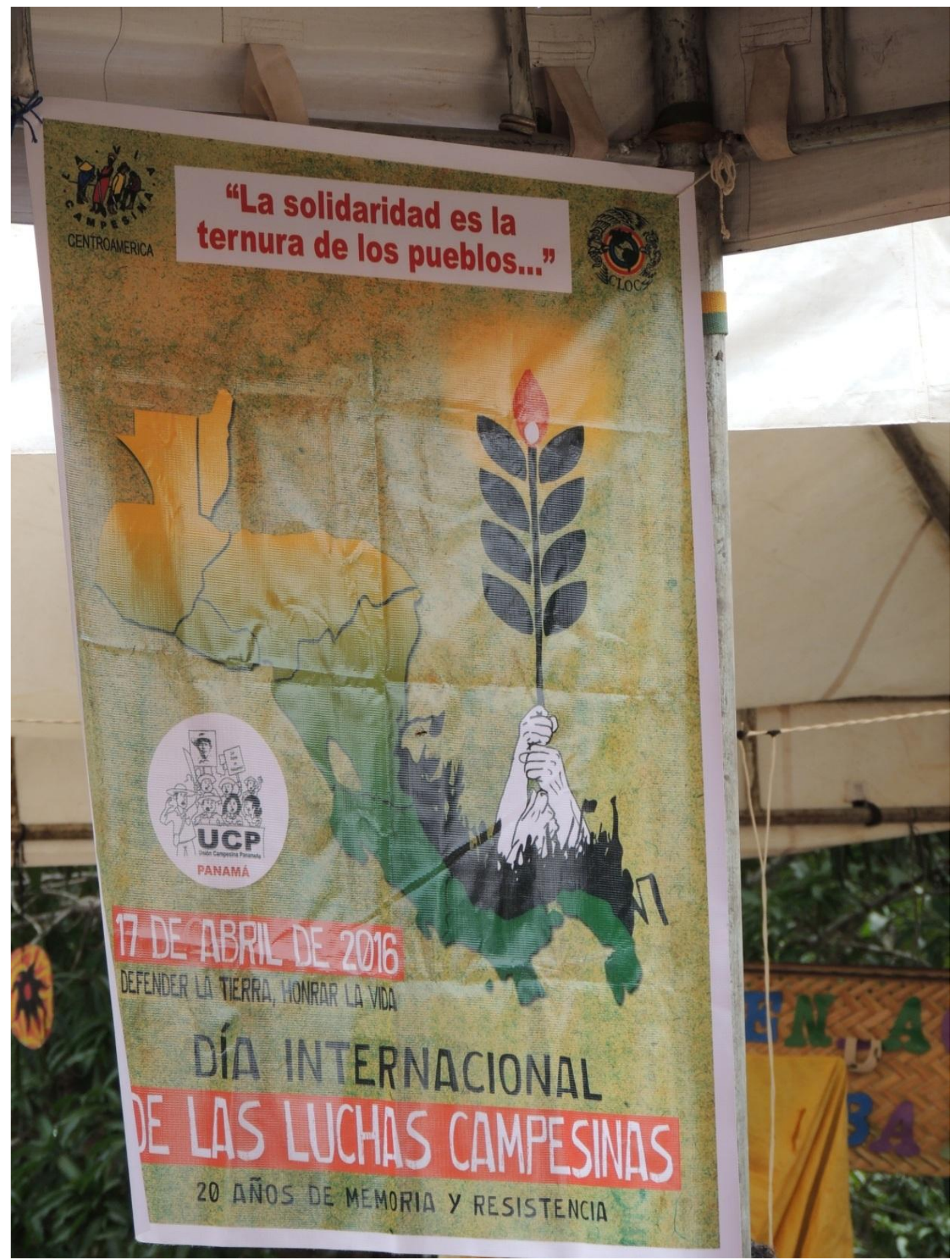

Fonte: Rogério Rego Miranda, Eldorado dos Carajás, 2016.

"Globalizemos a luta, globalizemos a esperança!” (Via Campesina). 
Para a construção territorial e a permanência do MST no sudeste paraense, uma estratégia histórica e geograficamente bem demarcada foi a estruturação de uma rede de luta pela terra, que se utiliza da política de escala e ao mesmo tempo da construção de um bloco histórico que é igualmente geográfico na medida em que não é em todos os lugares que essas alianças são desenvolvidas: existe, nesse caso, uma condição temporal e espacial para que se constituam, devidamente discutida no Capítulo 2.

Nesse sentido vamos remontar, do ponto de vista histórico-territorial, à constituição do MST no sudeste paraense, a partir da reflexão dos sujeitos que estiveram presentes nessa trajetória de luta e conflito para a conquista dos assentamentos, ao mesmo tempo que vamos observar a composição da rede de luta pela terra.

\subsection{TERRITORIALIZAÇÃO DO MST A PARTIR DOS ASSENTAMENTOS}

A territorialização do MST no Pará, já explicitada anteriormente, de acordo com as lideranças, ocorreu entre o final dos anos 1980 e início dos 1990. Seu início se realizou, no sudeste paraense, particularmente em Conceição do Araguaia, com a ocupação da Fazenda Ingá no dia 10 de janeiro de 1990 e da Fazenda Canarana em junho do mesmo ano. Essas ocupações eram ainda pautadas na experiência dos posseiros, cuja luta era radicalizada, característica que foi incorporada à dinâmica do MST no Pará, para não ceder à violência dos fazendeiros e buscar a conquista da terra ${ }^{30}$.

Nesse primeiro momento de organização do MST, que abrange o período de 1986 a 1992, o movimento incorporou a luta posseira contra o latifúndio, porém estabeleceu outras frentes de ação que não estavam na estratégia dos posseiros, entre elas o conflito direto com o Estado com o intuito de pleitear a desapropriação da terra e a constituição do assentamento. Nesse momento, a formação política do movimento é em grande medida influenciada pelos sindicatos, cujos dirigentes provenientes da região de Conceição do Araguaia. A partir de 1992, depois de várias tentativas de ocupações de fazendas, o movimento começa a se organizar de maneira mais significativa com a conquista da terra pela luta, o assentamento de famílias e a constituição de uma militância, inaugurando um segundo momento da

\footnotetext{
${ }^{30}$ Para uma discussão mais minuciosa desse processo, ver o trabalho de Assis (2007) e Pereira (2015), que vão discutir as condições históricas de formação do MST no sudeste paraense, assim como as experiências sindicais, pautadas na cooperação e tensão, que serão de suma importância para a constituição desse movimento socioterritorial.
} 
territorialização do MST, que vai de 1992 até 1996, em que o movimento se torna uma referência na luta pela terra no sudeste paraense, passando atuar em cinco frentes de ação:

[...] eu acho que uns cinco movimentos que eu acho que eles são importantes: $1^{\circ}$ ) a gente supera esse trinômio "terra, arma e lote" (forma de luta posseira), a gente coloca outras coisas no lugar. Primeiro, a gente não só estabelece um conflito com o latifúndio, a gente estabelece conflito com o Estado, isso já acrescenta e muito. É por isso que as agrovilas, a importância da escola, da organização dos outros fatores da vida social vão ganhar uma relevância, vão ser muito relevantes na trajetória do MST Pará, no que alguns estudiosos chamam de repertório, um repertório social do MST, acabou fazendo a luta pela terra no sul e sudeste do Pará ganhar outra projeção; $2^{\circ}$ ) ninguém, ao conquistar a terra, ninguém vai cortar o seu lote, a conquista é coletiva; $3^{\circ}$ ) a luta pela terra não é só dos homens, é das mulheres; $4^{\circ}$ ) quem dirige esse movimento são aqueles que fazem parte dele, ou seja, é aí que a gente vai descobrir o talento de muitos companheiros, essa coisa da direção coletiva. Não havia o presidente do assentamento, ou seja, isso é muito importante, para dirigir esse movimento é um conjunto de tantas qualidades como a gente já mencionou; $5^{\circ}$ ) as outras formas de luta, desde a ocupação da terra à ocupação do INCRA, às assembleias nas margens [das estradas], então tudo isso são elementos que nós introduzimos nessa segunda fase do MST. (Charles Trocate, militante do MST, 37 anos, 18 ago. 2014)

O terceiro momento de territorialização do MST é marcado pelo Massacre de Eldorado dos Carajás. Nesse ponto é interessante a indagação elaborada por Charles Trocate, militante do MST, que questiona por que esse massacre ganhou uma repercussão que outros episódios não apresentaram, tais como o massacre dos garimpeiros na ponte rodoferroviária na cidade de Marabá $^{31}$, as chacinas nas Fazendas Ubá e Princesa ${ }^{32}$, dentre outros igualmente violentos. Para ele, três fatores foram decisivos, quais sejam: a) o massacre não ocorreu contra um grupo de resistência camponesa isolado, visto que o MST atua como uma organização em nível nacional - desta feita, a violência praticada no Pará acabou por ter ressonâncias nacionais e até mesmo internacionais; b) o momento histórico vivenciado era marcado por repressões contra os movimentos camponeses em todo o Brasil, a exemplo do massacre de

31 O evento ficou conhecido como "Massacre de São Bonifácio". Na ocasião, a policia militar do Pará cercou a ponte rodoferroviária de Marabá que havia sido ocupada por 4 mil garimpeiros que manifestavam contra as péssimas condições no garimpo de Serra Pelada. O conflito entre a polícia e os garimpeiros resultou em diversas mortes: segunda a PM, quatro garimpeiros morreram e vinte ficaram feridos; a imprensa registrou cinco mortos e trinta feridos; testemunhas indicaram dez mortos. A polícia alegou que se utilizou da forte repressão para viabilizar o tráfego na rodovia PA150 e a passagem dos trens de carga da linha Carajás-Ponta da Madeira (POLÍCIA militar mata garimpeiros no Pará, s/d. Disponível em: <http://www.memorialdademocracia.com.br/ card/policia-militar-mata-garimpeiros-no-para>. Acesso em: 13 maio 2017.)

32 A chacina na fazenda Ubá, localizada no município de São João do Araguaia, ocorreu a mando do fazendeiro José Edmundo Ortiz Vergolino, que contratou o pistoleiro "Sebastião da Terezona". No dia 13 de junho de 1985 , Sebastião assassinou cinco posseiros e uma mulher; três dias depois; voltou a matar mais três pessoas. Já a chacina na Fazenda Princesa ocorreu no dia 27 de setembro de 1995, no município de Marabá, e resultou em cinco mortes com requintes de crueldade, visto que as pessoas foram amarradas, torturadas e queimadas; posteriormente, os cadáveres foram lançados no rio Itacaiúnas (GUIMARÃES; BARP, 2011). 
Corumbiara em $1995^{33}$, no governo presidencial de Fernando Henrique Cardoso, importante intelectual brasileiro que refletiu sobre a desigualdade no país, porém acabou se comprometendo com os interesses da classe dominante; c) por fim, a presença da mídia que divulgou as cenas do massacre, ajudando a não minimizar o fato como era de interesse dos envolvidos, que indicavam haver um conflito armado envolvendo as duas partes, isto é, semterra e policiais.

Nesse terceiro momento, que vai de 1996 até aproximadamente 2000, houve um processo de reformulação do MST por conta do massacre, com a intensificação da ocupação de grandes áreas de terra, a ampliação de sua área de atuação para outras mesorregiões do Pará e o início de um processo de discussão sobre a forma de organização interna dos assentamentos, tendo em vista que os primeiros investimentos começam a ser implementados.

A partir de 2000 e até 2004, estabeleceu-se um período de relativa crise no movimento, pois de um lado havia uma judicialização da questão agrária mobilizada pelos fazendeiros e a mídia incitava um forte processo de criminalização dos movimentos sociais; por outro, começaram a surgir dificuldades internas referentes às tarefas a serem desenvolvidas pelo MST na luta pela terra no Brasil e na Amazônia, as quais transcendem a reivindicação da reforma agrária. Daí apareceu a necessidade de criar e/ou ampliar as alianças mediante debate sobre a questão agrária na Amazônia, cuja intepretação deveria prescindir da realidade concreta - nesse sentido, algumas tarefas para o momento atual do MST são colocadas:

[...] uma primeira tarefa nossa foi compreender a Amazônia, ou seja, dez anos depois há uma literatura presente na vida da nossa militância sobre a Amazônia e suas consequências, um pouco tentando se colocar num debate mais estratégico. Há a perspectiva de construção de um novo bloco histórico camponês e popular já que o bloco anterior parte dele está órfão (movimento sindical), porque houve uma retirada dos melhores quadros para disputas institucionais, e terceiro a necessidade de disputar a centralidade do poder a partir da prática política camponesa, isso num longo processo de acúmulo de força. Então é isso que tem nos trazido até este momento, que implica uma reorganização, de uma reestruturação em toda a organização, implica numa política de formação de quadros, implica numa disputa de uma formação, de disputa da hegemonia na sociedade, implica numa política de aliança, afinal, todos que estão em contradição com o capital e têm clareza de que o capital é seu inimigo, basicamente é essa última fase em que nós estamos vivendo e que vai, digamos assim, ainda tem muito para fazer, para avançar, ainda é muito incipiente, mas é uma forma de não estar sozinho nem na reflexão

\footnotetext{
${ }^{33}$ O episódio ocorreu em 09 de agosto de 1995, no município de Corumbiara, estado de Rondônia. Houve conflito entre policiais militares e um grupo de sem-terras que ocupava a Fazenda Santa Elida, que culminou na morte de 12 pessoas.
} 
teórica e nem na constituição de uma frente, de um... Com os camponeses, mas também com os outros explorados da sociedade, um pouco tentando dizer que o padrão da luta de classes na Amazônia ele não tem acento no operário, claro, porque a indústria paraense emprega 170 mil pessoas só, num universo de quase oito milhões de pessoas, é tão pouco a indústria do mega investimento, a indústria do mega investimento não emprega no Pará duzentas mil (pessoas), a indústria de transformação emprega 170 mil, essas pequenas manufaturas, a indústria dos grandes empreendimentos não emprega duzentos mil operários, o que nós temos, digamos, onde há um maior número de empregos na sociedade paraense é no setor de serviços, então quer dizer que o padrão da luta de classes na Amazônia ele está mais embaixo, ele está na disputa pelo capital natural, ou seja, ele reproduz, evidentemente, mas para isso ele precisa inviabilizar sociedades históricas inteiras, então quando a gente diz que é necessário construir um novo bloco e organizações camponesas e populares é imaginando que a luta pode ser feita em qualquer rincão desses, mas tentando e conformando conquistas civilizatórias também na sociedade, ou seja, na sociedade de modo geral e imagino que a cidade que nós temos é a cidade do capital, como já falou David Harvey, mas aqui ela ganha essa conformação, ela é a cidade empresa, ela é a cidade negócio, ela é uma não cidade para os pobres, ela é imperialista, ela só é cidade para aqueles que podem comprá-la, para aqueles que podem acessá-la, então ideologicamente uma cidade do capital, ela é endêmica como qualquer outra cidade de 150 anos, 200 anos atrás, é aqui na cidade que esse capital extrai a mais-valia social de uma massa pauperizada e quanto mais ele se retroalimenta dela, mais ele extingue essa massa na cidade. (Charles Trocate, militante do MST, 37 anos, 18 ago. 2014)

Essa leitura da territorialização do MST no Pará, particularmente no sudeste paraense, por parte das lideranças, indicando basicamente quatro importantes momentos é significativa para apontar que no atual contexto do movimento emerge a necessidade de avaliação das formas de disputa por hegemonia na realidade paraense. Muito embora as contradições e conflitos internos do movimento não se manifestem nas falas e periodizações, é importante termos esse quadro geral no qual os assentamentos, como base material do território do MST, vão se constituindo.

Como ficou patente somente a partir de 1990, o MST de fato consegue se organizar no sudeste paraense por meio de ocupações que resultaram na criação de assentamentos sob sua organização, conforme discutiremos a seguir.

\subsubsection{Projeto de Assentamento Palmares II}

O Projeto de Assentamento Palmares se constituiu no segundo momento de territorialização do MST: mais precisamente, corresponde a um dos primeiros assentamentos conquistados a partir da organização da luta pela terra por parte do movimento no estado do Pará. 
Como as ocupações em Conceição do Araguaia não surtiram o efeito desejado, o MST redirecionou suas ações para Parauapebas. Ocupou primeiramente a Fazenda Rio Branco, de propriedade da família Lunardelli, em 16 de julho 1992, com um total de 548 famílias semterra, porém a desocupação foi rápida, devido à ação de despejo ter ocorrido ainda no momento da ocupação, com atuação da polícia e de jagunços. Nesse ínterim, as famílias acamparam em frente à Prefeitura e conseguiram transporte para transferir o acampamento para a sede do INCRA em Marabá, onde ficaram por cinco meses, realizando paralelamente manifestações e negociações em Belém e Brasília com o intuito de alterar o cenário político colocado. Nesse período, o MST solicitou a vistoria da Rio Branco que acabou por ser negociada com o INCRA, mas foi preciso uma nova ocupação da fazenda para que o Instituto comprasse a área (FERNANDES, 1999). Assim, a primeira parte desse complexo de fazendas foi conquistada em abril de 1992, quando o INCRA sinalizou sua desapropriação, sendo criado o PA Rio Branco em 12 de agosto de 1993, com capacidade de assentar 251 famílias em uma área de 11.939 hectares.

Posteriormente, o MST desenvolveu a ação que desencadeou na constituição do PA Palmares II. Ela se iniciou no dia 26 de junho de 1994, quando aproximadamente 2.500 famílias sem-terra ocuparam uma área da Vale (antigamente Companhia Vale do Rio Doce CVRD ) de 411.946 hectares, denominada de "Cinturão Verde". A ocupação durou três dias e, segundo as lideranças do movimento sem-terra, tinha como significado enfrentar o projeto mineral no sudeste paraense. Entretanto, a repressão foi muito intensa, rápida e violenta. Esse processo foi minuciosamente descrito na fala de um dos assentados:

[...] eu lembro que no dia 26 de junho de 94 nós saímos, ajeitemos um negócio, que nós trabalhava com roça, pegamos plástico que era de bater arroz, pegamos toda a tralha e viemos para Parauapebas. [...] Chegamos, aí guardamos o material e disseram: "olha a reunião vai ser só a noitinha, às sete horas". Quando foi a noitinha nós fomos lá pro local da reunião, aí disseram: "não, tem que fazer um cadastro!" E aí eu cheguei, eu lembro que a média era esse horário às 19:00 horas eu fiz meu cadastro [...] e aí fizemos o cadastro e o cara disse: "olha, tá feito o cadastro, a gente reúne aqui, só que à meia noite, às doze horas nós todos os cadastrados aqui nesse local. Nós vamos ter outra reunião à meia noite", aí nos fomos lá pro local aonde nós tinha guardado os bagulho e quando deu próximo a esse horário, nós pegamos os bagulho e fomos para lá. Chegamos lá muita gente, aí fizeram a reunião e logo começou a chegar o carro, aí eu fiquei tranquilo, chegou um caminhão que era da vice-prefeita, na época era a Meire [...] chegou o caminhão dela e outros carros da Prefeitura e o homem disse: "olha nós já vamos para a terra" [...] e eu achei esse negócio tá mole, que até o carro da vice-prefeita vai levar o pessoal né! Aí reunimos lá, começou a encher de gente o caminhão e descer (seguiu o caminho em direção a área da ocupação). Pra onde é? ah, então, é pra cá. Aí nós descemos ali pro lado da dez, já com dois caminhões carregado e outros ficaram esperando o 
caminhão e quando nós entramos [...] aí eu conhecia a área, aí nós descemos ali na dez, "ah então é pra cá", eu pensei que era muito longe, aí pro lado do Itacaiúnas e tal. Aí quando nós chegamos lá na beira do rio meu camarada era para ocupar a "cinturão verde", essa área de reserva que é da Vale [...] e uma das coisas de marinheiro de primeira viagem né, eu pensava que fosse uma coisa menor, com poucas pessoas, eu não acreditava que era aquele tanto de gente e eu nunca imaginava que era também essa área né. Aí antes de nós chegar na beira do rio Parauapebas, pra atravessar, a gente já topou uns quatro caminhão que iam deixar o pessoal lá na beira do rio e iam retornando para ir buscar mais gente. Os caminhão que trouxeram gente do Curionópolis, da Serra Pelada, desse meio aí. Chegando lá tinha uns camarada com umas canoa só atravessando lá pro outro lado, né, botando gente e bagulho e atravessando gente no remo mesmo [...] quando nós acabamos de atravessar todo mundo, aí já era uma média de duas para três horas da manhã, aí ligeiro fizeram uma assembleia, chamaram para assembleia que eu não sabia que era assembleia também né, aí reuniu todo mundo dentro do mata aí disse "gente aqui é o seguinte, todo mundo se aquietar aqui no mato, dá um jeito de armar rede de um pau para esse outro, ata a rede pra gente aquietar um pouquinho aqui, que nós vamos sair cedinho daqui. Já tem um companheirada nossa aqui que já pesquisou um lugar de montar acampamento, um lugar que tem água e cedinho nós segue viagem" [...] quando deu cedinho chamou, vamo lá todo mundo, assembleia aqui e disse "oh gente agora nós vamos seguir viagem, vamos seguir pro acampamento, já pesquisamos o lugar do acampamento, lugar que tem água", aí descemos, um comboio na frente fazendo uma picadinha e outro atrás, era homem, mulher, criança, era todo mundo junto. Aí eu sei que nós andamos até perto de meio dia, aí parece que perderam um pouco o rumo que era para ser o acampamento, aí disse: "não, mas nós vamos acampar aqui, todo mundo vai fazer uma comida e depois a gente vai pesquisar que o lugar do acampamento ainda não é esse". Aí chegamos lá na beira de uma grota assim, começaram a limpar daqui para acolá, aí cortamos um pau e colocamos logo um plástico em cima, barraco beira no chão como falam, e ficamos lá de baixo. Aí loguinho chamaram para reunir, aí foi aonde criou os grupos, disseram olha aqui nos trabalha assim no movimento sem-terra, aí já apresentou a militância [...] aí foi criado os grupos, aí toda a turma elegeu lá dois coordenadores que era um coordenador do grupo e um coordenador de disciplina né, que disciplina, qualquer confusãozinha ele juntava lá pra resolver, se fosse preciso expulsar alguém, expulsava também. Aí eu sei que tiraram a coordenação de nosso grupo, era uma turma do CEDERE, inclusive nós colocamos o nome do grupo de CEDERE I, que era uma parte do CEDERE, o coordenador era o finado Zé Neto que era do CEDERE e que era meu cunhado e outra parte de nossa turma era de Curionópolis. Aí ficamos lá, fomos caçar meio de fazer um bandeco todo mundo, aí já limpamos um negócio lá para as mulher banhar, dos homens banhar, uma grotinha boa [...] aí quando foi no outro dia cedo, aí uma assembleia, reuniu todo mundo, aí eles falaram: "olha gente o lugar do acampamento ainda não é aqui, mas aí a gente sabe que pode vim alguém" e aí tirou uma turma, disseram "nós vamos tirar uma equipe que vai procurar o local certo do acampamento e outra turma fica por aqui, e um vai pra beira do rio, porque se por acaso vier alguém aí avisa com um foguete". Aí saiu essa turma para ir caçar o acampamento e meu amigo nesse negócio de caçar acampamento os homens toparam com os guardas florestais da Vale e correram aí, atravessaram o rio, perderam espingarda e nos ficamos lá, quando deu uma base de uma dez para onze horas o cara soltou o foguete na beira do rio aí a gente respondeu com outro aqui. Disse "olha pode vir alguém aqui, mas nós 
somos organizados, vamos conversar não vão machucar ninguém", então vamos lá, e chovendo, eu lembro do dia todinho chovendo [...] quando deu meio dia nós estava almoçando, quando eu ouvi gritar: "chega companheirada!" Eu já ouvi foi o tiro zoar, soldado para tudo quanto era lado, aí já entraram atirando, aí nós saímos todo mundo correndo, porque lá na boca da labareda tinha uma castanheira grande e foi colocado o cipó e foi colocado a bandeira né, bandeira do movimento estava bem na frente, aí na hora corremos todo mundo para lá. Meu amigo era polícia demais e os cara com a cara pintada que era pra gente não conhecer, tudo bem armado, já entraram atirando, ai foi que alguém falou: "rapaz não é assim não, aqui não é que nem vocês estão pensando não, vamos conversar que aqui não tem só gente boba aqui não, e nós somos trabalhador, não é vagabundo não" [...] a gente conseguiu negociar com eles, eles tomaram um facão velho que a gente tinha, foice, os que eram mais organizadinho não entregou, aí a gente foi conversar. Aí eu lembro que o Tubiano falou: "rapaz nós estamos aqui, somos organizados e só sai daqui com uma liminar de despejo assinado pela juíza”. Aí eles espertos saíram né, aí vieram, segundo informações, forjaram uma liminar e no outro dia cedo já chegou uma equipe dos guarda florestal, aí queriam instalar uma antena de rádio comunicativo lá, aí nós não aceitamos também, aí veio um oficial de justiça entregar a liminar. Aí eu lembro que o Tubiano falou: "olha só que uma liminar de despejo ela tem um horário, não é ela chegou aqui e nós sair", como já era tarde disse: "olha nós não vamos sair hoje. Nós só vamos sair amanhã", que já era no terceiro dia né. Aí no terceiro dia eles foram, levaram barco no rio, a voadeira, levaram ônibus, aí a gente resolveu sair. (Raimundo Nonato Mendes, militante do MST, 57 anos, 21 abr. 2014)

Com o despejo do "Cinturão Verde", os sem-terra se deslocaram em direção à Prefeitura Municipal de Parauapebas, cujo gestor os alojou em um campo de futebol denominado de "terra seca", ficando muito visíveis e suscetíveis às pressões sociais de comerciantes e moradores para que saíssem do local, especialmente pela imagem negativa que foi construída em torno do movimento. Após uns dias ali resolveram ir para Marabá acampar no INCRA e realizar caminhadas pelas ruas da cidade, ações que não surtiram o efeito desejado. Logo, retornaram para Parauapebas para ocupar a portaria da Vale, com o apoio da CUT (Central Única dos Trabalhadores), sendo novamente repreendidos violentamente pela polícia que chegou a prender algumas lideranças e a machucar alguns sem-terra. Ao término do ato se dirigiram para a Câmara Municipal, onde permaneceram por um curto período, pois na rua não era possível planejar outra ação de ocupação de terra, pois eram constantemente vigiados. Foram, então, deslocados pela Prefeitura novamente para uma área do atual bairro Novo Horizonte, com o intuito de os invisibilizarem do centro da cidade - apesar disso, nesse novo acampamento foi possível organizar melhor a ocupação de uma outra área das Fazendas Reunidas Rio Branco.

Essa ocupação ocorreu no dia 15 de maio, todavia, apenas as lideranças sabiam do local. Existia uma estratégia inicial de que, se houvesse homens suficientes, entrariam na área 
da Vale, o que não ocorreu, pois o grupo que estava à frente da ocupação da fazenda já havia cortado as cercas e montado acampamento, impossibilitando o movimento de lutar em duas frentes, ou seja, contra a mineradora e o latifundiário.

Uma vez que o acampamento foi construído, foram-se organizando as ruas, escolas, casas... Essa área ficou conhecida como "Vila da Barata", por haver muitos desses insetos no local - que, atualmente, constitui a vila do PA Palmares Sul. De acordo com Fernandes (1999), para acelerar a negociação da área o movimento organizou uma marcha de 700 quilômetros até Belém com o objetivo de pressionar o governador para que ele criasse o assentamento. A marcha teve seu início em 18 de outubro e o grupo conseguiu uma reunião com o INCRA e o governo estadual, que se dispuseram a vistoriar a Rio Branco mediante cancelamento do ato, o que não foi aceito pelo movimento por entender que os laudos técnicos eram uma armadilha, visto que muitas vezes concediam ganho de causa aos latifundiários, o que de fato ocorreu na Rio Branco. Com efeito, o MST continuou a marcha até Eldorado dos Carajás onde foram convidados a negociar em Brasília, momento em que o INCRA se dispôs a comprar a área do Rio Branco, que foi transformada em Projeto de Assentamento Palmares, com capacidade de acolher 844 famílias em uma área de 24.536 hectares.

Com a constituição do assentamento ocorreu uma fratura política dentro do grupo, o que levou o INCRA a criar dois assentamentos: Palmares (mais conhecido como Palmares II), em 11 de março de 1996 com uma área de 14.922 hectares, com capacidade de 517 famílias; e Palmares Sul (popularmente intitulado Palmares I), em 11 de dezembro de 2001, em uma área de 9.615 hectares e capacidade para 327 famílias (ver Mapa 11).

Com a ruptura de uma parte dos assentados com o próprio movimento do MST, constituído por aqueles que ficaram em Palmares I, uma parcela significativa dos assentados, especialmente as lideranças, deslocou-se para onde se localiza a atual vila da Palmares II, visto que não objetivava ficar próxima da cidade. Nessa vila foram construídas escolas, espaços coletivos etc. e se manteve a organização pautada nos núcleos de base existentes no período do acampamento. Assim, cada pessoa integrava um grupo de família, que possuía um nome, um número, uma coordenação baseada nos setores de segurança, saúde, educação e produção, forma organizativa que se manteve até aproximadamente os anos 2000. Após esse período a orientação é que os grupos fossem mais reduzidos e, muitas vezes, as pessoas começaram a perder suas referências de vizinhança que existiam nos grupos maiores aos quais pertenciam antes, contribuindo para a desmobilização social e os conflitos. 
Anteriormente existia uma coordenação ampla, com mais ou menos cinquenta coordenadores, que decidiam sobre a vida econômica, cultural e política do assentamento, estabelecendo um poder não hierarquizado, coletivo e popular que com o passar do tempo foi fragilizado, muito embora exista um movimento de reestabelecimento dessa forma de coordenação, que incorpora as representações das instituições existentes hoje, como escola, saúde, Igreja, segurança, dentre outras, com o intuito de reconstruir aquela organicidade com os assentados internos e inclusive com os de outros assentamentos, tal qual é informado por um dos assentados: 


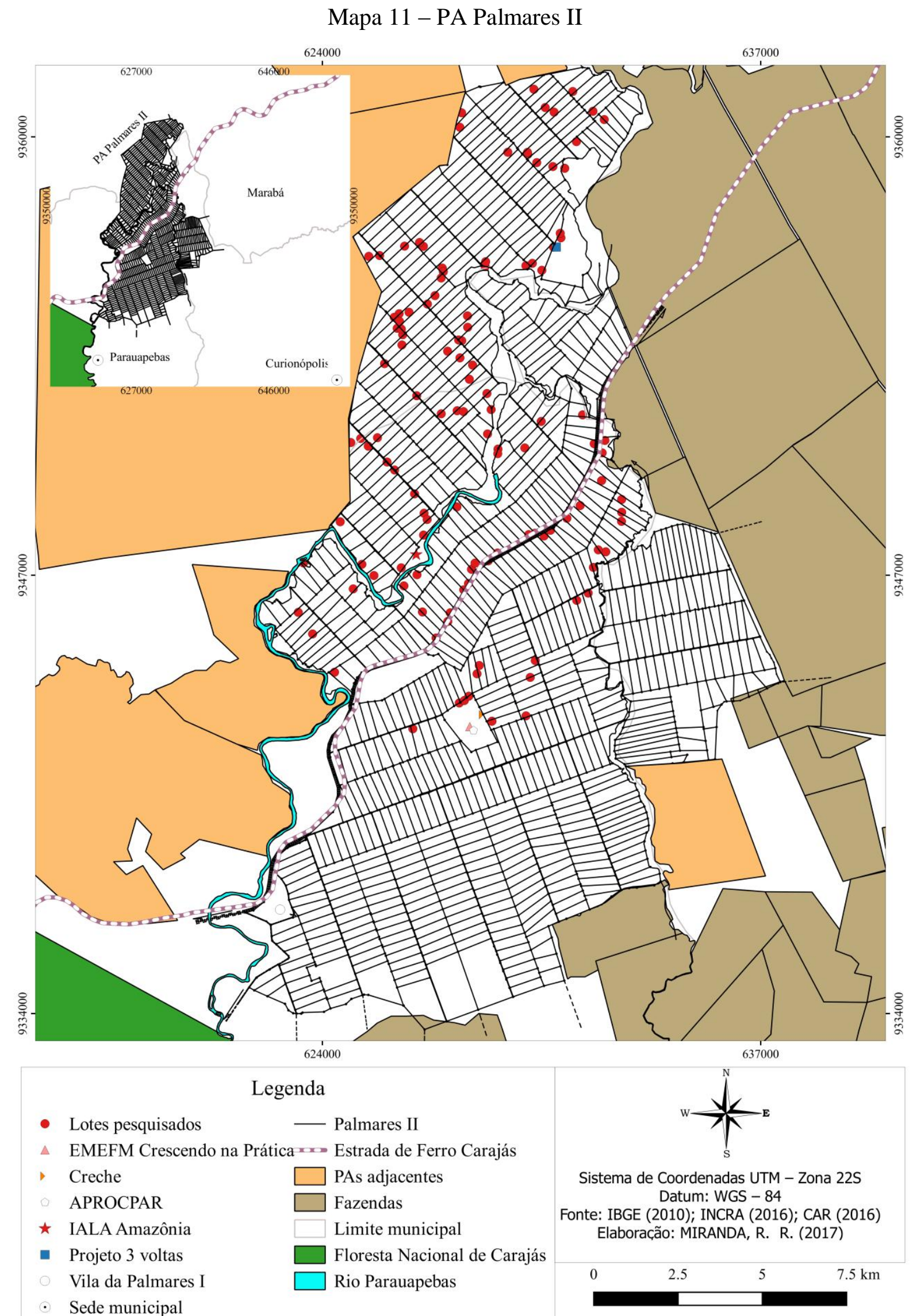

Fonte: IBGE, 2010; INCRA, 2016; CAR,201).Base cartográfica, cartografia e organização: Rogério Rego Miranda. 
Hoje tem uma coordenação que é representada pelas instituições, digamos assim, pela associação, pelas duas cooperativas que tem, pelo setor de saúde, pelo setor de educação, pela juventude, pelas igrejas que tem na comunidade, pelo setor de esporte, todo setorzinho tem representação nessa coordenação, porque quando a gente quer fazer uma grande atividade de massa todo mundo se movimenta para poder... A pauta geralmente é uma pauta que tem que tratar de vários assuntos, tem que ser uma coordenação que é... que depois vem das instituições que nós criamos, ela é representativa, eu acho que elas não bastam, elas têm que mergulhar para poder criar raízes nos territórios, então nós vamos reconstruir a ideia de que aqui na região tem que ter uma estrutura da associação e do assentamento, e lá na Três Voltas também e na Rio Novo também, a ideia é criar vários núcleos dentro do território para que o pessoal consiga discutir, que bom, será que vai vir hoje ou amanhã, quem define a política de arado de terra, quem é que faz essa coisa das estradas, das políticas públicas no território, como é que tu atua? E as decisões do assentamento como um todo, é uma questão de reconstruir as coisas, que é um pouco essa ideia da pesquisa, saber quem é que está no território, é o cara que comprou a terra, ou é o cara que ele é original, a gente sabe, reconstruir esse mapa, além do mapa do INCRA, como é que você achou esse mapa, com a nossa geografia, aquela que a gente conhece, que é a ramal tal, sinal tal [...] Mas a ideia é nossa, está ligada à ciência política geral e que nós temos que fazer ampliar aliança no território, nos entornos para a gente poder fazer as lutas que vêm pela frente, uma delas é contra a mineração, um ano, dois anos, três anos, não sei, estamos testando algumas coisas, mas são pequenos combates, acho que os grandes combates estão por vir. (Jorge Neri, militante do MST, 49 anos, 11 maio 2014)

O Assentamento Palmares II acabou por se tornar uma referência no processo de territorialização do MST no sudeste paraense, pois ainda resguarda muito da organicidade por meio de decisões coletivas envolvendo os diversos setores da sociedade; possuir uma escola que mantêm as premissas do movimento socioterritorial e o ideal da luta pela terra se contrapondo ao ensino técnico-formativo proposto pela Vale e o Estado; apresenta experiências interessantes em termos de projetos coletivos no âmbito da produção e do ensino camponês, além de ser um dos locais de maior formação de lideranças da região. Por esses motivos, apresenta uma centralidade territorial para o MST, conforme relata uma das lideranças:

[...] eu fico sempre olhando na Palmares, em vinte anos que nós celebramos agora, ou seja, primeiro assim, sem a Palmares certamente não existiria o MST Pará, ou seja, Palmares é decisiva no que nós somos hoje, e por quê? Porque todo mundo que saiu para espacializar o MST estão vinculados à Palmares, então tudo que se faz lá vira pedagogia na... Tudo que se acerta lá, se acerta, mas o que se erra também, o que é exemplo negativo também, e nessa perspectiva o assentamento Palmares em vinte anos de 517 lotes, 112 pessoas passaram sua parcela, em vinte anos, esse é um número muito pequeno. Em vinte anos de 517 famílias, 112 passaram sua parcela, então onde o assentamento tem mais condição de se perceber enfrentando a Vale, 
enfrentado uma burguesia raivosa da cidade, e tudo que ela tem é a partir da sua luta (Charles Trocate, militante do MST, 37 anos, 18 ago. 2014).

Com a constituição da Palameres II varias outras ocupações de terras foram planejadas com objetivo de avançar com o processo de territorialização do MST e a luta pela terra em relaçãos aos latifundiários da região e as empresas de mineração que se expandiam rapidamente na realidade do sudeste paraense.

\subsubsection{Projeto de Assentamento 17 de Abril}

Com o aprofundamento dos trabalhos de base do MST inicia-se o planejamento da ocupação do Complexo Macaxeira (Fazenda Macaxeira, Grota Verde, Ponta Grossa e Eldorado), uma área de 42 mil hectares, localizada no município de Eldorado dos Carajás.

De acordo com Fernandes (1999), muitas famílias que participaram da ocupação eram posseiras nas terras da Macaxeira, que já estavam sendo reivindicadas pelo MST desde a entrega dos lotes do PA Palmares pelo então presidente do INCRA, Francisco Graziano Neto, no dia 5 de novembro de 1995, ocasião em que, além dos beneficiados da reforma agrária, estavam presentes mais 1.500 famílias que reivindicavam a desapropriação da Fazenda Macaxeira, de propriedade de Plínio Pinheiro, pressionando para que houvesse a vistoria da área em questão.

Nesse mesmo dia cerca de 3.550 famílias ocuparam o Centro de Orientação e Formação Agropastorial e Artesanal de Curionópolis (COFAAC), onde ficaram por cinco meses aguardando o resultado da vistoria. Após esse período o acampamento foi alterado para a Fazenda Formosa cujo proprietário era Olavo Ribeiro.

No início de abril de 1996, decidiu-se realizar uma caminhada em direção a Belém para negociar a desapropriação da Fazenda Macaxeira. Acamparam no quilometro 21 e depois no quilômetro 16 da PA150, até chegarem à "Curva do S", no dia 16 de abril. Nesse momento foram visitados pelo promotor de justiça acompanhado de dois soldados, que solicitaram a desobstrução da estrada, pois no dia posterior, às onze horas, lhe seriam cedidos cinquenta carros e 10 mil quilos de alimentos para que seguissem viagem até seu destino na capital paraense. De acordo com os relatos dos assentados que estiveram presentes no ocorrido, a ideia era realizar uma averiguação acerca dos sem-terra, para observar se estavam armados, quantos eram etc.

No dia 17 de abril a rodovia foi novamente interditada pelos sem-terra às onze horas da manhã, pois o acordo não havia sido cumprido. Às duas horas da tarde chegou o primeiro 
batalhão, advindo de Parauapebas, que ficou aguardando o restante dos policiais que vinham de Marabá. Ao chegarem, cercaram os sem-terra nos dois sentidos da estrada e não se dispuseram a negociar, lançaram imediatamente gás lacrimogêneo. Entretanto, como os semterra resistiram, os batalhões passaram a dar tiros de fuzil, os quais ceifaram dezenove semterra, segundo números oficiais, muito embora alguns assentados aleguem que esse número seja superior devido à quantidade elevada de pessoas presentes entre homens, mulheres e crianças, e devido à procura de pessoas por parentes desaparecidos no local após o evento, o qual foi alvo de muitas histórias e estórias acerca das mortes. Foi um evento extremamente violento, como nos informa um dos assentados que esteve presente no massacre e sobreviveu:

[...] rapaz do massacre o que eu vi foi [...] muito companheiro caindo, tombando, muito sangue, muito miolo de cabeça de gente derramado na pista, onde nós... eu ajudei a juntar uma camisa quase cheia de miolo, nós juntamos dois mortos que estava, que já tinham levado um bocado, depois vieram pegar o resto e eu nesse dia, eu cheguei em casa umas cinco horas da manhã, peguei o carro para ir embora já quatro horas, três e meia pra quatro horas, fui chegar em casa, estava tipo assim um terror, entendeu! Na hora que chegava lá no trinta, os guarda, porque tinha os guardas, diziam assim "olha vocês andam que a polícia está rondando direto aí", então era mais ou menos isso (Manoel da Conceição Saraiva, assentado do 17 de Abril, 54 anos, 22 jun. 2016).

Após o episódio, o acampamento que era formado por aproximadamente 1.500 famílias foi reduzido para 690, em virtude da dispersão de uma parte dos sem-terra que desistiram e de outra parte que foi remanejada pelo INCRA para o Assentamento Tuerê em Novo Repartimento, criado em 1987. A ideia era criar de fato a desmobilização do MST no sudeste paraense, mas, ao contrário do que se pretendia, uma parte das pessoas que estavam no movimento ocupou a sede da Fazenda Macaxeira, enquanto a outra ficou na Fazenda Formosa para a colheita da roça coletiva do arroz.

Em maio de 1996 doze membros da Coordenação Nacional do MST se reuniram com o presidente FHC e o então ministro da reforma agrária Raúl Jungmann - na ocasião havia sido criado o Ministério Extraordinário de Política Fundiária em virtude do massacre -, e discutiram pautas acerca da reforma agrária, da responsabilização do governador Almir Gabriel e do ministro da justiça, além da prisão dos policiais envolvidos nos assassinatos na "Curva do S” e da desapropriação da Fazenda Macaxeira (FERNANDES, 1999).

No ano de 1997 foi realizada uma nova vistoria na área pleiteada pelo MST, que dessa vez foi atestada improdutiva. Assim o Complexo Macaxeira foi desapropriado para fins de reforma agrária e, dessa forma, foi criado em 19 de junho de 1997 o Projeto de Assentamento 
17 de Abril, em alusão ao massacre ocorrido nesse dia, com capacidade de abrigar 690 famílias em uma área de 18.090 hectares (ver Mapa 12).

Em homenagem aos que vieram a óbito no dia 17 de abril de 1996 foi criado um monumento na "Curva do S", onde estão fincados no chão troncos de castanheiras, simbolizando a violência com a qual a reforma agrária é tratada no estado do Pará, mas, ao mesmo tempo, a possibilidade de que esse projeto se realize ainda que seja por meio da luta, suor e sangue dos sem-terra (ver fotos 16 e 17).

Foto 16 - Monumento em homenagem aos dezenove sem terra mortos no massacre de Eldorado dos Carajás, na "Curva do S".

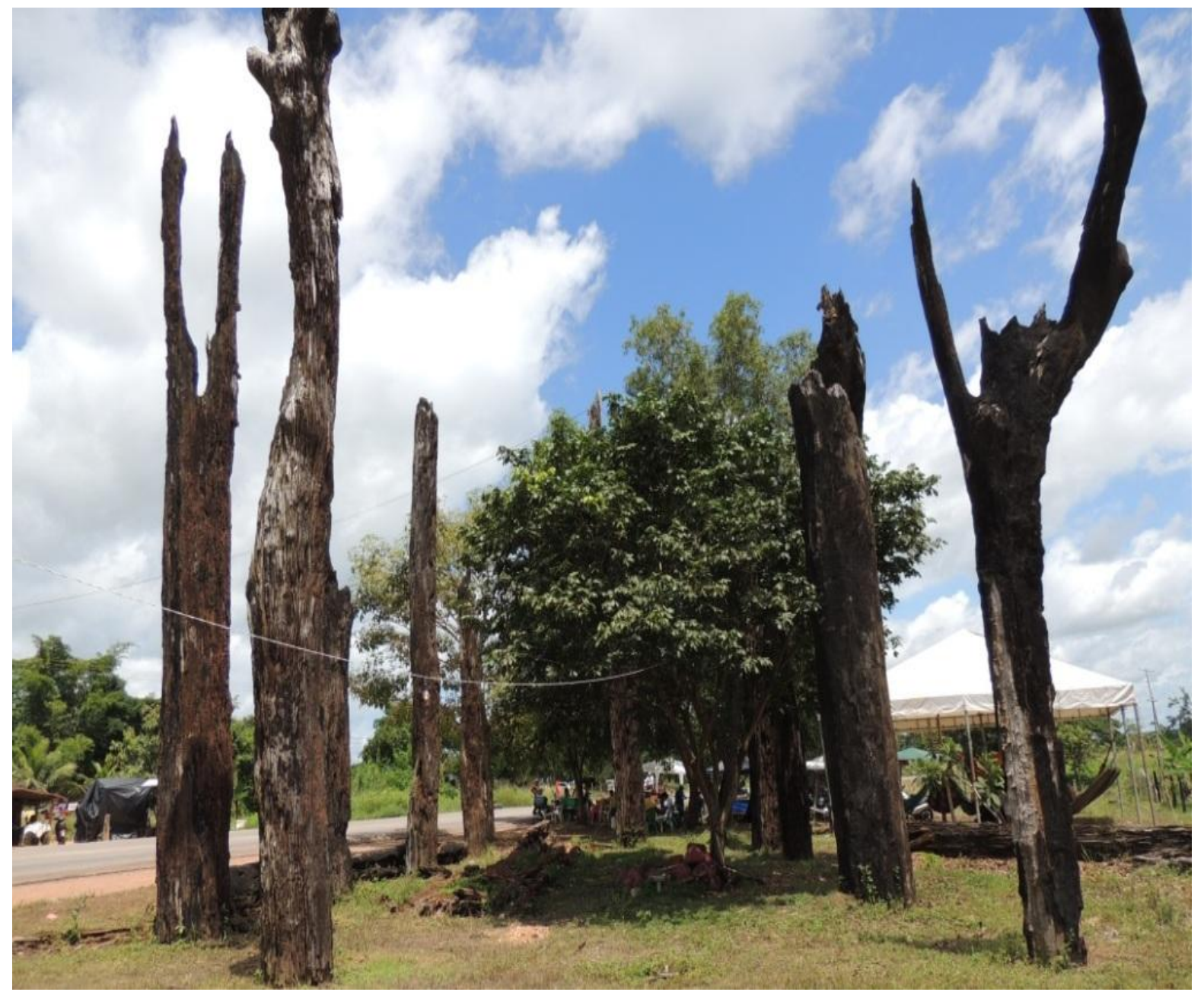

Fonte: Rogério Rego Miranda, Eldorado dos Carajás, 2016. 
Mapa 12 - PA 17 de Abril
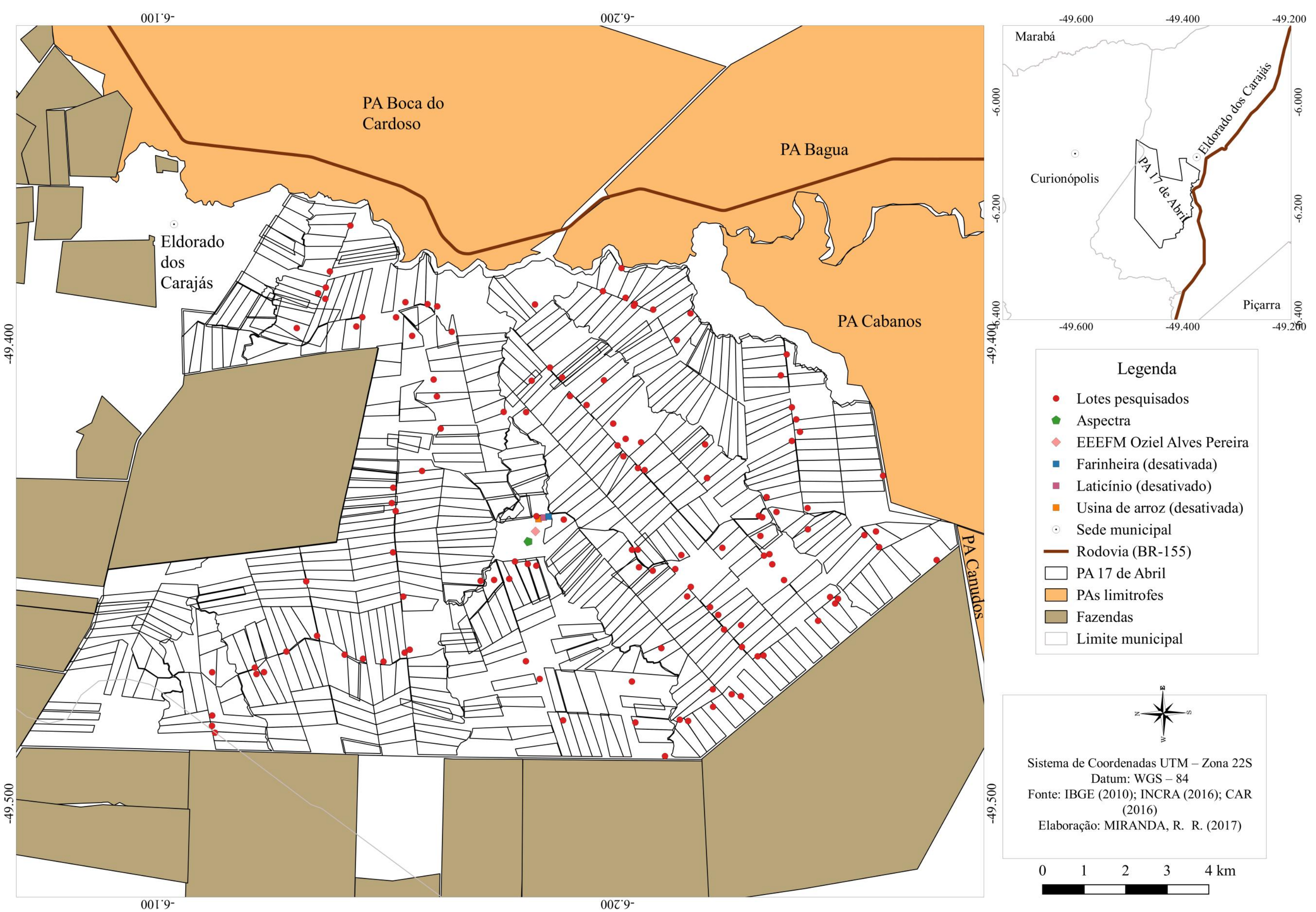

Fonte: IBGE, 2010; INCRA, 2016; CAR, 2016. Base cartográfica, cartografia e organização: Rogério Rego Miranda. 
Foto 17 - Cruzes simbolizando o local do massacre na "Curva do S"

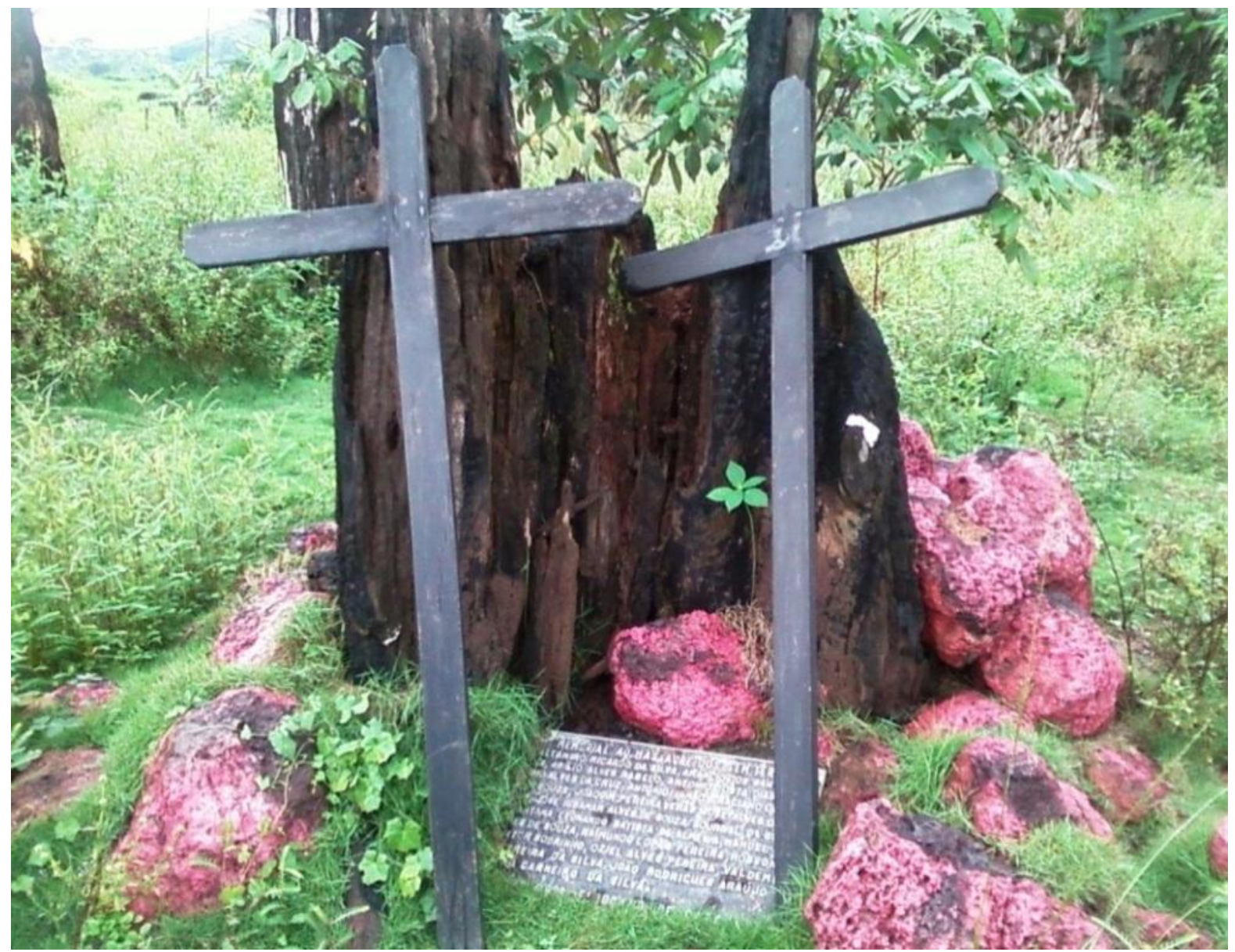

Fonte: Rogério Rego Miranda, Eldorado dos Carajás, 2016.

O Assentamento 17 de Abril, que inaugurou de maneira emblemática o terceiro momento da territorialização do MST no Pará, tal qual ao Palmares II, acabou se tornando uma grande referência territorial ao movimento, seja por sua visibilidade nacional e internacional decorrente do massacre, o que acabou definindo o dia 17 de abril como o "Dia Internacional da Luta camponesa", seja por sua importância em termos de continuidade da luta pela terra, devido à mobilização dos assentados no auxílio da construção de novos acampamentos e assentamentos; na organização de caminhadas, marchas etc., e na formação dos quadros de militância.

[...] na questão da mobilização, cadastramento, no momento da ocupação, a organização de grupos essas coisas assim, correr atrás de alguns benefícios, na primeira mão dos acampamentos esses negócios tudo é difícil, aí ajuda correr atrás de alimentação, essas coisas assim, tem toda essa demanda [...]. Justamente esses acampamentos que estão tudo aí se recriando agora, se criando [...] é São José que já estão, já tem mais de dez anos de assentado, Volta do Rio, Maria Bonita ali agora, tem Nega Madalena lá em Tucumã, tem outros mais, é que não estou sabendo o nome de todos, Lourival Santana 
(Peruana), tudo é a 17 de Abril que cria [...] Ajuda na criação de tudo, do início de cadastramento até chegar a sua terra, o que dificilmente tem acampamento que a direção não seja daqui, a militância criada daqui, é como hoje nós temos lá a Cedro, mas a militância foi tudo daqui, que fica organizando porque todo ano tem aquela formação de militante, o movimento na formação de militante [...] [famílias do acampamento Dalcídio Jurandir] não que ficaram acampadas aqui, as famílias foram daqui [...] digamos assim, quando se vai ter uma ocupação, aí vem a ordem da direção pra fazer o cadastramento das famílias que não tem terra aqui, fazem o cadastramento, aí fica até no dia que vai acontecer e tal, e que as pessoas podem ir se preparando, e enfim [...] da Lourival Santana ajudamos [...], na verdade nós aqui, já ajudamos até uma vez na Taba [...] a ajuda na Taba foi... teve a liminar de despejo lá, aí como nós já tinha a viagem pronta para ir participar do evento que ia ter, aí... o movimento sempre é segredo, que eu acho que a gente já foi diretamente para fazer essa ocupação lá, ajudar eles para ajudar a fazer essa ocupação lá [...] a peruana foi um dos primeiros acampamentos além da Volta do Rio e da São José foi um dos primeiros acampamentos a ser feito, e justamente o povo que tem lá, todos eram daqui, filho de assentado, morador que morava aqui mas não tinha cadastro aqui, que não tinha terra aqui, que muitas das vezes você era cadastrado e tinha um irmão seu ou irmã, ou seu pai também, vinha a família mas não era cadastrado, aí vinha e já aproveitaram e se cadastraram nesses novos acampamentos, a maioria do povo dali era daqui, inclusive aqui tem até um dizer que aqui a 17 de Abril é a mãe de todos esses outros acampamentos e assentamentos, que é o polo maior de tudo, é a 17 de Abril (Manoel da Conceição Saraiva, assentado do 17 de Abril, 54 anos, 22 jun. 2016).

Com a conquista do PA 17 de Abril se grafou definitivamente a territorialização do MST no sudeste paraense, culminando em outras conquistas posteriormente.

\subsubsection{Projeto de Assentamento $1^{\circ}$ de Março}

Com o massacre de Eldorado dos Carajás se intensificam as ações do MST, inclusive em outras mesorregiões paraenses, especialmente a porção nordeste do estado, em áreas próximas à Belém. No bojo dessas ocupações, o movimento começa a atuar incisivamente na área do antigo "Polígono dos Castanhais", a exemplo do Assentamento $1^{\circ}$ de Março, localizado no município de São João do Araguaia, na área da Fazenda São Tomé, que pertencia à Agropastoril e Extrativa do Brasil S/A, conhecida como "Pastoriza".

As lideranças do MST primeiramente realizaram o trabalho de base na periferia de Marabá e em São João do Araguaia. Como a fazenda que seria ocupada faz limite com o PA Araras e alguns de seus assentados possuíam relações com o MST, um caminhão foi cedido para o transporte das primeiras famílias entre a Agrópolis do INCRA e o lote de um dos assentados do PA Araras, onde construíram um acampamento provisório. Esse acampamento 
foi abrigando as pessoas que chegavam, até totalizar cerca de 900 famílias que, no dia $1^{\circ}$ de março de 1997, ocuparam a referida fazenda, por volta das vinte horas.

As famílias fizeram seu acampamento em meio à floresta, desenvolvendo as roças coletivas, a escola de palha, as casas de lona... Nesse período de acampamento foram feitos vários pedidos de reintegração de posse, porém o despejo nunca se efetivou, tal qual acontecia nos demais acampamentos existentes na região e organizados por outros movimentos sociais e sindicais como a FETAGRI. Isso porque, em função do episódio na "Curva do S", não foram desenvolvidos métodos coercitivos por parte da polícia e do fazendeiro, muito embora existissem ameaças constantes. Também devido ao apoio da Diocese de Marabá via CPT, em especial pela pessoa do padre Luís, de origem italiana, que assessorou os sem-terra, inclusive com alimentos.

Nesse período de luta pela terra, como é comum nas áreas organizadas pelo MST, o acampamento desenvolvia ações para conseguir melhorias infraestruturais e garantir serviços essenciais como educação e saúde. Para esse fim, algumas alianças foram feitas com outros acampamentos e assentamentos, como relata um dos assentados:

[...] a gente vivia num processo de luta pela terra, mas também associado à luta pela terra nós tínhamos que garantir educação para os nossos filhos e ter acesso ao atendimento de saúde, então era uma briga constante [...] inclusive aconteceu um fato marcante que inclusive esse episódio que ocorreu em 98 [...] é porque nós tínhamos uma pauta de reivindicação bastante extensa, inclusive reivindicando merenda escolar, estrada de acesso, e o prefeito na época que era o seu Mario Ferreira se recusou em receber uma comissão de acampados, porque nós já éramos do MST e o MST até então nos dias de hoje é mal visto por aqueles que tentam concentrar terras, concentrar direitos, centralizar poder, e na época o prefeito não nos recebeu enquanto comissão, a comissão composta por oito pessoas. Aí nós voltamos para a base, para o acampamento, fizemos uma grande mobilização inclusive com apoio do Castanhal Araras, com apoio do pessoal do Assentamento Prata que na época vivia num processo de transição também, era área de latifúndio, estava num processo de transição também para posteriormente ser o assentamento que é hoje, inclusive quando nós ocupamos a então Fazenda Pastoriza posteriormente teve a ocupação do Prata que era dos baianos e tal [...] então nós somamos as forças, tanto o acampamento nosso que era representado pelo MST e a Prata, o assentamento que hoje é representado pelo sindicato e o Castanhal Araras, então essas três comunidades tinham uma pauta de reivindicação, estrada, energia, merenda escolar, saúde e etc., então nós juntamos essas forças e ocupamos a Prefeitura de São João do Araguaia, foi assim um fato inédito que aconteceu em 1998, ocupamos a Prefeitura e ficamos lá acampados mais ou menos uma semana até o prefeito comparecer para negociar a pauta de reivindicação dessas três comunidades, a nossa, enquanto acampados, Ponta de Pedras também e o Araras, então foi um fato, assim, bastante interessante e inédito aqui em São João do Araguaia, e daí nós garantimos cem por cento dos pontos de pauta. (Claudemir Pereira Pinto, assentado do PA $1^{\circ}$ de Março, 51 anos, 24 de mar. 2015) 
Dentre os acampamentos do MST, esse foi o que permaneceu menos tempo, pois foi logo criado, no dia 15 de junho de 1998, o Assentamento $1^{\circ}$ de Março, em alusão ao momento da ocupação e início da conquista da terra, apresentando uma área de 10.961 hectares com capacidade para 350 famílias (ver Mapa 13).

Atualmente, o assentamento vem apresentando diversas mudanças decorrentes da venda de lotes, denunciadas pelo próprio MST, a qual altera a composição social e incita conflitos internos por terra. A própria relação com o movimento se modifica, pois a maioria das pessoas já não é oriunda do processo de ocupação nem é parente dos antigos sem-terra. Apesar disso, os assentados originais e/ou seus familiares correspondem a uma base territorial importante, inclusive a associação APROCTRAM (Associação de Produção e Comercialização dos Trabalhadores do Assentamento $1^{\circ}$ de Março) conta com lideranças do MST que desenvolvem ações reivindicatórias importantes, especialmente no de instalação da Hidrelétrica de Marabá, que poderá afetar o assentamento. Desta feita, busca-se realizar o debate sobre os impactos no local, em conjunto com o MAB. 


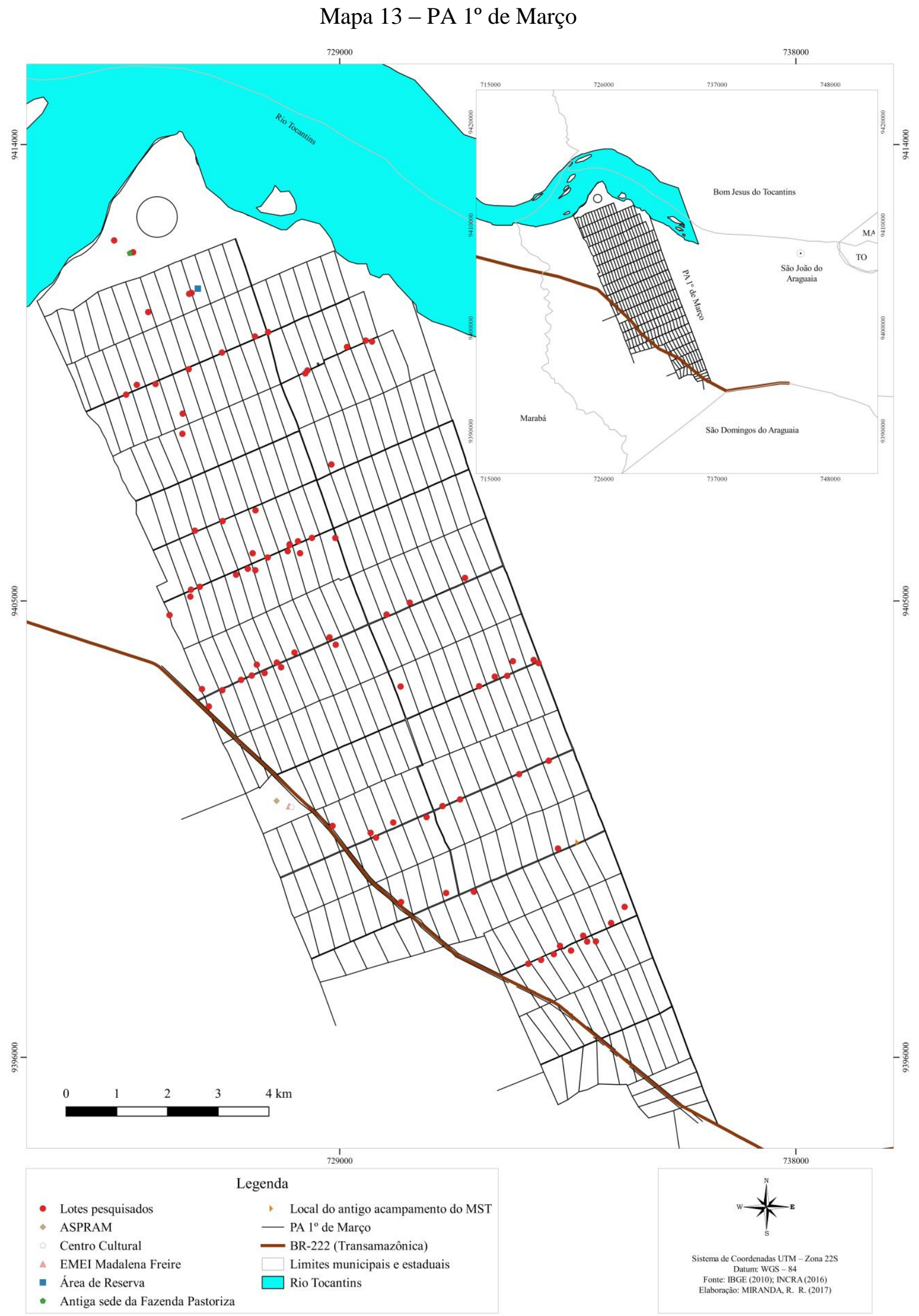

Fonte: IBGE, 2010; INCRA, 2016; CAR, 2016. Base cartográfica, cartografia e organização: Rogério Rego Miranda. 


\subsubsection{Projeto de Assentamento Onalício Barros}

O MST, a partir do PA Onalício Barros desenvolveu uma luta contra os latifundiários do sudeste paraense para recuperar a terra da União que fora definida para fins de reforma agrária na década de 1980 pelo GETAT.

No ano de 1982, esse órgão, em comum acordo com a CVRD, criou o Projeto de Assentamento Carajás I, II e III, com o intuito de assistir 1.551 famílias oriundas principalmente dos estados de Goiás e Maranhão. Para obter um maior controle sobre a área, o GETAT criou três Centros de Desenvolvimento Regional (CEDERE I, II e III) nos quais foram construídas vilas 70 quilômetros equidistantes uma da outra. O PA Carajás tinha por objetivo maior possibilitar um cinturão de proteção para a porção territorial de concessão minerária da CVRD de 411 mil hectares, atualmente Floresta Nacional de Carajás, de forma a evitar ocupações de terras na área por parte dos trabalhadores rurais e, também, foi definido como um polo agrícola para o abastecimento da região do Programa Grande Carajás para diminuir os conflitos de terra na região do Bico do Papagaio. Posteriormente o CEDERE II e III deram origem ao município de Canaã dos Carajás em 1994, enquanto o CEDERE I permaneceu sob a administração do município de Parauapebas e faz parte do PA Carajás II e III (CRUZ, 2015).

Os PAs Carajás II e III foram gradativamente reapropriados por grandes fazendeiros e/ou comerciantes da região, pois os antigos trabalhadores rurais assentados pelo GETAT não possuíam assistência técnica e financeira que lhes possibilitassem desenvolver suas produções de maneira satisfatória, além de dificuldades em termos de circulação para o escoamento das mercadorias, que muitas vezes eram feitas por meio de animais, e das pessoas. Muitos sofriam de doenças como malária e vinham a óbito por não ter assistência médica ou meios de se deslocar para obtê-la. Essas condições precárias levaram muitos camponeses a vender os lotes em que residiam.

A partir dessas áreas vendidas, foi formada a Fazenda Goiás II, do intitulado proprietário Carlos Antônio da Costa, conhecido popularmente como "Carlinhos da Casa Goiás", dono do comércio "Goiás Concreto", estabelecido em Marabá e Parauapebas. Sua fazenda possuía 1.487 hectares constituídos pela compra de 14 lotes de aproximadamente 50 hectares e mais 700 hectares de terras da União ocupados pelas 550 famílias que habitavam o assentamento (MST, 1998). 
A ocupação da área foi realizada por um grupo de sem-terras que anteriormente havia ocupado a Fazenda Bamerindus ${ }^{34}$, porém se retiraram do local por conflitos com os posseiros existentes ali. Nesse processo, se deslocaram para o PA Palmares II, onde construíram um acampamento provisório até o momento em que decidiram, por meio de uma assembleia, que iriam ocupar a Fazenda Goiás II, o que ocorreu na madrugada do dia 14 de março de 1998, com cerca de 550 famílias que acamparam às margens do rio Caboclo.

Após quatro dias, foi expedida a liminar de reintegração de posse cumprida no dia 26 de março por dois oficiais de justiça acompanhados de policiais militares que intimidaram os trabalhadores rurais, que, por sua vez, com receio de represálias mais violentas, decidiram se retirar da propriedade, especialmente porque um dos coordenadores do MST já estava preso e porque estavam entre os presentes pistoleiros contratados pelos fazendeiros da região.

$\mathrm{Na}$ ocasião trouxeram caminhões para a realização do despejo de forma a retirar os sem-terra da área, uma vez que a possibilidade de permanência deles nas vizinhanças significaria novas ocupações. Por esse motivo diversos fazendeiros se reuniram nesse momento para assegurar que os sem-terra fossem deslocados para o INCRA em Marabá ${ }^{35}$. Segundo relatos dos então acampados havia muitas pessoas armadas escondidas na capoeira, atrás de paus, cercando os acampados, que não sabiam se essas pessoas eram policiais ou pistoleiros.

No momento em que os acampados colocavam os pertences nos caminhões, chegaram ao acampamento as lideranças do MST (Onalício Araújo Barros, mais conhecido como o "Fusquinha", e Valentim Serra, denominado de "Doutor"), que tentaram argumentar com os oficiais de justiça, porém sem êxito. Desta feita, cumpriram a decisão judicial, todavia as lideranças resolveram montar outro acampamento na escola municipal do CEDERE I, com o intuito de se reorganizar. Foi nessa ocasião que assassinaram o "Fusquinha" e o "Doutor" - o episódio foi relatado em detalhes por um dos assentados que vivenciou o processo:

[...] o cara que se denominava dono dessa área era um grande empresário inclusive de Parauapebas e Marabá, lá da Casa Goiás [...], então por ser um grande empresário ele acumulou muito, tinha muito conhecimento, então ele juntou a pistolagem grande, com muito fazendeiro, vieram e mataram um boi na área e fizeram um churrasco junto com pistolagem para fazer o despejo das famílias, chegaram e meteram armas nas famílias, jogaram em cima do caminhão, bateram em acampado, jogaram crianças de rebolar em cima de

\footnotetext{
${ }^{34}$ Essa fazenda foi transformada em quatro projetos de assentamentos: Viveiro, Oziel Pereira, Barreira Branca e Vale do Mucura.

${ }^{35}$ Esses fazendeiros eram conhecidos na região, a saber: Donizete, Lazhino, Nozhino, Antonio Barcelos, Luciano Sartorio e o Carlos Antonio da Costa.
} 
caminhão e vieram pra matar as lideranças, então tanto que após eles tiraram a liderança de dentro da área, chegou numa área aqui vizinha, que é o CEDERE I, eles já tinham decretado, já vieram decretado pra matar as lideranças e terminaram que conseguiram matar duas lideranças nossas lá dentro do CEDERE I, que lá nossas lideranças lá separaram dizendo que já estavam fora da área da fazenda Goiás II e que as famílias iam ficar acampadas dentro do CEDERE I, na escola do CEDERE I, que já tinham arranjado o local e eles não, queriam levar o pessoal para Marabá, não queriam deixar nem no início de Parauapebas, e com isso quando as lideranças desciam do carro para conversar com eles, eles chegaram e efetuaram disparos neles, duas lideranças nossas aqui, o Fusquinha que era da direção estadual do MST, chegou a ser da coordenação Nacional do MST, e eles executaram ele né, e eles executaram o Doutor que era militante do movimento, era tesoureiro da associação da Palmares II e inclusive pegaram... o fusquinha quando pegou o tiro ele ainda correu ainda, ele correu pra dentro do mato e eles não conseguiram encontrar o corpo, e o Doutor morreu no local e eles levaram o corpo, e enterraram o corpo a uma distância de quinze quilômetros do local e enterraram dentro de um açaizal e nós conseguimos achar o corpo ainda, essas lideranças nossas, então aqui nos tivemos pistolagem armada e perdemos a vida de dois companheiros nossos. (Cleonilson Alves dos Santos, assentado do PA Onalício Barros, 41 anos, 13 maio 2015)

Os fazendeiros José Marques Ferreira "Donizete" e Carlos Antônio da Costa ${ }^{36}$ foram acusados pelos crimes, entretanto a principal testemunha de acusação, o agricultor Antônio Vicente da Silva, foi encontrado morto em 30 de abril de 1998. Consequentemente, os dois fazendeiros foram soltos juntamente com os policiais que participaram da desocupação da área (MATHE, 2000).

Com a execução das lideranças, os acampados retornaram para o Assentamento Palmares II, onde ficaram alojados em um galpão aguardando a tensão diminuir. Com o apoio dos assentados da Palmares II e da 17 de Abril, decidiram voltar três dias depois com 1.500 pessoas para novamente ocupar a fazenda, ocupando agora a sua sede e lá se reorganizaram em núcleos de base e permaneceram até a criação do PA Onalício Barros, em homenagem ao "Fusquinha", no ano 2000, assentando 68 famílias em uma área de 1.770 hectares (ver Mapa 14), destacando que o vultoso número de indivíduos que ocuparam a área era apenas para garantir a conquista da terra.

\footnotetext{
${ }^{36}$ Esses fazendeiros "acrescidos de Rafael Saldanha, Gabriel Saldanha, Dão Baiano, Ninha Baiano, Marcelo Catalão, Takinha, José Ulisses Guimarães, entre outros, que pressionam o INCRA e o Governo Federal para não vistoriar e nem desapropriar as fazendas reivindicadas pelo MST, desde 2007, das glebas Tabocas e Rio Novo. Ao mesmo tempo que montam, aos olhos dos órgãos de segurança pública do Estado, a maior milícia armada do Pará, para intimidar, assassinar e despejar famílias do Acampamento Frei Henri, acampados desde agosto de 2010, no município de Curionópolis, na área denominada "Fazendinha". Ainda em 2010, a Justiça Federal encerrou o processo de desapropriação, sem que o fazendeiro fosse indenizado pela posse das áreas, da antiga fazenda Goiás II.” (TROCATE, 2015, p. 14)
} 
Mapa 14 - PA Onalício Barros

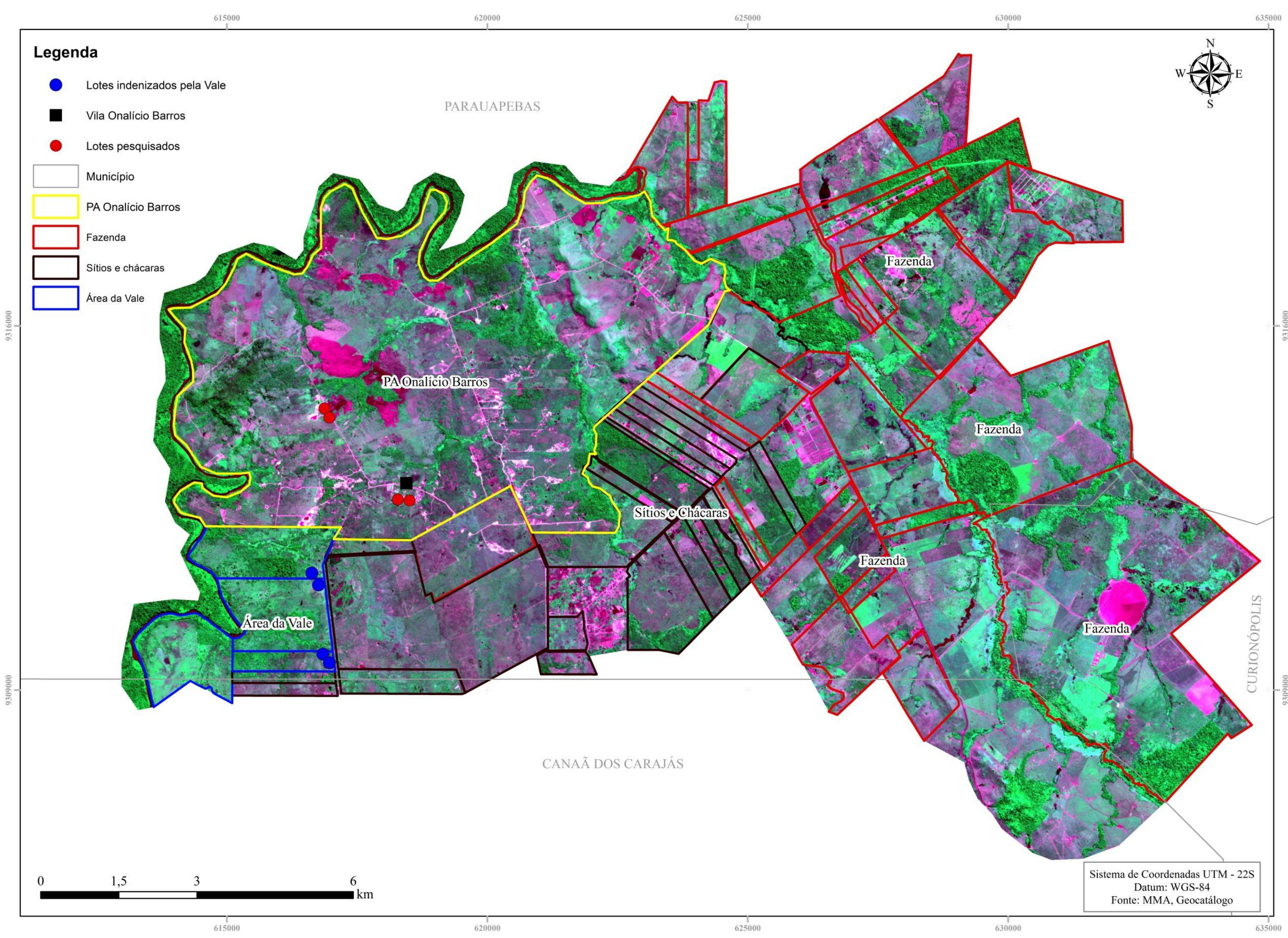

Fonte: IBGE, 2010; INCRA, 2016; CAR, 2016. Base cartográfica, cartografia e organização: Rogério Rego Miranda. 
Em decorrência de sua localização próxima ao projeto mineral da Vale, o assentamento vem sofrendo uma série de impactos, especialmente com o processo de duplicação da Estrada de Ferro Carajás (ver Fotos 18 e 19), que implicou na retirada de famílias de seus lotes com indenizações baixas, especulação imobiliária, imigração, problemas para os animais devido ao barulho da construção e, posteriormente, do próprio tráfego do trem.

Foto 18 - Canteiro de obras da duplicação da EFC.

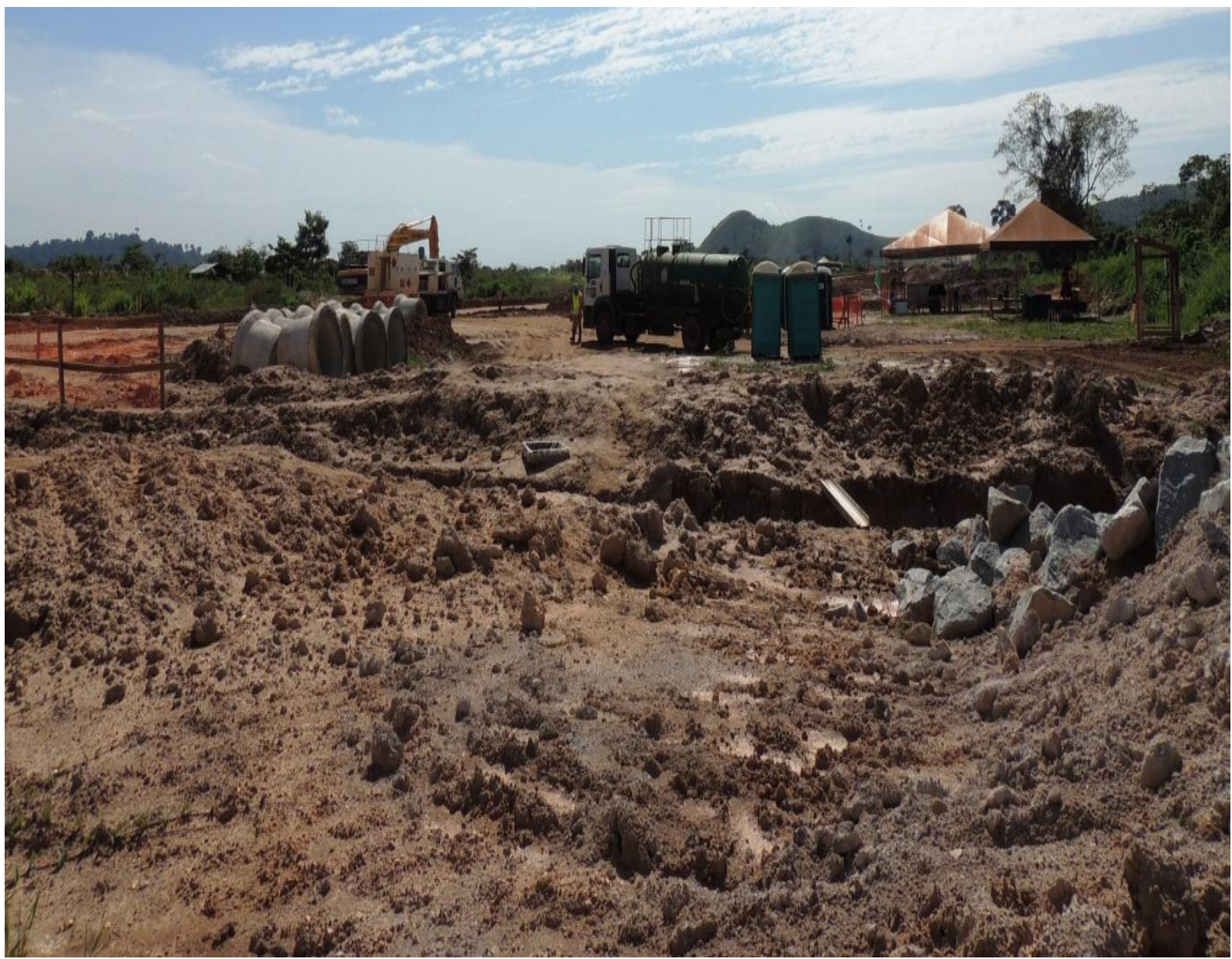

Fonte: Rogério Rego Miranda, Parauapebas, 2016. 
Foto 19 - Tratores redefinindo a paisagem do assentamento para a duplicação da EFC.

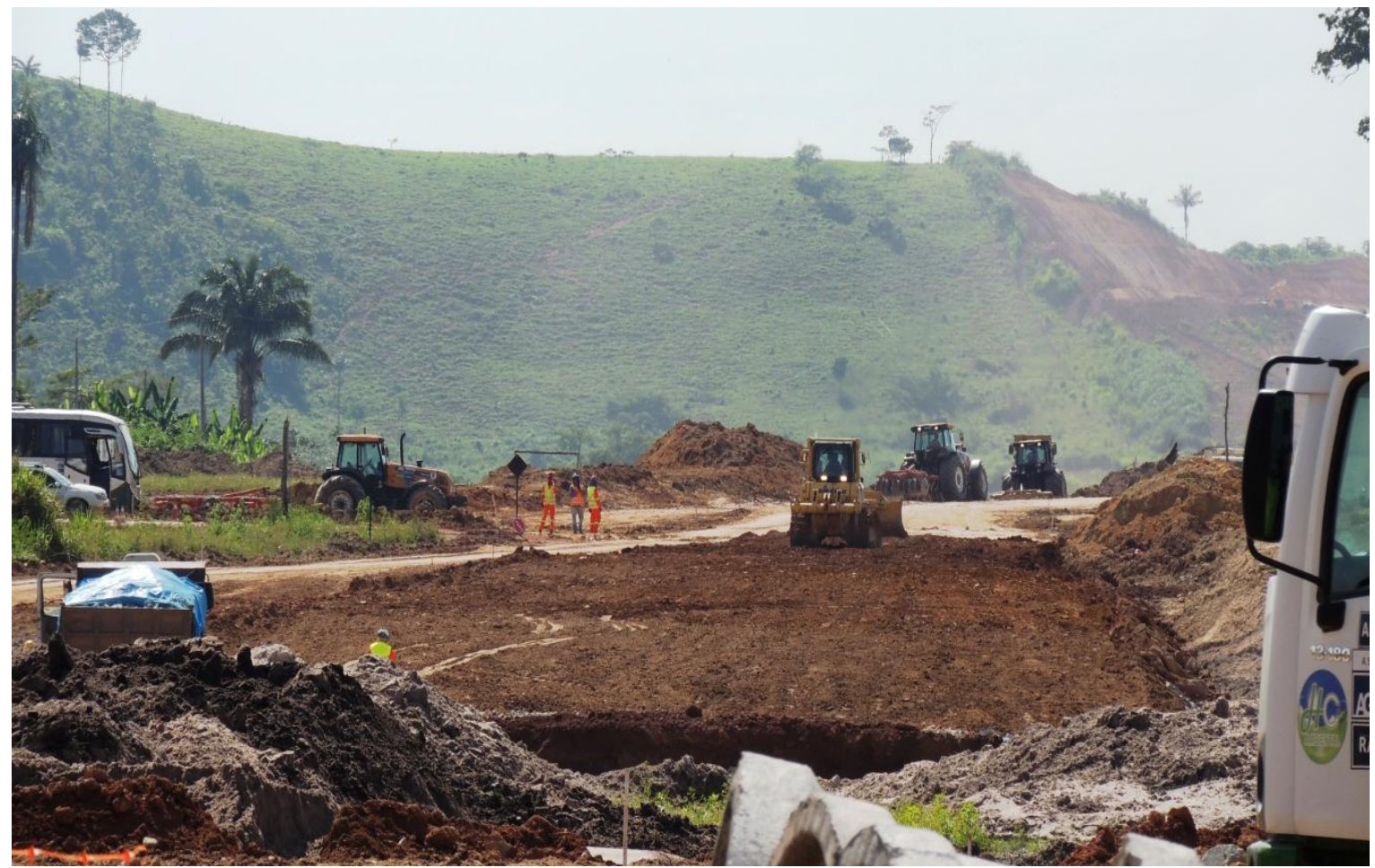

Fonte: Rogério Rego Miranda, Parauapebas, 2016.

\subsubsection{Projetos de Assentamento Cabanos e Canudos}

Com o avanço da territorialização do MST no sudeste paraense e seguindo a estratégia de aprofundar a luta na área do antigo "Polígono dos Castanhais", uma importante conquista foi alcançada ao proporem a ocupação da Fazenda Volta do Rio, cuja propriedade era da empresa Jorge Mutran Exportação e Importação, gerida por uma das famílias mais tradicionais do período da economia da borracha, que manteve sua hegemonia política e econômica após o processo de "modernização" da economia amazônica implementada pelo governo federal nos anos 1970. Desta feita, ainda era uma das maiores latifundiárias da região sudeste no início dos anos 1990, visto que permaneceu com áreas de aforamento concedidas pelo governo estadual e as transformou em pasto com o intuito de desenvolver o projeto agropecuário em vasta expansão na região.

A ocupação da área ocorreu com aproximadamente quatrocentas famílias no dia 30 de março de 1998, antecedida por trabalhos de base nos municípios de Eldorado dos Carajás, Curionópolis e Parauapebas. Para sua efetivação foi fundamental o suporte recebido pelo Assentamento 17 de Abril, o qual, por se encontrar na porção limítrofe da fazenda Volta do Rio, prestou ajuda aos sem-terra quando ali construíram seu acampamento denominado de 
Cabanos, seja com o quadro de militantes, seja com o mapeamento da área, alimentos, roupas etc.

A área já havia sido ocupada antes pelos posseiros, que foram, porém, violentamente reprimidos por pistoleiros, mas no caso dos sem-terra, organizados pelo MST, tal fato não ocorreu, na verdade não existiram ações coercitivas por parte de policiais ou do fazendeiro.

O acampamento acabou servindo de base para outros que sofriam com o processo de desapropriação, a exemplo do que ocorreu no Acampamento Irmã Adelaide, na Fazenda Jacaré Grande, localizada no município de Curionópolis, a qual foi ocupada por 350 famílias organizadas pelo MST, em 12 de novembro de 1998. Com a expulsão dessas famílias da área, muitas foram remanejadas para o Cabanos, o que faz parte da estratégia do movimento: possuir sempre uma alternativa em termos de recomposição territorial dos sem-terra caso exista a necessidade de deslocamento compulsório da área ocupada, como analisa uma das assentadas:

Foi que surgiu o acampamento no Adelaide, nós fomos para o acampamento, lá nós colocamos roça. Depois que a gente já estava colhendo, já tinha colhido um pouco de arroz, que eram três hectares, aí eu colhi só uma, aí nós fomos pro despejo, aí perdemos as coisas, o pouco que eu colhi a gente botou dentro do carro, mas teve deles lá que perderam o feijão, a fava, o arroz já no paiol, aí quando nós saímos ficamos na beira da estrada e só vi o fogo nos barracos, ai nós passamos a noite, aí de sobremesa deu uma chuva, chuva, chuva. Aí amanheceu o dia, aí arrumaram esse carro e viemos pra cá pra esse Cabanos ficamos ali uns três meses debaixo daquela mangueira, quando vinha a chuva com o vento, arrancava o plástico aí a gente saia e enchia d'água, ai foi que decidiram parar... era do movimento o Parasinho, ele vivia mais nesses acampamentos, aí foi tirado quinze famílias pra ficar aqui, e a outra foi pros outros acampamentos, porque o movimento tem essa, não deixa ninguém na mão né, essa é uma parte boa do movimento, só que uns não seguram, porque não tem paciência porque não quer né? Aí das quinze famílias que ficou aqui, acho que tem sete [...] dos que ficaram aqui já foram embora uns [...] nós viemos do acampamento irmão Adelaide ali na Fazenda Jacaré Grande que era do Osmar Ribeiro, fica poucos quilômetros lá pro trinta, lá que nós fomos despejados e viemos pra cá pros Cabanos aí estamos até hoje (Terezinha Carsoso da Silva, assentada do PA Cabanos, 68 anos, 16 maio 2015).

Após cinco anos de acampamento, a Fazenda Volta do Rio foi desapropriada para fins de reforma agrária, sendo criado o PA Cabanos no dia 07 de março de 2003, em uma área de 3.426 hectares, com capacidade de 85 famílias.

Diferente dos projetos de assentamentos existentes na região até o momento, esse seguiu um modelo de organização espacial denominado "Raio de Sol", proposto pelo MST com anuência do INCRA. Essa proposta foi discutida coletivamente entre os membros de cada núcleo de base (na época eram dez) e levada a cabo pelos sujeitos, uma vez que por ser 
um projeto piloto na região imaginaram que seriam assistidos com benefícios como escolas, postos de saúde, estradas dentre outros investimentos, o que de fato não foi efetivado por parte do Estado, de forma que o "corte" da terra, isto é, a abertura das vias de circulação e a topografia com a definição dos lotes foi realizada pela iniciativa dos próprios assentados, além da necessidade de luta constante para a eletrificação rural, a construção da escola de ensino fundamental e das casas, que nessa configuração ficam necessariamente nos espaços de produção (ver Mapa 15).

O Assentamento Canudos, por seu turno, foi construído a partir do Acampamento Cabanos. Na época da ocupação esse acampamento ficava próximo à rodovia, apresentando uma maior facilidade em termos de circulação. Entretanto, em suas proximidades existia a Fazenda São José do Refúgio, cercada por outras fazendas maiores, que limitavam a saída do proprietário daquela área, uma vez que era preciso passar por dentro de algumas das fazendas circunvizinhas.

Quando houve a ocupação da Volta do Rio, já existia um interesse também em relação à Fazenda São José e quando seu proprietário soube do acampamento do MST, manifestou sua intenção de negociar a terra.

Para evitar que outros grupos adentrassem a fazenda pelos fundos, os sem-terra resolveram ocupá-la com uma parte dos grupos de famílias da Cabanos, fato que ocorreu no ano de 1999. Nesse momento o próprio fazendeiro se propôs a dialogar com a coordenação dos sem-terra, indicando sua disposição em desocupar a área e que não haveria qualquer retaliação.

Desta feita, mediante negociações com o INCRA e o fazendeiro, foi criado o Projeto de Assentamento Canudos, no dia 16 de agosto de 2004, em uma área de 2.837 hectares, com capacidade de abrigar 62 famílias. Porém, divergindo do modelo "raio de sol" proposto para o PA Cabanos, os assentados, em coletivo, avaliaram ser melhor continuar com os modelos de projetos existentes na região, em que a agrovila fica na porção central e as pessoas definem onde preferem morar (ver Mapa 16). 
Mapa 15 - PA Cabanos

$-49$

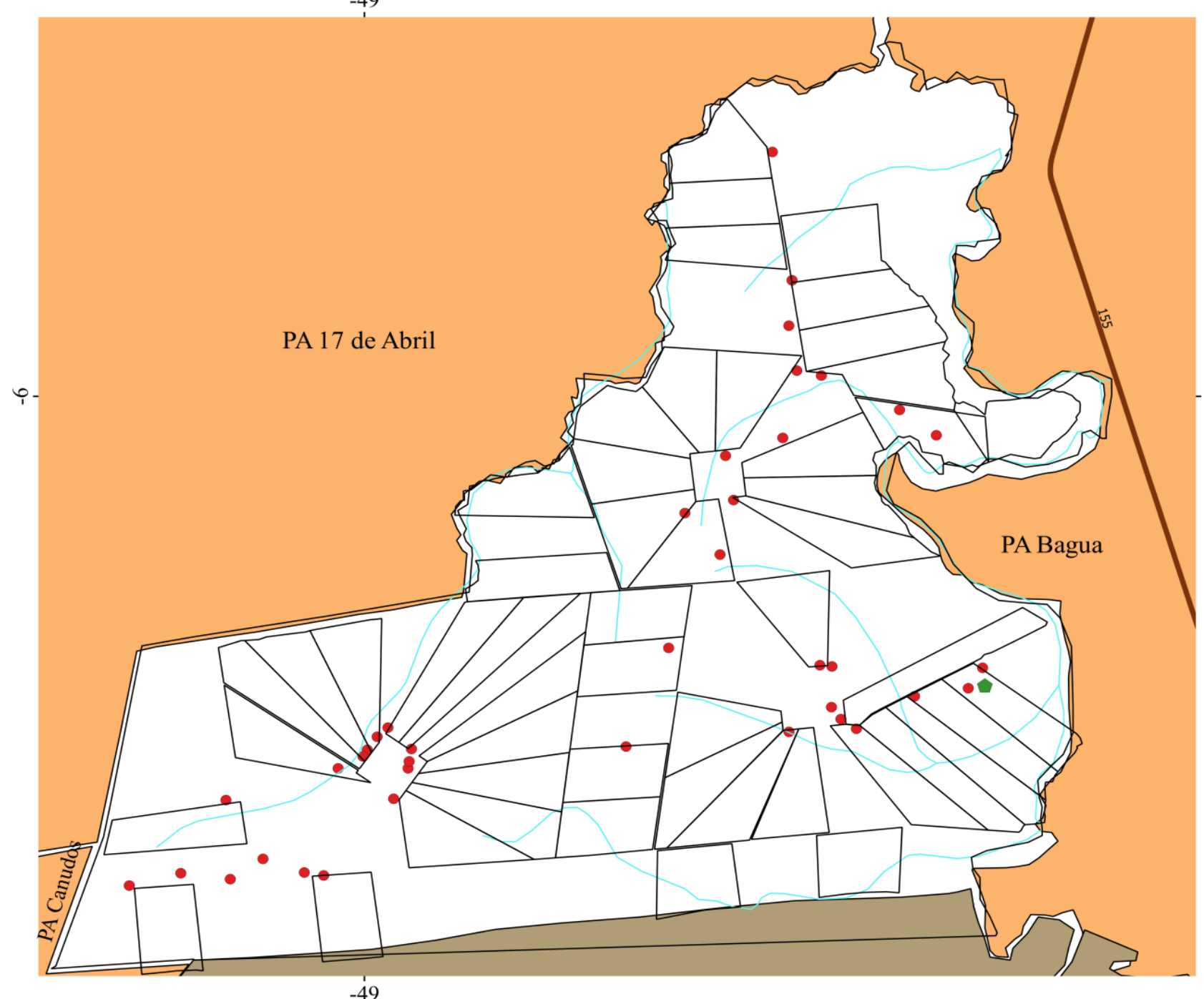

$\begin{array}{llll}-50 & -50 & -49 & -49\end{array}$

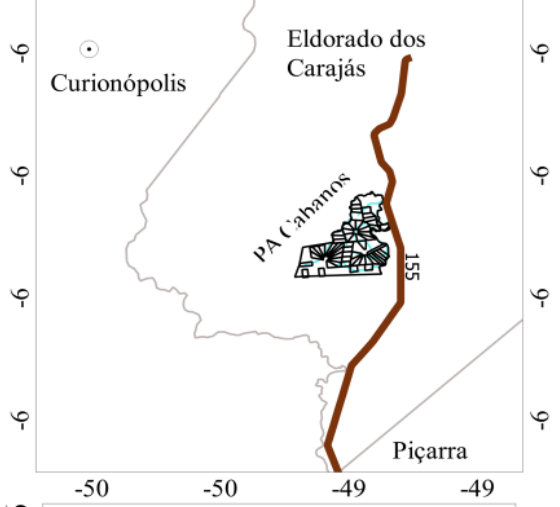

Legenda

- Lotes pesquisados

EMEI São José

Sede municipa

Rodovia (BR-155)

- Rios secundários

PA Cabanos

municipios do sudeste paraense

Pas adjacentes

Fazenda

$$
\text { 本. }
$$

Sistema de Coordenadas UTM - Zona 22S Datum: WGS - 84

Fonte: IBGE (2010); INCRA (2016); CAR

Elaboração: MIRANDA, R. R. (2017)

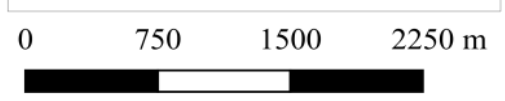

Fonte: IBGE, 2010; INCRA, 2016; CAR, 2016. Base cartográfica, cartografia e organização: Rogério Rego Miranda. 
Mapa 16 - PA Canudos

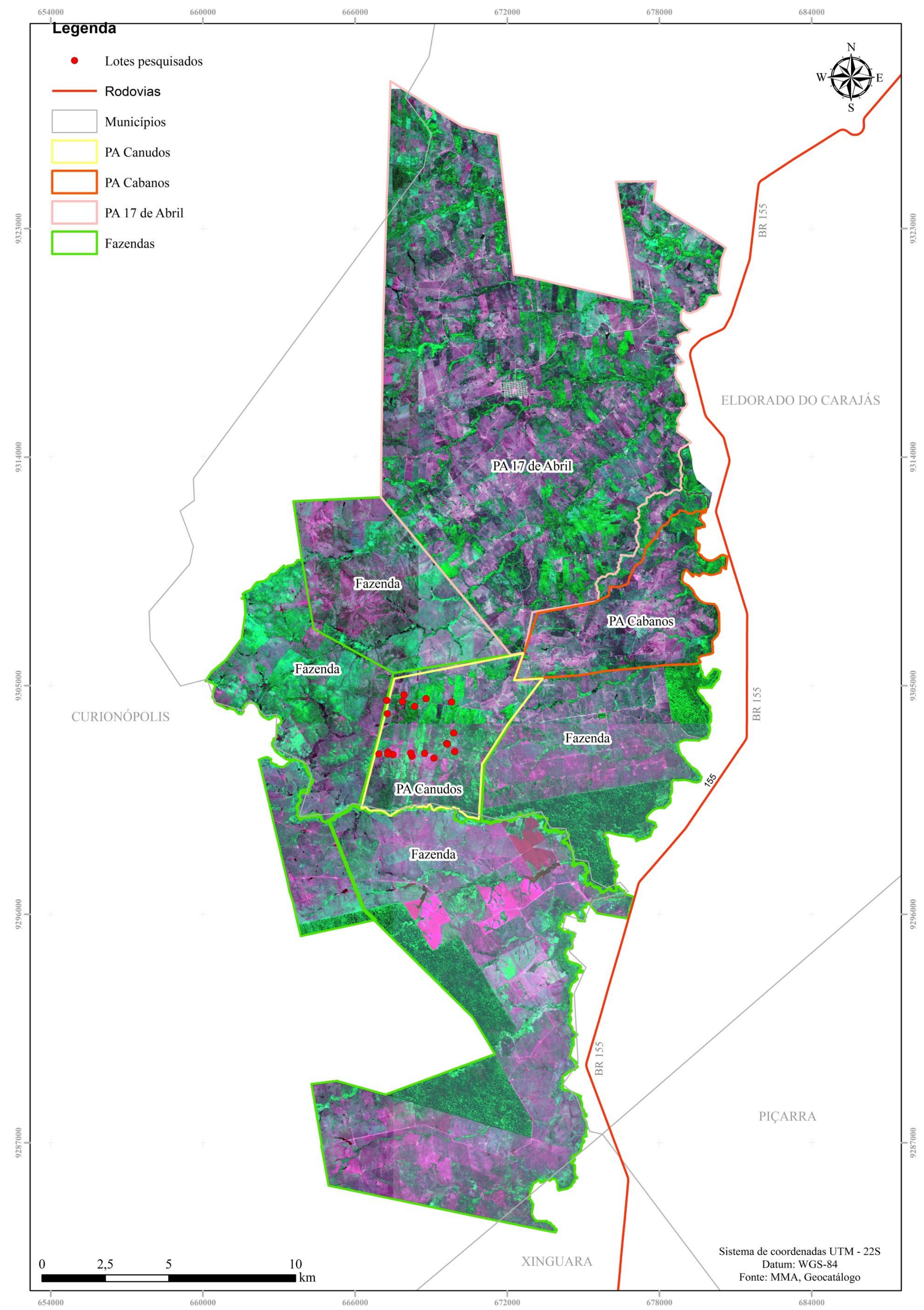

Fonte: INCRA, 2010; CAR, 2016. Base cartográfica, cartografia e organização: Rogério Rego Miranda. 


\subsubsection{Projeto de Assentamento 26 de Março}

Outra área da empresa Jorge Mutran Exportação e Importação Ltda. ocupada foi a Fazenda e Castanhal Cabaceiras. De acordo com Barros (2011), correspondia a uma propriedade modelo da pecuária extensiva de corte e era suspeita de ser uma área "grilada", todavia, a cadeia dominial identifica que se origina de dois títulos provenientes de trâmites legais: um referente a uma porção territorial de 3,6 mil hectares, que era de aforamento concedido a Nilo Alves de Almeida em 1959 para a extração da castanha e que foi transferida à família Mutran, passando a ser a responsável pelo castanhal com a anuência do Estado; outro título corresponde a uma parcela de 6.406,4620 hectares, cuja origem advém da compra de terra pública realizada em 1942 pela A. Mourão \& Cia, empresa de comércio e transporte de castanha que operava em Marabá no período da economia extrativista. Posteriormente, foi revendida a um comerciante de castanhas, Manoel Brito de Almeida, que, por sua vez, repassou à família Mutran em 1989, que desmembrou 232,057 hectares, ficando com uma dimensão de 6.174,405 hectares. Desta feita, ao somarmos com a área do primeiro título, os Mutran ficaram com 9.774,405 hectares. Na década de 1990, esta área total foi convertida em fazenda de gado de corte mediante derrubada da mata nativa para a implantação da pastagem; tal processo se valeu de trabalho análogo ao escravo, conforme foi constatado pelo Grupo Móvel de Fiscalização do MTE na Cabaceiras, a partir de 2001.

A ocupação da Fazenda Cabaceiras tem um caráter simbólico, pois apresenta como sentido a continuidade da luta pela terra nos territórios consolidados dos latifundiários tradicionais na região e, ao mesmo tempo, é uma homenagem às lideranças do MST assassinadas, o "Fusquinha" e o "Doutor". Por esse motivo a data da ocupação foi 26 de março, no ano de 1999, e o nome do assentamento igualmente faz alusão aos dois membros do movimento sem-terra.

A área em questão, por um lado, era objeto de desejo dos movimentos sindicais, entretanto, em decorrência das ações violentas dos Mutran na região, eles temiam represálias. O MST, por outro, por suas estratégias diferenciadas, reuniu as condições necessárias para a conquista da terra. Inicialmente, realizaram o trabalho de base nas periferias de Marabá e em áreas próximas, com o intuito de reunir o conjunto de famílias necessárias para o ato planejado.

No dia da ocupação, muitas famílias estavam em um Encontro de Educadores na vila da Palmares II, debatendo sobre a temática do desemprego, e foi programada uma manifestação em frente à Prefeitura Municipal de Marabá (PMM), que reuniu diversos 
movimentos sociais, entidades, dentre outros. Muitos já sabiam que após o ato haveria a ocupação, porém as lideranças do MST sabiam que isso não se efetivaria, portanto adotaram outra estratégia.

Muitos manifestantes se concentraram na portaria do INCRA para saírem em marcha às dezesseis horas em direção a PMM. Enquanto isso, as famílias que estavam em Palmares II se deslocaram em caminhões para se encontrarem com os demais em Marabá. Esses veículos estavam sendo acompanhados pela Polícia federal que vinha na frente, enquanto atrás estava a Polícia Militar de Eldorado dos Carajás. Porém, como a polícia passou direto para o centro de Marabá, onde estavam os manifestantes, as lideranças do MST imediatamente indicaram para que parassem na fazenda e realizassem a ocupação. Quando algumas pessoas descobriram de quem era a propriedade, desistiram imediatamente com medo.

Essa ação contou com a participação de aproximadamente 1.200 famílias com o objetivo de coibir retaliações por parte da polícia ou de pistoleiros. É importante destacar que muitas das pessoas que estavam concentradas em frente ao INCRA posteriormente foram para a Fazenda Cabaceiras para auxiliar na ocupação e na construção dos barracos do acampamento, mesmo embaixo de muita chuva.

Ao longo da vida em acampamento os sem-terra sofreram três processos de reintegração de posse, de forma bastante violenta:

[...] fomos despejados de uma forma muito cruel, com trezentos policiais, onde muitas pessoas apanharam, momentos de muita aflição, correria por toda parte, pessoas machucadas, principalmente crianças. (João Pereira da Silva, acampado na 26 de março, 13 jun. 2008) ${ }^{37}$

O primeiro mandato de reintegração de posse ocorreu por meio de um acordo entre o INCRA e os sem-terra, que aceitaram sair da área com a condição de que seria realizada uma vistoria na fazenda. Essa saída ocorreu acompanhada por quatrocento homens da PM, no entanto, o acampamento foi transferido provisoriamente para as margens do rio Sororó na espera da vistoria que não ocorreu. Dessa forma, deu-se uma nova ocupação da Cabaceiras, com a construção do novo acampamento em sua sede, que se localizava nas margens da rodovia PA150. Após quarenta dias foi cumprida outra liminar de despejo. Nesse ínterim, o MST denunciou a existência de um cemitério clandestino, nos quais supostamente estariam enterrados os restos mortais de trabalhadores rurais assassinados no período que a propriedade estava sob a responsabilidade dos Mutran. O fato foi apurado pelas Polícias Federal e Civil

\footnotetext{
${ }^{37}$ A entrevista foi realizada e cedida pela assentada e militante do MST Isabel Rodrigues Lopes Filha.
} 
que, após investigações, concluíram que os corpos encontrados nas covas eram provenientes de trabalhadores que enterravam seus familiares lá por não possuírem condições financeiras de levar para um cemitério. Também se indicou que, por meio do IML de Belém, as ossadas teriam mais de trinta anos, logo, não condiziam com a acusação do MST de que se referiam à restos mortais de peões assassinados por pistoleiros a mando dos Mutran. Tais conclusões foram refutadas pelo movimento socioterritorial, que indicava que os funcionários responsáveis pelas investigações teriam favorecido os acusados. Ao longo desse processo, em virtude de um desacordo com o INCRA, foi feito o segundo despejo, porém agora com um viés mais violento (BARROS, 2011).

Nesse episódio o secretário de Defesa Social do Pará, Paulo Sette Câmara, informou que a PM cumpriria cinco mandatos de reintegração de posse a fazendeiros em áreas ocupadas pelo MST, a exemplo da Cabaceiras. A ação seria realizada com cautela, de forma a evitar o que havia ocorrido no massacre de Eldorado dos Carajás. Para esse fim, foram mobilizados 120 homens para a retirada de 850 famílias acampadas na área aqui destacada (JORNAL DO COMMERCIO, 1999), o que não ocorreu sem atos de violência (ver Fotos 20 e 21).

Foto 20 - Reintegração de posse da Fazenda Cabaceiras no ano de 1999.

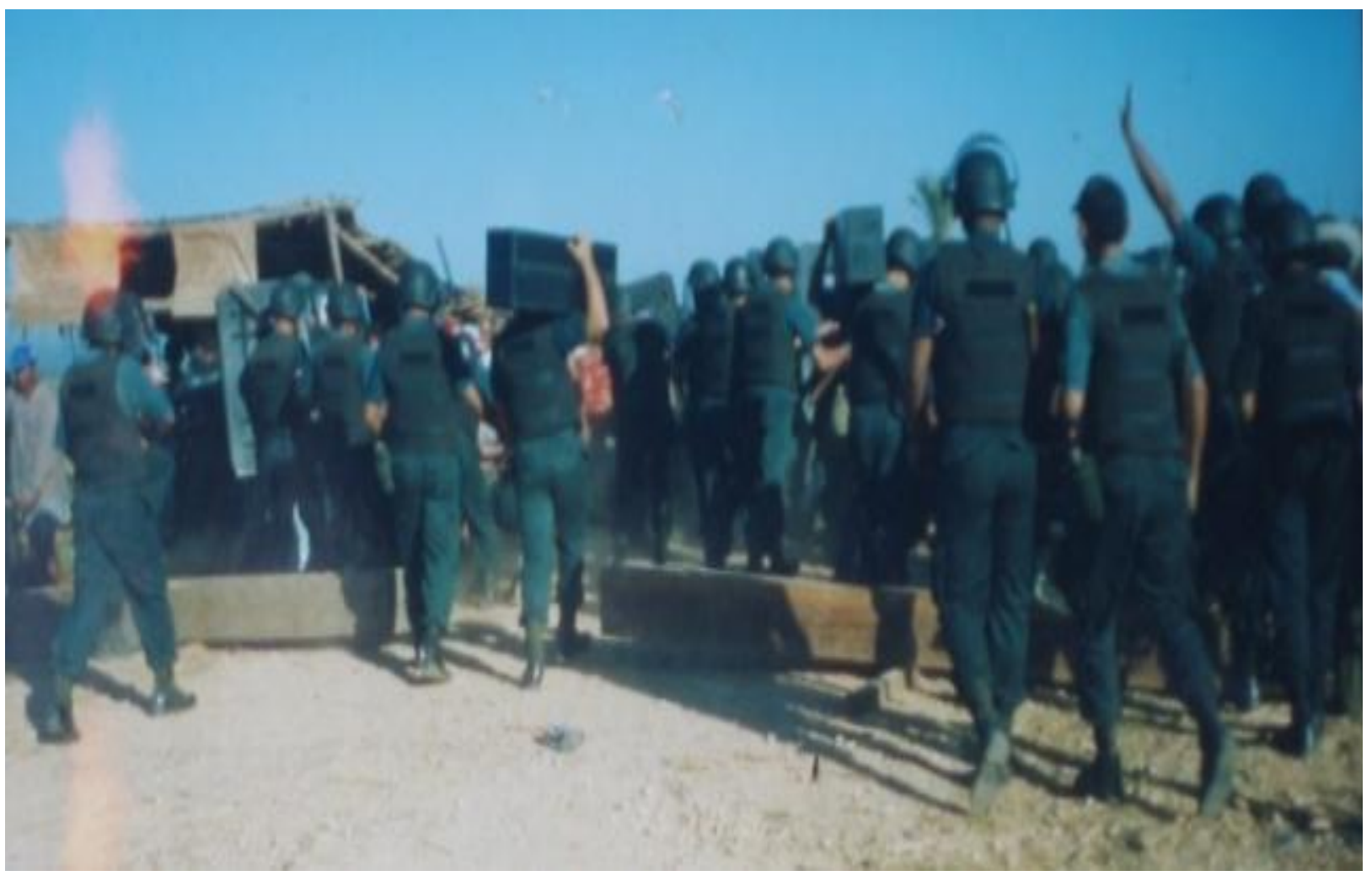

Fonte: Acervo da Secretaria Estadual MST-PA, 1999. 
Foto 21 - Ação violenta da Policia Militar no despejo da Fazenda Cabeiras, 1999.

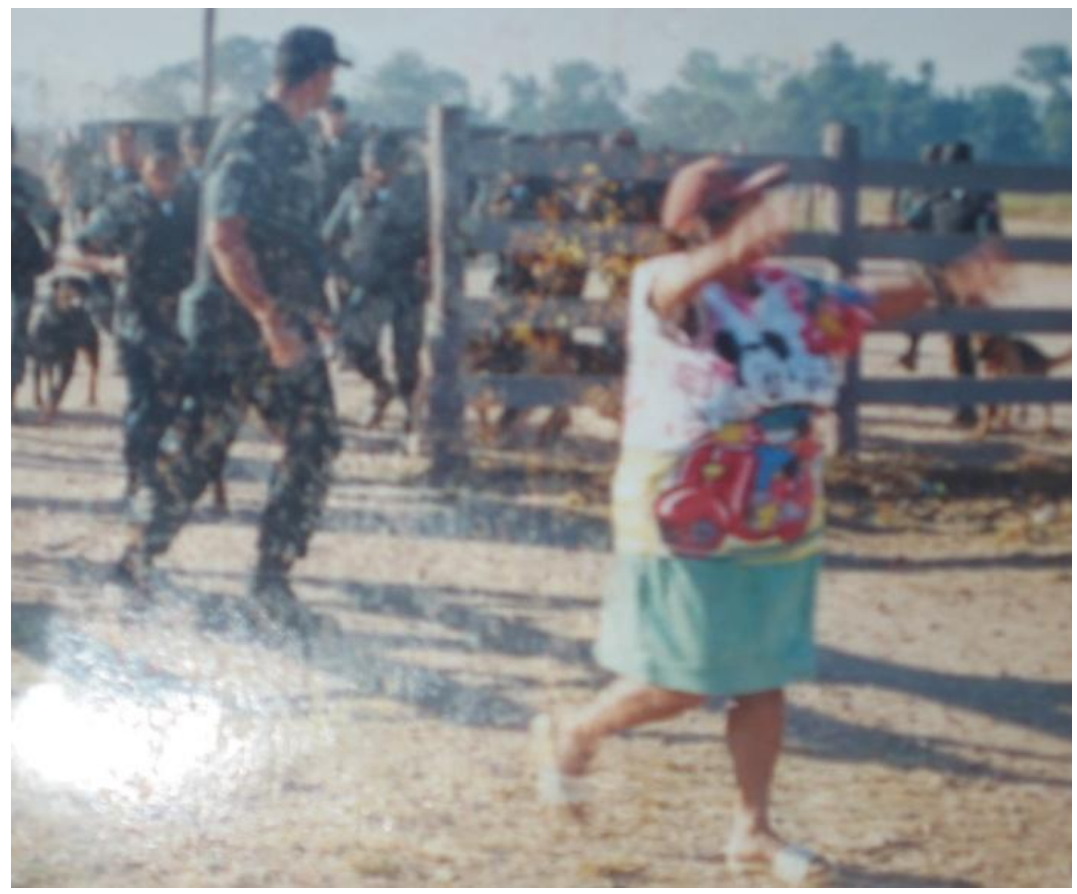

Fonte: Acervo da Secretaria Estadual MST-PA, 1999.

Desta feita, no dia 26 de julho de 1999 os sem-terra deixaram a terra ocupada e se dirigiram para a sede do INCRA em Marabá, onde se instalaram por vários dias com o objetivo de negociar com os órgãos competentes. Como isso, não voltaram pela terceira vez ao latifúndio dos Mutran, mas instalaram-se em uma porção de 81 hectares da fazenda Cabaceiras (BARROS, 2011).

Em junho de 2005, outra ação de despejo de dezessete áreas que abrigavam aproximadamente 20 mil sem-terras foi proposta pelo governo do estado do Pará, via Polícia Militar, dentre elas a Fazenda Cabaceiras.

De acordo com a reportagem do jornal Repórter Brasil (2005), as trezentas famílias remanescentes na área, acampadas há pelo menos sete anos, indicavam que iriam resistir à expulsão por parte da PM, marcada para ocorrer entre os dias 10 e 13 de junho de 2005 . Entretanto, a justiça suspendeu a desapropriação, pois a área estava em processo de negociação: poucos meses antes, em outubro de 2004, mediante decreto presidencial, a fazenda foi desapropriada para fins de reforma agrária por não cumprir com sua função social, desrespeitar a legislação ambiental e por flagrantes reincididos de utilização de trabalho escravo. Essa foi a primeira terra no Brasil a ser desapropriada por tais motivos. Contudo, no dia 22 de fevereiro de 2004, o supremo Tribunal Federal acatou um mandato de segurança da família Mutran, suspendendo os efeitos do decreto presidencial. Com efeito, a propriedade permaneceu sob a posse do latifundiário até o dia 19 de dezembro de 2008, momento em que 
finalmente foi criado o Projeto de Assentamento 26 de Março, com capacidade de 206 famílias.

Como podemos observar, em função das diversas reintegrações de posses, muitas das famílias sem-terra desestimularam-se e saíram do acampamento ao longo do árduo processo de conquista da terra. Assim, das 1.200 famílias que ocuparam a área, apenas 206 conseguiram seus lotes, o que demonstra quão difícil, longo e doloroso é o caminho da reforma agrária.

Com a definição do PA, o modelo de organização espacial proposto foi o Raio de Sol, já debatido por pelo menos dois anos, pois se desejava uma experiência nova de assentamento, com o objetivo de não permitir um distanciamento do assentado em relação a seu lote, tendo em vista que em geral os assentados escolhem ficar nas vilas devido à proximidade da escola para os filhos, postos de saúde etc. A ideia era pensar uma geografia que possibilitasse a moradia próxima, evitasse a perda do sentido de coletivo e não isolasse o sujeito em seu respectivo lote.

Essa iniciativa foi produzida pelos próprios sem-terra que planejaram e executaram a topografia do assentamento antes mesmo da desapropriação, por meio da contratação de uma equipe de topógrafos que realizou o serviço de loteamento com ajuda do trabalho voluntário de integrantes dos Núcleos de Base (NB). Assim, o assentamento ficou formado por seis núcleos de moradia, que comportam entre vinte e cinquenta famílias, e quatorze núcleos de base, dos quais são retirados representantes para compor os setores e/ou coletivos de educação, produção e juventude. Em cada núcleo, as famílias individualmente ficaram com lotes de 50 hectares (ver Mapa 17).

Muito embora essa proposta de Raio de Sol de fato permita uma maior interação entre os sujeitos, ela acaba sendo relativizada pela entrada de novos sujeitos no PA, que, por não possuírem relação com a história de conquista da terra e com o próprio MST, acabam deflagrando uma ruptura com esse coletivo, pois muitas vezes são contrários às ações de reinvindicação planejadas pelos assentados ou apenas usam a terra para fins econômicos, sem quaisquer relação com os demais sujeitos. 
Mapa 17 - PA 26 de Março
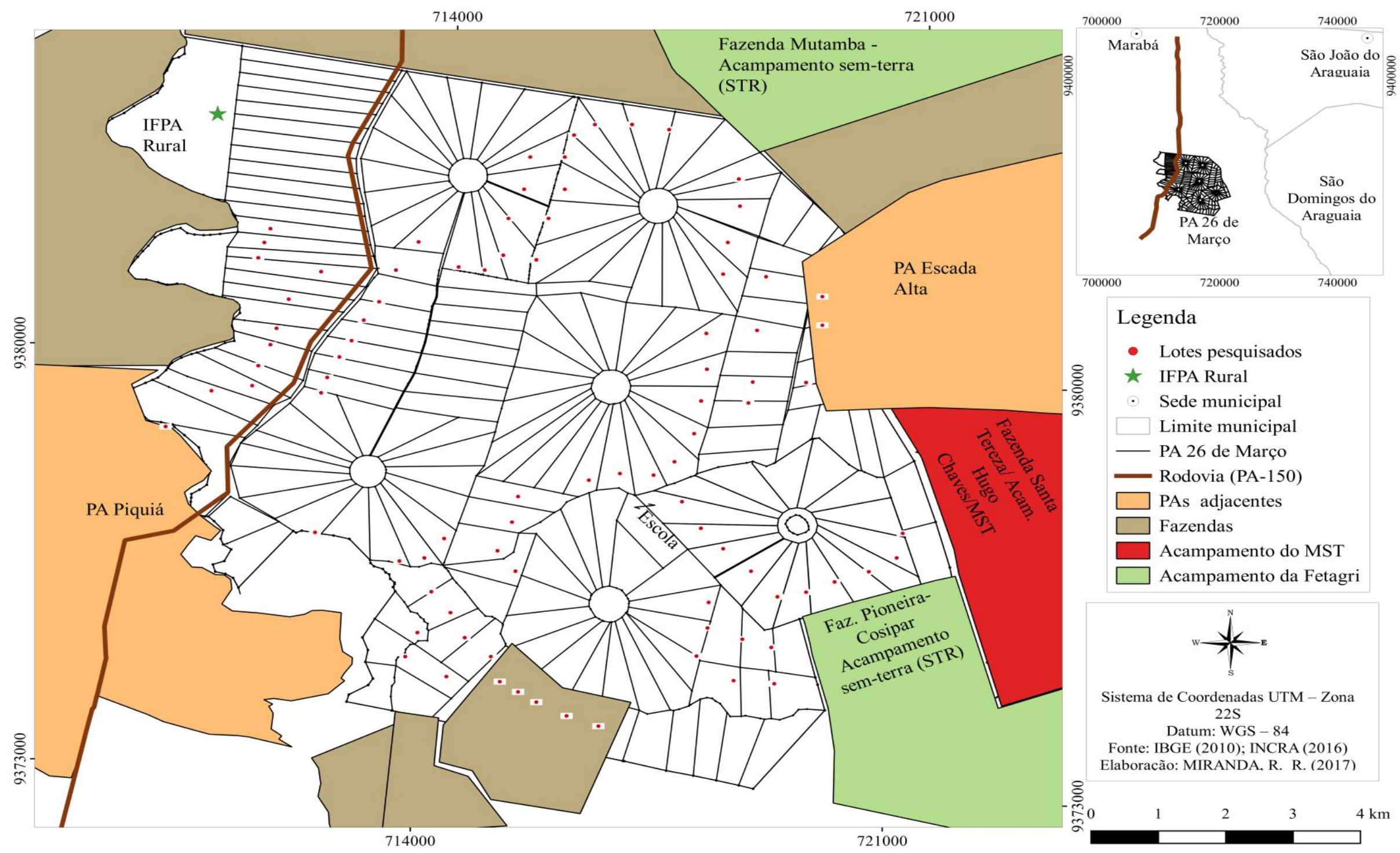

Fonte: IBGE, 2010; INCRA, 2016; CAR, 2016. Base cartográfica, cartografia e organização: Rogério Rego Miranda. 
Apesar dessas contradições internas, o PA 26 de Março se constitui um dos poucos que ainda permanecem com a organização espacial pautada nos Núcleos de Base (NB) constituídos no período de acampamento, com o intuito de perpetuar a organicidade construída naquele momento. Desta forma, internamente existe a seguinte organização:

Organograma 1 - Estrutura organizativa do Assentamento 26 de Março.

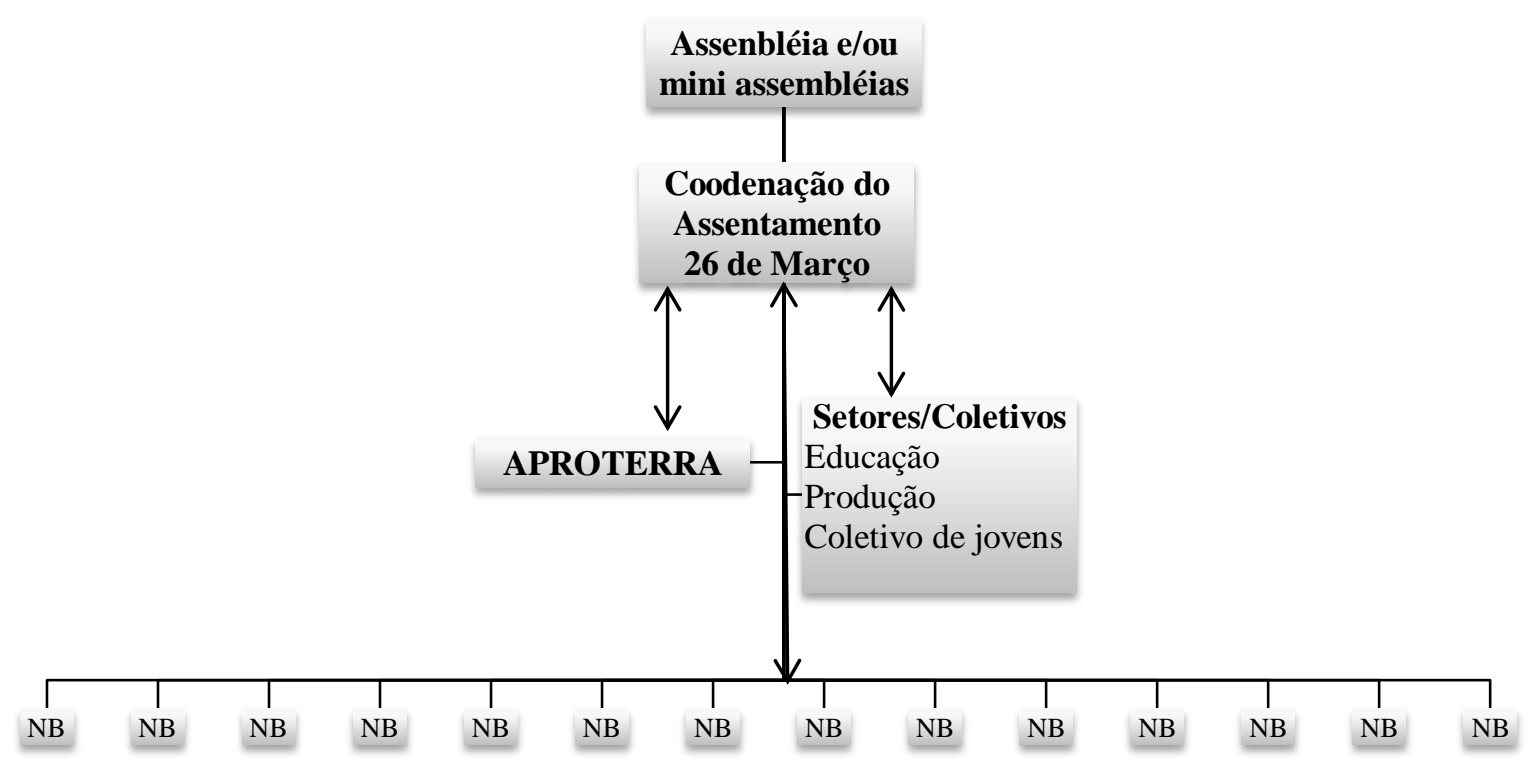

Fonte: Trabalho de campo, 2016.

No início, a coordenação do assentamento tentou se utilizar do núcleo de base como espaço jurídico com o objetivo de viabilizar a infraestrutura (residências, estradas, escola etc.) e o crédito agrícola, ou seja, a ideia era criar uma comissão composta por integrantes da coordenação do assentamento para coordenar essas ações, porém não foi possível pois o INCRA alegou que não possuía profissionais suficientes para acompanhar todos os núcleos de base, concorrendo para que fosse criada a Associação dos Trabalhadores Rurais do Assentamento 26 de Março (APROTERRA), fundada em 14 de maio de 2009, satisfazendo as exigências legais solicitadas pelos órgãos públicos (GOMES, 2009).

Conforme indica o organograma acima ainda são realizadas grandes assembleias que reúnem as representações dos núcleos de base ou assembleias menores com as famílias de cada núcleo. Essas reuniões não têm a mesma periodicidade do início do assentamento, correspondente a todos os sábados, mas são organizadas para atender necessidades da localidade, conforme relata uma das assentadas: 
[...] não tem mais uma regularidade, mas a necessidade faz tu reunir de repente até mais de duas, três vezes no mês, por exemplo, para debater a questão das estradas, nós reunimos todos os núcleos. Ainda hoje o pessoal contribuíram para comprar o combustível para as máquinas que a Prefeitura disse que não tinha, e nós arrecadamos mais de 6 mil reais, ainda fazemos isso, só que depois nós devolvemos porque a Prefeitura mandou uma parte, aí fizemos um trabalhão, fizemos todo um debate, nós vamos devolver cada centavo de cada um, porque esse dinheiro e para esse objetivo, a gente só iria gastar ele se debatesse para gastar em outra coisa [...] a gente reúne, inclusive os compradores também vem para a reunião, a maioria vem, tem uns que não vai porque não quer cem por cento, a maioria vem para a reunião, debate, contribui, participa. (Isabel Rodrigues Lopes Filha, assentada do PA 26 de Março e dirigente do MST, 52 anos, 30 set. 2016)

A partir do relato acima é possível observar que embora novos sujeitos adentrem o espaço do assentamento (compradores) e a regularidade das assembleias não seja a mesma, devido aos serviços cotidianos nos lotes, os assentados ainda resguardam elementos da organicidade desenvolvida no acampamento, a qual possibilitou sua materialização enquanto PA e a constituição de tantos outros assentamentos e acampamentos, como o Hugo Chaves, cuja existência decorre da solidariedade do 26 de Março.

\subsubsection{Projeto de Assentamento Lourival Santana}

O PA Lourival Santana, cujo nome homenageia um dos integrantes do MST morto durante o massacre de Eldorado dos Carajás, resulta da ocupação da Fazenda Peruano do intitulado proprietário Evandro Liege Chugia Mutran.

A área havia sido autuada pelo Ministério do Trabalho e Emprego (MTE) no dia 13 de dezembro de 2001, por existir trabalho análogo ao escravo: os empregados não recebiam salários e estavam em alojamentos precários feitos de madeira, palha e lona, além de pouco alimento, água imprópria ao consumo e exposição ao veneno utilizado no pasto por não utilizarem equipamentos de proteção. Ademais, a fazenda possuía parte de sua área pertencente à União, fato que foi levantado pela CPT e pelo MST. Essas, aliás, foram as principais justificativas para sua ocupação por parte do movimento socioterritorial.

Sua ocupação teve início a partir de um planejamento anterior que consistiu no trabalho de base no município de Eldorado dos Carajás e proximidades e com a alocação das famílias sem-terra primeiramente no Assentamento 17 de Abril, momento descrito como "processo de acumulação de forças", às margens do Rio Vermelho, enfrentando dificuldades como pouca água potável, chuvas, doenças... Nesse local permaneceram aproximadamente seis meses, inicialmente com 48 famílias, mas com a massificação dos trabalhos de base, o 
acampamento acabou comportando mais de 1.000 famílias. No dia 16 de abril de 2004, essas famílias se deslocaram para a "Curva do S", onde montaram acampamento.

No dia posterior, 17 de abril, na atividade anual de jornada da luta pela terra, que se realiza no local, em alusão ao massacre, foi deliberado pela coordenação do MST que se ocuparia uma fazenda de maneira simbólica ao momento em questão. Desta feita, foram convidados todos os que estavam participando da atividade, juntamente com os sem-terra que estavam acampados no Assentamento 17 de Abril, para marcharem pela PA150 em direção a uma fazenda cujo nome não foi revelado até o momento do ato da ocupação, que no caso era a Peruano (ver Fotos 22 e 23).

Foto 22 - Marcha para a ocupação da Fazenda Peruano, 2004.

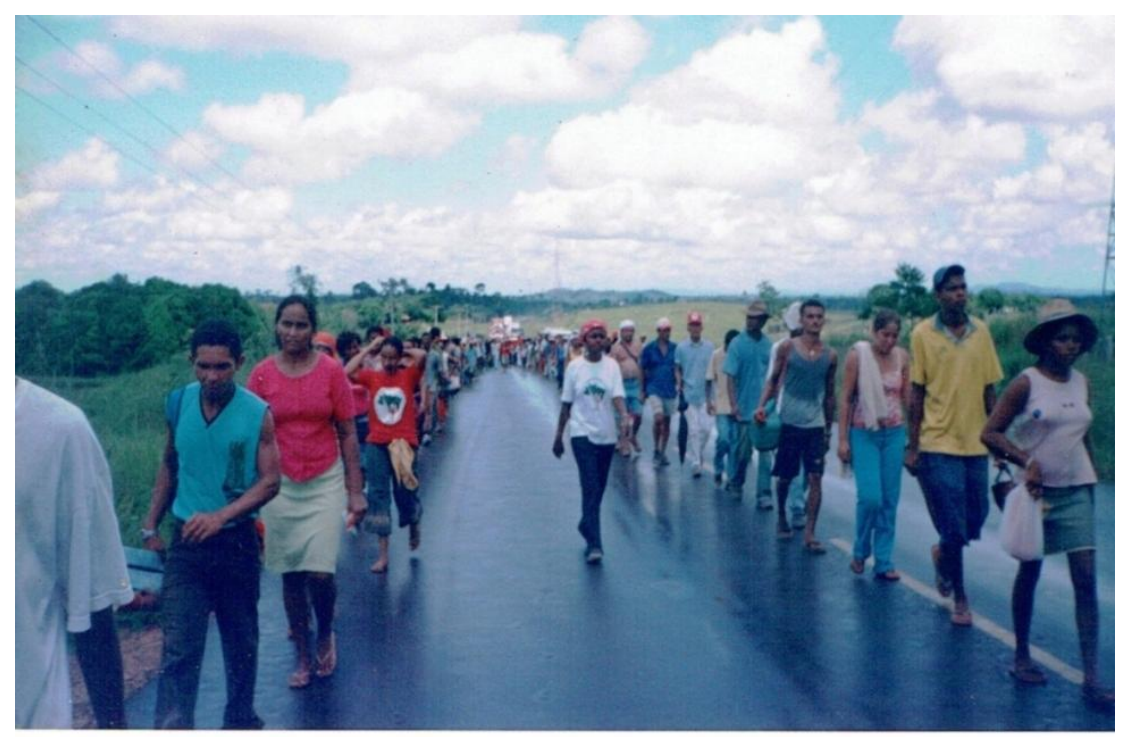

Fonte: Arquivo pessoal de Antônio Milanês, 2004.

Foto 23 - Ocupação da Fazenda Peruano, 2004.

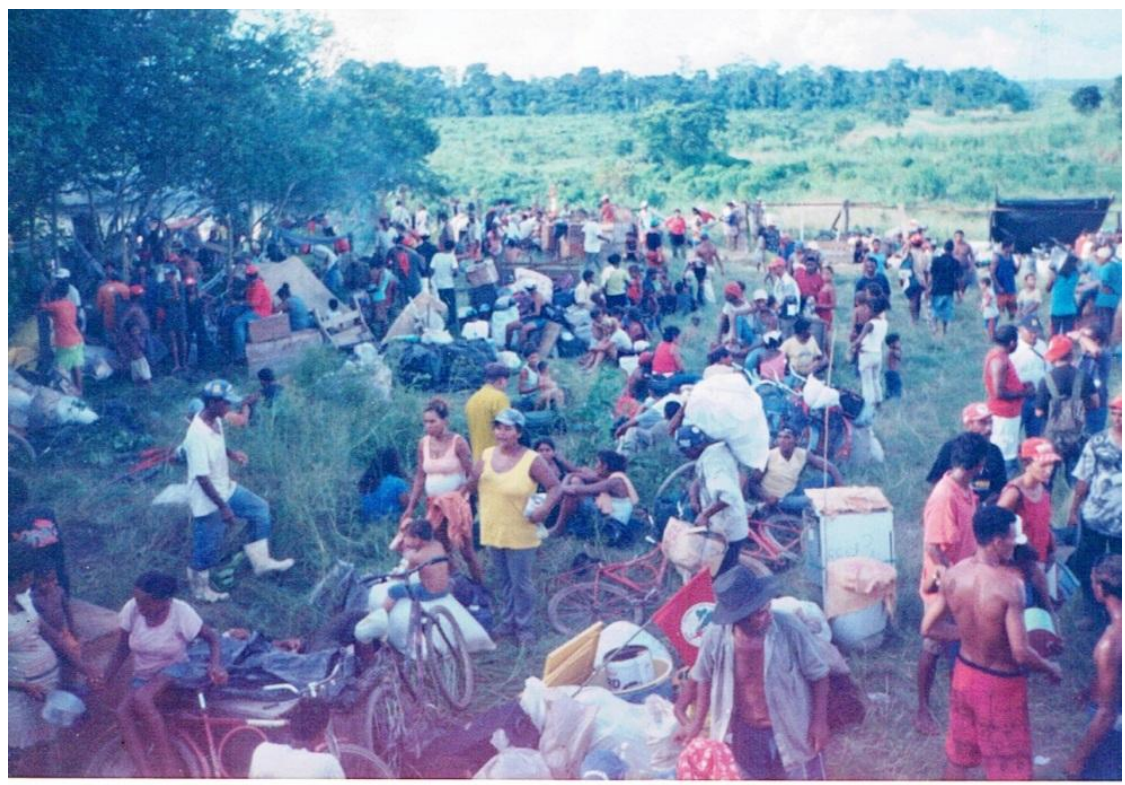

Fonte: Arquivo pessoal de Antônio Milanês, 2004. 
Essa ocasião da ocupação da Fazenda Peruano é discutida por um dos assentados:

[...] essa fazenda aqui foi ocupada por cinco mil pessoas, aquelas pessoas simpatizantes, vereador, padre, os jovens, moto táxi, o sindicato, tudo veio para ajudar nós, foi uma coisa bonita essa ocupação aqui, a gente olhava assim na pista, assim do lado para o outro assim, o restante assim de três, quatro, cinco quilômetros, assim o pessoal lá na pista, muita gente, muita, muita gente. Essa daqui ficou na história, essa fazenda aqui, ela é umas das maiores que tinha na época, estava em pleno vapor, gado de corte, gado de leite, só gado de boi caríssimo que dava para comprar não sei quantas Ferrari, quantos carros, coisa bonita [...] (Marcilenio Morais Feitosa, assentado do PA Lourival Santana, 50 anos, 25 maio 2015).

O acampamento construído no local foi composto inicialmente por cem núcleos de dez pessoas e durante o período de luta pela terra foram solicitados vários pedidos de reintegração de posse, os quais não chegaram a ser cumpridos por não haver a comprovação de que as terras foram legitimamente destacadas do patrimônio público para a posse particular de Evandro Mutran. Entretanto, no dia 30 de agosto de 2012, foi concedida uma liminar de despejo em favor do latifundiário, a qual foi respeitada pelos sem-terra, com intuito de evitar a violência policial. Desta feita, retiraram-se da margem da estrada e se deslocaram para a sede da fazenda levando consigo a produção de arroz, feijão, dentre outros mantimentos, mas sob a vigilância da segurança pública. Para pressionarem uma negociação com o INCRA os semterra na ocasião realizaram uma manifestação na rodovia em conjunto com os acampados da Fazenda Santa Maria (ocupação realizada pela FETAGRI no dia 26 de novembro de 2006) que fica na outra margem da rodovia, fato que resultou na permanência deles no local.

A constituição do Assentamento Lourival Santana, no entanto, demorou quase dez anos para ser efetivada e se deu de maneira fragmentada, porque a área pleiteada na verdade era composta por um conjunto de fazendas que apresentavam uma diferenciação geográfica em termos jurídicos, ou seja, uma parcela de fato era da União, oriunda de aforamento, mas a outra estava fora dessa situação, o que resultou em um impasse para o movimento, pois um grupo dos sem-terra indicara que as áreas pertencentes ao Estado poderiam ser de imediato disponibilizadas para fins de reforma agrária, possibilitando o assentamento de uma parte das famílias; mas outro grupo dos acampados propôs que a negociação deveria almejar o assentamento de todos ao mesmo tempo; a discussão gerou certo conflito interno.

Por determinação da maioria do coletivo, a primeira proposição acabou sendo levada a cabo. Desta feita, os próprios sem-terra contrataram o serviço de topografia para a divisão dos lotes, que seriam posteriormente sorteados, com a definição de que aqueles que obtivessem os lotes na área da União seriam provavelmente assentados mais rapidamente, ao passo que 
demorariam mais para ter sua situação regularizada os sem-terra sorteados com lotes na porção que não era comprovadamente do Estado.

A partir desses acordos elaborados pelos acampados foi possível constituir a primeira parte do assentamento, que foi criado em 10 de outubro de 2013, com capacidade de 264 famílias (embora na época tivessem sido assentadas apenas 146), em uma área de 3.760 hectares (ver Foto 24).

Os demais sem-terra, embora em uma situação juridicamente irregular, se mudaram e/ou iniciaram suas atividades agrícolas e pecuárias nos lotes definidos pelo sorteio, assim como os que já haviam sido assentados (na área da Fazenda Peruano), porém sem apoio financeiro do INCRA via PRONAF. Ficaram localizados nas áreas denominadas como Borracheira I (Fazenda Proteção Divina) e Borracheira II (Fazenda Borracheira), que compreendiam o complexo de fazendas de Evandro Mutran (ver Mapa 18). Após dois anos de negociação, esses territórios igualmente são conquistados definitivamente pelos sem-terra, com a criação dos PAs Lourival Santana II e Lourival Santana III no dia 4 de dezembro de 2015. O primeiro tem uma área de 4.312 hectares e capacidade para 287 famílias e o segundo, área de 1.054 hectares e capacidade para abrigar 58 famílias.

Foto 24 - Entrada do P.A. Lourival Santana

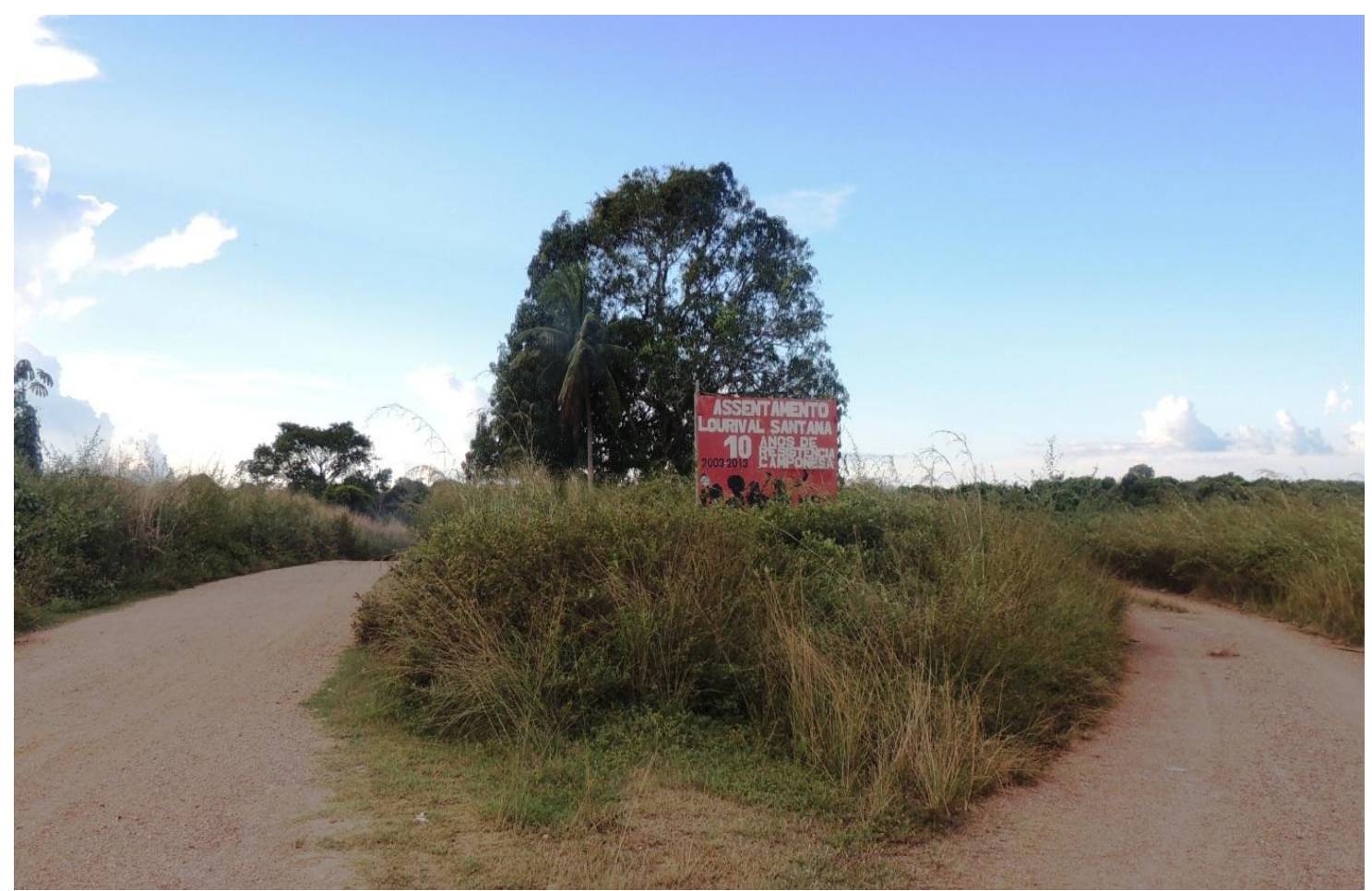

Fonte: Rogério Rego Miranda, Eldorado dos Carajás, 2016. 
Mapa 18 - PA Lourival Santana, 2016
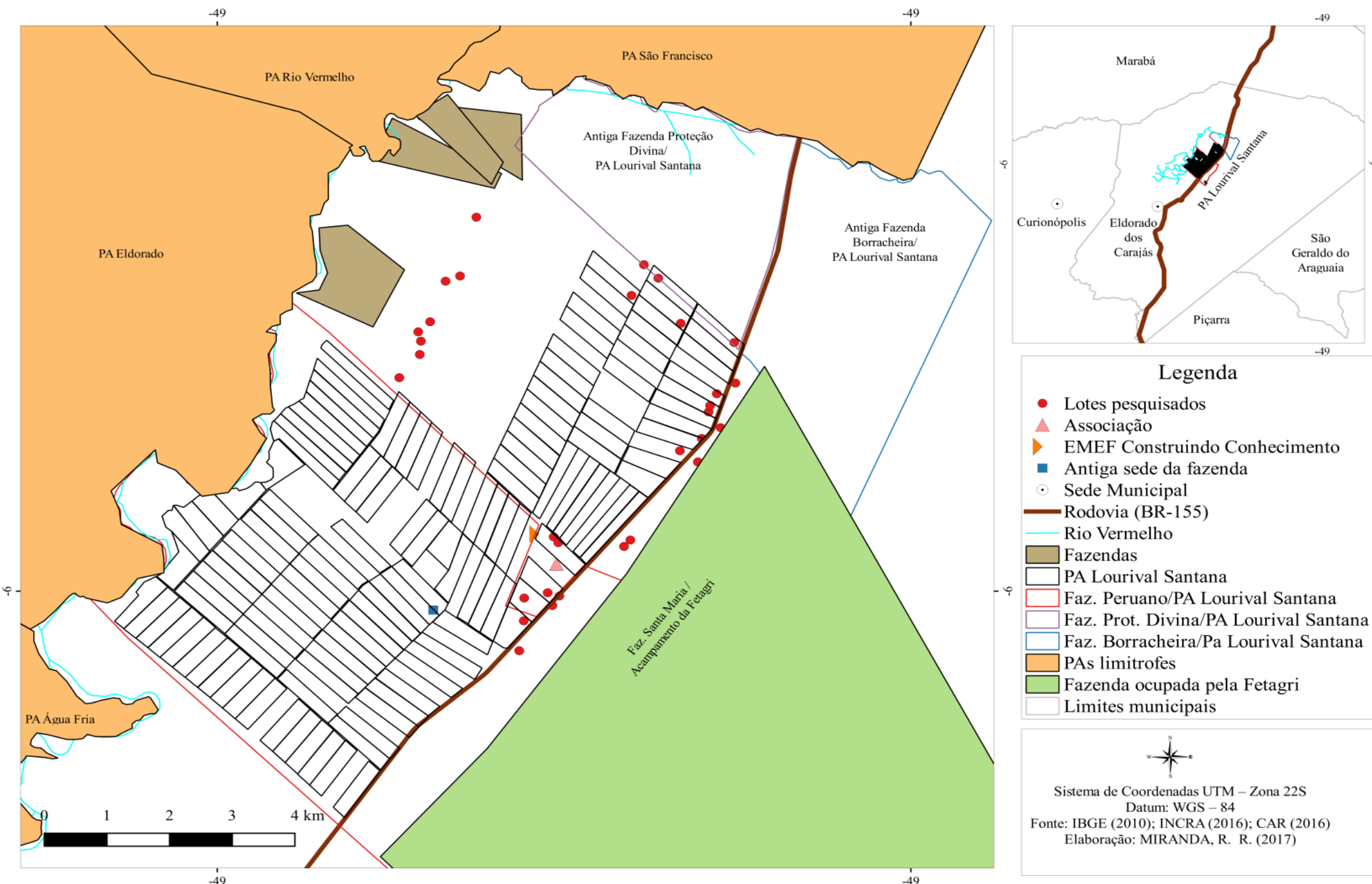

- Lotes pesquisados

$\triangle$ Associação

EMEF Construindo Conhecimento

- Antiga sede da fazenda

- Sede Municipal

- Rodovia (BR-155)

Rio Vermelho

$\square$ Fazendas

$\square$ PA Lourival Santana

$\square$ Faz. Peruano/PA Lourival Santana

Faz. Prot. Divina/PA Lourival Santana Faz. Borracheira/Pa Lourival Santana PAs limitrofes

Fazenda ocupada pela Fetagri

Limites municipais

$$
\text { 来. }
$$

Sistema de Coordenadas UTM - Zona 22S

Fonte: IBGE (2010); INCRA (2016); CAR (2016) Elaboração: MIRANDA, R. R. (2017)

Fonte: INCRA; CAR, 2016 


\subsubsection{Projeto de Assentamento Nega Madalena}

O PA Nega Madalena se situa na porção mais ao sul da mesorregião sudeste do Pará, no município de Tucumã, vinculado a um projeto de colonização privada mal sucedida promovida pela empresa Andrade Gutierrez na década de 1980, denominado Projeto Tucumã, em uma área de 400 mil hectares.

O projeto Tucumã se situou na antiga Gleba Carapanã que apresentava elementos atrativos como solos de alta qualidade (terra roxa), proximidade das rodovias, e maior dificuldade em termos de ocupação por posseiros, por estar entre duas reservas indígenas (Xikrin e Kayapó). A área foi adquirida por meio de uma licitação pública no dia 11 de janeiro de 1979, sancionada pelo Conselho de Segurança Nacional (CSN) e aprovada pelo Senado Federal. Porém o processo de tramitação que tratava da aquisição da área foi demorado e por se tratar de uma porção territorial interessante do ponto de vista da fertilidade do solo, mas também pela existência de ouro e madeira, acabou sendo parcialmente ocupada por grileiros, atrelados à extração madeireira, e posseiros que alegavam estar na área há bastante tempo. A empresa acabou ganhando o direito de compra da terra em 1982 (WOOD; SCHMINK, 2012).

Esse projeto de colonização seria dividido em três seções com um total de quase 3 mil lotes, além da construção de 1.000 quilômetros de estradas, três centros urbanos, sessenta comunidades rurais, escolas, hospitais, prédios administrativos, armazéns, mercados, aeroporto, terminal rodoviário, água e eletricidade. Todavia, vários problemas surgiram: o primeiro foi o alto custo de implantação para os colonos; o segundo decorreu da crise econômica que atingiu o Brasil em 1983, aumentando as taxas de juros e limitando as linhas de crédito ofertadas aos colonos, situação que melhorou apenas em 1985 com a diminuição da recessão, a venda de 750 lotes e o assentamento de 184 famílias de agricultores. Como o Projeto Tucumã foi incorporado ao Programa Grande Carajás, do Polamazônia, recebia recursos e proteção do governo, o que concorreu para que a empresa controlasse o acesso por terra para área do projeto, especialmente daqueles descapitalizados (WOOD; SCHMINK, 2012).

Um elemento desestabilizador importante do projeto foi o garimpo que já existia nas proximidades de Tucumã, no local chamado de Cuca, cujo acesso, embora controlado, não inibiu a invasão por garimpeiros, que foram expulsos em um primeiro momento mas que acabaram retornando posteriormente com mais força. A corrida pelo ouro se tornou o suporte da economia de Tucumã, e em 1983 já se observavam aproximadamente 15 mil pessoas 
trabalhando com a mineração. Com a mudança no quadro político do país, o projeto Tucumã já não gozava das mesmas proteções estatais e diversas investidas de posseiros e madeireiras ocorriam. Desta feita, em 1985 existiam mais de 3 mil pessoas que haviam "invadido" o projeto, levando a seu término, com a proposição, em 1985, de reversão da área privada em pública, o que ocorreu apenas em 1988, após a indenização de 6,6 bilhões de doláres para a empresa (WOOD; SCHMINK, 2012).

O município inteiro de Tucumã está cadastrado no INCRA como Projeto de Assentamento Tucumã, mas na realidade corresponde a um grande mosaico de fazendas, sítios, garimpos, reservas indígenas... Dentro desse PA foi criado o Assentamento Nega Madalena, que era de propriedade de Luiz Fernando da Costa, conhecido como "Fernandinho Beira-Mar" e Leonardo Mendonça, presos por tráfico de drogas.

A ocupação da área ocorreu em 30 de agosto de 2008 e envolveu 322 famílias organizadas pelo MST. A fazenda estava sob a responsabilidade da $5^{\circ}$ Vara da Justiça Federal de Goiás, porém, em vez de ser disposta para fins de reforma agrária seria leiloada; por esse motivo, o movimento construiu um acampamento com o intuito de pressionar os órgãos competentes a desapropriarem-na.

No acampamento, criado na sede da fazenda, se desenvolveu uma pequena vila com escola, ruas, casas etc. Entretanto, no mês de outubro de 2008, foi entregue aos sem-terra uma liminar de despejo, executada pela ação conjunta entre polícias federal, civil e militar de maneira bastante violenta, com a queima dos barracos, derrubada das casas de madeira e prisões como forma de desmobilizar a ocupação, conforme relata um dos assentados:

[...] mês de outubro de 2008 veio uma liminar de despejo muito violenta e acabou queimando os barracos de todos os moradores, casa de tábua foi derrubada de motosserra, queimada, pegando o próprio colono com motosserra e levanta a casa e diz assim, ou você corta a casa ou então a gente prende você com motosserra e tudo [...] e no qual tem o despejo, famílias jogadas na rua, família jogada na vila, no Cuca, e família sendo quase espancada, empurrada, alguns veículos sem documento, só ferro velho, foi preso. (Domingo Souza Martins, assentado do PA Nega Madalena, 37 anos, 28 jun. 2015)

Com o episódio muitos sem-terra desistiram, outros permaneceram na Vila do Cuca, de onde se reorganizaram e ocuparam novamente a sede da fazenda, construíram no lugar outra vila e aguardaram o resultado da justiça, que determinou que se retirassem. Para não sofrerem violência física, resolveram em coletivo montar um acampamento na margem da estrada, onde eram constantemente vigiados pela polícia, e onde permaneceram até o início de 2011, fazendo também manifestações em frente aos órgão públicos de Marabá e Belém para solicitar a vistoria da área pleiteada, que demorou a ser efetivada, contribuindo para a 
desmobilização de mais uma parte dos sem-terra, que acabaram ficando reduzidos a 39 famílias. Estas resolveram sair da estrada e acampar a 30 metros da fazenda, concorrendo para que fossem novamente alvos de investidas da polícia, o que os motivou a acampar no INCRA de Marabá por 45 dias. No retorno desse ato, já realizaram o mapeamento da fazenda com o intuito de dividir os lotes e realizar o recorte da terra e o posterior sorteio entre as famílias. Com as mobilizações e a organização do MST, a fazenda acabou transformada em assentamento no ano de 2011 (ver Mapa 19).

Da fazenda foi herdada uma área de plantação de cacau, cultivo de elevada rentabilidade econômica no município, que foi divida entre as famílias: cada uma ficou com 1080 pés. (ver Foto 25 ).

Foto 25 - Área de produção de cacau dos assentados.

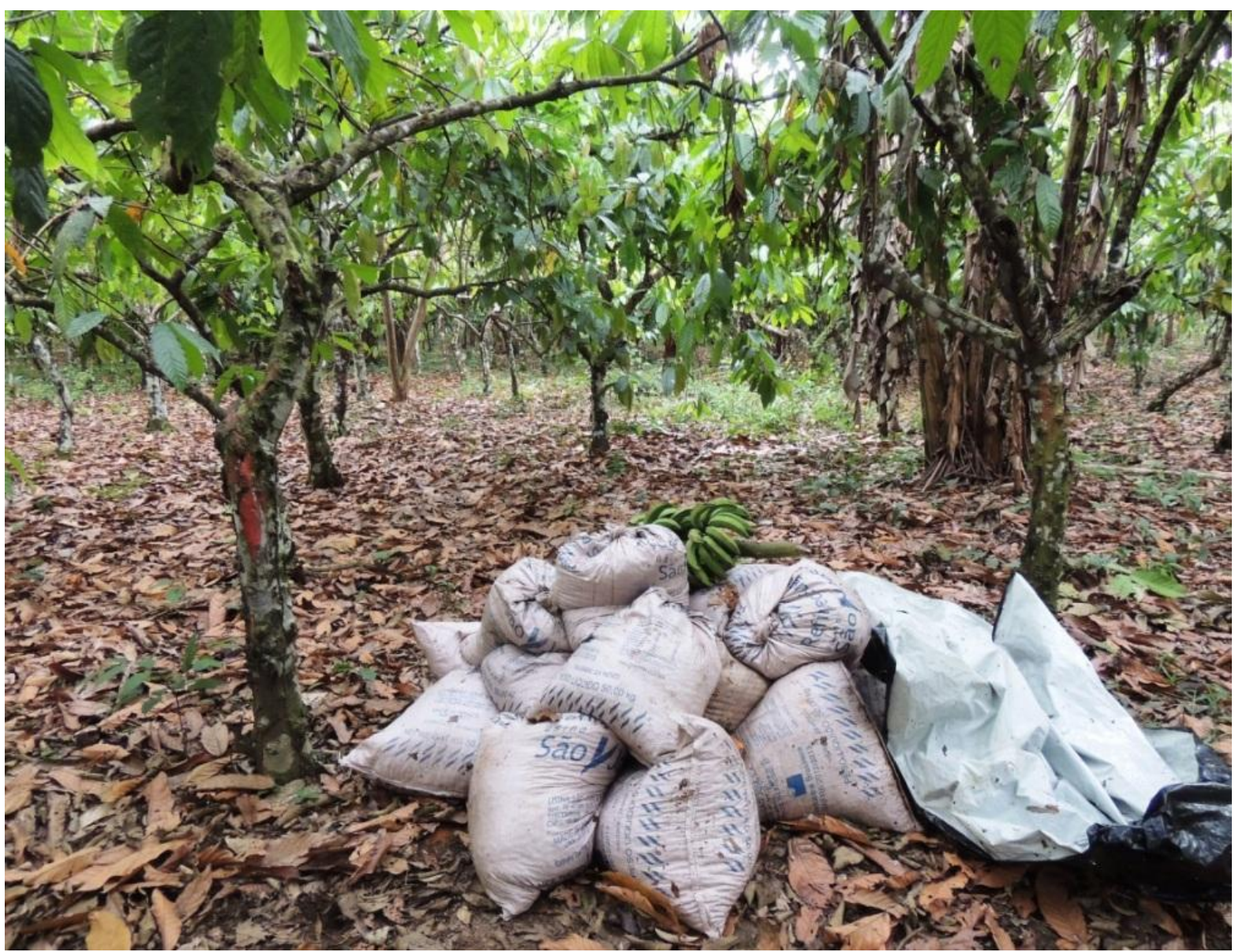

Fonte: Rogério Rego Miranda, Tucumã, 2015. 
Mapa 19 - PA Nega Madalena, 2016.

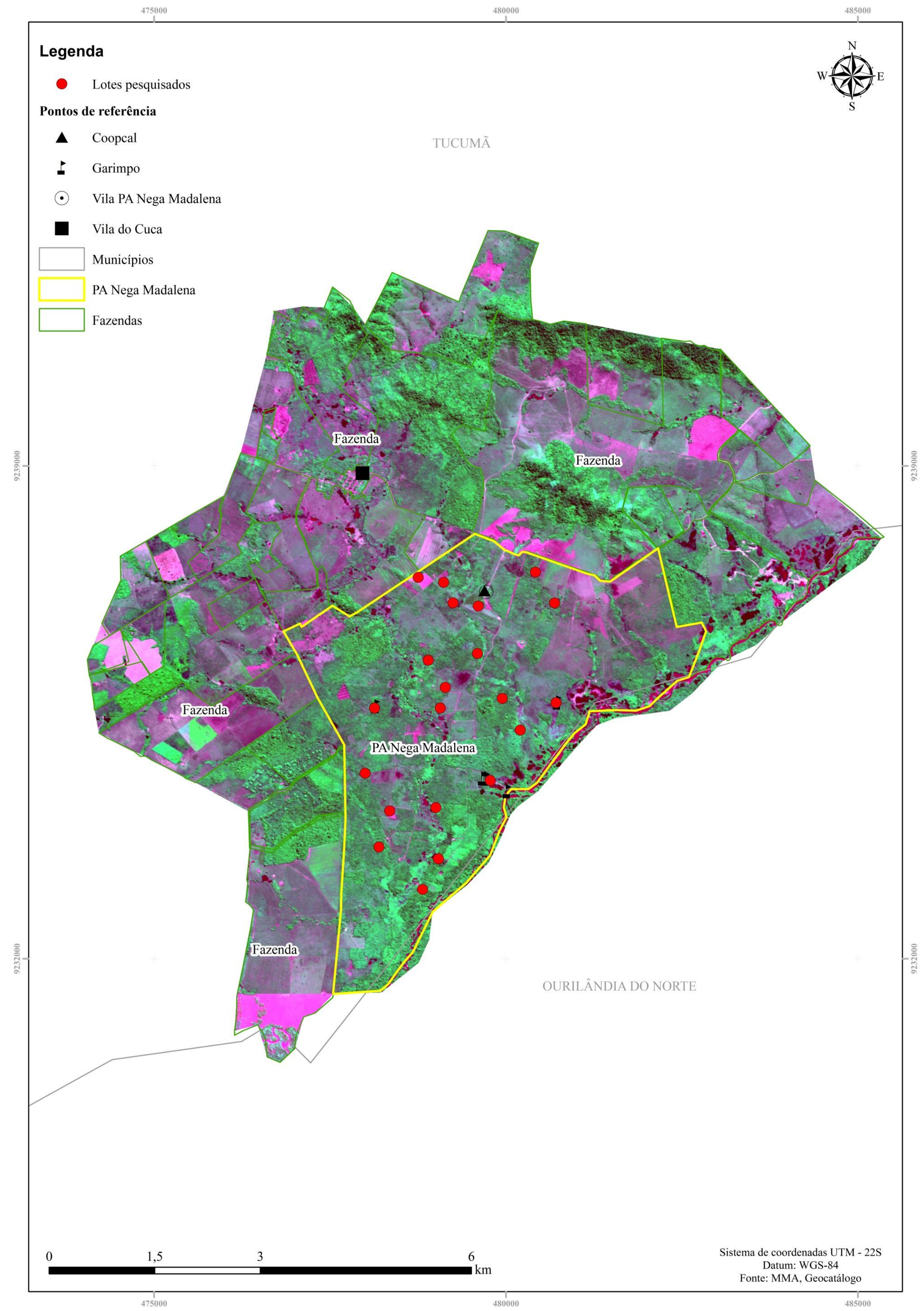

Fonte: INCRA, 2015; CAR, 2016. Base cartográfica, cartografia e organização: Rogério Rego Miranda. 
A história do garimpo como forma de enriquecimento, atividade complementar à agricultura ou mesmo à pecuária ainda permanece na realidade de Tucumã, sendo hoje uma área de relativo afluxo de pessoas em busca de ouro, assim como de empresas que se lançam na procura do minério, ainda que de maneira clandestina, nas reservas indígenas e assentamentos, a exemplo do Nega Madalena, o que pode a longo prazo comprometer a rentabilidade do agricultor, uma vez que as máquinas reviraram o solo e deixaram imensos buracos com acúmulo de água parada, interferindo na fertilidade e uso do solo e favorecendo a proliferação de doenças (ver Fotos 26 e 27).

Foto 26 - Extração de ouro em um dos lotes do P.A. Nega Madalena.

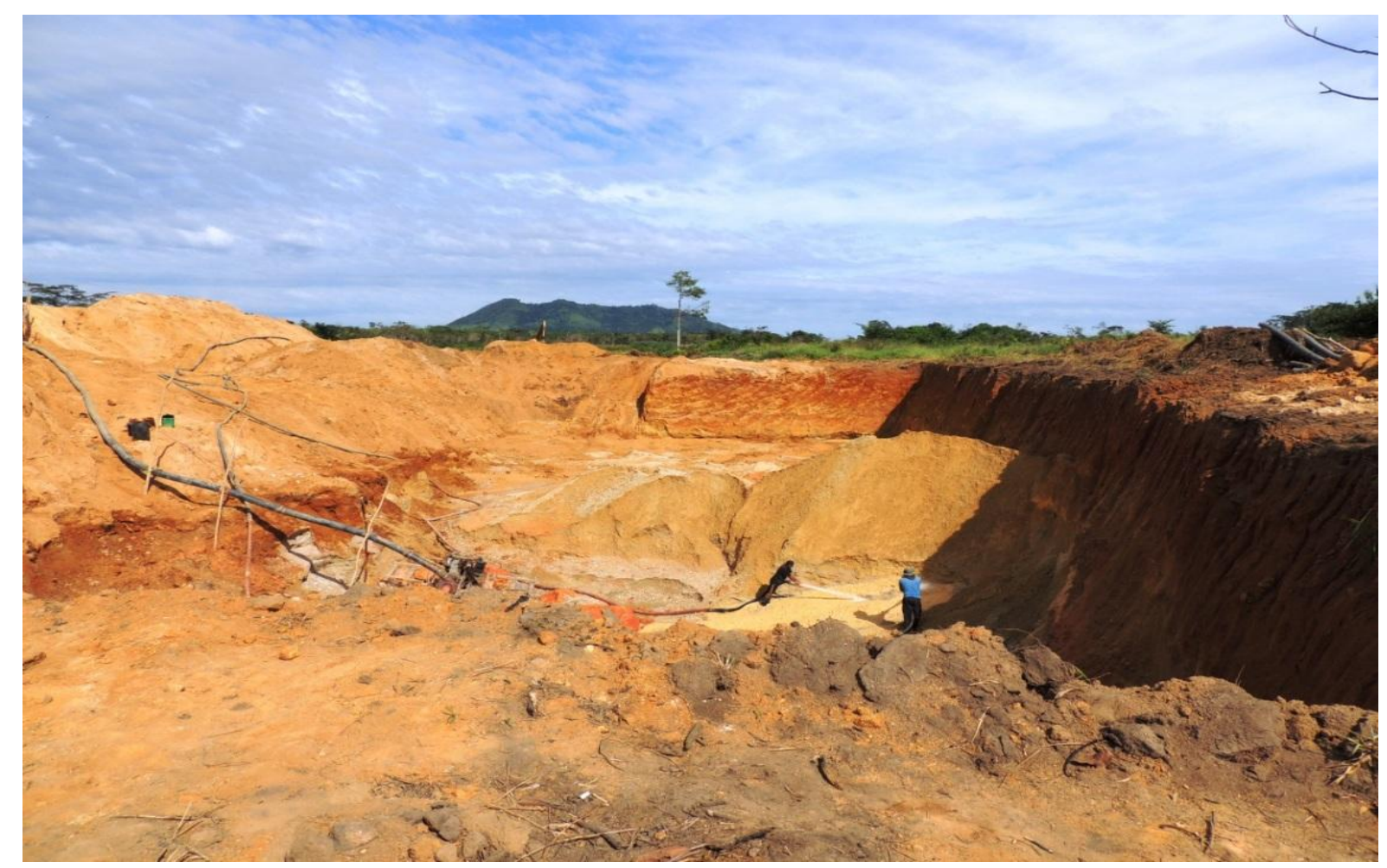

Fonte: Rogério Rego Miranda, Tucumã, 2015. 
Foto 27 - Solo revirado devido ao garimpo no P.A. Nega Madalena.

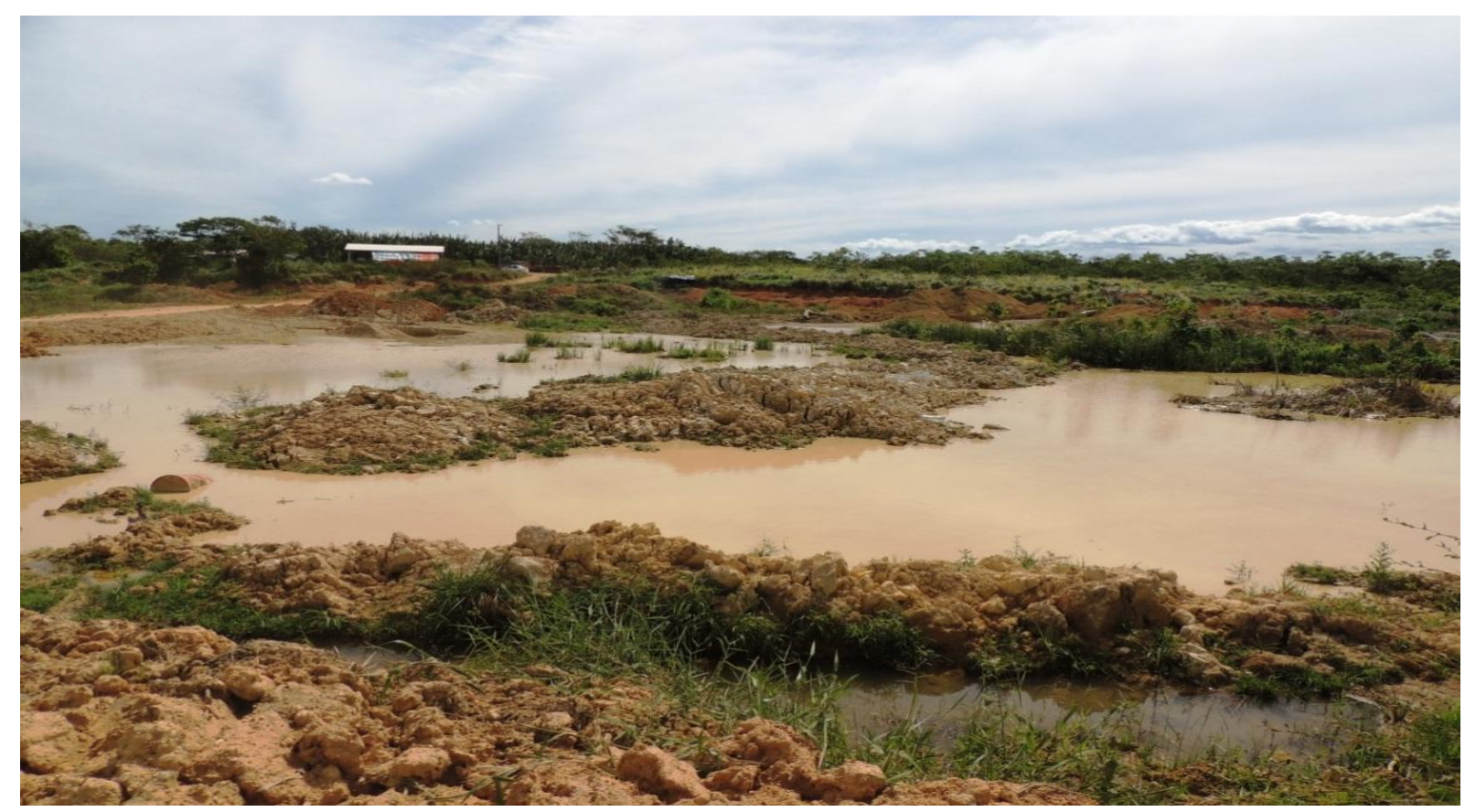

Fonte: Rogério Rego Miranda, Tucumã, 2015.

Essa reconstrução da territorialização do MST por meio da conquista dos assentamentos possibilita qualificar de maneira mais aprofundada uma face de sua proposta contra-hegemônica, qual seja, a luta pela terra, que se realiza continuamente, porém de maneira bastante conflituosa em relação aos diversos sujeitos envolvidos e prenhe de contradições. Ela revela algumas estratégias de perpetuação da luta, com destaque para a rede geográfica solidária camponesa de luta pela terra, que garante articulação, comunicação e ajuda mútua em graus diversos entre os assentamentos e acampamentos que possivelmente tornar-se-ão PAs, seja por meio da organização da ocupação de terra, negociação com o INCRA e manifestações; seja através da rede de parentesco que se desenvolve entre as áreas, devido aos parentes e/ou amigos dos assentados se lançarem na luta pela conquista por seus próprios territórios de sobrevivência.

Nessa rede, os assentamentos são fundamentais para a permanência da luta, pois são bases logísticas de novos acampamentos. Isto ocorre de duas maneiras: a primeira é acolher aqueles sujeitos que efetuarão uma ocupação em uma dada fazenda próxima, depois ajudar a planejar a ação e a executá-la, destacando membros do assentamento e de outros para mobilizar o maior contingente de pessoas possível, e, assim, ter maior possibilidade de êxito ao entrar na área pretendida, evitando fortes retaliações dos fazendeiros e do aparelho policial do Estado. A ocupação pode desenvolver a construção de um acampamento, passível de sofrer processos de reintegração de posse por parte do governo, que concorrem para a retirada, 
muitas vezes violenta, dos sem-terra da fazenda. Surge então o segundo momento de ajuda do assentamento, que serve novamente de local ao reagrupamento dos acampados até surgir outra oportunidade de ocupar a área, tal qual nos informa um dos assentados de Eldorado de Carajás:

Ajudamos a ocupar a Peruana [PA Lourival Santana], eu morava aqui [PA
Cabanos], na época não fazia parte da coordenação do MST, fui
voluntariamente ajudar, eu morava aqui e tinha a ocupação e me chamaram...
fui lá. Da Maria Bonita [Acampamento Dalcídio Jurandir] nós fizemos o
acampamento aqui, dentro de nosso assentamento, fizemos ali no lote do
meu cunhado, fizemos o acampamento lá, depois que os companheiros
estavam todos aglomerados e de lá que nós saímos então para a fazenda
porque [...] usamos dessa estratégia, trouxemos todo mundo pra cá de
pouquinho, cinco nessa semana, cinco na outra, passamos quatro meses
levantando gente, quando nós tinha umas quatrocentas e poucas famílias, nós
fomos e ocupamos a Maria Bonita. (Gilberto Fernandes de Oliveira,
Presidente da Associação do Assentamento Cabanos, 41 anos, 22 maio
2015)

Esta relação é mútua porque nos momentos em que os assentados necessitam realizar ações de manifestação, ocupações de prédios públicos, passeatas para reivindicar determinadas melhorias, os acampados se mobilizam conjuntamente, assim como se houver a necessidade por parte dos acampados, os assentamentos igualmente ajudam, além destes últimos doarem alimentos e vestimentas para os acampamentos. Essa solidariedade também ocorre entre os acampamentos, especialmente nos momentos de violência, conforme relata um dos acampados do Frei Henri:

Aqui a gente não pode ultrapassar dos limites aqui, a gente vive oprimido aqui, porque se a gente atravessar um pouquinho para dentro da grota prá lá, eles metem bala na gente, isso aqui é constante, inclusive no mês passado teve, como teve tiro que pegou em nós aqui, ai foi preciso chamar o INCRA o DECA $^{38}$, polícia de conflito agrário que cuida disso, ai foi a gente falou, a gente não mexe com eles [...] a gente resiste porque o MST é muita gente né, aqui nós tava pouco, somo 150, mas que Deus o livre quando eles vem pra cima da gente os outros acampamento socorre a gente [...] Isso é tipo coletivo, que a gente faz tudo coletivo, trabalha coletivo, o encaminhamento das coisa tem que ser aprovado na base em torno do acampamento [...] ai vai encaminhando, então se lá no Hugo Chaves, na Cedro [Acampamento Helenira Resende], na Maria Bonita precisar é só ligar pra gente... não tem aquele negocio de dizer como é que vai, é só dizer: - oh! A gente do acampamento está precisando de tantas pessoas, bora? A gente só bota a rede na boroca quando dá tempo, quando não dá vai só a gente mesmo, mas é uma coisa que gera um coletivo, é a gente mesmo, se for preciso, que nem a gente tem acampamento lá no Tocantins, se Deus o livre precisar de nós ir lá pro Tocantins, nós vamos, como nós já fomos duas vezes, as mulheres foram duas vezes lá dá um pau na Kátia Abreu lá, é assim se precisar nós ir lá no

\footnotetext{
${ }^{38}$ Delegacia de Conflitos Agrários.
} 
Tocantins, nós vamos, se precisar ir lá no Maranhão nós vamos, qualquer lugar do mundo. Nós trabalha assim, nós somos assim. As vezes nos pega ajuda (de outros assentamentos) assim que nem Palmares, 17 (de Abril), agora mesmo a 17, maior parte da assistência lá na Curva do S a 17 tá ajudando (Entrevistado Raimundo Ferreira, acampado no Frei Henri, 57 anos, entrevista concedida em 9 de abr. 2015).

A rede geográfica solidária camponesa de luta pela terra resultou na permanência a longo prazo nos acampamentos que existem na realidade e possibilitou a criação de novos assentamentos.

O organograma 2 abaixo representa sinteticamente o processo de construção da territorialidade do MST, no sudeste paraense, por meio dos assentamentos e acampamentos desenvolvidos entre a década de 1990 e o ano de 2016, muito embora nosso foco da pesquisa sejam os PAs.

Nessa representação percebemos que a criação do Assentamento Palmares II foi de fundamental importância no âmbito territorial, visto que sua conquista possibilitou a condição geográfica de ampliação da área de atuação do MST, pois serviu de alicerce para diversas ações desse movimento em outros locais, principalmente porque a organicidade ali construída foi levada a cabo em outras ocupações que vieram a ser tornar assentamentos ulteriormente.

Os assentamentos que obtiveram ajuda por meio dos assentados e militantes da Palmares II, por seu turno, irão ajudar na constituição de outros PAs e acampamentos existentes através dessa rede geográfica solidária camponesa de luta pela terra, embora o primeiro PA ainda seja central devido a nele se localizarem as principais lideranças do MST e ser muito presente a organicidade que possibilita e intensifica a luta pela reforma agrária no sudeste paraense, apesar de ela ter se metamorfoseado devido às contradições que permeiam a realidade em questão. 
Organograma 2 - Processo de construção da territorialidade do MST por assentamentos e acampamentos no sudeste paraense, 1994-2016 ${ }^{39}$

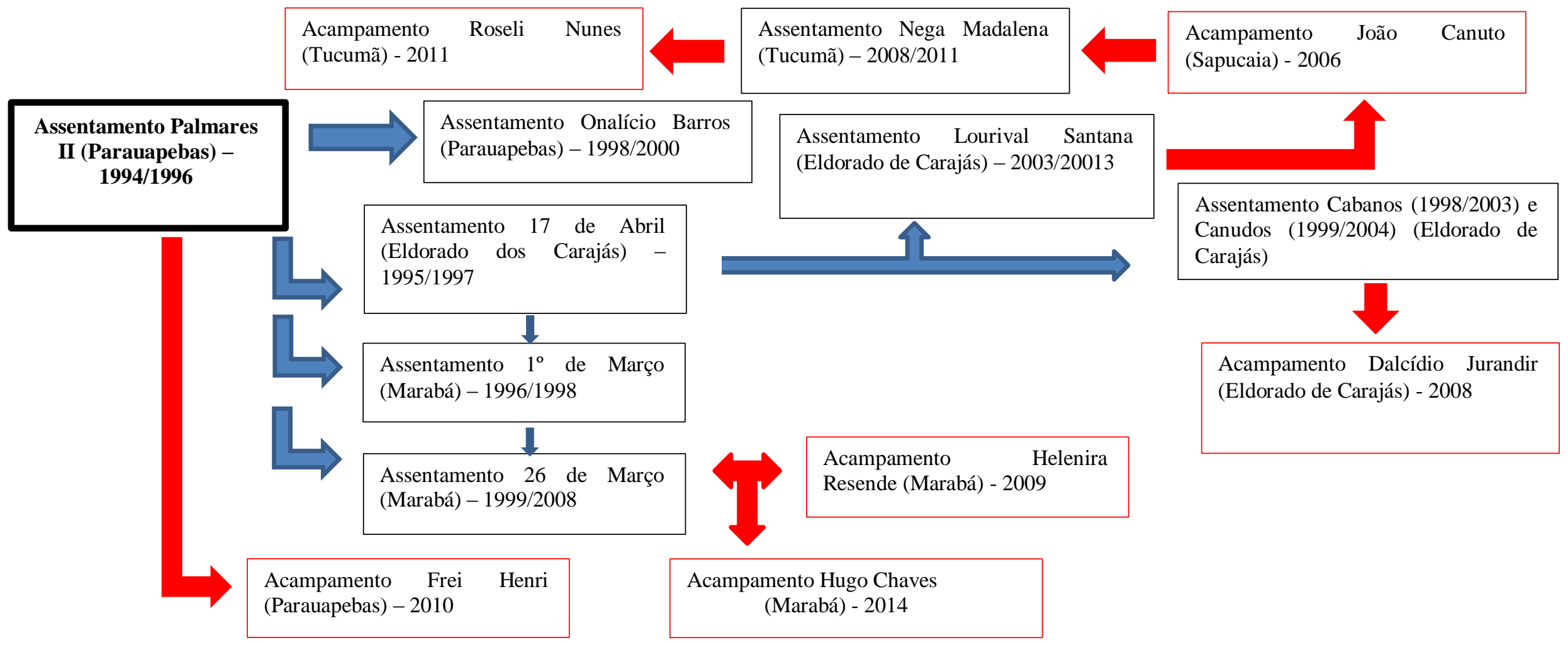

Fonte: Trabalho de campo, 2016. Organização Rogério Rego Miranda.

${ }^{39}$ As datas após os nomes de assentamentos correspondem aos anos de ocupação da área e criação do assentamento, respectivamente. A data após os nomes de acampamentos corresponde ao ano de ocupação da área. 
Além dessa articulação entre assentamentos e acampamentos, o MST cria outras alianças que possibilitam desenvolver uma política de escalas, ampliando a arena de disputa por outro modelo de desenvolvimento territorial. Nesse sentido, regionalmente vêm se constituindo ações conjuntas com os Sindicatos de Trabalhadores Rurais (STR), organizados na FETAGRI.

De acordo com Assis (2007), isso decorre de uma abertura maior dos dirigentes sindicais a partir dos anos 1990, inicialmente da FETAGRI Regional, que reconhecem as mútuas competências, diferenças e potencialidades entre MST e FETAGRI, passando de um momento de deslegitimação recíproca - marcado pelo desentendimento e com negociações separadas - para um de reconhecimento recíproco - manifesto pelo reconhecimento das diferenças e das ações coletivas -, decorrente da necessidade de se fortalecerem para enfrentar conjuntamento o Estado. Tal junção de interesses não significou a extinção das diferenças, mas possibilitou uma relação mais próxima para realizar embates nas arenas de disputa por políticas públicas, a partir, por exemplo, dos Grandes Acampamentos para reivindicar alterações e inclusões na Programação Operacional (PO) do INCRA e conseguir conquistas importantes, no âmbito da criação de assentamentos, assistência técnica e educação do campo. Esses Grandes Acampamentos assumem uma particularidade regional, devido à grande extensão territorial, composta atualmente por 39 municípios, à elevada quantidade de agricultores envolvidos na ação, geralmente em torno de 10 mil pessoas, à diversidade das pautas de reinvindicações, que variam entre políticas agrárias e agrícolas, assistência técnica, políticas sociais, infraestrutura e políticas específicas para mulheres e jovens agricultores, e devido à diversidade de sujeitos envolvidos, como STR, associações, cooperativas, federações, movimentos, agências de mediação, partidos políticos e entidades de representação de trabalhadores urbanos.

Essa articulação é denominada pelas lideranças locais de arco da aliança, e consistem em ações coletivas de maior envergadura por: a) demandar um contingente de pessoas maior, pois envolve um enfrentamento com sujeitos econômico-políticos de grande expressão como a Vale ou o próprio Estado; b) as manifestações pontuais não resultarem em soluções referentes às pautas requeridas; (c) morosidade no atendimento de determinadas pautas como cestas básicas para os acampamentos, infraestrutura (estrada, saúde, escola) crédito e extensão rural para os assentamentos e a desapropriação de terras ocupadas.

Para atingir seus objetivos, as organizações definem previamente uma programação e uma pauta conjunta entre MST e FETAGRI, e em alguns casos com a FETRAF, e sua ação geralmente culmina em um grande acampamento no INCRA que perdura vários dias; 
paralelamente, realizam bloqueios de estradas, caminhadas, manifestações em outros órgãos públicos e privados, mas a concentração principal fica no INCRA.

Para que o arco da aliança não resulte em conflitos internos pactuam-se alguns pontos, especialmente no que tange aos recursos para os assentamentos, pois em termos numéricos temos uma quantidade maior de PAs organizados pela FETRAGRI, seguido pela FETRAF e, em menor número, pelo MST, apesar de, muitas vezes, as mobilizações apresentarem um contingente maior de pessoas do MST. Isso pode levar ao questionamento sobre qual organização sindical ou movimento socioterritorial irá ficar com maior parte do investimento conseguido pela ação, pois o INCRA delega a responsabilidade de divisão para aqueles sujeitos, como forma de criar uma cisão

[...] a gente fala assim, arco da aliança compreende alguns pactos antes da luta, por que senão tu já tens também a... ou, se vai ser em partes iguais, a gente fala, vamos fazer divisão em partes iguais, por que vai ser diferente? Pela quantidade? Assim, a quantidade de assentamentos, mas também a gente tem território que dá quase cinco assentamentos como a 17 de Abril, Palmares, são assentamentos grandes que compreendem um território maior do que se tu juntar dela [FETAGRI] e do outro [FETRAF], de outras áreas, aí essas coisas sempre acontecem, parece uma disputa mesquinha, mas é a forma como o Estado se relaciona, dialoga com os movimentos e depois coloca um contra o outro e fragmenta a luta, então esse tal do arco da aliança é com quem mais, com quem tu se junta, para que tu vai se juntar e depois se houver conquistas como que a gente divide. (Maria Raimunda César de Sousa, dirigente do MST e professora, 42 anos, 12 jul. 2016)

Muitas dessas ações são assistidas pela CPT ou são encampadas por ela, especialmente nos momentos de manifestações. Nacionalmente o MST se articula a suas outras instâncias, além da CPT e da própria FETAGRI e, internacionalmente, possui relações com a Via Campesina.

A Via Campesina corresponde a um movimento de caráter internacional que se intitula "autônomo, pluralista e multicultural sem nenhuma filiação política ou econômica, que surge em defesa da agricultura sustentável como forma de promover justiça social e dignidade além de se opor fortemente às multinacionais do agronegócio" (FEAB, 2011, s/p). Congrega camponeses, pequenos agricultores, estudantes, sem-terra, indígenas, migrantes e trabalhadores rurais do mundo. Tem sua origem nas discussões entre representantes de oito organizações da América Central, Caribe, Europa, Canadá e Estados Unidos que participaram do $2^{\text {o }}$ Congresso da Unión Nacional de Agricultores y Ganaderos, em Manágua, na Nicarágua, em 1992. Na ocasião, camponeses e agricultores definiram uma base comum compartilhada entre as famílias do campo dos hemisférios sul e norte e se comprometeram a criar relações entre suas organizações e as vincular com outras existentes no mundo, no 
intuito de somar forças para pensar alternativas ao neoliberalismo. Mas foi apenas em maio de 1993 que a Via Campesina foi formalmente criada em Mons, na Bélgica, com a participação de 46 líderes de agricultores do mundo todo. Essas lideranças elegeram cinco regiões e constituíram uma Comissão Coordenadora de cinco pessoas composta de representantes de cinco regiões: o MST (América do Sul); a Asocode (América Central, Caribe e América do Norte); Solidariedade Camponesa da Polônia (Europa Oriental); Movimento Camponês das Filipinas (Ásia); e a CPE (Europa Ocidental). (DESMARAIS, 2013)

Atualmente a Via Campesina representa 164 organizações locais e nacionais em 73 países da África, Ásia, Europa e América, com aproximadamente 200 milhões de camponeses. (VIA CAMPESINA, 2011, s/p)

Esse movimento que congrega diversos outros movimentos sociais apresenta sua ramificação amazônica e, especificamente no Pará, por meio do MAB, CPT, MST, Movimento dos Pequenos Agricultores (MPA), Movimento de Mulheres Camponesas (MMC), Pastoral da Juventude Rural (PJR), associações, comunidades indígenas, quilombolas, pescadores artesanais e ribeirinhos, Cáritas, Conferência dos Religiosos do Brasil (CRB), Conselho Pastoral dos Pescadores (CPP) e o Conselho Indigenista Missionário (CIMI) (VIA CAMPESINA, 2014). A ideia era fazer

[...] um esforço de ajudar a instituir aqui para a gente, ter um bloco de organizações que pudesse pelo menos fazer uma leitura comum sobre essa lógica do capital aqui na região. E, a partir dessa base comum de leitura, é cada um ir desenhando sua estratégia de resistência ou de territorialização, a partir do que são os seus objetivos, os objetivos mais específicos já que o estratégico era imputar essas derrotas a essa leitura que nós estávamos tendo do capital, então quando nós ensaiamos consolidar a Via Campesina nos anos 2000 aqui foi nessa ideia (Ayala Lindabeth Dias Ferreira, dirigente do MST e representante da Via Campesina na Amazônia, 37 anos, 11 jul. 2016).

No Brasil, assim como na Amazônia, a Via Campesina congrega movimentos que apresentam pautas distintas, como reforma agrária, educação, reconhecimento dos povos e comunidades tradicionais, demarcação de terras indígenas. Todavia, tem seu foco no debate da agroecologia em contraposição ao agronegócio, às sementes transgênicas, à apropriação das terras pelo grande capital, que são temas recorrentes na América Latina, visto que os projetos hegemônicos existentes expropriam os mais diversos sujeitos do campo.

No Pará, as primeiras iniciativas de construir um vínculo mais direto com a Via Campesina se deram no início dos anos 2000, a partir de reuniões, processos formativos e de lutas conjuntas enquanto Via Campesina, isto porque 
[...] se o capital vem analisando estrategicamente sua territorialização, aqui os processos de luta e resistência também teriam que olhar isso. Então onde houvesse o empreendimento do grande capital para aniquilar outras formas de vida que havia aqui, teria que ter uma organização da Via [Campesina] para fazer esse contraponto, para provocar, para organizar os sujeitos, para efetivar esse contraponto. (Ayala Lindabeth Dias Ferreira, dirigente do MST e representante da Via Campesina na Amazônia, 37 anos, 11 jul. 2016)

Esse processo formativo e de articulação dos movimentos sociais em torno da construção da Via Campesina na Amazônia foi mediado pelo MST, que após os debates percebeu a impossibilidade de se sustentar territorialmente em todo o estado do Pará, principalmente pelo quadro de militantes reduzido. Entretanto poderia contribuir a partir de sua experiência de luta com a territorialização de outros movimentos sociais mais consolidados como a CPT, no oeste do Pará, ou o MAB, nas áreas atingidas por hidrelétricas; e igualmente com movimentos sociais mais incipientes, a exemplo do Juruti em Ação, que atua no município de Juruti e desenvolveu ocupações na área da Aluminium Company of America (ALCOA), que explora bauxita, conforme relata uma das lideranças da Via Campesina:

[...] a turma do Juriti em Ação lá nas baixadas, que ninguém nem lembraria, os caras de repente escutando as ideias da Via [Campesina] vieram debater e disseram, olha, o nosso inimigo é um grande empreendimento minerário aqui na região, então nós temos que fazer resistência e luta contra esse pessoal até para enquadrar eles. Aí vieram na reunião, olha, precisamos da ajuda de vocês, nos ensinem como fazer. Beleza! Coloque na região dois quadrozinhos nossos lá e, em treze reuniões, eles desenharam uma das maiores ocupações via águas de uma empresa como a Alcoa, e enquadrou os caras. Isso é resultado dessa construção da Via Campesina, os meninos até disseram assim: "nunca imaginei que um dia eu ia participar de uma ocupação por rabeta", diz que de repente marcaram lá no mesmo horário, aí são várias ilhas, nós, tal hora, no eixo tal [...] cinco horas todo mundo tem que estar lá, seis horas todo mundo tem que estar lá, teve gente que teve de sair três horas da manhã lá da ilha para estar exatamente naquele horário. De repente começou a chegar cinco, dez, de repente quando viram quinhentas pequenas embarcações cheias de gente ocupando... Disse que foi a cena mais linda que ele viu em toda a vida dele, mas foi fruto desse processo de dizer o MST nunca vai para aquela região, pode ser até que vá, mas nunca imaginou trabalhar diretamente com ribeirinhos que as estradas são os rios e que o tempo histórico dele é outro. (Ayala Lindabeth Dias Ferreira, dirigente do MST e representante da Via Campesina na Amazônia, 37 anos, 11 jul. 2016)

Essa articulação entre movimentos sociais que é promovido pela Via Campesina amplia as redes de cooperação e de luta pelo território em múltiplas escalas.

A Via Campesina fez um documento intitulado Ideias para o pensamento político da Via Campesina na Amazônia - 2004-2013, no qual identifica a natureza do enfrentamento existente na região amazônica, cujo desenvolvimento se baseia em três frentes: a) espoliação 
dos recursos da natureza por meio do capital nacional e estrangeiro; b) precarização das relações de trabalho; c) monopolização dos recursos e concentração de riquezas, gerando uma grande massa de excluídos. Desta feita, deve-se pensar na conformação de um Bloco Camponês e Popular Amazônico, que enfrenta diversos desafios: a) a conformação de um bloco de organizações camponesas, produto das contradições do capital e seu bloco de dominação, deve fazer contraposição a partir das particularidades regionais; b) politicamente, o bloco camponês não deve ser guiado por uma política ingênua ou sectária mas orientar para que força política e social construir; c) o bloco camponês por sua diversidade e historicidade proveniente da disputa com o capital apresenta uma construção permanente, logo, manifesta diferenças internas em torno das táticas e métodos e também dos ritmos das forças políticas e organizações que estão envoltas com a unidade de análise e o princípio de ação (VIA CAMPESINA, 2014).

Esse bloco histórico-geográfico proposto pela Via Campesina mostra a importância da disputa pelo território, respeitando a particularidade regional do enfrentamento pautado pelo agronegócio e a mineração, assim como respeita a diversidade dos sujeitos envolvidos, seus ritmos históricos e proposições, o que não implica na ausência de tensões internas.

Outra estratégia adotada pelo MST para desenvolver um projeto contra-hegemônico reside na disputa pelos aparelhos privados de hegemonia no seio da sociedade civil, salvaguardando as relações de poder assimétricas que engendram tais disputas. Com efeito, o MST desenvolve ações no âmbito da educação em diversos níveis, da escola básica dos acampamentos e assentamentos até a Universidade e os Institutos; propõe um modelo de agricultura camponesa que valoriza a diversidade produtiva e experiências agroecológicas face ao modelo monocultural do agronegócio; atua igualmente no permanente debate em torno de uma mudança de visão de mundo, de um consenso que venha de baixo. Esses elementos serão objeto de estudo do capítulo seguinte. 
5. TERRITORIALIZAÇÃO CONTRA-HEGEMÔNICA DO MST NO SUDESTE PARAENSE A PARTIR DA REAPROPRIAÇÃO DOS APARELHOS PRIVADOS DE HEGEMONIA

Foto 28 - Acampamento Hugo Chavez em Marabá, 2015.

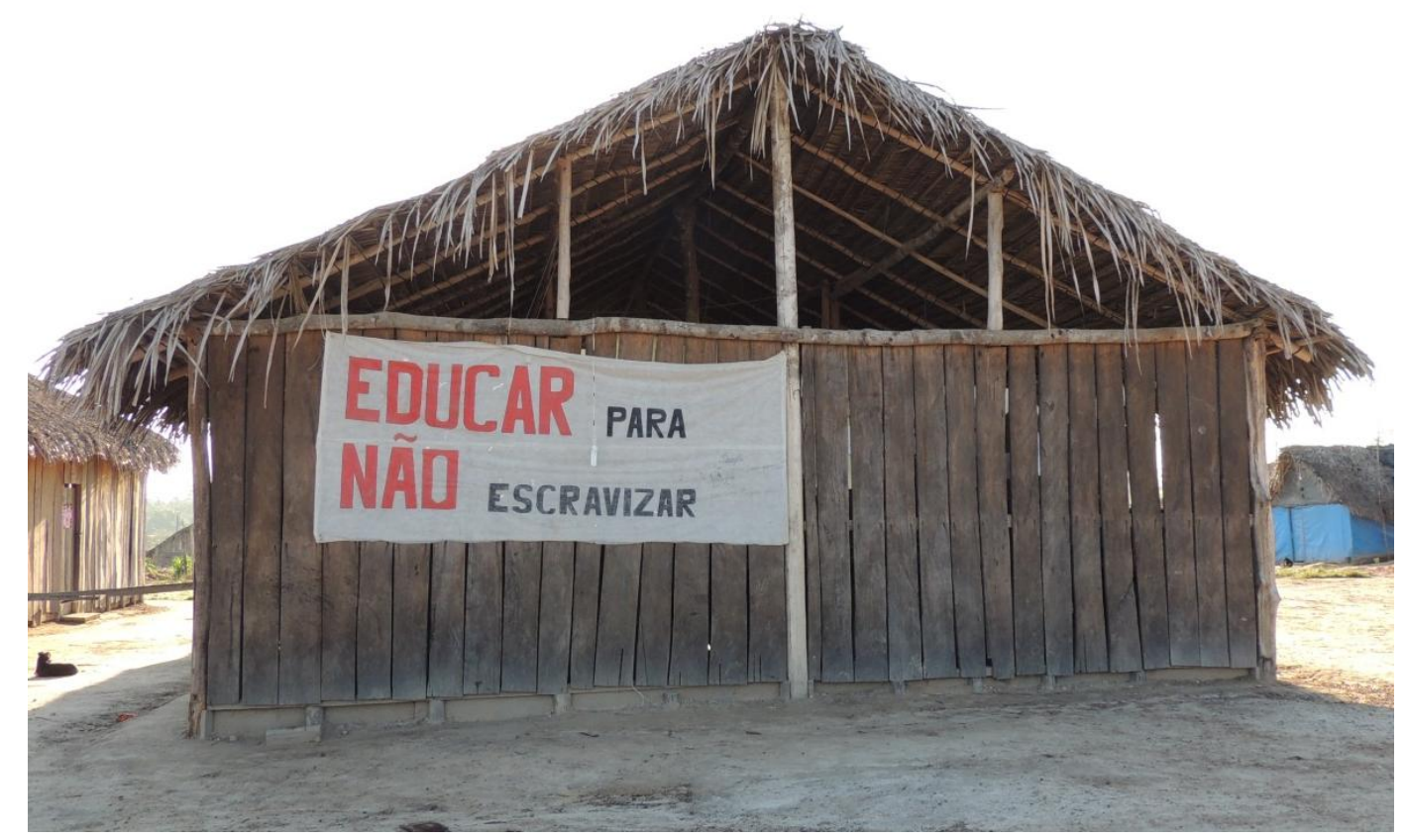

Fonte: Rogério Rego Miranda, Marabá, 2015.

Foto 29 - Assentamento Palmares II em Parauapebas, EMEF Crescendo na Prática, 2015.

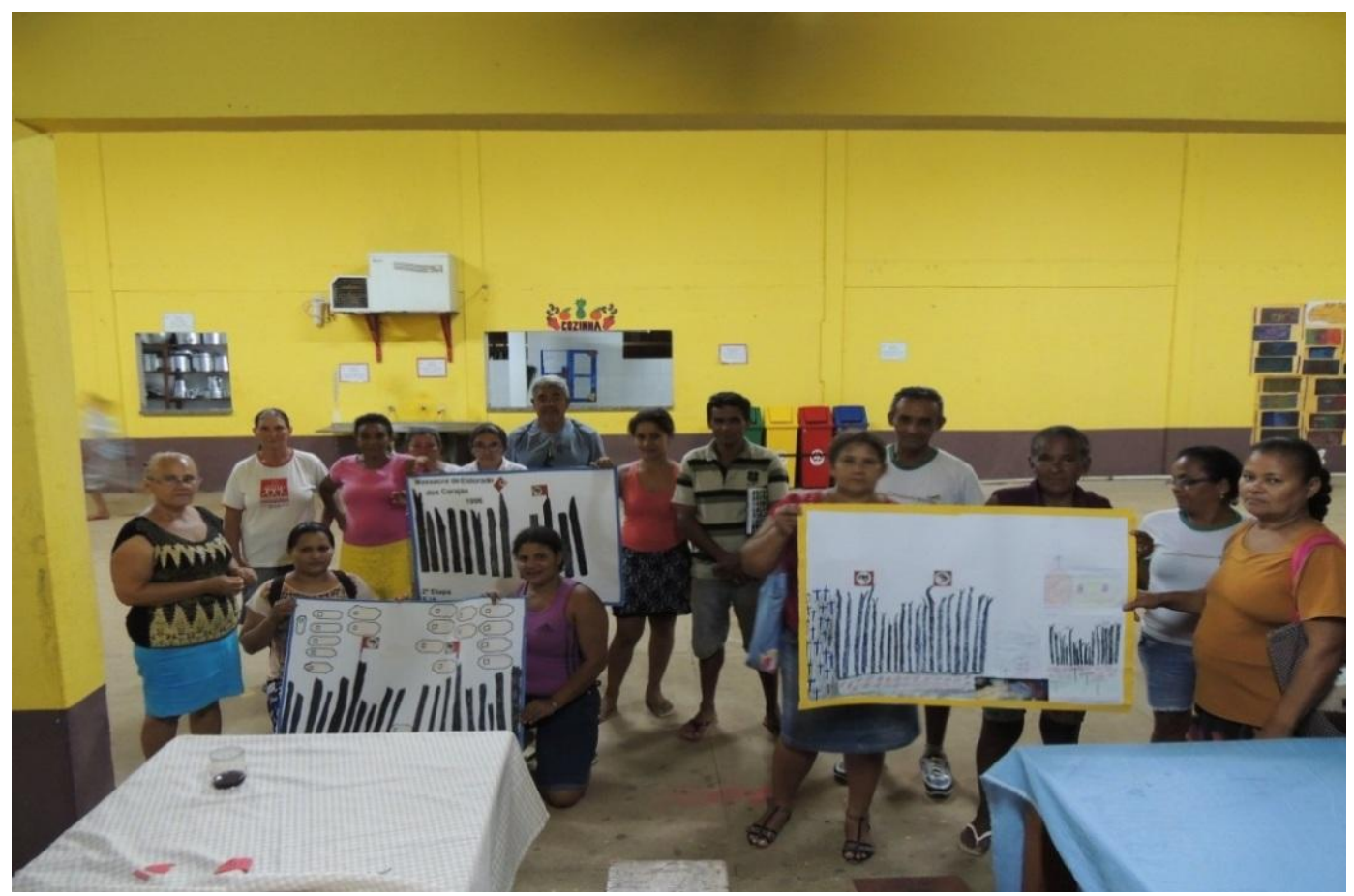

Fonte: Rogério Rego Miranda, Parauapebas, 2015. 


\section{Permanente}

Fizemos...

Fizemos da noite $o$ ato permanente de incitação e marcha dos insurgentes

Das noites monótonas as figuras permanentes da conspiração

Das noites acidentadas a "guerra de posição" de brigadas convictas

Das noites de blackout o circulo da leitura revolucionária nas fábricas

Das noites de chuva intensa a produção clandestina de panfletos e artigos

Das noites órfãs a leitura exaustiva de "A Mãe"

Das noites de economia complexa os conscientes "sábados comunistas"

Das noites de desilusão e baixa o trem da agitprop

Das noites dispersas a união da juventude comunista

Das noites complexas a projeção permanente de madrugar e triunfar

Fizemos, fazemos, faremos permanentemente

Márcio Jandir (Coletânea de Poesias Amazônicas, VI Congresso Nacional do MST, Brasília, 2014)

Um cuidado que devemos ter no início desse capítulo se refere ao termo contrahegemonia, muito utilizado ao longo do trabalho. Para Souza (2003b), Gramsci não desenvolveu tal conceito, que fora cunhado por outros autores, a exemplo de Williams (1979), 
com o intuito de atribuir um sentido de resistência ao propor um debate sobre hegemonia e suas implicações para a teoria política marxista e a teoria cultural.

Para Williams (1979), Gramsci desenvolveu a ideia de uma hegemonia alternativa (contrastante com a hegemonia da classe dirigente) mediante conexão prática entre diferentes maneiras de luta e originária da classe trabalhadora concreta que apresenta uma potência hegemônica contrária às pressões e imposições da hegemonia dominante. Essa hegemonia é vivida e constitui um processo, ou seja, um complexo oriundo de experiências, relações e atividades que são pressionadas, limitadas e transformadas historicamente e não se manifesta unicamente como uma forma passiva de dominação, por isso é continuamente redefinida, alterada e recriada, visto que apresenta resistências frequentes e é desafiada por diferentes formas de pressão. Assim, Williams (1979) propõe o conceito de contra-hegemonia ou hegemonia alternativa, uma vez que a hegemonia, no sentido de dominante, não se coloca como uma realidade total e única, podendo ser contraposta por formas políticas e culturais alternativas, que devem ser consideradas em uma análise histórica por afetarem significativamente o processo hegemônico, indicando inclusive aquilo que esse processo objetivou controlar. Desta feita, a título de método, não se deve reduzir as iniciativas políticoculturais aos termos da hegemonia, visto que nos escaparia seu processo ativo, formativo e transformador. Por fim, é necessário reconhecer que as iniciativas alternativas estão interligadas ao processo hegemônico, que produz e limita, ao mesmo tempo, suas formas de contra-hegemonia.

De fato, Gramsci não utilizou em seus escritos o termo contra-hegemonia, isto porque, segundo Dore (2006), para ele não se tratava de permanecer no nível do anti, ou seja, de realizar uma resistência contra a classe dominante, visto que propunha que as classes subalternas construíssem sua própria hegemonia por meio da passagem catártica do econômico ao político.

Nesse sentido, ao utilizarmos "contra-hegemonia" devemos tecer algumas considerações. Para nós, o termo apresenta o sentido de resistência, especialmente contra o latifúndio, manifesto nos projetos agropecuários e minerais do sudeste paraense, porém não significa uma ação de se opor sem uma proposição, isto é, um projeto territorial que se disputa de diversas formas, em diferentes frentes e nas mais variadas escalas. Na verdade, a contrahegemonia implica estratégias de luta pelo território em suas múltiplas dimensões. $\mathrm{Na}$ dimensão material, a disputa se relaciona à propriedade da terra propriamente dita, que é a condição fundamental de reprodução dos camponeses sem-terra. Na dimensão imaterial, que 
se articula e integra a primeira, existe uma disputa que se realiza no seio da sociedade civil, por meio dos aparelhos privados de hegemonia, foco de nossa reflexão neste capítulo.

Essa outra face do projeto contra-hegemônico se desenvolve dentro e fora dos assentamentos, com o intuito de possibilitar aos assentados que permaneçam em seus territórios e, ao mesmo tempo, ampliem as escalas de ação, utilizando-se da política de escala para difundir sua luta, construír alianças que sejam o germe de um bloco histórico portador de outro consenso.

Destarte, o projeto contra-hegemônico do MST se assenta principalmente no tripé terra-educação-produção, conceitos que se entrelaçam para pensar uma reforma agrária popular e geradora de um projeto territorial alternativo disputado no seio da sociedade civil. A respeito dessa proposição, discutimos longamente as formas de luta pela terra, que corresponde ao centro das disputas por ser a condição material de reprodução dos sujeitos, mas paralelamente houve a necessidade de se pensar um projeto para além da conquista da terra, que subsidiasse a reprodução camponesa e a permanência da luta por outras gerações. Por esse motivo ao longo da territorialização do MST foi pensado um processo formativo que inclua a educação em sua dimensão mais ampla, ou seja, que congregue as disciplinas formais, porém integrando-as aos princípios do movimento socioterritorial e à dinâmica dos sujeitos do campo, em particular a sua produção - tais elementos serão mais bem explorados a seguir.

\subsection{A ESCOLA NOS ASSENTAMENTOS E O PROJETO DA EDUCAÇÃO DO CAMPO EMANCIPATÓRIA}

Um dos pilares do projeto contra-hegemônico do MST se assenta na educação, que não pode ser confundida como um processo formal, restrito ao âmbito da escola; nem mesmo a escola pode ser restrita a um espaço de repasse de informações disciplinares.

Para Caldart (2000), o significado da experiência de educação no/do MST transcende a escola: enquanto processo formativo, a educação perpassa o conjunto das ações do MST e as vivências dos sujeitos, constituindo um movimento sociocultural de formação do sem-terra, que se constrói enquanto sujeito cultural a partir de suas ações. Para a autora, o MST desenvolveu um processo de ocupação das escolas, que não ocorreu de maneira homogênea em todos os assentamentos e acampamentos tampouco se encontra acabado. Mas, a título de sistematização desse movimento de ocupação das escolas, consideramos três significados, a saber: a) os sem-terra se mobilizam pelo direito à escola, que deve ser, contudo, um espaço de significado concreto para os sujeitos; nesse primeiro momento, por volta do início dos anos 
1980, as ações educativas envolviam as mães e os professores, posteriormente os pais e algumas lideranças do movimento e aos poucos as crianças foram se envolvendo; b) o MST assumiu a tarefa de organizar e articular, endogenamente a sua organicidade, uma mobilização para propor uma pedagogia específica às escolas conquistadas e construir condições de formar educadores capazes de trabalhar nessa direção; para este fim, criou-se em 1987 o Setor de Educação, formalizando a intencionalidade que vem ampliando o próprio conceito de escola: incialmente a luta se desenvolveu em torno das escolas de ensino infantil e hoje são disputados os espaços nas universidades, aglutinam-se esforços na alfabetização dos jovens e adultos e fomentam-se processos de escolarização e formação da militância; c) a partir dos dois momentos anteriores, o MST incorporou a escola a sua dinâmica, isto é, a escola passou a fazer parte do cotidiano e das preocupações das famílias sem-terra, logo, os acampamentos e assentamentos necessariamente devem ter escolas baseadas nos princípios do movimento, politizando o debate em torno da escola e colocando-a como uma questão central na luta pela reforma agrária.

Essa contextualização mais geral é importante para compreendermos o processo de incorporação da educação como uma forma de se apropriar da escola, direito antes negado aos sujeitos do campo - e muitas vezes da cidade. Essa apropriação, porém, ressignifica, a partir da valorização de sua realidade concreta, seus saberes, suas formas de aprender e ensinar.

Especificamente nesse trabalho não é nosso objetivo tratar da educação do MST de maneira detalhada, analisando pormenorizadamente os currículos das escolas, institutos e universidades que se estruturaram ou tiverem cursos estruturados a partir da ação do MST, em conjunto ou não com outros movimentos socioterritoriais. Propomo-nos, no entanto, a analisar como esses espaços são disputados territorialmente pelo MST a partir de uma proposta de construção de um projeto contra-hegemônico que, embora seja construído no sudeste paraense, se encontra articulado a outras escalas geográficas de luta camponesa.

Entretanto, é importante destacar os princípios que norteiam a proposta de Educação do MST. No ano de 1992, em seu Boletim da Educação, o movimento indica os princípios norteadores das escolas dos assentamentos, quais sejam:

1. A escola de assentamento deve preparar as crianças para o trabalho no meio rural;

2. a escola deve capacitar para a cooperação;

3. a Direção da Escola deve ser coletiva e democrática;

4. a Escola deve refletir e qualificar as experiências de trabalho produtivo das crianças no assentamento;

5. a Escola deve ajudar no desenvolvimento cultural dos Assentados;

6. o Ensino deve partir da prática e levar ao conhecimento científico da realidade; 
7. o Coletivo da Escola deve se preocupar com o desenvolvimento pessoal de cada aluno;

8. o professor tem que ser militante;

9. a Escola deve ajudar a formar militantes e exercitar a mística da luta popular;

10. a Escola também é lugar de viver e refletir sobre uma nova ética. (MST, 1992, p. 1)

Essas propostas eram vinculadas principalmente às escolas de ensino básico e já esboçavam as linhas gerais da educação para o MST, mas estas são aprimoradas e ampliadas com a compreensão de educação em seus diversos níveis no ano de 1996, em seu Caderno de Educação $n^{o}$ 8, intitulado Princípios da Educação no MST. Esse documento define que a educação corresponde ao processo formativo da sociedade por meio do qual as pessoas se transformam e transformam a sociedade, por isso se vincula a um projeto político que se realiza, em geral, na escola, mas não se restringe a ela. No caso do MST, esse debate é tratado pelo Setor de Educação, que trabalha mais diretamente com as escolas dos assentamentos, que, na prática, vêm apresentando uma ampliação de seu conceito que se expande para além desse setor. Em suma, para o MST, a educação envolve as escolas do ensino básico dos assentamentos e dos acampamentos (regularizadas ou não), alfabetização de jovens e adultos, educação infantil, ensino médio e superior, além de cursos de formação de professores e de militância.

A educação, por seu turno, apresenta princípios que compreedem as ideias, convicções e formulações nas quais estão pautadas o trabalho de educação no MST, constituindo o ponto de partida das ações, mas são resultantes das práticas realizadas pelo movimento, das experiências históricas que acumulou ao longo dos anos de trabalho. Esses princípios se subdividem em filosóficos (referentes à visão de mundo, concepções mais abrangentes em relação à sociedade e à educação) e pegagógicos (elementos condizentes com a forma de fazer e de pensar a educação, em que se reflete sobre a metodologia dos processos educativos) - salientamos que as duas categorias encontram-se imbricadas (MST, 1996).

Nesse sentido, a educação para o MST (1996) segue alguns princípios filosóficos, a saber:

1) Educação para a transformação social: corresponde a um processo pedagógico que apresenta um caráter político, vinculando-se organicamente aos processos sociais que almejam a transformação da sociedade atual com o intuito de constituir uma outra ordem social, pautada na justiça social, radicalidade democrática e valores humanistas e socialistas. Dessa perspectiva derivam algumas características importantes: a) educação de classe: a educação se 
organiza com o objetivo de selecionar conteúdos e métodos que viabilizem a possibilidade de construção de uma hegemonia do projeto político das classes trabalhadoras, vislumbrando o fortalecimento do poder popular e a formação de militantes para a organização dos trabalhadores; b) educação massiva: proposta de uma educação estendida a todos e de diversas formas, especialmente por meio da escolarização; c) educação organicamente vinculada ao movimento social: proposta de construção de uma educação do MST, ou seja, integrada às lutas, aos objetivos e sua organicidade; d) educação aberta para o mundo: a proposta de educação deve ser alargada pela prática de outras realidades; e) educação para a ação: que construa sujeitos capazes de intervir e transformar materialmente a realidade, ou seja, que possibilite ir para além da "consciência cítica" (de denúncia e discussão acerca dos problemas) e constitua uma "consciência organizativa" (de intervenção concreta na realidade), sem cair no pragmatismo que desvincula o saber da prática; f) educação aberta para o novo: aberta para a constituição de novas relações sociais e de interação que surgem nos processos político-econômicos em que o MST se insere.

2) Educação para o trabalho e a cooperação: este princípio considera que a educação e a escola devem ser relacionadas aos desafios de seu tempo histórico, especificamente no espaço rural, e devem levar em conta a luta pela reforma agrária. Logo, a educação voltada para o campo se baseia na realidade e nos problemas dos assentamentos e acampamentos, objetivando a construção de alternativas de permanência no campo de maneira mais digna. Para esse fim, destaca-se a formação para a cooperação visando a educação como fundamento para novas relações sociais, pautadas na experiência da organização da luta pela terra como uma nova mentalidade para a organização do espaço agrário, superando inclusive a oposição entre campo e cidade.

3) Educação para o trabalho e a cooperação: este princípio considera que a educação e a escola devem ser relacionadas aos desafios de seu tempo histórico, especificamente no espaço rural, e devem levar em conta a luta pela reforma agrária. Logo, a educação voltada para o campo se baseia na realidade e nos problemas dos assentamentos e acampamentos, objetivando a construção de alternativas de permanência no campo de maneira mais digna. Para esse fim, destaca-se a formação para a cooperação visando a educação como fundamento para novas relações sociais, pautadas na experiência da organização da luta pela 
terra como uma nova mentalidade para a organização do espaço agrário, superando inclusive a oposição entre campo e cidade.

4) Educação com/para valores humanistas e socialistas: proposta educativa de construção de um novo sujeito que rompa com os valores dominantes da sociedade capitalista, fundamentada no individualismo e no mercado. Nesse sentido, novos valores devem ser trabalhados, que evidenciem a transformação social e a liberdade em termos coletivos sem perder de vista as diferenças, com a socialização dos bens materiais e culturais, distribuição mais equitativa dos bens e igualdade na participação do processo decisório.

5) Educação como um processo permanente de formação e transformação humana: partindo do princípio de que as pessoas se transformam e ao mesmo tempo transformam a realidade social, igualmente educam e são educadas, o trabalho de educação deve considerar: a) a discussão metodológica sobre como educar e aprender, considerando a diversidade dos sujeitos; b) a base da educação deve ser a existência concreta das pessoas; c) a educação deve ser um processo intencionalmente planejado e provocado com o intuito de possibilitar a mudança social; d) a educação deve considerar o raciocínio, mas igualmente os afetos e sentimentos.

Para além dos princípios filosóficos, o MST definiu alguns de caráter pedagógicos:

1) Relação entre prática e teoria: para uma educação com fins de uma ação transformadora devem ser consideradas a teoria e prática de maneira inserapável. Portanto, aquela visão da escola como local de conhecimentos teóricos deve ser superada: ao contrário, a prática social dos educandos deve ser a base de seu processo formativo, produzindo dialógos entre a elaboração teórica e a prática.

2) Combinação metodológica entre processos de ensino e de capacitação: Os processos de aprendizado não podem ser homogeneizados, consequentemente, as metodologias devem ser pensadas de acordo com o objetivo proposto. Nesse sentido, existem processos de produção do saber que apresentam lógicas distintas, definidas como processos de ensino e processos de capacitação. Os primeiros caracterizam-se pela antecedência da teoria sobre a prática, que é ensinada pelo educador; já para os segundos, a prática antecede a teoria e o processo de capacitação é realizado por uma atividade objetivada, mediante uma situaçãoproblema que estimula o educando a aprender com o intuito de reagir em relação a um problema concreto, logo, a capacitação resulta em saberes práticos 
denominados de saber-fazer. Esses dois saberes necessitam ser combinados, porém devem ser priorizados de acordo com o objetivo formativo, especialmente nas escolas que devem ser "oficinas alternativas" em que os educandos aprendem a produzir conhecimentos importantes para a transformação social que se almeja.

3) A realidade como base da produção do conhecimento: a ideia é partir da realidade para a produção do conhecimento, mas entendendo que esta é também o ponto de chegada, pois é ela que se quer transformar. Todavia, a realidade em questão não é apenas aquela circundante, pois sua existência é mais ampla. Daí resultam alguns princípios metodológicos: a) a realidade e suas problemáticas são a matéria-prima da construção do conhecimento, pois geram a necessidade de aprender, especialmente a partir dos "temas geradores"; b) partir de uma realidade mais próxima para facilitar o aprendizado, porém sem perder de vista outras realidades (regional, nacional e mundial), transitando do particular para o geral e vice-versa.

4) Conteúdos formativos socialmente úteis: os conteúdos são selecionados de maneira instrumental para atingir determinados objetivos, seja no âmbito do ensino, seja no da capacitação. Ainda que muito dessa seleção apresente certas imposições pelas secretarias de educação ou pelo governo federal via Parâmetros Curriculares Nacionais (PCN), sempre existe uma margem de manobra sobre os conteúdos.

5) Educação para o trabalho e pelo trabalho: os sujeitos privilegiados na educação do MST são os trabalhadores, assim a vinculação entre educação e trabalho apresenta duas dimenções: a) educação ligada ao mundo do trabalho: os processos pedagógicos devem considerar a produção na sociedade em geral e no assentamento em particular, assim, a escola deve primar por conteúdos ligados ao mundo do trabalho e da produção; b) o trabalho como método pedagógico: a combinação entre estudo e trabalho de maneira instrumental para o desenvolvimento das dimensões da educação proposta (trabalho como gerador das necessidades de aprendizagem e como construtor de relações de trabalho, especialmente por meio da cooperação, resultando em novas relações interpessoais e coletivas).

6) Vínculo orgânico entre processos educativos e processos políticos: os processos políticos referem-se ao modo de governar a vida social, envolvendo relações de poder que visam a manutenção ou a transformação social. E a 
educação é sempre um exercício político pois se encontra inserida em um projeto de transformação ou de conservação social; desta feita, existe uma relação orgânica entre educação e política, que significa fazer a política atravessar os processos pedagógicos das escolas.

7) Vínculo orgânico entre processos educativos e processos econômicos: os processos econômicos se vinculam a produção, distribuição e consumo de bens e serviços necessários ao desenvolvimento da sociedade. Essa dimensão econômica necessita ser objeto do ensino e das práticas pedagógicas dos educandos, inserindo-os em processos econômicos existentes no interior do curso ou da escola.

8) Vínculo orgânico entre educação e cultura: a educação é considerada um processo de socialização e produção da cultura, assim como um processo de transformação cultural dos sujeitos. As escolas e cursos do MST privilegiam a vivência e a produção da cultura através da comunicação, da arte, da história, da festa, do convívio comunitário etc.

9) Gestão democrática: a democracia se torna um princípio educativo com fins de discutir seu significado teórico e prático, com participação efetiva que se realiza a partir de duas dimensões: a) a direção coletiva das etapas do processo pedagógico envolve os participantes diretos (educandos e educadores) e também a própria comunidade na gestão escolar e o conjunto de outras escolas atreladas ao MST; b) a participação de todos os envolvidos no processo de gestão implica em responsabilidade compartilhada e respeito às decisões tomadas coletivamente.

10) Auto-organização dos/das estudantes: a auto-organização se refere a um tempo e a um espaço autônomos para encontros, discussões e tomadas de decisão, proporcionando o desenvolvimento da consciência organizativa dos educandos.

11) Criação de coletivos pedagógicos e formação permanente dos educadores/as educadoras: os princípios pedagógicos necessitam de um coletivo de educadores atuando de maneira cooperativa para serem levados a cabo; em especial, esse coletivo pedagógico pode ser o espaço de autoformação permanente mediante reflexão acerca da prática, do estudo e do planejamento das atividades promovidas pelo MST.

12) Atitude e habilidades de pesquisa: a pesquisa aqui é empregada como uma investigação sobre a realidade, com certa sistematização e rigor para entender de maneira mais qualificada um determinado problema, com o intuito de levantar 
possíveis soluções a partir da produção do conhecimento de sua situação atual e de historicizar o problema em questão.

13) Combinação entre processos pedagógicos coletivos e individuais: privilegiar a dimensão coletiva dos processos pedagógicos não significa pormenorizar as diferenças ou o sujeito individualmente envolvido no conjunto de educandos, pois se observa a importância do acompanhamento personalizado, por existir ritmos diversos de aprendizado peculiares a cada estudante.

Essas premissas filosóficas e pedagógicas que pautam a compreensão de educação do MST apresentam ressonâncias gramscianas, especialmente quando Gramsci (1978) destaca a ideia de que somos todos filósofos, não constituindo, sobremaneira, uma especialidade profissional. Assim, existe uma filosofia espontânea que se manifesta na linguagem, visto que carregamos conosco um conjunto de noções e de conceitos determinados, no senso comum e no bom senso, na religiosidade popular e em todo o sistema de crenças e formas de interpretar o mundo, que se denomina habitualmente de "folclore", contudo, essa filosofia espontânea pode ser desenvolvida em uma perspectiva crítica, em que se questiona a "concepção de mundo 'imposta' mecanicamente pelo ambiente exterior e, portanto, por um dos grupos sociais em que todos estamos automaticamente mergulhados desde a nossa entrada no mundo consciente" (GRAMSCI, 1978, p. 10) e se propõe elaborar sua "própria concepção do mundo, ser guia de si mesmo e não aceitar passiva e dolentemente que a nossa personalidade seja formada a partir de fora" (GRAMSCI, 1978, p. 10).

É importante sublinhar que essa concepção de mundo está vinculada a um grupo social e a todos os elementos sociais que partilham um modo de pensar e agir. Nesse sentido, criticar a própria concepção de mundo na qual estamos imersos, significa torná-la unitária e coerente, e também indagar a filosofia existente até o presente momento, em virtude de esta ter contribuído para uma estratificação na filosofia popular. Deste modo, devemos nos conhecer como produtos do processo histórico (e acrescentaríamos geográfico). Destarte, a crítica perpassa pela "consciência de sua historicidade, da fase de desenvolvimento que representa e do fato de estar em contradição com outras concepções ou com elementos de outras concepções" (GRAMSCI, 1978, p. 11). A concepção do mundo decorre igualmente de determinados problemas colocados pela realidade.

Esse movimento de crítica corresponde à filosofia da práxis que rompe com a separação entre teoria e prática e coloca a necessidade de um contato constante com as "gentes simples", visto que é essa relação que historiciza a filosofia. Em outras palavras, a filosofia da práxis se apresenta inicialmente sempre como uma ação polêmica e crítica diante 
da concepção de mundo existente, ou ainda, do senso comum e dos intelectuais. Isso porque se busca conduzir as "pessoas simples" a uma concepção superior de vida, em que os intelectuais devem ter um contato direto com os sujeitos, de forma a constituir um bloco intelectual-moral que possibilite um avanço intelectivo da massa e não de grupos específicos. Nesse sentido, a massa deve primar por uma compreensão crítica de si mesma, que é resultante de uma luta de

[...] "hegemonia" política, de direções contrastantes, primeiro no campo da ética, depois no da política para chegar a uma elaboração superior da própria concepção do real. A consciência de fazer parte de uma determinada força hegemônica (isto é, a consciência política) é a primeira fase para uma ulterior e progressiva autoconsciência, em que teoria e prática finalmente se unificam [...]. Por isso, deve colocar-se em destaque que o desenvolvimento político do conceito de hegemonia representa um grande avanço políticoprático, porque supõe necessariamente uma unidade intelectual e uma ética conforme a uma concepção do real que superou o senso comum e se fez crítico, embora dentro de limites ainda estreitos (GRAMSCI, 1978, p. 23).

Essa autoconsciência crítica histórica e politicamente leva à constituição dos intelectuais, visto que os grupos sociais não se distinguem e se tornam independentes sem que produzam uma organização, que fica sob a incumbência dos intelectuais: os organizadores e dirigentes. E quando o subalterno se torna dirigente e lhe é delegada a responsabilidade pela atividade econômica da massa, coloca-se em perigo a hegemonia dominante, visto que se produz uma revisão do modo de pensar em função da mudança no modo de ser social. $\mathrm{O}$ subalterno que era colocado como objeto, na condição de dirigente se apresenta como uma pessoa histórica, um protagonista, que não apenas resiste, mas propõe outra ordem (GRAMSCI, 1978).

Com relação aos intelectuais, Gramsci (1995) esclarece que aqueles possuem uma relação orgânica com o grupo social ao qual se vinculam:

Cada grupo social, nascendo no terreno originário de uma função essencial no mundo da produção econômica, cria para si, ao mesmo tempo e de um modo orgânico, uma ou mais camadas de intelectuais que lhe dão homogeneidade e consciência da própria função, não apenas no campo econômico, mas também no social e no político: o empresário capitalista cria consigo o técnico da indústria, o cientista da economia política, o organizador de uma nova cultura, de um novo direito etc. (Gramsci, 1995, p. $3-4)$.

Esses intelectuais, no entanto, podem apresentar um caráter tradicional, quando são provenientes de uma estrutura econômico-social anterior a do presente, dando sentido a uma continuidade histórica. Consideram-se autônomos e independentes do grupo social dominante. 
Assim como todos são passíveis de serem filósofos, Gramsci (1995) chama a atenção para fato de que não existe essa separação entre trabalho intelectivo e trabalho manual/instrumental, visto que neste usam-se elementos qualitativos de ordem intelectual. Desse modo, "todos os homens são intelectuais, poder-se-ia dizer então: mas nem todos os homens desempenham na sociedade a função de intelectuais" (GRAMSCI, 1995, p. 7).

Historicamente se formam categorias especializadas de intelectuais, que estão em conexão com os grupos sociais dominantes. A organização escolar, em seu sentido mais amplo, buscou multiplicar essas especializações e se propôs a elaborar intelectuais de níveis diversos. Assim, a diversidade de tipos de escola (profissionais e clássicas) no território econômico e os interesses das camadas sociais definem os ramos de especialização intelectual, existindo, sobremaneira, uma relação entre os intelectuais e o mundo da produção, mediada pelo contexto social, ou melhor, pelo conjunto das superestruturas às quais os intelectuais estão a serviço. Destacam-se nessas superestruturas dois planos: o da sociedade civil (organismos privados) e o da sociedade política ou Estado, que apresentam a função de hegemonia exercida pelo grupo dominante no seio da sociedade e o domínio direto que se manifesta no Estado e em suas formas jurídicas. Destarte, os intelectuais são sujeitos do grupo dominante para o exercício das funções subalternas de hegemonia social e governamental, em dois sentidos:

1) do consenso "espontâneo" dado pelas grandes massas da população à orientação impressa pelo grupo fundamental dominante à vida social, consenso que nasce "historicamente" do prestígio (e, portanto, da confiança) que o grupo dominante obtém, por causa de sua posição e de sua função no mundo da produção; 2) do aparato de coerção estatal que assegura "legalmente" a disciplina dos grupos que não "consentem" nem ativa nem passivamente, mas que é constituído para toda a sociedade, na previsão dos momentos de crise no comando e na direção, nos quais fracassa o consenso espontâneo. (GRAMSCI, 1995, p. 11)

Gramsci (1995) aprofunda o debate ao correlacionar o partido à construção dos intelectuais. Para esse fim elabora algumas distinções: 1) alguns grupos sociais entendem que o partido político corresponde a uma forma de constituir sua categoria de intelectuais orgânicos; 2) o partido para todos os grupos sociais representa na sociedade civil a função desenvolvida pelo Estado, visto que funde os intelectuais orgânicos de uma determinada classe e os intelectuais tradicionais, com o intuito de elaborar seus componentes,

[...] elementos de um grupo social nascido e desenvolvido como "econômico", até transformá-los em intelectuais políticos qualificados, dirigentes, organizadores de todas as atividades e funções inerentes ao desenvolvimento orgânico de uma sociedade integral, civil e política. (GRAMSCI, 1995, p. 14) 
Partindo dessas premissas gramscianas é possível perceber a intencionalidade do MST na construção de uma filosofia da práxis, que fundamenta seus intelectuais orgânicos, os quais não devem cair no equívoco de acreditar que se "possa saber sem compreender e, principalmente, sem sentir e estar apaixonado (não só pelo saber em si, mas também pelo objeto do saber)" (GRAMSCI, 2014a, p. 221). Dessa forma, deve-se primar por uma relação direta com os grupos subalternos, com o objetivo de sentir e compreender suas paixões, “explicando-as e justificando-as em determinada situação histórica, bem como relacionandoas dialeticamente com as leis da história, com uma concepção do mundo superior, científica e coerentemente elaborada, com o 'saber'” (GRAMSCI, 2014a, p. 221-222).

O MST em sua proposta formativa busca não recriar as hierarquias verticais próprias da sociedade capitalista, baseada no individualismo e na divisão intelectual/instrumental, o que, por sua vez, leva a uma divisão do trabalho e, consequentemente, a "toda uma gradação de qualificações, em algumas das quais não mais aparece nenhuma atribuição diretiva e organizativa" (GRAMSCI, 1995, p.11).

Ao contrário, por meio da educação, articulada à luta pela terra, o movimento almeja a constituição de relações coletivas, solidárias e com a participação de todos os sujeitos nos diversos níveis escolares. Aliás, assim como propôs Gramsci (1995), para além das especializações, considera-se a práxis educativa, que articula o desenvolvimento da capacidade de trabalhar manualmente e a capacidade de trabalho intelectual. A escola igualmente não é pensada por sua marca social, na qual cada grupo social apresenta um tipo de escola específica, perpetuando assim uma determinada função tradicional, ou seja, dirigente ou instrumental. Se a proposta é romper com essa forma de ensino, deve-se priorizar um tipo único de escola "preparatória (primária-média) que conduza o jovem até os umbrais da escolha profissional, formando-o, durante esse meio tempo, como pessoa capaz de pensar, de estudar, de dirigir ou de controlar quem dirige" (GRAMSCI, 1995, p. 136).

Desta feita, o que o MST propõe é a reelaboração de conceitos e valores por meio de uma escola que tenha um caráter emancipatório, estabelecendo uma contra-hegemonia. Por esse motivo, para Souza "o MST é na história do Brasil do tempo presente o moderno príncipe educativo" (SOUZA, 2008, p. 197 grifado no original). Compreendemos que o moderno príncipe, como já foi discutido no Capítulo 1, corresponde ao partido em sentido amplo, ou seja, refere-se a todo aparelho privado de hegemonia que desenvolva uma organização social, produzindo a vontade coletiva organizada. Desta feita, o moderno príncipe é um 
viveiro de organizadores selecionados de um conjunto de intelectuais enquanto persuasores permanentes, por seu papel politicamente indissociável de organização e de instrumento de elevação moral das massas, isto é, de tomada de consciência crítica, que só pode ser viável através da cultura comum. (SOUZA, 2008, p. 197 grifado no original)

Essa compreensão do MST enquanto o moderno príncipe se define, para Souza (2008), por alguns aspectos expostos aqui de maneira geral: a) pela capacidade de estabelecer alianças com outros movimentos sociais do campo e da cidade (construção do bloco histórico e geográfico) - especialmente porque a luta não se esgota na reforma agrária, mas se amplia para outras problemáticas, conforme foi descrito por Charles Trocate em sua entrevista que consta no capítulo 4, a respeito do quarto momento da territorialização do MST no sudeste paraense; b) pela proposta de uma educação emancipatória que se pauta na construção de uma contra-hegemonia; c) pela construção gradativa de uma espacialização da luta camponesa no Brasil que se articula com outros segmentos de luta internacional com o intuito de produzir um movimento camponês mundial a partir da Via Campesina - é nesse sentido que o movimento desenvolve a política de escala, explicitada no Capítulo $1-$, questionando as formas de propriedade da terra como relação à produtividade e criando um debate acerca da função social da terra (especificamente no Brasil).

Particularmente no sudeste paraense a disputa pela escola, em seu sentido amplo, advém das experiências e articulações que o MST desenvolve em outras escalas em que atua. Como indicado anteriormente, a escola caminha lado a lado com a luta pela terra, tendo em vista que ela apresenta dois componentes importantes, descritos a seguir.

$\mathrm{O}$ primeiro se refere a uma estratégia do movimento socioterritorial para que os acampados criem vínculos com a terra que lutam para conquistar, isto porque além de a escola ser uma das primeiras infraestruturas sociais disputadas internamente - para que o Estado não apenas a construa, mas a reconheça considerando as especificidades, como contratação de professores alinhados ao MST, oferta de transporte aos alunos que moram longe, disponibilização de material escolar alinhado aos princípios do MST, construção do espaço físico da escola no local indicado pelo movimento - a escola é pensada como mecanismo de socialização e de permanência dos familiares, pois garante a esses sujeitos um direito que outrora fora negado.

[...] organizamos logo e imediatamente, a construção imediatamente da escola. A escola é o alicerce de qualquer acampamento, se não tem escola não existe acampamento por muito tempo, isso é comprovado, que é a escola e que vem dar vida ali, tu vai ter a mulher, vai ter a criança, quando tu faz, se tu não tiver escola tu não tem criança, não tem mulher, aí fica o homem sozinho, de repente "não vou ali matar a saudade" e nunca mais volta. 
(Isabel Rodrigues Lopes Filha, assentada do PA 26 de Março e dirigente do MST, 52 anos, 30 set. 2016)

O segundo componente da escola é sua função de construção da organicidade, pois o setor de educação fica responsável por envolver toda a comunidade. As decisões e as lutas são coletivas, assim como se inicia um processo formativo dos sujeitos que tem por premissa o questionamento dos valores e conceitos dominantes, especialmente no que se refere à luta pela terra.

É importante frisar que as escolas organizadas pelo MST ou com algum grau de relação com o movimento buscam um ensino pautado nos princípios filosóficos e pedagógicos elencados acima. Para esse fim, ainda no período do acampamento, foram realizadas formações políticas e educacionais daqueles sem-terra que tinham algum nível de instrução, para que iniciassem as atividades de alfabetização dos demais e, ao mesmo tempo, continuassem se aperfeiçoando enquanto educadores.

Nesse sentido, foi criado o Programa Nacional de Educação na Reforma Agrária (PRONERA), destinado aos assentados, cuja origem está no I Encontro Nacional de Educadores e Educadoras da Reforma Agrária (Enera), ocorrido em 1997 em Brasília e promovido pelo MST em articulação com a Conferência Nacional dos Bispos do Brasil (CNBB), o Fundo das Nações Unidas para a Infância (United Nations Children's Fund Unicef), a Organização das Nações Unidas para a Educação, a Ciência e a Cultura (United Nations Educational, Scientific and Cultural Organization - Unesco) e a Universidade de Brasília (UnB).

Em outubro do mesmo ano, diversas universidades se reúnem em Brasília para discutir sua participação no processo educacional nos assentamentos. Inicialmente priorizou-se a questão do analfabetismo de jovens e adultos, mas sem descartar outras modalidades de ensino. Em novembro de 1997, no III Fórum do Conselho de Reitores das Universidades Brasileiras foi apresentada e aprovada uma proposta de educação do meio rural e, em abril de 1998, por meio da Portaria n. 10/1998, foi criado o PRONERA, vinculado ao Ministério de Política Fundiária. Em 2001 o programa foi incorporado ao INCRA, sendo aprovado na ocasião um novo Manual de Operações (TAVARES; BORGES, 2012).

No atual contexto, o PRONERA promove a alfabetização de jovens e adultos no ensino fundamental e médio, a capacitação e escolarização de educadores para o ensino fundamental nas áreas de reforma agrária, formação inicial e continuada de professores (ensino médio ou superior), ensino médio integrado ou não com o ensino profissional; formação de nível superior, pós-graduação lato sensu ou stricto sensu (BRASIL, 2016). 
De acordo com Andrade (2009), as primeiras experiências do PRONERA no Pará ocorreram entre os anos de 1998 e 2001, concentrando-se nas mesorregiões do nordeste paraense e sudeste do Pará e foram oferecidas pela Universidade Federal do Pará (UFPA), porém com pouca participação dos movimentos sociais, que ficaram responsáveis apenas pelo levantamento das demandas dos alunos e indicação de monitores. Essa participação dos movimentos se tornou mais efetiva a partir da mobilização desses sujeitos para terem uma ação maior nas decisões pedagógicas e na gestão dos cursos, especialmente em 2002, quando se realizou a primeira reunião nacional do PRONERA, na qual se constatou que não havia no Pará uma direção política-pedagógica comum nem grande envolvimento dos diversos sujeitos que compõem o programa. Diante desse diagnóstico, os movimentos sociais em conjunto com a UFPA redirecionaram o PRONERA para pensar uma Educação do Campo como um projeto de formação permanente, e não pontual e transitória. Assim, as parcerias se desenvolveram com uma maior participação dos movimentos sociais e com projetos educacionais voltados às questões regionais, logo, os projetos, a partir desse momento, só poderiam ser aprovados mediante participação das instituições e entidades parceiras, devidamente acompanhadas de uma carta de aceite dos movimentos sociais, uma declaração da universidade e um parecer do assegurador do INCRA. Desse modo, o PRONERA, mais do que um mero financiador ,se torna um meio de intensificar a parceria, da qual resultaram os cursos indicados no Quadro 8, a seguir. 
Quadro 8 - Cursos e projetos ofertados pelo PRONERA no estado do Pará, 2001-2011

\begin{tabular}{|c|c|c|c|}
\hline $\begin{array}{c}\text { Modalidades } \\
\text { de Ensino }\end{array}$ & Cursos & Instituição Responsável ${ }^{40}$ & Vigência \\
\hline Pós Graduação & Especialização em agricultura familiar camponesa e educação do campo (residência agrária). & UFPA / campus Marabá & 22/11/2005-10/07/2007 \\
\hline \multirow{5}{*}{ Graduação } & Graduação em pedagogia para educadores(as) do campo no sudeste do Pará & UFPA / campus Marabá & 28/12/2005-27/12/2011 \\
\hline & Licenciatura em letras em áreas de assentamentos da reforma agrária & UFPA / campus Marabá & 28/12/2005-27/12/2011 \\
\hline & Licenciatura plena em pedagogia para educadores(as) da reforma agrária - pedagogia das águas & UFPA / campus Abaetetuba & 09/01/2006-08/01/2010 \\
\hline & Agronomia: formação de recursos humanos em ciências agrárias & UFPA / campus Marabá & $12 / 12 / 2003-11 / 06 / 2009$ \\
\hline & Pedagogia para assentados de reforma agrária & UFPA / campus Belém & 27/12/2001-18/07/2005 \\
\hline \multirow{6}{*}{$\begin{array}{c}\text { Formação } \\
\text { Profissional e } / \\
\text { ou de nivel } \\
\text { médio }\end{array}$} & Ensino médio e técnico-profissional para jovens agricultores(as) assentados no sul e sudeste do Pará - $2^{\mathrm{a}}$ turma & UFPA / campus Marabá & 28/12/2005-27/06/2009 \\
\hline & Curso técnico de formação integrada em sujeito comunitário de saúde (educação profissional) & UFPA /campus Altamira & 09/01/2006-08/07/2011 \\
\hline & Ensino médio com formação técnica profissionalizante para trabalhadores rurais no nordeste do Pará & UFPA / campus Abaetetuba & 09/01/2006-08/01/2009 \\
\hline & Técnico profissionalizante em agropecuária com ênfase em desenvolvimento sustentável & UFPA /campus Altamira & $18 / 02 / 2005-22 / 04 / 2008$ \\
\hline & Nível médio e técnico profissional & UFPA / campus Marabá & 28/11/2003-01/02/2007 \\
\hline & Médio e técnico em agropecuária com ênfase em & IFPA / campus Castanhal & 26/12/2005-30/09/2010 \\
\hline \multirow{10}{*}{$\begin{array}{c}\text { Alfabetização } \\
\text { de Jovens } e \\
\text { Adultos }\end{array}$} & Educação cidadã: alfabetização de jovens e adultos & UFPA /campus Castanhal & 26/12/2005-27/04/2007 \\
\hline & Escolarização cidadã & CSE / UFPA & 09/01/2006-08/02/2009 \\
\hline & $\begin{array}{l}\text { Alfabetização cidadã na Transamazônica (escolarização de séries iniciais para } 1.788 \text { jovens e adultos } \\
\text { trabalhadores rurais) }\end{array}$ & UFPA / campus Altamira & 29/12/2004-31/03/2006 \\
\hline & Educação cidadã na transamazônica II & UFPA / campus Alt & $17 / 02 / 2005-30 / 08 / 2007$ \\
\hline & Alfabetização cidadã no nordeste paraense & UFPA / campus Bragança & 29/12/2004-31/03/2006 \\
\hline & Alfabetização de jovens e adultos na região oeste d & UFPA / campus Santarém & $29 / 12 / 2004-22 / 12 / 2006$ \\
\hline & Educação cidadã na Transamazônica: alfabetização cidadã (formação de 117 turmas) & UFPA / campi Belém e Altamira & 24/12/2003-31/07/2005 \\
\hline & $\begin{array}{c}\text { Escolarização de séries iniciais de jovens e adultos trabalhadores rurais em PAs do INCRA na } \\
\text { Transamazônica (87 turmas) }\end{array}$ & UFPA / campi Belém e Altamira & $31 / 12 / 2003-31 / 07 / 2005$ \\
\hline & Educação para jovens e adultos (EJA) no ensino fundamental no Pará (700 educandos) & UFPA / campus Marabá & $16 / 12 / 2003-16 / 02 / 2006$ \\
\hline & Alfabetização de jovens e adultos trabalhadores rurais no oeste do Pará (formação de 115 turmas) & UFPA / campi Belém e Altamira & $01 / 11 / 2002-08 / 05 / 2004$ \\
\hline \multirow{3}{*}{ Magistério } & Formação continuada e escolaridade de professores(as) em nível médio (magistério) em Tucuruí & NPI; UFPA / campus Cametá & 28/12/2005-29/06/2009 \\
\hline & Formação continuada e escolaridade de professores(as) em nível médio (magistério) em Itaituba & NPI; CE / UFPA & 09/01/2006-08/04/2011 \\
\hline & Formação continuada e escolaridade de professores(as) em nível médio (magistério) em Altamira & NPI; UFPA / campus Altamira & $17 / 02 / 2005-31 / 05 / 2008$ \\
\hline
\end{tabular}

Fonte: Fundação de Amparo e Desenvolvimento da Pesquisa - Fadesp (2013) apud IPEA, 2016, p. 10. Adaptação: Rogério Rego Miranda.

${ }^{40}$ As siglas na tabela significam: IFPA: Instituto Federal do Pará; CSE: Centro Socioeconômico; NPI: Núcleo Pedagógico Integrado, atual Escola de Aplicação da UFPA, CE: Centro de Educação. 
Como podemos observar, diversos cursos foram conseguidos por meio do PRONERA no sudeste paraense, especificamente desenvolveram-se cursos de alfabetização de jovens e adultos, formação profissionalizante e/ou do ensino médio, graduação em Agronomia, Letras e Pedagogia e pós-graduação lato sensu em Agricultura Familiar Camponesa e Educação do Campo (Residência Agrária). Salientamos que no ano de 2016 foi aprovado o curso de bacharelado em Direito, denominado Direito da Terra, junto a UNIFESSPA, campus de Marabá.

É importante deixar claro que toda essa luta pela democratização da educação no/do campo no Brasil, e, particularmente no sudeste paraense, não é exclusiva do MST, ao contrário, o movimento se articula com outros para a construção dessa pauta de reinvindicação de direito comum.

Na realidade pesquisada, no ano de 1997, já existia um projeto local de educação rural em construção com a parceria dos movimentos sociais do campo, com destaque para o MST e a FETAGRI, também para a UFPA/Campus de Marabá. Essa iniciativa foi realizada por um grupo de trabalho em alfabetização de jovens e adultos nos assentamentos e acampamentos da região, denominado de GRUTA, que se readequou para dar início ao PRONERA/Sudeste do Pará (ANJOS, 2009).

É a partir dessas ações articuladas nas escalas nacional, regional e sub-regional que a proposta de uma educação do campo vai ganhando maior expressão e, no caso das escolas em que o MST atua, isso só se tornou possível em virtude do processo de formação de seus educadores pelo PRONERA ou outras vias de formação. Desta feita, a luta pela educação, para a construção do projeto territorial contra-hegemônico, é tão importante quanto a luta pela terra:

[...] não deixar de considerar com o mesmo nível de importância que tem a ocupação da terra, de ter a escola, de ter a formação dos educadores, mas também de ter, e aí o conjunto de formação que a gente foi fazendo depois do agrônomo, do profissional da arte, do profissional disso e daquilo, do conjunto de pessoas para construir, então ir para o enfrentamento no território para além da ocupação da terra. Agora outra coisa é isso, a gente nunca deixou de fazer ocupação de terras, então esse questionamento, essa denúncia e esse processo de resistência para conquista da terra aqui na região ele também não deixar de lutar é a parte que eu acho da história, porque muitos lutaram e depois deixaram de lutar, e a parte da história que vai compor então essa constituição do MST como um fato fundamental da gente ter feito as lutas históricas necessárias, que eu acho que o momento histórico pedia e a gente tentou a se arriscar fazê-los, né! Então, assim, o MST no Pará ele luta com o latifúndio atrasado, a fazendeirada, a pistolagem, depois o MST passa já para esse nível mais de latifúndio mais moderno, que é quando você chega nos casos do... que o mesmo grupo, quando os mesmos grupos, os Mutrans da vida ali na [Fazenda] Cedro e lá no [assentamento] Lourival 
que começou com latifúndio de explorador atrasado, com pistoleiro, depois ele se moderniza e depois a gente está agora... mas era uma modernização ainda do ponto de vista de melhoramento de produção, de exploração da fazenda que eles foram melhorando para ter nome internacional e depois eles dão lugar já para esse outro latifúndio já mais moderno ainda que é o do agronegócio que já dado a empresa da terra, não mais o fulano de tal que se modernizou, mas uma empresa, que se constituiu dos consórcios para matar, então, assim, o MST passa por esses ciclos aí de forma, as três formas mais presentes, e agora gente nem sabe mais qual que vai... a próxima que está chegando aí para a gente enfrentar, e as três o MST enfrentou, todas com muitas perdas, pela eliminação física de suas lideranças, eu acho que nas três formas a gente teve perdas muito grandes, assim como os outros movimentos também tiveram, não foi só a gente, mas a gente conseguiu avançar do ponto de vista de dizer que a gente não ia desistir de lutar, e para isso a gente ia se preparando, e o se preparar meio assim... não desistir da luta era exatamente fazer um conjunto de atividades que compõem a nossa organização pra andar, é ocupar a terra, fazer escola, é fazer formação, é fazer parceria com universidade, porque nós saímos, inicialmente eu falei, que antes nós éramos poucas pessoas com curso superior, depois com o PRONERA e as parcerias, por exemplo, aqui em Marabá que a gente tem desde 1999. Com essas parcerias a gente também conseguiu avançar, e hoje praticamente todas as nossas escolas praticamente $100 \%$, as escolas mais antigas das áreas maiores, até as merendeiras tem curso superior, eu estou falando até porque era uma... não que elas não tenham direito, porque não é obrigatório, o povo diz assim, ah, os professores chega um tempo que era obrigatório ter curso superior, e, mesmo fora da obrigatoriedade, a merendeira, o vigia, o zelador, a cozinheira, quem limpa o chão já foram ingressando nos cursos superiores, então a licenciatura mesmo agora, o pessoal que trabalha nas equipes de cozinha, em vigia de escola, compreender a educação como um direito mesmo e o processo de escolarização como um direito, então que as pessoas tem direito de escolher o que quer ser, o profissional que quer ser, e estudar até onde quiser, independentemente, ah, eu vou ser merendeira, ou então eu vou deixar de ser merendeira porque me formei, então, assim, por que a merendeira não pode ter curso superior e continuar sendo merendeira se ela quiser, ou então viceversa, ou dizer, eu estou aqui, mas eu quero... eu fui merendeira até hoje, mas a partir de agora eu quero ser médica, ou quero ser professora, então eu acho que essa possibilidade e aí essa realidade hoje de escolarização no movimento ainda tem muito, não é universalizado por uma questão de instrucional [instrução] mesmo, de política pública, no geral das áreas, mas as nossas áreas as que são mais próximas na cidade no geral, a gente conseguiu avançar com muita luta, briga, chute no pé, ocupação, mas a gente deu uma boa avançada no processo de escolarização da nossa militância, das famílias que moram nas áreas de acampamento e assentamento, então a gente... tem territórios que a gente não declarou livre do analfabetismo porque também essas áreas passou a ser compostas por outros sujeitos, que não mais só os assentados, mas por exemplo, quando você pega o Assentamento Palmares, Mártires de Abril em Belém, das pessoas que foram assentadas, os primeiros assentados, as quinhentos e dezessete famílias, dessas famílias a gente pode considerar zero de analfabetismo, então as primeiras áreas nossas, os programas, o trabalho que a gente fez, a gente botou foi para zerar mesmo, compreendendo a importância do conhecimento para luta e para esse ser humano, para emancipação humana mesmo, a gente não acredita que ele se emancipa se a gente não fizer um enfrentamento do 
ponto de vista do conhecimento. (Maria Raimunda César de Sousa, dirigente do MST e professora, 42 anos, 12 jul. 2016).

A fala acima é muito incisiva quando retoma os principais sujeitos com os quais o MST disputa o território. Estes remontam momentos históricos distintos que coexistem na fronteira amazônica, isto é, o latifundiário "dono dos castanhais", o latifundiário que vivia do extrativismo e se moderniza a partir da produção agropecuária e a empresa que atua no agronegócio e/ou na mineração. Para fazer frente a esses sujeitos hegemônicos com o intuito de lutar pela terra e permanecer nela é necessário construir um projeto emancipatório que perpassa pelo "enfrentamento do ponto de vista do conhecimento", cujo histórico no sudeste paraense é relatado pela dirigente do MST:

[...] o MST já vai nascendo e se construindo nessa nova forma organizativa, já compreendendo que era possível, que era preciso para além da luta pela terra ter esse processo de resistência, incorporar outras lutas, e aí a educação entra como umas dessas necessidades. No MST incialmente foi o trabalho com jovens e adultos, que era exatamente a questão da alfabetização, assim incomodava, o Brasil tinha um alto índice de analfabetismo e incomodava muito o movimento o analfabetismo nas áreas de acampamento e assentamento, então começaram os primeiros programas, na realidade é que primeiro foi uma parceria que teve naquela época, aí não tinha, as Prefeituras não trabalhavam ainda como prática, como política pública a questão da educação em jovens e adultos de forma a oferta regular, então ele ofertava mais por projetos, programas, esses convênios que tinham, e o MST começa então com a educação de jovens e adultos aqui na região, depois que a gente vai então compreendendo a necessidade de que para você não ter esse passivo depois na sequência que a gente tinha então que se adentrar na construção do ensino fundamental que naquela época não era fundamental, era de primeiro grau, que era o famoso primeira à quarta série, quinta a oitava, nas áreas de acampamentos e de assentamentos, só depois, um pouquinho mais a diante e que a gente compreende, começa a buscar as turmas de ensino médio, então inicialmente mesmo que a gente quisesse ter turma de ensino médio nas áreas não tinha, não tinha gente com o primeiro grau, então essa primeira turma de PRONERA que a gente teve para alfabetização ela era uma turma de alfabetização de jovens e adultos. Aí nós tínhamos vinte e oito educadores, se não me falha a memória, esses vinte e oito educadores todos tinham só até a quarta série, aí do mesmo programa, mesmo projeto a gente tinha que alfabetizar, eles alfabetizavam e tinha o período do ano intervalar que eles vinham para cá para fazer de quinta a oitava série, então eles fizeram o fundamental nessa parceria, e aí a parceria com a universidade. A universidade tinha que fazer as duas formações, foi a escolarização deles de quinta, o currículo aqui de quinta a oitava e mais a formação de prática pedagógica porque eles ensinavam a ler e escrever jovens e adultos, então essa era uma realidade que a gente tinha, tinha muito no campo, tinha de primeira à quarta série, e aí esmagadoramente a gente tinha a questão do analfabetismo, então a gente começou se desafiando nessa frente da alfabetização de jovens e adultos, que ele acontecia mais por convênios, foi o primeiro, eu acho que o primeiro não sei se foi... O primeiro foi com a UNESCO [...] esse primeiro momento, esse convênio de alfabetização, depois passou a ser PRONERA, aí depois do PRONERA a gente participou de outros, outra parcerias para alfabetização, e logo quando 
a gente começou no front aí para briga, para garantir o ensino fundamental, aí já foi com as Prefeituras, e essa briga foi grandiosa com as Prefeituras, porque quando a gente dizia que a gente queria uma escola no acampamento, no assentamento aí eles já achavam que não, que tinha que levar todo o mundo para a cidade, não reconhecia os sujeitos do campo, que na época ainda chamada escola rural, depois quando... Beleza, então vai e abre a turma, se tiver demanda garante, aí gente brigava porque a gente queria debater a questão dos professores, as Prefeituras não aceitavam, e depois a gente queria debater o currículo, as Prefeituras também não aceitaram, então cada uma dessas questões, elas eram um pé de briga, então tu tinha que ocupar a Prefeitura, tu tinha que brigar, ou eles diziam... Nós tivemos um caso na Palmares II, um período que eles tiraram todos os professores que era do movimento, aí o argumento deles e que a gente não tinha, que a turma nossa que estava atuando não tinha o ensino médio, então só podia trabalhar na escola quem tinha ensino médio. De fato a nossa turma não tinha, porque inicialmente a gente construía essas turmas com o trabalho voluntário de educadores, todo mundo ia, a gente levantava uma demanda, fazia um trabalho, levantava toda demanda de quantas crianças tinham no acampamento, a faixa etária, e qual a série que elas estavam, aí depois a gente fazia um outro trabalho para ver quais as pessoas que tinham maior índice de escolaridade e se tinha disponibilidade em educar os outros, então era assim que a gente vinha construindo, aí depois a gente levava a demanda para as Prefeituras, e aí nós tivemos um período que eles demitiram, na Palmares demitiu todo mundo, todos os educadores vinculados ao movimento foram demitidos, se não me falha a memória parece que ficou só a Francisca, para não ser injusta com a Prefeitura ficou uma, aí o próximo concurso que teve na sequência, o primeiro concurso que teve depois dessa demissão, a gente já tinha feito então um processo de formação de uma outra turma boa, e todo mundo fez o concurso, e a maioria passou, então voltou a ocupar então as salas de aula na escola, mas teve um tempo que o limpa foi geral, aí claro teve ocupação de Prefeitura também, uns enfrentamentos necessários com a rede municipal de ensino, e esse enfrentamento ele se dá com todas as comunidades, sempre, a primeira reunião com as Prefeituras, eles perguntam por que vocês querem uma escola em um acampamento? Era sempre essa pergunta, por que tem que ser lá? Por que vocês querem que tem que ser alguém de vocês? Por que vocês querem... Ah, vocês querem ensinar revolução, vocês querem ensinar... eles não entendiam que na situação e como era vista a luta pela terra na região, como o movimento era criminalizado, a violência, várias formas de violência, aqueles sujeitos tinham o direito de também se educar entre os seus, e garantir uma formação, e que também as pessoas que moravam no campo que já faziam aquilo, porque viam aquela necessidade, sentiam o desejo, por que elas não podiam ficar alfabetizando, por que elas não podiam escolarizar, por que elas não podiam ensinar de primeira à quarta série, de quinta a oitava, o ensino médio e assim sucessivamente. A gente teve que ir avançando, avançava na luta, no enfrentamento lá na Prefeitura, mas também a gente fazia autocrítica, aí foram também as legislações nacionais foram saindo, aí disse, bom, nós temos que também nos preocupar com isso, a gente não pode só querer uma escola dentro do assentamento e ser nossa, o nosso pessoal está lá, mas a gente não atingir um principal objetivo de uma escola, que é apropriação pelos indivíduos ali de um conhecimento, um conhecimento a serviço da sociedade, mas também esse conhecimento universal que foi construído da filosofia, das artes, das ciências e assim sucessivamente, a gente debatia isso, a escola tem que aprender ler e escrever o mínimo, ler, escrever, e ler e escrever o que e como, você faz a sua parte, mas ela precisa 
cumprir parte desse currículo que se relacionava, então a gente passou, então como que a gente faz isso, aí tem o I Encontro Nacional de Educadores da Reforma Agrária, que faz o diagnóstico dessa realidade da educação nas áreas de acampamentos e assentamentos do MST, aí quando foi feito o levantamento era muitas pessoas analfabetas, muitas áreas sem escola, as que tinham não tinham o reconhecimento pelas Prefeituras, pela Secretaria de Educação, aí tinha o casos de demissão que era geral, então pessoal o que a gente pode fazer, aí surge então os primeiros convênios para essa turma de alfabetização, logo, também com a capacitação de professores e vinculado a um processo de escolarização, e a gente no caso aqui tinha fundamental, depois fomos para o magistério, mas outros estados, aí teve uma primeira turma nacional de pedagogia que foi exatamente para o grupo que debatia essa realidade da educação nas áreas de reforma agrária, e via que era preciso formar em cada estado um grupo de pessoas para tocar atividade no setor de educação, aqui do Pará foram três companheiras [...] todo estado tinha de duas a três pessoas para fazer esse curso de pedagogia [...] e que ela tinha essa tarefa de o pessoal se formar em pedagogia para ajudar a construir os processos de escolarização das pessoas e da construção do setor de educação, dessas parcerias nos estados para a gente, dá conta de avançar, porque a relação não era nem um pouco tranquila com as Prefeituras, e logo eles iam pelo lado de que a gente não tinha profissional capacitado para aquilo, que não podia, tudo não podia, tudo não podia, em outros casos quando a gente dizia que queria uma escola, e quando a gente dizia como queria a escola era como se a gente tivesse cometendo um crime, e eles perguntavam, mas o que vocês querem então é uma escola particular, não é! Então a gente ouvia muito isso das Prefeituras, não, eu estou entendendo, vocês querem uma escola conveniada, não é, e nós não, a gente quer escola pública com oferta do ensino, a oferta disso, toda legalizada pela Secretaria Municipal de Educação, que a oferta é isso, nós somos sujeitos desse processo, a gente quer dizer como que a gente deve ser educado, e que a gente quer ser educado, e eles não entendiam isso. Ah tá! Então vocês querem ser escola particular ou é convênio? Uma coisa, nós não, vocês não estão entendendo isso, é escola pública com participação do povo, o povo dizendo que educação quer, é isso que a gente está dizendo, que educação nós queremos, nós estamos dizendo para o poder público isso, nós queremos essa educação, mas eles não entendiam, achava que essa, tipo assim, vocês não estão entendendo nós queremos que o Estado oferte a educação, mas a gente quer dizer que tipo de educação a gente quer, e que a gente precisa, que currículo nos interessa, é isso, foi muito difícil o embate, mas a gente conseguiu, e hoje alguns casos nós tivemos que ir para o Ministério Público, para poder manter escola em acampamento, para a Prefeitura poder pagar professor em assentamento e acampamento, era preciso o Ministério Público autorizar, e assim como teve escolas que foi fechada pelo Ministério Público, aí a gente ocupava o Ministério Público, o Ministério Público abria a escola de novo, e assim sucessivamente, era uma disputa permanente, e era uma disputa permanente até hoje. (Maria Raimunda César de Sousa, dirigente do MST e professora, 42 anos, 12 jul. 2016)

Esse longo relato é importante para explicitar como o ensino, e consequentemente as escolas, são disputados na região, além das estratégias utilizadas pelo movimento para conseguir alcançar algumas conquistas nesse âmbito. Especialmente porque a educação de jovens e adultos deixou de ser uma política pontual e transitória das prefeituras e se torna um 
projeto permanente, notadamente com parcerias existentes com as universidades, e pela conquista das escolas tanto em assentamentos quanto em acampamentos.

Desta feita, a maioria das escolas construídas no período do acampamento são incorporadas ao assentamento. Porém, nesse momento metamorfoseiam-se, pois são disputadas internamente e externamente. No primeiro caso, os novos sujeitos que adentram o PA começam a questionar o ensino e os princípios norteadores dele, pois preferem uma desvinculação com o movimento socioterritorial. No segundo caso, existem iniciativas de imposição por parte dos governos municipais e/ou estaduais do currículo formal como o único conteúdo a ser ministrado (e muitas vezes distante da realidade dos assentamentos).

Esse processo é mais bem evidenciado no caso dos assentamentos $1^{\circ}$ de Março, Palmares II e 17 de Abril.

No primeiro PA, $1^{\circ}$ de Março, em decorrência da entrada de novos sujeitos econômicos se desenvolveu uma divergência entre eles e o MST em torno da escola. De acordo com o relato dos assentados, por um lado, esses novos sujeitos foram aliciados pela prefeitura de São João do Araguaia, que igualmente não queria mais vínculos entre o colégio e os movimentos sociais. O MST, por outro, discutia a necessidade de permanência dos seus princípios educacionais no espaço escolar. Nesse contexto, aquelas pessoas que se aproximavam desta luta empreendida pelo MST passaram a ser hostilizadas pelos representantes do poder público municipal, fato que se aprofundou no início dos anos 2000, quando um incêndio supostamente criminoso levou a Prefeitura a reconstruir o colégio de madeira, porém neste local os alunos cuja família tinha afinidade com o MST passaram a sofrer preconceitos. Concorrendo para que o MST em conjunto com os pais dos discentes se reunissem para construir outra escola, denominada de Madalena Freire, para que os filhos dos "sem-terra" estudassem. Para este fim, os pais e o movimento socioterritorial arrecadaram doações - como madeira, alimentos, material escolar etc. - e os professores, serventes, dentre outros, trabalharam voluntariamente em suas respectivas atividades na escola, constituindo assim no PA a "escola do MST" e a "escola da Prefeitura".

Essa situação perdurou até a construção em alvenaria da atual escola Educar Para Crescer - salientando que ela teve sua origem no acampamento e agora passa a ser objeto de disputa interna - que, por decisão judicial, teve de atender a todas as crianças, o que só se deu após os professores do MST lutarem pelo reconhecimento dos discentes que estudavam na escola Madalena Freire, inclusive por meio da ocupação da Secretaria de Educação do Estado do Pará (SEDUC-PA). Desse momento em diante, a Escola Madalena Freire tornou-se de ensino infantil e a Escola Educar para Crescer lecionava para os ensinos fundamental e médio, 
atendendo sem distinção a todos os alunos do PA, muito embora no cotidiano escolar ainda haja conflitos com relação ao ensino, conforme relata uma das professoras:

[...] quando passa a esse momento de assentamento as situações se voltam mais para o contexto do livro, o que as secretarias impõem, as próprias famílias elas têm resistência em aceitar um conteúdo que está voltado para a realidade do aluno, teve uma professora aqui que ela... [...] ela tentou trabalhar, tentou fazer esse link entre a prática e a teoria, deslocar os alunos, ir para um sítio, uma roça, olhar, fazer essa pesquisa, ver o que a família produz, houve uma reunião na escola, os pais convocaram uma reunião na escola somente para dizer que o filho deles já sabia o que era roça e não precisava dizer de novo o que era roça para o filho deles não, porque eles já moravam na roça e ensinar era coisa que o menino aprendesse, chegasse lá na cidade e soubesse sobressair, então as próprias famílias por si só já vão criando uma certa resistência. Eu acho assim, as famílias têm que ser alfabetizadas nesse sentido porque enquanto os professores do ensino médio, por exemplo [...] uma professora do ensino médio veio dizer, assim, que a realidade desses assentamentos era sempre a mesma, as famílias numa situação de miséria, tudo vivendo numa condição medíocre, porque eles mesmos queriam assim, porque quando saiu projetos iam comprar era moto, eram sim, então era, eles que queriam permanecer naquela condição, aí, assim, é você colocar seu filho numa escola e pensar que a escola vai ensinar seu filho a crescer, a desenvolver num mundo que não existe, porque se tu é camponês, teu filho tem esse enraizamento, mora na roça, então teu filho tem que aprender não desconhecendo o que tem lá fora, mas compreender que é dali do campo é ali que ele vive, é ali que ele garante a sua sobrevivência, é ali que ele tem que ir melhorando seus conhecimentos para continuar permanecendo na terra e dali criar novas formas, novas estratégias de viver cultivando a terra, mas de uma forma menos sacrificada, menos penosa. É para isso que o estudo serve, só que os próprio professores vem com essa concepção de dizer assim, tu tem que sair daqui e ir para a cidade, o que está fazendo no campo, o campo vai te ajudar em que, vai te formar em que, tu quer continuar vivendo essa vida sofrida como seus pais, os próprios pais dizem assim, meu filho, estuda, para tu não repetir o sofrimento que eu vivo aqui, os próprios pais falam isso, então precisamos tanto de professores com essa mente aberta e aí esses cursos de educação do campo [...] é um presente que os trabalhadores receberam [...] porque é uma abertura onde no futuro nós possamos ter campo, com pessoas do campo, pessoas que compreendam o campo como território de camponês, porque até então continua no território aonde as pessoas que estão lá são pessoas deslocadas de um mundo para outro mundo que não é dele que ele não se reconhece, ele não se identifica e vê aquele espaço como espaço de negócios, vou passar um tempo aqui até onde der, passo em frente, vou para a cidade porque a cidade é lá que eu tenho que viver, é lá que é o progresso que está muito distante de ser um progresso que vem incluí-lo, mas ele não vê dessas forma, eu acho que esse curso de educação do campo vai melhorar a qualidade de vida daqui há mais um tempo, porque não é só a qualificação eu acho que ainda não é suficiente, mas os professores tem que se olhar e se ver com aquele compromisso de mudar a realidade. (Cícera Justino Ferreira Pinto, assentada e professora no PA $1^{\circ}$ de Março, 39 anos, 12 jul. 2016)

No Assentamento Palmares II, a escola Crescendo na Prática principiou em 1994 a partir de um acampamento em frente ao INCRA e foi formada a partir de voluntários, que 
posteriormente passaram a ser contratados como professores da instituição de ensino, após seu reconhecimento legal no ano de 1996. A partir de 1998, devido a um concurso público, muitos desses educadores "que vinham desde o início com essa proposta [...] do movimento, de uma educação mais vinculada à luta" ${ }^{41}$ perderam o cargo para os novos professores concursados, havendo uma ruptura com o projeto de ensino que era levado a cabo. Com o intuito de "reocupar a escola", esses educadores retornam para o processo formativo voltado para o magistério e, posteriormente, em graduações na universidade. Com essa formação, conseguem voltar à escola gradativamente por meio de contratos ou por novos concursos públicos. Nesse ínterim, o movimento consegue, em conjunto com os educadores que permaneceram na instituição, manter sua gestão democrática e coletiva, com ampla participação da comunidade, que inclusive elege a direção, ainda que em diversos momentos tenha havido a intervenção da Secretaria de Educação da Prefeitura de Parauapebas, como ocorreu recentemente em janeiro de 2017, conforme noticiou o jornal Carajás, quando os alunos ocuparam o prédio da escola e interditaram estradas para protestar contra a nomeação direta de novos diretores sem que se tenha realizado a eleição, a qual ocorre a cada três anos (ver Foto 30).

Como forma de contrariar a decisão, a comunidade também realizou um plebiscito popular por eleições diretas para a direção escolar no PA Palmares II, cujo resultado indicou que, dentre os 1.029 votantes, 966 assinalaram "sim” para a proposta (ver Figura 8).

\footnotetext{
${ }^{41}$ Clívia Regina da Silva, professora e diretora do PA Palmares II, 39 anos, 20 abr. 2015.
} 
Foto 30 - Ocupação da EMEFM “Crescendo na Prática” e obstrução da estrada, 2017

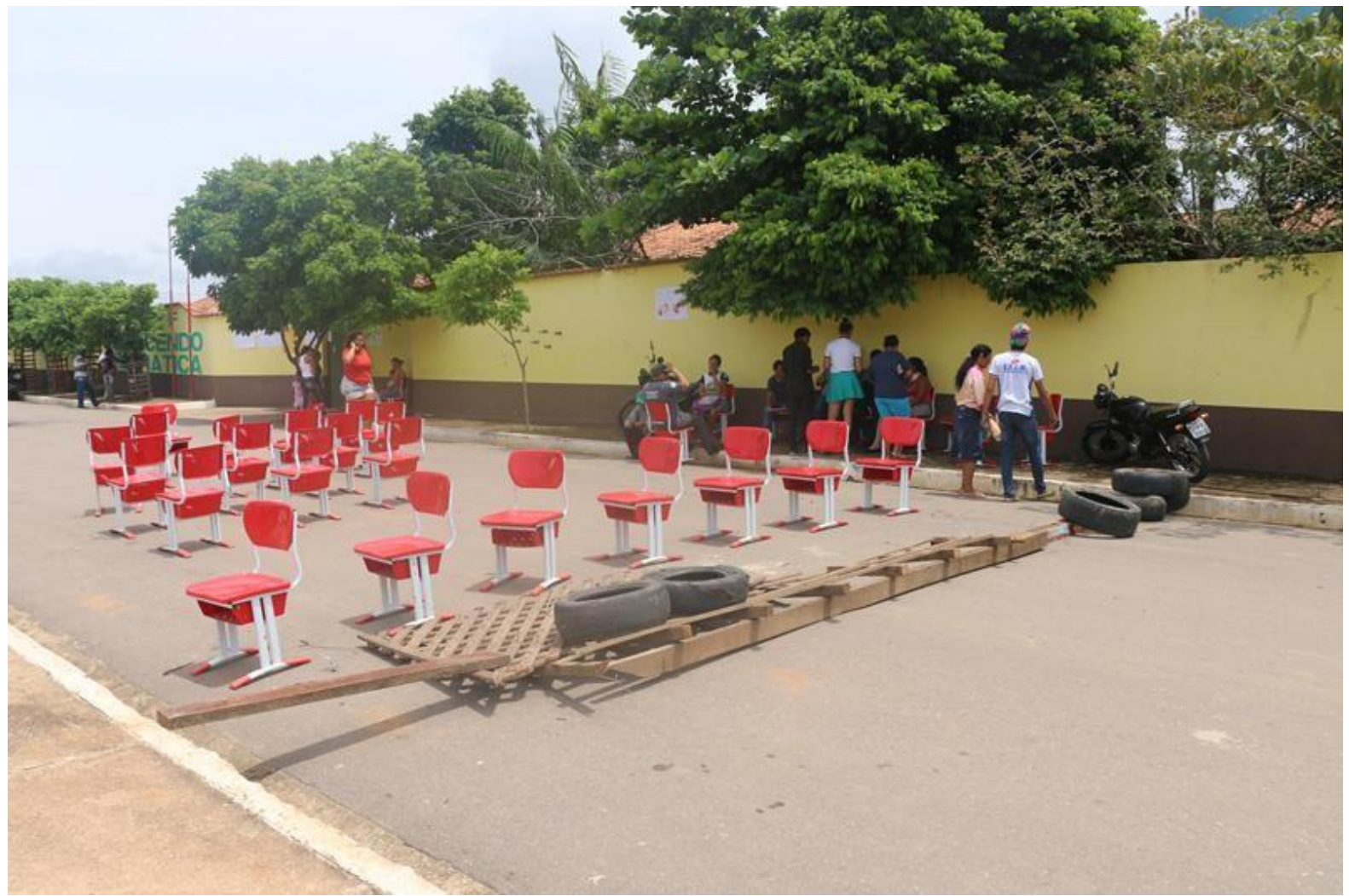

Fonte: Jornal Carajás, 23 jan. 2017, s/n.

Essa disputa interna visa reforçar a autonomia da escola para torná-la partícipe da comunidade e não alinhada às ações governamentais, almejando construir permanentemente uma relação entre o movimento e o assentamento, em virtude da entrada de outros sujeitos que não possuam vínculos com a história do assentamento - em outras palavras,

[...] tentar fazer com que as pessoas que não conhecem o movimento, através das nossas ações, um pouco apresentar para eles o que é o movimento, sem perder de vista essa questão do papel da escola que é ensinar a ler e escrever, sem perder esse foco também, mas pensando em uma educação em que a luta esteja presente, tanto é que nas atividades do movimento nós sempre participamos, Encontro dos sem-terrinha, Jornada da Juventude, Encontro de Educadores, então a gente sempre está participando, direta ou indiretamente. Então às vezes não dá para ir todo mundo, mas o bairro vem representando a escola, reunião da associação, tem um representante da escola lá para debater também e para pensar quais os rumos que a associação tem que tomar, então na última eleição, por exemplo, eu disse "nós enquanto escola, setor de educação contribuindo, que se a gente não se une nesse momento para tentar ir meio que apontando alguns caminhos nós vamos ser engolidos pelas empresas que já estão ali”. (Clívia Regina da Silva, professora e diretora do PA Palmares II, 39 anos, 20 abr. 2015) 
Figura 8 - Plebiscito por eleições diretas para direção escolar em Palmares II, 2017

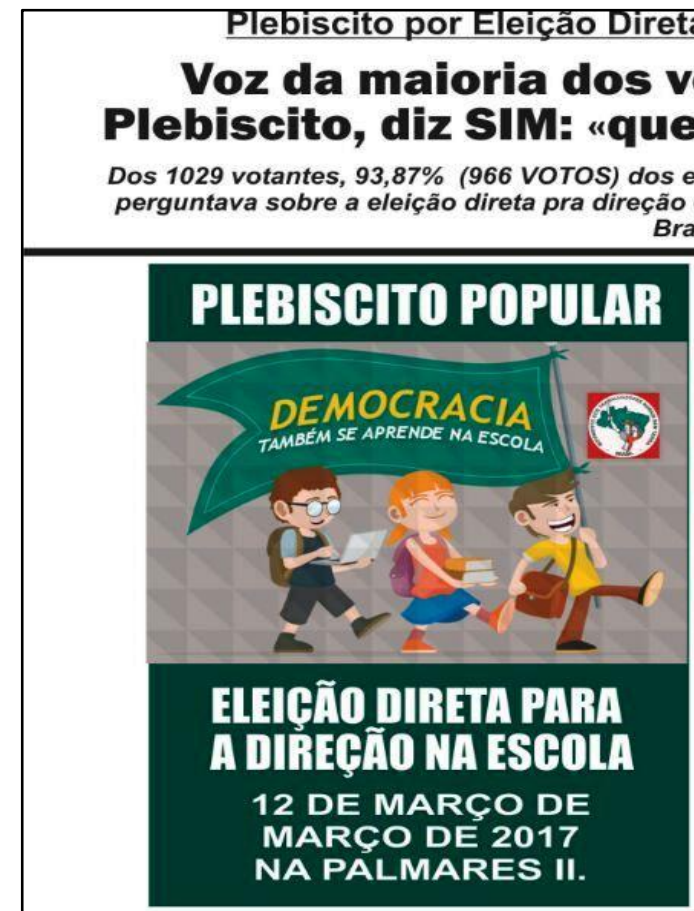

A consulta popular realizada no dia 12 de março (domingo) e estendida até o dia 13 (segunda) pela Comissão Eleitoral do Plebiscito Popular para Eleição Diretas para Direção Escolar, teve seu resulta anunciado na noite de segunda, motivado pelo pedido de vários cidadãos que por motivos diversos não puderam acessar os locais de votação.

Urnas itinerantes e fixas ainda permaneceram a disposição da comunidade para receber votos sobre o Plebiscito. O número de participantes (votantes) surpreendeu os organizadores que acreditavam numa baixa participação haja visto que o plebiscito popular não é obrigatório, ou seja é voluntario. Comparado com as eleições oficiais, geralmente marcadas por campanhas milionárias, compra de voto, pagamento de boca de urna e troca de votos por favores ou algum tipo de retorno material, a votação foi um sucesso.

Divididas por urnas espalhadas no núcleo urbano de Palmares (2), que ficaram a disposição na escola crescendo na prática, feira livre, regional das três voltas, na região do limão (no lala) urnas itinerantes circularam na comunidade. Estradas cortadas, ponte quebradas e as péssimas condições das estradas, criaram muitas dificuldades de acesso no domingo,12, por isso o pedido para que a votação se estendesse até o dia 13.

\section{Os resultados.}

Dos 1029 votantes, 93,87\% (966 VOTOS) dos eleitores votaram pelo SIM, que respondia ao quesito que perguntava sobre a eleição direta pra direção escolar. Trinta oito votos $(3,69)$ votaram NÃO, e 25 foram Brancos e Nulos.

O Plebiscito, como forma de consulta popular, é um modo de luta da sociedade civil para expressar sua opinião quando a autoridade não Ihes proporciona canais para tanto. Embora seja um instrumento que pode ser convocado pela Câmara de Vereadores, por exemplo, para ouvir a opinião da sociedade sobre vários temas importantes entre elas sobre a forma de eleger a gestão das escolas públicas.

Tanto o Conselho Municipal de Educação de Parauapebas, como o Sindicato dos Trabalhadores em Educação Pública do Pará, Sintepp, reivindicam a adoção da Lei para que o municipio possa ter todas suas escolas da rede pública participando de métodos mais democráticos de gestão nas escolas, incluindo a Eleição Direta.

O resultado do plebiscito popular em Palmares, deve ser encaminhado, junto com outros documentos, para o Ministério Público do Estado, a Câmara de Vereadores do Município, a Secretário de Educação do Município, ao chefe do Executivo Municipal, a Ordem dos Advogados do Brasil, e aos órgãos de defesa dos Direitos Humanos e em defesa da democracia, dentro e fora do Brasil.

Direção ilegítima

Do ponto de vista interno na comunidade de Palmares II, a vitória do SIM torna do ponto de vista da comunidade a atual gestão da Escola Crescendo na Prática, ilegítima, o que já vinha sendo demonstrado pela indignação de pais, alunos e educadores, com a forma arbitrária e autoritária de como se deu a intervenção realizada, de acordo com comentários vários, a suposto mando de uma vereadora e seus cabos eleitorais, com a chancela do Chefe do Executivo e do Secretário de Agricultura .

Os coordenadores do Plebiscito afirmam que novas batalhas virão da luta por democracia e participação popular na comunidade e no municipio...

Fonte: Aprocpar, 2017.

Paralelamente, existe uma disputa com a proposta de ensino em desenvolvimento pela empresa Vale, que realiza parceiras com as instituições governamentais municipais e estaduais por meio de sua fundação. Essa articulação é chamada pela empresa de Parceria Social Público-Privada (PSPP), conceito que remete a uma noção de investimento social pactuada entre sociedade civil, governo e empresas para o desenvolvimento de "projetos sociais nos territórios que envolvem a articulação de pactos de ação conjunta não apenas entre parceiros locais [...], mas também entre parceiros externos" (FUNDAÇÃO VALE, 2015, p. 
9). Dentre os programas educacionais se destacam: Programa Estação Conhecimento, Programa de Qualificação Profissional, Programa de Formação Continuada de Professores Alfabetizadores e Gestores de Educação, Programa de Aperfeiçoamento das Práticas Pedagógicas, Programa Ação Educação, Programa Escola que Vale, Programa Torre Gente, Programa Vale Juventude, Programa Escola Modelo e Programa Vale Alfabetizar.

Essas iniciativas educativas da Vale encontram-se disseminadas nos municípios em que a empresa possui projetos de exploração mineral. Com relação à Escola Crescendo na Prática se destacam Programa de Formação Continuada de Professores Alfabetizadores e Gestores de Educação e o Programa Vale Juventude. Esses, na verdade apresentam um projeto formativo homogêneo, cujas especificidades dos sujeitos são invisibilizadas, pois desconsideram o campo como espaço de vivência dos educadores e alunos, definindo uma "pedagogia da hegemonia", que adota uma mesma temática para todos os espaços escolares, desvinculando o saber disciplinar do saber do educando e sua realidade. Desta feita, existe um embate entre a formação hegemônica e a formação pautada na pedagogia do movimento (FERREIRA, 2012), sabendo-se que a primeira se pauta em um conhecimento fragmentado e/ou profissional, que define as linhas de construção de um intelectual especializado que irá reproduzir os ideais e valores hegemônicos, ao passo que a segunda formação anseia por um conhecimento omnilateral, que prima pela construção de um intelectual orgânico em diálogo com a filosofia da práxis.

Outro projeto da Vale que se sobressai para proporcionar uma formação hegemônica é a Estação Conhecimento, em que o empreendedorismo corresponde ao eixo transversal de suas ações:

Para que os alunos aprendam a ter, são incentivados a reconhecer seus saberes, potencialidades, possibilidades e limites. Assim, serão capazes de superar dificuldades, resolver problemas, enfrentar desafios, fazer escolhas de como agir e que estratégias usar para mostrar seu valor com a perspectiva de empreender as suas vidas.

O processo de aprendizagem é inspirado nos quatro pilares da educação apresentados pela Organização das Nações Unidas para a Educação UNESCO (conhecer, fazer, ser, conviver). Para o modelo da Estação Conhecimento, incluímos um quinto pilar: o ter. (FUNDAÇÃO VALE, 2010, s/p.)

Essa matriz educacional que busca observar as potencialidades regionais objetiva incluir o estudante em uma subjetividade atravessada pela ideologia do consumo e do empreendedorismo (PANTOJA, 2012), inserindo igualmente o agricultor em uma lógica de mercado que aumenta sua dependência em relação aos sujeitos econômicos dominantes e vinculados ao agronegócio, especialmente com o incentivo às atividades relativas à pecuária. 
$\mathrm{Na}$ realidade paraense as Estações Conhecimento estão dispostas espacialmente em Tucumã, Parauapebas e Marabá (ver Quadro 9), exatamente onde existem os projetos de mineração, logo, têm a intenção de atenuar os conflitos sociais com os sujeitos locais via projetos sociais e, ao mesmo tempo, incutir valores que legitimam sua atuação na região, como promotora de emprego, sustentabilidade ambiental e desenvolvimento regional.

Quadro 9 - Espacialização das Estações Conhecimento da Fundação Vale no Pará, 2016

\begin{tabular}{|c|c|c|c|c|}
\hline $\begin{array}{c}\text { Localização } \\
\text { no Pará }\end{array}$ & $\begin{array}{l}\text { Ano de } \\
\text { criação }\end{array}$ & Objetivo & Infraestrutura & Pessoas atendidas \\
\hline Тисита̃ & 2008 & $\begin{array}{l}\text { Ensino e a prática regular } \\
\text { de futebol, atletismo, } \\
\text { natação, karatê, música, } \\
\text { teatro e dança, além de } \\
\text { aulas complementares de } \\
\text { linguagem, matemática, } \\
\text { informática e cursos } \\
\text { profissionalizantes. }\end{array}$ & $\begin{array}{l}\text { Salas de aula, ginásio } \\
\text { poliesportivo, campo } \\
\text { de futebol, cineteatro, } \\
\text { etc. }\end{array}$ & $\begin{array}{l}650 \text { crianças e adolescentes } \\
\text { em atividades educativas, } 420 \\
\text { jovens no programa esportivo, } \\
1.500 \text { pessoas nos programas } \\
\text { regulares. }\end{array}$ \\
\hline $\begin{array}{c}\text { APA do } \\
\text { Igarapé } \\
\text { Gelado } \\
\text { (Paraupeba } \\
\text { s) }\end{array}$ & 2010 & $\begin{array}{lcc}\text { Geração de } & \text { trabalho e } \\
\text { aumento de renda das } \\
\text { famílias de produtores } \\
\text { locais, com foco na } \\
\text { bovinocultura leiteira. }\end{array}$ & $\begin{array}{lr}\text { Salas de } & \text { aula, } \\
\text { Laticínio } & \text { para } \\
\text { processamento de } & \text { leite para fabricação } \\
\text { de leite pasteurizado, } \\
\text { manteiga, queijo } \\
\text { muçarela, etc. }\end{array}$ & $\begin{array}{l}120 \text { famílias de produtores } \\
\text { rurais. }\end{array}$ \\
\hline Marabá & 2013 & $\begin{array}{l}\text { Atende crianças } \mathrm{e} \\
\text { adolescentes com } \\
\text { atividades esportivas como } \\
\text { futebol e atletismo, karatê } \\
\text { e capoeira, além de } \\
\text { atividades educativas e } \\
\text { culturais incluindo } \\
\text { linguagem, matemática, } \\
\text { teatro, música e dança. }\end{array}$ & $\begin{array}{l}\text { Salas de aula, quadra } \\
\text { poliesportiva etc. }\end{array}$ & $\begin{array}{l}\text { 1.000 pessoas em programas } \\
\text { regulares, } 520 \text { crianças e } \\
\text { adolescentes em atividades } \\
\text { educativas, esportivas e } \\
\text { culturais, } 240 \text { adultos em } \\
\text { atividades educativas, como } \\
\text { cursos profissionalizantes e } \\
\text { oficinas de saúde. }\end{array}$ \\
\hline
\end{tabular}

Fonte: FUNDAÇÃO VALE, 2016. Organização: Rogério Rego Miranda.

Por fim, observamos os conflitos envolvendo a escola do PA 17 de Abril, que também começou no acampamento criado na Fazenda Formosa, com três professores voluntários. Depois do massacre foi transferida para a Fazenda Macaxeira e finalmente se consolidou na atual vila do assentamento, onde funcionou até 2010 de maneira provisória e precária, pois funcionava em um barracão com cinco salas, cozinha, um banheiro e não dispunha de encanamento ou energia elétrica.

Para que essa realidade fosse alterada houve uma manifestação no quilômetro 4 da estrada PA-275, que dá acesso ao assentamento. Nesse lugar, os professores deram aulas para as crianças durante uma semana, deslocando para ali carteiras, quadros, alimentação, serventes, ou seja, todos os instrumentos necessários para que as aulas transcorressem no meio da estrada. Com essa ação, o governo do estado do Pará se comprometeu, em 2009, a 
construir uma escola no PA com condições adequadas de atender a crianças, jovens e adultos que residiam na localidade, assim como os demais moradores dos assentamentos limítrofes, a exemplo de Canudos e Cabanos.

A escola de fato foi construída e entregue no ano de 2010, nomeada como EMEFM Oziel Alves Pereira (ver Foto 31), em homenagem a uma das militâncias que faleceram no massacre. Sua estrutura conta com doze salas de aula, salas da direção, de professores, de leitura, laboratórios de informática, de ciências, cozinha, refeitório, almoxarifado, auditório, lavanderia, banheiros e uma quadra poliesportiva: é considerada uma escola modelo na região.

Foto 31 - EEEFM Oziel Alves Pereira, 2016

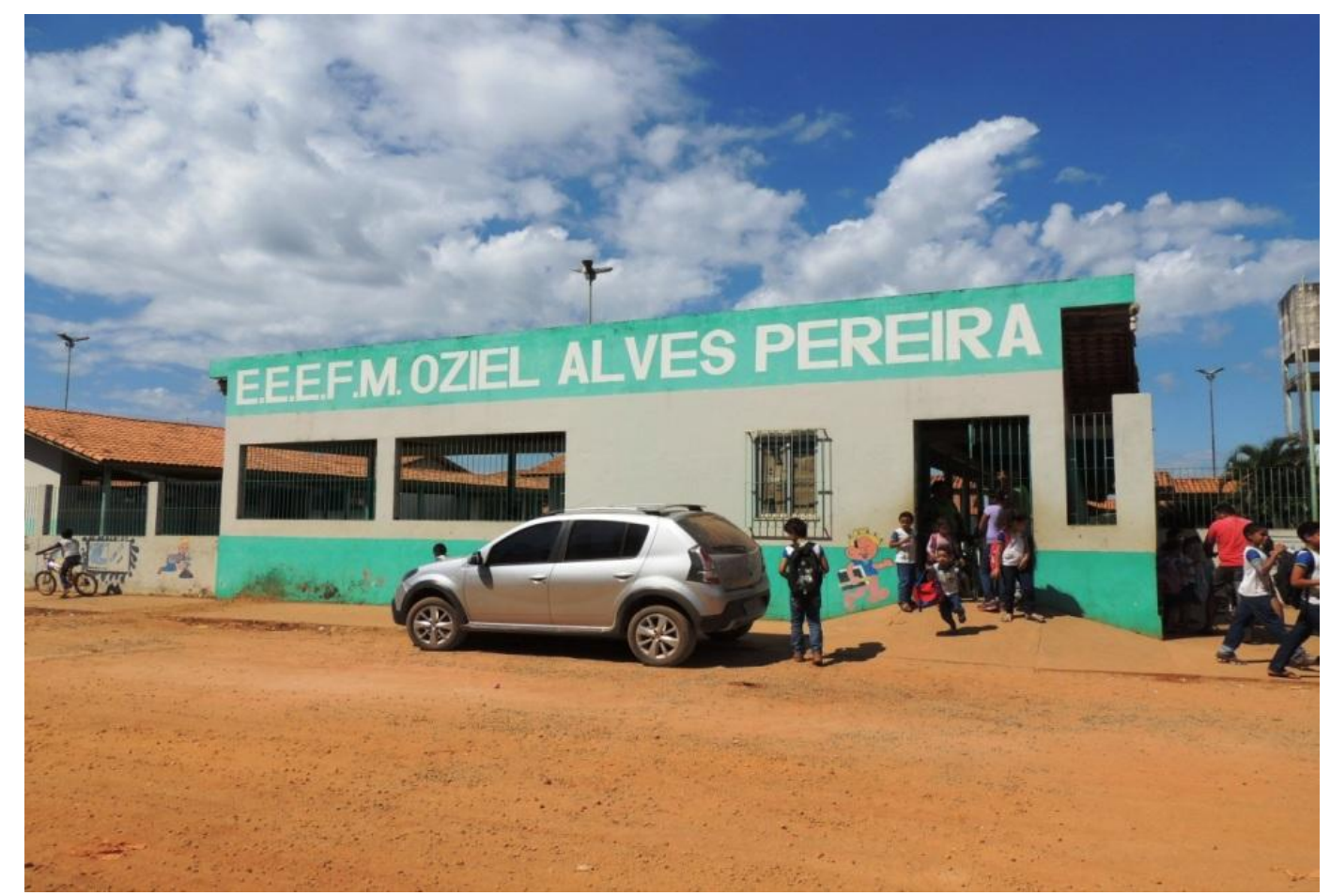

Fonte: Rogério Rego Miranda, Eldorado dos Carajás, 2016.

Em virtude dos programas de formação do PRONERA em parceria com a universidade, os educadores que atuam na escola são em sua maioria oriundos do momento do acampamento ou são ex-alunos que retornam para "ocupar a escola", agora como formadores.

Assim como ocorreu em Palmares II, existiram momentos de disputa pelo controle da gestão escolar, que ficava sob a responsabilidade do município de Eldorado dos Carajás, mas em virtude de uma luta cotidiana mobilizada pelos professores e o MST, a coordenação da instituição retornou para a delegação da comunidade, que escolhe os diretores por meio de eleição direta, assim como discute coletivamente o currículo, agora voltado para a educação do campo. Esse fato ocorre por uma reaproximação da escola com o MST, cuja relação ficou 
atenuada por conflitos internos até aproximadamente o ano de 2011; após essa data, a escola voltou inclusive a contar com atividades do movimento socioterritorial no calendário escolar:

A relação da escola com o MST ela passou assim uma temporada meio ausente, sabe, mas de 2012, 2011 para cá a escola ela está interagindo mais com o MST, nós estamos tendo assim mais visita deles, a gente está participando mais dos movimentos, das organizações que eles fazem, então hoje o relacionamento na medida do possível é boa, eu posso dizer para você que é um relacionamento. A gente sabe o que está acontecendo lá, a gente leva as crianças para o sem-terrinha, a gente vai em encontro, agora mesmo em julho no dia 06, no dia 07 e 08 nós temos um encontro que é organizado pelo MST em Açailândia, então a gente está interagindo, nós temos aqui dois professores, que esses eles estão designados para passar informação, eles quando precisa eles saem para trabalhar lá para o MST, a gente registra o trabalho, já é de conhecimento do secretário da educação, esses dois professores ficam à disposição, quando não tem nada eles estão na sala, mas se precisou eles saem, passa até uma semana. (Edna Souza dos Santos Silva, assentada e coordenadora pedagógica no PA 17 de Abril, 51 anos, 26 jun. 2016)

Uma síntese dessas disputas que o MST empreende no interior das escolas dos assentamentos pode ser visualizada no Quadro 10, observando que, em algumas, o movimento consegue por em prática parcialmente seus princípios pedagógicos e filosóficos, mas em outras, não. 
Quadro 10 - Disputas territoriais no âmbito da educação nos assentamentos organizados pelo MST, 2016

\begin{tabular}{|c|c|c|c|c|c|}
\hline Assentamento & Escola & $\begin{array}{c}\text { Momento de } \\
\text { construção da } \\
\text { escola } \\
\end{array}$ & Relação com os Princípios do MST & Professores & Disputas \\
\hline Palmares II & $\begin{array}{l}\text { EMEF Crescendo } \\
\text { na Prática }\end{array}$ & Acampamento & $\begin{array}{c}\text { Parte dos princípios é colocada em prática, } \\
\text { mas em virtude das disputas internas em } \\
\text { torno do projeto educacional nem tudo é } \\
\text { levado a cabo. }\end{array}$ & $\begin{array}{l}\text { Parte dos professores é oriunda dos cursos de } \\
\text { formação do MST e outra parte é concursada, } \\
\text { sem vínculos com o movimento. }\end{array}$ & $\begin{array}{c}\text { - Com o Estado, via prefeitura } \\
\text { - Interna, com novos sujeitos } \\
\text { econômicos no assentamento. } \\
\text { - Com a Vale, via Estação } \\
\text { Conhecimento. }\end{array}$ \\
\hline 17 de Abril & $\begin{array}{l}\text { EEEFM Oziel } \\
\text { Alves Pereira }\end{array}$ & Acampamento & $\begin{array}{c}\text { Parte dos princípios é colocada em prática, } \\
\text { mas em virtude das disputas internas em } \\
\text { torno do projeto educacional nem tudo é } \\
\text { levado a cabo. }\end{array}$ & $\begin{array}{l}\text { Parte dos professores é oriunda dos cursos de } \\
\text { formação do MST e outra parte é concursada, } \\
\text { sem vínculos com o movimento. }\end{array}$ & $\begin{array}{l}\text { - Com o Estado, via prefeitura } \\
\text { - Interna, com novos sujeitos } \\
\text { econômicos no assentamento. }\end{array}$ \\
\hline Cabanos e Canudos & $\begin{array}{l}\text { EMEFM Oziel } \\
\text { Alves Pereira }\end{array}$ & Acampamento & $\begin{array}{c}\text { Parte dos princípios é colocada em prática, } \\
\text { mas em virtude das disputas internas em } \\
\text { torno do projeto educacional nem tudo é } \\
\text { levado a cabo. }\end{array}$ & $\begin{array}{l}\text { Parte dos professores é oriunda dos cursos de } \\
\text { formação do MST e outra parte é concursada, } \\
\text { sem vínculos com o movimento. }\end{array}$ & $\begin{array}{l}\text { - Com o Estado, via prefeitura } \\
\text { - Interna, com novos sujeitos } \\
\text { econômicos no assentamento. }\end{array}$ \\
\hline Onalício Barros & $\begin{array}{c}\text { EMEF Antônio } \\
\text { Vilhena (Localizada } \\
\text { no Cedere I) }\end{array}$ & $\begin{array}{l}\text { Escola sem } \\
\text { vínculos com o } \\
\text { movimento } \\
\text { socioterritorial }\end{array}$ & $\begin{array}{c}\text { Nenhum professor tem relação direta } \\
\text { com o movimento socioterritorial }\end{array}$ & $\begin{array}{l}\text { Os professores não mantêm vínculos com o } \\
\text { movimento. }\end{array}$ & Não há disputas. \\
\hline Nega Madalena & $\begin{array}{l}\text { EMEF Anexo do } \\
\text { Cuca (Localizada } \\
\text { na Vila do Cuca) }\end{array}$ & $\begin{array}{l}\text { Escola sem } \\
\text { vínculos com o } \\
\text { movimento } \\
\text { socioterritorial }\end{array}$ & $\begin{array}{c}\text { Nenhum professor tem relação direta } \\
\text { com o movimento socioterritorial }\end{array}$ & $\begin{array}{l}\text { Os professores não mantêm vínculos com o } \\
\text { movimento. }\end{array}$ & Não há disputas. \\
\hline 26 de Março & $\begin{array}{l}\text { EMEF Carlos } \\
\text { Marighela }\end{array}$ & Acampamento & $\begin{array}{c}\text { Parte dos princípios é colocada em prática, } \\
\text { mas em virtude das disputas internas em } \\
\text { torno do projeto educacional nem tudo é } \\
\text { levado a cabo. }\end{array}$ & $\begin{array}{l}\text { Parte dos professores são oriundos dos cursos de } \\
\text { formação do MST e outra parte são concursados } \\
\text { sem vínculos com o movimento e/ou a realidade } \\
\text { do assentamento. }\end{array}$ & $\begin{array}{c}\text { - Com o Estado, via prefeitura } \\
\text { - Interna, com novos sujeitos } \\
\text { econômicos no assentamento. } \\
\text { - Com a Vale, via Estação } \\
\text { Conhecimento. } \\
\end{array}$ \\
\hline $1^{\circ}$ de Março & $\begin{array}{c}\text { EMEF Educar Para } \\
\text { Crescer e EMEI } \\
\text { Madalena Freire }\end{array}$ & Acampamento & $\begin{array}{c}\text { Parte dos princípios é colocada em prática, } \\
\text { mas em virtude das disputas internas em } \\
\text { torno do projeto educacional nem tudo é } \\
\text { levado a cabo. }\end{array}$ & $\begin{array}{c}\text { Há duas escolas a de ensino infantil possui } \\
\text { vínculo com o MST e seus princípios e a de } \\
\text { ensino fundamental e médio atualmente possui } \\
\text { uma relação parcial com o MST }\end{array}$ & $\begin{array}{l}\text { - Com o Estado, via prefeitura } \\
\text { - Interna, com novos sujeitos } \\
\text { econômicos no assentamento. }\end{array}$ \\
\hline
\end{tabular}

Fonte: Pesquisa de campo, 2016. 
Outro nível dessa disputa por hegemonia se encontra no seio da universidade, isso porque seu espaço é produto do diálogo com os movimentos sociais (MST e FETAGRI principalmente), que identificaram a necessidade de uma formação em nível superior para discutir problemáticas que lhes atingem diretamente, tais como degradação ambiental, geração de emprego e renda no campo, políticas públicas de desenvolvimento rural, reforma agrária etc. Desta feita, foi pleiteado pelos movimentos sociais da mesorregião Sudeste do Pará um campus universitário em Marabá que garantisse a formação dos professores para as escolas no campo, auxiliando igualmente na construção de um projeto de desenvolvimento contraposto à concepção dominante na região (SCALABRIN, 2011).

O campus universitário de Marabá foi criado no ano de 1987 como uma política de descentralização efetuada pela Universidade Federal do Pará (UFPA), com o intuito de aproximar a universidade da demanda da mesorregião. Para esse fim, o campus oferta cursos estratégicos, especialmente na área da licenciatura, como Pedagogia, Letras, Matemática, História e Geografia. Pela Lei Federal $\mathrm{n}^{\mathrm{o}}$ 12.824, de 5 de junho de 2013, esse campus foi transformado em Universidade Federal do Sul e Sudeste do Pará (UNIFESSPA), com sede em Marabá-Pará, mas de caráter multicampi - pois tem campus também em Rondon do Pará, Santana do Araguaia, São Félix do Xingu e Xinguara -, ampliando ou consolidando os cursos ofertados em licenciatura (Física, Matemática, Química, Geografia, História, Ciências Sociais, Pedagogia, Letras e Educação do Campo) e bacharelado (Sistema de Informação, Artes Visuais, Ciências Biológicas, Saúde Coletiva, Ciências Contábeis, Administração, Direito, Ciências Econômicas, Geografia, Agronomia, Geologia, Engenharia de Materiais, Engenharia de Minas e Meio Ambiente, Engenharia Civil, Engenharia Elétrica, Engenharia Mecânica, Engenharia da Computação e Engenharia Química).

Como podemos perceber, há um fortalecimento das licenciaturas, dentre as quais destacamos o aparecimento da Educação do Campo, que advém de um diálogo com os movimentos sociais do campo presentes no sudeste paraense e tem por premissa em seu projeto político-pedagógico "produzir, socializar e transformar o conhecimento na Amazônia para a formação de sujeitos do campo capazes de promover a construção de assentamentos, comunidades e escolas rurais, visando a uma sociedade sustentável” (PPC, 2014, p. 4). Isso porque o contexto da produção do conhecimento das "escolas rurais"

[...] tem sido feita, hegemonicamente, desprestigiando os saberes, realidade e demandas locais e contribuindo para reproduzir um processo que faz da escola o lócus onde a cultura culta [liberal, burguesa, branca, de classe média e urbana] é aprendida e onde os estudantes experimentam a hierarquia e a fragmentação das relações, práticas e saberes que justificam as distinções de status e classe que existem na sociedade urbanizada. Assim, 
ao mesmo passo em que se faz sociocêntrica e etnocêntrica, centrada nos valores de uma classe social e de um grupo étnico, a escola contribui também para reafirmar uma visão estereotipada e negativa dos povos do campo [não civilizados, pobres coitados, atrasados e sem contribuições à sociedade] que os toma como sujeitos não produtores de conhecimento e cultura, a quem a escola urbana deve salvar, nem que seja apenas com as "primeiras letras" (PPC, 2014, p. 9 grifado no original).

Esse curso é produto de uma série de iniciativas realizadas no sudeste paraense que visam aproximar e consolidar uma parceria entre a universidade e os movimentos sociais. Assim, em 1999 foram realizadas ações de educação do campo com financiamento do Ministério de Desenvolvimento Agrário através do PRONERA para alfabetização das populações camponesas. Nesse mesmo ano houve o Projeto de Formação / Escolarização em Ensino Fundamental ( $5^{\mathrm{a}}$ a $8^{\mathrm{a}}$ séries) para jovens e adultos dos PAs, organizado pelo MST e a FETAGRI. Já em 2001, ocorreu o Projeto de Formação / Escolarização em Ensino Médio Magistério e o Projeto de Alfabetização de Jovens e Adultos. Em 2003, foi realizado o Projeto de Formação em Nível Médio Agrotécnico e o Projeto de Alfabetização / Escolarização em Ensino Fundamental (séries iniciais) em parceria com a FETAGRI, beneficiando assentados de 22 PAs. Em 2004, via PRONERA, observa-se o primeiro projeto de ensino superior, o Projeto de Formação em Nível Superior em Agronomia, atendendo jovens do Pará, Maranhão e Tocantins que residiam em assentamentos organizados pelo MST. E, em 2006, o Projeto de Formação em Nível Médio Agrotécnico, o Projeto de Formação em Nível Superior Curso de Pedagogia, em parceria com a FETAGRI; e o Projeto de Formação em Nível Superior Curso de Letras, em parceria com o MST (PPC, 2014).

Ao passo que os movimentos sociais avançam no diálogo com a universidade, observa-se a constituição de diversos cursos de Engenharia, financiados ou em parceria com a empresa Vale, existindo uma disputa entre as formas de conhecimento produzidas no âmbito da instituição.

É importante frisar que essa relação entre universidade e movimentos se inicia com os sindicatos em 1989, no Programa de Extensão Rural no interior do Centro Agroambiental do Tocantins (CAT) do campus de Marabá, com o propósito de integrar a pesquisadesenvolvimento e a formação de profissionais de Ciências Agrárias. A ideia era contribuir para a formação de profissionais oriundos de outras instituições que pudessem pensar uma formação questionadora do modelo de transferência de tecnologia e revolução verde, relacionado à monocultura e fundamentado na produção de base diversificada. Para esse fim, foram criados programas e espaços como a Especialização em Agricultura Familiar Amazônica e Desenvolvimento Agroambiental em 1991, Centro Agropecuário em 1994, 
Licenciatura Plena em Ciências Agrárias nos municípios de Altamira e Marabá, respectivamente nos anos de 1997 e 1999, o curso de Mestrado em 1996 e o curso de Graduação em Agronomia em 2001. (SCALABRIN, 2011)

Como podemos perceber, diversos níveis de ensino foram disputados pelos movimentos sociais a partir de alianças entre diferentes sujeitos, possibilitando a conquista de territórios importantes, como as escolas nos acampamentos e assentamentos e cursos universitários voltados para a realidade da educação do campo e que pensam, a partir de um diálogo com os sujeitos, a construção de outro projeto de sociedade, em termos educacionais e igualmente produtivos, conforme iremos discutir a seguir.

\subsection{A AGROECOLOGIA COMO UNIDADE DA EDUCAÇÃO E DA LUTA PELA/NA TERRA}

O MST nos anos 1980, em meio a um período de transição da ditadura civil-militar para "redemocratização", diante de uma forte repressão à luta pela terra e da estagnação das políticas de assentamento, direcionou sua atenção para a organização da produção nos assentamentos rurais.

Nesse período, a militância do MST tinha forte vínculo com a Igreja Católica e a evangélica de confissão luterana no Brasil, influenciadas pela Teologia da Libertação como forma de ler a realidade. Por esse motivo, entre 1979 e 1985 houve uma orientação política do movimento para construir grupos coletivos, mutirões e associações. Essas últimas foram bastante estimuladas pelos órgãos governamentais de extensão rural, resultando na multiplicação de associações nos assentamentos no período de1985 - 1989. Nesse último ano, entretanto, constataram-se diversos limites políticos e legais em termos de avanços econômicos aos assentamentos, tais como: a falta de compromissos formais entre os associados, predomínio do individualismo na gestão associativa, parca capacidade administrativa, desconhecimento dos princípios da cooperação, dificuldades de implementar e ampliar grupos coletivos na produção e comercialização, inabilidade em ampliar as escalas de produção e comercialização, existência de problemas e conflitos com assentamentos individuais, pouco planejamento das atividades, dispersão de esforços e utilização inadequada da mão de obra, dissolução rápida das associações diante do aparecimento dos problemas administrativos e dificuldade de acesso ao crédito rural de maneira coletiva (CONCRAB, 1999).

Diante dessas limitações, a direção do MST iniciou uma discussão acerca de outras formas de organização com o intuito de viabilizar a organicidade aos assentamentos no país, 
uma vez que com a eleição de Fernando Collor de Melo em 1989, houve uma ampliação da repressão ao MST, contribuindo para que o movimento construísse meios de fortalecer sua organização interna, fato que resultou no aprofundamento da ideia da organização dos núcleos de base e das cooperativas (CONCRAB, 1999).

Para esse fim, por um lado, o movimento estabeleceu uma estrutura administrativa para coordenar a implantação de um modelo de cooperação agrícola, concebida como a principal via de organização do trabalho em termos econômicos, disseminada pelo movimento em todo o país, a partir da integração das experiências locais que foram, ao longo dos anos, aperfeiçoadas pelo Setor de Produção, especialmente com a introdução do Sistema Cooperativista dos Assentados (SCA), constituída a partir da política governamental de crédito, denominada de Programa de Crédito Especial para a Reforma Agrária (PROCERA), em 1986. Esse financiamento, por outro, definiu a matriz de uma agricultura moderna, logo, adotou-se a agroindustrialização da produção nos assentamentos, o que originou problemas relativos à dificuldade de comercialização e competição com os produtos oriundos das grandes empresas. De modo geral, o PROCERA instituiu uma feição demasiadamente econômica, com créditos destinados a lavouras temporárias, designadas à industrialização ou que poderiam ser compradas pelas empresas agroexportadoras. Outro entrave era a falta de acompanhamento técnico ou fiscalização, que levou a diversos problemas para os agricultores em termos produtivos e a um processo de endividamento junto ao banco (BORGES, 2007). Em suma,

Houve um notável direcionamento do sistema de créditos para a produção de grãos, um processo produtivo marcado por elevada dependência com relação ao uso de insumos agroindustriais e financiamentos governamentais, uma acentuada prescrição técnica e uma ampla fiscalização e controle de agências bancárias e estatais. Por outro lado, os recursos disponibilizados eram sabidamente insuficientes para a realização da produção. A inserção dos assentados nas linhas de crédito disponíveis evidenciava suas primeiras limitações e contradições (NORDER, 2004, p. 109).

Essa perspectiva de desenvolvimento rural pautada pelo PROCERA era incompatível com a lógica organizativa dos assentamentos e aumentava o grau de dependência dos sujeitos do campo em relação ao mercado.

Essa política governamental ajuda a compreender a matriz de produção do MST e seus instrumentos de execução, visto que sua implantação deu origem ao Sistema Cooperativista dos Assentados (SCA) em 1988 e este, por sua vez, iniciou a Confederação Nacional das Cooperativas de Reforma Agrária do Brasil (CONCRAB) em maio de 1992 (BORGES, 2007), que começa suas atividades com seis Cooperativas Centrais (Rio Grande do Sul, Santa 
Catarina, Paraná, Espírito Santo, Bahia e Ceará), que congregavam vinte Cooperativas de Produção Agropecuária (CCA) sendo que para atingir o objetivo de:

[...] gerar emprego e renda no meio rural e impedir o êxodo de trabalhadores rurais para as grandes cidades, a CONCRAB procura traçar uma estratégia global de organização do SCA e implantar agroindustrialização nos próprios assentamentos (JST, 1994, p. 8).

Conforme podemos perceber, o MST se alinha a uma ideia de produção pautada na organização de cooperativas, na agroindústria, na tecnicização e na maior integração ao mercado, por meio de uma produção em larga escala:

Diante de uma política econômica e agrícola que penaliza o pequeno agricultor, o assentado não pode se contentar com a conquista de um pedaço de terra. Há a necessidade de encontrar meios que lhe possibilitem ter acesso a recursos financeiros e técnicos, condições favoráveis de produção e comercialização, acesso a técnicas de produção mais desenvolvidas e à mecanização. Recursos esses hoje somente ao alcance dos grandes proprietários. É para proporcionar essas condições que estamos implantando a organização de cooperativas em nossos assentamentos. [...] (JST, 1991, p. 02).

O cooperativismo proposto pelo MST foi se constituindo com base em experiências locais e internacionais, a partir de visitas em países da América Latina, tais como Nicarágua, Peru, Honduras, Cuba, Chile e México (MORISSAWA, 2001). Ele se pautava em um modelo homogêneo destinado aos projetos de assentamento, com base em uma proposta organizacional destacadamente econômica (BORGES, 2007). Criou-se, desse modo, o Sistema Cooperativista dos Assentados, setor do MST responsável pela:

[...] organização de base dos assentados, pela organização da produção, da tecnologia, da transformação ou agroindústria, pela boa aplicação do crédito rural, pela comercialização e, também, pela mobilização social dos assentados frente à política agrícola do governo, a política econômica e pelas condições básicas dos assentamentos (CONCRAB, 1997, p. 9).

O modelo do SCA tinha por finalidade intensificar a cooperação agrícola nos assentamentos e ao mesmo tempo criar condições de continuidade da luta e desenvolver a consciência política na base e sua organicidade (CONCRAB, 1997), ou seja, criar condições para uma produção coletiva que pudesse "substituir o 'meu' pelo 'nosso' e mudar o jeito artesão de trabalhar e enxergar o mundo" (CONCRAB, 1997, p. 13). Para o MST, existem três modalidades de cooperação, dispostas no Quadro 11, a seguir. 
Quadro 11 - Principais formas de cooperação agrícola

\begin{tabular}{|c|c|c|c|}
\hline Características & \begin{tabular}{|l|} 
Grupo Coletivo \\
\end{tabular} & Associação & Cooperativa \\
\hline Quem participa & $\begin{array}{l}\text { Vizinhos, parentes ou amigos, } \\
\text { geralmente só homens. }\end{array}$ & $\begin{array}{l}\text { Famílias, homens e às vezes } \\
\text { também mulheres. }\end{array}$ & $\begin{array}{l}\text { Familías: homens, mulheres e } \\
\text { jovens acima de } 16 \text { anos. }\end{array}$ \\
\hline $\mathrm{N}^{\mathrm{o}}$ de sócios & Geralmente menos de 10. & Entre 20 e 400 conforme o tipo. & Mínimo exigido por lei é 20. \\
\hline $\begin{array}{c}\text { Forma de } \\
\text { participação nas } \\
\text { decisões }\end{array}$ & $\begin{array}{l}\text { Combinação verbal entre todos } \\
\text { os membros do grupo. }\end{array}$ & Assembleia. & $\begin{array}{l}\text { Assembleias, conselhos dos } \\
\text { representantes dos setores. }\end{array}$ \\
\hline Para que se unem & $\begin{array}{l}\text { Geralmente para: compra de } \\
\text { implementos; venda de } \\
\text { produtos; construção de } \\
\text { benfeitorias; ajuda mútua no } \\
\text { trabalho. }\end{array}$ & $\begin{array}{l}\text { Geralmente para: prestação de } \\
\text { serviços de comércio e } \\
\text { transporte; encaminhamento } \\
\text { das reinvindicações da } \\
\text { comunidade. }\end{array}$ & $\begin{array}{l}\text { Geralmente para: organização } \\
\text { coletiva da produção e } \\
\text { comercialização; criação de } \\
\text { agroindústrias. }\end{array}$ \\
\hline Uso da terra & Geralmente individual. & Individual e semicoletivo. & Semicoletivo e coletivo. \\
\hline $\begin{array}{l}\text { Divisão do } \\
\text { trabalho }\end{array}$ & $\begin{array}{l}\text { No máximo, mutirões de ajuda } \\
\text { mútua. }\end{array}$ & $\begin{array}{l}\text { Formas simples de divisão } \\
\text { social do trabalho. }\end{array}$ & $\begin{array}{l}\text { Especialização do trabalho } \\
\text { pelos setores de atividades. }\end{array}$ \\
\hline $\begin{array}{l}\text { Estatuto e } \\
\text { registro }\end{array}$ & $\begin{array}{l}\text { Não tem estatuto; geralmente } \\
\text { não tem regimento interno; } \\
\text { quando existem registros, os } \\
\text { principais são os contratos } \\
\text { assinados por todos. }\end{array}$ & $\begin{array}{l}\text { Precisa de estatuto; pode ter } \\
\text { registro interno; não pode ter } \\
\text { bloco de notas fiscais. }\end{array}$ & $\begin{array}{l}\text { Tem estatuto regulamentado } \\
\text { pela lei cooperativista; deve ter } \\
\text { registro interno; pode ter bloco } \\
\text { de produtor e notas fiscais; } \\
\text { deve ter registro oficial da } \\
\text { contabilidade. }\end{array}$ \\
\hline
\end{tabular}

Fonte: $\operatorname{MST}(1993, p .32)$.

Essas formas de cooperação agrícola manifestam uma evolução quanto ao grau de complexidade em relação à participação, à organicidade, ao uso da terra (individual e/ou coletivo), às atividades produtivas e à regulamentação jurídica.

Com relação à implantação desse modelo cooperativista pelo MST, Carvalho (1999b) faz uma avaliação bastante interessante e crítica. Segundo o autor, no período de 1989 a 1999, houve o que ele denominou de "paradigma da década de 1990", em que se observam contradições internas devido a várias formas de cooperação previstas no Plano Nacional do MST (1989-1993) terem se reduzido a um sistema institucional técnico-burocrático de cooperativas, isso porque as diversas manifestações de cooperação historicamente desenvolvidas pelos assentados foram desconsideradas, o que deriva de múltiplos fatores: a) a dimensão da cooperação entre os assentados é bastante enfatizada, e nisso os núcleos de base desempenham um papel central, mas existe uma contradição entre a proposição e a capacidade de executá-la, uma vez que os documentos do MST relacionados às cooperativas não fazem referência aos núcleos de base e, quando o fazem, ele apresenta um caráter funcional para cooperativa, chegando-se a confundi-lo com núcleo de produção; b) a organicidade do MST gravitou em torno do SCA, concorrendo para que houvesse uma precarização na formação política-ideológica dos dirigentes, dos assentados e dos núcleos de base, prevalecendo o economicismo e o corporativismo das ações internas; c) os documentos do MST, embora sugiram uma crítica com relação a formação político-ideológica no seio do 
movimento, não dão a devida relevância a essa questão, em comparação com as demandas provenientes dos interesses econômicos e pragmáticos dos assentados e a necessidade de solucionar os problemas concernentes à gestão das cooperativas; d) apesar de existir no Plano Nacional do MST (1989-1993) e em outros documentos a identificação de objetivos relativos à transformação social para a construção de uma sociedade socialista, daí a necessidade da construção de alianças de classe trabalhadora para a luta, há uma debilidade políticoideológica, resultante dos problemas citados anteriormente.

Diante do exposto observamos que o sistema cooperativista do MST viveu, nos anos 1990, um crise com relação a sua efetividade nos assentamentos. Isso decorre de problemas internos e externos.

No âmbito interno visualizamos as seguintes contradições: a) embora existisse a discussão em torno da autonomia dos assentamentos, havia pouca abertura nesse sentido, resultando no rompimento daquelas cooperativas que não se adequavam às diretrizes do MST por considerarem-nas impositivas e autoritárias, uma vez que o cooperativismo não levava em conta as trajetórias individuais e os projetos de autonomia; b) o uso de técnicas de produção, maquinários e insumos modernos entrava em contradição com a lógica de organização do trabalho coletivo, visto que essa modernização visava a uma alta produtividade e à competição no mercado, levando as Cooperativas Agroindustriais (CPAs) a direcionarem-se para as culturas de larga escala (milho, algodão e soja), concorrendo para resultados econômicos negativos nos assentamentos e a problemas relativos à mão de obra abundante, pois a lógica tecnicista promove a redução do número de pessoas empregadas, além de levar a uma grande dependência em relação aos fatores externos como o preço dos produtos, a oferta dos implementos agrícolas e a própria instabilidade do mercado ao comercializar a produção, afluindo para a diminuta rentabilidade dos cooperados (BARROS, 2007).

No que tange aos agravantes externos, temos a atuação do Estado, que enquanto sujeito financiador desse modelo de agricultura, via PROCERA, definiu suas linhas mestras, visto que vinculava o desenvolvimento econômico dos assentamentos ao paradigma da modernização do campo, com vistas à chamada Revolução Verde, pautada na tecnicização e na produção em larga escala e dependente dos recursos externos (BARROS, 2007). Posteriormente, esse financiamento veio a ser extinto em 1999, sem qualquer tipo de debate, definindo a supressão do crédito especial para a Reforma Agrária e enquadrando os assentados como agricultores familiares por meio do PRONAF (ALMEIDA, 2000).

Essas dificuldades relativas ao desenvolvimento do cooperativismo foram anunciadas pelo próprio MST, ao informar que "temos muitas experiências onde foram tomadas decisões 
teoricamente bonitas e avançadas, mas na prática, não funcionaram e acabaram quebrando o coletivo" (CONCRAB, 1996a, p. 73). Desta feita, o movimento, mediante crise, começa a enveredar para outras formas organizativas e propostas produtivas, pautadas agora pela agroecologia.

Essa perspectiva agroecológica se coloca em contraponto à Revolução Verde, que é uma transformação capitalista da agricultura e da pecuária, mediante sua mecanização, visando o aumento da produção e dos lucros. Para esse fim, realiza-se o cultivo intensivo do solo, a monocultura, o uso de fertilizantes inorgânicos, de agrotóxicos para controlar as pragas e manipulação genética de plantas e animais a partir da transgenia, sem haver uma preocupação com os impactos nos diversos ecossistemas, com destaque para a perda da variabilidade do material genético e de alternativas no âmbito alimentar. Essas mutações extravasam para a dimensão social, visto que promovem a desigualdade espacial pelo avanço da expropriação do território camponês e a consequente expansão do latifúndio e da concentração fundiária, além de criar relações de dependência do campesinato com as empresas fabricantes dos pacotes tecnológicos. Isso porque a agricultura da Revolução Verde contribui para substituir a interação simbiótica entre solo, água, animais e plantas da agricultura camponesa pela utilização integrada de insumos, sementes e produtos químicos, com o intuito de aumentar a produtividade de um determinado componente da propriedade. Como contra medida, há a redução dos diversos outros componentes do sistema, em outras palavras, a Revolução Verde substitui os ciclos ecológicos por fluxos lineares de insumos químicos, que precisam ser adquiridos a cada nova safra (MALAGODI, 2005; PEREIRA, 2012).

A agroecologia tem se difundido no Brasil a partir da década de 1990 e de maneira mais contundente nos anos 2000, principalmente por conta de sua utilização pelos movimentos sociais, especialmente aqueles vinculados à Via Campesina, que a incorporaram em seu debate como uma estratégia política (GUHUR; TONÁ, 2012).

Embora sua definição não seja um consenso, para Altiere (2012) a ideia central da agroecologia é conseguir se projetar para além das práticas agrícolas alternativas e desenvolver agroecossistemas que possam diminuir bruscamente a dependência em torno de agroquímicos e energia externa. Ela apresenta uma base científica e se baseia em um conjunto de práticas. Como ciência, se pauta na "aplicação da Ecologia para o estudo, o desenho e o manejo de agroecossistemas sustentáveis" (ALTIERE, 2012, p. 15-16, grifado no original). A intenção é produzir uma diversificação agrícola que promova interações biológicas e sinergias benéficas entre os componentes do agroecossistema, permitindo a regeneração da fertilidade 
do solo e a manutenção da produtividade e proteção dos víveres ali existentes. Como prática social, a agroecologia se fundamenta no conjunto de conhecimentos e técnicas provenientes dos agricultores e suas experimentações, assim, seu "enfoque tecnológico está enraizado na diversidade, na sinergia, na reciclagem e na integração, assim como em processos sociais baseados na participação da comunidade" (ALTIERE, 2012, p. 16). Com isso objetiva-se ampliar as possibilidades produtivas dos camponeses e sanar as necessidades alimentares mediante fomento à autossuficiência. Seu enfoque busca privilegiar a escala local, por concentrar seus esforços no abastecimento dos mercados mais próximos para que os circuitos entre produção e consumo dos alimentos sejam encurtados.

A agroecologia, portanto, apresenta para além de um viés técnico e científico uma dimensão sociocultural importante que dialoga com o saber local (camponês e indígena), se contrapõe à lógica tecnicista da Revolução Verde e, consequentemente, ao padrão agroindustrial hegemônico. Dessa maneira, oferece formas de ação social coletiva de manejo ecológico que almejam criar propostas participativas em torno de uma produção alternativa que contribua para diminuir a deterioração ecológica e social ocasionada pelo neoliberalismo em curso (SEVILLA-GUZMÁN, 2001).

$\mathrm{Na}$ agroecologia, o camponês passa a assumir o papel de sujeito pesquisador das suas experiências e da particularidade de seu agroecossistema para que possam propor tecnologias apropriadas às condições locais e às interações ecológicas, sociais, econômicas e culturais em outras palavras, ele vai produzir o conhecimento em conjunto com outros sujeitos. Em suma, a agroecologia vai além do desenvolvimento de experiências de agricultura sustentável, pois envolve a organização social orientada para uma luta política para a transformação social, que transcende a luta econômica pragmática e corporativa de ações pontuais, visto que objetiva a construção de outro projeto de campo, levada a cabo pelos movimentos sociais que entendem a agroecologia como parte de sua estratégia de luta em relação ao agronegócio, sendo inseparável da disputa por soberania alimentar, por reforma agrária e urbana e por alianças entre os diversos trabalhadores do campo e da cidade (GUHUR; TONÁ, 2012).

Nessa disputa se desenvolve uma guerra de posição, na qual o MST defende a soberania alimentar por meio da agroecologia. Assim, a luta pela terra ganha uma amplitude maior, pois é igualmente uma luta por formas mais sustentáveis de agricultura e da manutenção do território camponês e de seu modo de vida - em linhas gerais, de um projeto territorial contra-hegemônico.

De acordo com Rodrigues (2014), historicamente o MST desde sua origem teve essa relação com a questão ambiental, devido ao vínculo irrestrito entre acesso, controle e uso da 
terra, recurso fundamental à reprodução camponesa; daí o desafio que se coloca à realidade dos assentamentos e acampamentos que o movimento ajuda a organizar, pois este defende outra concepção e forma de relacionamento com a natureza, de maneira oposta àquela proposta pela lógica de acumulação capitalista dominante.

O MST assume o conceito de preservação socioambiental, considerando os homens e mulheres como sujeitos principais de sua construção identitária enquanto movimento socioterritorial. Essa preocupação socioambiental inicialmente foi proveniente dos diálogos com a CPT e posteriormente foi ganhando cada vez mais importância em sua pauta de luta (NEGRI, 2005).

No Plano Nacional do MST de 1989, por exemplo, já existe a proposta de “desenvolver um trabalho de educação entre as famílias assentadas, principalmente jovens e crianças, sobre a importância da preservação dos recursos naturais (fauna, flora, solo e água)" (PLANO NACIONAL, 1989, p. 19). Em 1995, a agroecologia se torna tema de discussão no $1^{\circ}$ Encontro Nacional de Mulheres Trabalhadoras Rurais:

No encontro, as trabalhadoras também se afirmaram sua opção [sic] pela construção de um novo modelo de desenvolvimento econômico e social no campo, buscando novas alternativas de produção pela ótica da agroecologia e tendo com central o ser humano (JST, 1995, s.p.).

No mesmo ano se realiza o $3^{\circ}$ Congresso Nacional do MST, que trazia novamente a questão do desenvolvimento sustentável e da agroecologia e, ainda nesse período, o movimento adentra a Via Campesina como estratégia de ampliar sua rede de articulação em uma escala cada vez mais internacional.

Essa integração à Via Campesina fortaleceu ainda mais as preocupações socioambientais do MST, sobretudo porque a Via Campesina, após sua criação em Mons, na Bélgica, no ano de 1993, tornou-se um sujeito importante no debate sobre alimentação e agricultura, especialmente a partir da difusão de seu conceito sobre "soberania alimentar", hoje adotado por diversos movimentos sociais locais, nacionais e internacionais e até mesmo por instituições mundiais como a Organização das Nações Unidas para a Alimentação e a Agricultura (FAO) (DESMARAIS, 2013).

A partir desse momento, várias experiências foram levadas a cabo nos assentamentos conquistados por meio do MST, o que motivou a criação da Rede de Sementes Agroecologicas Bionatur em 1997, que consiste em uma organização de agricultores assentados da reforma agrária e produtores de sementes variadas (hortaliças, plantas ornamentais, grãos etc.). Atualmente, integra também a Via Campesina e congrega 160 
famílias de agricultores com uma produção de aproximadamente 20 toneladas de sementes (SILVA et al., 2014).

Mas foi a partir dos anos 2000 que a agroecologia se projetou com mais força enquanto modelo de produção a ser disputado como estratégia política, cujo marco foi o $4^{\circ}$ Congresso Nacional do MST, que firmou os seguintes compromissos:

1. Amar e preservar a terra e os seres da natureza.

2. Aperfeiçoar sempre nossos conhecimentos sobre a natureza e a agricultura.

3. Produzir alimentos para eliminar a fome da humanidade. Evitar a monocultura e o uso de agrotóxicos.

4. Preservar a mata existente e reflorestar novas áreas.

5. Cuidar das nascentes, rios, açudes e lagos. Lutar contra a privatização da água.

6. Embelezar os assentamentos e comunidades, plantando flores, ervas medicinais, hortaliças, árvores etc.

7. Tratar adequadamente o lixo e combater qualquer prática de contaminação e agressão ao meio ambiente.

8. Praticar a solidariedade e revoltar-se contra qualquer injustiça, agressão e exploração praticada contra a pessoa, a comunidade e a natureza.

9. Lutar contra o latifúndio pra que todos possam ter terra, pão, estudo e liberdade.

10. Jamais vender a terra conquistada. A terra é um bem supremo para as gerações futuras (JST, 2000, s.p.).

Nesse evento ficou patente a intencionalidade do movimento de correlacionar a luta pela terra com a agroecologia por meio de ações coletivas, solidárias e sustentáveis, valorizando a produção do saber local. O próprio setor de produção é transformado, em 2001, em Setor de Produção, Cooperação e Meio Ambiente (SPCMA).

Essa estratégia do movimento de difusão da agroecologia se articula com o setor de educação do MST, que decide criar escolas com enfoque agroecológico. Nesse intuito, o movimento ajudou a construir escolas de agroecologia em diferentes estados brasileiros, muito embora estas estejam ainda concentradas principalmente na região Sul do país. Nesses espaços, os currículos são heterogêneos e orgânicos, com características técnicas e políticas e forte criticidade à agricultura da Revolução Verde, em âmbito mais geral, ao sociometabolismo do capital. Essas escolas trabalham um ensino integrado entre teoria e prática, mas apresentam algumas contradições e limites como o não comprometimento orgânico de todos os educadores, permanência da fragmentação do conhecimento, precariedade nas infraestruturas das escolas e poucos docentes Universitários desenvolvendo pesquisas agroecológicas (NOVAES et al., 2015).

No que se refere à realidade do sudeste paraense, de acordo com Pereira (2015), há uma construção histórica em torno de um saber camponês que não degrada o ambiente, 
advindo da miscigenação social e cultural entre posseiros e indígenas; tal construção, muito embora marcada por conflitos e negociações, mobiliza os saberes agrícolas autóctones e permite que sejam apropriados por agroextrativistas, a exemplo da mandioca, espécime vegetal manipulada pelos índios da Amazônia, que passou a ser a base alimentar dos camponeses. Entretanto, com o avanço do capital na porção sudeste do Pará na década de 1970, o acúmulo agroecológico desse "campesinato florestal" acabou prejudicado em decorrência do processo de expropriações de seus territórios ou do reassentamento a partir de uma nova lógica produtiva, pautada na derrubada da mata para extração da madeira, no cultivo de roças e depois do capim para o gado. A pecuária acabou se tornando o principal meio de sustento dessas populações, em decorrência da dificuldade de circulação e acesso aos mercados, sendo o gado mais fácil de comercializar. Paralelamente, o próprio Estado, nos anos 1990, foi um indutor da pecuarização na região por meio dos financiamentos, como o Fundo Constitucional do Norte (FNO). Por seu turno, os migrantes advindos principalmente do Maranhão, quando chegavam ao sudeste paraense não conseguem replicar os cultivos outrora praticados, pois não recebiam assistência técnica necessária para produzir em meio à floresta, concorrendo para a proliferação de pragas e doenças nas lavouras dos assentamentos. Essa questão é debatida em suas representações organizativas, inicialmente no sindicalismo e posteriormente no próprio MST.

Conforme indicamos anteriormente, o debate em torno de uma formação envolvendo uma agricultura sustentável tem sua origem nos sindicatos, a partir de suas discussões com a UFPA em Marabá. Nesse sentido foi criado o CAT, com o objetivo de gestar um curso voltado para os camponeses, em parceria também com a CPT e o Groupe de Recherche et d'Échanges Technologiques (França). Nesse contexto, para haver uma representação jurídica do CAT, foi criada a Fundação Agrária do Tocantins-Araguaia (FATA) e para o desenvolvimento e organização das pesquisas acerca da realidade do sudeste paraense foi fundado o Laboratório Sócio-Agronômico do Tocantins (LASAT). A partir dessa rede foi discutida uma maneira de inserção da produção camponesa no mercado, surgindo como 
proposta o cooperativismo: as diversas cooperativas ${ }^{42}$ que surgiram passaram a integrar a Federação de Cooperativas Araguaia-Tocantins (FECAT) (PEREIRA, 2015).

Essa experiência sindical constituiu o adubo que nutriu a construção formativa do MST, pois muito de seus quadros advém dos sindicatos, que historicamente também estabeleceram as condições materiais para que a universidade se abrisse ao diálogo, assim como realizou com o MST diversas ações conjuntas que possibilitaram a construção de um bloco histórico-geográfico que luta pela educação e a agroecologia em contraponto à hegemonia agromineral da região.

Nesse ponto de nossa pesquisa, entretanto, focaremos na experiência do MST que visa construir territorialmente uma base material, através dos assentamentos organizados, para que o debate da agroecologia possa se desenvolver no sudeste paraense. Mas, antes contextualizararemos o porquê de alguns limites e contradições existentes hoje em torno da questão agroecológica.

Uma premissa importante a considerar é a diferença do ritmo com o qual esse processo de transição para agroecologia se desenvolve em termos nacionais em comparação à região amazônica, isso porque o tempo histórico da fronteira e as condições objetivas são diferentes, o que interfere na própria organização e estratégia do MST no sudeste paraense, visto que, enquanto em nível nacional, na década de 1990, já havia um relativo desenvolvimento do cooperativismo, principalmente no Sul do Brasil, na realidade pesquisada pouco se tinha avançado na luta pela conquista da terra,

Em alguns momentos na realidade o MST a gente segue né, as deliberações nacionais do movimento, a luta, o calendário, agora nosso tempo histórico aqui na Amazônia por a gente ter... essa distância do Centro-Sul [...] e esse tempo histórico nosso que é outro [...]. Essa questão dos interesses da organização e da estratégia, na realidade era discordância de estratégia, é que nosso tempo histórico exigia fazer coisas que os outros ainda... ou já tinham superado [...]. Na negociação nacional (do MST) a pauta do Sul e Sudeste era muito para as cooperativas, nós era a pauta da terra, não tinha nem a terra ainda desapropriada e eles já estavam lá num processo de agroindustrialização [...] mas nós não tinha nem a terra ainda, como não temos a terra, e eles [Coordenação Nacional do MST] a negociação era para ter agroindústria, então não era divergente, era só tempo histórico diferente mesmo. O nosso tempo histórico era da ocupação da terra, do lutar pela

\footnotetext{
42 Participavam a Cooperativa Mista da Agricultura Familiar de Eldorado dos Carajás (COOMAFEC); a Cooperativa Mista da Agricultura Familiar de Itupiranga (COOMAFI); a Cooperativa Mista da Agricultura Familiar de Marabá (COOMFAMA); a Cooperativa Mista da Agricultura Familiar de São João do Araguaia (COOMASJA); a Cooperativa Mista daAgricultura Familiar de São Domingos do Araguaia (COOMASDA); Cooperativa Mista dos Produtores Rurais da Região de Carajás (COOPER); e a Cooperativa Agroextrativista de Nova Ipixuna (COORENTÃO).
} 
resistência na terra, pela desapropriação e aí isso não era vontade política do governo federal, que preferiu ter como linha política o melhoramento dos assentamentos, então a região Sul foi contemplada com essa vontade do governo com o melhoramento dos assentamentos, que eles tinham assentamentos e tinham o que ser melhorado, nós aqui nem tínhamos assentamentos ainda, na maioria do nosso público. E os que tinham estavam muito aquém ainda inclusive do processo de agroindustrialização, porque a gente ainda tinha o desafio da estrada, da implantação do crédito de moradia, não sei o que, então esse tempo histórico era muito diferente [...] de fato o enfrentamento aqui e a disputa pela terra é muito pesado mesmo. Então aqui leva doze, dez anos, quinze anos... no Maranhão tem assentamento de vinte e cinco anos, acampamento de vinte e cinco anos e que ainda estava com liminar de despejo. Então é uma realidade própria da Amazônia, então quando o Pará e o Maranhão estavam querendo desapropriar a terra, o Sul já estava negociando as agroindústrias, melhoramento das agroindústrias, ampliação de agroindústria, então o tempo deles era um e o nosso era outro. (Maria Raimunda César de Sousa, dirigente do MST e professora, 42 anos, 12 jul. 2016)

Essa é uma questão fundamental para compreender como, na Amazônia e particularmente no sudeste paraense, a construção de um projeto de produção alternativa começa a ser discutido tardiamente. Mas outros fatores interferiram decisivamente nesse sentido.

Os primeiros assentamentos que vão se constituir sob a organização do MST de forma mais incisiva são os PAs Palmares II, 17 de Abril e $1^{\circ}$ de Março. Nessas realidades foram implementados o crédito fomento e habitação por meio do INCRA e, posteriormente, o financiamento para atividades produtivas por meio do PROCERA, a partir de um investimento grupal.

No Assentamento Palmares II foram construídas estruturas agroindustriais para o beneficiamento de leite, arroz e mandioca, além de um local para armazenamento da produção agropecuária (PDA Palmares, 2008a). No 17 de Abril, muito em função do massacre de Eldorado dos Carajás, foi implantado uma grande infraestrutura agroindustrial: laticínio com capacidade de pasteurizar e embalar 2.400 litros de leite por dia; aviário com capacidade de produzir 20 mil frangos a cada 45 dias, com sistema de abate e congelamento e um caminhão frigorífico para realizar sua distribuição; uma agroindústria de arroz com capacidade de beneficiar 22.500 quilos por dia; e uma agroindústria de farinha de mandioca com capacidade de beneficiar 22.500 quilos de raiz de mandioca e produzir 6.500 quilos de farinha embalada por dia (PDA 17 de Abril, 2008b). Por fim, no $1^{\text {o }}$ de Março não foi possível conseguir créditos pelo PROCERA, mas no ano de 2000 foi obtido o PRONAF “A”, porém sem uma grande infraestrutura e apenas para o desenvolvimento das seguintes atividades agropecuárias: pecuária leiteira; suinicultura de cria e engorda; avicultura de corte; piscicultura de engorda; 
implantação de cultura de cupuaçu, banana, café, coco da Bahia e pimenta-do-reino; e custeio para arroz, milho e mandioca (PDA $1^{\circ}$ de Março, 2008c).

Nessas realidades é possível observar pelas infraestruturas e projetos aprovados uma intencionalidade de diversificação, ao menos nos primeiros financiamentos, entretanto esses projetos apresentaram diversos problemas no que tange à organização coletiva, à infraestrutura e à forma de crédito.

Em termos de organização coletiva existia uma parca experiência no âmbito produtivo, especialmente porque os assentados em sua grande maioria eram oriundos de uma trajetória geográfica marcada trabalho individual, seja como vaqueiro, peão, agricultor e principalmente garimpeiro, este proveniente de Serra Pelada, cuja história

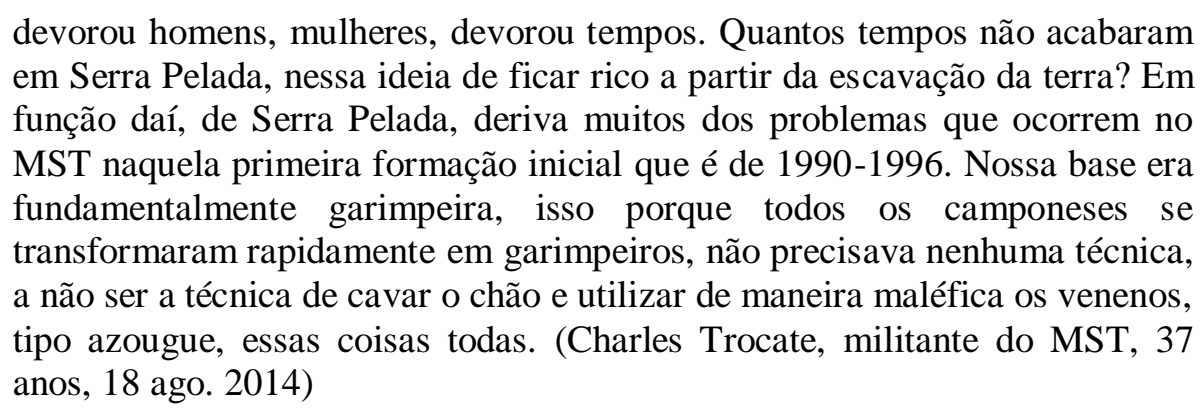

Essa fala acima revela dois aspectos dos sujeitos que vão compor inicialmente o MST: um é a relação social mediada pelo dinheiro que acaba sendo imperativa nesse primeiro momento, devido às formas de sociabilidades que existiam anteriormente entre os garimpeiros serem pautadas no individualismo, elemento que foi sendo parcialmente descontruído ao longo do acampamento nos núcleos de base, mas que na forma assentamento acaba sendo refeito ou reconfigurado. O segundo aspecto se refere às técnicas utilizadas pelos assentados, visto que anteriormente não possuíam uma preocupação no que tange ao uso de veneno ou ao impacto que o desmatamento e a queima da vegetação poderia vir a provocar. Essa técnica de derrubada da mata e posterior queima vai provocar no interior dos assentamentos uma série de incidentes e conflitos, pois aqueles que focavam na atividade da pecuária, ao fazer uso do fogo para limpar áreas para o pasto, por não terem assistência técnica e/ou conhecimento acerca de formas de contenção da queimada, contribuem para que o fogo se propague em direção à mata e ao plantio dos outros assentados que acabam perdendo seus cultivos, árvores frutíferas e animais.

Somando-se a esses fatores, a organização do MST no âmbito produtivo propõe "novos planos sociais que seriam vivenciados pelas pessoas pertencentes a esses grupos com práticas sociais produtivas e vida social coletivizadas que não derivam historicamente de um processo crescente e acumulativo de transformações psicossociais a nível das pessoas" 
(CARVALHO, 1999b, p. 29), ou melhor, "houve uma ruptura política, a partir de fatores ideológicos externos, que determinou de fora para dentro (a ideia de alguns para a realidade de muitos) o ensaio das novas relações sociais e a tentativa de identidade e coesão sociais" (CARVALHO, 1999b, p. 29). Nesse sentido, foi imposto um projeto coletivo com base no ideal do cooperativismo da organização nacional do MST, cuja principal forma de cooperação disseminada foi a de caráter semicoletiva, que apresenta as seguintes características, de acordo com o Caderno de Formação, n. 21:

Terra: Parte da terra é destinada para uso do coletivo e parte permanece para uso do indivíduo. A proporção destinada a um ou outro varia de grupo para grupo.

Capital: Parte dos investimentos para os meios de produção é feita de forma coletiva e parte de forma individual.

Trabalho: No grupo de produção semicoletivizada já existe um certo grau de divisão social do trabalho porque parte da produção é desenvolvida de forma coletiva. O tempo restante é trabalhado pelas pessoas, em seus lotes, de forma individual.

Planejamento da produção: Na parte individual quem planeja a produção é o indivíduo com sua família. Na área destinada à produção coletiva quem planeja é o conjunto dos sócios através de suas instâncias de decisão (ex. Assembleia).

Moradia: Normalmente a moradia é organizada em forma de agrovila, mas há muitas experiências aonde as casas permanecem nos lotes individuais.

Aspectos legais: Normalmente os grupos de produção semicoletivizada são organizados informalmente, isto é, não têm registro legal. Porém, pode haver grupos de produção semicoletivizada organizados em forma de associações ou mesmo CPAs. Mesmo que não esteja legalizado, o grupo deve elaborar seu regimento interno, registrar suas decisões em livro de atas e manter em dia a contabilidade básica. (MST, 1996, p. 15-16)

O resultado dessa decisão foi a construção de alguns projetos produtivos coletivos que deveriam ser compatibilizados com as atividades desenvolvidas nos lotes individuais porém com sua posterior individualização, por já haver, em escala nacional, experiência concreta de cooperação, de modo que tais projetos coletivos acabam se fortalecendo com o financiamento coletivo, mas na realidade pesquisada o

[...] recurso forçou uma forma de cooperação que não existia, que era para dizer assim, não, vamos pegar o (PROCERA) Teto II que é para agroindústria, então vamos pensar aqui em uma farinheira para Palmares, uma fábrica de ração, não sei o que, vai ser tudo coletivo, só que não olhou para trás para dizer assim, tem matéria-prima para isso? Tem o recurso? Nós vamos juntar e vamos fazer? Esse foi o primeiro que em outros estados, em alguns estados deram certo, acabaram com esses recursos fortalecendo essas formas de cooperação, mas por que já tinha uma base, já tinha matériaprima, já tinham famílias que produziam, o pessoal na Palmares não tinha nem o lote, só sabiam onde era a vila, a casa da vila, porque os lotes ainda não tinham sido distribuídos, mas aí chegou o recurso, o projeto foi feito, o banco aprovou, vamos pagar, temos as instalações montadas, mas não tem uma produção já que ninguém tinha lote, a primeira roça foi coletiva no 
entorno da vila porque não tinha ainda lote definido, então esse foi um problema. (Giselda Pereira Coelho, assentada no PA 26 de Março e dirigente do Setor de Produção do MST, 42 anos, 13 jul. 2016)

De acordo com a dirigente do Setor de Produção do MST o financiamento, em consonância com a própria lógica de organização do MST, levou a uma cooperação forçada. Assim, observamos a destinação de alguns lotes para atividades coletivas (piscicultura, gado, mandioca etc.) por grupos de até dez famílias que estivessem localizadas próximas (estas correspondiam na época aos Núcleos de Base). Entretanto, essas áreas acabaram sendo posteriormente repartidas individualmente, devido aos seguintes fatores:

1) os camponeses preferiam resguardar sua autonomia em seus respectivos lotes individuais, embora a troca de experiência e de ajuda mútua permanecesse;

2) a falta de acompanhamento técnico para a implementação das atividades levou, em casos extremos, a perda total do cultivo ou dos animais, como peixes e gado (voltado em grande parte para extração de leite);

3) a liberação de financiamento para determinados víveres se deu fora do período adequado para sua plantação;

4) o envolvimento dos agricultores foi desigual, em termos de tempo de trabalho destinado ao projeto coletivo, visto que muitos acabavam se dedicando quase que exclusivamente a seu lote individual;

5) houve conflitos culturais quanto ao manejo e uso do solo e quanto aos cultivos e/ou animais que deveriam ser priorizados;

6) as infraestruturas coletivas para o beneficiamento dos artigos agropecuários em muitos casos nem chegaram a funcionar ou foram desativadas, pois a) existia pouca oferta de matéria-prima uma vez que os assentamentos eram recentes; b) o recurso financeiro recebido foi apenas para a aquisição dos equipamentos e instalação das agroindústrias e não para sua manutenção; c) faltava energia elétrica para viabilizar o funcionamento das máquinas e de um acompanhamento técnico especializado para garantir seu desempenho satisfatório; d) não havia recursos que garantissem a compra de matéria-prima e a manutenção das infraestruturas adquiridas.

Ainda nesse período da década de 1990, quando os lotes não eram coletivos, os projetos deveriam ter esse caráter: a disponibilização do recurso por parte do órgão financeiro só era obtida por meio da criação de um grupo de assentados que adquiririam o financiamento para um determinado fim por meio de um contrato coletivo, segundo o qual um indivíduo 
deveria ser o avalista do outro - em outros termos, caso um viesse a deixar de pagar, todos ficariam inadimplentes.

Desta feita, mais uma vez há uma cooperação forçada entre os sujeitos pertencentes ao núcleo de base, referência espacial para a construção desses projetos, mas cuja organização não era respeitada pelo banco, pois não havia uma consulta prévia sobre quem iria ficar responsável pela coordenação do grupo.

Nesses casos, apesar de o projeto ser coletivo, a destinação do recurso era para o desenvolvimento de atividades individuais e/ou para investimento no lote de uma determinada pessoa, entrando em contradição com o objetivo central e gerando diversos problemas, dentre eles o fato de que quando um assentado se desfazia do lote por meio da venda ou o repassava para um parente, o novo proprietário não tinha a obrigatoriedade legal de continuar pagando pelo crédito adquirido por meio do grupo, corroborando para que os demais membros que compõem o projeto coletivo ficassem endividados e impedidos de conseguirem novos financiamentos.

Em casos extremos, a infraestrutura coletiva que foi construída no lote acabou sendo apropriada individualmente, pois o novo proprietário geralmente não desenvolvia relações de parceria internamente, principalmente aqueles que adquiriam a terra por meio da compra, resultando em uma série de conflitos internos.

Esse processo "acabou desgastando o que era para ser um processo de formação acumulativo e de força organizativa" ${ }^{\text {43 }}$, dificultando a construção daquele que era o projeto posterior do MST, que seria a implementação de cooperativas, que acabaram ficando inviabilizadas em função dos diversos problemas, elencados acima, decorrentes da adoção do modelo produtivista, que levou ao endividamento progressivo do assentado, conforme relata uma das lideranças do MST,

[...] as primeiras conquistas nossas nos levaram a um profundo endividamento, que faz parte desse processo de aprendizado, porque nós optamos pelo modelo produtivista, não tinha essa percepção de que agricultura fazer [...], todos os nossos créditos tinham que dar resposta para o mercado, muitas vezes a nossa turma deixava de comer porque o frango iria fazer falta na contabilidade do mercado. Eu diria que essa primeira leva, essa concepção mais produtivista, ela não existe mais na nossa base social, o resultado é o endividamento, nós estamos fazendo um esforço para se desendividar e, nessa perspectiva, de concluir uma concepção de agricultura e fazer uma agricultura a partir do que você tem, para ir desnaturalizando,

\footnotetext{
${ }^{43}$ Giselda Pereira Coelho, assentada no PA 26 de Março e dirigente do Setor de Produção do MST, 42 anos, 13 jul. 2016.
} 
assim, todos os nossos territórios deveriam se preocupar em produzir comida. (Charles Trocate, militante do MST, 37 anos, 18 ago. 2014)

No lugar das cooperativas foram criadas as diversas associações que tinham um papel mais de gestão dos créditos do que propriamente de organicidade, desenvolvendo poucas relações com os outros setores (educação, formação, cultura, massa etc.) existentes nos assentamentos.

A partir dos anos 2000, após os problemas provenientes dos projetos coletivos, os assentamentos começaram a possuir mais de uma associação; isto se deu por dois motivos gerais: o primeiro é proveniente do endividamento contraído pela instituição em função do alto índice de inadimplência e em casos específicos devido à existência de fraudes envolvendo os financiamentos gerenciados pela associação; o segundo fator são os problemas gerados aos assentados por meio da cooperação forçada e do modelo produtivista adotado pelo MST, resultando em dissidências por parte dos assentados que buscam construir bases institucionais com relativa autonomia em relação ao movimento (ver Quadro 12).

As cooperativas que surgem acabam tendo um papel funcional, ou seja, gerenciar financiamentos obtidos para uma determinada atividade específica. Pouco contribuem efetivamente para a construção de um projeto pautado na organicidade e na cooperação, embora essa perspectiva seja um dos objetivos do Setor de Produção do MST no sudeste paraense.

A partir do final da década de 1990, o PRONAF se instaurou como principal política pública para os assentados. Sua formulação adveio dos estudos da FAO/INCRA sobre agricultura familiar que definiriam um conjunto de diretrizes norteadoras para as diferentes modalidades de agricultor familiar, identificadas conforme a renda. Mas também foi uma resposta do Estado às diversas pressões dos movimentos sociais do campo que historicamente eram alijados das políticas públicas existentes. Dessa forma, o Presidente Fernando Henrique Cardoso instituiu o PRONAF através do Decreto Presidencial n ${ }^{\circ}$ 1.946, datado de 28/07/1996. Nesse ano as ações dessa política pública se restringiram ao crédito e custeio, e foram ampliadas em 1997 em termos de programas em áreas de investimento, infraestrutura e serviços municipais, capacitação e pesquisa, passando a operar em todo o território nacional (SCHNEIDER et al., 2004). 
Quadro 12 - Relação de cooperativas e associações nos PAs organizados pelo MST

\begin{tabular}{|c|c|c|c|c|}
\hline $\begin{array}{c}\text { Projeto de } \\
\text { assentamento }\end{array}$ & Cooperativa & \begin{tabular}{c|}
$\begin{array}{c}\text { Relação com } \\
\text { o MST }\end{array}$ \\
\end{tabular} & Associação & \begin{tabular}{|c|} 
Relação com \\
o MST
\end{tabular} \\
\hline \multirow{3}{*}{$1^{\circ}$ de Março } & \multirow{3}{*}{$\begin{array}{c}\text { Cooperativa de Produtores Rurais do } \\
\text { Assentamento } 1^{\circ} \text { de Março - } \\
\text { COOPERPRAM }\end{array}$} & \multirow{3}{*}{ NÃO } & $\begin{array}{c}\text { Associação de Produção e Comercialização dos Trabalhadores Rurais do } \\
\text { Assentamento } 1^{\circ} \text { de Março - APROCTRAM }\end{array}$ & SIM \\
\hline & & & Associação dos Produtores Rurais do Assentamento $1^{\circ}$ de Março - ASPRAM & $\mathrm{NÃO}$ \\
\hline & & & Associação de Mulheres Organizadas na Reforma Agrária - AMORA & SIM \\
\hline Onalício Barros & ------ & ------ & Associação dos Trabalhadores Rurais da Vila Onalício Barros - APROCNOB & SIM \\
\hline 17 de Abril & ------ & ------ & Associação de Produção e Comercialização do PA 17 de Abril - ASPCTRA & SIM \\
\hline Cabanos & ------ & ------ & $\begin{array}{l}\text { Associação de Produção e Comercialização das Famílias dos Trabalhadores Rurais } \\
\text { do Projeto de Assentamento Canudos - ASPROCFAC }\end{array}$ & SIM \\
\hline Canudos & ------ & ------ & Associação de Produção e Comercialização do Assentamento Canudos - APROCAN & SIM \\
\hline Lourival Santana & ------ & ------ & $\begin{array}{l}\text { Associação de Produção e Comercialização do Assentamento Lourival Santana - } \\
\text { APROCALS }\end{array}$ & SIM \\
\hline \multirow{2}{*}{26 de Março } & \multirow{2}{*}{------} & \multirow{2}{*}{------ } & $\begin{array}{c}\text { Associação dos Trabalhadores Rurais do Assentamento } 26 \text { de Março - } \\
\text { APROTERRA }\end{array}$ & SIM \\
\hline & & & $\begin{array}{l}\text { Associação dos Pequenos Produtores Rurais do Assentamento } 26 \text { de Março - } \\
\text { ASPRUPAM }\end{array}$ & NÃO \\
\hline \multirow{3}{*}{ Palmares II } & \multirow{3}{*}{$\begin{array}{c}\text { Cooperativa Mista de Transporte e } \\
\text { Turismo dos Condutores Automotivos } \\
\text { de Veículos Utilitários do } \\
\text { Assentamento Palmares do Município } \\
\text { de Parauapebas - COOPALMAS }\end{array}$} & \multirow{3}{*}{ SIM } & $\begin{array}{c}\text { Associação de Produção e Comercialização dos Trabalhadores Rurais do } \\
\text { Assentamento Palmares - APROCPAR }\end{array}$ & SIM \\
\hline & & & Associação Rural de Reivindicação de Créditos - ASSOPAR & SIM \\
\hline & & & Associação dos Produtores Familiares de Palmares - APROFAP & $\mathrm{NA} O$ \\
\hline Nega Madalena & $\begin{array}{l}\text { Cooperativa Agromineral de Produção } \\
\text { e Comercialização do Assentamento } \\
\text { Nega Madalena - COOPCAL }\end{array}$ & SIM & ------ & ------ \\
\hline
\end{tabular}

Fonte: Pesquisa de Campo, 2016. 
Para o MST, o PRONAF não atende às expectativas de valorização da agricultura familiar, ao contrário, há um decréscimo dos recursos alocados frente às necessidades reais dos trabalhadores rurais, além dos impedimentos burocráticos que dificultam o acesso ao crédito. Em verdade, se constitui, na avaliação do movimento, uma política periférica e compensatória que busca suavizar os efeitos excludentes da modernização do campo e cooptar as populações marginalizadas, com o intuito de criar uma conformidade ideológica do padrão de vida e trabalho. Em suma, corresponde à definição de um projeto das elites para a agricultura, baseado na grande fazenda produtora de grãos destinados ao mercado externo, dotada de um elevado grau de mecanização e incorporação de tecnologias, sendo o mercado interno abastecido pelas agroindústrias monopolistas e importações que barateiam os preços dos produtos agrícolas, arrochando os salários dos trabalhadores rurais e inviabilizando a agricultura camponesa (CONCRAB, 2000).

Nesse novo cenário das políticas públicas e das próprias reformulações do MST, que faz uma autocrítica com relação ao modelo produtivista adotado nos assentamentos e incentivado pelo governo federal, observamos no sudeste paraense que, de um lado, o movimento intensifica o discurso e a prática da agroecologia, inclusive com a construção de parcerias e infraestruturas destinadas a esse fim, mas, por outro, há um aprofundamento das contradições nos assentamentos decorrente da ampliação do grau de dependência em relação ao mercado, devido ao intenso processo de pecuarização em curso, proporcionado pela ampla orientação do Estado e das instituições financeiras nesse sentido.

Os assentamentos conquistados pelo MST a partir dos anos 2000 (Onalício Barros, Cabanos, Canudos, 26 de Março, Lourival Santana e Nega Madalena) não vão apresentar projetos coletivos, pois o próprio direcionamento do banco, via PRONAF "A" e depois "A/C", é para créditos individuais, tal qual vai ocorrer nos assentamentos mais antigos a partir desse momento. Nesse contexto, há grande incentivo e adesão em relação à atividade da pecuária, por diversos motivos:

1) O banco condiciona a criação de projetos para gado, principalmente leiteiro, pois constitui para a instituição financeira a forma mais segura de se obter o retorno com relação ao pagamento do crédito concedido.

2) O gado representa, em tese, a forma mais segura de se obter renda diária e garantir a reprodução familiar, pois o leite pode ser comercializado ao valor variável de $\mathrm{R} \$ 0,50$ a $\mathrm{R} \$ 0,80$ por litro, com os atravessadores e/ou laticínios; e ao mesmo tempo é fonte de alimento para o núcleo familiar; 
3) O gado é a forma mais viável de pagamento de dívidas contraídas, especialmente com o banco, pois próximo ao período de vencimento das parcelas pode haver duas situações: a) um bezerro é vendido para fazendeiros residentes nas proximidades ou para médios proprietários moradores dos assentamentos - estes, por sua vez, revendem o animal para os grandes frigoríficos da região; ou b) o animal adulto é comercializado com os donos de açougues locais;

4) O manejo da área não tem custos demasiadamente elevados, uma vez que não é necessária a mecanização nem é preciso que a criação do animal seja intensiva.

Essa nova dinâmica provoca uma série de consequências no âmbito da autonomia do campesinato e de problemas ambientais:

1 Aumento da área destinada para a pastagem e redução de área de mata e da própria agricultura, assim como do extrativismo, embora tais atividades ainda sejam praticadas, por representarem tanto a condição de reprodução do núcleo familiar quanto uma renda extra com a venda da polpa de frutas regionais (principalmente açaî), artigos agrícolas como hortaliças, milho e mandioca (para a produção de farinha), além de outros animais como suínos, caprinos e aves;

2 Pouca produtividade leiteira, variando entre 3,5 a 5 litros por vaca, pela raça dos animais ser composta por espécimes mestiças e a dieta alimentar ser pouco nutritiva, especialmente pela má qualidade de conservação das pastagens. Isso implica em um dispêndio de trabalho maior do agricultor para que consiga uma renda mais elevada e, assim, aumente o rebanho bovino;

3 Maior dependência em relação ao mercado regional, visto que, por não possuírem cooperativas ou infraestruturas coletivas que possibilitem armazenar, beneficiar e comercializar o leite e seus derivados, os assentados são obrigados a negociar com atravessadores e/ou laticínios que lhes impõem o preço que entendem ser justo, o qual varia de acordo com a flutuação do valor do produto no mercado e do grau de organização dos agricultores para pressionar por um pagamento compatível com os custos dispendidos.

Essa lógica de financiamento e de pecuarização nos assentamentos contribui para o processo de retroalimentação existente na rede capitalista agropecuária do sudeste paraense, conforme podemos visualizar no Organograma 4. 
Organograma 3 - Rede de comercialização do gado de corte e de leite no sudeste paraense

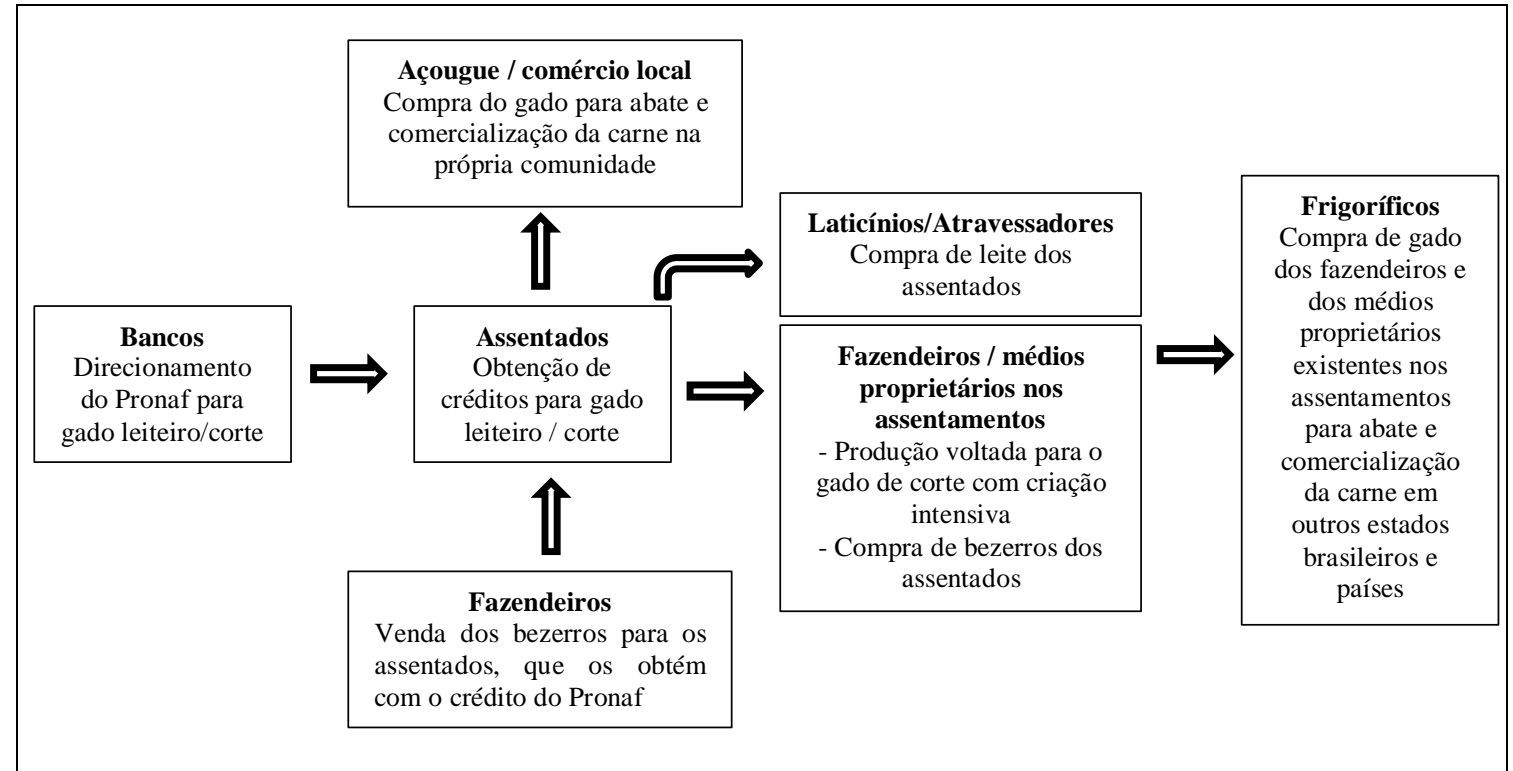

Fonte: Pesquisa de campo, 2016.

Com relação aos financiamentos obtidos via PRONAF no período de 2000 a 2016, observamos que o número de contratos para atividade agrícola foi de 207.069 , dos quais $25.116(12 \%)$ foram alocados no sudeste paraense. A pecuária, por seu turno, apresentou no Pará 282.269 contratos, dos quais 157.432 (55,77\%) destinaram-se ao sudeste paraense. Se avaliarmos o valor do crédito concedido para a agricultura no Pará, que foi de $\mathrm{R} \$$ 1.525.441.342,00, disponibilizou-se ao sudeste paraense $\mathrm{R} \$ 139.805 .309,00(9,1 \%)$. Na pecuária, o valor investido no Pará foi de $\mathrm{R} \$$ 2.731.053.280,00; deste valor, $\mathrm{R} \$ 1.599 .906 .826,00$ (58,58 \%) foram para o sudeste paraense (BACEN, 2017).

Se compararmos os projetos destinados à agricultura e à pecuária no estado do Pará, percebemos que, em termos de número de contratos, existe uma diferença de 75.200 contratos a mais para atividades pecuaristas. Em termos de investimento a diferença é de $\mathrm{R} \$ 1.205 .611 .938,00$, ou seja, o recurso foi quase o dobro para a pecuária.

Essa tendência de investimento maior na pecuária no sudeste paraense adquire um caráter muito forte, pois $58,58 \%$ de todo o recurso do PRONAF estadual para a pecuária ficou alocada nessa mesorregião. Observemos os Gráficos 17 e 18. 
Gráfico 17 - Número de contratos do Pronaf para pecuária e agricultura no sudeste paraense, $2000-2016$

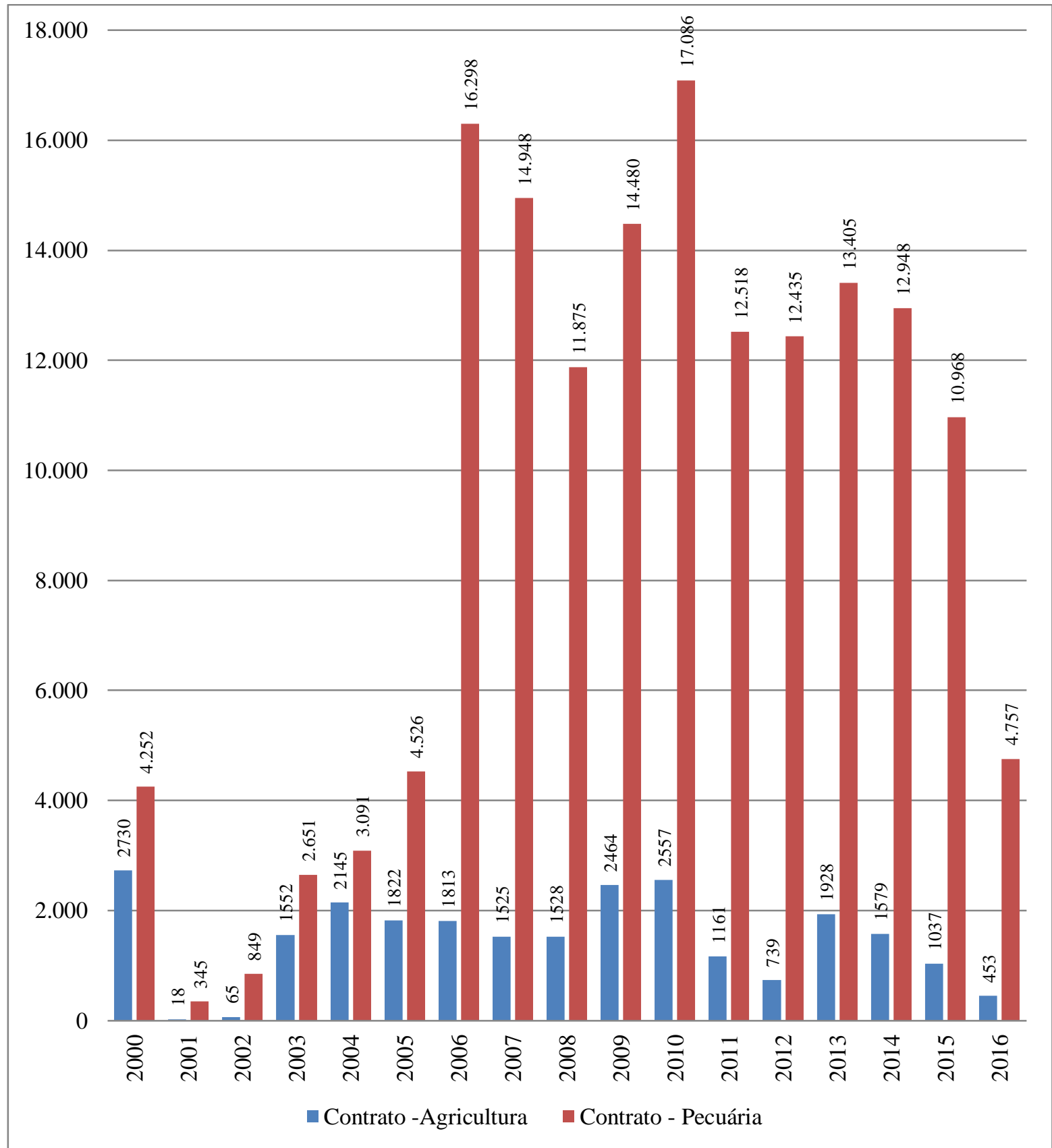

Fonte: BACEN, 2017. Organização: Rogério Rego Miranda. 
Gráfico 18 - Valor (R\$) dos créditos do Pronaf para pecuária e agricultura no sudeste paraense, $2000-2016$

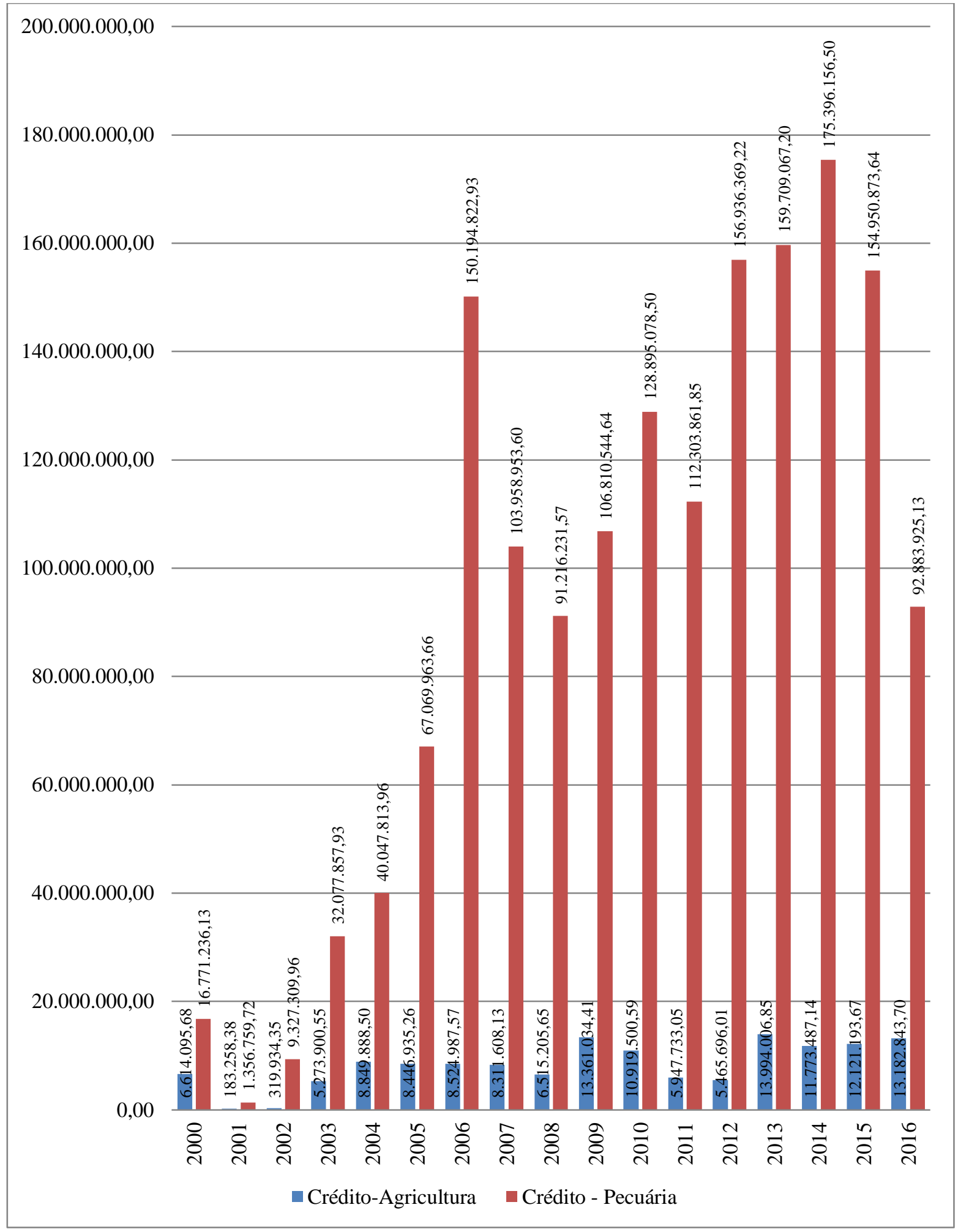

Fonte: BACEN, 2017. Organização: Rogério Rego Miranda. 
Inferimos, a partir dos dados acima, que tanto o número de contratos quanto o valor de crédito destinado para a pecuária, em comparação à agricultura, vem crescendo, especialmente a partir do ano de 2001. Nesse ano, houve 345 contratos que somavam R\$ 1.356.759,00, mais tarde, em 2014, vemos a quantidade de 12.948 contratos que somaram o valor de R\$ 175.396.156,00. Nos anos subsequentes, 2015 e 2016, tivemos uma relativa queda de 10.968 para 4.757 contratos e uma redução de $\mathrm{R} \$ 154.950 .873,00$ para $\mathrm{R} \$$ 92.883.925,00.

Desta feita, há uma ampliação do número de contratos e de créditos liberados para a pecuária entre o ano de 2000 e 2016, que no sudeste paraense se concentra principalmente nos seguintes municípios: Novo Repartimento (17.976 contratos, com investimento de R\$146.512.920,63); São Félix do Xingu (17.503 contratos, com investimento de R\$122.448.916,78); São Geraldo do Araguaia (5.892 contratos, com investimento de R\$111.923.641,21); Marabá (12.327 contratos, com investimento de $\mathrm{R} \$ 106.914 .196,00)$; Itupiranga (12.088 contratos, com investimento de $\mathrm{R} \$ 105.205 .001,23)$; Eldorado dos Carajás (10.861 contratos, com investimento de R\$95.956.170,22); Água Azul do Norte (3.509 contratos, com investimento de $\mathrm{R} \$ 69.275 .388,63)$; Rondon do Pará (5.690 contratos, com investimento de R $\$ 65.487 .049,40)$; Santana do Araguaia (6.254 contratos, com investimento de R\$62.015.244,22); e Conceição do Araguaia (6.526 contratos, com investimento de $\mathrm{R} \$ 60.538 .234,36)$. Tais dados estão ilustrados no Mapa 20. 
Mapa 20 - Número de contratos para agricultura e pecuária no sudeste paraense, 2000-2016.

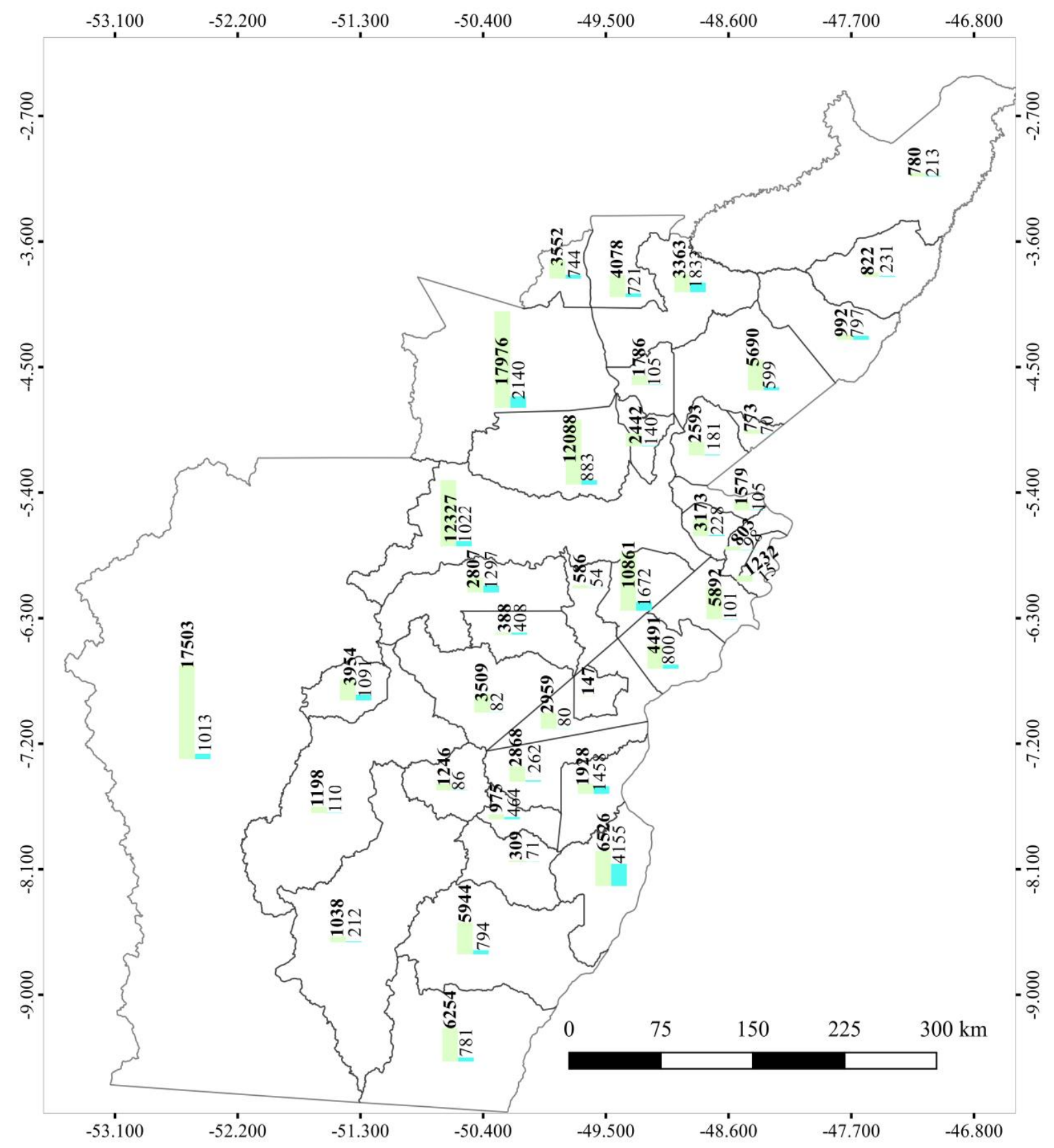

\section{Legenda}

Sudeste Paraense

Quantidade de contratos para pecuária - Pronaf

Quantidade de contratos para agricultura - Pronaf

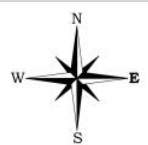

Sistema de Coordenadas UTM - Zona 22S

Datum: WGS - 84

Fonte: IBGE (2010); INCRA (2016); BACEN (2017) Elaboração: MIRANDA, R. R. (2017)

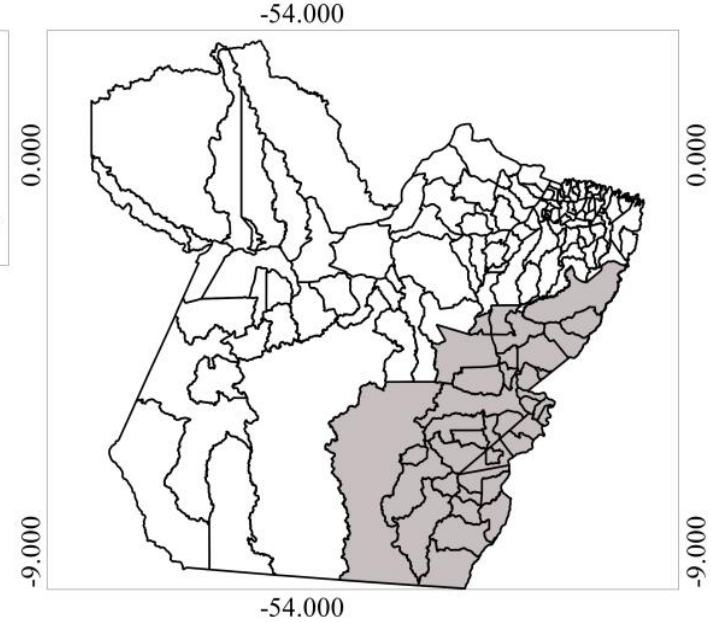

Fonte: BACEN, 2017. Organização: Rogério Rego Miranda. 
Ao adentramos a realidade dos assentamentos enfocados por esta pesquisa, visualizamos na Tabela 8 que, dos 689 assentados pesquisados, 406 afirmaram ter contraído financiamento, geralmente do PRONAF (405 assentados), que foi majoritariamente investido na criação de gado (305 assentados, cerca de $75 \%$ dos entrevistados).

Tabela 8 - Financiamentos PRONAF e PROCERA para agricultura e pecuária nos PAs pesquisados, 2016

\begin{tabular}{|c|c|c|c|c|c|c|c|}
\hline \multirow{2}{*}{$\begin{array}{c}\text { Projetos de } \\
\text { assentamentos } \\
\text { pesquisados }\end{array}$} & \multirow{2}{*}{$\begin{array}{c}\mathbf{N}^{\circ} \text { de } \\
\text { assentados } \\
\text { pesquisados } \\
\text { por PA }\end{array}$} & \multicolumn{2}{|c|}{$\begin{array}{c}N^{0} \text { de assentados } \\
\text { que pegaram } \\
\text { financiamentos } \\
\text { por } \mathbf{P A}\end{array}$} & \multicolumn{2}{|c|}{$\begin{array}{c}\mathrm{N}^{\mathbf{0}} \text { de assentados que } \\
\text { acessaram crédito por } \\
\text { tipo de } \\
\text { Financiamento em } \\
\text { cada PA } \\
\end{array}$} & \multicolumn{2}{|c|}{$\begin{array}{c}\mathrm{N}^{\circ} \text { de assentados que } \\
\text { acessaram financiamentos por } \\
\text { tipo de investimento em cada } \\
\text { PA }\end{array}$} \\
\hline & & Sim & Não & PROCERA & PRONAF & $\begin{array}{l}\text { Agricultura e } \\
\text { outros animais } \\
\text { (aves, suínos, } \\
\text { caprinos) }\end{array}$ & $\begin{array}{c}\text { Gado e } \\
\text { infraestrutura } \\
\text { para sua criação }\end{array}$ \\
\hline Palmares II & 144 & 86 & $48^{44}$ & 0 & 86 & $47^{45}$ & 53 \\
\hline 17 de Abril & 175 & 125 & 50 & 0 & 125 & $32^{46}$ & 102 \\
\hline $1^{\circ}$ de Março & 99 & 74 & 25 & 1 & 73 & 29 & 45 \\
\hline Onalício Barros & 27 & 20 & 7 & 0 & 20 & 6 & 14 \\
\hline Cabanos & 40 & 25 & $13^{47}$ & 0 & 25 & 2 & 23 \\
\hline Canudos & 30 & 25 & 5 & 0 & 25 & 0 & 25 \\
\hline 26 de Março & 89 & 40 & 49 & 0 & 40 & 8 & 32 \\
\hline Lourival Santana & 60 & 0 & 60 & 0 & 0 & 0 & 0 \\
\hline Nega Madalena & 25 & 11 & 14 & 0 & 11 & 0 & 11 \\
\hline Total & 689 & 406 & 271 & 1 & 405 & 124 & 305 \\
\hline
\end{tabular}

Fonte: Pesquisa de Campo, 2016.

É interessante compreender que essa lógica de pecuarização nos assentamentos impõe aos movimentos sociais mais um campo de disputa, pois não é apenas a produção que se altera, mas os valores também, visto que outra simbologia surge no cotidiano das pessoas, que é a da fazenda, isto é, essa forma territorial que antes aprisionava ou excluía o sem-terra hoje os seduz para reproduzir em pequena escala o que existe na região, ou seja, de acumular mais gado como representação de poder econômico,

[...] porque eles se veem fazendeirinho, se olha no... pode ter gente que se vê isso, gado pode ser também, não só a terra, mas o gado pode ser algo que dá poder, tenho tantas cabeças de gado, eu sou o cara! Isso pode ser também no imaginário das pessoas, a pessoa sempre viu, foi peão de fazenda, quando

\footnotetext{
${ }^{44}$ Dez assentados responderam não saber se algum membro da família havia conseguido o crédito.

${ }^{45}$ Dois assentados responderam não saber se algum membro da família havia conseguido o crédito.

${ }^{46}$ A soma total deveria ser 33 , entretanto o resultado foi 47 pessoas, pois os primeiros créditos foram consorciados para gado e/ou outro cultivo e/ou animal.

${ }^{47}$ A soma total deveria ser 23 , entretanto o resultado foi 32 pessoas, pois os primeiros créditos foram consorciados para gado e/ou outro cultivo e/ou animal.
} 
vira assentado quer ser o dono do gado. (Giselda Pereira Coelho, assentada no PA 26 de Março e dirigente do Setor de Produção do MST, 42 anos, 13 jul. 2016)

Uma forte expressão desse processo é a Cavalgada, manifestação cultural muito forte da agropecuária regional, que hoje adentra os assentamentos, especialmente nos momentos de comemoração do aniversário de conquista daquele território, competindo com a mística que celebra a história de luta dos sujeitos desde o acampamento até o recebimento dos lotes, reconstrói os conflitos e episódios em que companheiros vieram a óbito pelo conflito com o latifúndio. Esse elemento é discutido por uma assentada do PA $1^{\circ}$ de Março:

[...] Aí o elemento novo que entrou dentro da nossa festa que eu olho com aquele olhar assim, poxa, não poderia ser em outro momento, que é a questão da cavalgada. A festa do assentamento ela começa a ser discutida um mês, dois meses antes, mas essa cavalgada já se fala o ano inteiro, e qual o cavalo que eu vou, e que tipo de equipamento eu vou comprar para o meu cavalo, qual a equipe que eu vou participar, como é que vai ser a roupa da equipe, então o ano inteiro já se discuti a questão da cavalgada [...] e o foco da festa nesse momento é desconstruído, porque tudo se volta para a questão da cavalgada, eu não vejo a cavalgada como tipo é negativo, não, eu acho que é uma manifestação, já que a ideia do assentamento era ser um assentamento de produção e que essa produção hoje está voltada para um outro tipo de produção que é a questão da pecuária. A gente não pode negar, mas aí é assim, é desfocar esse momento único que é o festejo das famílias, se tu vier aqui numa festa de aniversário do assentamento tu vai contar as famílias que são históricas aqui que estão participando [...] então a gente tentamos fazer aqui até um almoço para os veteranos no dia da festa, montamos slides, nós já montamos quatro programações envolvendo slides, mística, mas nós não conseguimos apresentar, não consegue, porque pela manhã é montado o momento do culto ecumênico, depois do culto ecumênico vem o café da manhã, aí pronto, depois do café da manhã você não encontra mais brecha para nada [...]. (Cícera Justino Ferreira Pinto, assentada e professora no PA $1^{\circ}$ de Março, 39 anos, 12 jul. 2016)

É importante ressaltar que esse processo não se realiza com a mesma intensidade em todos os assentamentos, isso vai depender do grau de organização interna. Por exemplo, no PA 17 de Abril ainda é muito forte a mística do MST, reunindo todos os assentamentos e acampamentos da região.

Em face dessa crescente contradição nos assentamentos, o MST, em articulação com outros movimentos sociais regionais, nacionais e internacionais, tem se mobilizando em torno da agroecologia em sua dimensão educativa, como forma de pensar gradativamente uma possibilidade de mudança produtiva e de relação mais cooperativa entre os assentados, valorizando o conhecimento camponês e suas experiências de luta para que possam permanecer na terra. 
Nesse sentido, sobressaem-se duas experiências fundamentais, quais sejam, o Campus Rural de Marabá (CRMB) do Instituto Federal do Pará (IFPA) e o IALA Amazônico, que se originam da articulação entre diversos sujeitos da sociedade civil, como a universidade, os assentados, os acampados, os movimentos sociais (MST, FETAGRI, Via Campesina) e o Estado a partir das políticas públicas, especialmente o PRONERA.

\title{
5.2.1 CRMB/IFPA
}

A construção do Campus Rural de Marabá do IFPA, assim como as licenciaturas na atual UNIFESSPA (antigo campus da UFPA em Marabá), do IALA Amazônico, dentre outras instituições e cursos formativos, advém

\begin{abstract}
desse processo de luta e de enfrentamento aqui na região, por esse direito à universalização da educação [...] a educação tem que ser universalizada, a educação como um direito da classe trabalhadora [...] a formação como um direito humano [...] toda pessoa tem direito de se formar, de se escolarizar, de saber algumas coisas, de conhecer isso independente da profissão [...] e essas instituições, esses cursos são conquistas a partir desses embates, debates e construções coletivas [...] a partir do percurso formativo dentro do próprio PRONERA, dentro dessas parcerias para além do PRONERA que depois foram acontecendo (Maria Raimunda César de Sousa, dirigente do MST e professora, 42 anos, 12 jul. 2016).
\end{abstract}

De acordo com as lideranças do MST, no que tange especificamente ao CRMB/IFPA, sua gestação adveio da pauta da escola agrotécnica, que se tornou uma questão fundamental aos movimentos sociais nos anos 2000 ao colocarem esse anseio formalmente em um grande acampamento no INCRA nesse período ${ }^{48}$.

Esse debate posteriormente é retomado no Fórum Regional de Educação do Campo (FREC) do sudeste do Pará, criado no ano de 2005, a partir da $2^{\text {a }}$ Conferência Regional de Educação do Campo, correspondendo a uma forma de organização e luta dos movimentos e organizações sociais, além da universidade, por uma educação do campo. (FREC/SUPA 2011)

Esse debate acompanha as discussões nacionais por uma educação do campo, que ganhou força dentro do MEC com a criação da Coordenação Geral de Educação do Campo,

\footnotetext{
${ }^{48}$ Segundo Assis (2007) houve nesse período quatro grandes acampamentos nos anos de 1997, 1999, 2000 e 2001 que integravam o MST, FETAGRI, STRs, associações, dentre outros, que conseguiam mobilizar em cada acampamento 10 mil pessoas. Suas pautas de reivindicação se concentravam inicialmente na desapropriação de terras e créditos agrícolas, mas posteriormente começou a se pleitear como bandeira de luta a educação do campo e a assistência técnica.
} 
produzindo as Diretrizes Operacionais para a Educação Básica nas Escolas do Campo (CNE/CEB, 36/2001) e a construção de uma estratégia nacional que incluía a consolidação do programa Saberes da Terra, a implementação de um Plano Nacional de Formação de Profissionais da Educação do Campo e, no âmbito da sociedade civil, o fortalecimento dos fóruns de educação do campo, que, no sudeste paraense, foram produtos de sujeitos que atuavam desde as décadas de 1980 e 1990 em prol dos direitos educativos dos povos da região, envolvendo sindicatos, movimentos sociais, cooperativas, setores da universidade, CPT, alguns representantes progressistas das secretarias de educação da região, e posteriormente, funcionários do INCRA, da EMATER e ONGs, culminando em uma diversidade de sujeitos e, consequentemente, de concepções em torno da educação para os povos do campo, gerando diversos conflitos. Estes fizeram com que os movimentos sociais e sindicais se apropriassem da argumentação jurídico-científica para fazer frente aos representantes da classe dominante, produzindo alterações concretas no espaço agrário em termos educacionais (PEREIRA, 2015).

No FREC, a educação do campo passa a ser compreendida como um processo de formação dos camponeses, cujo conhecimento - enquanto práxis, pesquisa e alternância - é definido como um direito de todo sujeito do espaço rural, sendo de fundamental importância a relação trabalho-educação e, assim, a agroecologia ganha centralidade no fórum. Essa temática já era discutida por determinados sujeitos como professores e militantes do PRONERA e da Escola Familiar Agrícola (EFA) e pelos cooperados da COOPSERVIÇOS através da FATA, mas até 2011 existia pouco avanço no que concerne a uma análise crítica das experiências acumuladas na região de forma a incorporar a agroecologia nas formações camponesas. Os participantes do fórum indicaram que a educação do campo poderia mediar e sustentar cientificamente e institucionalmente essa nova proposta produtiva. No âmbito do fórum foi criado o Grupo de Trabalho em Agroecologia, com representantes da antiga UFPA, da CPT, da COOPSERVIÇOS, do MST, da FETAGRI, da EMATER e do CEPASP, para aprofundar o conceito e preparar a Conferência de Educação do Campo de 2011 que teria a agroecologia como temática central (PEREIRA, 2015).

Neste GT foram identificado dois problemas: a) havia poucas experiências agroecológicas que pudessem potencializar a articulação entre universidade e movimentos sociais nas áreas de reforma agrária, no intuito de obter um instrumento educativo de diferenciação entre os sistemas agroecológicos e os convencionais; b) havia dificuldade de articular a problemática local da agroecologia com a escala global na qual se insere o agronegócio. Desta feita, a Conferência acabou servindo como espaço de aprofundamento 
dessas questões, criando, com o apoio da Associação Brasileira de Agroecologia (ABA), um projeto de extensão intitulado de "A Construção do Conhecimento Agroecológico: Valorizando Práticas Inovadoras" por meio do CRMB/IFPA, já existente na época. Salientamos que a agroecologia começa a ser incorporada nas propostas de formação dos educadores dos agricultores e indiretamente nos projetos político-pedagógicos dos cursos do PRONERA a partir de 2010, assim como nos cursos do IFPA (PEREIRA, 2015).

É no bojo desse debate e das lutas em torno da educação do campo que se constitui a disputa pelo CRMB/IFPA no âmbito territorial, pois ele envolve o conflito geográfico de sua posição político-educacional. De um lado existia a proposta dos movimentos sociais e sindicais a respeito de onde seria a construção da instituição e do projeto educacional, que reforçaria a luta pela terra assim como a permanência nela a partir de outra matriz produtiva, pautada na agroecologia. Do lado oposto existia a discussão do agronegócio com o intuito de ceder um espaço para o desenvolvimento das atividades, o que implicaria ingerência sobre os cursos e demandas do IFPA.

A FETAGRI tinha o objetivo do transformar a EFA em uma escola agrotécnica e, para esse fim, a ideia era que o governo federal adquirisse, por meio da compra, o espaço em que a EFA funcionava para a instalação da escola agrotécnica, mas o governo entendia que, por ser uma área da União, não era passível de venda; além disso, o projeto previa apenas o orçamento para a construção da infraestrutura física.

Nesse ínterim, os movimentos sociais conseguem que o debate sobre o projeto político-pedagógico do Instituto Federal fosse construído por todos os movimentos no seio do FREC, assim como a discussão sobre o local de seu funcionamento, pois havia a intenção também de que fosse no Distrito Industrial de Marabá, onde funcionam as siderúrgicas, o que, por ser uma demanda do camponeses, não teria sentido, pelo enfrentamento histórico com as empresas siderúrgicas e agropecuárias e pelo distanciamento político-econômico que o projeto camponês propõe.

A ideia era pensar um espaço de formação para capacitação de profissionais para atuar no campo: "que esse profissional seja do campo e que vá viver nesse campo, que vai pensar esse campo, que vai pensar alternativas para o campo, para construir uma agricultura, um processo de formação" ${ }^{\text {49 }}$. Nesse sentido, o IFPA de Marabá surge do

[...] desejo dos camponeses e das camponesas nessa região, articulados nos mais variados movimentos sociais e das parcerias que foram construindo,

\footnotetext{
${ }^{49}$ Maria Raimunda César de Sousa, dirigente do MST e professora, 42 anos, 12 jul. 2016.
} 
dessa necessidade de fortalecer a educação nos acampamentos e nos assentamentos da reforma agrária, de colocar essas comunidades num outro patamar de disputa, então porque sem o curso superior a gente disputava com as prefeituras até certo ponto, depois não dava mais, porque eles usavam o argumento da legislação ou do concurso público, que só com pessoas com curso superior (podiam lecionar) e a gente tinha que cair fora, porque a gente não tinha. Então, assim, o Campus Rural de Marabá, que antes foi uma luta, antes era escola agrotécnica federal, ele foi uma luta, necessidade que a gente foi sentindo desde 1997, quando chegou o Projeto Lumiar aqui na região, que era um programa de assistência técnica do governo federal para os assentamentos da reforma agrária e a gente foi perceber que não tinham técnicos nessa região formados aqui, e a maioria dos técnicos, quem era formado mais próximo, era formado ali na escola agrotécnica de Araguatins (Tocantins) e depois tinha Castanhal, que era mais distante do que Tocantins, e os outros técnicos eles vinham todos do Nordeste. Então, do Nordeste foram companheiros valorosos, competentíssimos, mas era outro bioma lá, então, assim, o solo, o processo da região, o território eram outros. E a gente: "por que não formar os filhos dos próprios agricultores daqui?" Aí teve as experiências desde então e houve a escola agrotécnica de Marabá, toda luta, todos os movimentos pautavam, quando estavam fazendo luta colocavam na sua pauta de reivindicação a escola agrotécnica de Marabá. (Maria Raimunda César de Sousa, dirigente do MST e professora, 42 anos, 12 jul. 2016)

A luta era por uma formação profissional que viabilizasse uma assistência técnica compatível com as questões socioambientais da realidade amazônica e com vínculos relacionados à agricultura camponesa e não ao agronegócio, que dialogasse com os sujeitos do campo e com os movimentos sociais, incorporando os princípios da agroecologia.

Por esses motivos, travou-se a disputa pelo local do CRMB/IFPA para além do Distrito Industrial de Marabá: existia o projeto vinculado aos fazendeiros de que esse campus fosse instalado em uma área a ser doada pela fazenda Revemar, dentro de seus limites. Em contraposição, o MST, em 2008, acabava de conquistar definitivamente o PA 26 de Março, e existia ali a discussão sobre os espaços coletivos, dentre eles um local de formação dos agricultores. Assim, foi feita a proposição de que o CRMB/IFPA se constituísse em uma área doada dentro do assentamento. Essa proposta foi aceita pelos sujeitos envolvidos e efetivada em 2009 pelo Estado, que construiu o IFPA rural no território camponês.

Após essa definição do local e, consequentemente, da posição político-econômica que permearia o processo formativo do instituto, diversas reuniões e plenárias foram desenvolvidas no FREC para que fosse construído o projeto político-pedagógico, a partir das contribuições da universidade, dos movimentos sociais, da EMATER, dentre outras entidades. Seu conselho diretor é composto por representantes do MST, FETAGRI, FETRAF, FREC, estudantes, pais, técnicos, professores e direções (ensino, extensão e pesquisa), de forma que as decisões são tomadas de forma coletiva. 
Os cursos são oriundos das lutas históricas em torno da licenciatura e do convênio com o PRONERA e partem do princípio de que a agroecologia deve ser o elemento central da educação do campo, visto que os principais sujeitos abarcados com o Instituto Federal seriam sem-terra e assentados, mas igualmente o indígena devido a sua forte presença na região.

\subsubsection{IALA Amazônico}

Assim como o CRMB/IFPA, o Instituto Latino Americano de Agroecologia (IALA) Amazônico surge de uma articulação entre os movimentos sociais, a Via Campesina, a universidade e o INCRA.

Sua gestação advém do diagnóstico de que na região praticamente inexistia um sistema de ciência e tecnologia amazônico que subsidiasse as experiências no âmbito científico para o aperfeiçoamento de processos referentes à recuperação de áreas degradas e sistemas de produção sustentáveis. Além disso, os lotes destinados aos assentamentos são incompatíveis com a prática de exploração florestal extensiva e de baixo impacto, devido ao reduzido espaço destinado às famílias nos PAs, o que contribui para uma intensificação do uso do solo nessas realidades e dificulta o desenvolvimento de agroecossistemas sustentáveis sem a devida incorporação de inovações agroecológicas. Para além de iniciativas sustentáveis nos sistemas de produção familiar e nos sistemas técnicos locais, isso implica também uma

luta pela hegemonia de um projeto de desenvolvimento popular e emancipatório na região como um todo e que enfrenta forte oposição de outros projetos de desenvolvimento, articulados na escala regional, nacional e mundial (UFPA, 2010, p. 5).

O espaço do IALA Amazônico se localiza em um lote coletivo do Assentamento Palmares II. Esse local é produto de um projeto oriundo de um dos núcleos de famílias existentes entre os anos iniciais da década de 2000, intitulado Núcleo Filhos da Terra. O objetivo era desenvolver atividades em conjunto que, embora não tenham gerado o resultado esperado de cooperação, conseguiram criar um espaço para formação dos sujeitos sob a coordenação do MST (ver Foto 32). 
Foto 32 - Salão de reunião e aulas do IALA Amazônico

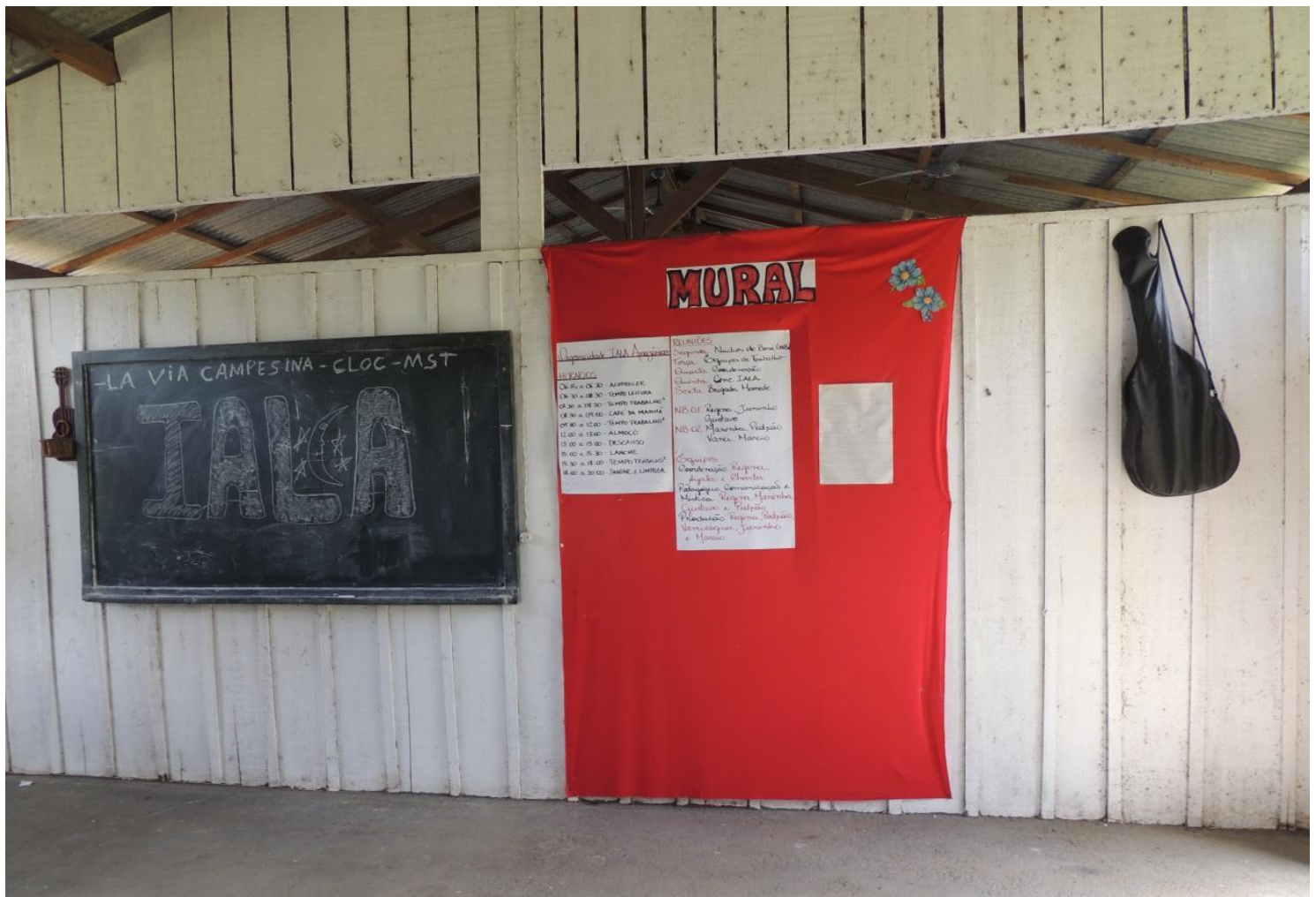

Fonte: Rogério Rego Miranda, Parauapebas, 2015.

A rede de IALAs surgiu no interior da Alternativa Bolivariana das Américas (ALBA) a partir da articulação do governo venezuelano e da Via Campesina, como o objetivo de desenvolver

[...] cursos de graduação em outras áreas do conhecimento, bem como cursos informais, seminários, oficinas, centro de pesquisa agroecológica - com um banco de sementes internacionais - [que] fazem parte dos planejamentos e missão político-estratégica dos IALAs para enfrentar a ofensiva do capital financeiro na agricultura e a política do agronegócio (STRONZAKE, 2009, p. 13)

Atualmente existem a Escola Latino Americana de Agroecologia no Paraná, criada em 2005; o IALA Paulo Freire na Venezuela, criado em 2006; o IALA Guarani no Paraguai, criado em 2008. Foram discutidos no ano de 2009 o IALA Andino na Colômbia; a Escola Nacional de Agroecologia no Equador e o IALA Yacucho no Peru. O IALA Amazônico, em Parauapebas, surgiu de reflexões que se iniciam em 2008.

A ideia é pensar, a partir dos IALAs, alternativas agroecológicas que considerem as particularidades dos biomas e, ao mesmo tempo, constituir uma rede internacional de conhecimento por onde transitem experiências e acúmulos histórico-geográficos que permitam refletir alternativas de uso do solo e de enfrentamento do agronegócio. 
[...] assim, como o que a gente vai pensar aqui não vai servir para muitas regiões do Brasil, que vai ser muito do vínculo e do jeito de fazer agricultura dos camponeses dessa região, dos sujeitos que tem o ribeirinho, que tem o indígena, que tem o quilombola, tem o clima, os bichos, a fauna e a flora nossa. Eles vão se diferenciar, então requer uma formulação específica. Então os IALAs, eles foram pensados nesse sentido, de como você pensar essa matriz de forma global do ponto de vista dos trabalhadores, mas com as especificidades de cada grande região, de cada território. Então ele foi um pouco pensado assim, o amazônico vai pensar isso, ele foi isso, uma instituição vinculada aos camponeses para pensar de que forma a gente se articula para fortalecer a agricultura camponesa mesmo, dentro desse bloco de movimentos sociais vinculados à Via Campesina, uma espécie de como que a gente constrói na ciência, na tecnologia um contraponto ao agronegócio, a matriz do capital na agricultura, é o nosso contraponto, é formação [...] e aí os IALAs é assim, o agronegócio considera só a produtividade do ponto de vista do produto e desconsidera toda a biodiversidade, desconsidera toda a vida do sujeito, todos os valores, então os IALAs, estão denunciando isso como é que o IALA então pensa essa agricultura, pensa essa matriz, essas técnicas considerando a biodiversidade, considerando os sujeitos envolvidos em cada território. (Maria Raimunda César de Sousa, dirigente do MST e professora, 42 anos, 12 jul. 2016)

Nesse sentido, o IALA Amazônico vem a contribuir com a construção do intercâmbio de saberes, ou seja, o científico e o popular, a partir da particularidade da Pan-Amazônia e seus países (Brasil, Bolívia, Peru, Equador, Colômbia, Venezuela, República da Guiana, Suriname e Guiana Francesa). Seus principais objetivos são:

a) formar técnicos-pedagogos dos movimentos sociais do campo em agroecologia, para contribuírem para a organização do campesinato e da classe trabalhadora latino-americana, na busca da promoção de projetos de desenvolvimento mais condizentes com a sócio-diversidade da Amazônia, tendo como referência a agroecologia na geração de formas sociais de cooperação do trabalho;

b) ser uma ferramenta de luta política e prática de construção da soberania alimentar e energética na região amazônica;

c) contribuir diretamente para a execução de uma política ampla de reabilitação da diversidade florestal/ambiental, promovendo dinâmicas transitórias de valorização e aprimoramentos tecnológicos, rejeitando a hegemonia da matriz tecnológica convencional, tendo como protagonistas as comunidades camponesas e as demais variações da agricultura familiar amazônica;

d) construir alianças políticas, pedagógicas e escolares com as universidades, escolas, entidades ambientais e organizações sociais do bioma amazônico (UFPA, 2010, p. 5-6).

O primeiro curso desenvolvido no IALA Amazônico foi o de especialização, no ano de 2011, denominado de "Educação do Campo, Agroecologia e Questão Agrária na Pan- 
Amazônia", que compunha o programa Residência Agrária $^{50}$ e tinha como parceiros a universidade (responsável pelo quadro docente e o processo de qualificação dos estudantes); o INCRA (sua participação consistia em articular, implantar e acompanhar o programa Residência Agrária); a Via Campesina (incumbida de mobilizar assentados, sem-terra, pescadores, ribeirinhos, extrativistas, indígenas, quilombolas, dentre outros, a participarem das atividades propostas pelo projeto, além de cooperar com a seleção dos educandos e a elaboração e acompanhamento deles ao longo do curso); os movimentos sociais (que devem mobilizar suas lideranças para divulgar e participar do projeto); e o MST (que cedeu o espaço físico do assentamento e contribui para a organização do projeto em conjunto com a universidade e a Via Campesina). O público esperado era de quarenta educandos da Amazônia Brasileira e dez dos outros países que integram a Via Campesina Internacional e a Pan-Amazônia (UFPA, 2010).

Entretanto essa primeira turma, ofertada entre os anos de 2011 e 2012, atendeu apenas 28 educandos provenientes do Equador, Colômbia e Brasil (Pará, Maranhão, Tocantins, Mato Grosso e Rondônia), que eram docentes em escolas do campo, técnicos de extensão rural e mobilizadores de organizações políticas (MICHELOTTI, 2015).

Dessa primeira experiência formativa se realizou um conjunto de reflexões com fundamentos que balizariam a estratégia do IALA Amazônico:

1. A estrutura física do IALA Amazônico (a atual e a que será construída) deverá romper com o modelo convencional de construção arquitetônica, incorporando o acúmulo histórico dos camponeses amazônicos a respeito dos princípios da permacultura e do trabalho voluntário daqueles que passam pelo IALA Amazônico. Não perdendo de vista o diálogo com a Educação do Campo, em especial a do trabalho (agrícola e não agrícola) como princípio educativo, e o fortalecimento de um sistema produtivo integrado passível de ser desenvolvido em uma unidade de produção camponesa.

2. O IALA Amazônico deverá ser um centro de convergência das diversas experiências contra-hegemônicas e ou emancipatórias desenvolvidas no âmbito da Pan-Amazônia, contribuindo com a ressignificação das práticas políticas, pedagógicas organizativas e produtivas das organizações camponesas, diante de um processo cada vez mais acelerado de hegemonização do grande capital com a apropriação privada dos territórios e dos recursos naturais transformando-os, tudo e todos, em mercadorias.

3. O IALA Amazônico deverá ser um centro de articulação das diversas organizações sociais que estão em luta na Pan-Amazônia, dialogando com as

\footnotetext{
50 "Residência Agrária é uma modalidade de pós-graduação lato sensu (nível de especialização) atendida pelo Programa Nacional de Educação na Reforma Agrária (PRONERA) cujo objetivo é garantir uma formação de diferentes sujeitos que atuam nos assentamentos (assentados, técnicos e educadores de escolas do campo) baseada na inter-relação entre assistência técnica, educação do campo e desenvolvimento rural. Para tanto, é prevista uma ampla vivência dos educandos da especialização nos assentamentos de reforma agrária e comunidades rurais" (MICHELOTTI, 2015, p. 384).
} 
lutas insurgentes emergidas na América Latina em articulação com outros camponeses e camponesas organizados em escala global, com a perspectiva de construir lutas permanentes em âmbito local, regional e internacional contra o sistema capitalista e em prol de uma nova sociedade com base nos princípios humanistas e socialistas. (IALA, 2013, s/p)

É importante percebermos como esse diálogo de saberes que se inicia no IALA - a partir de reflexões oriundas das experiências dos educandos e dos princípios da agroecologia, correlacionando-os à problemática da questão agrária em diversas escalas geográficas apresenta um caráter teórico e prático, pois sempre desencadeia um projeto de intervenção que tem como laboratório o Assentamento Palmares II e o próprio IALA, com a discussão e a execução, por exemplo, da horta mandala (ver Foto 33), do minhocário, das fossas biossépticas, do sistema de captação de água, dentre outras ações que podem ser replicadas nos locais de moradia dos educandos.

A partir do que discutimos até o presente momento, observamos que no âmbito da luta pela terra a educação do campo e a agroecologia compreendem pilares de sustentação importantes, que se desenvolvem a partir do que Meek (2014) vai denominar de políticas de escala educacional, pois embora sejam projetos contra-hegemônicos realizados na escala local, são provenientes de ações territoriais que mobilizam múltiplas escalas e sujeitos para que se efetive.

\section{Foto 33 - Horta mandala do IALA Amazônico}

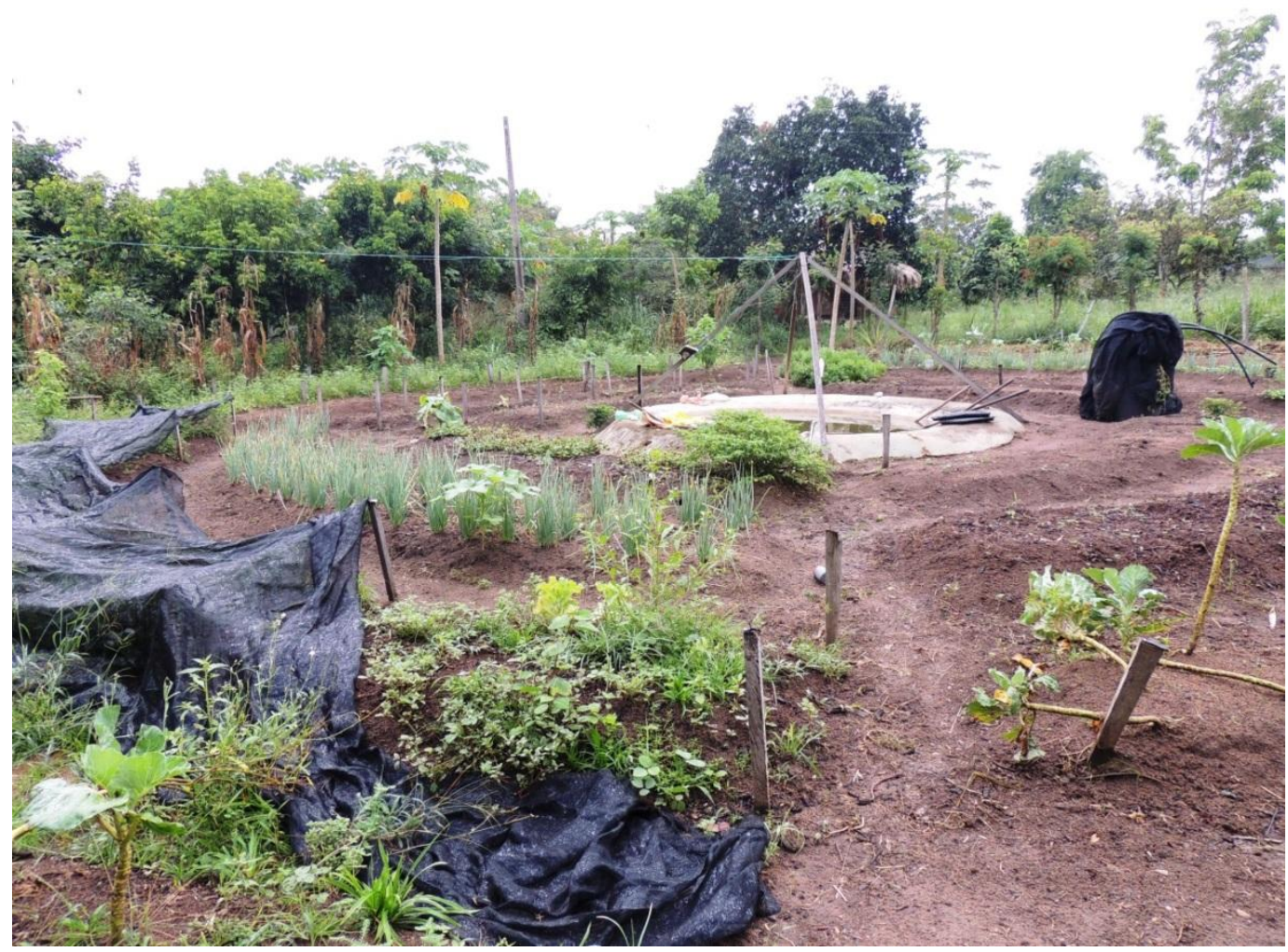

Fonte: Rogério Rego Miranda, Parauapebas, 2015. 
Para Meek (2014), que refletiu sobre a dimensão educacional e agroecológica sob o prisma do que ele intitula de "ecologia política da educação", tomando como referência empírica o Assentamento 17 de Abril, os movimentos sociais se envolvem em lutas simultaneamente locais, regionais e nacionais em torno da reforma da educação, resultando em alterações nas políticas públicas e nas práticas de aprendizagem sobre a dimensão socioambiental, a exemplo do PRONERA e do próprio PRONAF, que criou uma linha de crédito para agroecologia, em resposta à pressão dos movimentos sociais.

No sudeste paraense a agroecologia assume uma importância discursiva no seio do MST, muito embora sua prática efetiva nos assentamentos que o MST ajudou a construir ainda seja muito incipientemente, conforme pudemos observar em nossa pesquisa e igualmente foi identificado nos trabalhos de Meek (2014) e Costa (2014). Isso é reflexo, por um lado, de uma estrutura territorial muito marcada por conflitos de terra e que demanda do movimento a permanente luta pelo território, além de refletir experiências produtivas pouco exitosas com base na perspectiva da cooperativa e a crescente pecuarização nos projetos de assentamento. Por outro, os espaços de discussão da agroecologia e da educação do campo vêm ajudando a construir um outro consenso em torno do território, pautado nas experiências camponesas e dos movimentos sociais, como o MST.

De uma maneira geral, nosso trabalho buscou compreender, por um lado, como o MST vem construindo no seio da sociedade civil a proposta de uma contra-hegemonia, fundada em uma base territorial que expressa as relações de poder e suas assimetrias no sentido da disputa pela hegemonia, particularmente na realidade do sudeste paraense. Esta apresenta seu espaço agrário marcado por conflitos de terra, tanto no âmbito de sua conquista quanto no da permanência, face às diversas ações de desterritorialização implementadas pelo Estado e as empresas mineradoras e/ou agropecuárias, atreladas ao capital financeiro.

Por outro, o MST historicamente vem construindo territorialmente condições de implantação de uma proposta de outro projeto de sociedade que está em aberto, é conflituosa, contraditória, mas acima de tudo, é advinda da classe subalterna camponesa articulada com os trabalhadores da cidade.

Para melhor compreensão de como se estrutura a estratégia de contra-hegemonia do MST nos pautamos nas reflexões gramscianas sobre hegemonia e seu instrumental analítico que permite, a partir da formação econômico-social, perceber como o MST constrói sua territorialidade no sudeste paraense frente a hegemonia do projeto agropecuário e mineral. Para esse fim, formulamos o Quadro 13, que pretende fornecer uma síntese desse processo. 
$\mathrm{O}$ quadro a seguir retoma os principais conceitos de Gramsci trabalhados em nossa pesquisa, com o intuito de compreender a dimensão territorial da contra-hegemonia implementada pelo MST, a partir da estratégia de construção de uma rede de luta pela terra e pela educação, da utilização de uma política de escala e do desenvolvimento de um bloco histórico-geográfico mediante alianças territoriais com outros movimentos sociais. Tais ações permitiram a estruturação dos assentamentos e acampamentos, assim como a alteração das políticas públicas no âmbito educacional e a criação de experiências institucionais pautadas na agroecologia, que auxiliam na luta cotidiana de permanência na terra. 
Quadro 13 - Territorialização contra-hegemônica do MST no sudeste paraense

\begin{tabular}{|c|c|c|c|c|c|}
\hline $\begin{array}{l}\text { Elementos importantes } \\
\text { para a construção da } \\
\text { contra-hegemonia }\end{array}$ & \begin{tabular}{|c} 
Palavras de ordem do MST \\
(simbolismo da disputa \\
territorial)
\end{tabular} & $\begin{array}{l}\text { Tripé do projeto contra- } \\
\text { hegemônico do MST }\end{array}$ & Concepção & Formas de luta territorial & $\begin{array}{l}\text { Estratégias locais, } \\
\text { regionais, nacionais, } \\
\text { internacionais }\end{array}$ \\
\hline \multirow{3}{*}{$\begin{array}{c}\text { - Filosofia da práxis } \\
\text { - Guerra de posição } \\
\text {-Bloco histórico-geográfico } \\
\text {-Formação de intelectuais } \\
\text { orgânicos } \\
\text {-Construção de um consenso } \\
\text { ativo }\end{array}$} & $\begin{array}{c}\text { "Reforma agrária: uma luta } \\
\text { de todos"; } \\
\text { "Ocupar, resistir e produzir". }\end{array}$ & Terra & Terra de trabalho & $\begin{array}{l}\text { - Manifestações } \\
\text { - Ocupações } \\
\text { - Assentamentos }\end{array}$ & $\begin{array}{l}\text { - Rede geográfica solidária } \\
\text { camponesa de luta pela terra; } \\
\text { - Política de escala } \\
\text { camponesa de luta pela terra; } \\
\text { - Alianças territoriais. }\end{array}$ \\
\hline & $\begin{array}{l}\text { "Educação é um direito e não } \\
\text { uma mercadoria!"; } \\
\text { "Ocupar, resistir e produzir } \\
\text { também na educação". }\end{array}$ & Educação & Formação emancipatória & $\begin{array}{l}\text { - Disputa pelos aparelhos } \\
\text { privados de hegemonia; } \\
\text { - Filosofia da Práxis } \\
\text { - Intelectual orgânico }\end{array}$ & $\begin{array}{c}\text { - Educação do campo; } \\
\text { - Rede de ensino em diversos } \\
\text { níveis que integram } \\
\text { acampamentos e } \\
\text { assentamentos; } \\
\text { - Disputa por políticas } \\
\text { públicas específicas à } \\
\text { educação do campo; } \\
\text { - Disputa de cursos na } \\
\text { universidade e no IFPA; } \\
\text { - Construção do IALA } \\
\text { Amazônico. } \\
\end{array}$ \\
\hline & $\begin{array}{c}\text { "Pela soberania alimentar, } \\
\text { contra a violência e o } \\
\text { agronegócio". }\end{array}$ & Produção & Agroecologia & \begin{tabular}{|c|}
-Produção coletiva/individual \\
contraposta ao agronegócio \\
-Produção agroecológica \\
como uma expressão da \\
filosofia da práxis \\
\end{tabular} & $\begin{array}{l}\text { - Educação do campo com } \\
\text { ênfase na agroecologia; } \\
\text {-Experiências agroecológicas } \\
\text { nos assentamentos. }\end{array}$ \\
\hline
\end{tabular}

Fontes: Gramsci (1978; 1987; 1995; 2000; 2001; 2005; 2014); Pesquisa de Campo, 2016. Organização: Rogério Rego Miranda. 


\section{CONCLUSÕES}

As discussões tecidas até o presente momento revelam a necessidade de observarmos os movimentos sociais de uma maneira mais aprofundada, destacando sua dimensão territorial que nos indica a complexidade com a qual esses movimentos desenvolvem suas estratégias; daí a proposição de pensarmos os movimentos socioterritoriais (FERNANDES, 2001). Estes compreendem o território como um trunfo (RAFFESTIN, 1993) que corresponde ao principal meio de reprodução (recurso), assim como o é para o agronegócio pautado no capitalismo rentista próprio da formação econômico-social do Brasil e, particularmente, da Amazônia. Para Raffestin o território corresponde ao campo de ação dos trunfos, dentre os quais destacamos neste trabalho a terra, envolta em "relações de produção e de propriedade" (1993, p. 230) que, ao interagir, "produzem um sistema de relações de poder" (1993, p. 230).

Segundo Fernandes (2005), movimento social e movimento socioterritorial compreendem o mesmo sujeito coletivo, cuja organização conjunta objetiva uma determinada ação que possibilite a defesa de seus interesses e a transformação da realidade; logo, estão disputando um projeto de desenvolvimento territorial, daí o conflito fazer parte do cotidiano dos movimentos socioterritoriais. Estes, igualmente, devem ser compreendidos em sua multidimensionalidade - econômica, política, social, cultural e ambiental - e podem atuar em escalas diversas, dependendo do grau de organização e articulação. Por exemplo, os movimentos socioterritoriais isolados são mais restritos à escala local, enquanto que os movimentos socioterritoriais territorializados trabalham em mais de uma escala geográfica. Em suma, tanto movimentos isolados quanto territorializados representam a disputa por um tipo de território que é divergente do território do capital - embora, contraditoriamente, os assentamentos conquistados e organizados pelos movimentos socioterritoriais sejam atrelados ao capital e, em determinados contextos, orientados por ele -, por isso observamos a presença de múltiplas territorialidades na realidade concreta:

Temos então uma disputa territorial entre capital e campesinato. As propriedades camponesas e as capitalistas são territórios distintos, são totalidades diferenciadas, onde se produzem relações sociais diferentes, que promovem modelos divergentes de desenvolvimento. Territórios camponeses e territórios capitalistas como diferentes formas de propriedades privadas disputam o território nacional. Para se compreender essa disputa é importante uma análise dos níveis e escalas territoriais: o primeiro território e o segundo território. O primeiro território é formado pelos espaços de governança em diferentes escalas: nacional, regional, estadual, municipal, distrital. O segundo território é formado pelos diferentes tipos de propriedades particulares. Por exemplo: o segundo território é uma fração 
do primeiro território, ou seja, os diferentes tipos de propriedades são frações do território municipal, que é uma escala do primeiro território. Este é fração do território estadual, que por sua vez é fração do território nacional. (FERNANDES, 2008, p. 280)

Pedon (2009) acrescenta que o movimento socioterritorial se fundamenta pela organização de uma agenda permanente, com medidas sistemáticas com o intuito de transpor os obstáculos impostos à organização do movimento, construindo paulatinamente planos e metas. Essa agenda corresponde a uma prática política, cujo processo de construção se vale de três momentos: a comunicação - reuniões de socialização dos valores intrínsecos aos movimentos; a edificação do espaço interativo - mobilização de trocas de experiências e aprendizados, que possibilitem a conscientização de que são excluídos; e a definição dos espaços geradores de sujeitos - produção de reflexões e da (re)elaboração de estratégias e objetivos, em conformidade com as especificidades do movimento socioterritorial.

Em concordância com essas proposições, nosso trabalho também entende que a leitura dos movimentos sociais carece de uma discussão sobre o território, em suas manifestações material e imaterial, que se encontram interligadas. Porém, analisamos o caráter contrahegemônico do projeto territorial dos movimentos, com destaque ao MST, foco de nossa pesquisa na realidade do sudeste paraense.

A contra-hegemonia aqui discutida não se limita à produção de um conjunto de estratégias que visam apenas resistir em um dado espaço-tempo específico, mas que, como anuncia Pedon (2009), almejam igualmente uma agenda permanente, em que se (re)elabore o projeto de desenvolvimento territorial proposto ao campo; em outras palavras, uma guerra de posição de longa duração. Nesse sentido, a contribuição gramsciana é de fundamental importância, pois seus conceitos nos ajudam a compreender, à luz da formação territorial da realidade, de que maneira o MST vislumbra a condição do moderno príncipe, a partir da disputa pelo território, contudo não apenas como trunfo, no seu sentido material, mas igualmente como meio de constituir um projeto contra-hegemônico desenvolvido mediante um consenso ativo, produzido com base nas experiências, necessidades, trajetórias geográficas dos sujeitos. Por isso há a disputa pela (re)apropriação dos aparelhos privados de hegemonia, ressaltando que essa hegemonia prossupõe a construção de um domínio e de um consenso - no caso dos movimentos socioterritoriais, de um domínio coletivo e um consenso advindo da classe subalterna.

Esses elementos são fundamentais para a compreensão do nosso objetivo de pesquisa, que versa sobre a análise $\mathrm{da}(\mathrm{s})$ forma(s) de territorialização contra-hegemônica desenvolvida(s) pelo MST, na realidade do sudeste paraense, e que tem como recorte espacial 
os assentamentos consquistados por esse movimento socioterritorial, no período de 1994 a 2016.

Nesse sentido, compreendemos que o MST utilizou como estratégia inicial de territorialização a luta pela terra, apropriando-se da experiência da resistência posseira, cuja ação sindical, em um primeiro momento, divergiu do MST por esse movimento socioterritorial representar a possibilidade de disputa pelas ações relativas à reforma agrária na região, além de apresentar estratégias bem diferentes em termos da forma como se realizava a ocupação das terras por parte dos posseiros até a década de 1980. Porém, estes últimos, posteriormente, acabaram por tecer com o MST uma aliança territorial, conformando um bloco histórico-geográfico ainda em aberto, contraditório, com ações conjuntas momentâneas no caso de ocupações de terras, todavia cada vez mais frequentes no que tange à disputa pelos aparelhos privados de hegemonia, com destaque para o âmbito educacional, ações coletivas que são conhecidas regionalmente como "arco da aliança".

Como a luta pela terra era a principal forma de territorialização do MST nos anos iniciais da década de 1990, ele adotou como táticas a ocupação de grandes fazendas, enfrentando os agentes econômicos hegemônicos da região, como os antigos donos dos castanhais, que reinavam política e economicamente até os anos 1960, mas que passaram por uma relativa crise de hegemonia em decorrência da modernização empreendida pelo governo federal na década de 1970, que priorizou o capital internacional e empresários do Centro-Sul do país. Esses donos dos castanhais igualmente se modernizaram e transformaram as áreas de extrativismo em locais de exploração madeireira e, seguidamente, de pecuária.

Além desses sujeitos, o MST vai conflitar com os novos agentes econômicos que se apropriaram irregularmente de grandes extensões de terras por meio da compra de áreas dos antigos donos dos castanhais ou de porções pertencentes a assentamentos criados pelo GETAT, que, por não apresentarem condições mínimas de reprodução social e econômica, perderam muitos assentados, que acabavam se desfazendo da propriedade para mais uma vez se tornarem migrantes ou que simplemente eram expulsos. Um terceiro agente com que o movimento socioterritorial entrou em choque foram as empresas mineradoras, com destaque para a atual Vale.

Muitas dessas ocupações de terra desencadearam ou não a construção de acampamentos, local de permanência dos sem-terra ao longo de anos, desenvolvendo, por meio dos núcleos de base, relações de sociabilidade e ações coletivas, dentre as quais destacamos as manifestações desenvolvidas em conjunto com outros assentamentos e/ou acampamentos do MST ou dos demais movimentos sindicais, principalmente a FETAGRI. 
A partir dessas táticas o MST pode conquistar os assentamentos que priorizamos em nossa pesquisa, quais sejam: $1^{\circ}$ de Março, em São João do Araguaia; 26 de Março, em Marabá; 17 de Abril, Cabanos, Canudos e Lourival Santana, de Eldorado dos Carajás; Palmares II e Onalício Barros, em Parauapebas; e Nega Madalena, de Tucumã.

Salientamos que, durante a produção desta tese, visitamos diversos acampamentos organizados pelo MST com o intuito de compreender melhor essa condição de extrema precariedade territorial e de violência simbólica e física devido, entre outras razões, às restrições de deslocamento que os acampados sofrem cotidianamente, pois podem vir a óbito ou serem agreditos ao realizar muitas de suas atividades diárias como caça na mata; à assepsia e pesca nos rios próximos; à saída para trabalhar na cidade ou nas vilas rurais da região; à saída para estudar. Nos locais visitados, interagimos com sujeitos de trajetórias geográficas diversas, mas que convergiam em processos histórico-geográficos comuns, marcados por expropriação, negação de direitos, perda de entes queridos, preconceito, exploração exacerbada do seu trabalho e necessidade de migrar compulsoriamente, elementos que fizeram esses diversos sujeitos encontrarem-se no movimento sem-terra e ressocializarem-se como protagonistas da luta pela conquista de sua terra.

Ao findar nossa pesquisa de campo em 2016 alguns desses acampamentos estavam na eminência de se tornar assentamentos, gozando da condição de "pré-assentamento", como dizem os acampados nessa situação, a exemplo do Dalcídio Jurandir, em Eldorado de Carajás; João Canuto, em Sapucaia; e Roseli Nunes, em Tucumã. Todos já estavam com os lotes devidamente "cortados" e distribuídos entre os sem-terra, com anuência do INCRA, que, por sua vez, já havia feito a vistoria da fazenda e estava, em alguns casos, apenas negociando o preço a ser pago pela área. Noutros acampamentos visitados, a saber: Helenira Resende e Hugo Chávez, em Marabá, e Frei Henri de Roisiers, em Curionópolis, ainda não se tinha, em 2016, uma definição sobre se seriam transformados em assentamentos, contudo eram alvos de diversas investidas por parte dos fazendeiros, que se utilizam da tática de bloqueio das estradas para chamar atenção da sociedade e da mídia, tal qual fazem os movimentos socioterritoriais e sindicais, no sentido de "denunciar" que os seus direitos de propriedade privada estão sendo lesados. Também, utilizam a antiga tática de intimidação com a contratação de pistoleiros para queimar os barracos, destruir as roças e atirar em direção ao acampamento.

Muitas dessas violências e precariedades que, no período estudado, observamos nos acampamentos existentes no sudeste paraense foram relatadas e experienciadas pelos assentados. Estes, por seu turno, atualmente enfrentam a luta pela permanência no seu 
território face às disputas que desenvolvem em relação aos fazendeiros que moram nas proximidades, os novos agentes econômicos que redefinem relações internas com a compra de propriedades, intimidações, mercantilização das relações e distanciamento do movimento socioterritorial.

Nesse contexto o MST teve de implementar estratégias que vão além da luta pela terra - embora esta permaneça importante no contexto do sudeste paraense, em decorrência da forte concentração fundiária - visando a construção de um outro projeto de desenvolvimento territorial a ser disputado com a hegemonia do capital agromineral na região, o que denominamos de projeto contra-hegemônico.

Para esse fim, somando-se às ocupações de terras e manifestações, ou mesmo para a permanência da territorialidade do movimento socioterritorial, foi necessário a estruturação histórica da rede geográfica solidária camponesa de luta pela terra, que permitiu ao MST a construção dos assentamentos existentes, assim como dos acampamentos, estabelecendo entre eles relações de solidariedade e ajuda mútua, além de uma rede de parentesco.

Paralelamente, expandiu-se o bloco histórico-geográfico por meio de alianças territoriais mais amplas, através da Via Campesina, que se articula em diversas escalas geográficas, ou ainda, utilizou-se da política de escala para criação dos assentamentos e a implementação de políticas públicas, dentre as quais destacamos o PRONAF e o PRONERA, consubstanciando o tripé no qual atua mais incisivamente o MST: Terra-ProduçãoEducação.

A rede geográfica solidária camponesa de luta pela terra e do bloco históricogeográfico em desenvolvimento possibilitaram a construção de propostas contra-hegemônicas e a implementação destas nos PAs como medidas para que os assentados e suas gerações futuras permaneçam nos territórios conquistados por meio de muito sangue, suor e luta. Para este fim, foi importante a disputa dos aparelhos privados de hegemonia para pensar um outro modelo de educação que considere os sujeitos do campo e suas especificidades - daí o MST formular um conjunto de princípios que deveriam nortear o ensino nos acampamentos e assentamentos, contribuindo para a formação de intelectuais orgânicos.

O MST, em conjunto com outros movimentos socioterritoriais e sindicais, vai se utilizar de políticas de escalas educacionais (MEEK, 2014) para repensar regionalmente e nacionalmente as políticas públicas, no intuito de construir a Educação do Campo, com a ampla participação dos movimentos, sendo importante nesse processo o PRONERA, que garantiu gradativamente a alfabetização de crianças, jovens e adultos residentes no espaço agrário brasileiro e, particularmente, do sudeste paraense. 
Entretanto, mais do que isso, o PRONERA reforçou o projeto do MST de "ocupar as escolas" com professores formados a partir dos seus princípios, e igualmente ajudou a construir cursos nas Universidades e Institutos Federais do Pará, que se tornam outro local de disputa com os agentes econômicos hegemônicos, como as empresas mineradoras, que incentivam os cursos de engenharias, e os fazendeiros, que priorizam os cursos voltados para o agronegócio.

Articulada a proposta de uma reforma agrária popular e a uma educação emancipatória, o MST hoje também incentiva uma produção agroecológica. Antes dessa proposta contra-hegemônica no sudeste paraense foi desenvolvida uma ação pouco exitosa de cooperativas agroindustriais, cujas estruturas foram implementadas pelo estado nos PAs, principalmente em virtude do massacre de Eldorado dos Carajás. A ideia era construir projetos produtivos coletivos, mas o ponto de partida era uma relação social regional pautada em relações individuais devido às atividades anteriores dos sem-terra serem marcadas por sociabilidades mais distantes e pouco coletivas: atuavam como garimpeiros, peões, vaqueiros, empregados em empresas etc.

Em princípio, as cooperativas foram desenvolvidas pelo MST a partir de modelos externos ao sudeste paraense e pouco consideraravam as experiências históricas de ações coletivas dos sujeitos, suas próprias expectativas, necessidades e anseios; esse modelo acabou consubstanciado em ideias fora do lugar.

Nesse contexto, por um lado, a construção de cooperativas não surtiu o efeito esperado de consolidar o cooperativismo entre os assentados, que findaram por retomar projetos individuais em suas propriedades; por outro lado, esses sujeitos sentiram a necessidade de criar algumas ações coletivas que não partiram de modelos impostos mas de produtos que achavam mais condizentes com suas trajetórias geográficas de uso do solo e com aqueles sujeitos que, ao longo da história do assentamento, teceram um conjunto de relações de proximidade, seja de vizinhança ou de parentesco.

Contrariamente à intencionalidade de uma produção coletiva e diversificada, há hoje nos assentamentos um forte processo de pecuarização incentivada pelo próprio Estado via políticas públicas como o PRONAF e pelos atravessadores, fazendeiros, laticínios efrigoríficos que compram direta ou indiretamente os produtos oriundos da pecuária, como o leite e a carne bovina, contribuindo para uma forte dependência dos assentados em relação ao mercado, muito embora a diversificação não deixe de existir, pois é a condição da reprodução camponesa face às crises do próprio mercado que concorrem para oscilação dos preços do leite e da arroba do animal. 
Com o intuito de contribuir com a diminuição dos problemas causados pela pecuarização nos PAs no âmbito econômico (maior dependência em relação ao mercado), político (distanciamento do próprio movimento socioterritorial e das estratégias de defesa do território historicamente desenvolvidas por aqueles que integram o movimento), ambiental (degradação progressiva do solo e das áreas de matas, contribuindo inclusive para o assoreamento e contaminação dos rios) e cultural (com a perda da identidade sem-terra e da memória da conquista da luta pela terra materializada nas místicas, que dão lugar à cavalgada), o MST vem discutindo cada vez mais a importância de uma produção agroecológica.

A agroecologia envolve a construção de um projeto territorial contra-hegemônico que se pauta na filosofia da práxis, ou seja, em um conjunto de valores produzidos a partir das experiências dos sujeitos do campo, cujos saberes são fundamentos para a construção de uma teoria transformadora da realidade, em que o papel dos movimentos socioterritoriais e sindicais, em consonância com a participação das Universidades (Unifesspa) e dos Institutos (campus Rural de Marabá do IFPA e IALA Amazônico), é de grande importância para garantir a inclusão desses saberes em políticas públicas, em cursos de ensino básico e superior e na própria realidade dos PAs. Apesar disso, a agroecologia ainda tem uma difusão mais discursiva do que prática nessas realidades, visto o longo tempo de luta pelo território, as experiências pouco frutíferas de cooperativismo, o forte incremento da pecuária e a diminuta assistência técnica (especialmente porque ela ainda está fortemente marcada por um viés produtivista e não agroecológico), o que está sendo repensadado pelos Institutos nos cursos direcionados aos filhos dos assentados.

Em termos gerais, a proposta contra-hegemônica do MST no sudeste paraense compreende a terra como locus de reprodução camponesa em suas mais diversas dimensões, compreendendo-a como terra de trabalho, conflitando com a terra de negócio, conforme conceitua Martins:

Quando o capital se apropria da terra, esta se tranforma em terra de negócio, em terra de exploração do trabalho alheio; quando o trabalhador se apossa da terra, ela se tranforma em terra de trabalho. São regimes distintos de propriedade, em aberto conflito um com o outro. Quando o capitalista se apropria da terra, ele o faz com o intuito do lucro, direto ou indireto. Ou a terra serve para explorar o trabalho de quem não tem terra; ou a terra serve para ser vendida por alto preço a quem dela precisa para trabalhar e não a tem. Por isso, nem sempre a apropriação da terra pelo capital se deve à vontade do capitalista de se dedicar à agricultura. (1980, p. 60, grifado no original) 
Nesse caso, o que se está disputando é a possibilidade de se ter um regime de propriedade distinta daquela pautada na propriedade capitalista da terra, elemento que unifica as lutas dos diversos sujeitos expropriados ou não no campo (MARTINS, 1980), os quais desenvolvem relações não capitalistas de produção.

Na realidade dos PAs conquistados e organizados pelo MST se observa essa luta pela permanência em um território que lhes garanta segurança em relação a uma longa trajetória de migração e insegurança territorial, com relações de maior proximidade e coletividade, o que não significa a inexistência de conflitos e contradições em graus diferentes e de natureza diversa, conforme buscamos demarcar neste trabalho.

Em consonância à terra de trabalho, o movimento socioterritorial almeja a perpetuação da luta pela/na terra por meio de uma educação emancipatória em que cada "cidadão" possa tornar-se "governante" e que a sociedade o ponha, ainda
que "abstratamente", nas condições gerais de poder fazê-lo: a democracia
política tende a fazer coincidir governantes e governados (no sentido de
governo com o consentimento dos governados), assegurando a cada
governado o aprendizado gratuito das capacidades e da preparação técnica
geral necessárias a essa finalidade. (GRAMSCI, 1995, p. 137)

Essa ideia de Gramsci de pensar uma outra hegemonia por meio da emancipação do subalterno perpassa por uma emancipação cultural e por uma compreensão de que tanto o econômico quanto o político-filosófico são manifestações da mesma realidade que se encontra em movimento, assim a

emancipação do subalterno passa pela construção de um novo bloco histórico e, como constituitivo desse processo, de uma reforma moral e intelectual (uma revolução cultural gerada na auto-educação das massas). (DEL ROIO, 2007, p. 69)

Desta feita, a Educação do Campo pode vir a se constituir como um dos caminhos possíveis para a construção dessa emancipação do camponês subalterno e para a cisão com a educação profissional demandada pela classe dirigente. A Educação do Campo é importante também para a manutenção dos sujeitos na terra, especialmente com a proposta da agroecologia que unifica a luta pela terra e por um projeto contra-hegemônico que dispute o território do sudeste paraense com o modelo agromineral em franca expansão nessa realidade. Tal expansão se dá por meio dos diversos empreendimentos minerais ou pelo avanço do agronegócio atrelado à soja e à pecuária e resulta na expropriação dos sujeitos do campo ou na violência física que ceifa constantemente aqueles que se opõem à propriedade capitalista da terra, buscando negar-lhes o direito ao território - daí os vários massacres, como o de Eldorado dos Carajás, se repetirem initerruptamente: o último deles ocorreu na manhã do dia 24 de maio de 2017, pouco antes de finalizarmos esta tese, no município de Pau D’arco, onde 
dez posseiros, sendo nove homens e uma mulher, foram assassinados durante uma ação de reitegração de posse no acampamento existente na Fazenda Santa Lúcia, levada a cabo pelas Polícias Civil e Militar do estado do Pará (CHAGAS FILHO, 2017).

Esta tese, que teve seu inicío a partir de uma inquietação quanto ao que recorrentemente os movimentos socioterritoriais da região denominam de contra-hegemonia, especialmente o MST, finda com outros questionamentos que foram se desdobrando ao longo da pesquisa para entender melhor as contradições envoltas nesse projeto de contrahegemonia: como o bloco histórico-geografico amazônico composto pela Via campesina pode ser potencializado no contexto de ampla expansão da hegemonia do capital agromineral? Quais outras estratégias seriam possíveis de serem desenvolvidas para coibir o avanço dessa hegemonia do capital? Quais estratégias territoriais, igualmente contrahegemônicas ou não, mobilizadas pelos outros sujeitos do campo no contexto atual como os posseiros, quilombolas, indígenas, quebradeiras de coco-babaçu, ribeirinhos, dentre outros? $\mathrm{E}$ quais os meios para que essa diversidade constitua uma unidade para pensar ações coletivas? 


\section{REFERÊNCIAS}

ACEVEDO MARIN, Rosa E. Civilização do rio, civilização da estrada: transportes na ocupação da Amazônia no século XIX e XX. In: SITREAMA, I, 2002, Belém. Anais... Belém, não paginado, cópia impressa.

ALENTEJANO, Paulo. Uma análise geográfica dos conflitos no campo brasileiro. In: OLIVEIRA, Márcio Piñon de; COELHO, Maria Célia Nunes; CORRÊA, Aureanice de Mello. (Orgs.). O Brasil, a América Latina e o mundo: espacialidades contemporâneas (II). Rio de Janeiro: Lamparina/Faperj/Anpege, 2008. p. 238-253.

ALMEIDA, Alfredo Wagner Berno de. Terra de quilombo, terras indígenas, "babaçuais livres", "castanhais do povo", faxinais e fundos de pasto: terras tradicionalmente ocupadas. Manaus: PGSCA-UFAM, 2006.

O GETAT e a arrecadação de áreas rurais como terra devoluta. Belém: IDESP, 1985. p. 1-32. (Estudos Paraenses, v. 55.)

GETAT - Segurança nacional e o revigoramento do poder regional. Reforma Agrária (Boletim da Abra), Campinas, v. 11, n. 2, mar.-abr. 1981. p. 24-41.

ALMEIDA, Rogério Henriquez. Territorialização camponesa no sudeste do Pará. 2006. Dissertação (Mestrado em Desenvolvimento Sustentável do Trópico Úmido) - Universidade Federal do Pará, 2006.

ALMEIDA, Rosemeire Aparecida de. PROCERA versus PRONAF: vejo o futuro repetir o passado... Geografia, Londrina, v. 9, n. 1, jan./jun. 2000.

ALTIERI, Miguel. Agroecologia: bases científicas para uma agricultura sustentável. São Paulo/Rio de Janeiro: Expressão Popular/AS-PTA, 2012.

ALUNOS do assentamento Palmares II ocupam escola como forma de protesto. Carajás, o Jornal, Parauapebas, 23 jan. 2017. Disponível em: <http://carajasojornal.com.br/ cidades/parauapebas/item/5230-alunos-do-assentamento-palmares-ii-ocupam-escola-comoforma-de-protesto.html>. Acesso em: 24 jan. 2017.

ANDRADE, Luciane Almeida Mascarenhas de. O desafio da parceria na implementação do PRONERA: o caso do projeto alfabetização cidadã no nordeste Paraense. $186 \mathrm{f}$. Dissertação (Mestrado em Educação) - Universidade Federal do Rio Grande do Norte, Natal, 2010.

ANGELI, José Mário. A questão meridional de Antonio Gramsci: elementos emergentes para uma geografia política. Universidade e sociedade. Rio de Janeiro, ano VI, n. 10, 1996, p. 128-133.

ANJOS, Maura Pereira dos. Experiência de formação de professores no PRONERA Sudeste do Pará. 2009. Dissertação (Mestrado em Agriculturas Familiares e Desenvolvimento Sustentável) - Universidade Federal do Pará, Belém, 2009. 
ARRIGHI, Giovanni. O longo século XX: dinheiro, poder e as origens de nosso tempo. Rio de Janeiro: Contraponto, 2012.

ASSIS, William Santos de. A construção da representação dos trabalhadores rurais no sudeste paraense. 2007. Tese (Doutorado em Desenvolvimento, Agricultura e Sociedade) Instituto de Ciências Humanas e Sociais, Universidade Federal Rural do Rio de Janeiro, Rio de Janeiro, 2007.

BACEN. Matriz do crédito rural. 2017. Disponível em: <http://www.bcb.gov.br/ptbr/\#!/c/MICRRURAL/>. Acesso em: 10 abr. 2017.

BARATTA, Giorgio. Antonio Gramsci em contraponto: diálogos com o presente. São Paulo: Editora Unesp, 2011.

BARROS, Maria Vitória Martins. A zona castanheira do médio Tocantins e vale do Itacaiúnas: reorganização do espaço sob os efeitos das políticas públicas para a Amazônia. 1992. Monografia (Trabalho de Conclusão de Curso de Geografia) - Universidade Federal do Pará, Marabá, 1992.

BENTES, Rosineide; EMMI, Marília F.; MARIN, Rosa A. Os cemitérios das castanheiras do Tocantins. Pará desenvolvimento, Belém, v. 23, n. 1, 1988, p. 18-24.

BORGES, Juliano Luis. A transição do MST para a agroecologia. 2007. 183 f. Dissertação (Mestrado em Ciências Sociais) - Universidade Estadual de Londrina, Londrina, 2007.

BORON, Atílio A. Hegemonia e imperialismo no sistema internacional. In: (org.). Nova Hegemonia Mundial: alternativas de mudança e movimentos sociais. Buenos Aires: Clacso, 2004.

BRASIL. Programa nacional de educação na reforma agrária: manual de operações. 2016. Disponível em: <http://www.incra.gov.br/sites/default/files/uploads/reformaagraria/projetos-e-programas/pronera/manual_pronera_-_18.01.16.pdf $>$. Acesso em 03 mar. 2017.

BRENNER, Neil. The urban question:: reflections on Henri Lefebvre, urban theory and the politics of scale. International journal of urban and regional research, v. 24, n. 2, jun. 2000, p. 361-378.

The limits to scale? Methodological reflections on scalar structuration. Progress in human geography, v. 25, n. 4, dez. 2001, p. 591-614.

BRITO, Daniel C. A modernização da superfície: Estado e desenvolvimento na Amazônia. Belém: UFPA/NAEA, 2001.

BURAWOY, Michael. O marxismo encontra Bourdieu. Campinas: Editora da Unicamp, 2010.

CALDART, R. S. Pedagogia do Movimento Sem Terra: escola é mais que escola. Petrópolis: Vozes, 2000.

CARNEIRO, Aldair José Dias. Castanheiros, agricultores e índios: conflitos pelos usos da terra em castanhais do médio Tocantins (1948-1980). 2009. 139 f. Dissertação (Mestrado em 
História) - Instituto de Filosofia e Ciências Humanas, Universidade Federal do Pará, Belém, 2009.

CARVALHO, Horácio Martins de. A interação social e as possibilidades de coesão e de identidade sociais no cotidiano da vida social dos trabalhadores rurais nas áreas oficiais de reforma agrária no Brasil. Curitiba: IICA/NEAD/MIPF, 1999a. p. 1-63.

As contradições internas no esforço de cooperação nos assentamentos de reforma agrária do MST (período 1989-1999). In: CONCRAB. A evolução da concepção de cooperação agrícola do MST (1989 a 1999). São Paulo: CONCRAB/MST, 1999b. (Caderno de cooperação agrícola, $n^{\circ}$ 8). p. 27-38.

CARVALHO, Izabel de (org.). Migrantes: êxodo forçado. São Paulo: Centro de estudos migratórios, 1980.

CASTELLS, Manuel. A questão urbana. Seleção de Textos, n. 3, São Paulo, AGB, 1977.

CASTRO, Iná Elias de. O problema da escala. In: (org.). Geografia: conceitos e temas. $7^{\mathrm{a}}$ ed. Rio de Janeiro: Bertrand Brasil, 2005. p. 117-140.

CECEÑA, Ana Esther. Estratégias de construção de uma hegemonia sem limites. In: (Org.). Hegemonias e emancipações no século XXI. Buenos Aires: Clacso, 2005.

CHAGAS FILHO. Conflito tem 10 pessoas mortas. Correio do Tocantins, Marabá, 25 maio 2017. Disponível em: <http://www.ctonline.com.br/?inicial\&noticia= policia\&titulo=4gLKAxvLOVmmRFcOnA\%3D\%3D>. Acesso em: 25 maio 2017.

COELHO, Maria Célia Nunes et all. Impactos ambientais da Estrada de Ferro Carajás no sudeste do Pará. In: TEIXEIRA, João Batista Guimarães (org.). Carajás: geologia e ocupação humana. Belém: Museu Paraense Emílio Goeldi, 2006.

COELHO, Maria Célia Nunes. A CVRD e o processo de (re)estruturação e mudança na área de Carajás (Pará). In: COELHO, Maria Célia Nunes; COTA, Raymundo Garcia. (Orgs.). Dez anos de Estrada de Ferro Carajás. Belém: UFPA/NAEA, 1997. v. 1, p. 51-78.

Unidades de conservação: populações, recursos e territórios. Abordagens da geografia e da ecologia política. In: GUERRA, Antonio José Teixeira; COELHO, Maria Célia Nunes (Orgs.). Unidades de conservação: abordagens e características geográficas. Rio de Janeiro: Bertrand Brasil, 2009. p. 67-112.

COLETIVO DE COMUNICAÇÃO DO IALA. Manda-Lá notícias: Informativo do Instituto de Agroecologia Latino Americano Amazônico - IALA, ano 3, n. 4, jun. 2013. Disponível em $<$ https://docs.google.com/file/d/0B-8BTIOXyA-RUkJhVXBRVUV1ckE /edit>. Acesso em 07 jun. 2017.

COOMARSP. Plano de Recuperação do Projeto de Assentamento Palmares. Parauapebas: INCRA, 2008a.

. Plano de recuperação do Projeto de Assentamento "17 de abril". Eldorado dos Carajás: INCRA, 2008b. 
Plano de desenvolvimento do PA $1^{\circ}$ de Março. São João do Araguaia: INCRA, 2008c.CONCRAB. Cooperativas de produção: questões práticas. São Paulo: Concrab/MST, 1996.

Sistema cooperativista dos assentados. São Paulo: CONCRAB/MST, 1997. (Caderno de cooperação agrícola, n. 5.)

. A evolução da concepção de cooperação agrícola do MST (1989 a 1999). São Paulo: CONCRAB/MST, 1999. (Caderno de cooperação agrícola, n. 8)

. Os compromissos do governo federal com os movimentos sociais do campo. São Paulo: CONCRAB/MST, 2000. (Cadernos de cooperação agrícola, n. 9)

COSTA, Caetano De'Carli Viana. Sonhos de abril. A luta pela terra e a reforma agrária no Brasil e em Portugal. Os casos de Eldorado dos Carajás e Baleizão. 2014. 454 p. Tese (Doutoramento em Pós-Colonialismos e Cidadania Global). Universidade de Coimbra, Coimbra, 2014.

COSTA, Francisco de Assis. Formação Agropecuária da Amazônia: os desafios do desenvolvimento sustentável. Belém: UFPA/NAEA, 2000.

COSTA, Ricardo. Gramsci e o conceito de hegemonia. Salvador/São Paulo: Quarteto/ICP, 2011. (Cadernos do ICP, n. 1.)

COUTINHO, Carlos Nelson; COMPARATO, Fábio Konder; OLIVEIRA, Francisco de. Como pensar? Lua nova: revista de cultura e política, São Paulo, n. 54, 2001, p. 87-132.

COX, Kevin. Spaces of dependence, spaces of engagement and the politics of scale, or: looking for local politics. Political Geography, v. 17, n. 1, jan. 1998, p. 1-23.

CPT. Caderno conflitos. 1988-2015. <https://www.cptnacional.org.br/index.php/ component/ jdownloads/category/3-cadernoconflitos?Itemid=1028 >. Acesso em: 06 jun. 2016.

CRUZ, Thiago Martins da. Mineração e campesinato em Canaã dos Carajás: o avanço cruel do capital no sudeste paraense. 2016. 112 f. Tese (Doutorado em Dinâmicas Territoriais e Sociedade na Amazônia) - Universidade Federal do Sul e Sudeste do Pará, Marabá, 2016.

DA MATTA, Roberto; LARAIA, Roque de Barros. Índios e castanheiros: a empresa extrativa e os índios no médio Tocantins. Rio de Janeiro: Paz e Terra, 1978.

DEL ROIO, Marcos. Gramsci e a emancipação do subalterno. Rev. de Sociol. e Polít., Curitiba, n. 29, nov. 2007, p. 63-78.

DESMARAIS, Annette Aurélie. A Via Campesina: a globalização e o poder do campesinato. São Paulo: Cultura Acadêmica/Expressão Popular, 2013.

DIAGONAL. Diagnóstico socioeconômico integrado. Sudeste do Pará, 2010.

DIAS, Catarina V. Marabá - centro comercial da Castanha. Revista Brasileira de Geografia, ano XX, n. 4, 1958, p. 383-428. 
Aspectos geográficos do comércio da castanha no médio Tocantins. Revista Brasileira de Geografia, Ano XXI, n. 4, 1959, p. 517-531.

DIAS, Edmundo Fernandes. Hegemonia: racionalidade que se faz história. In: DIAS, Edmundo Fernandes (Org.). O outro Gramsci. São Paulo: Xamã, 1996.

DIAS, Leila C. Redes: emergência e organização. In: CASTRO, Iná Elias de (Org.). Geografia: conceitos e temas. $7^{\mathrm{a}}$ ed. Rio de Janeiro: Bertrand Brasil, 2005. p. 141-162.

DOQUOIS, Guy. La formación económico-social como combinación de modos de produción. In: LUPORINI, C., SERENI, E. El concepto de formación económico-social. México: Siglo XXI, 1976.

DORE, Rosemary. Gramsci e o debate sobre a escola pública no Brasil. Cadernos Cedes, Campinas, v. 26, n. 70, set.-dez. 2006. p. 329-352.

EKERS, Michael; LOFTUS, Alex. Introduction. In: EKERS, Michael et alli (Eds.). Gramsci: Space, Nature, and Politics. Malden, MA: Wiley-Blackwell, 2013.

EMMI, Marilia F. A oligarquia do Tocantins e o domínio dos castanhais. Belém: UFPA/NAEA, 1999.

. Os castanhais do Tocantins e a indústria extrativa no Pará até a década de 60. Belém: UFPA/NAEA, 2002. p. 1-25. (Papers do NAEA, n. 166)

EMMI, Marília F.; MARIN, Rosa A.; BENTES, Rosineide. Polígono castanheiro do Tocantins: espaço contestado de oligarquias decadentes. Revista Pará Agrário, Belém, v. 1, 1987, p. 12-24.

EMMI, Marilia F.; MARIN, Rosa. E. A. Crise e rearticulação das oligarquias no Pará. Belém: UFPA/NAEA, 1996. p. 1-16. (Papers do NAEA, n. 104)

FEAB. Via Campesina. 2011. Disponível em: <https://feab.wordpress.com/via-campesina-emsp\%C2\%B4s/>. Acesso em: 07 fev. 2017.

FERNANDES, Bernardo Mançano. MST: formação e territorialização. São Paulo: Hucitec, 1999.

Contribuição ao estudo do campesinato brasileiro: formação e territorialização do Movimento dos Trabalhadores Rurais Sem Terra - MST (1979-1999). 1999. 318 p. Tese (Doutorado em Geografia) - Universidade de São Paulo, São Paulo, 1999.

Formação, espacialização e territorialização do MST. In: STÉDILE, João Pedro (Org.). A reforma agrária e a luta do MST. Rio de Janeiro: Vozes, 1997. p. 133-155.

. A ocupação como forma de acesso à terra. In: ENCONTRO DE GEÓGRAFOS DA AMÉRICA LATINA, 8, 2001, Santiago de Chile. Anais ... Santiago de Chile: Universidad de Chile, 2001.

. Questão agrária: conflitualidade e desenvolvimento territorial. In: STÉDILE, João Pedro. (Org.). A questão agrária do Brasil: o debate da década de 2000. São Paulo: Expressão Popular, 2013. p. 173-238. 
Impactos socioterritoriais da luta pela terra e a questão da reforma agrária. In: FRANÇA, C. G.; SPAROVER, G. (Coords.). Assentamentos em debate. Brasília: NEADDEBATE, 2005. p.113-132.

Movimentos socioterritoriais e espacialização da luta pela terra. Presidente Prudente, 5 ago. 2005. Disponível em: <http://www2.fct.unesp.br/nera/publicacoes/ Construcaoconceitual.pdf $>$. Acesso em: 20 jan. 2016.

Entrando nos territórios do território. In: PAULINO, E. T.; FABRINI, J. E. (Orgs.). Campesinato e territórios em disputa. $1^{a}$ ed. São Paulo: Expressão Popular/UNESP, 2008. p. 273-301.

FERRAZ, Iara. Os Parkatêjê das matas do Tocantins: a epopeia de um líder Timbira. 1984. Dissertação (Mestrado em Antropologia) - Universidade de São Paulo, São Paulo, 1984.

FERREIRA, Ayala Lindabeth Dias. Realidades e desafios da educação do campo na escola Crescendo na Prática - Parauapebas/PA. 2012. Monografia (Aperfeiçoamento/Especialização em Educação do Campo, Agroecologia e Questão Agrária) - Universidade Federal do Pará, Marabá, 2012.

FREC/SUPA. Convocatória para a 5 ${ }^{\text {a }}$ Conferência Regional de Educação do Campo. Marabá, 2011. 4 p. (mimeografado).

FUNDAÇÃO VALE. Relatório de atividades. 2015. Disponível em: <http://www.fundacaovale.org/SiteAssets/Paginas/Relatorio-Atividades-2015/RelatorioAtividades-2015.pdf >. Acesso em: 03 mar. 2017.

GIL, Antônio Carlos. Métodos e técnicas da pesquisa social. São Paulo: Atlas, 1999.

GOHN, Maria da G. Novas teorias dos movimentos sociais. São Paulo: Loyola. 2009.

GOMES, Maria Suely Ferreira. A construção da organicidade no MST: a experiência do assentamento 26 de Março-PA. 2009. Dissertação (Mestrado em Geografia Humana) - Centro de Humanidades, Universidade Federal de Campina Grande, Campina Grande, 2009.

GONÇALVES, Carlos Walter Porto. Amazônia, Amazônias. São Paulo: Contexto, 2001.

A geograficidade do social: uma contribuição para o debate metodológico para os estudos de conflitos sociais na América Latina. Revista eletrônica da Associação dos Geógrafos Brasileiros, Três Lagoas, v. 1, n. 3, 2006, p. 5-25.

GRAMSCI, Antonio. Maquiavel, a política e o estado moderno. Rio de Janeiro: Civilização Brasileira, 1968.

Introdução à filosofia da práxis. Lisboa: Antídoto, 1978.

A questão meridional. Rio de Janeiro: Paz e Terra, 1987.

1995.

Os intelectuais e a organização da cultura. Rio de Janeiro: Civilização Brasileira,

Cadernos do cárcere, v. 1. Rio de Janeiro: Civilização Brasileira, 2014a. 
Cadernos do cárcere, v. 2. Rio de Janeiro: Civilização Brasileira, 2000.

Cadernos do cárcere, v. 3. Rio de Janeiro: Civilização Brasileira, 2001.

Cadernos do cárcere, v. 5. Rio de Janeiro: Civilização Brasileira, 2014 b.

Cartas do cárcere, v. 2. Rio de Janeiro: Civilização Brasileira, 2005.

GRANDI, Matheus da Silveira. A construção escalar da ação no movimento sem-teto. 2014. Tese (Doutorado em Geografia). Universidade Federal do Rio de Janeiro, Rio de Janeiro, 2014.

GRUPPI, Luciano. O conceito de hegemonia em Gramsci. Rio de Janeiro: Graal, 1978.

O pensamento de Lênin. Rio de Janeiro: Graal, 1979.

GRZYBOWSKI, Cândido. Caminhos e descaminhos dos movimentos sociais no campo. Rio de Janeiro: FASE, 1990.

GUERRA, Armando Dinis. O posseiro da fronteira: campesinato e sindicalismo no sudeste paraense. Belém: UFPA/NAEA, 2001.

GUHUR, Dominique Michèle Perioto; TONÁ, Nilciney. Agroecologia. In: CALDART, Salete et alli. (Orgs.). Dicionário da educação do campo. Rio de Janeiro/São Paulo: Escola Politécnica de Saúde Joaquim Venâncio/Expressão Popular, 2012. p. 59-67.

GUIMARÃES, Ed Carlos de Sousa; BARP, Wilson José. Pistolagem no contexto do Judiciário: o caso do Pará. Revista brasileira de segurança pública, São Paulo, ano 5 ed. 9, ago./set. 2011, p. 120-133.

HAESBAERT, Rogério. O mito da desterritorialização: do "fim dos territórios" à multiterritorialidade. Rio de Janeiro: Bertrand Brasil, 2004.

HARVEY, D. Espaços de esperança. São Paulo: Loyola, 2004.

Condição pós-moderna. São Paulo: Loyola, 1999.

HÉBETTE, Jean et al. Cruzando uma zona de fronteira em conflitos: o leste do médio Tocantins. 1983. Relatório de Pesquisa, mimeografado.

HÉBETTE, Jean. A luta sindical em resposta às agressões dos grandes projetos. In: (Org.). O cerco está se fechando. Rio de Janeiro: Vozes, 1991. p. 54-77.

A ocupação humana recente na microrregião de Marabá. In: HÉBETTE, Jean (Org.). Cruzando a fronteira: 30 anos de estudo do campesinato na Amazônia. Belém: EDUFPA, 2004. p. 63- 71.

HÉBETTE, Jean; ACEVEDO MARIN, Rosa. E. Colonização para quem? Belém: UFPA/NAEA, 1979.

HINDESS, Barry; HIRST, P. Q. Modo de produção e formação social: uma auto-crítica de modos de produção Pré-capitalistas. Rio de Janeiro: Zahar, 1978. 
IBGE. Censo Agropecuário, 2006. Disponível em < ftp://ftp.ibge.gov.br/Censos/Censo_Agropecuario_2006/Segunda_Apuracao/censoagro2006_2 aapuracao.pdf> Acesso em 10 abr. 2014.

INCRA. Obtenção de terras. 2016. Disponível em <http://www.incra.gov.br/ Aquisicao_de_terras> Acesso em 08 nov. 2016.

IPEA. II Pesquisa nacional sobre educação na reforma agrária: repercussões no estado do Pará (regiões sul e sudeste). Relatório de pesquisa. Rio de Janeiro, 2016. Disponível em: $<$ http://www.ipea.gov.br/portal/images/stories/PDFs/relatoriopesquisa/ relatorio_pnera_sul_sudeste_web.pdf >. Acesso em: 07 jun. 2017

JESSOP, Bob. Gramsci as a spatial theorist. Critical Review of International Social and Political Philosophy, v. 8, n. 4, 2005, p. 421-437.

JONES, Katherine T. Scale as epistemology. Political Geography, v. 17, n. 1, jan. 1998, p. 25-28.

JST: Jornal dos Trabalhadores Rurais Sem Terra. São Paulo, n. 101, ano X, 1991.

JST: Jornal dos Trabalhadores Rurais Sem Terra. São Paulo, n. 136, ano XIII, 1994.

JST: Jornal dos Trabalhadores Rurais Sem Terra. São Paulo, n. 153, ano XIV, 1995.

JST: Jornal dos Trabalhadores Rurais Sem Terra. São Paulo, n. 203, ano XVIII, 2000.

KARRIEM, Abdurazack. Space, Ecology, and Politics in the Praxis of the Brazilian Landless Movement. In: EKERS, Michael et alli (Eds.). Gramsci: Space, Nature, and Politics. Malden, MA: Wiley-Blackwell, 2013.

KIPFER, Stefan. How Lefebvre urbanized Gramsci: hegemony, everyday life, and difference In: GOONEWARDENA, Kanishka et alli (Eds.). Space, Difference, Everyday Life: Reading Henri Lefebvre. Abingdon: Routledge, 2008.

LABICA, Véase George. Cuatro observaciones sobre los conceptos de modo de producción y formación económica de la sociedade. In: LUPORINI, C., SERENI, E. El concepto de formación económico-social. México: Siglo XXI, 1976.

LACLAU, Ernesto; MOUFFE, Chantal. Hegemonia e estratégia socialista: por uma política democrática radical. São Paulo: Intermeios, 2015.

LEFEBVRE, Henri. La production de l'espace. Paris: Anthropos, 2000.

. O pensamento de Lenine. Lisboa: Moraes, 1969.

1976.

. De l'État, tome II: De Hegel à Marx par Staline. Paris: Union Générale d'Editions,

LÊNIN, Vladimir Ilitch. Quem são os "amigos do povo" e como lutam os social-democratas? In: Obras escolhidas. Rio de Janeiro: Vitória, 1955. 
O desenvolvimento do capitalismo na Rússia: o processo de formação do mercado interno para a grande indústria. São Paulo: Abril Cultural, 1988.

LEROY, Jean-Pierre. Da fronteira sem lei nem direitos a uma democracia em construção: o campesinato da região de Marabá nos anos 80 e a criação do CAT. In: HÉBETTE, Jean (Org.). CAT - Ano décimo: etnografia de uma utopia. Belém: UFPA/CAT, 2000. p. 3-25.

LIGUORI, Guido. Movimentos sociais e papel do partido no pensamento de Gramsci e hoje. In: SEMERARO, Giovane (Org.). Gramsci e os movimentos populares. Rio de Janeiro/Niterói: EDUFF, 2011. p.257-270.

LUKÁCS, Georg. Introdução a uma estética marxista: sôbre a particularidade como categoria da estética. Tradução de Carlos Nelson Coutinho e Leandro Konder. Rio de Janeiro: Civilização Brasileira, 1970.

LUPORINI. Cesare. Dialética marxista e historicismo. In: LUPORINI, C., SERENI, E. EI concepto de formación económico-social. México: Siglo XXI, 1976.

MACKINNON, Danny. Reconstructing scale: Towards a new scalar politics. Progress in Human Geography, v. 35, n. 1, jul. 2010, p. 21-36.

MAGALHÃES, Sônia Barbosa. Direitos e projetos: uma leitura sobre a implantação de assentamentos no Sudeste do Pará. In: MARTINS, José de Souza (org.). Travessia: a vivência da reforma agrária nos assentamentos. Porto Alegre: Editora da UFRGS, 2009.

MALAGODI, Edgard. Revolução Verde. In: MOTTA, Márcia (Org.). Dicionário da terra. Rio de Janeiro: Civilização Brasileira, 2005. p. 407-408.

MARIN, Rosa. E. A.; EMMI, Marilia. F. De posseiros a assentados: a precariedade das ações fundiárias no sudeste do pará. In: COELHO, Maria Célia Nunes; COTA, Raymundo Garcia. (Orgs.). Dez anos da Estrada de Ferro Carajás. Belém: UFPA/NAEA, 1997, v. 1, p. 251274.

MARSON, Sallie; SMITH, Neil. States, scales and households: limits to scale thinking? A response to Brenner. Progress in Human Geography, v. 25, n. 4, dez. 2001, p. 615-619.

MARTINS, José de Souza. Frente pioneira: contribuição para uma caracterização sociológica. In:

Capitalismo e tradicionalismo: estudos sobre as contradições da sociedade agrária no Brasil. São Paulo: Pioneira, 1975.

Expropriação e violência: a questão política no campo. São Paulo: Hucitec, 1980.

A militarização da questão agrária no Brasil: terra e poder - o problema da terra na crise política. Petrópolis: Vozes, 1985.

Hucitec, 1986.

A reforma agrária e os limites da democracia na "Nova República”. São Paulo: A chegada do estranho. São Paulo: Hucitec, 1993. 
As temporalidades da história na dialética de Lefebvre. In: (Org.). Henri

Lefebvre e o retorno à dialética. São Paulo: Hucitec, 1996.

Exclusão social e a nova desigualdade. São Paulo: Paulus, 1997a.

O significado da criação da Comissão Pastoral da Terra na história social e contemporânea do Brasil. In: CPT. A luta pela terra: a Comissão Pastoral da Terra 20 anos depois. São Paulo: Paulus, 1997b.

2009.

Fronteira: a degradação do Outro nos confins do humano. São Paulo: Contexto,

O cativeiro da Terra. 9a ed. revista e ampliada. São Paulo: Contexto, 2010.

MARX, Karl. Contribuição à critica da economia política. São Paulo: Expressão Popular, 2008.

MASSEY, Doreen. Um sentido global do lugar. In: ARANTES, Antonio (Org.). O espaço da diferença. São Paulo: Papirus, 2000. p. 176-185.

MATHE, Fernando Gomes et alli. Brasil: graves violações de direitos humanos na zona rural. 2000. Disponível em: <http://www.dhnet.org.br/dados/relatorios/nacionais/ r_fidh_brasil.pdf $>$. Acesso em: 01 mar. 2017.

MEDEIROS, Leonilde Sérvolo de. Trabalhadores do campo, luta pela terra e o regime civilmilitar. In: PINHEIRO, Milton (Org.) Ditadura: o que resta da transição. São Paulo: Boitempo, 2014. p.195-229.

A luta por terra no Brasil e o Movimento dos Trabalhadores Rurais Sem Terra. 2009. Disponível em <http://www.planalto.gov.br/gsi/saei/palestra/cgeevf.pdf> Acesso em 10 ago. 2015.

MEEK, David Duncan. Movements in education: the political ecology of education in the brazilian landless workers' movement. 2014. 281 f. Tese (Doutorado em Antropologia) University of Georgia, Athens, 2014. Disponível em: $<$ http://bc.ufpa.br/site/images/DocumentosPDF/Meek Movements in Education.pdf >. Acesso em: 12 jan. 2017.

MELAZZO, Everaldo Santos; CASTRO, Cloves A. A escala geográfica: noção, conceito ou teoria? Terra livre, Presidente Prudente, ano 23, v. 2, n. 29, ago-dez. 2007, p. 133-142.

MICHELOTTI, Fernando. IALA Amazônico: a pesquisa-ação-participante e a construção do diálogo universidade-movimentos sociais. In: CONGRESSO INTERNACIONAL DE EDUCACIÓN SUPERIOR UNIVERSIDAD, 9., 2014, La Habana. Anais..., v. IV, n. 1. La Habana: Congreso Universidad, 2015. p. 381-394.

MINAYO, Maria Cecília de S. et alli (Org.). Pesquisa social: teoria, método e criatividade. Rio de Janeiro: Vozes, 1994.

MIRANDA, Rogério Rego. Interfaces do rural e do urbano em área de colonização antiga na Amazônia: estudo de colônias agrícolas em Igarapé-Açu e Castanhal (PA). 2009. 
212 f. Dissertação (Mestrado) - Curso de Geografia, Programa de Pós-graduação em Geografia, Universidade Federal do Pará, Belém, 2009.

MOORE, Adam. Rethinking scale as a geographical category: from analysis to practice. Progress in human geography, v. 32, n. 2, 2008, p. 203-225.

MORAES, Antônio Carlos Robert. Em busca da ontologia do espaço. In: MOREIRA, Ruy (Org.) Geografia: teoria e crítica: o sabere posto em questão. Rio de Janeiro: Vozes, 1982.

. Bases da formação territorial do Brasil: o território colonial brasileiro no "longo" século XVI. São Paulo: Hucitec, 2000.

Território e história no Brasil. São Paulo: Annablume, 2005.

Contabilidade ambiental e geografia econômica. Investigaciones Geográficas, Ciudad de México, n. 70, dez. 2009, p. 77-92.

MORAIS, Clodomir S. Elementos sobre a teoria da organização no campo. São Paulo: MST, 1986. (Caderno de formação, n. 11.)

MORBACH, Frederico. Marabá. In: BRAZ, Ademir (Org.). Antologia tocantina. Marabá: Grafecort, 1998. p. 58-59.

MOREIRA, Ruy. Pensar e ser em geografia: ensaios de história, epistemologia e ontologia do espaço geográfico. São Paulo: Contexto, 2007.

MORISSAWA, Mitsue. A história da luta pela terra e o MST. São Paulo: Expressão Popular, 2001.

MST. A cooperação agrícola nos assentamentos. São Paulo: MST, 1993. (Caderno de formação, n. 20.)

MST. Cooperativas de Produção, questões práticas. São Paulo: MST, 1996. (Caderno de formação, n. 21)

MST. Plano Nacional do MST (1989 a 1993). São Paulo: MST, 1989. (Cadernos de formação, n. 17.)

MST. Revista sem terra, ano I, n. 3, jan./fev./mar. 1988, p. 1-48.

NEGRI, Paulo S. A identidade ecológica do Movimento dos Trabalhadores Rurais Sem Terra - MST: o caso do Assentamento Dorcelina Folador no município de Arapongas - Paraná. 2005. Dissertação (Mestrado em Ciências Sociais), Universidade Estadual de Londrina, Londrina, 2005.

NEVES, Delma Pessanha. Assentamento rural: confluência de formas de inserção social. Estudos sociedade e agricultura, Rio de Janeiro, n. 13, out. 1999, p. 5-28.

NIMUENDAJÚ, Curt. The eastern Timbira. University of California, 1946. Disponível em <http://www.etnolinguistica.org/biblio:nimuendaju-1946-timbira> Acesso em 08ago. 2015. 
NORDER, Luiz A. C. Políticas de assentamento e localidade: os desafios da reconstituição do trabalho rural no Brasil. 2004. Tese (Doutorado em Ciências Sociais) - Universidade de Wageningen, Wageningen, 2004.

NOVAES, Henrique T. et alli.A economia política da "Revolução Verde", a agroecologia e as escolas de agroecologia do MST. In: NOVAES, Henrique; MAZIN, Ângelo D.; SANTOS, Lais (Orgs.). Questão agrária, cooperação e agroecologia. v. I. São Paulo: Expressão Popular, 2015.

OLIVEIRA, Ariovaldo Umbelino de. A geografia agrária e as transformações territoriais recentes no campo brasileiro. In: CARLOS, A. F. A (Org.). Novos caminhos da geografia. São Paulo: Contexto, 2002.

Amazônia: monopólio, expropriação e conflitos. Campinas: Papirus, 1987.

- "Quem sabe faz a hora não espera acontecer": o MST como movimento socioterritorial moderno. Revista USP, São Paulo, v. 64, 2005, p. 156-172.

ORNELAS, Raúl. Contra-hegemonias e emancipações: apontamentos para um início de debate CECEÑA, A. E. (Org.). Os desafios das emancipações em um contexto militarizado. 1. ed. São Paulo: Expressão Popular, 2008.

PANTOJA, Igor. Planejamento privado social: práticas da CVRD (Vale S.A.) em municípios do Maranhão. 2012. Dissertação (Mestrado em Planejamento Urbano e Regional) - Universidade Federal do Rio de Janeiro, Rio de Janeiro, 2012.

PATERNOSTRO, Júlio. Viagem ao Tocantins. [São Paulo]: Companhia Editora Nacional, 1945.

PEDON, Nelson Rodrigo. Movimentos socioterritoriais: uma contribuição conceitual à pesquisa geográfica. 2009. 235 f. Tese (Doutorado em Desenvolvimento Regional e Planejamento Ambiental) - Universidade Estadual Paulista Júlio de Mesquita Filho, Presidente Prudente, 2009.

PEET, Richard. Milton Santos no exílio: os anos 70. In: SOUZA, Maria Adélia Aparecida de (Org.). $O$ mundo do cidadão, um cidadão do mundo. São Paulo: Hucitec, 1996. p. 164 168.

PEREIRA, Airton dos Reis. Do posseiro ao sem-terra: a luta pela terra no sul e sudeste do Pará. Recife: Editora UFPE, 2015.

PEREIRA, Kelci Anne. Educação do Campo e rede de movimentos no sudeste do Pará: agroecologia e cooperativismo na relação entre trabalho e educação. 2015. 300 f. Tese (Doutorado em Educação) - Universidade de São Paulo, São Paulo, 2015. Disponível em: $<$ http://www.teses.usp.br/teses/disponiveis/48/48134/tde-09032016-104156/en.php〉. Acesso em: 03 mar. 2017.

PEREIRA, Mônica Cox de Britto. Revolução Verde. In: CALDART, Salete et alli (orgs.). Dicionário da Educação do Campo. Rio de Janeiro/São Paulo: Escola Politécnica de Saúde Joaquim Venâncio/Expressão Popular, 2012. p. 687-691. 
POLÍCIA militar mata garimpeiros no Pará, Memorial da democracia. s/l: Instituto Lula, s/d. Disponível em: <http://www.memorialdademocracia.com.br/card/policia-militar-matagarimpeiros-no-para $>$. Acesso em: 13 maio 2017.

PPC. PROJETO PEDAGÓGICO DO CURSO DE LICENCIATURA EM EDUCAÇÃO DO CAMPO. 2014. Disponível em: < https://fecampo.unifesspa.edu.br/index.php/projetopedagogico-lpec>. Acesso em: 01 nov. 2016.

RAFFESTIN, Claude. Escala e ação, contribuições para uma interpretação do mecanismo de escala na prática da Geografia. Revista brasileira de geografia. Rio de Janeiro, ano 45, n. 1, 1983, p. 123-135.

Por uma geografia do poder. São Paulo: Ática, 1993.

REDE DATALUTA. Relatório Brasil 2015. São Paulo: Presidente Prudente, 2016.

ROCHA André Carlos. O MST e a luta pela terra no Pará. Pará: Iguana, 2015.

ROCHA, Gilberto de Miranda. A dinâmica territorial político-administrativa municipal na região Norte do Brasil (1988-2010). Novos cadernos NAEA, v. 16, 2013, p. 211-228.

RODRIGUES, Lysias Augusto. Roteiro do Tocantins. Rio de Janeiro: Livraria José Olympio Editora, 1943.

RODRIGUES, Mônica Aparecida Grossi. Politização da questão ambiental no MST: a agroecologia como estratégia produtiva e política. 2014. 279 f. Tese (Doutorado em Serviço Social) - Universidade Federal do Rio de Janeiro, Rio de Janeiro, 2014

ROSSETTO, Neuri D. O MST e a reforma agrária popular: desafios e perspectivas. In: SEMERARO, Giovane (Org.). Gramsci e os movimentos populares. Rio de Janeiro/Niterói: EDUFF, 2011. p. 53-68.

SAID, Edward. Reflexões sobre o exílio. In: Reflexões sobre o exílio e outros ensaios. São Paulo: Companhia das Letras, 2003. p. 46-60.

SANTOS, Milton. Espaço e sociedade: e formação da sociedade como teoria e como método, In: Boletim paulista de geografia, São Paulo, n. 54,1977.

SAYAD, Abdelmalek. A imigração ou os paradoxos da alteridade. São Paulo: EDUSP, 1998.

SCALABRIN, Rosemeri. Diálogos e aprendizagens na formação em agronomia para assentados. Tese. (Doutorado em Educação) - da Universidade Federal do Rio Grande do Norte, Natal, 2011.

SCHERER-WARREN, Ilse. Redes de movimentos sociais. São Paulo: Loyola, 1993.

SCHLESENER, Anita Helena. Hegemonia e cultura: Gramsci. Curitiba: Editora UFPR, 2007.

SCHMINK, Marianne; WOOD, Charles. Conflitos sociais e a formação da Amazônia. Belém: EDUFPA, 2012. 
SCHNEIDER Sergio; MATTEI, Lauro; CAZELLA, Ademir Antonio. Histórico, caracterização e dinâmica recente do PRONAF - Programa Nacional de Fortalecimento da Agricultura Familiar. In: SCHNEIDER, Sergio (Org.). Políticas públicas e participação social no Brasil rural. Porto Alegre: Editora da UFRGS, 2004. p. 21-49.

SEMERARO, Giovane. Gramsci e os movimentos populares: uma leitura a partir do caderno 25. In: (Org.). Gramsci e os movimentos populares. Rio de Janeiro/Niterói: EDUFF, 2011. p. 287-302.

2006.

Gramsci e os novos embates da filosofia da práxis. Aparecida: Ideias \& Letras,

SERENI, Emilio. De Marx a Lênin: a categoria de "formação econômico-social". Revista de geografia meridiano, n. 2, 2013, p. 297-346.

SEVILLA-GUZMÁN, Eduardo. La agroecología como estrategia metodológica de transformación social. Córdoba, Espanha: Instituto de Sociología y Estudios Campesinos de la Universidad de Córdoba, [s.d.]. Disponível em: <http://www.agroeco.org/socla/pdfs/ la_agroecologia_como.pdf>. Acesso em: 29 mar. 2017.

SIGAUD, Lygia Maria. A forma acampamento: notas a partir da versão pernambucana. Novos estudos. CEBRAP, São Paulo, v. 58, 2000, p. 73-92.

As condições de possibilidade das ocupações de terra. Tempo social: revista de sociologia da USP, São Paulo, v. 17, n. 1, 2005, p. 255-280.

SILVA, Cristiano Bento da. A comunicação da usina hidrelétrica de Marabá traduzindo uma situação social de conflito: reflexões a partir de um território ribeirinho do sudeste paraense. Dissertação (Mestrado em Dinâmicas Territoriais e Sociedade na Amazônia) Universidade Federal do Sul e Sudeste do Pará, Marabá, 2014.

SILVA, Marcos Aurélio da. Dialética e Geografia em Antonio Gramsci. Lutas Sociais (PUCSP), v. 17, 2013, p. 21-32.

SILVA, Patrícia M. et alli. Rede de sementes agroecológicas BioNatur, uma trajetória de luta e superação. Revista Agriculturas, Rio de Janeiro, v. 11, n. 1, 2014.

SILVA. Armando Corrêa da. Geografia e lugar social. São Paulo: Contexto, 1991.

SIMIONATTO, Ivete. Gramsci: sua teoria, incidência no Brasil, influência no serviço social. São Paulo: Cortez, 2011.

SMITH, Neil. Contornos de uma política espacializada: veículos dos sem-teto e produção de escala geográfica. In: ARANTES, Antônio (Org.). O espaço da diferença. São Paulo: Papirus, 2000. p. 132-175.

Scale bending and the fate of the national. In: SHEPPARD, E.; MCMASTER, R. B. (Eds.). Scale and geographic inquiry: nature, society and method. Oxford: Blackwell, 2004. p. 192-212.

Geografia, diferencia y políticas de escala. Terra livre, São Paulo, ano 18, v. 2, n. 19, jul.-dez. 2002, p. 127-146. 
SOUZA, Carlos Henrique Lopes de. A trajetória da força de trabalho no sudeste paraense: de agricultores migrantes a garimpeiros, de garimpeiros a posseiros, a excluídos, a sem-terra. In: ENCONTRO NACIONAL DE ESTUDOS POPULACIONAIS, XIII., 2002, Ouro Preto. Anais... [s.l.]: 2002. ABEP, Disponível em: http://www.abep.org.br/publicacoes/index.php/anais/issue/view/33/showToc > . Acesso 12 mar. 2013.

SOUZA, Herbert Glauco de. Contra-hegemonia: um conceito de Gramsci? 2013. Dissertação (Mestrado em Educação: Conhecimento e Inclusão Social). - Universidade Federal de Minas Gerais, Belo Horizonte, 2013.

SOUZA, José Carlos Lima de. O Movimento dos Trabalhadores Rurais Sem Terra (MST): o moderno príncipe educativo brasileiro na história do tempo presente. 2008. $260 \mathrm{f}$. Tese (Doutorado) - Curso de História, Pós- Graduação em História, Universidade Federal Fluminense, Niterói, 2008. Disponível em: <http://www.historia.uff.br/stricto/teses/Tese2008_SOUZA_Jose_Carlos_Lima_de-S.pdf>. Acesso em: 20 nov. 2016.

SOUZA, Marcelo Lopes. Redes. In: Os conceitos fundamentais da pesquisa sócioespacial. Rio de Janeiro: Bertrand Brasil, 2013. p. 163-178.

STÉDILE, João Pedro. A luta pela reforma agrária e o MST. In: (Org.). A reforma agrária e a luta do MST. Rio de Janeiro: Vozes, 1997. p. 95-110.

STÉDILE, João Pedro; FERNANDES, Bernardo Mançano. Brava Gente: a trajetória do MST e a luta pela terra no Brasil. São Paulo: Fundação Perseu Abramo, 1999.

STRONZAKE, Judite. MST. IALA: do sonho coletivo à experiência concreta. Jornal Sem Terra, 2009. Disponível em: <http://docvirt.com/docreader.net/docmulti.aspx ?lista=crv_cedemLST\&pesq=> . Acesso 12 mar. 2017.

SUZUKI, Júlio César. De povoado a cidade: a transição do rural ao urbano em Rondonópolis. 1997. 204 f. Dissertação (Mestrado) - Curso de Geografia, Programa de Pósgraduação em Geografia Humana, Universidade de São Paulo, São Paulo, 1997.

A gênese da moderna cidade de São Paulo. 2002. 158 f. Tese (Doutorado) - Curso de Geografia, Programa de Pós-graduação em Geografia Humana, Universidade de São Paulo, São Paulo, 2002.

Questão agrária na América Latina: renda capitalizada como instrumento de leitura da dinâmica sócio-espacial. In: LEMOS, Amália Inés Geraiges de; ARROYO, Mónica; SILVEIRA, María Laura. (Orgs.). América Latina: cidade, campo e turismo. Buenos Aires: Clacso, 2006. p. 213-223.

Modernização, território e relação campo-cidade - uma outra leitura da modernização da agricultura. Agrária, São Paulo, v. 6, 2007, p. 83-95. (Online.)

Território, modo de vida e patrimônio cultural em sociedades tradicionais brasileiras.

Espaço e Geografia, Brasília, n. 16, 2013, p. 627-640. 
José de Souza Martins: percursos metodológicos de leitura da sociedade brasileira. [2016]. Disponível em: <http://fflch.usp.br/sites/fflch.usp.br/files/José de Souza Martins.pdf>. Acesso em: 25 mar. 2017.

TAVARES, Maria Trindade dos Santos; BORGES, Heloisa da Silva. O Pronera como política para a Educação do Campo. In: GHEDIN, Evandro (org.). Educação do Campo: epistemologia e práticas. São Paulo: Cortez, 2012.

TEXIER, Jacques. Desacuerdos sobre la definición de los conceptos. In: LUPORINI, C., SERENI, E. El concepto de formación económico-social. México: Siglo XXI, 1976.

THIOLLENT, M. Os conceitos de modo de produção e formação econômico-social. Campinas: UNICAMP, 1976.

TROCATE, Charles. Quando floram os ipês. A dialética de formação do MST/PA. (in): ROCHA, André Carlos. O MST e luta pela Terra no Pará. Ed. Iguana. Marabá, 2015.

TURATTI, Maria Cecília Manzoli. Acampamentos do MST - uma discussão crítica sobre sociabilidade e poder. In: ENCONTRO ANUAL DA ASSOCIAÇÃO NACIONAL DE PESQUISA E PÓS-GRADUÇÃO EM CIÊNCIAS SOCIAIS - ANPOCS, 23., 1999, Minas Gerais. Anais... Minas Gerais: Caxambu, 1999. p. 1-30.

UFPA. Projeto Pedagógico: Curso de Especialização em Educação do Campo, Agroecologia e Questão Agrária na Pan-Amazônia. Marabá, 2010.

URQUIDI, Vivian. Movimento cocaleiro na Bolívia. São Paulo: Hucitec, 2007.

VELHO, Otávio Guilherme. Frentes de expansão e estrutura agrária: estudo do processo de penetração numa área da Transamazônica. Rio de Janeiro: Zahar, 1981.

Marabá, régua e compasso. Humanitas, Belém, v. 23, 2007, p. 13-31.

VIA CAMPESINA. Ideias para o pensamento político da Via Campesina na Amazônia 2004-2013. In: TROCATE, Charles (Org.). Ideias para o pensamento político da Via Campesina na Amazônia: pela construção de um bloco camponês e popular. Marabá: Iguana, 2014.

VIDAL, Lux Boelitz. A questão indígena. In: GONÇALVES JR.; José Maria (Org.). Carajás: desafio político, ecologia e desenvolvimento. São Paulo/Brasília: Brasiliense/Conselho Nacional de Desenvolvimento Científico e Tecnológico, 1986.

. Os índios da Amazônia: um desafio recíproco. In: HÉBETTE, Jean (Org.). O cerco está se fechando. Rio de Janeiro: Vozes, 1991. p. 54-77.

WAIBEL, Leo. As zonas pioneiras no Brasil. Revista brasileira de geografia, ano 27, v. 4, 1955.

WILLIAMS, Raymond. Marxismo e literatura. Rio de Janeiro: Zahar, 1979. 
ANEXO I - RELAÇÃO DOS CASTANHAIS - CORRESPONDE A FIGURA Nº 5. 


\begin{tabular}{|c|c|c|c|c|c|c|c|c|c|}
\hline $\begin{array}{l}\mathbf{N}^{o} . \text { de } \\
\text { ordem }\end{array}$ & Denominação do Castanhal & Proprietário atual & Proprietário anterior & $\begin{array}{c}\text { Área } \\
\text { (ha) }\end{array}$ & $\begin{array}{c}\text { Tipo } \\
\text { de } \\
\text { documento }\end{array}$ & $\begin{array}{c}\text { Ano } \\
\text { da } \\
\text { posse }\end{array}$ & $\begin{array}{c}\text { Ano de } \\
\text { Exped do } \\
\text { Doc. pelo } \\
\text { INTERPA }\end{array}$ & $\begin{array}{l}\text { Município de } \\
\text { localização } \\
\text { atual }\end{array}$ & Obs. \\
\hline 01 & São Jorge & Farid Salame & Governo do Estado & 2.028 & TA & 1940 & - & Marabá & $\mathrm{AC}$ \\
\hline 02 & São Pedro & Aurélio A. de Oliveira & & 2.028 & TA & 1940 & - & Marabá & $\mathrm{AC}$ \\
\hline 03 & Pat. São Felix & P. Municipal de Marabá & & 3.600 & Doc.Div & 1930 & - & Marabá & - \\
\hline 04 & Légua Patrimonial & P. Municipal de Marabá & Governo do Estado & 5.000 & $\mathrm{TD}$ & 1913 & 1932 & Marabá & - \\
\hline 05 & Burgo & João A. de Queiroz Filho & Constância M. de Queiroz & 2.172 & TD & 1929 & 1929 & Marabá & - \\
\hline 06 & Viraçãozinha & João A. de Queiroz Filho & Constância M. de Queiroz & 4.345 & TD & 1937 & 1937 & Marabá & - \\
\hline 07 & Quindangues & P. Municipal de Marabá & Uadi Moussalem & 4.438 & TD & 1940 & 1940 & Marabá & TD \\
\hline 08 & Taboquinha I & Auzira M. Mutran & Maria Brito & 4.636 & $\mathrm{E}$ & 1949 & 1960 & Marabá & - \\
\hline 09 & Taboquinha II & Auzira M. Mutran & Deodoro M. de Mendonça & 6.371 & $\mathrm{TD}$ & 1949 & 1951 & Marabá & - \\
\hline 10 & Novilhas & João A. de Queiroz & Constância M. de Queiroz & 794 & TD & 1949 & 1952 & Marabá & - \\
\hline 11 & Itacaiunas & Antônio Zucatelli & Hugo Cardoso Rosa & 3.600 & TA & 1948 & 1959 & Marabá & - \\
\hline 12 & N. S. de Nazaré & Querubina A. de Almeida & Governo do Estado & 2.000 & TD & 1957 & 1961 & Marabá & - \\
\hline 13 & Burgo & Antônio Zucatelli & Demosthene A. de Azevedo & 3.600 & TA & 1940 & 1957 & Marabá & - \\
\hline 14 & Surubim & INCRA & Alice Silau Amoury & 3.600 & TA & 1957 & 1957 & Marabá & PA \\
\hline 15 & Tartaruga & José Lima Mutram & Governo do Estado & 3.600 & TA & 1960 & - & Marabá & $\mathrm{AC}$ \\
\hline 16 & Princesa & Aparecido D. Correa & & 3.600 & TA & 1957 & - & Marabá & $\mathrm{AC}$ \\
\hline 17 & Gincana ou Balões & Auzira M. Mutran & Nagib Mutran & 4.608 & $\mathrm{Td}$ & 1951 & 1963 & Marabá & - \\
\hline 18 & Mutamba & Azis Mutam Neto & Perina Gomes & 6.352 & $\mathrm{TD}$ & 1951 & 1966 & Marabá & - \\
\hline 19 & Bela Aurora & José F. Diamantino & Nelito. Ind. Com. S/A & 3.600 & TA & 1962 & & Marabá & - \\
\hline 20 & Cabaceira & José F. Diamantino & Nelito. Ind. Com. S/A & 6.406 & TA & 1953 & 1960 & Marabá & - \\
\hline 21 & Cabaceirinha & Herd. M. B. de Almeida & Manoel Brito de Almeida & 920 & $\mathrm{P}$ & 1953 & & Marabá & - \\
\hline 22 & Cabaceirinha & Herd. M. B. de Almeida & Manoel Brito de Almeida & 736 & TD & 1956 & & Marabá & - \\
\hline 23 & Leal & Herd. M. B. de Almeida & Manoel Brito de Almeida & 3.600 & TA & 1956 & & Marabá & - \\
\hline 24 & Murumuru & Herd. M. B. de Almeida & Manoel Brito de Almeida & 2.700 & $\mathrm{P}$ & 1955 & & Marabá & - \\
\hline 25 & Lagedo & Jorge Bastos Gaby & Tufi Gaby & 8.558 & TD & 1957 & 1965 & Marabá & - \\
\hline 26 & Cedrinho & Jorge Bastos Gaby & Tufi Gaby & 3.077 & TD & 1956 & 1960 & Marabá & - \\
\hline 27 & Cedro & Benedito Mutram Filho & Lourdes Gaby & 4.327 & TD & 1956 & & Marabá & - \\
\hline 28 & Arapary & Miguel Gomes da Silva & Chafia Brito Abdelno & 7.308 & TD & 1956 & & Marabá & - \\
\hline 29 & Rato & Maria Rosa S. Ribeiro & Antônio Farah & 3.600 & TA & 1956 & & Marabá & \\
\hline 30 & Itacaiunas & Clausio F. P. Santos e outros & Antônio Ribeiro Filho & 3.600 & TA & 1960 & & Marabá & \\
\hline 31 & Maravilha & Herd. de L. M. Vergolino & Leonel M. Vergolino & 3.600 & TA & 1957 & & Marabá & \\
\hline 32 & S/ Denominação & Antonio Farah & & 3.600 & TA & 1957 & & Marabá & \\
\hline 33 & Central & Clewes Alegrette & & 3.600 & TA & 1960 & & Marabá & \\
\hline 34 & Cochoeira Preta & INCRA & CIB & 3.600 & TA & 1940 & 1960 & Marabá & $\mathrm{PA}$ \\
\hline 35 & Castanheira & INCRA & CIB & 3.600 & TA & 1940 & 1960 & Marabá & PA \\
\hline 36 & Piquiá & Antônio C. de Miranda & Faud Nazar & 3.600 & TA & 1956 & & Marabá & $\mathrm{AC}$ \\
\hline 37 & Bar. Barnca I & José Queiroz da Silva & Dionor Maranão & 3.600 & TA & 1956 & & Marabá & - \\
\hline 38 & Bar Branca II & José Queiroz da Silva & Dionor Maranão & 3.600 & TA & 1956 & 1960 & Marabá & - \\
\hline
\end{tabular}




\begin{tabular}{|c|c|c|c|c|c|c|c|c|c|}
\hline 39 & João Lobo & Azis Mutram Neto & Otamires L. Mutram & 3.600 & TA & 1956 & 1966 & Marabá & - \\
\hline 40 & Escada Alta & Raimundo C. Gaby & & 3.600 & TA & 1956 & & Marabá & - \\
\hline 41 & C. da Cabaceira & Nilo Alves de Almeida & Governo do Estado & 3.600 & TA & 1959 & 1966 & Marabá & - \\
\hline 42 & Sta. Tereza & Nagib Mutran Neto & Michel Moussallem & 3.600 & TA & 1956 & & Marabá & - \\
\hline 43 & Gama & Eneida M. C. da Silva & Deocleciano Rodrigues & 3.600 & TA & 1956 & 1966 & Marabá & - \\
\hline 44 & Tadeu & Eneida M. C. da Silva & Deocleciano Rodrigues & 3.600 & TA & 1956 & 1966 & Marabá & - \\
\hline 45 & Tadeu Excesso & Eneida M. C. da Silva & Deocleciano Rodrigues & 1.420 & TA & 1956 & 1966 & Marabá & - \\
\hline 46 & Centão & Paulo Gaby Almeida & & 3.000 & $\mathrm{P}$ & 1956 & & Marabá & - \\
\hline 47 & Terras de Monsão & CVRD & Nelito. Ind. Com. S/A & 3.600 & TA & 1960 & 1966 & Marabá & - \\
\hline 48 & Terras de Monsão & CVRD & Nelito. Ind. Com. S/A & 9.627 & TD & 1960 & 1966 & Marabá & - \\
\hline 49 & São Sebastião & CVRD & Nelito. Ind. Com. S/A & 3.600 & TA & 1960 & 1963 & Marabá & - \\
\hline 50 & São Benedito I & INCRA & Maria M. Quadros & 3.147 & TA & 1956 & & Marabá & $\mathrm{PA}$ \\
\hline 51 & São Benedito II & INCRA & Maria M. Quadros & 2.733 & TA & 1956 & & Marabá & $\mathrm{PA}$ \\
\hline 52 & Z. de Oliveira & Herd. de R. F. de Olieveira & Raimundo F. de Oliveira & 3.600 & TA & 1957 & & Marabá & - \\
\hline 53 & Oito Barracas & Herd. de C. V. Holanda & Carlos Victor Holanda & 3.600 & TA & 1960 & & Marabá & - \\
\hline 54 & Pardinho & Herd. de C. V. Holanda & Carlos Victor Holanda & 3.600 & TA & 1962 & & Marabá & - \\
\hline 55 & Terra Vermelha & Herd. de C. V. Holanda & Carlos Victor Holanda & 3.600 & TA & 1959 & & Marabá & - \\
\hline 56 & Belo Horizonte & Herd. de C. V. Holanda & Carlos Victor Holanda & 3.600 & TA & 1960 & & Marabá & - \\
\hline 5 & Papagaio & Cosipar & Herd. de P. M. de Olieveira & 4.199 & $\mathrm{TD}$ & 1950 & 1963 & Marabá & - \\
\hline 58 & Alto Bonito & Cosipar & Herd. de P. M. de Olieveira & 3.600 & TA & 1956 & & Marabá & - \\
\hline 59 & São José & Cosipar & Herd. de P. M. de Olieveira & 3.600 & TA & 1956 & 1962 & Marabá & - \\
\hline 60 & Pontal & Cosipar & Herd. de P. M. de Olieveira & 3.600 & TA & 1956 & 1962 & Marabá & - \\
\hline 61 & Carasco & Nilo Maranhão & Dionor Maranhão & 4.362 & $\mathrm{E}$ & 1956 & 1061 & Marabá & - \\
\hline 62 & São José & Herd. de Evandro S. Azevedo & Evandro S. Azevedo & 3.600 & TA & 1956 & & Marabá & - \\
\hline 63 & Cajueiro & INCRA & CIB & 3.600 & TA & 1956 & 1960 & Marabá & PA \\
\hline 64 & Deus Ajude & Herd. Evandro S. Azevedo & Evandro Santos Azevedo & 3.600 & TA & 1956 & 1966 & Marabá & - \\
\hline 65 & Alto Bonito & Herd. de P. M. de Oliveira & Pedro Marinho de Oliveira & 3.600 & TA & 1956 & & Marabá & $\mathrm{AC}$ \\
\hline 66 & N. S. das Graças & Herd. de P. M. de Oliveira & Pedro Marinho de Oliveira & 2.792 & TA & 1965 & 1966 & Marabá & - \\
\hline 67 & Cajueiro & Anto. de Almeida Braga & J. B. Gaby & 3.600 & TA & 1950 & 1960 & Marabá & - \\
\hline 68 & Cristalândia I & INCRA & Antônio de A. Braga & 3.600 & TA & 1956 & & Marabá & $\mathrm{PA}$ \\
\hline 69 & Cristalândia II & INCRA & Alice J. Maranhão & 3.600 & TA & 1956 & & Marabá & $\mathrm{PA}$ \\
\hline 70 & Fortaleza I & INCRA & Almir Queiroz de Moraes & 3.600 & TA & 1956 & & Marabá & $\mathrm{PA}$ \\
\hline 71 & Fortaleza II & INCRA & Almir Queiroz de Moraes & 3.600 & TA & 1956 & 1960 & Marabá & $\mathrm{PA}$ \\
\hline 72 & Mãe Maria I & João A. de Queiroz Filho & Constância M. de Queiroz & 3.946 & TD & 1930 & & B. G. TOO & SUB-UDIO \\
\hline 73 & Mãe Maria II & João A. de Queiroz Filho & Constância M. de Queiroz & 4.284 & TD & 1930 & 1933 & B. G. TOO & SUB-UDIO \\
\hline 74 & Apertada a Hora & $52^{\circ} \mathrm{BIS}$ & Demosthens A. de Azevedo & 3.600 & TD & 1940 & & SJ. Araguaia & - \\
\hline 75 & Landy & P. M. de S. J. do Araguaia & Governo do Estado & 9.292 & TD & 1940 & & SJ. Araguaia & - \\
\hline 76 & Gaeteu & Pastoriza & CIB & 8.712 & TD & 1940 & 1956 & SJ. Araguaia & - \\
\hline 77 & Genipapo & Pastoriza & $\mathrm{CIB}$ & 7.184 & TD & 1940 & 1956 & SJ. Araguaia & - \\
\hline 78 & Araras & INCRA & Lúcio Miranda & 6.811 & TD & 1940 & & SJ. Araguaia & $\mathrm{PA}$ \\
\hline 79 & Prata & José Martins Ferreira & Governo do Estado & 2.801 & TD & 1940 & & SJ. Araguaia & - \\
\hline 80 & Couro de Veado & P. M. de S. J. do Araguaia & Governo do Estado & 3.517 & TD & 1940 & & SJ. Araguaia & \\
\hline
\end{tabular}




\begin{tabular}{|c|c|c|c|c|c|c|c|c|c|}
\hline 81 & Ubã & & José Mendonça Vergolino & 4.284 & TD & 1940 & & SJ. Araguaia & \\
\hline 82 & J. A. Q & Alzira M. Mutram & P. M. de S. J. do Araguaia & 3.600 & $\mathrm{E}$ & 1956 & & SJ. Araguaia & \\
\hline 83 & Pimenteira & Alzira M. Mutram & Nagib Mutram & 3.468 & TD & 1956 & & SJ. Araguaia & \\
\hline 84 & Consulta & INCRA & Elzebio O. da M. Silveira & 4.417 & TD & 1956 & & SJ. Araguaia & PA \\
\hline 85 & Vanessa e Cotovelo & INCRA & Alzira M. Mutram & 5.400 & TA & 1965 & 1966 & SJ. Araguaia & PA \\
\hline 86 & Sto Antônio I & INCRA & Osvaldo dos Reis Mutram & 496 & TA & 1955 & & SJ. Araguaia & PA \\
\hline 87 & Sto Antônio II & INCRA & Osvaldo dos Reis Mutram & 600 & TA & 1955 & & SJ. Araguaia & $\mathrm{PA}$ \\
\hline 88 & Cuxiu I & INCRA & Helena Chiquita Mutram & 1742 & TA & 1956 & & SJ. Araguaia & $\mathrm{PA}$ \\
\hline 89 & Cuxiu II & INCRA & Helena Chiquita Mutram & 5.735 & TA & 1956 & & SJ. Araguaia & $\mathrm{PA}$ \\
\hline 90 & Boa Esperança & INCRA & Helena Chiquita Mutram & 3.749 & TA & 1956 & & SJ. Araguaia & $\mathrm{PA}$ \\
\hline 91 & Sto Onofre & P. M. de S. J. do Araguaia & Governo do Estado & 3.657 & TD & 1940 & & SJ. Araguaia & \\
\hline 92 & Pedro de Amolar & Minase Ysonobo & & 3.600 & TA & 1965 & & SJ. Araguaia & - \\
\hline 93 & Almescão & Antônio Garcia Pombo & Raimundo O. Vergolino & 3.600 & TA & 1957 & & SJ. Araguaia & - \\
\hline 94 & Croá & & Okerlina T. Torres & 3.600 & TA & 1950 & & SJ. Araguaia & - \\
\hline 95 & Belo Horizonte & Herd. de D. A. de Azevedo & Demosthenes A. de Azevedo & 3.600 & TA & 1950 & & SJ. Araguaia & - \\
\hline 96 & São Raimundo & Brasispania & Ligia Ma. Aparício & 3.600 & TA & 1957 & & SJ. Araguaia & - \\
\hline 97 & Gameleira & Carlos A. Sampaio & CIB & 3.600 & TA & 1956 & 1966 & Curionop. & - \\
\hline 98 & Pernambuco & Carlos Eduardo Borges & $\mathrm{CIB}$ & 3.600 & TA & 1956 & & Curionop. & - \\
\hline 99 & Cajueiro & INCRA & $\mathrm{CIB}$ & 3.600 & TA & 1954 & 1963 & Curionop. & $\mathrm{PA}$ \\
\hline 100 & M. Queimado I & INCRA & CIB & 2.400 & TA & 1950 & 1960 & Curionop. & $\mathrm{PA}$ \\
\hline 101 & M. Queimado II & INCRA & $\mathrm{CIB}$ & 3.600 & TA & 1957 & 1960 & Curionop. & $\mathrm{PA}$ \\
\hline 102 & Porção do óleo & INCRA & $\mathrm{CIB}$ & 3.600 & TA & 1957 & 1962 & Curionop. & $\mathrm{PA}$ \\
\hline 103 & Fortaleza & Anto. C. Mathias & Governo do Estado & 1.800 & TA & 1955 & & Curionop. & - \\
\hline 104 & $2 \mathrm{R}$ & Adão Ruy Mathias & & 1.500 & $\mathrm{P}$ & 1957 & & Curionop. & - \\
\hline 105 & São José & Vários Posseiros & João A. de Almeida & 2.800 & $\mathrm{P}$ & 1949 & & Curionop. & - \\
\hline 106 & Piranha & Vários Posseiros & Nelito Ind. Com. S/A & 2.800 & $\mathrm{P}$ & 1950 & & Curionop. & - \\
\hline 107 & Limão & Vários Posseiros & Manoel Brito de Almeida & 2.900 & $\mathrm{P}$ & 1950 & & Curionop. & - \\
\hline 108 & Anta & Vários Posseiros & Rosa M. A. de Almeida & 2.250 & $\mathrm{P}$ & 1950 & & Curionop. & - \\
\hline 109 & Vira - Sebo & Osvaldo dos Reis Mutram & Antônio da Rocha Maia & 3.600 & $\mathrm{E}$ & 1925 & 1925 & Curionop. & - \\
\hline 110 & Capinzal & Malaquias Q. Silveira & Nelito Ind. Com. S/A & 3.600 & PA & 1960 & & Curionop. & - \\
\hline 111 & Sta. Maria do Pontal & Joaquim Silveira & Nelito Ind. Com. S/A & 4.335 & TD & 1956 & & Curionop. & $\mathrm{AC}$ \\
\hline 112 & Boca do Lago & Joaquim Silveira & Nelito Ind. Com. S/A & 3.600 & TA & 1956 & 1962 & Curionop. & $\mathrm{AC}$ \\
\hline 113 & N. S. P Socorro & Malaquias Q. Silveira & Nelito Ind. Com. S/A & 3.600 & TA & 1959 & 1960 & Curionop. & $\mathrm{AC}$ \\
\hline 114 & Santos Reis & Mauricio P. Fraga & Nelito Ind. Com. S/A & 4.406 & TD & 1976 & & Curionop. & - \\
\hline 115 & São Domingos & Mauricio P. Fraga & Nelito Ind. Com. S/A & 3.600 & TA & 1960 & & Curionop. & - \\
\hline 116 & Peruano & Nagib Chamom & Marcos Athias & 4.338 & $\mathrm{E}$ & 1951 & & Curionop. & - \\
\hline 117 & Peruano Central & João Anísio Ferreira & Governo do Estado & 3.600 & TA & 1956 & & Curionop. & - \\
\hline 118 & Agua Branca & João Anísio Ferreira & & 3.600 & $\mathrm{E}$ & 1957 & 1965 & Curionop. & - \\
\hline 119 & Sta. Adélia & Huascar N. Gomes & João Anísio Ferreira & 3.600 & TA & 1956 & & Curionop. & - \\
\hline 120 & Sta. Maria & Huascar N. Gomes & Rosalina M. Ferreira & 3.600 & TA & 1957 & & Curionop. & - \\
\hline 121 & Mutamba & Huascar N. Gomes & Rosalina M. Ferreira & 2.800 & $\mathrm{P}$ & 1964 & & Curionop. & - \\
\hline 122 & Ponto de Pedra & Abie Ferreira & & 2.800 & $\mathrm{P}$ & 1964 & & Curionop. & - \\
\hline
\end{tabular}




\begin{tabular}{|c|c|c|c|c|c|c|c|c|c|}
\hline 123 & Itauba & Herd. Evandro S. Azevedo & Evandro S. Azevedo & 3.600 & TA & 1956 & 1966 & Curionop. & - \\
\hline 124 & Cedrinho & Herd. Evandro S. Azevedo & Evandro S. Azevedo & 3.600 & TA & 1956 & 1966 & Curionop. & - \\
\hline 125 & Cocal & Helena Chiquita Mutram & & 1.800 & $\mathrm{P}$ & 1966 & & Curionop. & - \\
\hline 126 & Cocal & INCRA & Helena Chiquita Mutram & 6.392 & TA & 1956 & & Curionop. & $\mathrm{PA}$ \\
\hline 127 & Gorgulho & INCRA & Helena Chiquita Mutram & 3.578 & TA & 1956 & & Curionop & $\mathrm{PA}$ \\
\hline 128 & Gameleira & INCRA & Helena Chiquita Mutram & 3.743 & TA & 1956 & & Curionop & PA \\
\hline 129 & Figuras & INCRA & Helena Chiquita Mutram & 4.302 & TA & 1956 & & Curionop & $\mathrm{PA}$ \\
\hline 130 & Castanheiras & INCRA & CIB & 3.600 & TA & 1956 & 1961 & Curionop & PA \\
\hline 131 & S. P do Centro & INCRA & CIB & 3.600 & TA & 1956 & 1965 & Curionop & PA \\
\hline 132 & S. J do Centro & INCRA & CIB & 3.600 & TA & 1956 & 1959 & Curionop & PA \\
\hline 133 & S. F do Centro & INCRA & CIB & 3.600 & TA & 1956 & & Curionop & PA \\
\hline 134 & Sta. Cruz da Tona & INCRA & $\mathrm{CIB}$ & 3.600 & TA & 1956 & 1951 & Curionop & $\mathrm{PA}$ \\
\hline 135 & Pau ferrado & José Olintho Contente & & & TA & 1956 & & Curionop & \\
\hline 136 & Boa Esperança & José Olintho Contente & Antônio da P. Capucho & 3.600 & TA & 1956 & 1966 & Curionop & - \\
\hline 137 & Pimenteira & INCRA & Benedito Mutram e CIA & 2.972 & TD & 1954 & & Curionop & $\mathrm{PA}$ \\
\hline 138 & Boca do Cardoso & INCRA & Benedito Mutram e CIA & 8.708 & TD & 1954 & & Curionop & $\mathrm{PA}$ \\
\hline 139 & Lagedo & INCRA & Benedito Mutram e CIA & 4.305 & TD & 1954 & & Curionop & $\mathrm{PA}$ \\
\hline 140 & Água Fria & Paulo Veloso & Dionor Maranhão & 3.600 & TA & 1956 & & Curionop & $\mathrm{AC}$ \\
\hline 141 & Cristino & Geraldo Mendonça & Dionor Maranhão & 3.600 & TA & 1956 & & Curionop & - \\
\hline 142 & Macacheira & Claudina M. Pinheiro & Plinio Pinheiro & 10.218 & TA & 1936 & 1956 & Curionop & - \\
\hline 143 & F. da Macacheira & Claudina M. Pinheiro & Ozório M. Pinheiro & 11.048 & TA & 1956 & & Curionop & - \\
\hline 144 & Volta do Rio & Plinio Pinheiro Neto & Plinio Pinheiro & 3.600 & TA & 1946 & 1956 & Curionop & - \\
\hline 145 & Grota Verde & Plinio Pinheiro Neto & Plinio Pinheiro & 3.600 & TA & 1946 & 1966 & Curionop & - \\
\hline 146 & Sinha Moça & Cesário Galli Neto & J. H. O. H. Vergolino4. & 4.558 & TA & & 1957 & Curionop & - \\
\hline 147 & S. J. Refugio & José Ulisses Guimarães & Sebastiana M. Salame & 3.600 & TA & 1957 & & Curionop & - \\
\hline 148 & São José & José Ulisses Guimarães & Sebastiana M. Salame & 3.600 & TA & 1957 & & Curionop & - \\
\hline 149 & Limão I & INCRA & Délio Chuquia Mutram & 6.886 & TA & 1957 & & Curionop & $\mathrm{PA}$ \\
\hline 150 & Limão II & INCRA & Délio Chuquia Mutram & 3.600 & TA & & & Curionop & $\mathrm{PA}$ \\
\hline 151 & Pau Preto & INCRA & Aziz Mutram Neto & 8.681 & TA & 1957 & & Curionop & $\mathrm{PA}$ \\
\hline 152 & São Jose & Herd. Evandro S. Azevedo & Evandro S. Azevedo & 3.600 & TA & & & Curionop & \\
\hline 153 & Bela Vista & INCRA & Evandro L. Chuquia Mutram & 3.600 & TA & 1961 & & Curionop & PA \\
\hline 154 & Pacus & INCRA & Benedito Mutram & 4.602 & TA & 1956 & 1960 & Curionop & PA \\
\hline 155 & Centro Novo & INCRA & Benedito Mutram & 2.779 & TA & & & Curionop & $\mathrm{PA}$ \\
\hline 156 & Bagua & Celso Chuquia Mutram & Nilce Chuquia & 5.800 & TA & 1956 & 1963 & Curionop & \\
\hline 157 & Caroço do Olho & Herd. de L. M. Vergolino & Governo do Estado & 3.600 & TA & 1950 & & Curionop & - \\
\hline 158 & Queimadas & & Jorge L. de M. Vergolino & 1.200 & $\mathrm{P}$ & 1958 & & Curionop & - \\
\hline 159 & Refugio I & Agropecuária Carajás & & 3.600 & TA & 1957 & & Curionop & - \\
\hline 160 & Refugio III & Agropecuária Carajás & & 3.600 & TA & 1960 & & Curionop & - \\
\hline 161 & Refugio III & Agropecuária Carajás & & 3.600 & TA & 1961 & & Curionop & - \\
\hline 162 & Maria Bonita & Cesário Galli Neto & & 3.600 & TA & 1957 & & Curionop & - \\
\hline 163 & Cajazeiras & Cesário Galli Neto & & 3.600 & TA & 1957 & & Curionop & - \\
\hline 164 & Jandaia/Junco & José Cristino Ferreira & Paulo Augusto & 3.600 & TA & 1961 & 1966 & Curionop & $\mathrm{AC}$ \\
\hline
\end{tabular}




\begin{tabular}{|c|c|c|c|c|c|c|c|c|c|}
\hline 165 & Esperancinha I & Fausto Ribeiro Marquez & & 3.600 & TA & 1963 & & Curionop & - \\
\hline 166 & Esperancinha II & Fausto Ribeiro Marquez & & 3.600 & TA & 1957 & & Curionop & - \\
\hline 167 & Surubim I & Mauricio P. Fraga & Nelito Ind. Com. S/A & 3.600 & TA & 1956 & & Curionop & - \\
\hline 168 & Surubim III & Mauricio P. Fraga & Nelito Ind. Com. S/A & 1.680 & TA & & 1966 & Curionop & - \\
\hline 169 & Canta Galo & Mauricio P. Fraga & Nelito Ind. Com. S/A & 2.950 & $\mathrm{P}$ & & & Curionop & - \\
\hline 170 & Angico & Marabá Agrop. Past. S/A & Nelito Ind. Com. S/A & 3.600 & TA & 1962 & 1965 & Curionop & - \\
\hline 171 & Formiga & Marabá Agrop. Past. S/A & Osório F. M. Pinheiro & 3.600 & TA & 1960 & 1964 & Curionop & - \\
\hline 172 & Carumbe & Marabá Agrop. Past. S/A & & 3.600 & TA & 1960 & & Curionop & - \\
\hline 173 & Barreira Branca & Marabá Agrop. Past. S/A & Nelito Ind. Com. S/A & 10.800 & TA & 1960 & & Curionop & \\
\hline 174 & Gorg. Do Cardoso & Marabá Agrop. Past. S/A & & 3.600 & TA & 1965 & & Curionop & - \\
\hline 175 & Carajás & Benedito Mutram Filho & & 3.600 & TA & 1960 & & Xinguar & - \\
\hline 176 & Espirito Santo & Benedito Mutram Filho & & 7.200 & TA & 1952 & & Xinguar & \\
\hline 177 & Mundo Novo & Luis Pereira Martins & Salomy Silva Costa & 3.600 & TA & 1960 & & Xinguar & \\
\hline 178 & Porangai ou Lua & Mauricio P. Fraga & & 3.600 & TA & 1959 & & Xinguar & \\
\hline 179 & Poço Rico & INCRA & Nagib Chamom & 3.600 & TA & 1959 & 1966 & Xinguar & $\mathrm{PA}$ \\
\hline 180 & Cedro & Mauricio P. Fraga & Nilo Alves de Almeida & 2.900 & $\mathrm{P}$ & 1960 & & Xinguar & \\
\hline 181 & Surubim II & Mauricio P. Fraga & Nelito Ind. Com. S/A & 3.600 & TA & 1956 & & S. G. Arag & \\
\hline 182 & Nova Descoberta & INCRA & CIB & 3.600 & TA & 1957 & & S. G. Arag & $\mathrm{PA}$ \\
\hline 183 & Centro Novo & INCRA & CIB & 7.200 & TA & & & S. G. Arag & $\mathrm{PA}$ \\
\hline 184 & S. José do Centro & Marabá Agrop. Past. S/A & CIB & 3.600 & TA & 1957 & & S. G. Arag & \\
\hline 185 & Bom Futuro & Marabá Agrop. Past. S/A & & 3.600 & TA & & & S. G. Arag & \\
\hline 186 & Serra Rica & Marabá Agrop. Past. S/A & & 3.600 & TA & & & S. G. Arag & \\
\hline 187 & Mutam & Marabá Agrop. Past. S/A & & 3.600 & TA & 1956 & & S. G. Arag & \\
\hline 188 & Ponta da Serra & Marabá Agrop. Past. S/A & & 3.600 & TA & 1957 & & S. G. Arag & \\
\hline 189 & São Bento & Marabá Agrop. Past. S/A & & 3.600 & TA & 1956 & & S. G. Arag & \\
\hline 190 & Gorg. do Sororo & Marabá Agrop. Past. S/A & & 3.600 & TA & 1956 & & S. G. Arag & \\
\hline 191 & Sta. C. da Mucura & Marabá Agrop. Past. S/A & & 1.200 & TA & 1960 & & S. G. Arag & \\
\hline 192 & São Sebastião & Marabá Agrop. Past. S/A & & 3.600 & TA & 1960 & & S. G. Arag & \\
\hline 193 & São José & Anto. Olyntho Contente & & 3.600 & TA & 1963 & & S. G. Arag & \\
\hline 194 & Tabocão ou Cajazeiras & INCRA & Alzira M. Mutram & 3.600 & TA & 1956 & 1962 & S. G. Arag & PA \\
\hline 195 & Terra Nova & INCRA & Alzira M. Mutram & 3.600 & TA & 1956 & & S. G. Arag & PA \\
\hline 196 & Juruti ou Limão & INCRA & Benedito Mutram & 3.521 & TA & 1956 & 1966 & S. G. Arag & PA \\
\hline 197 & Caititu Podre & INCRA & Aziz Mutram Neto & 3.600 & TA & 1956 & & S. G. Arag & PA \\
\hline 198 & Formiga & INCRA & Aziz Mutram Neto & 3.600 & TA & 1959 & & S. G. Arag & PA \\
\hline 199 & Fortaleza I & INCRA & Helena Chuquia Mutram & 3.600 & TA & 1956 & & S. G. Arag & $\mathrm{PA}$ \\
\hline 200 & Fortaleza II & INCRA & Helena Chuquia Mutram & 7.200 & TA & 1956 & & S. G. Arag & $\mathrm{PA}$ \\
\hline 201 & Boa fé & INCRA & Evandro L. C. Mutram & 3.600 & TA & 1960 & & S. G. Arag & $\mathrm{PA}$ \\
\hline 202 & Bom Lugar & Herd. P. E. Marquez & Herd. Deocleciano Rodrigues & 3.600 & TA & 1956 & & S. G. Arag & \\
\hline 203 & Boa Sorte & Palmiro Vilela Marques & Eneida M. Correia & 3.600 & TA & 1956 & & S. G. Arag & \\
\hline 204 & Limpeza I, II, III & INCRA & Benedito Mutram Filho & 4.242 & TA & & & S. G. Arag & PA \\
\hline 205 & Sampaio I & INCRA & Evandro S. Azevedo & 4.417 & TA & 1960 & & S. G. Arag & PA \\
\hline 205 & Sampaio II & INCRA & Evandro S. Azevedo & 3.642 & TA & 1960 & & S. G. Arag & PA \\
\hline
\end{tabular}




\begin{tabular}{|c|c|c|c|c|c|c|c|c|c|}
\hline 207 & Abobora & INCRA & Evandro S. Azevedo & 4.413 & TA & 1960 & & S. G. Arag & PA \\
\hline 208 & Brasilzinho I & Herd. de J. B. de Almeida & José Brito de Almeida & 3.600 & TA & 1960 & & S. G. Arag & \\
\hline 209 & Brasilzinho II & Herd. de J. B. de Almeida & José Brito de Almeida & 3.600 & TA & 1956 & & S. G. Arag & \\
\hline 210 & Mal Arrumado & INCRA & Antônio A. Braga & 1.800 & TA & 1963 & & S. G. Arag & PA \\
\hline 211 & Pedra Branca & INCRA & Almir Queiroz de Moraes & 3.685 & TA & 1956 & & S. G. Arag & PA \\
\hline 212 & José Leandro & INCRA & Almir Queiroz de Moraes & 3.600 & TA & 1956 & 1961 & S. G. Arag & PA \\
\hline 213 & Lagoa Bonita & INCRA & Almir Queiroz de Moraes & 3.600 & $\mathrm{TA}$ & 1956 & 1966 & S. G. Arag & PA \\
\hline 214 & Sacrifício & INCRA & Almir Queiroz de Moraes & 3.714 & TA & 1956 & 1960 & S. G. Arag & PA \\
\hline 215 & Sacrifício & Herd. de C. V. Holanda & Carlos Victor Holanda & 3.600 & TA & 1960 & 1960 & S. G. Arag & \\
\hline
\end{tabular}

Fonte: Barros (1992, p. 56-59). Organização: Rogério Rego Miranda. 
ANEXO II - RELAÇÃO DOS CASTANHAIS ADQUIRIDOS PELA UNIÃO E TRANSFORMADOS EM PROJETOS DE ASSENTAMENTO. 
INSTITUTO NACIONAL DE COLONIZAÇÃO E REFORMA AGRÁRIA - INCRA

SUPERINTENDÊNCIA REGIONAL DO SUL DO PARÁ SR(27)

DIVISÃO TÉCNICA/CARTOGRAFIA E RECURSOS NATURAIS

MARABÁ - PARÁ

\section{RELAÇÃO DOS CASTANHAIS ADQUIRIDOS PELA UNIÃO E TRANSFORMADOS EM PROJETOS DE}

\section{ASSENTAMENTO}

\begin{tabular}{|c|c|c|c|c|c|}
\hline $\begin{array}{l}\mathbf{N}^{\mathbf{0}} \\
\text { ORD }\end{array}$ & $\begin{array}{c}\text { ANO } \\
\text { DESAP }\end{array}$ & CASTANHAL & ÁREA & PA & MUNICÍPIO \\
\hline 01 & 1987 & ARARAS & $5.058,4728$ & ARARAS & S. JOÃO DO ARAGUAIA \\
\hline 02 & \multirow{18}{*}{1988} & ABOBÓRA & $4.413,2492$ & ABOBÓRA & \multirow{2}{*}{ SÃO GERALDO DO ARAGUAIA } \\
\hline 03 & & BELA VISTA & $3.598,0000$ & EMÍDIO BATISTA DE MOURA & \\
\hline 04 & & BOA ESPERANÇA & $3.744,3000$ & PAULO FONTELES & SÃO DOMINGOS DO ARAG. \\
\hline 05 & & BOA FÉ & $3.600,0000$ & EMÍDIO BATISTA DE MOURA & SÃO GERALDO DO ARAGUAIA \\
\hline 06 & & BOCA DO CARDOSO & $8.704,3000$ & BOCA DO CARDOSO & ELDORADO DO CARAJÁS \\
\hline 07 & & CACHOEIRA PRETA & $3.227,3725$ & CASTANHEIRA & MARABÁ \\
\hline 08 & & CAITITU PODRE & $3.600,0000$ & REGULARIZAÇÃO FUNDIÁRIA & \multirow{2}{*}{ SÃO GERALDO DO ARAGUAIA } \\
\hline 09 & & CAJUEIRO & $3.600,0000$ & REGULARIZAÇÃO FUNDIÁRIA & \\
\hline 10 & & CASTANHEIRA & $3.226,9574$ & CASTANHEIRA & MARABÁ \\
\hline 11 & & CASTANHEIRA & $3.593,7000$ & REGULARIZAÇÃO FUNDIÁRIA & SÃO GERALDO DO ARAGUAIA \\
\hline 12 & & CENTRO NOVO & $7.180,0000$ & REGULARIZAÇÃO FUNDIÁRIA & \\
\hline 13 & & CENTRO NOVO & $2.779,0900$ & REGULARIZAÇÃO FUNDIÁRIA & PIÇARRA \\
\hline 14 & & COCAL & $6.885,0000$ & GAMELEIRA & SÃO GERALDO DO ARAGUAIA \\
\hline 15 & & CONSULTA & $4.716,6350$ & VENEZA & SÃO DOMINGOS DO ARAG. \\
\hline 16 & & CRISTALÂNDIA I & $3.600,0000$ & GAMELEIRA & \multirow{2}{*}{ SÃO GERALDO DO ARAGUAIA } \\
\hline 17 & & CRISTALÂNDIA II & 3.025 .5650 & GAMELEIRA & \\
\hline 18 & & CUXIU I & $1.756,0000$ & PAULO FONTELES & SÃO DOMINGOS DO ARAG. \\
\hline 19 & & CUXIU II & $5.738,3000$ & PAULO FONTELES & SÃO GERALDO DO ARAGUAIA \\
\hline 20 & & FIGURAS & $4.302,0000$ & REGULARIZAÇÃO FUNDIÁRIA & \multirow{2}{*}{ SÃO GERALDO DO ARAGUAIA } \\
\hline 21 & & FORMIGAS & $3.600,0000$ & REGULARIZAÇÃO FUNDIÁRIA & \\
\hline
\end{tabular}




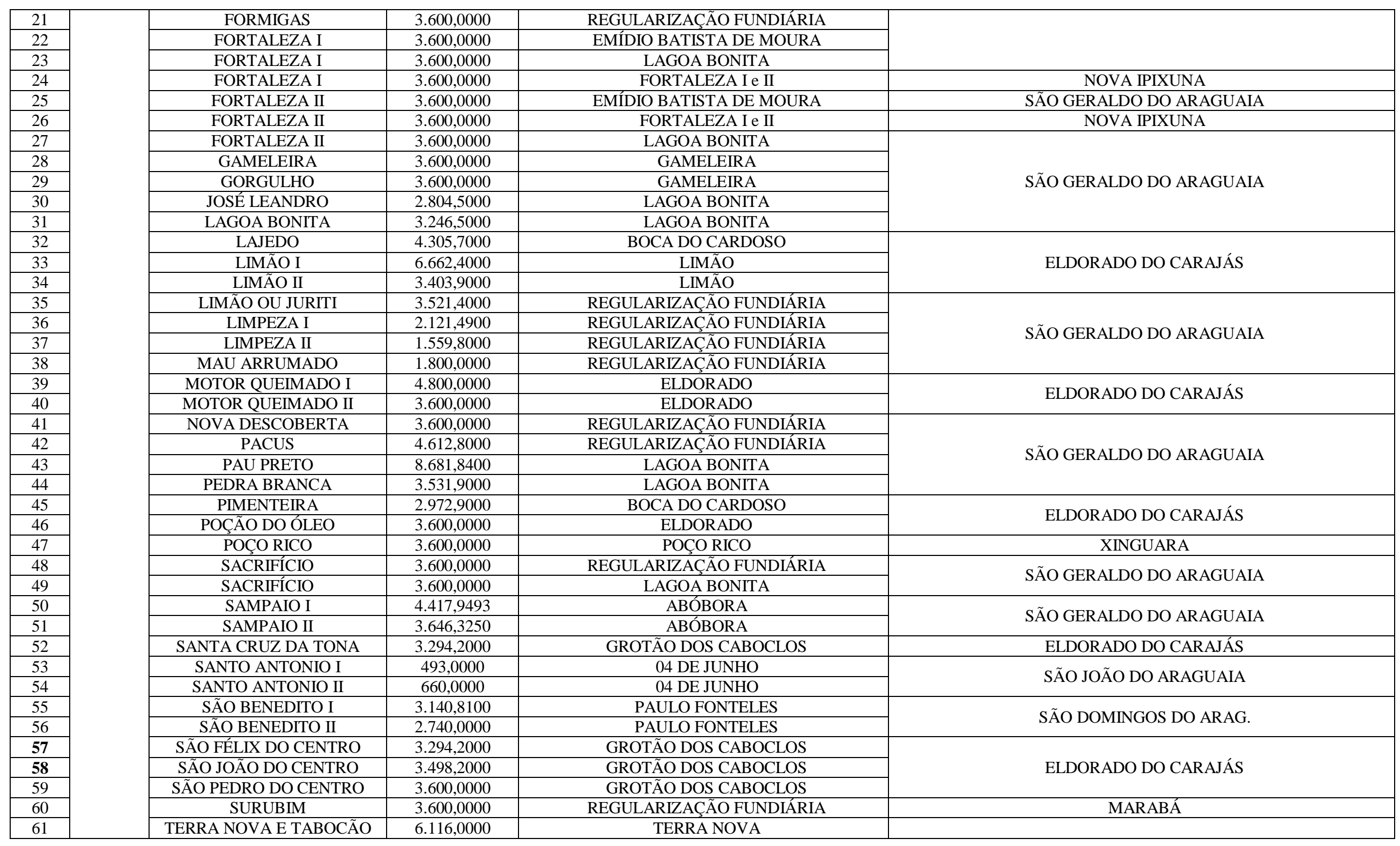




\begin{tabular}{|c|c|c|c|c|c|}
\hline 62 & & VENEZA OU COTOVELO & $5.780,0000$ & VENEZA & SÃO JOÃO/SÃO DOMINGOS \\
\hline 63 & 1995 & CEDRINHO & $3.077,1198$ & CEDRINHO & MARABÁ \\
\hline 64 & \multirow{7}{*}{1997} & COMPLEXO MACACHEIRA & $18.089,7346$ & 17 DE ABRIL & ELDORADO DO CARAJÁS \\
\hline 65 & & ESCADA ALTA & $3.600,0000$ & ESCADA ALTA & MARABÁ \\
\hline 66 & & OITO BARRACAS & $3.600,0000$ & OITO BARRACAS & S. DOMINGOS DO ARAG \\
\hline 67 & & DEUS AJUDA & $3.600,0000$ & PATAUÁ & \multirow{2}{*}{ MARABÁ } \\
\hline 68 & & PAU PRETO & $3.600,0000$ & PATAUÁ & \\
\hline 69 & & PIMENTEIRA & $3.400,0000$ & PIMENTEIRA & S. JOÃO DO ARAG. \\
\hline 70 & & LÉGUA J.A.Q. & $3.600,0000$ & PRIMAVERA DO ARAGUAIA & S. JOÃO DO ARAG. \\
\hline 71 & \multirow{15}{*}{1998} & ANGICO & $3.600,0000$ & \multirow{15}{*}{$\begin{array}{l}\text { PA's VIVEIRO, BARREIRA BRANCA, OZIEL } \\
\text { PEREIRA e VALE DO MUCURA (antiga fazenda } \\
\text { Bamerindus) }\end{array}$} & \multirow{15}{*}{ ELDORADO, SÃO GERALDO e PIÇARRA } \\
\hline 72 & & FORMIGA & $3.600,0000$ & & \\
\hline 73 & & BARREIRA BRANCA & $10.800,0000$ & & \\
\hline 74 & & CARUMBÉ & $3.600,0000$ & & \\
\hline 75 & & MUTUAM & $3.600,0000$ & & \\
\hline 76 & & GORGULHO DO CARDOSO & $3.600,0000$ & & \\
\hline 77 & & PONTA DA SERRA & $3.600,0000$ & & \\
\hline 78 & & SÃO JOSÉ DO CENTRO & $1.200,0000$ & & \\
\hline 79 & & SANTA CRUZ DA TONA & $3.600,0000$ & & \\
\hline 80 & & SERRA RICA & $3.600,0000$ & & \\
\hline 81 & & LAGOA BONITA & $2.900,0000$ & & \\
\hline 82 & & BOM FUTURO & $3.600,0000$ & & \\
\hline 83 & & SÃO BENTO & $3.600,0000$ & & \\
\hline 84 & & SÃO SBASTIÃO & $3.600,0000$ & & \\
\hline 85 & & GORGULHO & $3.600,0000$ & & \\
\hline 86 & \multirow{15}{*}{1999} & ALTO BONITO & $3.600,0000$ & ALTO BONITO DO AXIXÁ & ELDORADO DO CARAJ. \\
\hline 87 & & BELO HORIZONTE & $3.600,0000$ & BELO HORIZONTE & S. DOMINGOS DO ARAG \\
\hline 88 & & BETH & $1.369,0000$ & BETH & S. DOMINGOS DO ARAG \\
\hline 89 & & BOA ESPERANÇA & $3.600,0000$ & BOA ESPERANÇA DO BURGO & MARABÁ \\
\hline 90 & & CRISTO REI $^{3}$ & $3.600,0000$ & CRISTO REI & ITUPIRANGA \\
\hline 91 & & SANTA MARIA & $3.600,0000$ & GRANDE VITÓRIA & MARABÁ \\
\hline 92 & & LA ESTÂNCIA & $3.600,0000$ & LASTÂNCIA & ITUPIRANGA \\
\hline 93 & & LAGO AZUL & $3.600,0000$ & LAGO AZUL & NOVA IPIXUNA \\
\hline 94 & & MÃE MARIA & $3.600,0000$ & MÃE MARIA & BOM JESUS DO TOCANTINS \\
\hline 95 & & TERRA NOVA ou TABOCÃO & $6.116,5215$ & TERRA NOVA & SÃO GERALDO DO ARAG. \\
\hline 96 & & PRINCESA & $3.600,0000$ & PRINCESA & ITUPIRANGA \\
\hline 97 & & RAINHA & $3.600,0000$ & RAINHA & ITUPIRANGA \\
\hline 98 & & SÃO RAIMUNDO & $3.600,0000$ & BRASILESAPNHA & SÃO DOMINGOS DO ARAG. \\
\hline 99 & & MOÇA BONITA & $3.307,0099$ & MOÇA BONITA & ELDORADO DO CARAJÁS \\
\hline 100 & & TARTARUGA & $3.600,0000$ & TARTARUGA & MARABÁ \\
\hline 101 & \multirow{2}{*}{2001} & NOSSA S ${ }^{\text {a }}$. PERP. SOCORRO & $1.593,0000$ & NOSSA SENHORA DAS GRAÇAS & ELDORADO DO CARAJÁS \\
\hline 102 & & BELO MIRAR & $3.400,0000$ & BELO MIRAR & ELDORADO DO CARAJÁS \\
\hline
\end{tabular}




\begin{tabular}{|l|c|c|c|c|}
\hline 103 & PAU FERRADO & $3.600,0000$ & BOA ESPERANÇA DO ARAGUAIA & S. GERALDO DO ARAG. \\
\hline 104 & BOCA DO LAGO & $3.554,3824$ & BOCA DO LAGO & ELDORADO DO CARAJÁS \\
\hline 105 & RATO I & $1.452,4309$ & RATO I & MARABÁ \\
\cline { 2 - 5 } & RATO II & 2700.6880 & RATO II & MARABÁ \\
\cline { 2 - 5 } & Fonte: INCRA (2015). & &
\end{tabular}

